\title{
Low-Valent Tungsten Redox Catalysis Enables Controlled Isomerization and Carbonylative Functionalization of Alkenes
}

Tanner Jankins, William Bell, Yu Zhang, Zi-Yang Qin, Milan Gembicky, Peng Liu, Keary Engle Submitted date: 02/04/2021 - Posted date: 05/04/2021

Licence: CC BY-NC-ND 4.0

Citation information: Jankins, Tanner; Bell, William; Zhang, Yu; Qin, Zi-Yang; Gembicky, Milan; Liu, Peng; et al. (2021): Low-Valent Tungsten Redox Catalysis Enables Controlled Isomerization and Carbonylative Functionalization of Alkenes. ChemRxiv. Preprint. https://doi.org/10.26434/chemrxiv.14362238.v1

Tungsten catalysis has played an instrumental role in the history of organometallic chemistry, with electrophilic, fully oxidized $\mathrm{W}(\mathrm{VI})$ catalysts featuring prominently in olefin polymerization and metathesis reactions. Here, we report that the simple $\mathrm{W}(0)$ precatalyst, $\mathrm{W}(\mathrm{CO})_{6}$, catalyzes the isomerization and hydrocarbonylation of alkenes via a W(0)/W(II) redox couple. The 6- to 7-coordinate geometry changes associated with this redox process are key in allowing isomerization to take place over multiple positions and stop at a defined unactivated internal site that is primed for in situ functionalization. DFT studies and crystallographic characterization of multiple directing-group-bound W(II) model complexes illuminate potential intermediates of this redox cycle and showcase the capabilities of the 7-coordinate W(II) geometry to facilitate challenging alkene functionalizations.

File list (6)

Manuscript.pdf (4.94 MiB)

view on ChemRxiv - download file

Supporting Info.pdf (33.29 MiB)

view on ChemRxiv - download file

2u.cif (408.74 KiB)

view on ChemRxiv - download file

W-2.cif $(559.85 \mathrm{KiB})$

view on ChemRxiv - download file

W-3.cif (341.66 KiB)

view on ChemRxiv - download file

W-3'.cif (0.94 MiB)

view on ChemRxiv - download file 


\section{Low-Valent Tungsten Redox Catalysis Enables Controlled Isomerization and Carbonylative Functionalization of Alkenes}

Authors: Tanner C. Jankins ${ }^{\mathrm{a}}$, William C. Bell ${ }^{\mathrm{b}}$, Yu Zhang ${ }^{\mathrm{b}}, \mathrm{Zi}-$ Yang Qin $^{\mathrm{a}}$, Milan Gembicky ${ }^{\mathrm{c}}$, Peng Liu ${ }^{b *}$, Keary M. Engle ${ }^{a *}$.

\section{Affiliations:}

a Department of Chemistry, The Scripps Research Institute 10550 North Torrey Pines Road, La Jolla, CA 92037 (USA).

${ }^{\mathrm{b}}$ Department of Chemistry, The University of Pittsburgh 219 Parkman Avenue, Pittsburgh, PA 15260 (USA).

${ }^{c}$ Department of Chemistry and Biochemistry, The University of California San Diego 9500 Gilman Drive La Jolla, CA 92093, (USA).

*Correspondence to: pengliu@pitt.edu; keary@scripps.edu

Abstract: Tungsten catalysis has played an instrumental role in the history of organometallic chemistry, with electrophilic, fully oxidized W(VI) catalysts featuring prominently in olefin polymerization and metathesis reactions. Here, we report that the simple $W(0)$ precatalyst, $\mathrm{W}(\mathrm{CO})_{6}$, catalyzes the isomerization and hydrocarbonylation of alkenes via a $\mathrm{W}(0) / \mathrm{W}$ (II) redox couple. The 6- to 7-coordinate geometry changes associated with this redox process are key in allowing isomerization to take place over multiple positions and stop at a defined unactivated internal site that is primed for in situ functionalization. DFT studies and crystallographic characterization of multiple directing-group-bound W(II) model complexes illuminate potential intermediates of this redox cycle and showcase the capabilities of the 7-coordinate W(II) geometry to facilitate challenging alkene functionalizations.

Main Text: Tungsten is widely employed in commercial applications of central importance to modern society, including hard materials (e.g., tungsten carbide and metal alloys) and petroleum upgrading processes (1) (e.g., the Shell Higher Olefin Process and the Neohexene Process). Tungsten has also played an historically important role in the development of the field of homogeneous catalysis (2). Most notable in this context are catalytic processes that employ highvalent tungsten (e.g., +6) in a fixed oxidation state for alkene and alkyne metathesis (3) and polymerization reactions (4). Low-valent tungsten (e.g., +0 ), on the other hand, has a strikingly different reactivity profile, in that it possesses the potential for redox reactions, such as oxidative addition and reductive elimination. Moreover, the archetypal $\mathrm{W}(0)$ complex, $\mathrm{W}(\mathrm{CO})_{6}$, is a benchstable solid with high functional group tolerance, whereas fully oxidized W(VI) species are generally highly Lewis acidic and oxophilic, manifesting in sensitivity to air, moisture, and many common Lewis basic functional groups. Despite these promising features and the intriguing reactivity that has been demonstrated with stoichiometric low-valent tungsten, such as dearomatization (5-6) and alkene hydrofunctionalization (7-9), low-valent tungsten redox catalysis has been limited to a few specific types of transformations, including alkene isomerization, hydrogenation, and allylic substitution (10-12) (Fig. 1a). 


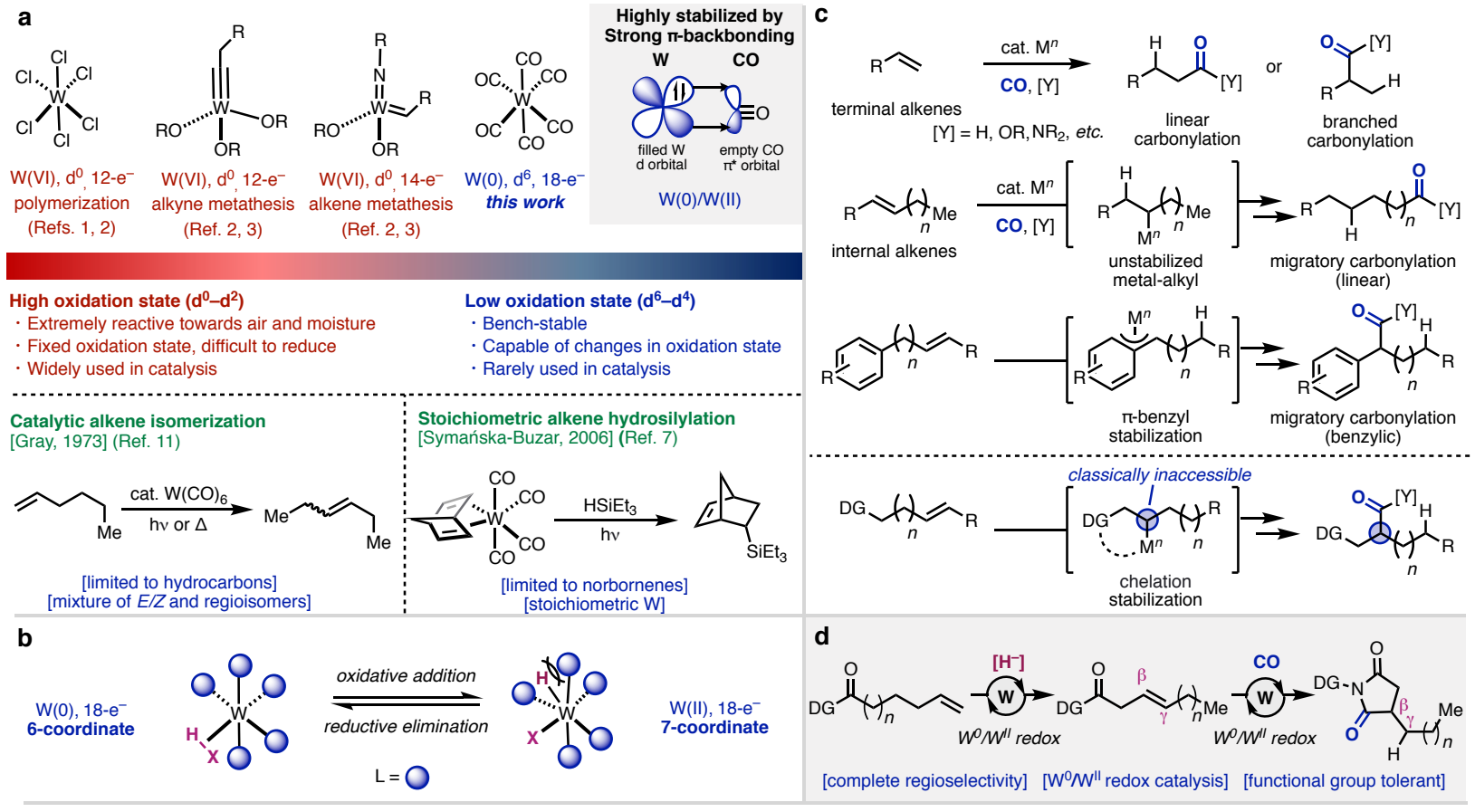

Fig. 1. (a) Background of tungsten catalyzed reactions. (b) Coordination chemistry of W(0)/W(II) redox cycle. (c) Known regioselective methods for hydrocarbonylation reactions. (d) This work.

We were drawn to the $\mathrm{W}(0) / \mathrm{W}(\mathrm{II})$ redox cycle because of the ability of the metal to naturally fluctuate between 6-coordinate octahedral and noncanonical 7-coordinate geometries (Fig. 1b). In theoretical (13-14) and experimental (15-17) studies it has been shown that the facile nature of migratory insertion and reductive elimination at 7-coordinate $\mathrm{W}$ (II) or Mo(II) is due to the spatial proximity of the ligands and attractive non-bonding interactions. Additionally, 6coordinate alkyltungsten(II) species are known to undergo rapid $\beta$ - $\mathrm{H}$ elimination to form 18 electron 7-coordinate W(II)-H species (18-19).

With these findings in mind, we hypothesized that the interplay between 6- and 7coordinate species could be exploited to address a synthetically important problem, namely tandem isomerization and hydrocarbonylation of alkenes at a classically disfavored position. Alkene isomerization/hydroformylation is one of the highest volume homogenous catalytic reactions in the chemical industry (20), making it a useful reaction for benchmarking reactivity and selectivity patterns. Typically, in this family of reactions, the regioselectivity is dictated by thermodynamics, with functionalization occurring at the most stable alkylmetal intermediate (21-22). In particular, migration of the metal to the terminal position or to a carbon next to a $\pi$-system can reliably give 20 linear or $\alpha$-functionalized products, respectively, in high regioselectivity. Nevertheless, for a given molecule of interest, alternative positions cannot generally be functionalized with current methodology (Fig. 1c). More broadly speaking, controlled alkene isomerization to classically inaccessible internal positions has been limited to a few examples where the isomerization is coupled to an intramolecular cyclization or rearrangement, including 5-endo cyclizations by Kochi (23-26) and [3,3]-sigmatropic rearrangements by Marek (27). Capturing these intermediates via intermolecular functionalization, namely coupling with $\mathrm{CO}$, would offer new possibilities in regiocontrolled alkene functionalization. 
We reasoned that the isomerization and tandem carbonylation process could be guided to a traditionally unfavorable position via metallacycle ring contraction (28) or "metallacycle zipping," with site-selectivity governed by the nature of the directing group employed (29). We envisioned the geometric flexibility of 7-coordinate W(II) would facilitate otherwise challenging endocyclic $\beta-\mathrm{H}$ eliminations required for the directed alkene isomerization. Stabilizing an alkylmetal species of a defined ring size through coordination of the directing group would then allow carbonylative functionalization (30) to take place (Fig. 1c) with high regioselectivity (31). The development of a W(0)-catalyzed directed migratory carbonylation would complement other substrate-directed tandem alkene isomerization/functionalization reactions, such as oxidative arylation and hydroalkylation catalyzed by nickel (32-33).

To initiate the study, we tested a library of known directing groups (DGs) for their ability to facilitate isomerization and carbonylation of an alkenyl carboxylic acid derivative with stoichiometric $\mathrm{W}(\mathrm{CO})_{6}$ at $150{ }^{\circ} \mathrm{C}$ (Fig. 2a). Chatani's NHPic (Pic = 2-picolinyl) directing group (DG4), which was originally developed for ruthenium-catalyzed $\mathrm{C}\left(s p^{2}\right)-\mathrm{H}$ carbonylation (34), gave quantitative yield of the desired product as a single regioisomer. All other directing groups examined failed to give any carbonylated products. Given that $\mathrm{W}(\mathrm{CO})_{6}$ readily dissociates $\mathrm{CO}$ upon UV irradiation $(7-8,11,18-19,35-36)$ we questioned whether the reaction would take place at lower temperature $\left(25^{\circ} \mathrm{C}\right)$ under photocatalytic conditions. Indeed, the desired product was formed in good yield when using stoichiometric $\mathrm{W}(\mathrm{CO})_{6}$ under an argon atmosphere with irradiation from a 450 Watt UV lamp (Fig. 2, entry 1). With $20 \mathrm{~mol} \% \mathrm{~W}(\mathrm{CO})_{6}$, there was evidence of turnover (entry 2), but all reactivity shut down with catalytic tungsten under an atmosphere of $\mathrm{CO}$ (Fig. 2, entries 3-6). One explanation is that the relatively high concentration of CO in solution at room temperature leads to poisoning of the catalyst. Under thermal conditions $\left(150{ }^{\circ} \mathrm{C}\right), 93 \%$ of product 2 a was obtained using $20 \mathrm{~mol} \% \mathrm{~W}(\mathrm{CO})_{6}$ under 1 atm $\mathrm{CO}$ (entry 8). Other homoleptic metal carbonyls were less effective (Mo, entry 10) or ineffective all together ( $\mathrm{Cr}$ and $\mathrm{Fe}$, entries 11-12). Although molybdenum is known to exhibit similar reactivity and coordination chemistry to tungsten $(9-11,17)$ we attribute the higher yield of tungsten in this case to its greater kinetic stability (35). Additionally, a representative panel of $\mathrm{Rh}, \mathrm{Ru}, \mathrm{Co}$, and $\mathrm{Ir}$ precatalysts failed to promote the reaction or did so with low efficiency (See SI for additional screening data).

a
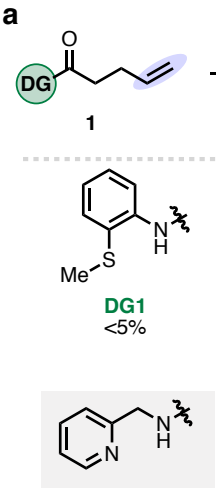

DG4 (PicNH) $97 \%$
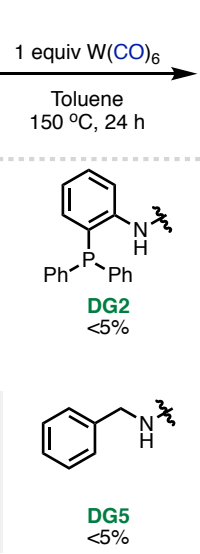
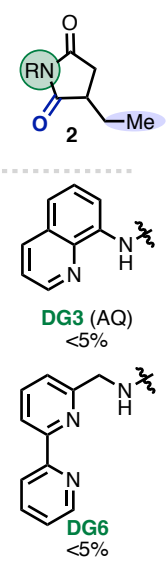

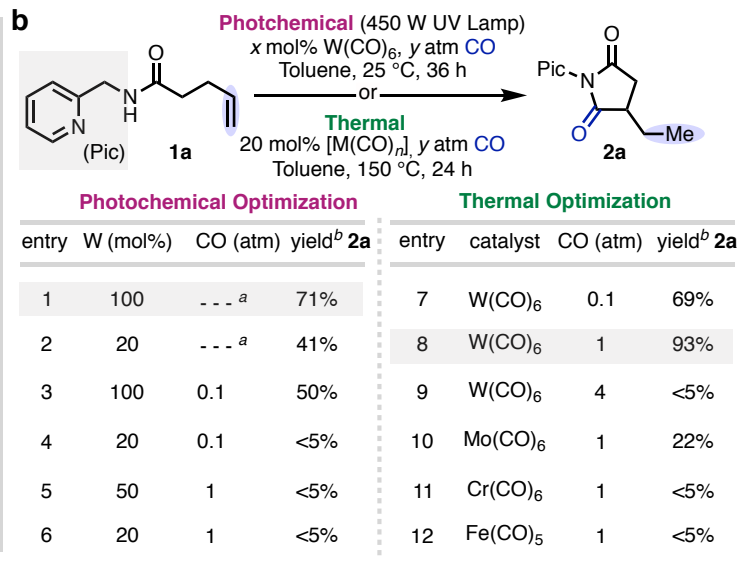

Fig. 2. (a) Directing group optimization (see Supporting Information for details). (b) Reaction condition optimization. ${ }^{a} 1 \mathrm{~atm}$ of argon with no added CO. ${ }^{b}$ Yield determined by ${ }^{1} \mathrm{H}$ NMR. 
Having optimized the reaction conditions, we next investigated the reaction scope (Fig. 3a). Notably, $\gamma, \delta$-unsaturated amides bearing various substitution patterns are readily accessible via numerous robust organic reactions (37) including the Diels-Alder cycloaddition, Ireland- or Johnson-Claissen rearrangement, and Wittig olefination. $\gamma, \delta$-Unsaturated amides containing a terminal alkene and $\alpha$-monosubstitution afforded the products with high yields and moderate d.r. (2b-2c), while an $\alpha, \alpha$-disubstituted alkenyl amide (2d) gave lower yield. A derivative of $(S)$ allylglycine underwent the transformation (2e) and retained high ee (98\%) at the $\alpha$-stereocenter in the case of the major diastereomer. The minor diastereomer showed erosion to $52 \%$ ee, suggesting epimerization of the kinetically favored cis product to the thermodynamically preferred trans product. The reaction was effective with 1,1- and 1,2-disubstituted alkenes $(\mathbf{2} \mathbf{f}-\mathbf{2 h})$. The presence of a primary alkyl chloride $(\mathbf{2} \mathbf{i})$ or a second, more distal alkene $(\mathbf{2} \mathbf{j})$ was well tolerated.

Next, we investigated substrates that require thermodynamically uphill alkene isomerization, which we reasoned could be compensated for in the highly exergonic carbonylation step (vide infra). Indeed, trisubstituted alkenes were isomerized to disubstituted alkenes, which then afforded the desired carbonylated products $(\mathbf{2} \mathbf{k}-\mathbf{2 n}, \mathbf{2 w})$ in moderate to high yields. Endocyclic alkenes represent another class of challenging substrates for selective alkene isomerization/functionalization reactions. Pleasingly, Diels-Alder-derived substrates bearing di$(\mathbf{2 u}-\mathbf{2 v})$ or trisubstituted (2w) alkenes gave moderate yield with exclusively cis stereochemistry at the ring juncture. A cyclopentenyl substrate (2t) also reacted in high yield. Remarkably, exocyclic methylidene cyclobutane was efficiently isomerized and carbonylated via the intermediacy of a highly strained endocyclic cyclobutene, providing 20 in modest yield and $>20: 1 \mathrm{dr}$. Various conjugated alkenes were next evaluated. An $\alpha, \beta$-unsaturated ester (2q) provided the product in high yield and with high chemoselectivity. Styrenes with versatile (and potentially sensitive) functional handles, including aryl iodides, bromides, and nitriles (2q-2s) proceeded in high yields.

Lastly, we probed the distance dependence of this isomerization/carbonylation process (Fig. 3b). A substrate requiring no initial isomerization $(\mathbf{2 x})$ or isomerization over one position (2a) gave the corresponding products in greater than $90 \%$ yield. Moving the alkene farther away led to a gradual decrease in yield from $71 \%(\mathbf{2 g})$ to $6 \%(\mathbf{2 h})$. In cases with incomplete conversion to carbonylated product, we observed formation of a mixture of internal alkene isomers accompanied by gradual catalyst death, as evidenced by precipitation of tungsten black. We attribute the decrease in product yield over distance to increased activation entropy in the directed isomerization pathway and the sluggish nature of the alternative non-directed pathway (11). Synthesis of 2a on $5 \mathrm{mmol}$ scale provided the product in $89 \%$ yield $(951 \mathrm{mg})$, which could then be hydrolyzed to provide the corresponding 1,4-dicarboxylic acid in 92\% yield (See SI).

We were then curious if chiral branched variants of DG4 could control relative stereochemistry in the $\mathrm{CO}$ insertion step to provide diastereoselective carbonylated products (Fig. 3c). Introduction of a methyl group at the benzylic carbon (DG7) led to 5:1 d.r. and 82\% yield, while progressively more bulky alkyl groups (DG8-DG10) did not lead to further improvement in diastereoselectivity and eventually led to a drastic drop in yield. Use of commercially available, 40 enantiopure $(S)$-DG7 under catalytic conditions provided the product 2aa in 75\% yield and 5:1 d.r. ( $>99 \%$ ee for both diastereomers). Overall, this result establishes a platform for further development of chiral directing auxiliaries for stereocontrolled isomerization/hydrofunctionalization reactions. 
a
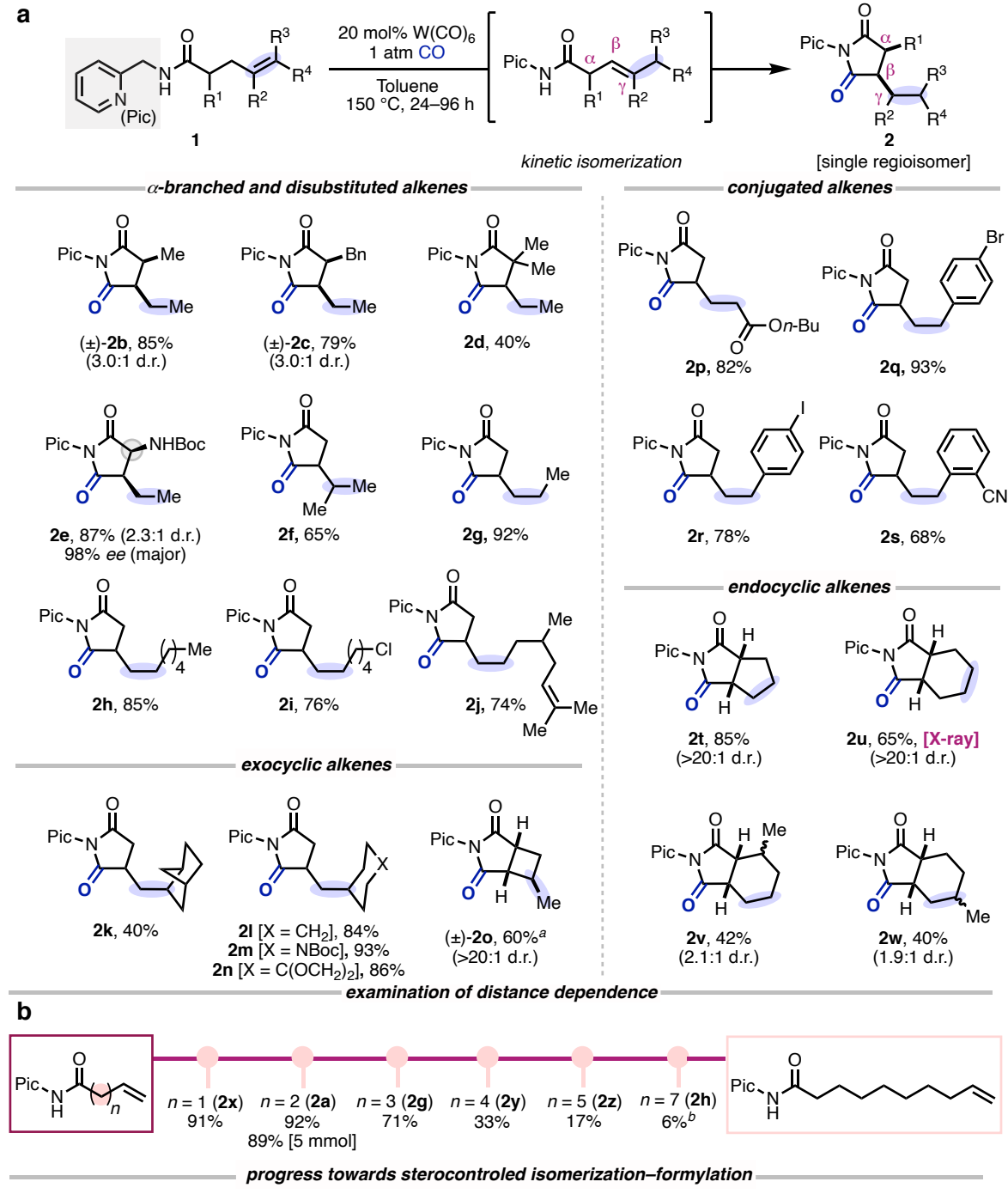

c
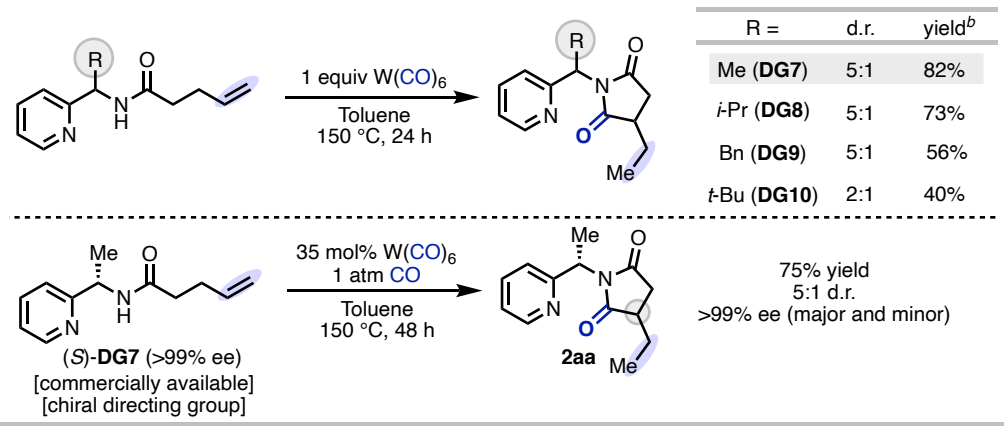

Fig. 3. (a) Substrate scope. (b) Isomerization over multiple positions. (c) Progress towards stereocontroled isomerization-carbonylation. ${ }^{a} 1$ equiv. $\mathrm{W}(\mathrm{CO})_{6}$ under argon. ${ }^{b}$ Yield determined by ${ }^{1} \mathrm{H}$ NMR. All reactions run on 0.1-0.2 mmol scale unless otherwise stated; See SI for full details.

The unique features of this catalytic isomerization/carbonylation process motivated us to interrogate the reaction mechanism and the underlying coordination chemistry of the intermediates involved. To examine the potential involvement of $\mathrm{W}(0) / \mathrm{W}(\mathrm{II})$ redox processes, we first attempted direct synthesis of organometallic intermediates from an alkenyl amide starting material (1xa) by treatment with $\mathrm{W}(\mathrm{MeCN})_{3}(\mathrm{CO})_{3}$ (1 equiv) in $\mathrm{CDCl}_{3}$ at temperatures ranging from $3-60{ }^{\circ} \mathrm{C}$, but 
these experiments only showed formation of the organic product $\mathbf{2} \mathbf{x}$ and unreacted starting material $1 x a$ by ${ }^{1} \mathrm{H}$ NMR (see SI). Thus, we next turned our attention to independent synthesis of isolable model complexes $\mathbf{W}-\mathbf{1}-\mathbf{W}-\mathbf{3}$ in an effort to establish the feasibility of these W(II) intermediates to undergo $\mathrm{CO}$ migratory insertion and reductive elimination (Fig. 4a). Oxidative addition of alkyl iodide SM-1 to $\mathrm{W}(\mathrm{MeCN})_{3}(\mathrm{CO})_{3}$ furnished model complex $\mathbf{W}-\mathbf{1}$ which is stable in solution for several days. After full conversion of SM-1, AgOTf and $\mathrm{KO} t$-Bu/18-crown-6 were added to W-1 at room temperature, triggering migratory insertion and reductive elimination to afford the desired product (P-1) in high yield. Due to our inability to isolate this alkyltungsten(II) intermediate in crystalline form, further studies focused on more thermally stable aryltungsten(II) species (37) to facilitate analysis by X-ray crystallography.
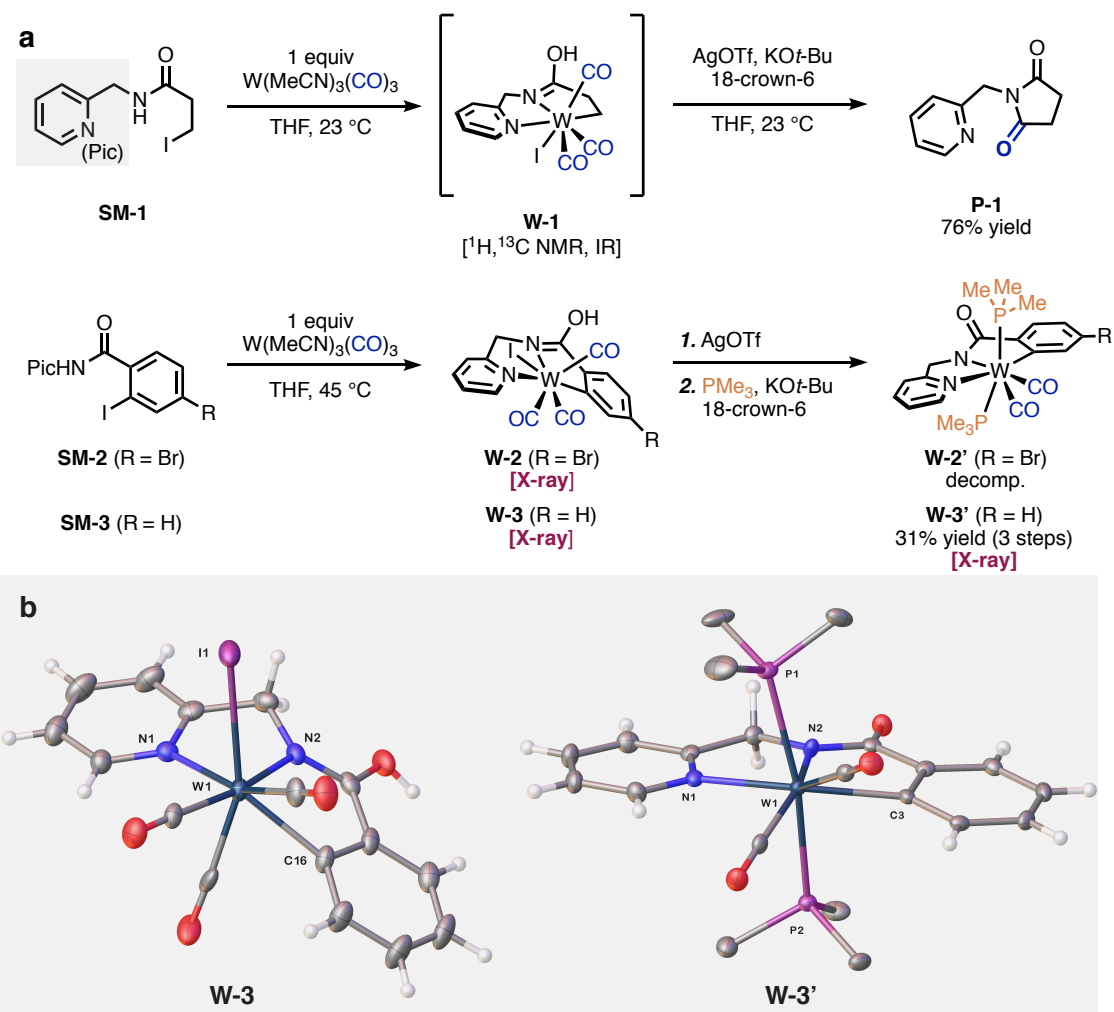

Fig. 4. (a) Synthesis and reactivity studies of organotungsten model complexes. (b) X-ray structures of complexes W-3 (CCDC 2020047) and W-3' (CCDC 204639) with solvent omitted for clarity.

Using an analogous synthetic sequence, the complexes $\mathbf{W}-\mathbf{2}$ and $\mathbf{W}-\mathbf{3}$ were prepared by oxidative addition of the corresponding aryl iodides SM-2 and SM-3 to W(0) (39). W-3 was then treated with AgOTf to abstract the iodide, and further treatment with $\mathrm{KO} t$-Bu/18-crown-6 deprotonated the amide. $\mathrm{PMe}_{3}$ (2.5 equiv) was added to prevent migratory insertion and reductive elimination, as was observed with $\mathbf{W}-\mathbf{1}$. Without addition of $\mathrm{PMe}_{3}$, we were unable to isolate any organotungsten species at this stage, and other ligands $\left(\mathrm{PPh}_{3}, \mathrm{PhCN}\right.$, tert-butyl isocyanide, or pyridine) failed to form isolable complexes. While $\mathbf{W}-2$ ' was found to be unisolable, $\mathbf{W}-\mathbf{3}^{\prime}$ ' is airand moisture-stable and can be purified by column chromatography on neutral alumina. The Xray structure of $\mathbf{W}-3$ ' revealed the directing group to be bound in the amidate-form, demonstrating the feasibility of this coordination mode. 
Having established plausible oxidation states and coordination structures for many of the key proposed intermediates, we next investigated the mechanism of alkene isomerization. Earlier observations that the amino acid substrate (2e) maintained its stereochemistry at the $\alpha$-position and that the $\alpha, \alpha$-disubstituted substrate (2d) gave product indicated that the carbonylation reaction likely proceeds through the $\beta, \gamma$-unsaturated isomer (as drawn in Fig. 3a). To further exclude the alternative hypothesis that the carbonylation proceeds through the conjugated $\alpha, \beta$-unsaturated amide, we subjected crotonyl amide $\mathbf{1 x b}$ to the standard reaction conditions, and $<10 \%$ product $\mathbf{2 3}$ was observed by ${ }^{1} \mathrm{H}$ NMR of the crude reaction mixture, with the remainder being unreacted starting material (Fig. 5).

Having established the positional aspects of isomerization, we then considered possible mechanisms, namely 1,2- and 1,3-hydride shift pathways (40-41), through a series of deuterium labeling experiments and DFT calculations. To test the feasibility of tungsten to undergo $\mathrm{N}-\mathrm{H}$ oxidative addition and $\mathrm{W}(\mathrm{II})-\mathrm{H}$ insertion into alkenes, we conducted a series of experiments in which the amide $\mathrm{N}-\mathrm{H}$ was exchanged to $\mathrm{N}-\mathrm{D}$ in situ via treatment with excess $\mathrm{CH}_{3} \mathrm{OD}$ under the reaction conditions (see SI). Evaluation of different deuterated substrates with terminal alkenes (Fig. 5) of varying distances from the amide gave evidence for this mechanism with 52-96\% deuterium incorporation into the terminal position.

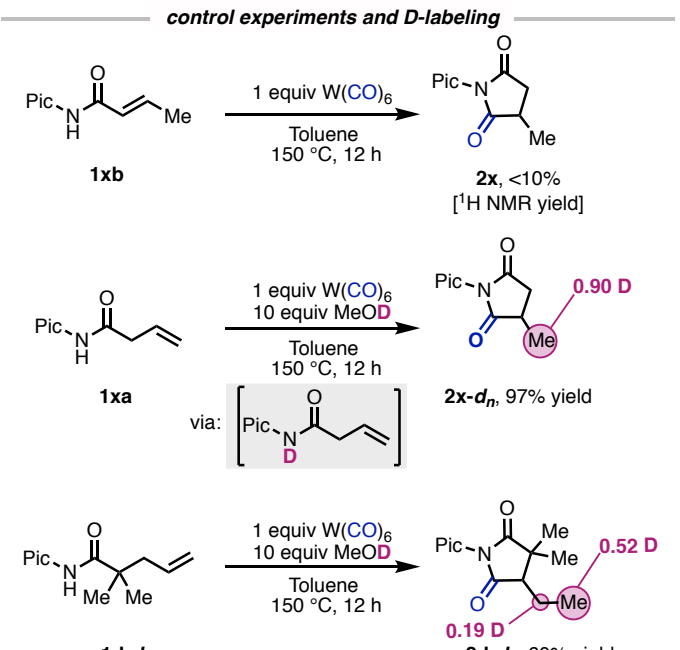

$1 \mathrm{~d}-\boldsymbol{d}_{n}$ $2 \mathrm{~d}-\boldsymbol{d}_{n}, 60 \%$ yield

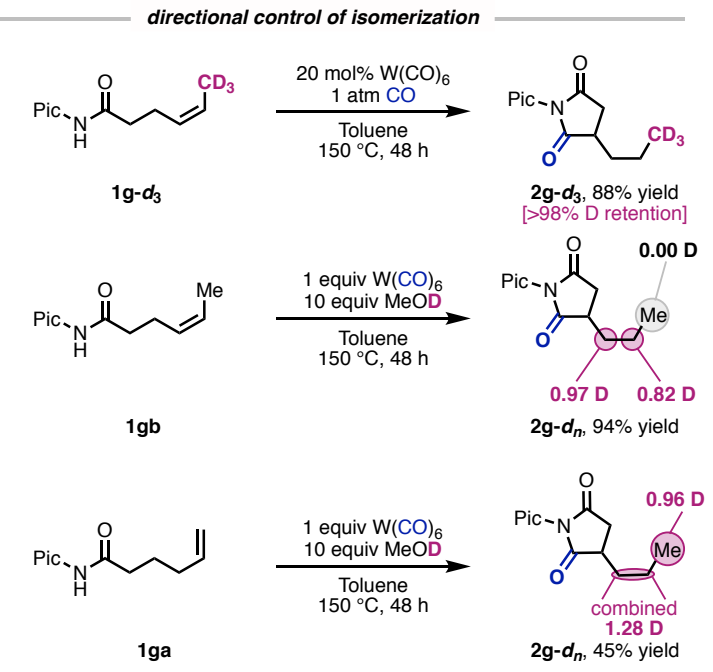

Fig. 5. Mechanistic experiments and deuterium labeling studies.

Density functional theory (DFT) calculations were performed to identify the catalytically active $\mathrm{W}$ species and its reactivity in promoting $\mathrm{N}-\mathrm{H}$ oxidative addition and alkene isomerization (Fig. 4b) (42). The six-coordinate W(0) complex I-1 was found to be the most likely species in N$\mathrm{H}$ oxidative addition (see SI for details), leading to a seven-coordinate W(II)-H (I-2). Subsequent metal-hydride insertion (TS2), endocyclic $\beta$-hydride elimination (TS3), and metal-hydride reinsertion (TS4) are all facile, leading to a more stable five-membered metallacycle (I-5). An agostic interaction with the endocyclic $\beta-\mathrm{C}-\mathrm{H}$ bond in $\mathbf{I - 3}$ promotes the otherwise challenging endocyclic $\beta$-hydride elimination (TS3). The seven-coordinate geometry of TS3 and the flexibility of the DG are both critical to alleviate strain in the transition state with a bidentate DG. After CO insertion (TS5) and binding with another $\mathrm{CO}$ molecule, the $\mathrm{C}-\mathrm{N}$ reductive elimination from the seven-coordinate W(II) (I-7) requires a very low barrier (TS6) and is highly exergonic. These DFT results in combination with the mechanistic experiments above show that this 1,2-hydride shift 
pathway is the prevailing mode of isomerization, while 1,3-hydride shift is kinetically less favorable (see SI for details).

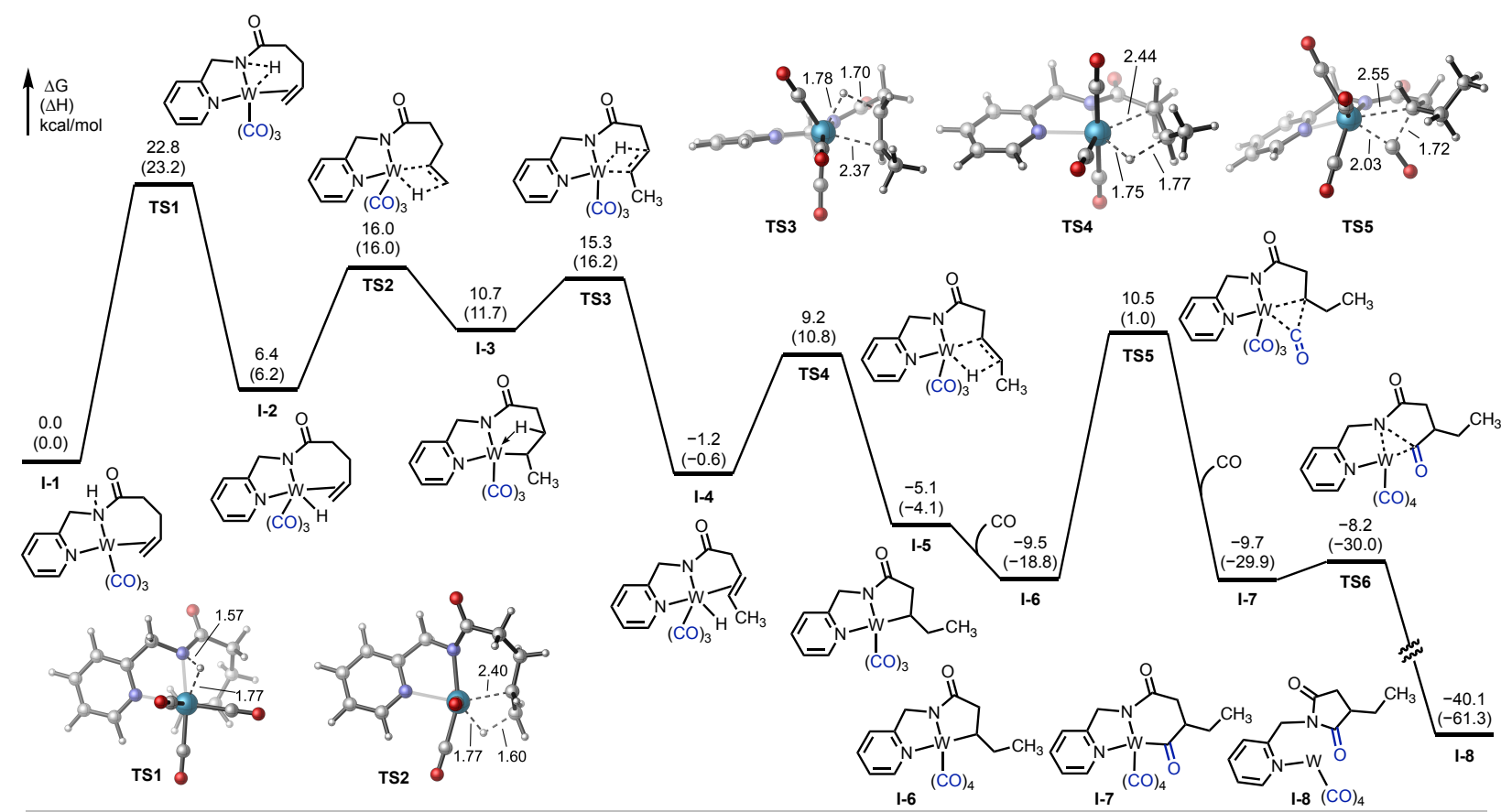

Fig. 6. DFT energy profile of the reaction from 1a to $\mathbf{2 a}$.

During the course of the isomerization process, buildup of intermediate internal alkenes is detected for reactions halted prior to completion (see SI), suggesting substrate dissociation and reassociation are likely occurring, which is further supported by incorporation of multiple deuterium equivalents at different chain positions. DFT also predicts that ligand exchange of the coordinated alkene with free $\mathrm{CO}$ is energetically feasible (see SI for details), which can explain why intermediate internal alkenes can be observed when stopping the reaction early. In chain-walking reactions, premature dissociation of the alkene from the substrate is typically deleterious and leads to side products or intermediates that cannot feed back into the catalytic cycle (43); however, in this reaction it appears to have little effect on the overall yield and regioselectivity.

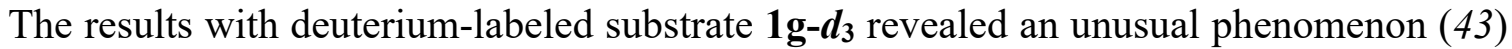
that isomerization proceeds in a uni-directional fashion exclusively towards the directing group. Running the complementary experiment with internal alkene 1gb further corroborated the unidirectional nature of isomerization, as no deuterium was detected in the terminal position (Fig. 5). The uni-directional alkene isomerization is consistent with the greater stability of the $\pi$-complex with internal alkene (I-4) than the terminal alkene complex (I-2).

When compared to relevant industrial carbonylation processes, this method still has drawbacks that will be addressed in future work, namely the requirement for a stoichiometric auxiliary and relatively high catalyst loadings. Along these lines, directed alkene isomerization/functionalization employing native functional groups holds great promise owing the ability of $\mathrm{W}(0)$ to form table adducts with weakly Lewis basic groups (44). Nevertheless, these findings provide an experimental and computational framework for exploring W(0)/W(II) catalytic processes and illustrate how this catalytic cycle can enable exceptional regioselectivity with a diverse range of alkenes in a challenging tandem isomerization/functionalization transformation. 


\section{References and Notes:}

1. T. M. Trnka, R. H. Grubbs, The development of $\mathrm{L}_{2} \mathrm{X}_{2} \mathrm{Ru}=\mathrm{CHR}$ olefin metathesis catalysts: an organometallic success story. Acc. Chem. Res. 34, 18-29 (2001).

2. R. R. Schrock, Multiple metal-carbon bonds for catalytic metathesis reactions (Nobel lecture). Angew. Chem. Int. Ed. 45, 3748-3759 (2006).

3. R. R. Schrock, A. H. Hoveyda, Molybdenum and tungsten imido alkylidene complexes as efficient olefin-metathesis catalysts. Angew. Chem. Int. Ed. 42, 4592-4633 (2003).

4. T. Masuda, T. Higashimura, Synthesis of high polymers from substituted acetylenes: exploitation of molybdenum- and tungsten-based catalysts. Acc. Chem. Res. 17, 51-56

$10 \quad$ (1984).

5. B. K. Liebov, W. D. Harman, Group 6 dihapto-coordinate dearomatization agents for organic synthesis. Chem. Rev. 117, 13721-13755 (2017).

6. J. A. Smith, K. B. Wilson, R. E. Sonstrom, P. J. Kelleher, K. D. Welch, E. K. Pert, K. S. Westendorff, D. A. Dickie, X. Wang, B. H. Pate, W. D. Harman, Preparation of cyclohexene isotopologues and stereoisotopomers from benzene. Nature 581, 288-293 (2020).

7. B. Adrjan, T. Szymańska-Buzar, Photochemical reactions of $\left[\mathrm{W}(\mathrm{CO})_{4}\left(\eta^{4}\right.\right.$-nbd) $]$ with hydrosilanes: generation of new hydrido complexes of tungsten and their reactivity. $J$. Organometallic Chem. 693, 2163-2170 (2008).

8. J. Handzlik, A. Kochel, T. Szymańska-Buzar, H-Ge bond activation by tungsten carbonyls: An experimental and theoretical study. Polyhedron 31, 622-631 (2012).

9. J. Handzlik, T. Szymańska-Buzar, The formation of a $\sigma$-bond complex vs. an oxidation addition product in reaction of $\left[\mathrm{M}(\mathrm{CO})_{4}\left(\eta^{4}-\mathrm{nbd}\right)\right](\mathrm{M}=\mathrm{W}, \mathrm{Mo})$ and $\mathrm{H}-\mathrm{EEt}_{3}(\mathrm{E}=\mathrm{Si}, \mathrm{Ge}, \mathrm{Sn})$ : DFT optimized structures and predicted chemical shifts of hydride ligands. $J$. Organometallic Chem. 769, 136-143 (2014).

10. S. Chakraborty, H. Berke, Homogeneous hydrogenation of nitriles catalyzed by molybdenum and tungsten amides. ACS Cat. 4, 2191-2194 (2014).

11. M. Wrighton, G. S. Hammond, H. B. Gray, Group VI metal carbonyl photoassisted isomerization of olefins. J. Organometallic Chem. 70, 283-301 (1974).

12. C. Moberg, "Molybdenum-catalyzed and tungsten-catalyzed enantioselective allylic substitutions" in Transition Metal Catalyzed Enantioselective Allylic Substitution in Organic Synthesis. U. Kazmaier, Ed. (Springer, Berlin, Heidelberg, 2011) vol. 38 of Topics in Organometallic Chemistry, pp. 209-234.

13. R. Hoffmann, B. F. Beier, E. L. Muetterties, A. R. Rossi, Seven-coordination. A molecular orbital exploration of structure, stereochemistry, and reaction dynamics. Inorg. Chem. 16, 511-522 (1977).

14. R. Hoffmann, C. N. Wilker, S. J. Lippard, J. L. Templeton, D. C. Bower, Theoretical prescription for reductive coupling of carbonyl or isocyanide ligands. J. Am. Chem. Soc. 105, 146-147 (1983). 
15. C. T. Lam, P. W. R. Corfield, S. J. Lippard, Reductive coupling of adjacent ligands in a seven-coordinate molybdenum(II) isocyanide complex. J. Am. Chem. Soc. 99, 617-618 (1977).

16. C. M. Giandomenico, C. T. Lam, S. J. Lippard, Higher coordinate cyanide and isocyanide complexes. Reductive coupling of coordinated alkyl isocyanides in sevencoordinate molybdenum(II) and tungsten(II) complexes. Removal of the coupled ligand as an oxamide. J. Am. Chem Soc. 104, 1263-1271 (1982).

17. C. T. Lam, M. Novotny, D. L. Lewis, S. J. Lippard, Higher coordinate cyanide and isocyanide complexes. Synthesis and characterization of seven-coordinate molybdenum(II) and tungsten(II) isocyanide complexes. Inorg. Chem., 17, 2127-2133 (1978).

18. R. J. Kazlauskas, M. S. Wrighton, Photogeneration of intermediates involved in catalytic cycles. $\beta$-Hydride elimination from the 16-electron alkyl species generated by irradiation of tricarbonyl $\left(\eta^{5}\right.$-cyclopentadienyl)(n-pentyl)tungsten(II). J. Am. Chem. Soc. 102, 1727-1730 (1980).

19. R. J. Kazlauskas, M. S. Wrighton, Photochemistry of metal carbonyl alkyls. Study of thermal $\beta$-hydrogen transfer in photogenerated, 16-valence-electron alkyldicarbonylcyclopentadienylmolybdenum and -tungsten complexes. J. Am. Chem. Soc. 104, 6005-6015 (1982).

20. G. T. Whiteker, C. J. Cobley, “Applications of rhodium-catalyzed hydroformylation in the pharmaceutical, agrochemical, and fragrance industries" In Organometallics as Catalysts in the Fine Chemical Industry, M. Beller, H.-U. Blaser, Eds. (Springer, Berlin, Heidelberg, 2012) pp. 35-46.

21. A. Vasseur, J. Bruffaerts, I. Marek, Remote functionalization through alkene isomerization. Nat. Chem. 8, 209-219 (2016).

22. H. Sommer, F. Juliá-Hernández, R. Martin, I. Marek, Walking metals for remote functionalization. ACS Cent. Sci. 4, 153-165 (2018).

23. T. Kochi, T. Hamasaki, Y. Aoyama, J. Kawasaki, F. Kakiuchi, Chain-walking strategy for organic synthesis: catalytic cycloisomerization of 1,n-dienes. J. Am. Chem. Soc 134, 16544-16547 (2012).

24. T. Hamasaki, Y. Aoyama, J. Kawasaki, F. Kakiuchi, T. Kochi, Chain walking as a strategy for carbon-carbon bond formation at unreactive sites in organic synthesis: catalytic cycloisomerization of various 1,n-dienes. J. Am. Chem. Soc 137, 16163-16171 (2015).

25. Y. Yamasaki, T. Kumagai, S. Kanno, F. Kakiuchi, T. Kochi, Selective long-distance isomerization of terminal alkenes via nondissociative chain walking. J. Org. Chem. 83, 9322-9333 (2018).

26. T. Kochi, K. Ichinose, M. Shigekane, T. Hamasaki, F. Kakiuchi, Metal-catalyzed sequential formation of distant bonds in organic molecules: palladium-catalyzed hydrosilylation/cyclization of $1, n$-dienes by chain walking. Angew. Chem. Int. Ed. 58, 52615265 (2019).

27. H. Sommer, T. Weissbrod, I. Marek, A tandem iridium-catalyzed "chain-walking"/Cope rearrangement sequence. ACS Catal. 9, 2400-2406 (2019). 
28. C.-H. Jun, H. Lee, S.-G. Lim, The $\mathrm{C}-\mathrm{C}$ bond activation and skeletal rearrangement of cycloalkanone imine by Rh(I) catalysts. J. Am. Chem. Soc 123, 751-752 (2001).

29. M. L. O’Duill, R. Matsuura, J. L. Turnbull, J. A. Gurak, Jr. D.-W. Gao, G. Lu, P. Liu, K. M. Engle, Tridentate directing groups stabilize 6-membered palladacycles in catalytic alkene hydrofunctionalization. J. Am. Chem. Soc. 139, 15576-15579 (2017).

30. J. E. McCluster, J. Logan, L. McElwee-White, Oxidative carbonylation of primary amines to ureas using tungsten carbonyl catalysts. Organometallics 17, 4037-4041 (1998).

31. B. Breit, "Directed Rhodium-Catalyzed Hydroformylation of Alkenes" in Directed Metallation. N. Chatani. Ed. (Springer, Berlin, Heidelberg, 2007) pp. 145-168.

32. X. Chen, W. Rao, T. Yang, M. J. Koh, Alkyl halides as both hydride and alkyl sources in catalytic regioselective reductive olefin hydroalkylation. Nat. Commun. 11, 5857 (2020).

33. H. Lv, H. Kang, B. Zhou, X. Xue, K. M. Engle, D. Zhao, Nickel-catalyzed intermolecular oxidative Heck arylation driven by transfer hydrogenation. Nat. Commun. 10, 5025 (2019).

34. S. Inoue, H. Shiota, Y. Fukumoto, N. Chatani, Ruthenium-catalyzed carbonylation at ortho $\mathrm{C}-\mathrm{H}$ bonds in aromatic amides leading to phthalimides: $\mathrm{C}-\mathrm{H}$ bond activation utilizing a bidentate system. J. Am. Chem. Soc. 131, 6898-6899 (2009).

35. M. Wrighton, Photochemistry of metal carbonyls. Chem. Rev. 74, 401-430 (1974).

36. S. A. Trushin, W. Fuß, W.E. Schmid, Conical intersections, pseudorotation and coherent oscillations in ultrafast photodissociation of group-6 metal hexacarbonyls. Chem. Phys. 259, 313-330 (2000).

37. E. J. Corey, X. M. Cheng, The Logic of Chemical Synthesis. (Wiley, Hoboken, NJ, 1989).

38. D. J. Darensbourg, R. K. Hanckel, C. G. Bauch, M. Pala, D. Simmons, J. N. White, A kinetic investigation of carbon dioxide insertion processes involving anionic tungsten-alkyl and -aryl derivatives: effects of carbon dioxide pressure, counterions, and ancillary ligands. Comparisons with migratory carbon monoxide insertion processes. J. Am. Chem. Soc. 107, 7463-7473 (1985).

39. B. P. Buffin, M. J. Poss, A. M. Arif, T. G. Richmond, Synthesis and reactivity of a tungsten $(0)$ anion stabilized by chelating tertiary amines. The oxidative addition and reductive elimination of a carbon-tin bond at tungsten. Inorg. Chem. 32, 3805-3806 (1993).

40. S. Biswas, Mechanistic understanding of transition-metal-catalyzed olefin isomerization: metal-hydride insertion-elimination vs. $\pi$-allyl pathways. Comments Inorg. Chem. 35, 300330 (2015).

41. T. Szymańska-Buzar, M. Jaroszewski, M. Wilgocki, J.J. Ziółkowski, Reactivity of bis(alkene) tetracarbonyl complexes of tungsten: evidence for alkene to $\pi$-allyl hydride rearrangement. J. Mol. Cat. A: Chem. 112, 203-210 (1996).

42. Y. Sheng, D. G. Musaev, K. S. Reddy, F. E. McDonald, K. Morokuma, Computational studies of tungsten-catalyzed endo-selective cycloisomerization of 4-pentyn-1-ol. J. Am. Chem. Soc. 124, 4149-4157 (2002).

43. T. Kochi, S. Kanno, F. Kakiuchi, Nondissociative chain walking as a strategy in catalytic organic synthesis. Tet. Lett. 60, 150938 (2019). 
44. A. Salzer, Zur reaktivität komplexgebundener carbocyclen: II. Darstellung und eigenschaften einiger neuer triolefin-komplexe des molybdäns und wolframs. J. Organomet. Chem. 107, 79-86 (1976).

Acknowledgments: Dr. Jason Chen is acknowledged for assistance in conducting pressurized reactions. Brittany Sanchez, and Emily Sturgell (Scripps Research Automated Synthesis Facility) are acknowledged for HPLC and SFC analysis. Hanh Nguyen, Tucker Huffman, and Cheng Bi are acknowledged for donation of various starting materials. We also thank Prof. Julien Vantourout, Prof. Clark Landis, and Prof. Hans Renata for helpful discussion.

Funding: Financial support for this work was provided by the National Institutes of Health (R35GM125052, R35GM128779, and 1S10OD025208). DFT calculations were performed at the Center for Research Computing at the University of Pittsburgh, the Frontera supercomputer at the Texas Advanced Computing Center, and the Extreme Science and Engineering Discovery Environment (XSEDE) supported by the NSF.

Author contributions: T.C.J. carried out the experiments and data analysis. Z.Y.Q. carried out synthesis of alkene starting materials. M.G. carried out collection and analysis of X-ray data. W.C.B, Y.Z., P.L. carried out computation work. T.C.J., P.L., K.M.E. wrote the manuscript with input from all authors.

Competing interests: The authors declare no competing interests.

Data and materials availability: All data is available in the main text or the supplementary materials.

\section{Supplementary Materials:}

Materials and Methods

Figures S1-S22

Tables S1-S28

Schemes S1-S7

References (42-57) 


\section{SUPPORTING INFORMATION}

\section{Low-Valent Tungsten Redox Catalysis Enables Controlled Isomerization and Carbonylative Functionalization of Alkenes}

Tanner C. Jankins ${ }^{\mathrm{a}}$, William Bell ${ }^{\mathrm{b}}$, Zi-Yang Qina ${ }^{\mathrm{a}}$, Milan Gembickyc, Peng Liü ${ }^{\mathrm{b} *}$ and Keary M. Engle ${ }^{\mathrm{a} *}$

${ }^{a}$ Department of Chemistry, The Scripps Research Institute, 10550 North Torrey Pines Road, La Jolla, California 92037 (USA)

${ }^{b}$ Department of Chemistry, The University of Pittsburgh 219 Parkman Avenue, Pittsburgh, PA 15260 (USA).

${ }^{c}$ Department of Chemistry and Biochemistry, The University of California San Diego 9500 Gilman Drive La Jolla, CA 92093 (USA).

*Corresponding authors: pengliu@pitt.edu; keary@scripps.edu

\section{Table of Contents}

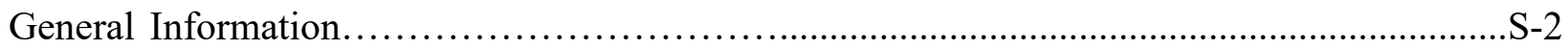

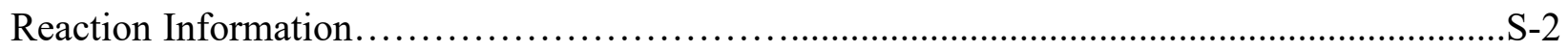

Reaction Optimization.......................

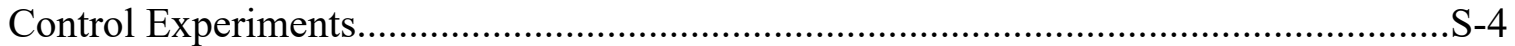

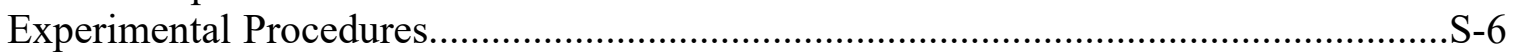

Characterization of New Compounds.......................................................................

Removal of DG from 2a..........................................................................................

Synthesis and Reactivity of Organotungsten Complexes................................. S-38

Monitoring Reaction Progress of the Formation of 2a ................................ 39

Determination of Deuterium Incorporation ..............................................

Determination of Enantiomeric Excess of Compounds 2e and DG7-P.......................S-44

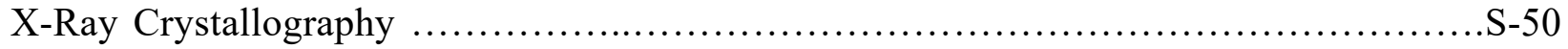

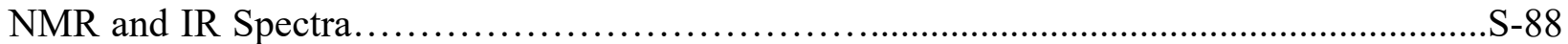

NMR Spectra for Deuterium Incorporation Experiments.................................................. -172

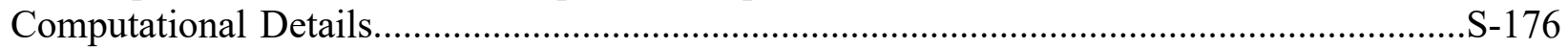

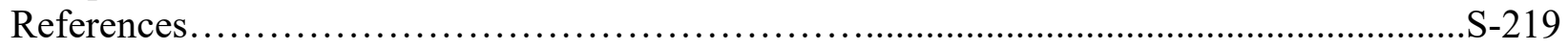




\section{GENERAL INFORMATION}

General Safety Considerations: Carbon monoxide (CO) is a colorless, odorless gas that is extremely toxic. Filling or opening reaction tubes that contain $C O$ needs to be done in a wellventilated fume hood with a $C O$ monitor. $W(C O)_{6}$ and other $M(C O)_{x}$ complexes used in this study thermally decompose to give off free $C O$, so all reactions run with $M(C O)_{x}$ complexes should be handled with the same precautions as those using gaseous $C O$, while taking into account any potential hazards introduced by the metal carbonyl species themselves.

All sealed reactions run at or above the boiling point of the solvent were run with a blast shield placed in front of the stir plate. Upon completion, the reaction vessels were allowed to cool to room temperature before being carefully vented behind the blast shield.

All materials were used as received from commercial sources without further purification. W(CO)6 was purchased from Strem Chemicals 99.9\% purity (Lots 31397600 and 31679900). Carbon monoxide (CO) was purchased from Praxair at $>99.99 \%$ purity. Toluene was purchased from MilliporeSigma in 100-mL Sure/Seal bottles and used as received. The Schlenk tubes used in this study were purchased from Chemglass and Synthware. ${ }^{1} \mathrm{H}$ and ${ }^{13} \mathrm{C}$ NMR spectra were recorded on a Bruker DRX equipped with a $5 \mathrm{~mm}$ DCH cryoprobe (600 MHz and $151 \mathrm{MHz}$, respectively). ${ }^{1} \mathrm{H}$ spectra were reported relative to residual solvent signals unless otherwise stated. ${ }^{13} \mathrm{C}$ NMR spectra were calibrated to residual solvent signals. The following abbreviations (or combinations thereof) were used to explain multiplicities: $\mathrm{s}=$ singlet, $\mathrm{d}=$ doublet, $\mathrm{t}=$ triplet, $\mathrm{q}=$ quartet, hept $=$ heptet and $\mathrm{m}=$ multiplet. High-resolution mass spectra (HRMS) were recorded on an Agilent LC/MSD TOF mass spectrometer by electrospray ionization (Positive mode) time of flight experiments. IR data was collected on a Thermo Fischer Nicolet 380 FTIR. 


\section{REACTION OPTIMIZATION}

The following reactions were run according to "General Procedure A" substituting the catalysts shown in the table for $\mathrm{W}(\mathrm{CO})_{6}$. Photochemical reactions were run in standard Schlenk tubes. For entries 1 and 2, a slightly modified procedure was used where the reaction was sealed inside the glovebox under argon and used directly without a gas exchange step. For reactions run at 0.1 atm, the same procedure was used from "General Procedure A", but a 10\% CO in argon mixture (mixture prepared by Praxair) was used instead. All yields were calculated by ${ }^{1} \mathrm{H}$ NMR using $\mathrm{CH}_{2} \mathrm{Br}_{2}$ as an internal standard.

a<smiles>C=CCCC(=O)O</smiles>

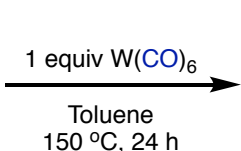

$150{ }^{\circ} \mathrm{C}, 24 \mathrm{~h}$<smiles>[X]c1ccccc1SO[Na]</smiles><smiles>[Y]C([Y])Cc1ccccn1</smiles>
DG4 (PicNH) $97 \%$
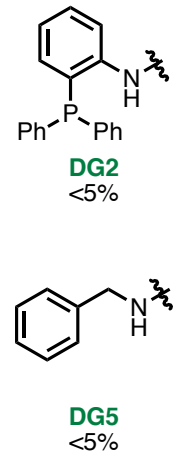
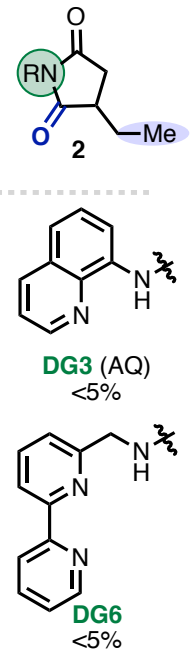
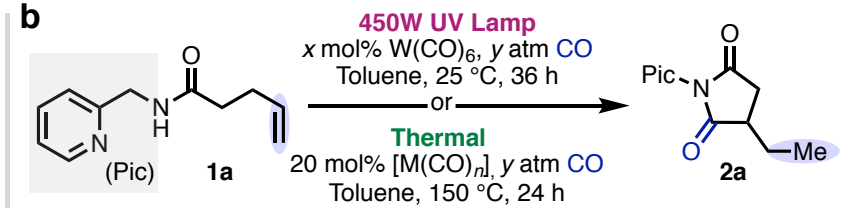

Photochemical Optimization

Thermal Optimization entry $\mathrm{W}(\mathrm{mol} \%) \quad \mathrm{CO}(\mathrm{atm})$ yield $^{b} \mathbf{2 a}$ entry catalyst $\mathrm{CO}(\mathrm{atm})$ yield $^{b} \mathbf{2 a}$ $\begin{array}{llll:lllll}1 & 100 & - & -a & 71 \% & 7 & \mathrm{~W}(\mathrm{CO})_{6} & 0.1 & 69 \%\end{array}$ $\begin{array}{llll:lllll}2 & 20 & - & -a & 41 \% & 8 & \mathrm{~W}(\mathrm{CO})_{6} & 1 & 93 \%\end{array}$ $\begin{array}{llllllll}3 & 100 & 0.1 & 50 \% & 9 & \mathrm{~W}(\mathrm{CO})_{6} & 4 & <5 \%\end{array}$ $\begin{array}{llllllll}4 & 20 & 0.1 & <\% & 10 & \mathrm{Mo}(\mathrm{CO})_{6} & 1 & 22 \%\end{array}$ $\begin{array}{llllllll}5 & 50 & 1 & <\% & 11 & \mathrm{Cr}(\mathrm{CO})_{6} & 1 & <5 \%\end{array}$ $\begin{array}{llllllll}6 & 20 & 1 & <5 \% & 12 & \mathrm{Fe}(\mathrm{CO})_{5} & 1 & <5 \%\end{array}$

Figure S1 (a) Directing group optimization; (b) Reaction condition optimization. ${ }^{a} 1$ atm of Ar with no added CO. ${ }^{b}$ Yield calculated by ${ }^{1} \mathrm{H}$ NMR.

In section "a" the reactions were all analyzed by both LCMS and ${ }^{1} \mathrm{H}$ NMR to detect possible products. No detectable amounts of product were found for any of directing groups screened except DG4. In all of the reactions, the starting material was consumed resulting in a mixture of various internal alkenes in both $E$ and $Z$ configuration. No reduced products were detected by LCMS $(\mathrm{M}+2)$, nor cyclized products that would likely result in a larger change in retention time.

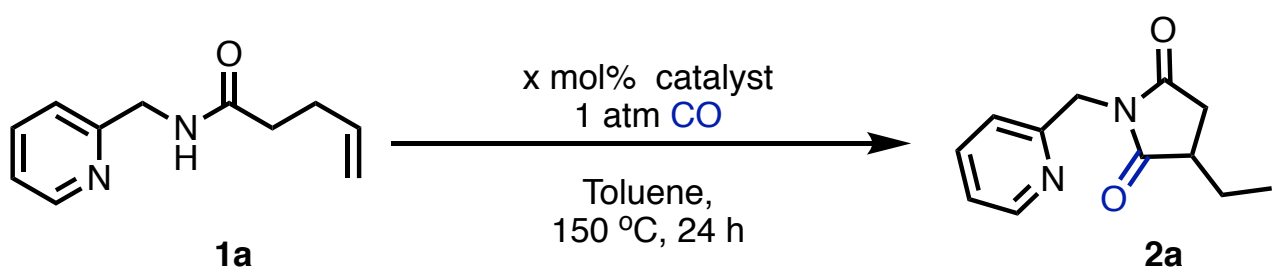

\begin{tabular}{cccc}
\hline Entry & Catalyst & $\mathrm{x} \mathrm{mol} \%$ catalyst & Yield 2a \\
\hline 1 & $\mathrm{Ru}_{3}(\mathrm{CO})_{10}$ & 5 & $<5 \%$ \\
\hline 2 & $\mathrm{RhPPP}_{3} \mathrm{Cl}$ & 5 & nd \\
\hline 3 & {$[\mathrm{Rh}(\mathrm{COD}) \mathrm{Cl}]_{2}$} & 5 & nd \\
\hline 4 & $\mathrm{Rh}(\mathrm{acac})(\mathrm{CO})_{2}$ & 5 & $12 \%$ \\
\hline 5 & {$[\mathrm{Ir}(\mathrm{COD}) \mathrm{OH}]_{2}$} & 5 & nd \\
\hline 6 & $\mathrm{Co}_{2}(\mathrm{CO})_{8}$ & 10 & trace \\
\hline 8 & $\mathrm{~W}(\eta-6$ toluene $)(\mathrm{CO})_{3}$ & 20 & $32 \%$ \\
\hline
\end{tabular}

Table S1 Screening data of different metal pre-catalysts. All yields were determined by ${ }^{1} \mathrm{H}$ NMR using $\mathrm{CH}_{2} \mathrm{Br}_{2}$ as an internal standard. 


\section{CONTROL EXPERIMENTS}

To demonstrate that the observed reactivity did not arise from trace metal contaminants present in the stir bars, solvents, or the commercial tungsten source, we conducted an experiment in which $\mathrm{W}(\mathrm{CO})_{6}$ underwent in situ sublimation from an open inner capillary into an outer vessel (disposable vial) containing the starting material and reaction solvent with no stir bar. As can be seen below, in this case the reaction still proceeded to furnish the product in $23 \%$ yield. We attribute the diminished yield compared to that obtained from General Procedure A to a combination of solidstate decomposition and incomplete transfer into the outer toluene solution. Here, we note that the $\mathrm{W}(\mathrm{CO})_{6}$ used in this study was $>99.9 \%$ pure (trace metals basis) and purified by sublimation by the vendor.

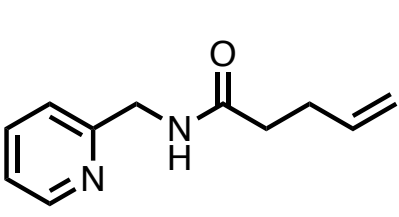

$1 \mathrm{a}$

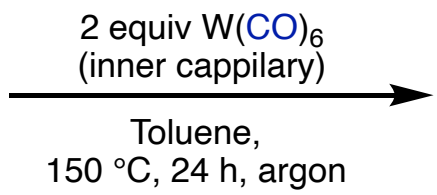

$150^{\circ} \mathrm{C}, 24 \mathrm{~h}$, argon

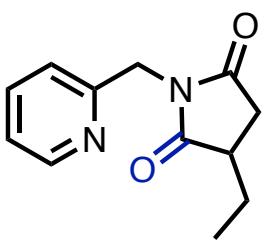

$2 a, 23 \%$

Scheme $\mathbf{S} 1$ in situ sublimation of $\mathrm{W}(\mathrm{CO})_{6}$ to test rule out precious metal contamination

Experimental procedure: Outside of the glovebox, a disposable glass capillary was carefully filled with $\mathrm{W}(\mathrm{CO})_{6}(70 \mathrm{mg}, 0.2 \mathrm{mmol}, 2$ equiv. $)$. The outside of the capillary was wiped with Kimwipes ${ }^{\circledR}$. The 6-mL disposable reaction vial was charged with starting material $\mathbf{2 4 b}$ (19 mg, $0.1 \mathrm{mmol}, 1$ equiv.) and then capped and moved inside an argon-filled glovebox along with the glass capillaries packed with $\mathrm{W}(\mathrm{CO})_{6}$. Once inside the glovebox, toluene $(1 \mathrm{~mL}$, from freshly opened Sure/Seal bottle) was added to the $6 \mathrm{~mL}$ vial to dissolve the starting material. The capillary was then carefully placed inside the 6-mL vial, which was capped and sealed with electrical tape. The reactions were removed from the glovebox and placed in a preheated oil bath at $150{ }^{\circ} \mathrm{C}$ for $24 \mathrm{~h}$ without stirring or agitation. The vials were then removed from the oil bath and allowed to cool to room temperature before being carefully vented to release pressure. The crude material from the outer 6-mL reaction vial was then passed through a plug of celite that was then washed with acetone, and the filtrate was evaporated to dryness. The crude reaction mixture was analyzed by ${ }^{1} \mathrm{H} \mathrm{NMR}$ with $\mathrm{CBr}_{2} \mathrm{H}_{2}$ as an internal standard. A graphical representation of the experiments is shown below.

Experiments were conducted in triplicate using a different freshly opened bottle of toluene and a different batch of starting material for each trial, all of which resulted in $>20 \%$ product formation. 

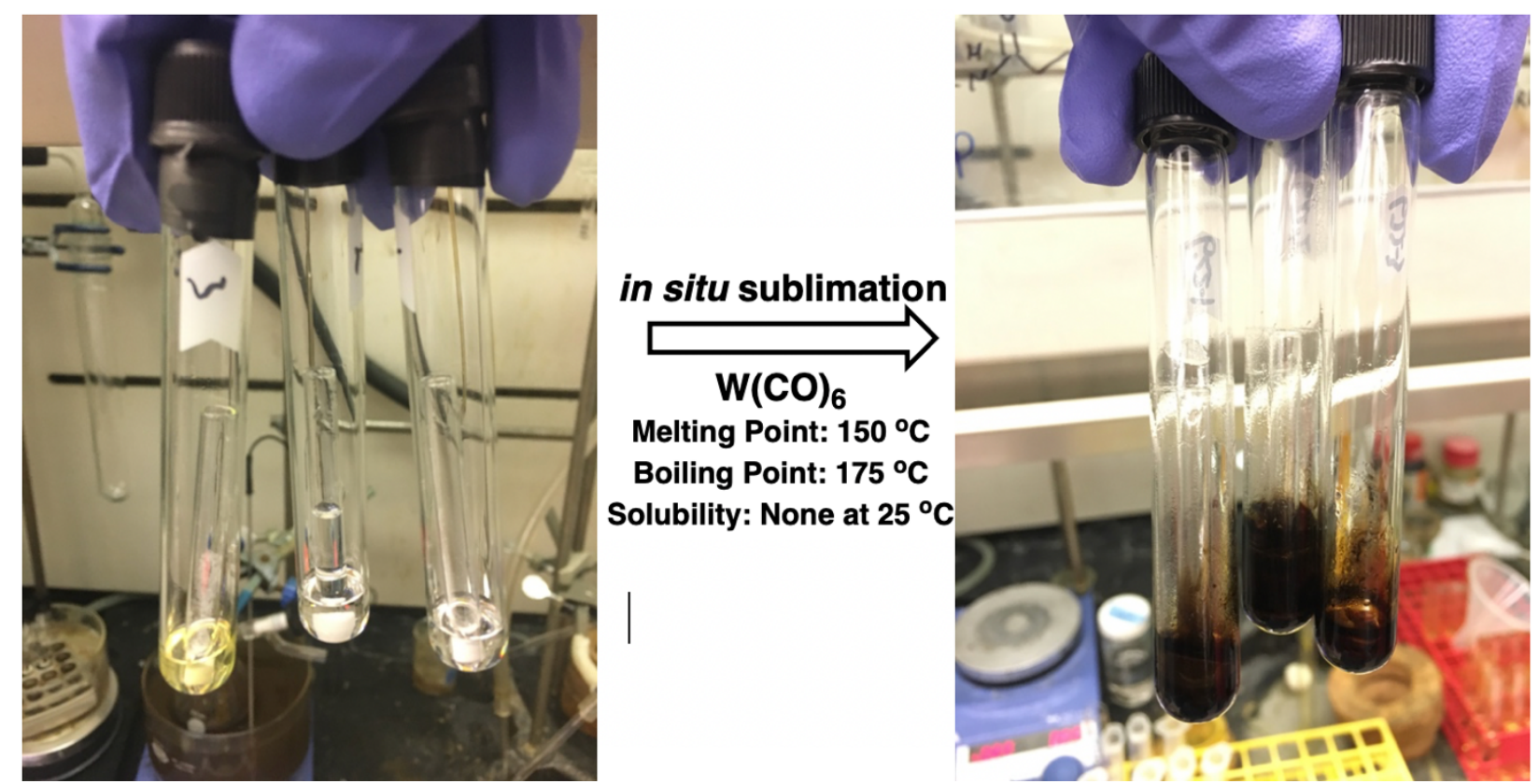

Figure S2 Graphical depiction of in situ sublimation control reactions

Although other homoleptic metal carbonyls such as $\mathrm{Fe}(\mathrm{CO})_{5}, \mathrm{Mo}(\mathrm{CO})_{6}$ and $\mathrm{Cr}(\mathrm{CO})_{6}$ are potential contaminants in the commercial source and would also be volatile at the reaction temperature used in the above experiment, these complexes were independently tested under the optimized reaction conditions and were found to give no product or inferior yield to $\mathrm{W}(\mathrm{CO})_{6}$. Collectively this data is consistent with a mechanism in which tungsten acts as the catalyst, rather than a trace metal contaminant $(<10 \mathrm{ppm})$. 


\section{EXPERIMENTAL PROCEDURES}

\section{General Procedure for Catalytic Reactions}

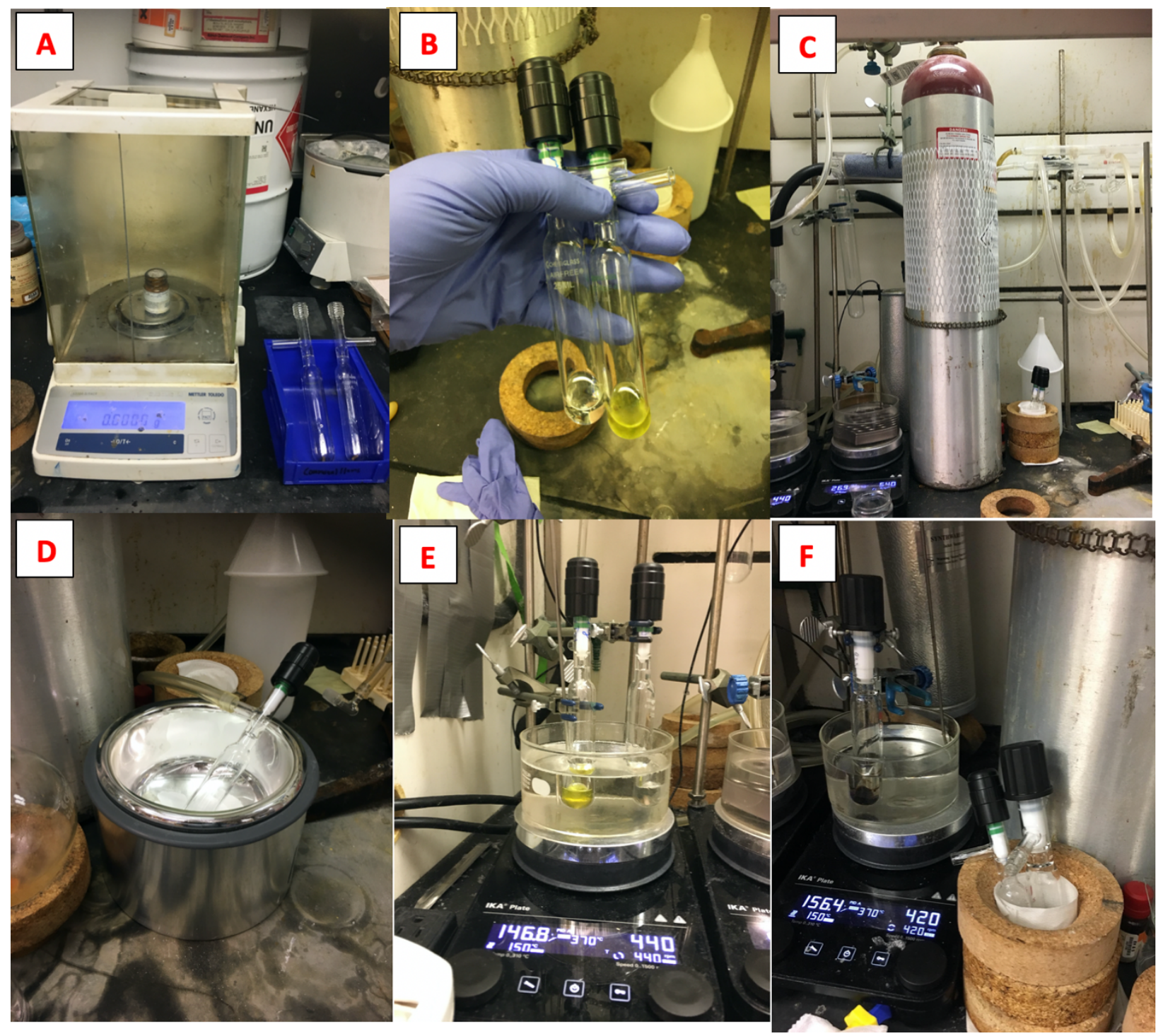

Figure S3 A) Weighing out $\mathrm{W}(\mathrm{CO})_{6}$ and starting material. B) Addition of solvent. C) Connecting $\mathrm{CO}$ tank to Schlenk line. D) Gas exchange of reaction. E) Heating of reaction. F) Letting reactions cool down before opening Schlenk tube.

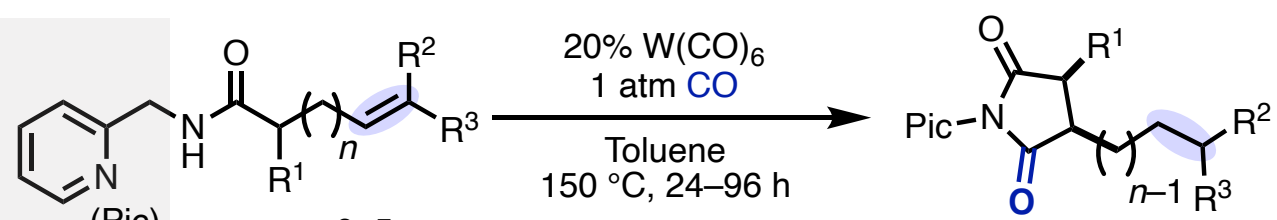

$n=0-5$

\section{Single Regioisomer}

Catalytic Carbonylation Procedure (General Procedure A) Inside an argon-filled glovebox $\left(\mathrm{O}_{2}\right.$ levels between 35.0-55.0 ppm, $\mathrm{H}_{2} \mathrm{O}$ levels unknown), to an oven-dried 25-mL Schlenk tube with a Teflon-coated magnetic stir bar containing $\mathrm{W}(\mathrm{CO})_{6}(14 \mathrm{mg}, 0.4 \mathrm{mmol})$ and the appropriate alkene $(0.2 \mathrm{mmol})$, toluene $(2.0 \mathrm{~mL})$ was added via micropipette, with care taken to ensure that solids on the wall were washed into the bottom of the tube. The flask was removed from the glovebox. A carbon monoxide tank was directly connected to a Schlenk line, and the line was 
purged with $\mathrm{CO}$ for $5 \mathrm{~min}$ at flow rate that resulted in $\sim 2$ bubbles/second in the attached oil bubbler. The vessel was attached to the Schlenk line and the rubber tubbing connection was exposed to vacuum. The reaction tube was submerged in a cooling bath of dry ice and acetone $\left(-78^{\circ} \mathrm{C}\right)$ for 1 min, and the reaction solution was then carefully exposed to vacuum until the pressure monitor for the line stabilized at $0.7-1.1$ mTorr. $C O$ was then back-filled into the Schlenk tube. The tube was immediately removed from the cooling bath with the line left open to $\mathrm{CO}$ for an additional $30 \mathrm{sec}$, before being sealed. The reaction vessel was allowed to warm room temperature and was then submerged into a preheated oil bath at $150{ }^{\circ} \mathrm{C}$ and heated for $24-72 \mathrm{~h}$.

The vessel was allowed to cool to room temperature and was then carefully vented inside the fumehood. The reaction solution was diluted with acetone and filtered through a plug of celite, which was washed with additional acetone. The filtrate was then evaporated to dryness. The crude material was purified by flash silica gel column chromatography using $30-40 \%$ acetone:hexanes as eluent. The alkene starting material and isomerized intermediates can be recovered by using $50-60 \%$ acetone:hexanes as eluent.

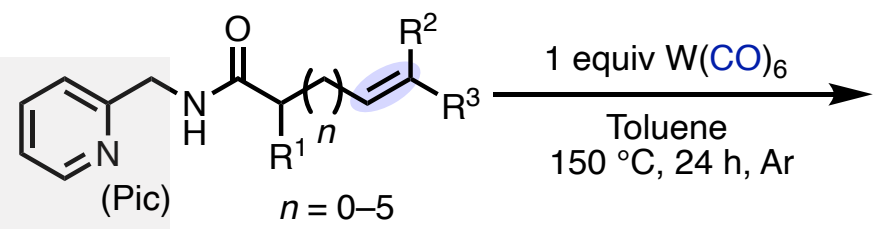

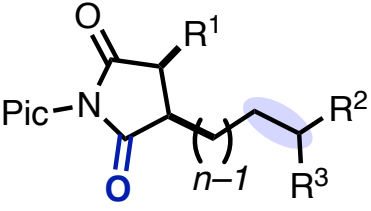

Single Regioisomer

Stoichiometric Carbonlyation Procedure (General Procedure B) Inside an argon-filled glovebox $\left(\mathrm{O}_{2}\right.$ levels between 35.0-55.0 ppm, $\mathrm{H}_{2} \mathrm{O}$ levels unknown), to an oven dried 6-mL vial with a Teflon-coated magnetic stir bar were added $\mathrm{W}(\mathrm{CO})_{6}(36 \mathrm{mg}, 0.1 \mathrm{mmol})$, the appropriate alkene $(0.1 \mathrm{mmol})$, and toluene $(1.0 \mathrm{~mL})$, with care taken to ensure that solids on the wall were washed to the bottom of the tube. The vial was sealed tightly with a disposable cap, and electric tape was placed around the cap. The vial was placed in a preheated oil bath at $150{ }^{\circ} \mathrm{C}$ and allowed to heat for the allotted amount of time.

The vessel was allowed to cool to room temperature and was then carefully vented inside the fumehood. The reaction solution was diluted with acetone and filtered through a plug of celite, which was washed with additional acetone. The filtrate was then evaporated to dryness. The crude material was purified by flash silica gel column chromatography using $30-40 \%$ acetone:hexanes as eluent. The alkene starting material and isomerized intermediates can be recovered by using $50-60 \%$ acetone:hexanes as eluent.

Important notes about experimental setup:

- A standard freeze-pump-thaw procedure using liquid $\mathrm{N}_{2}$ for $\geq 3$ cycles results in only trace product formation. This is likely due to additional $\mathrm{CO}$ in the vessel inhibiting substrate association.

- Schlenk tubes that have additional head space will likely result in reduced yield. During the optimization process, when a 50-mL Schlenk tube was used for 0.2 mmol reaction under otherwise standard conditions, the yield of $\mathbf{2 a}$ decreased by $15 \%$.

- $\mathrm{W}(\mathrm{CO})_{6}$ that is not washed off the walls into the bottom of the tube can decompose much faster, resulting in reduced yield.

- The reaction does not appear to be mass-transfer-limited, as different stir rates (250-1000 rpm) resulted in similar yields; however, "splashing" or uneven stirring can result in higher levels of tungsten deposition on the walls and can lead to lower yields. 


\section{Reaction Optimization Substrates}

The starting materials below were prepared via amide coupling of 4-pentenoic acid with the corresponding amine according to the procedure below.

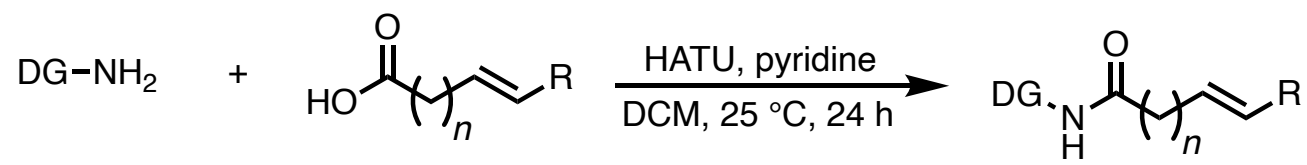

\section{HATU-Mediated Amide Coupling (General Procedure C)}

In a 50-mL round bottomed flask with Teflon-coated magnetic stir bar, the alkenyl carboxylic acid ( $1 \mathrm{mmol}, 1.0$ equiv), DCM $(2 \mathrm{~mL})$, and pyridine $(0.24 \mathrm{~mL}, 3 \mathrm{mmol}, 3$ equiv) were added in that order. HATU (0.456 g, $1.2 \mathrm{mmol}, 1.2$ equiv) was added slowly, and after addition was complete addition, the amine ( $1 \mathrm{mmol}, 1$ equiv) was added dropwise by syringe. The reaction solution was allowed to stir for $24 \mathrm{~h}$, at which point it was diluted with DCM (5 mL) and quenched with a saturated solution of aq. $\mathrm{NaHCO}_{3}(5 \mathrm{~mL})$. The aqueous layer was extracted with $\mathrm{DCM}(\times 3)$, and the organic layers were combined, washed successively with water and brine, dried over $\mathrm{MgSO}_{4}$, filtered, evaporated to dryness. The crude material was purified by flash silica gel chromatography. Tetramethyl urea commonly co-eluted with the product and could be removed by under vacuum $\left(1 \mathrm{mT}\right.$ orr at $\left.50^{\circ} \mathrm{C}\right)$. 


\section{CHARACTERIZATION OF NEW COMPOUNDS}

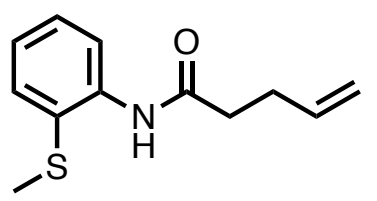

N-(2-(methylthio)phenyl)pent-4-enamide (DG1-SM): The title compound was prepared according to the General Procedure $\mathrm{C}$ from 2(methylthio)aniline $(0.139 \mathrm{~g}, 1 \mathrm{mmol})$ to afford $180 \mathrm{mg}$ ( $80 \%$ yield) of DG1-SM as a pale-yellow oil. ${ }^{1} \mathbf{H}$ NMR $\left(600 \mathrm{MHz}, \mathrm{CDCl}_{3}\right) \delta 8.39-8.21$ $(\mathrm{m}, 2 \mathrm{H}), 7.47(\mathrm{~d}, J=7.8 \mathrm{~Hz}, 1 \mathrm{H}), 7.36-7.24(\mathrm{~m}, 1 \mathrm{H}), 7.06(\mathrm{t}, J=7.5 \mathrm{~Hz}$, 1H), 5.90 (ddt, $J=16.1,11.3,5.8 \mathrm{~Hz}, 1 \mathrm{H}), 5.14(\mathrm{~d}, J=17.1 \mathrm{~Hz}, 1 \mathrm{H}), 5.05(\mathrm{~d}, J=10.3 \mathrm{~Hz}, 1 \mathrm{H})$, $2.52(\mathrm{q}, J=5.6 \mathrm{~Hz}, 4 \mathrm{H}), 2.37(\mathrm{~s}, 3 \mathrm{H}) .{ }^{13} \mathbf{C} \mathbf{N M R}\left(151 \mathrm{MHz}, \mathrm{CDCl}_{3}\right) \delta 171.06,138.41,136.76$, 133.03, 129.03, 125.20, 124.43, 120.76, 116.04, 37.29, 29.51, 19.09. HRMS calcd. for $\mathrm{C}_{12} \mathrm{H}_{15} \mathrm{NOS}^{+}[\mathrm{M}+\mathrm{H}]+$ : 222.0947, Found: 222.0948 .<smiles>C=CCCC(=O)Nc1ccccc1P(c1ccccc1)c1ccccc1</smiles>

$N$-(2-(diphenylphosphaneyl)phenyl)pent-4-enamide (2-(pent-4-enamido)phenyl)diphenylphosphonium (DG2-SM): The title compound was prepared according to the General Procedure $\mathrm{C}$ using 2-(diphenylphosphaneyl)aniline (42) $(0.279 \mathrm{~g}, 1 \mathrm{mmol})$ as the amine to afford $153 \mathrm{mg}$ (42\% yield) of DG2-SM as a white solid. ${ }^{\mathbf{1}} \mathbf{H}$ NMR (600 $\left.\mathrm{MHz}, \mathrm{CDCl}_{3}\right) \delta 10.95(\mathrm{~s}, 1 \mathrm{H}), 8.78-8.01(\mathrm{~m}, 1 \mathrm{H}), 7.74-7.23(\mathrm{~m}, 12 \mathrm{H}), 7.21-6.71(\mathrm{~m}, 2 \mathrm{H}), 5.75$ $(\mathrm{dtd}, J=27.9,16.9,14.2,8.3 \mathrm{~Hz}, 1 \mathrm{H}), 5.26-4.73(\mathrm{~m}, 2 \mathrm{H}), 2.50-2.18(\mathrm{~m}, 4 \mathrm{H}) .{ }^{13} \mathrm{C}$ NMR $(151 \mathrm{MHz}$, $\left.\mathrm{CDCl}_{3}\right) \delta 171.29,136.66(\mathrm{~d}, J=16.0 \mathrm{~Hz}), 133.97,133.65(\mathrm{~d}, J=19.3 \mathrm{~Hz}), 133.42,132.05(\mathrm{~d}, J=$ $10.0 \mathrm{~Hz}), 130.58,129.57,128.95(\mathrm{~d}, J=7.6 \mathrm{~Hz}), 128.77$ (d, $J=12.5 \mathrm{~Hz}), 124.82,122.60,115.50$ $(\mathrm{d}, J=37.4 \mathrm{~Hz}), 37.02(\mathrm{~d}, J=83.1 \mathrm{~Hz})$, 30.95. ${ }^{31} \mathbf{P}$ NMR $\left(162 \mathrm{MHz}, \mathrm{CDCl}_{3}\right) \delta 37.49$. HRMS calcd. for $\mathrm{C}_{23} \mathrm{H}_{23} \mathrm{NOP}^{+}[\mathrm{M}+\mathrm{H}]^{+}: 360.1512$, Found: 360.1514 .<smiles>C=CCCC(=O)Nc1cccc2cccnc12</smiles>

$\boldsymbol{N}$-(quinolin-8-yl)pent-4-enamide (DG3-SM): This compound has previously been synthesized in our laboratory and the procedure and characterization has previously been reported (42).<smiles>C=CCCC(=O)NCc1ccccn1</smiles>

N-(pyridin-2-ylmethyl)pent-4-enamide (DG4-SM): This compound has previously been synthesized in our laboratory and the procedure and characterization has previously been reported (47).<smiles>C=CCCC(=O)NCc1ccccc1</smiles>

N-benzylpent-4-enamide (DG5-SM): This compound has previously been synthesized in our laboratory and the procedure and characterization has previously been reported (47).

$N$-([2,2'-bipyridin]-6-ylmethyl)pent-4-enamide (DG6-SM): The preparation of the crude amine used in the amide coupling is described below. LAH (314.2 $\mathrm{mg}, 1.5$ equiv, $8.278 \mathrm{mmol}$ ) is suspended in THF $(10 \mathrm{ml})$ and stirred at $0^{\circ} \mathrm{C}$. [2,2'-bipyridine]-6-carbonitrile (1.000 g, 1 equiv, $5.519 \mathrm{mmol})$ is dissolved in THF $(10 \mathrm{ml})$ and added to the suspension over $30 \mathrm{~min}$. The reaction is stirred at $0{ }^{\circ} \mathrm{C}$ for $1 \mathrm{~h}$. The 
reaction is quenched by the addition of aq. $\mathrm{Na}_{2} \mathrm{SO}_{4}(27.0 \mathrm{ml})$. The reaction mixture is filtered, and diluted with EtOAc. The organic layer is dried over $\mathrm{MgSO}_{4}$, filtered and concentrated to give a red oil which was used directly in the next step. The title compound was prepared according to the General Procedure $\mathrm{C}$ using [2,2'-bipyridin]-6-ylmethanamine (185mg, $1 \mathrm{mmol}$ ) as the amine to afford $177 \mathrm{mg}$ (66 \% yield) of DG6-SM as a white solid. ${ }^{\mathbf{1}} \mathbf{H}$ NMR (600 MHz, $d_{6}$-DMSO) $\delta 8.69$ $(\mathrm{ddd}, J=4.7,1.8,0.9 \mathrm{~Hz}, 1 \mathrm{H}), 8.52(\mathrm{t}, J=6.0 \mathrm{~Hz}, 1 \mathrm{H}), 8.42(\mathrm{dt}, J=7.9,1.1 \mathrm{~Hz}, 1 \mathrm{H}), 8.26(\mathrm{dd}, J$ $=7.8,1.0 \mathrm{~Hz}, 1 \mathrm{H}), 7.96(\mathrm{td}, J=7.7,1.8 \mathrm{~Hz}, 1 \mathrm{H}), 7.92(\mathrm{t}, J=7.8 \mathrm{~Hz}, 1 \mathrm{H}), 7.46(\mathrm{ddd}, J=7.5,4.8$, $1.2 \mathrm{~Hz}, 1 \mathrm{H}), 7.34(\mathrm{dd}, J=7.7,0.9 \mathrm{~Hz}, 1 \mathrm{H}), 5.95-5.72(\mathrm{~m}, 1 \mathrm{H}), 5.07$ (dt, $J=17.0,1.7 \mathrm{~Hz}, 1 \mathrm{H})$, 5.03-4.84 (m, 1H), $4.46(\mathrm{~d}, J=6.0 \mathrm{~Hz}, 2 \mathrm{H}), 2.35-2.30(\mathrm{~m}, 4 \mathrm{H}) .{ }^{13} \mathbf{C}$ NMR $\left(151 \mathrm{MHz}, d_{6}\right.$-DMSO) $\delta 171.73,158.56,155.15,154.51,149.28,137.83,137.75,137.22,124.18,121.26,120.51,118.61$, 115.08, 44.25, 34.48, 29.26. HRMS calcd. for $\mathrm{C}_{16} \mathrm{H}_{18} \mathrm{~N}_{3} \mathrm{O}^{+}[\mathrm{M}+\mathrm{H}]^{+}: 268.1444$, Found: 268.1444.

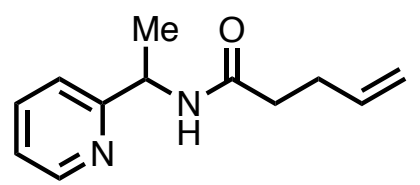

$N$-(1-(pyridin-2-yl)ethyl)pent-4-enamide (DG7-SM): The title compound was prepared according to the general procedure $\mathrm{C}$ using 1(pyridin-2-yl)ethan-1-amine ( $0.123 \mathrm{~g}, 1 \mathrm{mmol})$ as the amine to a to afford $145 \mathrm{mg}$ (71 \% yield) of DG7-SM as a white solid. ${ }^{1} \mathbf{H}$ NMR $\left(600 \mathrm{MHz}, \mathrm{CDCl}_{3}\right) \delta 8.54(\mathrm{~d}, J=4.2 \mathrm{~Hz}, 1 \mathrm{H}), 7.65(\mathrm{dd}, J=7.6,1.7 \mathrm{~Hz}, 1 \mathrm{H}), 7.24-7.09(\mathrm{~m}, 2 \mathrm{H})$, $6.89(\mathrm{~s}, 1 \mathrm{H}), 5.83(\mathrm{tt}, J=11.7,5.9 \mathrm{~Hz}, 1 \mathrm{H}), 5.14(\mathrm{t}, J=6.9 \mathrm{~Hz}, 1 \mathrm{H}), 5.06(\mathrm{dq}, J=17.2,1.7 \mathrm{~Hz}$, $1 \mathrm{H}), 5.01-4.94(\mathrm{~m}, 1 \mathrm{H}), 2.42(\mathrm{p}, J=6.6 \mathrm{~Hz}, 2 \mathrm{H}), 2.33(\mathrm{t}, J=7.7 \mathrm{~Hz}, 2 \mathrm{H}), 1.45(\mathrm{~d}, J=6.8 \mathrm{~Hz}, 3 \mathrm{H})$. ${ }^{13}$ C NMR (151 MHz, $\left.\mathrm{CDCl}_{3}\right) \delta 171.60,161.14,149.16,137.24,137.00,122.48,121.73,115.59$, 49.82, 36.17, 29.81, 23.00. HRMS calcd. for $\mathrm{C}_{12} \mathrm{H}_{17} \mathrm{~N}_{2} \mathrm{O}^{+}[\mathrm{M}+\mathrm{H}]^{+}:$205.1335, Found: 205.1336.

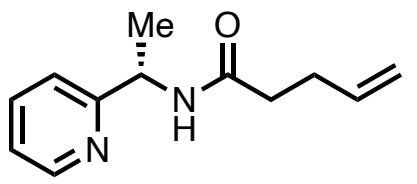

$N$-(1(S)-(pyridin-2-yl)ethyl)pent-4-enamide ((S)-DG7-SM): The title compound was prepared according to the General Procedure $\mathrm{C}$ using 1(pyridin-2-yl)ethan-1-amine $(0.500 \mathrm{~g}, 1 \mathrm{mmol})$ as the amine to a to afford $350 \mathrm{mg}$ (42\% yield) of (S)-DG7-SM as a white solid. The analytical data matches that of the racemic compound.

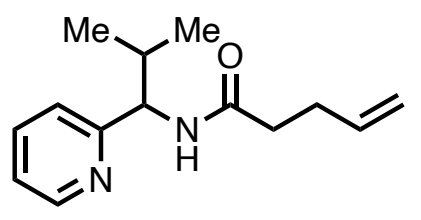

N-(2-methyl-1-(pyridin-2-yl)propyl)pent-4-enamide (DG8-SM): The title compound was prepared according to the General Procedure C using 2-methyl-1-(pyridin-2-yl)propan-1-amine (0.151 g, $1 \mathrm{mmol})$ as the amine to a to afford $132 \mathrm{mg}(56 \%$ yield $)$ of DG8-SM as a white solid. ${ }^{1} \mathbf{H}$ NMR $\left(600 \mathrm{MHz}, \mathrm{CDCl}_{3}\right) \delta 8.54(\mathrm{ddd}, J=4.8,1.8,1.0 \mathrm{~Hz}, 1 \mathrm{H})$, $7.62(\mathrm{td}, J=7.6,1.8 \mathrm{~Hz}, 1 \mathrm{H}), 7.21-7.14(\mathrm{~m}, 2 \mathrm{H}), 6.73(\mathrm{~d}, J=8.7 \mathrm{~Hz}, 1 \mathrm{H}), 5.92-5.72(\mathrm{~m}, 1 \mathrm{H})$, $5.05(\mathrm{dq}, J=17.1,1.6 \mathrm{~Hz}, 1 \mathrm{H}), 4.97$ (ddt, $J=10.1,1.8,1.2 \mathrm{~Hz}, 1 \mathrm{H}), 4.89$ (dd, $J=8.7,6.9 \mathrm{~Hz}, 1 \mathrm{H})$, $2.45-2.28(\mathrm{~m}, 4 \mathrm{H}), 2.10(\mathrm{~h}, J=6.8 \mathrm{~Hz}, 1 \mathrm{H}), 0.93(\mathrm{~d}, J=6.8 \mathrm{~Hz}, 3 \mathrm{H}), 0.79(\mathrm{~d}, J=6.8 \mathrm{~Hz}, 3 \mathrm{H}) .{ }^{13} \mathbf{C}$ NMR $\left(151 \mathrm{MHz}, \mathrm{CDCl}_{3}\right) \delta 171.86,159.48,149.19,137.27,136.35,123.30,122.39,115.57,58.93$, $36.30,34.14,29.89,19.28,18.80$. HRMS calcd. for $\mathrm{C}_{14} \mathrm{H}_{21} \mathrm{~N}_{2} \mathrm{O}^{+}[\mathrm{M}+\mathrm{H}]^{+}: 233.1648$, Found: 233.1648 .

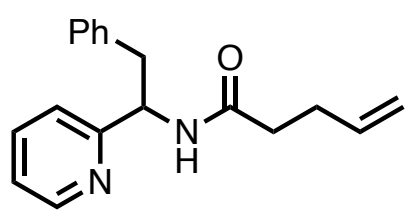

N-(2-phenyl-1-(pyridin-2-yl)ethyl)pent-4-enamide (DG9-SM): The preparation of the crude amine used in the amide coupling is described below. In a $100 \mathrm{~mL}$ Schlenk flask, picolinonitrile (1.0411 g, 1 equiv, $10.000 \mathrm{mmol})$ was dissolved ether $(15 \mathrm{~mL})$ at $-10^{\circ} \mathrm{C}$. Once completely dissolved, benzylmagnesium chloride $(1.5089 \mathrm{~g}, 10.000 \mathrm{~mL}, 1.0$ molar in ether, 1 equiv, $10.000 \mathrm{mmol}$ ) was added dropwise then stirred for $3 \mathrm{~h}$ at temperature. The reaction was quenched with methanol $(3.204 \mathrm{~g}, 4.05 \mathrm{~mL}, 10$ equiv, $100.00 \mathrm{mmol})$ at $-10{ }^{\circ} \mathrm{C}$ and 
stirred for $10 \mathrm{~min}$ before the addition of sodium borohydride (454.0 mg, 1.2 equiv, $12.000 \mathrm{mmol})$. After stirring for $10 \mathrm{~min}$ at temperature the reaction was brought to room temperature and allowed to stir for an additional $3 \mathrm{~h}$. The reaction was diluted with EtOAc $(25 \mathrm{~mL})$ and quenched with a saturated solution of aq. $\mathrm{NaHCO}_{3}(5 \mathrm{~mL})$. The aqueous layer was extracted with EtOAc x3 and the organic layers combined, washed with water then brine, and then dried with $\mathrm{MgSO}_{4}$, filtered and evaporated to dryness. The crude material was then used directly for the subsequent amide coupling. Using the crude amine in the General Procedure $\mathrm{C}$ procedure using 2-phenyl-1-(pyridin2-yl)ethan-1-amine (1.900 g, $4.79 \mathrm{mmol})$ as the amine afforded $930 \mathrm{mg}$ (40\% yield) of DG9SM as a white solid. ${ }^{1} \mathbf{H}$ NMR $\left(400 \mathrm{MHz}, \mathrm{CDCl}_{3}\right) \delta 8.62(\mathrm{~d}, J=4.8 \mathrm{~Hz}, 1 \mathrm{H}), 7.58(\mathrm{td}, J=7.6,1.8$ $\mathrm{Hz}, 1 \mathrm{H}), 7.24$ (dt, $J=16.7,5.6 \mathrm{~Hz}, 4 \mathrm{H}), 7.14-7.03(\mathrm{~m}, 2 \mathrm{H}), 6.98$ (d, $J=7.8 \mathrm{~Hz}, 1 \mathrm{H}), 5.88$ (ddt, $J$ $=16.8,10.3,6.2 \mathrm{~Hz}, 1 \mathrm{H}), 5.42(\mathrm{td}, J=7.9,5.8 \mathrm{~Hz}, 1 \mathrm{H}), 5.13(\mathrm{~d}, J=17.1 \mathrm{~Hz}, 1 \mathrm{H}), 5.06(\mathrm{~d}, J=$ $10.3 \mathrm{~Hz}, 1 \mathrm{H}), 3.35(\mathrm{dd}, J=13.3,5.9 \mathrm{~Hz}, 1 \mathrm{H}), 3.17(\mathrm{dd}, J=13.3,8.0 \mathrm{~Hz}, 1 \mathrm{H}), 2.55-2.34(\mathrm{~m}, 4 \mathrm{H})$. ${ }^{13}$ C NMR $\left(126 \mathrm{MHz} \mathrm{CDCl}_{3}\right) \delta 171.69,158.95,149.14,137.34,137.16,136.41,129.64,128.27$, $126.55,122.96,122.60,115.55,55.38,42.63,36.05,29.68$. HRMS calcd. for $\mathrm{C}_{18} \mathrm{H}_{21} \mathrm{~N}_{2} \mathrm{O}^{+}$ $[\mathrm{M}+\mathrm{H}]^{+}:$281.1684, Found: 281.1684 .

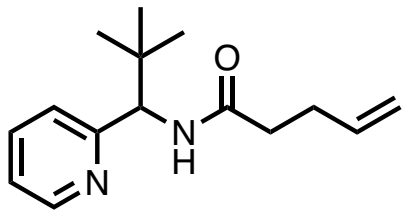

$N$-(2,2-dimethyl-1-(pyridin-2-yl)propyl)pent-4-enamide (DG10SM): The title compound was prepared according to the General Procdure C using 2,2-dimethyl-1-(pyridin-2-yl)propan-1-amine (185mg, $1 \mathrm{mmol})$ as the amine to a to afford $37 \mathrm{mg}(81 \%$ yield) of DG10-SM as a white solid. ${ }^{1} \mathbf{H}$ NMR $\left(500 \mathrm{MHz}, \mathrm{CDCl}_{3}\right) \delta 8.57-8.48$ (m, 1H), $7.59(\mathrm{td}, J=7.7,1.8 \mathrm{~Hz}, 1 \mathrm{H}), 7.17(\mathrm{dd}, J=7.7,4.2 \mathrm{~Hz}, 2 \mathrm{H}), 6.95(\mathrm{~d}, J=9.3 \mathrm{~Hz}, 1 \mathrm{H})$, 5.80 (ddd, $J=16.9,10.4,6.3 \mathrm{~Hz}, 1 \mathrm{H}), 5.10-5.00(\mathrm{~m}, 1 \mathrm{H}), 4.96(\mathrm{dt}, J=10.3,1.6 \mathrm{~Hz}, 1 \mathrm{H}), 4.92(\mathrm{~d}$, $J=9.3 \mathrm{~Hz}, 1 \mathrm{H}), 2.53-2.23(\mathrm{~m}, 4 \mathrm{H}), 0.90(\mathrm{~s}, 9 \mathrm{H}) .{ }^{13} \mathbf{C ~ N M R}\left(126 \mathrm{MHz}, \mathrm{CDCl}_{3}\right) \delta 171.93,158.56$, 148.60, 137.26, 135.79, 124.46, 122.32, 115.53, 60.84, 36.38, 36.25, 29.90, 26.83. HRMS calcd. for $\mathrm{C}_{15} \mathrm{H}_{23} \mathrm{~N}_{2} \mathrm{O}^{+}[\mathrm{M}+\mathrm{H}]^{+}: 247.1805$, Found: 247.1850 .

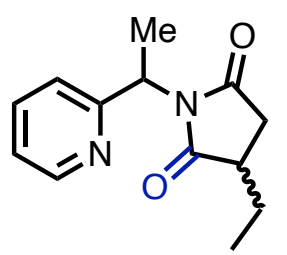

3-ethyl-1-(1-(pyridin-2-yl)ethyl)pyrrolidine-2,5-dione (DG7-P): The title compound was synthesized according to General Procedure B of DG7-SM (20 $\mathrm{mg}$ ) with a reaction time of $24 \mathrm{~h}$ to afford $19 \mathrm{mg}$ (82\% yield; 5:1 d.r.) of DG7$\mathbf{P}$ as a colorless oil. The two diastereomers could be separated analytically by SFC but could not be separated on a preparative scale. The two diastereomers are reported as mixture. ${ }^{1} \mathbf{H}$ NMR $\left(600 \mathrm{MHz}, \mathrm{CDCl}_{3}\right) \delta 8.52(\mathrm{~d}, J=4.9 \mathrm{~Hz}, 1 \mathrm{H})$, $7.68(\mathrm{t}, J=7.5 \mathrm{~Hz}, 1 \mathrm{H}), 7.37(\mathrm{~d}, J=7.9 \mathrm{~Hz}, 1 \mathrm{H}), 7.18(\mathrm{dd}, J=7.5,5.0 \mathrm{~Hz}, 1 \mathrm{H}), 5.47(\mathrm{q}, J=7.3$ $\mathrm{Hz}, 1 \mathrm{H}), 2.93-2.74(\mathrm{~m}, 2 \mathrm{H}), 2.49-2.35(\mathrm{~m}, 1 \mathrm{H}), 1.97-1.84(\mathrm{~m}, 1 \mathrm{H}), 1.82(\mathrm{~d}, J=7.4 \mathrm{~Hz}, 3 \mathrm{H}), 1.71-$ $1.56(\mathrm{~m}, 1 \mathrm{H}), 0.98(\mathrm{~m}, 3 \mathrm{H}) .{ }^{13} \mathbf{C}$ NMR $\left(151 \mathrm{MHz}, \mathrm{CDCl}_{3}\right) \delta 179.82,176.65,158.16,148.98,148.93$, $136.84,136.80,122.38,120.95,50.90,50.81,40.98,40.96,33.86,33.80,24.41,24.35,15.97$, 15.94, 10.78, 10.73. HRMS calcd. for $\mathrm{C}_{13} \mathrm{H}_{17} \mathrm{~N}_{2} \mathrm{O}_{2}{ }^{+}[\mathrm{M}+\mathrm{H}]^{+}:$233.1285, Found: 233.1287 .

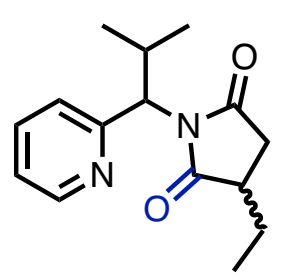

3-ethyl-1-(2-methyl-1-(pyridin-2-yl)propyl)pyrrolidine-2,5-dione (DG8-P): The title compound was synthesized according to General Procedure B with 23 $\mathrm{mg}$ of DG8-SM and run for $24 \mathrm{~h}$ to afford $17 \mathrm{mg}$ (73\% yield; 5:1 d.r.) of DG8$\mathbf{P}$ as a colorless oil. The two diastereomers could be separated analytically by LCMS, but could not be separated on a preparative scale. The two diastereomers are reported as mixture. ${ }^{1} \mathbf{H}$ NMR $\left(600 \mathrm{MHz}, \mathrm{CDCl}_{3}\right) \delta 8.55(\mathrm{dt}, J=4.9,1.3 \mathrm{~Hz}$, 1H), 7.65 (td, $J=7.6,1.8 \mathrm{~Hz}, 1 \mathrm{H}), 7.63-7.58(\mathrm{~m}, 1 \mathrm{H}), 7.17$ (ddd, $J=7.4,4.9,1.3 \mathrm{~Hz}, 1 \mathrm{H}), 4.92$ $(\mathrm{dd}, J=11.5,1.7 \mathrm{~Hz}, 1 \mathrm{H}), 3.16(\mathrm{dp}, J=11.4,6.6 \mathrm{~Hz}, 1 \mathrm{H}), 2.82-2.62(\mathrm{~m}, 2 \mathrm{H}), 2.40-2.29(\mathrm{~m}, 1 \mathrm{H})$, 1.86 (dddd, $J=21.4,14.0,7.3,3.4 \mathrm{~Hz}, 1 \mathrm{H}), 1.63-1.52(\mathrm{~m}, 1 \mathrm{H}), 0.94(\mathrm{~d}, J=6.7 \mathrm{~Hz}, 4 \mathrm{H}), 0.89(\mathrm{t}$, $J=7.3 \mathrm{~Hz}, 6 \mathrm{H}) .{ }^{13} \mathbf{C}$ NMR $\left(151 \mathrm{MHz}, \mathrm{CDCl}_{3}\right) \delta 180.04,179.99,176.80,176.77,157.88,157.84$, 
$149.41,149.39,136.57,136.54,123.47,122.86,64.35,40.85,40.81,33.70,33.57,26.96,26.95$, 24.59, 24.45, 20.65, 19.96, 19.92, 10.98, 10.65. HRMS calcd. for $\mathrm{C}_{15} \mathrm{H}_{21} \mathrm{~N}_{2} \mathrm{O}_{2}{ }^{+}[\mathrm{M}+\mathrm{H}]^{+}: 261.1598$, Found: 261.1598 .

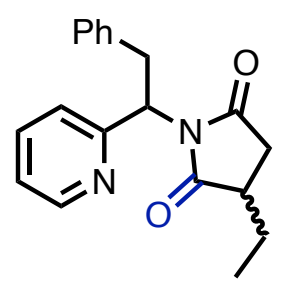

3-ethyl-1-(2-phenyl-1-(pyridin-2-yl)ethyl)pyrrolidine-2,5-dione (DG9-P):

The title compound was synthesized according to General Procedure B with 28 $\mathrm{mg}$ of DG9-SM and run for $24 \mathrm{~h}$ to afford $17 \mathrm{mg}$ (56\% yield; 5:1 d.r.) of DG9$\mathbf{P}$ as a colorless oil. The two diastereomers could be separated analytically by LCMS, but could not be separated on a preparative scale. The two diastereomers are reported as mixture. The assignments for major and minor are made when chemical shift distinct peaks are present. ${ }^{1} \mathbf{H}$ NMR $\left(500 \mathrm{MHz}, d_{6}\right.$-DMSO) $\delta 8.54$ (ddd, $J=4.8,1.9,1.0 \mathrm{~Hz}, 1 \mathrm{H}), 7.80(\mathrm{td}, J=7.7,1.9 \mathrm{~Hz}, 1 \mathrm{H}), 7.47$ (ddq, $J=8.0,2.3,1.0 \mathrm{~Hz}, 1 \mathrm{H})$, 7.32 (ddt, $J=7.5,4.8,0.9 \mathrm{~Hz}, 1 \mathrm{H}), 7.30-7.24$ (m, 2H), 7.20 (td, $J=6.0,5.5,2.8 \mathrm{~Hz}, 3 \mathrm{H}), 5.51$ (td, $J=11.6,11.2,5.2 \mathrm{~Hz}, 1 \mathrm{H}), 3.74-3.60(\mathrm{~m}, 1 \mathrm{H}), 3.54(\mathrm{ddd}, J=13.6,11.6,5.6 \mathrm{~Hz}, 1 \mathrm{H}), 2.85-2.60$ (m, 2H), [major $2.24(\mathrm{dd}, J=17.5,3.7 \mathrm{~Hz}, 1 \mathrm{H})$, minor $2.17(\mathrm{dd}, J=18.2,4.5 \mathrm{~Hz}, 1 \mathrm{H})$ ], [minor 1.60 (ddd, $J=13.6,7.4,5.1 \mathrm{~Hz}, 1 \mathrm{H})$, major 1.47-1.35 (m, $1 \mathrm{H})$, minor 1.34-1.28 (m, 1H), major 1.24-1.09 (m, 1H)], [minor $0.79(\mathrm{t}, J=7.4 \mathrm{~Hz}, 1 \mathrm{H})$, major $0.60(\mathrm{t}, J=7.4 \mathrm{~Hz}, 3 \mathrm{H})] .{ }^{13} \mathbf{C}$ NMR $\left(126 \mathrm{MHz}, d_{6}\right.$-DMSO) $\delta 179.57,176.66,157.25,148.74,137.87,136.79,136.77,128.93,128.91$, $128.88,128.32,128.30,128.24,126.43,122.52,121.03,120.99,56.16,34.59,32.82,23.37,9.99$. HRMS calcd. for $\mathrm{C}_{19} \mathrm{H}_{21} \mathrm{~N}_{2} \mathrm{O}_{2}{ }^{+}[\mathrm{M}+\mathrm{H}]^{+}: 309.1598$, Found: 309.1598 .

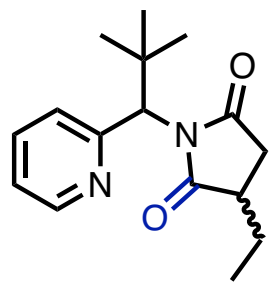

1-(2,2-dimethyl-1-(pyridin-2-yl)propyl)-3-ethylpyrrolidine-2,5-dione (DG10-P): The title compound was synthesized according to General Procedure B with $13.6 \mathrm{mg}$ of DG10-SM, $19.5 \mathrm{mg}$ of $\mathrm{W}(\mathrm{CO})_{6}$ in $0.6 \mathrm{~mL}$ of toluene and run for $24 \mathrm{~h}$ to afford $6 \mathrm{mg}$ (40\% yield; 2:1 d.r.) of DG10-P in as a colorless oil. The two diastereomers could be separated analytically by LCMS, but could not be separated on a preparative scale. ${ }^{1} \mathbf{H}$ NMR $\left(600 \mathrm{MHz}, \mathrm{CDCl}_{3}\right) \delta 8.54(\mathrm{ddd}, J$ $=4.9,1.9,1.0 \mathrm{~Hz}, 1 \mathrm{H}), 7.74(\mathrm{~d}, J=8.1 \mathrm{~Hz}, 1 \mathrm{H}), 7.63(\mathrm{ddd}, J=7.8,6.7,2.0 \mathrm{~Hz}$, 1H), 7.17 (ddd, $J=7.5,4.9,1.2 \mathrm{~Hz}, 1 \mathrm{H}), 5.36$ (d, $J=2.3 \mathrm{~Hz}, 1 \mathrm{H}), 2.87-2.67$ (m, 2H), 2.48-2.34 (m, 1H), $1.90(\mathrm{ddd}, J=19.0,9.5,4.6 \mathrm{~Hz}, 1 \mathrm{H}), 1.14(\mathrm{~s}, 10 \mathrm{H}), 0.95$ (dt, $J=15.3,7.4 \mathrm{~Hz}, 3 \mathrm{H})$. one sp3 proton is chemical shift equivilant with water and cannot be seen. ${ }^{13} \mathbf{C ~ N M R}(151 \mathrm{MHz}$, $\left.\mathrm{CDCl}_{3}\right) \delta 180.60,177.42,157.28,148.75,136.13,124.75,122.59,66.66,40.99,36.07,33.82$, 33.73, 28.83, 24.67, 10.96, 10.83. HRMS calcd. for $\mathrm{C}_{16} \mathrm{H}_{23} \mathrm{~N}_{2} \mathrm{O}_{2}{ }^{+}[\mathrm{M}+\mathrm{H}]^{+}$: 275.1754, Found:275.1755.

\section{Starting Material Synthesis (All yields unoptimized) General amide coupling procedures}

The starting materials below can be prepared directly via amide coupling of the commercial acid with 2-picolyl amine $\left(\mathrm{PicNH}_{2}\right)$ via General Procedure D or from reaction between with 2-picolyl amine $\left(\mathrm{PicNH}_{2}\right)$ and the corresponding commercial alcohol via General Procedure D. In some cases, the carboxylic acids were previously synthesized at The Scripps Research Institute and donated for this project. Their preparation and characterization have previously been published (44-45). 


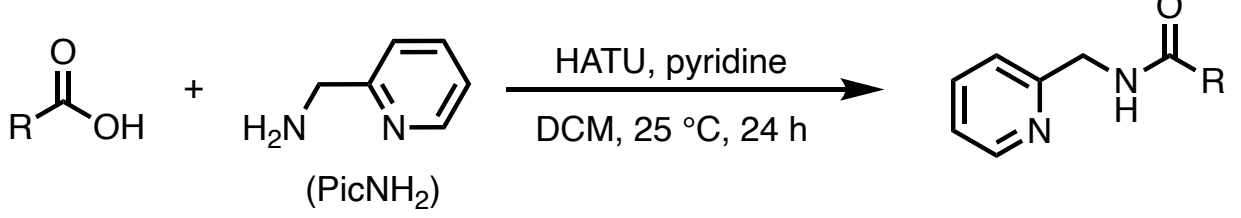

\section{HATU-Mediated Amide Coupling (General Procedure D)}

In a 50-mL round bottomed flask with Teflon coated magnetic stir bar, carboxylic acid (1.0 equiv), $\operatorname{DCM}(0.5 \mathrm{M})$, pyridine (3.0 equiv) were added in that order. HATU (1.2 equiv) was added slowly and after complete addition, $\mathrm{PicNH}_{2}$ (1.0 equiv) was added dropwise by syringe. The reaction was allowed to stir for $24 \mathrm{~h}$, at which point it was diluted with DCM (30 mL for $10 \mathrm{mmol} \mathrm{scale}$ ) and quenched with a saturated solution of aq. $\mathrm{NaHCO}_{3}(30 \mathrm{~mL})$. The aqueous layer was extracted with $\operatorname{DCM}(\times 3)$, and the organic layers were combined, washed with water nad brine, dried over $\mathrm{MgSO}_{4}$, filtered, and evaporated to dryness. The crude material was purified by flash silica chromatography using 55\% acetone:hexanes to elute the product. Tetramethyl urea commonly co-eluted with the product and could be removed under vacuum $\left(1 \mathrm{mTorr}\right.$ at $\left.50^{\circ} \mathrm{C}\right)$.

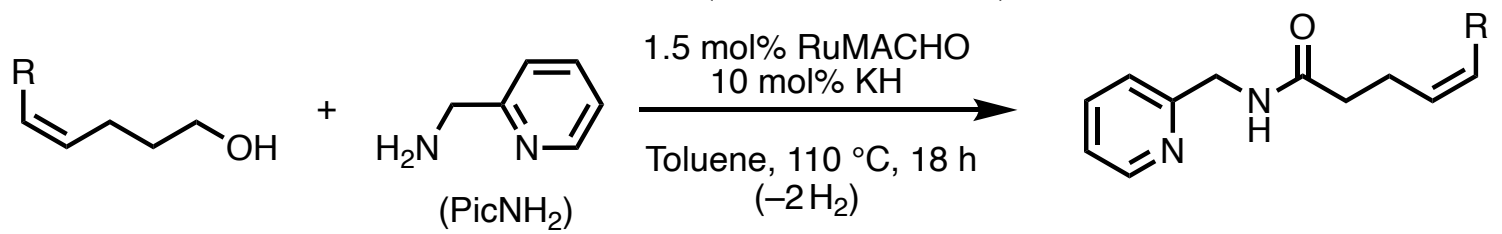

\section{Ru-Catalyzed Amide Coupling (General Procedure E)}

In an argon-filled glovebox, a 25-mL round-bottomed flask was charged with Ru-MACHO (0.015 equiv) and $\mathrm{KH}$ (0.1 equiv), and the solids were suspended in toluene [2 M]. Next, $\mathrm{PicNH}_{2}$ (1 equiv) and alkenyl alcohol (1.2 equiv) were added in that order. A reflux condenser was attached, and the glassware was sealed inside the glovebox and removed. A steady flow of nitrogen was attached, and the reaction was run under reflux for $18 \mathrm{~h}$. The reaction mixture was allowed to cool to room temperature and was then loaded directly onto a silica column and purified by flash silica chromatography using 55\% acetone:hexanes to elute the product.

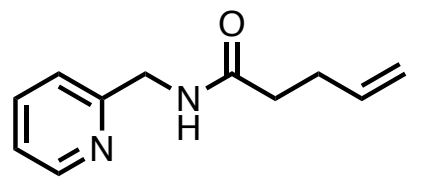

$\mathrm{N}$-(pyridin-2-ylmethyl)pent-4-enamide (1a): The title compound was prepared according to General Procedure D using 4-pentenoic acid (10 $\mathrm{mmol})$ as the carboxylic acid to afford $1.205 \mathrm{~g}$ (63\% yield) of $1 \mathrm{a}$ as a pale-yellow oil. ${ }^{1} \mathbf{H}$ NMR $\left(600 \mathrm{MHz}, d_{6}\right.$-DMSO) $\delta 8.55-8.48(\mathrm{~m}, 1 \mathrm{H})$, $8.43(\mathrm{t}, J=6.1 \mathrm{~Hz}, 1 \mathrm{H}), 7.75(\mathrm{td}, J=7.7,1.9 \mathrm{~Hz}, 1 \mathrm{H}), 7.36-7.13(\mathrm{~m}, 1 \mathrm{H}), 6.00-5.70(\mathrm{~m}, 1 \mathrm{H}), 5.05$ (dq, $J=17.1,1.6 \mathrm{~Hz}, 1 \mathrm{H}), 4.97$ (ddt, $J=10.2,2.3,1.2 \mathrm{~Hz}, 1 \mathrm{H}), 4.35$ (d, $J=6.0 \mathrm{~Hz}, 2 \mathrm{H}), 2.36-$ $2.20(\mathrm{~m}, 4 \mathrm{H}) .{ }^{13} \mathbf{C}$ NMR (151 MHz, $d_{6}$-DMSO) $\delta 171.62,158.78,148.78,137.74,136.66,122.03$, 120.91, 115.07, 44.13, 34.44, 29.24. HRMS calcd. for $\mathrm{C}_{11} \mathrm{H}_{15} \mathrm{~N}_{2} \mathrm{O}^{+}[\mathrm{M}+\mathrm{H}]^{+}:$191.1179, Found: 191.1180 .<smiles>C=CCC(C)C(=O)NCc1ccccn1</smiles>

2-methyl- $N$-(pyridin-2-ylmethyl)pent-4-enamide (1b): The title compound was prepared according to General Procedure D using 2methyl-4-pentenoic acid $(10 \mathrm{mmol})$ as the carboxylic acid to afford $1.370 \mathrm{~g}(67 \%$ yield $)$ of $\mathbf{1 b}$ as a yellow oil. ${ }^{1} \mathbf{H} \mathbf{~ N M R}\left(600 \mathrm{MHz}, \mathrm{CDCl}_{3}\right)$ $\delta 8.58-8.48(\mathrm{~m}, 1 \mathrm{H}), 7.66(\mathrm{td}, J=7.7,1.8 \mathrm{~Hz}, 1 \mathrm{H}), 7.27-7.24(\mathrm{~m}, 1 \mathrm{H}), 7.20(\mathrm{dd}, J=7.5,4.9 \mathrm{~Hz}$, $1 \mathrm{H}), 6.74(\mathrm{~s}, 1 \mathrm{H}), 5.82-5.68(\mathrm{~m}, 1 \mathrm{H}), 5.06(\mathrm{dq}, J=17.0,1.6 \mathrm{~Hz}, 1 \mathrm{H}), 5.00(\mathrm{dd}, J=10.3,1.9 \mathrm{~Hz}$, $1 \mathrm{H}), 4.56(\mathrm{~d}, J=4.9 \mathrm{~Hz}, 2 \mathrm{H}), 2.51-2.34(\mathrm{~m}, 2 \mathrm{H}), 2.19(\mathrm{dt}, J=13.6,6.9 \mathrm{~Hz}, 1 \mathrm{H}), 1.20(\mathrm{~d}, J=6.7$ $\mathrm{Hz}, 3 \mathrm{H}) .{ }^{13} \mathbf{C}$ NMR $\left(151 \mathrm{MHz}, \mathrm{CDCl}_{3}\right) \delta 175.94,156.62,149.11,136.90,136.04,122.48,122.31$, 
116.93, 44.47, 41.30, 38.54, 17.46. HRMS calcd. for $\mathrm{C}_{12} \mathrm{H}_{17} \mathrm{~N}_{2} \mathrm{O}^{+}[\mathrm{M}+\mathrm{H}]^{+}:$205.1335, Found: 205.1336 .

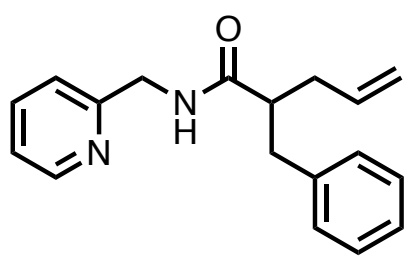

2-benzyl- $N$-(pyridin-2-ylmethyl)pent-4-enamide (1c): The title compound was prepared according to General Procedure D using 2benzyl-4-pentenoic acid $(10 \mathrm{mmol})$ as the carboxylic acid to afford $1.270 \mathrm{~g}(45 \%$ yield $)$ of $\mathbf{1 c}$ as a yellow oil. ${ }^{1} \mathbf{H} \mathbf{~ N M R}\left(400 \mathrm{MHz}, \mathrm{CDCl}_{3}\right)$ $\delta 8.45(\mathrm{~d}, J=5.1 \mathrm{~Hz}, 1 \mathrm{H}), 7.66-7.50(\mathrm{~m}, 1 \mathrm{H}), 7.24-7.09(\mathrm{~m}, 1 \mathrm{H}), 7.03$ $(\mathrm{d}, J=7.9 \mathrm{~Hz}, 1 \mathrm{H}), 6.37(\mathrm{~s}, 1 \mathrm{H}), 5.84-5.69(\mathrm{~m}, 1 \mathrm{H}), 5.12-5.04(\mathrm{~m}, 1 \mathrm{H})$, 5.04-4.98 (m, 1H), 4.52-4.38 (m, 2H), $2.96(\mathrm{dd}, J=13.6,8.3 \mathrm{~Hz}, 1 \mathrm{H}), 2.77(\mathrm{~d}, J=5.2 \mathrm{~Hz}, 1 \mathrm{H})$, 2.55-2.42 (m, 2H), 2.29 (q, $J=8.9 \mathrm{~Hz}, 1 \mathrm{H}) .{ }^{13} \mathbf{C}$ NMR $\left(151 \mathrm{MHz}, \mathrm{CDCl}_{3}\right) \delta 174.51,156.78$, $148.64,139.78,137.19,135.73,129.12,128.51,126.36,122.44,122.33,117.19,49.74,44.32$, 38.67, 36.92. HRMS calcd. $\mathrm{C}_{18} \mathrm{H}_{21} \mathrm{~N}_{2} \mathrm{O}^{+}$for $[\mathrm{M}+\mathrm{H}]^{+}: 281.1648$, Found: 281.1648.

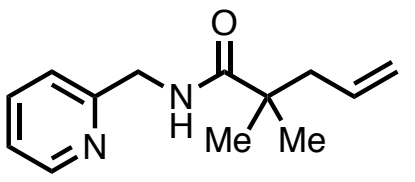

2,2-dimethyl- $N$-(pyridin-2-ylmethyl)pent-4-enamide (1d): The title compound was prepared according to General Procedure D using 2,2dimethyl-4-pentenoic acid $(10 \mathrm{mmol})$ as the carboxylic acid to afford $0.935 \mathrm{~g}(43 \%$ yield $)$ of $\mathbf{1 d}$ as a yellow oil. ${ }^{1} \mathbf{H} \mathbf{~ N M R}\left(600 \mathrm{MHz}, \mathrm{CDCl}_{3}\right)$ $\delta 8.54(\mathrm{dt}, J=5.0,1.3 \mathrm{~Hz}, 1 \mathrm{H}), 7.66(\mathrm{td}, J=7.7,1.8 \mathrm{~Hz}, 1 \mathrm{H}), 7.25(\mathrm{~s}, 1 \mathrm{H}), 7.23-7.17(\mathrm{~m}, 1 \mathrm{H})$, 7.00 (s, 1H), 5.74 (ddt, $J=17.4,10.1,7.4 \mathrm{~Hz}, 1 \mathrm{H}), 5.09-4.99$ (m, 2H), 4.54 (d, $J=4.8 \mathrm{~Hz}, 2 \mathrm{H})$, $2.32(\mathrm{dt}, J=7.3,1.2 \mathrm{~Hz}, 2 \mathrm{H}), 1.23(\mathrm{~s}, 6 \mathrm{H}){ }^{13} \mathbf{C}$ NMR $\left(151 \mathrm{MHz}, \mathrm{CDCl}_{3}\right) \delta 177.52,156.73,149.14$, $136.84,134.58,122.42,122.29,118.02,45.37,44.60,41.64,25.23$. HRMS calcd. $\mathrm{C}_{13} \mathrm{H}_{19} \mathrm{~N}_{2} \mathrm{O}^{+}$for $[\mathrm{M}+\mathrm{H}]^{+}:$219.1492, Found: 219.1493.

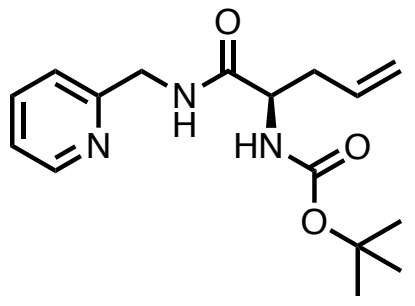

tert-butyl (R)-(1-oxo-1-((pyridin-2-ylmethyl)amino)pent-4-en-2yl)carbamate (1e): The title compound was prepared according to General Procedure D using $(S)-N$-Boc-allylglycine or $(R)-N$-Bocallylglycine $(10 \mathrm{mmol})$ as the carboxylic acid to afford $1.440 \mathrm{~g}(47 \%$ yield) of 1e as a yellow oil. Analytical data was identical for both enantiomers. ${ }^{1} \mathbf{H}$ NMR $\left(600 \mathrm{MHz}, \mathrm{CDCl}_{3}\right) \delta 8.55-8.50(\mathrm{~m}, 1 \mathrm{H}), 7.72-$ $7.68(\mathrm{~m}, 1 \mathrm{H}), 7.35(\mathrm{~s}, 1 \mathrm{H}), 7.31(\mathrm{~d}, J=7.8 \mathrm{~Hz}, 1 \mathrm{H}), 7.25-7.21(\mathrm{~m}, 1 \mathrm{H})$, 5.75 (tt, $J=17.0,8.2 \mathrm{~Hz}, 1 \mathrm{H}), 5.24-5.00(\mathrm{~m}, 3 \mathrm{H}), 4.58(\mathrm{~d}, J=5.3 \mathrm{~Hz}, 2 \mathrm{H}), 4.25(\mathrm{~s}, 1 \mathrm{H}), 2.71-$ $2.39(\mathrm{~m}, 2 \mathrm{H}), 1.44(\mathrm{~s}, J=12.1 \mathrm{~Hz}, 9 \mathrm{H}) .{ }^{13} \mathbf{C} \mathbf{N M R}\left(151 \mathrm{MHz}, \mathrm{CDCl}_{3}\right) \delta 172.39,156.39,155.74$, $145.68,140.72,132.93,123.74,119.51,80.99,54.46,43.17,36.55,28.41$. One $s p^{2}$ carbon could not be found likely due to chemical shift equivalence. HRMS calcd. for $\mathrm{C}_{16} \mathrm{H}_{24} \mathrm{~N}_{3} \mathrm{O}_{3}{ }^{+}[\mathrm{M}+\mathrm{H}]^{+}$: 306.1810, Found: 306.1810.

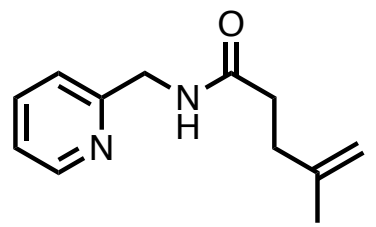

4-methyl- $\boldsymbol{N}$-(pyridin-2-ylmethyl)pent-4-enamide (1f): The title compound was prepared according to General Procedure E using 4methyl-4-penten-1-ol (4.8 mmol) as the alcohol. The crude material was purified by flash silica chromatography $60 \%$ acetone:hexanes to afford $780 \mathrm{mg}(96 \%$ yield $)$ of $\mathbf{1 f}$ as a yellowish oil. ${ }^{1} \mathbf{H} \mathbf{~ N M R}\left(600 \mathrm{MHz}, \mathrm{CDCl}_{3}\right)$ $\delta 8.61-8.42(\mathrm{~m}, 1 \mathrm{H}), 7.67(\mathrm{dq}, J=7.7,1.8 \mathrm{~Hz}, 1 \mathrm{H}), 7.27(\mathrm{~d}, J=9.2 \mathrm{~Hz}, 1 \mathrm{H}), 7.21(\mathrm{t}, J=6.6 \mathrm{~Hz}$, 1H), 6.79 (s, 1H), 4.73 (d, $J=17.6 \mathrm{~Hz}, 2 \mathrm{H}), 4.57$ (d, $J=4.9 \mathrm{~Hz}, 2 \mathrm{H}), 2.50-2.30$ (m, 4H), 1.74 (d, 
$J=13.3 \mathrm{~Hz}, 3 \mathrm{H}) \cdot{ }^{13} \mathbf{C}$ NMR $\left(151 \mathrm{MHz}, \mathrm{CDCl}_{3}\right) \delta 172.61,156.30,148.85,148.81,144.49,136.99$, $122.45,122.30,110.47,44.36,34.83,33.30,22.53$. HRMS calcd. for $\mathrm{C}_{12} \mathrm{H}_{17} \mathrm{~N}_{2} \mathrm{O}^{+}[\mathrm{M}+\mathrm{H}]^{+}$: 205.1335, Found: 205.1337.

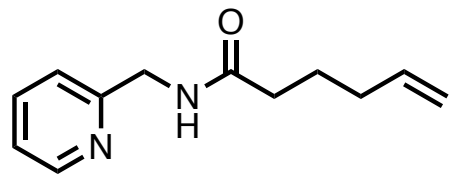

$N$-(pyridin-2-ylmethyl)hex-5-enamide (1ga): The title compound was prepared according to General Procedure D using 5-hexenoic acid $(10 \mathrm{mmol})$ as the carboxylic acid to afford $1.525 \mathrm{~g}$ (74\% yield) of 1ga as a yellowish oil. ${ }^{1} \mathbf{H}$ NMR $\left(600 \mathrm{MHz}, \mathrm{CDCl}_{3}\right) \delta 8.52-8.41$ (m, 1H), $7.60(\mathrm{tt}, J=9.5,7.7,3.4 \mathrm{~Hz}, 1 \mathrm{H}), 7.21(\mathrm{t}, J=7.5 \mathrm{~Hz}, 1 \mathrm{H}), 7.19-7.10(\mathrm{~m}, 1 \mathrm{H}), 6.95(\mathrm{~d}, J$ $=34.3 \mathrm{~Hz}, 1 \mathrm{H}), 5.72(\mathrm{ddt}, J=23.5,9.8,6.4 \mathrm{~Hz}, 1 \mathrm{H}), 5.13-4.79(\mathrm{~m}, 2 \mathrm{H}), 4.50(\mathrm{dt}, J=19.4,4.7 \mathrm{~Hz}$, 2H), $2.23(\mathrm{dt}, J=15.0,7.6 \mathrm{~Hz}, 2 \mathrm{H}), 2.05(\mathrm{dq}, J=14.3,7.3 \mathrm{~Hz}, 2 \mathrm{H}), 1.72(\mathrm{~h}, J=7.3 \mathrm{~Hz}, 2 \mathrm{H}) .{ }^{13} \mathbf{C}$ NMR $\left(151 \mathrm{MHz}, \mathrm{CDCl}_{3}\right) \delta 173.11,156.69,149.08,137.93,136.84,122.38,122.13,115.29,44.45$, 35.78, 33.19, 24.77. HRMS calcd. for $\mathrm{C}_{12} \mathrm{H}_{17} \mathrm{~N}_{2} \mathrm{O}^{+}[\mathrm{M}+\mathrm{H}]^{+}$: 205.1335, Found: 205.1335.

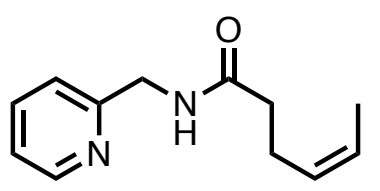

(Z)-N-(pyridin-2-ylmethyl)hex-4-enamide (1gb): The title compound was prepared according to General Procedure E using cis-4-hexen-1-ol $(4.8 \mathrm{mmol})$ as the alcohol. The crude material was purified by flash silica chromatography $60 \%$ acetone:hexanes to afford $755 \mathrm{mg}$ ( $92 \%$ yield) $\mathbf{1 g b}$ as a yellow oil. ${ }^{1} \mathbf{H}$ NMR $\left(600 \mathrm{MHz}, \mathrm{CDCl}_{3}\right) \delta 8.54(\mathrm{ddd}, J=5.0,1.8,0.9$ $\mathrm{Hz}, 1 \mathrm{H}), 7.73$ (ddt, $J=9.5,5.8,2.9 \mathrm{~Hz}, 1 \mathrm{H}), 7.36-7.31(\mathrm{~m}, 1 \mathrm{H}), 7.28-7.25(\mathrm{~m}, 1 \mathrm{H}), 6.99(\mathrm{~s}, 1 \mathrm{H})$, 5.49 (dqt, $J=10.8,6.8,1.5 \mathrm{~Hz}, 1 \mathrm{H}), 5.38(\mathrm{dtdd}, J=8.9,7.2,3.5,1.7 \mathrm{~Hz}, 1 \mathrm{H}), 4.59(\mathrm{~d}, J=5.1 \mathrm{~Hz}$, 2H), 2.42 (ddddt, $J=8.1,7.2,6.4,1.7,0.9 \mathrm{~Hz}, 2 \mathrm{H}$ ), 2.36-2.30 (m, 2H), 1.61 (ddt, $J=6.8,1.8,0.9$ $\mathrm{Hz}, 3 \mathrm{H}) .{ }^{13} \mathbf{C}$ NMR $\left(151 \mathrm{MHz}, \mathrm{CDCl}_{3}\right) \delta 172.87,156.31,148.19,138.25,128.76,125.55,122.90$, 122.81, 44.18, 36.43, 23.20, 12.95. HRMS calcd. for $\mathrm{C}_{12} \mathrm{H}_{17} \mathrm{~N}_{2} \mathrm{O}^{+}[\mathrm{M}+\mathrm{H}]^{+}:$205.1335, Found: 205.1335 .<smiles>O=C(O)/C=C\CCC(=O)NCc1ccccn1</smiles>

$(Z)-N$-(pyridin-2-ylmethyl)hex-4-enamide- $d 3$ (1gb- $\left.d_{3}\right)$ : The title compound was prepared according to General Procedure E using cis4-hexen-1-ol- $d_{3}(9.6 \mathrm{mmol})$ as the alcohol. The deuterium-labeled alcohol was prepared in a single step according to a known procedure (46). The purity of the alcohol is critical for obtaining high yield, as impurities can lead to reduced yields in the subsequent Ru-MACHO step. The crude material was purified by flash silica chromatography $60 \%$ acetone:hexanes to afford $495 \mathrm{mg}$ ( $25 \%$ yield) 1 gb$\boldsymbol{d 3}$ as a yellow oil. ${ }^{\mathbf{1}} \mathbf{H}$ NMR $\left(600 \mathrm{MHz}, \mathrm{CDCl}_{3}\right) \delta 8.53(\mathrm{~d}, J=5.0 \mathrm{~Hz}, 1 \mathrm{H}), 7.68(\mathrm{tt}, J=7.6,1.6$ $\mathrm{Hz}, 1 \mathrm{H}), 7.28(\mathrm{~d}, J=7.8 \mathrm{~Hz}, 1 \mathrm{H}), 7.24-7.18(\mathrm{~m}, 1 \mathrm{H}), 6.80(\mathrm{~s}, 1 \mathrm{H}), 5.48(\mathrm{~d}, J=11.0 \mathrm{~Hz}, 1 \mathrm{H}), 5.38$ $(\mathrm{dt}, J=10.7,7.1 \mathrm{~Hz}, 1 \mathrm{H}), 4.57(\mathrm{~d}, J=5.0 \mathrm{~Hz}, 2 \mathrm{H}), 2.42(\mathrm{q}, J=7.3 \mathrm{~Hz}, 2 \mathrm{H}), 2.33$ (t, $J=7.5 \mathrm{~Hz}$, 2H). ${ }^{13} \mathbf{C}$ NMR $\left(151 \mathrm{MHz}, \mathrm{CDCl}_{3}\right) \delta 172.82(\mathrm{~d}, J=3.9 \mathrm{~Hz}), 156.46(\mathrm{~d}, J=2.6 \mathrm{~Hz}), 148.60(\mathrm{~d}, J=$ $5.2 \mathrm{~Hz}), 137.22(\mathrm{~d}, J=4.4 \mathrm{~Hz}), 128.69,125.33,122.51,122.43$, 44.34, 36.30, 36.29, 23.11. HRMS calcd. for $\mathrm{C}_{12} \mathrm{H}_{14} \mathrm{D}_{3} \mathrm{~N}_{2} \mathrm{O}^{+}[\mathrm{M}+\mathrm{H}]^{+}:$208.1524, Found: 208.1524 .

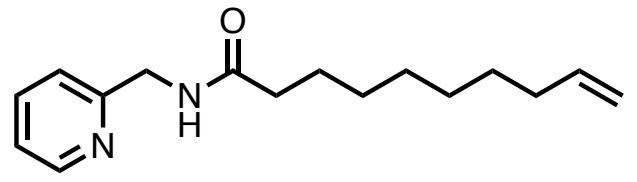

$N$-(pyridin-2-ylmethyl)dec-9-enamide (1ha): The title compound was prepared according to General Procedure D using 9-decenoic acid $(10 \mathrm{mmol})$ as the carboxylic acid to afford $1.553 \mathrm{~g} \mathrm{(60 \%} \mathrm{yield)} \mathrm{of} \mathbf{1 h a}$ as a pale-yellow oil. ${ }^{1}$ H NMR $\left(600 \mathrm{MHz}, d_{6}\right.$-DMSO) $\delta 8.49(\mathrm{dt}, J=4.4,1.7 \mathrm{~Hz}, 1 \mathrm{H}), 8.38(\mathrm{t}, J=6.0 \mathrm{~Hz}, 1 \mathrm{H}), 7.75(\mathrm{td}$, $J=7.7,1.8 \mathrm{~Hz}, 1 \mathrm{H}), 7.26$ (dd, $J=7.6,4.4 \mathrm{~Hz}, 2 \mathrm{H}), 5.80$ (ddt, $J=17.0,10.2,6.7 \mathrm{~Hz}, 1 \mathrm{H}), 5.10$ 
$4.87(\mathrm{~m}, 2 \mathrm{H}), 4.34(\mathrm{~d}, J=6.0 \mathrm{~Hz}, 2 \mathrm{H}), 2.17(\mathrm{t}, J=7.4 \mathrm{~Hz}, 2 \mathrm{H}), 2.02(\mathrm{tdd}, J=8.0,6.0,1.5 \mathrm{~Hz}, 2 \mathrm{H})$, $1.53(\mathrm{p}, J=7.2 \mathrm{~Hz}, 2 \mathrm{H}), 1.34(\mathrm{p}, J=7.0 \mathrm{~Hz}, 2 \mathrm{H}), 1.26(\mathrm{~h}, J=6.0,5.0 \mathrm{~Hz}, 8 \mathrm{H}) .{ }^{13} \mathbf{C}$ NMR $(151$ $\mathrm{MHz}, d_{6}$-DMSO) $\delta 172.32,158.89,148.77,138.82,136.63,122.00,120.85,114.65,44.09,35.28$, 33.16, 28.62, 28.57, 28.41, 28.21, 25.24. HRMS calcd. for $\mathrm{C}_{16} \mathrm{H}_{25} \mathrm{~N}_{2} \mathrm{O}^{+}[\mathrm{M}+\mathrm{H}]^{+}: 261.1961$, Found: 261.1961 .

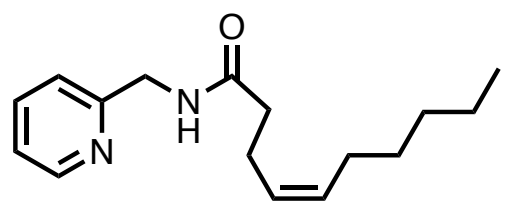

(Z)-N-(pyridin-2-ylmethyl)dec-4-enamide (1hb): The title compound was prepared according to General Procedure E using cis-4-decen-1-ol $(4.8 \mathrm{mmol})$ as the alcohol. The crude material was purified by flash silica chromatography $60 \%$ acetone:hexanes to afford $900 \mathrm{mg}$ (86\% yield) of $\mathbf{1 h b}$ as a yellow oil. ${ }^{\mathbf{1}} \mathbf{H}$ NMR $\left(600 \mathrm{MHz}, \mathrm{CDCl}_{3}\right) \delta 8.54(\mathrm{~d}, J=4.9 \mathrm{~Hz}, 1 \mathrm{H}), 7.70(\mathrm{td}, J=7.7,1.8 \mathrm{~Hz}, 1 \mathrm{H}), 7.30(\mathrm{~d}, J=7.8 \mathrm{~Hz}$, $1 \mathrm{H}), 7.23(\mathrm{dd}, J=7.4,5.0 \mathrm{~Hz}, 1 \mathrm{H}), 6.81(\mathrm{~s}, 1 \mathrm{H}), 5.52-5.25(\mathrm{~m}, 2 \mathrm{H}), 4.57(\mathrm{~d}, J=5.0 \mathrm{~Hz}, 2 \mathrm{H})$, 2.45-2.28 (m, 4H), $2.03(\mathrm{q}, J=7.3 \mathrm{~Hz}, 2 \mathrm{H}), 1.38-1.21(\mathrm{~m}, 6 \mathrm{H}), 0.87(\mathrm{t}, J=6.9 \mathrm{~Hz}, 3 \mathrm{H}) .{ }^{13} \mathbf{C} \mathbf{N M R}$ $\left(151 \mathrm{MHz}, \mathrm{CDCl}_{3}\right) \delta 172.82,156.41,148.62,137.46,131.78,127.74,122.68,122.66,44.36,36.71$, 31.64, 29.46, 27.34, 23.59, 22.71, 14.20. HRMS calcd. for $\mathrm{C}_{16} \mathrm{H}_{25} \mathrm{~N}_{2} \mathrm{O}^{+}[\mathrm{M}+\mathrm{H}]^{+}: 261.1961$, Found: 261.1962 .

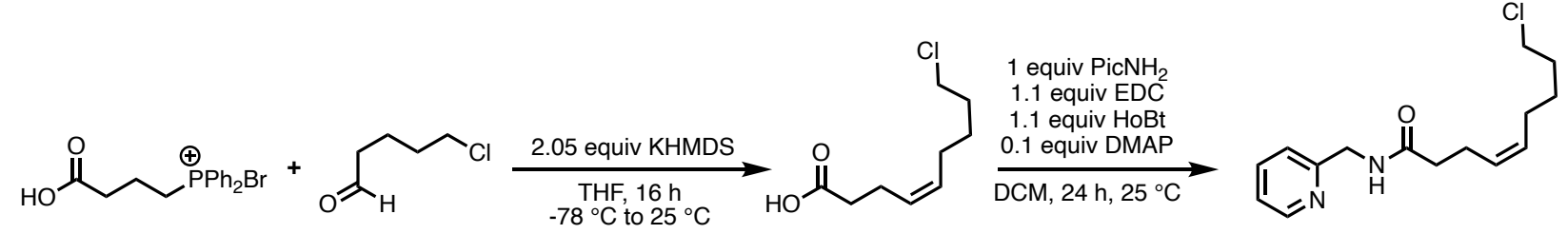

(Z)-9-chloro- $N$-(pyridin-2-ylmethyl)non-4-enamide (1i): The title compound was prepared via a 2-step sequence consisting of a Wittig reaction followed by amide coupling.

Step 1) Phosphonium salt (4.3 g, $10 \mathrm{mmol}, 1$ equiv) was suspended in THF (10 mL) and cooled to $0{ }^{\circ} \mathrm{C}$. A solution of KHMDS in THF (20.5 mL, 1 M, 2.05 equiv) was added dropwise. The mixture was stirred for $1 \mathrm{~h}$ until an orange suspension formed. The mixture was then further cooled to $-78{ }^{\circ} \mathrm{C}$, and 5-chloropentanal (1.21 g, $10 \mathrm{mmol}, 1$ equiv) was added over $20 \mathrm{~min}$. After addition was complete, the reaction was gradually warmed to room temperature and stirred overnight. The solvent was removed under reduced pressure. The residue was dissolved in water and washed with diethyl ether $(\times 2)$. The orange organic layer was discarded, while the aqueous layer was acidified with $2 \mathrm{M} \mathrm{HCl}$ until $\mathrm{pH}=1$. The aqueous layer was extracted with ethyl acetate $(\times 3)$, and the combined organic layers were dried over anhydrous $\mathrm{MgSO}_{4}$. The solvent was removed in vacuo, and the resulting crude product was carried on to the next step without further purification $(\sim 58 \%$ yield $)$.

Step 2) In a 50-mL round-bottomed flask with Teflon-coated magnetic stir bar, the crude acid was dissolved in DCM (6 mL), then DMAP (70 mg, $0.57 \mathrm{mmol}, 0.1$ equiv), HoBt (971 mg, $6.1 \mathrm{mmol}, 1.1$ equiv), and EDC (1.21 g, $6.1 \mathrm{mmol}, 1.1$ equiv) were added. 2-Picoyl amine (623 $\mathrm{mg}, 5.8 \mathrm{mmol}, 1$ equiv) was added dropwise by syringe and the reaction mixture was allowed to stir for $24 \mathrm{~h}$, at which point it was diluted with DCM (3 mL) and quenched with a saturated solution of aq. $\mathrm{NaHCO}_{3}(3 \mathrm{~mL})$. The aqueous layer was extracted with $\mathrm{DCM}(\times 3)$, and the organic layers were combined, washed with water and brine, dried with $\mathrm{MgSO}_{4}$, filtered, and evaporated to dryness. The crude material was purified by flash silica chromatography using 55\% acetone:hexanes to afford $976 \mathrm{mg}(60 \%$ yield) of $\mathbf{1 i}$ as a white solid. The product was obtained as an $E / Z$ mixture and directly used for the catalytic reaction. The data listed below corresponds to the major $(Z)$ isomer of the alkene. ${ }^{1} \mathbf{H}$ NMR $\left(600 \mathrm{MHz}, \mathrm{CDCl}_{3}\right) \delta 8.54(\mathrm{ddd}, J=5.0,1.8,1.0 \mathrm{~Hz}$, $1 \mathrm{H}), 7.70(\mathrm{td}, J=9.2,8.3,2.6 \mathrm{~Hz}, 1 \mathrm{H}), 7.32-7.27(\mathrm{~m}, 1 \mathrm{H}), 7.25-7.20(\mathrm{~m}, 1 \mathrm{H}), 6.82(\mathrm{~s}, 1 \mathrm{H}), 5.48-$ 
$5.34(\mathrm{~m}, 2 \mathrm{H}), 4.57(\mathrm{~d}, J=5.0 \mathrm{~Hz}, 2 \mathrm{H}), 3.54-3.45(\mathrm{~m}, 2 \mathrm{H}), 2.45-2.38(\mathrm{~m}, 2 \mathrm{H}), 2.38-2.29(\mathrm{~m}, 2 \mathrm{H})$, 2.08 (td, $J=7.5,5.8 \mathrm{~Hz}, 2 \mathrm{H}), 2.05-1.93(\mathrm{~m}, 3 \mathrm{H}), 1.84-1.66(\mathrm{~m}, 2 \mathrm{H}), 1.48(\mathrm{dq}, J=9.8,7.5 \mathrm{~Hz}$, 2H). ${ }^{13} \mathbf{C ~ N M R ~}\left(151 \mathrm{MHz}, \mathrm{CDCl}_{3}\right) \delta 172.16,156.34,148.70,137.68,130.72,128.57,122.68$, 122.62, 45.13, 44.37, 36.58, 32.26, 26.95, 26.55, 23.59. HRMS calcd. for $\mathrm{C}_{15} \mathrm{H}_{22} \mathrm{ClN}_{2} \mathrm{O}^{+}[\mathrm{M}+\mathrm{H}]^{+}$: 281.1415 , Found: 281.1415.

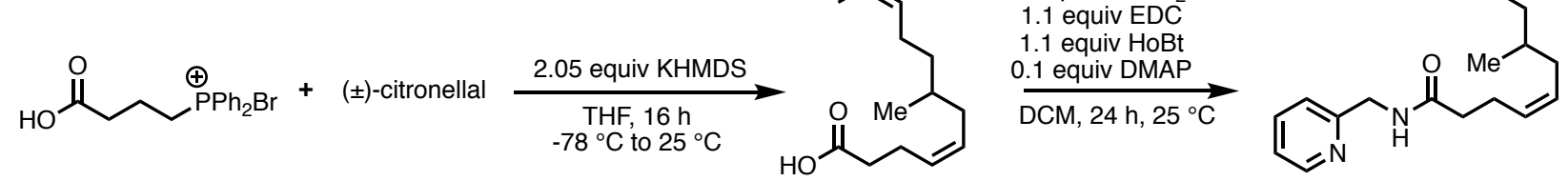

(Z)-7,11-dimethyl- $N$-(pyridin-2-ylmethyl)dodeca-4,10-dienamide (1j): The title compound was prepared via a 2-step sequence consisting of a Wittig reaction followed by amide coupling.

Step 1) Phosphonium salt (4.3 g, $10 \mathrm{mmol}, 1$ equiv) was suspended in THF (10 mL) and cooled to $0{ }^{\circ} \mathrm{C}$. A solution of KHMDS in THF (20.5 mL, 1 M, 2.05 equiv) was added dropwise. The mixture was stirred for $1 \mathrm{~h}$ until an orange suspension formed. The mixture was then further cooled to $-78{ }^{\circ} \mathrm{C}$, and $( \pm)$-citronellal $(1.543 \mathrm{~g}, 10 \mathrm{mmol}, 1$ equiv) was added over $20 \mathrm{~min}$. After addition was complete, the reaction was gradually warmed to room temperature and stirred overnight. The solvent was removed under reduced pressure. The residue was dissolved in water and washed with diethyl ether $(\times 2)$. The orange organic layer was discarded, while the aqueous layer was acidified with $2 \mathrm{M} \mathrm{HCl}$ until $\mathrm{pH}=1$. The aqueous layer was extracted with ethyl acetate $(\times 3)$, and the combined organic layers were dried over anhydrous $\mathrm{MgSO}_{4}$. The solvent was removed in vacuo, and the resulting crude product was carried on to the next step without further purification $(\sim 35 \%$ yield $)$.

Step 2) In a 50-mL round-bottomed flask with Teflon-coated magnetic stir bar, the crude acid was dissolved in DCM (4 mL), and DMAP (32 mg, $0.27 \mathrm{mmol}, 0.1$ equiv), HoBt (450 mg, $2.9 \mathrm{mmol}, 1.1$ equiv), and EDC (564 mg, $2.9 \mathrm{mmol}, 1.1$ equiv) were added. 2-Picoyl amine (289 $\mathrm{mg}, 5.8 \mathrm{mmol}, 1$ equiv) was added dropwise by syringe, and the reaction mixture was allowed to stir for $24 \mathrm{~h}$, at which point it was diluted with DCM (3 mL) and quenched with a saturated solution of aq. $\mathrm{NaHCO}_{3}(3 \mathrm{~mL})$. The aqueous layer was extracted with $\mathrm{DCM}(\times 3)$, and the organic layers were combined, washed with water and brine, dried over $\mathrm{MgSO}_{4}$, filtered, and evaporated to dryness. The crude material was purified by flash silica chromatography using 55\% acetone:hexanes to afford $655 \mathrm{mg}(78 \%$ yield $)$ of $\mathbf{1 j}$ as a white solid. ${ }^{\mathbf{1}} \mathbf{H} \mathbf{~ N M R}\left(400 \mathrm{MHz}, \mathrm{CDCl}_{3}\right)$ $\delta 8.54(\mathrm{dt}, J=4.8,1.4 \mathrm{~Hz}, 1 \mathrm{H}), 7.70(\mathrm{td}, J=7.7,1.8 \mathrm{~Hz}, 1 \mathrm{H}), 7.30(\mathrm{~d}, J=7.9 \mathrm{~Hz}, 1 \mathrm{H}), 7.25-7.20$ $(\mathrm{m}, 1 \mathrm{H}), 6.79(\mathrm{~s}, 1 \mathrm{H}), 5.44-5.38(\mathrm{~m}, 2 \mathrm{H}), 5.08(\mathrm{tdd}, J=7.2,3.0,1.6 \mathrm{~Hz}, 1 \mathrm{H}), 4.58(\mathrm{~d}, J=5.0 \mathrm{~Hz}$, 2H), 2.56-2.27 (m, 4H), $1.96(\mathrm{dtd}, J=41.7,14.2,7.5 \mathrm{~Hz}, 4 \mathrm{H}), 1.67(\mathrm{~d}, J=1.5 \mathrm{~Hz}, 3 \mathrm{H}), 1.59$ (s, 3H), 1.51-1.07 (m, 3H), 0.90-0.79 (m, 3H). ${ }^{13} \mathbf{C}$ NMR (101 MHz, $\left.\mathrm{CDCl}_{3}\right) \delta 172.77,137.46$, 131.27, 130.24, 128.59, 124.99, 122.68, 122.60, 36.87, 36.65, 34.59, 33.09, 25.86, 25.81, 23.70, 19.59, 17.80. HRMS calcd. for $\mathrm{C}_{20} \mathrm{H}_{31} \mathrm{~N}_{2} \mathrm{O}^{+}[\mathrm{M}+\mathrm{H}]^{+}: 315.2431$, Found: 315.2432

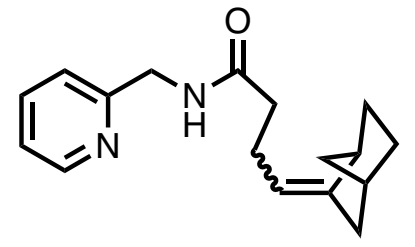

(Z)-4-(bicyclo[2.2.1]heptan-2-ylidene)- $N$-(pyridin-2ylmethyl)butanamide (1k): The title compound was prepared according to General Procedure D using (Z)-4-(bicyclo[2.2.1]heptan-2ylidene)butanoic acid (44) $(0.44 \mathrm{mmol})$ as the carboxylic acid to afford $98 \mathrm{mg}(82 \%$ yield $)$ of $1 \mathbf{k}$ as a yellow solid. ${ }^{1} \mathbf{H} \mathbf{~ N M R}\left(600 \mathrm{MHz}, \mathrm{CDCl}_{3}\right)$ $\delta 8.59-8.47(\mathrm{~m}, 1 \mathrm{H}), 7.65(\mathrm{dd}, J=7.7,1.7 \mathrm{~Hz}, 1 \mathrm{H}), 7.28-7.25(\mathrm{~m}, 1 \mathrm{H})$,

$7.20(\mathrm{ddd}, J=7.7,4.9,1.2 \mathrm{~Hz}, 1 \mathrm{H}), 6.72(\mathrm{~s}, 1 \mathrm{H})$, [mixture of $E / Z$ vinyl protons, total of $1 \mathrm{H}, 5.17$ 
$(\mathrm{tt}, J=6.3,2.7 \mathrm{~Hz})$ and $4.98(\mathrm{t}, J=7.4 \mathrm{~Hz}) 1 \mathrm{H}$ ], $4.56(\mathrm{t}, J=5.2 \mathrm{~Hz}, 2 \mathrm{H})$, [mixture of $E / Z$ allyl protons, total of $1 \mathrm{H}, 2.98-2.89(\mathrm{~m}), 2.61-2.55(\mathrm{~m}) 1 \mathrm{H}], 2.47-2.36(\mathrm{~m}, 1 \mathrm{H}), 2.36-2.21(\mathrm{~m}, 4 \mathrm{H})$, 2.16-2.05 (m, 1H), $1.81(\mathrm{dd}, J=15.6,5.4 \mathrm{~Hz}, 1 \mathrm{H}), 1.63-1.48(\mathrm{~m}, 2 \mathrm{H}), 1.32-1.11(\mathrm{~m}, 4 \mathrm{H}) .{ }^{13} \mathbf{C}$ NMR (151 MHz, $\mathrm{CDCl}_{3}$ ) (Carbon peaks listed below correspond to a mixture of $E$ and $Z$ isomers.) $\delta 173.05,156.65,149.10,147.98,147.18,136.94,122.49,122.31,115.91,115.16,45.43,44.59$, $40.28,39.23,39.21,38.98,37.33,36.74,36.60,36.36,35.85,29.99,29.50,28.72,28.51,25.71$, 25.10.HRMS calcd. for $\mathrm{C}_{17} \mathrm{H}_{23} \mathrm{~N}_{2} \mathrm{O}^{+}[\mathrm{M}+\mathrm{H}]^{+}: 271.1805$, Found: 271.1804 .

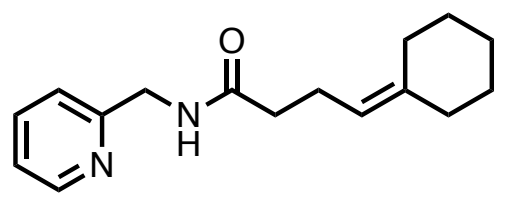

4-cyclohexylidene- $N$-(pyridin-2-ylmethyl)butanamide (11): The title compound was prepared according to General Procedure D using 4-cyclohexylidenebutanoic acid (44) $(0.45 \mathrm{mmol})$ as the carboxylic acid to afford $90 \mathrm{mg}(78 \%$ yield) of 11 as a yellow oil. ${ }^{1} \mathbf{H}$ NMR $\left(600 \mathrm{MHz}, \mathrm{CDCl}_{3}\right) \delta 8.54(\mathrm{ddd}, J=5.0,1.9,1.0 \mathrm{~Hz}, 1 \mathrm{H})$, $7.67(\mathrm{td}, J=7.7,1.8 \mathrm{~Hz}, 1 \mathrm{H}), 7.29-7.26(\mathrm{~m}, 1 \mathrm{H}), 7.21$ (dddd, $J=6.9,4.5,1.2,0.6 \mathrm{~Hz}, 1 \mathrm{H}), 6.73$ (s, 1H), 5.07 (ddt, $J=8.5,7.2,1.2 \mathrm{~Hz}, 1 \mathrm{H}), 4.56(\mathrm{~d}, J=5.0 \mathrm{~Hz}, 2 \mathrm{H}), 2.42-2.34(\mathrm{~m}, 2 \mathrm{H}), 2.30$ (ddd, $J=8.2,6.7,1.3 \mathrm{~Hz}, 2 \mathrm{H}), 2.15-2.10(\mathrm{~m}, 2 \mathrm{H}), 2.08-2.01(\mathrm{~m}, 2 \mathrm{H}), 1.49(\mathrm{dpd}, J=17.6,5.6,5.0,2.6$ $\mathrm{Hz}, 6 \mathrm{H}) .{ }^{13} \mathbf{C} \mathbf{N M R}\left(151 \mathrm{MHz}, \mathrm{CDCl}_{3}\right) \delta 172.98,156.62,149.01,141.51,137.06,122.54,122.40$, 119.48, 44.56, 37.25, 37.23, 28.83, 28.71, 27.94, 27.00, 23.54. HRMS calcd. for $\mathrm{C}_{16} \mathrm{H}_{23} \mathrm{~N}_{2} \mathrm{O}^{+}[\mathrm{M}+\mathrm{H}]^{+}:$259.1805, Found: 259.1804 .

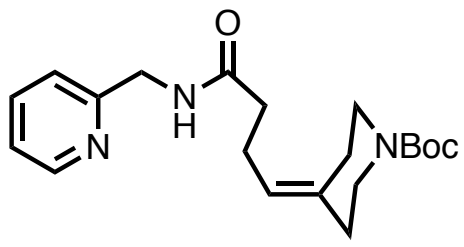

tert-butyl 4-(4-oxo-4-((pyridin-2-ylmethyl)amino)butylidene) piperidine-1-carboxylate (1m): The title compound was prepared according to General Procedure D using 4-(1-(tertbutoxycarbonyl)piperidin-4-ylidene)butanoic acid (44) $\quad(0.557$ mmol) as the carboxylic acid to afford $127 \mathrm{mg}$ (64\% yield) of $1 \mathrm{~m}$ as a yellow solid. ${ }^{1} \mathbf{H}$ NMR $\left(600 \mathrm{MHz}, \mathrm{CDCl}_{3}\right) \delta 8.53(\mathrm{ddd}, J=4.8$, $1.8,0.9 \mathrm{~Hz}, 1 \mathrm{H}), 7.66(\mathrm{td}, J=7.7,1.8 \mathrm{~Hz}, 1 \mathrm{H}), 7.26(\mathrm{~m}, 1 \mathrm{H}), 7.20$ (dddt, $J=7.4,5.0,1.3,0.6 \mathrm{~Hz}$, $1 \mathrm{H}), 6.74(\mathrm{~s}, 1 \mathrm{H}), 5.21(\mathrm{t}, J=7.2 \mathrm{~Hz}, 1 \mathrm{H}), 4.55(\mathrm{~d}, J=4.9 \mathrm{~Hz}, 2 \mathrm{H}), 3.35(\mathrm{t}, J=5.9 \mathrm{~Hz}, 4 \mathrm{H}), 2.40$ $(\mathrm{q}, J=7.3 \mathrm{~Hz}, 2 \mathrm{H}), 2.36-2.28(\mathrm{~m}, 2 \mathrm{H}), 2.21(\mathrm{~s}, 2 \mathrm{H}), 2.11(\mathrm{~d}, J=6.2 \mathrm{~Hz}, 2 \mathrm{H}), 1.46(\mathrm{~s}, 9 \mathrm{H}) .{ }^{13} \mathrm{C}$ NMR $\left(151 \mathrm{MHz}, \mathrm{CDCl}_{3}\right) \delta 172.58,156.40,154.93,149.08,137.01,122.59,122.38,122.23,81.58$, 48.59, 44.53, 38.76, 36.90, 29.77, 23.47. HRMS calcd. for $\mathrm{C}_{20} \mathrm{H}_{30} \mathrm{~N}_{3} \mathrm{O}_{3}{ }^{+}[\mathrm{M}+\mathrm{H}]^{+} 360.2282$ : Found: 360.2281 .

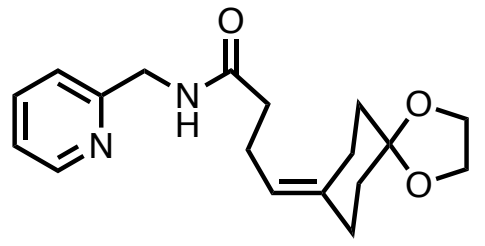

(Z)-N-(pyridin-2-ylmethyl)-4-(1,4-dioxaspiro[4.5]decan-7ylidene)butanamide (1n): The title compound was prepared according to General Procedure D using 4-(1,4dioxaspiro[4.5]decan-8-ylidene)butanoic acid (44) $(0.883 \mathrm{mmol})$ as the carboxylic acid to afford $193 \mathrm{mg}(69 \%$ yield) of $\mathbf{1 n}$ as a white solid. ${ }^{1} \mathbf{H}$ NMR $\left(600 \mathrm{MHz}, \mathrm{CDCl}_{3}\right) \delta 8.57(\mathrm{~d}, J=5.0 \mathrm{~Hz}, 1 \mathrm{H}), 7.76$ $(\mathrm{td}, J=7.7,1.8 \mathrm{~Hz}, 1 \mathrm{H}), 7.36(\mathrm{~d}, J=7.8 \mathrm{~Hz}, 1 \mathrm{H}), 7.29(\mathrm{~d}, J=7.7 \mathrm{~Hz}, 1 \mathrm{H}), 6.89(\mathrm{~s}, 1 \mathrm{H}), 5.17(\mathrm{t}, J$ $=7.3 \mathrm{~Hz}, 1 \mathrm{H}), 4.61(\mathrm{~d}, J=5.1 \mathrm{~Hz}, 2 \mathrm{H}), 3.98(\mathrm{~s}, 4 \mathrm{H}), 2.41(\mathrm{q}, J=7.4 \mathrm{~Hz}, 2 \mathrm{H}), 2.32(\mathrm{dt}, J=18.2$, $6.9 \mathrm{~Hz}, 4 \mathrm{H}), 2.23(\mathrm{t}, J=6.5 \mathrm{~Hz}, 2 \mathrm{H}), 1.66(\mathrm{q}, J=7.0 \mathrm{~Hz}, 4 \mathrm{H}) \cdot{ }^{13} \mathbf{C} \mathbf{N M R}\left(151 \mathrm{MHz}, \mathrm{CDCl}_{3}\right) \delta$ $172.88,156.25,148.25,138.56,137.90,122.92,122.83,121.09,109.09,64.43,44.16,36.98,36.30$, 35.53, 33.63, 25.20, 23.80.HRMS calcd. for $\mathrm{C}_{18} \mathrm{H}_{25} \mathrm{~N}_{2} \mathrm{O}_{3}{ }^{+}[\mathrm{M}+\mathrm{H}]^{+}: 317.1860$, Found: 317.1860 . 


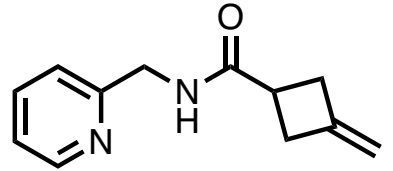

3-methylene- $\mathrm{N}$-(pyridin-2-ylmethyl)cyclobutane-1-carboxamide (10): The title compound was prepared according General Procedure D using 3-exo cyclobutene-1-carboxylic acid $(5.35 \mathrm{mmol})$ as the carboxylic acid to afford $625 \mathrm{mg}(74 \%$ yield $)$ of 10 as a white solid. ${ }^{1} \mathbf{H}$ NMR $\left(600 \mathrm{MHz}, \mathrm{CDCl}_{3}\right) \delta 8.60-8.50(\mathrm{~m}, 1 \mathrm{H}), 7.78(\mathrm{td}, J=7.7,1.8 \mathrm{~Hz}$, 1H), $7.39(\mathrm{~d}, J=7.8 \mathrm{~Hz}, 1 \mathrm{H}), 7.31(\mathrm{dd}, J=7.5,5.0 \mathrm{~Hz}, 1 \mathrm{H}), 6.95(\mathrm{~d}, J=18.8 \mathrm{~Hz}, 1 \mathrm{H}), 4.80(\mathrm{p}, J$ $=2.4 \mathrm{~Hz}, 2 \mathrm{H}), 4.62(\mathrm{~d}, J=5.2 \mathrm{~Hz}, 2 \mathrm{H}), 3.10-2.97(\mathrm{~m}, 3 \mathrm{H}), 2.88$ (ddt, $J=12.8,8.5,2.4 \mathrm{~Hz}, 2 \mathrm{H})$. ${ }^{13}$ C NMR $\left(151 \mathrm{MHz}, \mathrm{CDCl}_{3}\right) \delta 174.74,156.05,147.68,144.61,138.52,123.29,123.05,106.59$, 43.93, 35.69, 34.90. HRMS calcd. for $\mathrm{C}_{12} \mathrm{H}_{15} \mathrm{~N}_{2} \mathrm{O}^{+}[\mathrm{M}+\mathrm{H}]^{+}:$203.1179, Found: 203.1180.

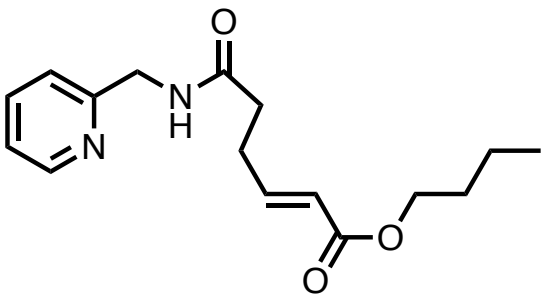

butyl (E)-6-0xo-6-((pyridin-2-ylmethyl)amino)hex-2-enoate (1p): The title compound was synthesized via cross-metathesis between compound 1a and $n$-butyl acrylate. In an argon-filled glovebox, compound $1 \mathbf{a}$ (250 mg, $1.3 \mathrm{mmol}, 1$ equiv), DCM $(10 \mathrm{~mL})$, Grubbs $2^{\text {nd }}$ generation catalyst $(55 \mathrm{mg}, 0.065 \mathrm{mmol}$, 0.05 equiv) and butyl acrylate $(1.32 \mathrm{~mL}, 9.1 \mathrm{mmol}, 7$ equiv) were added in that order to a $50-\mathrm{mL}$ round-bottomed flask. A reflux condenser was attached inside the glovebox, and the system was sealed and removed from the glovebox. The flask was then attached to a steady flow of $\mathrm{N}_{2}$ and placed in a preheated oil bath and brought to reflux for $16 \mathrm{~h}$. The flask was removed, and the solvent was evaporated to dryness. The crude material was purified by flash silica chromatography $50 \%$ acetone:hexanes to afford $108 \mathrm{mg}$ ( $28 \%$ yield, $>10: 1 \mathrm{E} / Z)$ of $1 \mathbf{p}$ as a colorless oil. The data below correspond to the $E$ isomer: ${ }^{1}$ H NMR $\left(600 \mathrm{MHz}, \mathrm{CDCl}_{3}\right) \delta 8.52(\mathrm{~d}, J=5.0 \mathrm{~Hz}, 1 \mathrm{H}), 7.67(\mathrm{td}, J=7.6,1.7 \mathrm{~Hz}, 1 \mathrm{H}), 7.27(\mathrm{~s}$, $1 \mathrm{H}), 7.21(\mathrm{dd}, J=7.5,4.9 \mathrm{~Hz}, 1 \mathrm{H}), 6.97(\mathrm{~s}, 1 \mathrm{H}), 6.94(\mathrm{dt}, J=15.7,6.8 \mathrm{~Hz}, 1 \mathrm{H}), 5.84(\mathrm{~d}, J=15.7$ $\mathrm{Hz}, 1 \mathrm{H}), 4.55(\mathrm{~d}, J=4.9 \mathrm{~Hz}, 2 \mathrm{H}), 4.09(\mathrm{t}, J=6.7 \mathrm{~Hz}, 2 \mathrm{H}), 2.64-2.52$ (m, 2H), 2.42 (dd, $J=8.4$, $6.6 \mathrm{~Hz}, 2 \mathrm{H}), 1.67-1.51(\mathrm{~m}, 2 \mathrm{H}), 1.41-1.30(\mathrm{~m}, 2 \mathrm{H}), 0.91(\mathrm{t}, J=7.4 \mathrm{~Hz}, 3 \mathrm{H}) .{ }^{13} \mathbf{C} \mathbf{N M R}(151 \mathrm{MHz}$, $\left.\mathrm{CDCl}_{3}\right) \delta 171.52,166.63,156.18,148.78,147.12,137.26,122.64,122.48,122.29,64.26,44.39$, $34.60,30.79,27.95,19.25,13.82$. HRMS calcd. for $\mathrm{C}_{16} \mathrm{H}_{23} \mathrm{~N}_{2} \mathrm{O}_{3}{ }^{+}[\mathrm{M}+\mathrm{H}]^{+}:$291.1703, Found: 291.1704 .

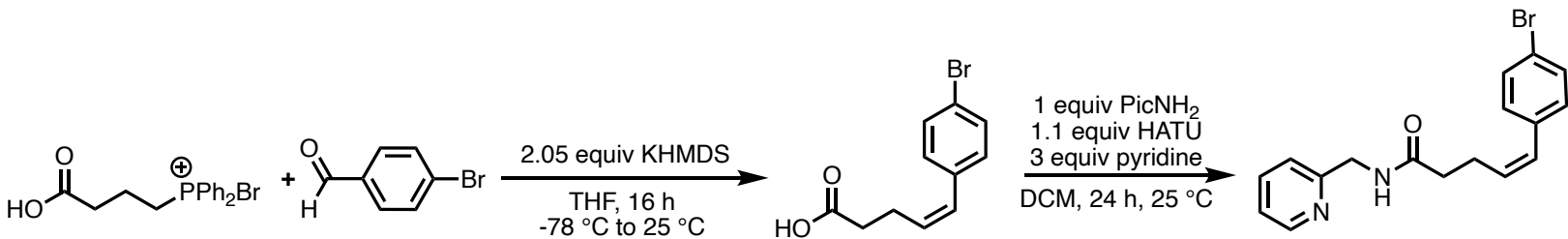

(Z)-5-(4-bromophenyl)- $N$-(pyridin-2-ylmethyl)pent-4-enamide (1q): The title compound was prepared via a 2 -step sequence consisting of a Wittig reaction followed by amide coupling.

Step 1) Phosphonium salt (0.50 g, $1.1 \mathrm{mmol}, 1$ equiv) was suspended in THF (1 mL) and cooled to $0{ }^{\circ} \mathrm{C}$. A solution of KHMDS in THF (1.1 mL, $2 \mathrm{M}, 2.05$ equiv) was added dropwise. The mixture was stirred for $1 \mathrm{~h}$ until an orange suspension formed. The mixture was then further cooled to $-78{ }^{\circ} \mathrm{C}$, and 3-bromobenzaldehyde $(215 \mathrm{mg}, 1.1 \mathrm{mmol}, 1$ equiv) was added over $20 \mathrm{~min}$. After addition was complete, the reaction was gradually warmed to room temperature and stirred overnight. The solvent was removed under reduced pressure. The residue was dissolved in water and washed with diethyl ether $(\times 2)$. The orange organic layer was discarded, while the aqueous layer was acidified with $2 \mathrm{M} \mathrm{HCl}$ until $\mathrm{pH}=1$. The aqueous layer was extracted with ethyl acetate $(\times 3)$, and the combined organic layers were dried over anhydrous $\mathrm{MgSO}_{4}$. The solvent was removed in vacuo, and the resulting crude product was carried on to the next step without further purification ( $\sim 74 \%$ yield). 
Step 2) In a $50 \mathrm{~mL}$ round bottomed flask with Teflon coated magnetic stir bar, the crude acid was dissolved in DCM (2 mL), then pyridine ( $0.22 \mathrm{~mL}, 2.7 \mathrm{mmol}, 3$ equiv) and HATU (386 $\mathrm{mg}, 1 \mathrm{mmol}, 1.1$ equiv) were added. 2-picoyl amine (71 $\mathrm{mg}, .9 \mathrm{mmol}, 1$ equiv) was added dropwise by syringe and the reaction was allowed to stir for $24 \mathrm{~h}$ then diluted with DCM ( $3 \mathrm{~mL})$ and quenched with a saturated solution of aq. $\mathrm{NaHCO}_{3}(3 \mathrm{~mL})$. The aqueous layer was extracted with DCM $(\times 3)$ and the organic layers combined, washed with water then brine, and then dried over $\mathrm{MgSO}_{4}$, filtered and evaporated to dryness. The crude material was purified by flash silica chromatography using 55\% acetone:hexanes to elute the product to afford $155 \mathrm{mg}$ (70\% yield) of $1 q$ as a brown oil. ${ }^{1} \mathbf{H}$ NMR $\left(400 \mathrm{MHz}, \mathrm{CDCl}_{3}\right) \delta 8.41(\mathrm{~d}, J=4.9 \mathrm{~Hz}, 1 \mathrm{H}), 7.54(\mathrm{td}, J=7.6,1.7$ $\mathrm{Hz}, 1 \mathrm{H}), 7.31(\mathrm{~d}, J=8.1 \mathrm{~Hz}, 2 \mathrm{H}), 7.23-7.13(\mathrm{~m}, 1 \mathrm{H}), 7.09(\mathrm{~d}, J=8.1 \mathrm{~Hz}, 3 \mathrm{H}), 6.78(\mathrm{~s}, 1 \mathrm{H}), 6.30$ $(\mathrm{d}, J=15.8 \mathrm{~Hz}, 1 \mathrm{H}), 6.14(\mathrm{dt}, J=15.8,6.7 \mathrm{~Hz}, 1 \mathrm{H}), 4.49(\mathrm{~d}, J=4.9 \mathrm{~Hz}, 2 \mathrm{H}), 2.51(\mathrm{q}, J=7.1 \mathrm{~Hz}$, 2H), $2.38(\mathrm{t}, J=7.3 \mathrm{~Hz}, 2 \mathrm{H}) .{ }^{13} \mathbf{C}$ NMR $\left(101 \mathrm{MHz}, \mathrm{CDCl}_{3}\right) \delta 172.22,156.36,149.03,136.96$, 136.45, 131.65, 130.01, 129.80, 127.73, 122.53, 122.29, 120.86, 44.51, 36.17, 29.05. HRMS calcd. for $\mathrm{C}_{17} \mathrm{H}_{18} \mathrm{BrN}_{2} \mathrm{O}^{+}[\mathrm{M}+\mathrm{H}]^{+}:$345.0587, Found: 345.0587

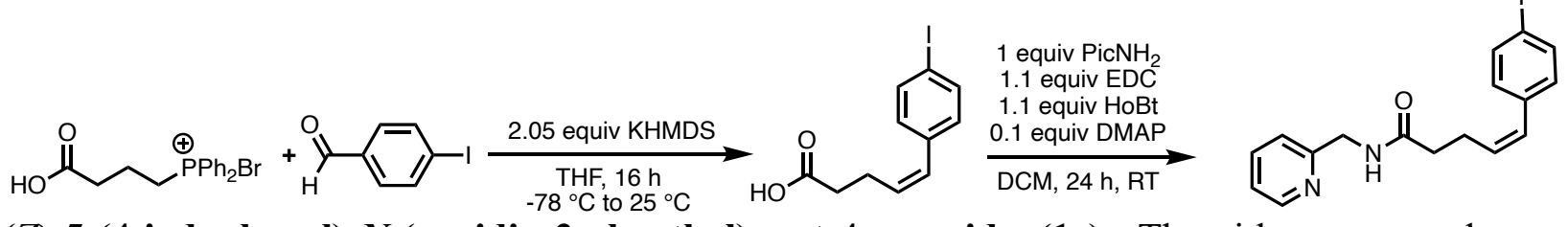

(Z)-5-(4-iodophenyl)- $N$-(pyridin-2-ylmethyl)pent-4-enamide (1r): The title compound was prepared via a 2 -step sequence consisting of a Wittig reaction followed by amide coupling.

Step 1) Phosphonium salt (2.0 g, $4.6 \mathrm{mmol}, 1$ equiv) was suspended in THF (5 mL) and cooled to $0{ }^{\circ} \mathrm{C}$. A solution of KHMDS in THF $(9.55 \mathrm{~mL}, 1 \mathrm{M}, 2.05$ equiv) was added dropwise. The mixture was stirred for $1 \mathrm{~h}$ until an orange suspension formed. The mixture was then further cooled to $-78{ }^{\circ} \mathrm{C}$, and 4-iodobenzaldehyde (1.21 g, $10 \mathrm{mmol}, 1$ equiv) was added over $20 \mathrm{~min}$. After addition was complete, the reaction was gradually warmed to room temperature and stirred overnight. The solvent was removed under reduced pressure. The residue was dissolved in water and washed with diethyl ether $(\times 2)$. The orange organic layer was discarded, while the aqueous layer was acidified with $2 \mathrm{M} \mathrm{HCl}$ until $\mathrm{pH}=1$. The aqueous layer was extracted with ethyl acetate $(\times 3)$, and the combined organic layers were dried over anhydrous $\mathrm{MgSO}_{4}$. The solvent was removed in vacuo, and the resulting crude product was carried on to the next step without further purification $(\sim 68 \%$ yield $)$.

Step 2) In a $50 \mathrm{~mL}$ round bottomed flask with Teflon coated magnetic stir bar, the crude acid was dissolved in DCM (4 mL), then DMAP (38 mg, $0.31 \mathrm{mmol}, 0.1$ equiv), HoBt (529 mg, $3.4 \mathrm{mmol}, 1.1$ equiv), and EDC (663 mg, $3.4 \mathrm{mmol}, 1.1$ equiv) were added. 2-picoyl amine (340 $\mathrm{mg}, 3.1 \mathrm{mmol}, 1$ equiv) was added dropwise by syringe and the reaction was allowed to stir for 24 $\mathrm{h}$ then diluted with DCM $(3 \mathrm{~mL})$ and quenched with a saturated solution of aq. $\mathrm{NaHCO}_{3}(3 \mathrm{~mL})$. The aqueous layer was extracted with $\operatorname{DCM}(\times 3)$. and the organic layers combined, washed with water then brine, and then dried over $\mathrm{MgSO}_{4}$, filtered and evaporated to dryness. The crude material was purified by flash silica chromatography using $55 \%$ acetone:hexanes to elute the product to afford $700 \mathrm{mg}$ (56\% yield) of $1 \mathrm{r}$ as a white solid. ${ }^{1} \mathbf{H} \mathbf{N M R}\left(600 \mathrm{MHz}, \mathrm{CDCl}_{3}\right) \delta 8.48$ $(\mathrm{ddd}, J=4.9,1.8,1.0 \mathrm{~Hz}, 1 \mathrm{H}), 7.63(\mathrm{td}, J=7.6,1.8 \mathrm{~Hz}, 1 \mathrm{H}), 7.61-7.56(\mathrm{~m}, 2 \mathrm{H}), 7.25(\mathrm{t}, J=1.0$ $\mathrm{Hz}, 1 \mathrm{H}), 7.19$ (ddd, $J=7.7,4.9,1.1 \mathrm{~Hz}, 1 \mathrm{H}), 7.10-7.00(\mathrm{~m}, 2 \mathrm{H}), 6.84(\mathrm{~s}, 1 \mathrm{H}), 6.37-6.32(\mathrm{~m}, 1 \mathrm{H})$, $6.23(\mathrm{dt}, J=15.8,6.8 \mathrm{~Hz}, 1 \mathrm{H}), 4.57(\mathrm{~d}, J=5.0 \mathrm{~Hz}, 2 \mathrm{H}), 2.66-2.52(\mathrm{~m}, 2 \mathrm{H}), 2.45(\mathrm{dd}, J=8.0,6.8$ $\mathrm{Hz}, 2 \mathrm{H}) .{ }^{13} \mathbf{C} \mathbf{N M R}\left(151 \mathrm{MHz}, \mathrm{CDCl}_{3}\right) \delta 172.21,156.30,148.86,137.64,137.15,137.06,130.14$, 129.95, 128.03, 122.60, 122.42, 92.26, 44.43, 36.17, 29.05. HRMS calcd. for $\mathrm{C}_{17} \mathrm{H}_{18} \mathrm{IN}_{2} \mathrm{O}^{+}$ $[\mathrm{M}+\mathrm{H}]^{+}:$393.0458, Found: 393.0457. 

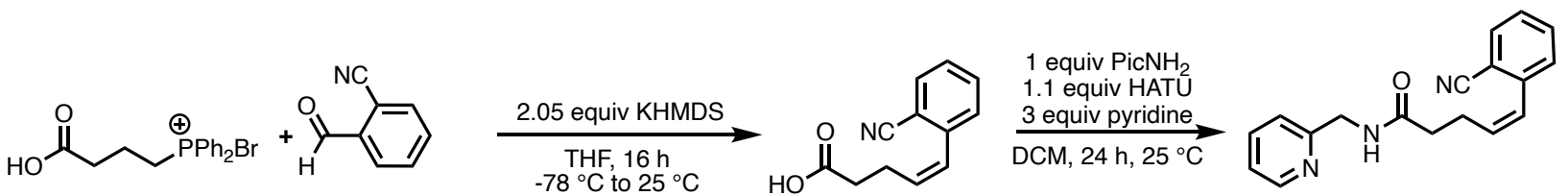

(Z)-5-(2-cyanophenyl)- $N$-(pyridin-2-ylmethyl)pent-4-enamide (1s): The title compound was prepared via a 2 -step sequence consisting of a Wittig reaction followed by amide coupling.

Step 1) Phosphonium salt ( $0.50 \mathrm{~g}, 1.1 \mathrm{mmol}, 1$ equiv) was suspended in THF (1 mL) and cooled to $0^{\circ} \mathrm{C}$. A solution of KHMDS in THF (1.1 mL, $2 \mathrm{M}, 2.05$ equiv) was added dropwise. The mixture was stirred for $1 \mathrm{~h}$ until an orange suspension formed. The mixture was then further cooled to $-78{ }^{\circ} \mathrm{C}$, and 2-cyanobenzaldehyde $(152 \mathrm{mg}, 1.1 \mathrm{mmol}, 1$ equiv) was added over $20 \mathrm{~min}$. After addition was complete, the reaction was gradually warmed to room temperature and stirred overnight. The solvent was removed under reduced pressure. The residue was dissolved in water and washed with diethyl ether $(\times 2)$. The orange organic layer was discarded, while the aqueous layer was acidified with $2 \mathrm{M} \mathrm{HCl}$ until $\mathrm{pH}=1$. The aqueous layer was extracted with ethyl acetate $(\times 3)$, and the combined organic layers were dried over anhydrous $\mathrm{MgSO}_{4}$. The solvent was removed in vacuo, and the resulting crude product was carried on to the next step without further purification ( $\sim 77 \%$ yield $)$.

Step 2) In a $50 \mathrm{~mL}$ round bottomed flask with Teflon coated magnetic stir bar, the crude acid was dissolved in DCM $(2 \mathrm{~mL})$, then pyridine $(0.19 \mathrm{~mL}, 2.3 \mathrm{mmol}, 3$ equiv) and HATU (332 $\mathrm{mg}, .875 \mathrm{mmol}, 1.1$ equiv) were added. 2-picoyl amine ( $86 \mathrm{mg}, 0.8 \mathrm{mmol}, 1$ equiv) was added dropwise by syringe and the reaction was allowed to stir for $24 \mathrm{~h}$ then diluted with DCM (3 mL) and quenched with a saturated solution of aq. $\mathrm{NaHCO}_{3}(3 \mathrm{~mL})$. The aqueous layer was extracted with DCM x3 and the organic layers combined, washed with water then brine, and then dried with $\mathrm{MgSO}_{4}$, filtered and evaporated to dryness. The crude material was purified by flash silica chromatography using 65\% acetone:hexanes to elute the product to afford $110 \mathrm{mg}$ (60\% yield) of 1s as a yellow oil. The product was obtained as a mixture of $E / Z$ isomers. Only the $Z$ isomer is reported below. ${ }^{1} \mathbf{H}$ NMR $\left(600 \mathrm{MHz}, \mathrm{CDCl}_{3}\right) \delta 8.65-8.42(\mathrm{~m}, 1 \mathrm{H}), 7.68(\mathrm{dtd}, J=11.7,7.7,1.8$ $\mathrm{Hz}, 1 \mathrm{H}), 7.56-7.45(\mathrm{~m}, 1 \mathrm{H}), 7.38-7.26(\mathrm{~m}, 4 \mathrm{H}), 7.25-7.17(\mathrm{~m}, 1 \mathrm{H}), 6.85(\mathrm{~s}, 1 \mathrm{H}), 6.80(\mathrm{~d}, J=1.6$ $\mathrm{Hz}, 1 \mathrm{H}), 6.50(\mathrm{dt}, J=15.8,6.9 \mathrm{~Hz}, 1 \mathrm{H}), 4.60(\mathrm{dd}, J=18.3,4.9 \mathrm{~Hz}, 2 \mathrm{H}), 2.84-2.62(\mathrm{~m}, 2 \mathrm{H}), 2.57-$ $2.41(\mathrm{~m}, 2 \mathrm{H}) .{ }^{13} \mathbf{C}$ NMR $\left(151 \mathrm{MHz}, \mathrm{CDCl}_{3}\right) \delta 171.94,156.32,149.14,140.87,136.94,134.80$, $133.01,132.78,127.35,127.03,125.75,122.53,122.30,118.19,110.74,44.56,35.86$, 30.11.HRMS calcd. for $\mathrm{C}_{18} \mathrm{H}_{18} \mathrm{~N}_{3} \mathrm{O}^{+}[\mathrm{M}+\mathrm{H}]^{+}: 292.1444$, Found: 292.1442.

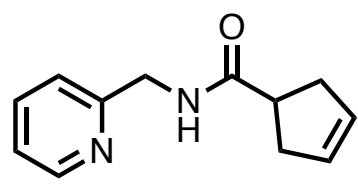

$N$-(pyridin-2-ylmethyl)cyclopent-3-ene-1-carboxamide (1t): The title compound was prepared according to General Procedure D using 3cyclopentene-1-carboxylic acid $(10 \mathrm{mmol})$ as the carboxylic acid to afford $1.589 \mathrm{~g}(78 \%$ yield $)$ of $\mathbf{1 t}$ as a white solid. ${ }^{\mathbf{1}} \mathbf{H} \mathbf{~ N M R}\left(600 \mathrm{MHz}, \mathrm{CDCl}_{3}\right) \delta$ $8.51(\mathrm{dd}, J=5.0,1.6 \mathrm{~Hz}, 1 \mathrm{H}), 7.66(\mathrm{tt}, J=7.7,1.8 \mathrm{~Hz}, 1 \mathrm{H}), 7.31-7.23(\mathrm{~m}, 1 \mathrm{H}), 7.23-7.15(\mathrm{~m}, 1 \mathrm{H})$, $6.88(\mathrm{~s}, 1 \mathrm{H}), 5.82-5.49(\mathrm{~m}, 2 \mathrm{H}), 4.55(\mathrm{~d}, J=5.1 \mathrm{~Hz}, 2 \mathrm{H}), 3.20-2.97(\mathrm{~m}, 1 \mathrm{H}), 2.74-2.42(\mathrm{~m}, 4 \mathrm{H})$. ${ }^{13} \mathrm{C}$ NMR $\left(151 \mathrm{MHz}, \mathrm{CDCl}_{3}\right) \delta 176.19,156.67,148.90,137.11,129.33,122.51,122.34,122.33$, 44.57, 43.54, 37.07. HRMS calcd. for $\mathrm{C}_{12} \mathrm{H}_{15} \mathrm{~N}_{2} \mathrm{O}^{+}[\mathrm{M}+\mathrm{H}]^{+}:$203.1179, Found: 203.1178 .<smiles>O=C(NCc1ccccn1)C1CC=CCC1</smiles>

$N$-(pyridin-2-ylmethyl)cyclohex-3-ene-1-carboxamide (1u): The title compound was prepared according to General Procedure D using 3cyclohexene-1-carboxylic acid $(10 \mathrm{mmol})$ as the carboxylic acid to afford $1.265 \mathrm{~g}(58 \%$ yield $)$ of $\mathbf{1} \mathbf{u}$ as a white solid. ${ }^{1} \mathbf{H} \mathbf{~ N M R}\left(600 \mathrm{MHz}, \mathrm{CDCl}_{3}\right) \delta 8.50(\mathrm{~d}, J=4.9 \mathrm{~Hz}, 1 \mathrm{H})$, 
$7.63(\mathrm{td}, J=7.7,1.8 \mathrm{~Hz}, 1 \mathrm{H}), 7.23(\mathrm{~d}, J=7.8 \mathrm{~Hz}, 1 \mathrm{H}), 7.17(\mathrm{dd}, J=7.5,4.9 \mathrm{~Hz}, 1 \mathrm{H}), 6.93(\mathrm{~s}, 1 \mathrm{H})$, $5.68(\mathrm{~s}, 2 \mathrm{H}), 4.54$ (d, $J=5.0 \mathrm{~Hz}, 2 \mathrm{H}), 2.48-2.43$ (dddd, $J=11.7,10.1,5.5,2.9 \mathrm{~Hz}, 1 \mathrm{H}), 2.32-2.23$ (m, 2H), 2.14-2.06 (m, 2H), 1.97-1.93 (ddt, $J=12.6,4.7,2.5 \mathrm{~Hz}, 1 \mathrm{H}), 1.77-1.69(\mathrm{~m}, 1 \mathrm{H}) .{ }^{13} \mathrm{C}$ NMR $\left(151 \mathrm{MHz}, \mathrm{CDCl}_{3}\right) \delta 176.00,156.64,149.05,136.86,126.83,125.53,122.41,122.17,44.42$, 41.32, 28.24, 25.84, 24.80. HRMS calcd. for $\mathrm{C}_{13} \mathrm{H}_{17} \mathrm{~N}_{2} \mathrm{O}^{+}[\mathrm{M}+\mathrm{H}]^{+}: 217.1335$, Found: 217.1336.

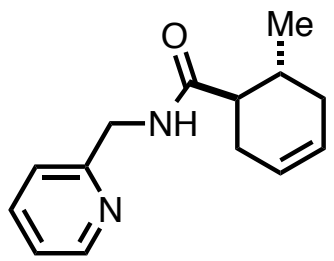

trans-6-methyl- $N$-(pyridin-2-ylmethyl)cyclohex-3-ene-1-carboxamide (1v): The title compound was prepared according to General Procedure D trans-6-methylcyclohex-3-ene-1-carboxylic acid (45) $(1.66 \mathrm{mmol})$ to afford $186 \mathrm{mg}$ ( $49 \%$ yield) of $\mathbf{1 v}$ as a yellow solid. ${ }^{1} \mathbf{H}$ NMR $\left(600 \mathrm{MHz}, d_{6}\right.$-DMSO) $\delta 8.52(\mathrm{t}, J=6.4 \mathrm{~Hz}, 2 \mathrm{H}), 7.81(\mathrm{t}, J=7.9 \mathrm{~Hz}, 1 \mathrm{H}), 7.48-7.11(\mathrm{~m}, 2 \mathrm{H}), 5.86-$ $5.45(\mathrm{~m}, 2 \mathrm{H}), 4.39(\mathrm{qd}, J=15.9,5.8 \mathrm{~Hz}, 2 \mathrm{H}), 2.36-1.96(\mathrm{~m}, 4 \mathrm{H}), 1.96-1.50$ $(\mathrm{m}, 2 \mathrm{H}), 0.85(\mathrm{dd}, J=21.0,6.6 \mathrm{~Hz}, 3 \mathrm{H}) .{ }^{13} \mathbf{C}$ NMR $\left(151 \mathrm{MHz}, d_{6}\right.$-DMSO) $\delta 174.87,158.62,148.32$, 137.27, 126.17, 125.58, 122.23, 121.08, 47.15, 43.84, 33.11, 30.17, 29.07, 19.55.HRMS calcd. for $\mathrm{C}_{14} \mathrm{H}_{19} \mathrm{~N}_{2} \mathrm{O}^{+}[\mathrm{M}+\mathrm{H}]^{+}$231.1492, Found: 231.1493.

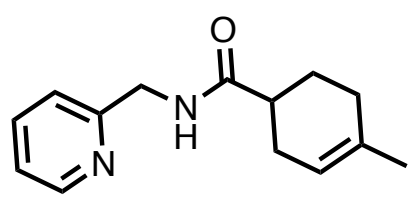

4-methyl- $N$-(pyridin-2-ylmethyl)cyclohex-3-ene-1-carboxamide (1w): The title compound was prepared according to General Procedure $\mathrm{D}$ using 4-methylcyclohex-3-ene-1-carboxylic acid $(10 \mathrm{mmol})$ as the carboxylic acid to afford $1.890 \mathrm{~g}(82 \%$ yield) of $1 \mathrm{w}$ as a yellow solid. ${ }^{1} \mathbf{H}$ NMR $\left(600 \mathrm{MHz}, \mathrm{CDCl}_{3}\right) \delta 8.59-8.44(\mathrm{~m}, 1 \mathrm{H}), 7.66(\mathrm{td}, J=7.7,1.8$ $\mathrm{Hz}, 1 \mathrm{H}), 7.25(\mathrm{~s}, 1 \mathrm{H}), 7.19(\mathrm{dd}, J=7.5,4.9 \mathrm{~Hz}, 1 \mathrm{H}), 6.83(\mathrm{~s}, 1 \mathrm{H}), 5.49-5.32(\mathrm{~m}, 1 \mathrm{H}), 4.57(\mathrm{~d}, J=$ $4.9 \mathrm{~Hz}, 2 \mathrm{H}), 2.42$ (dddd, $J=11.9,9.0,5.8,2.8 \mathrm{~Hz}, 1 \mathrm{H}), 2.34-2.15(\mathrm{~m}, 2 \mathrm{H}), 2.10-1.92(\mathrm{~m}, 3 \mathrm{H})$, 1.77 (dtd, $J=12.3,10.5,10.0,5.7 \mathrm{~Hz}, 1 \mathrm{H}), 1.68-1.64(\mathrm{~m}, 3 \mathrm{H}) .{ }^{13} \mathbf{C} \mathbf{N M R}\left(151 \mathrm{MHz}, \mathrm{CDCl}_{3}\right) \delta$ $176.11,156.68,149.15,136.89,134.11,122.47,122.26,119.53,44.48,41.31,29.65,28.52,26.27$, 23.59. HRMS calcd. for $\mathrm{C}_{14} \mathrm{H}_{19} \mathrm{~N}_{2} \mathrm{O}^{+}[\mathrm{M}+\mathrm{H}]^{+}$231.1492, Found: 231.1493 .

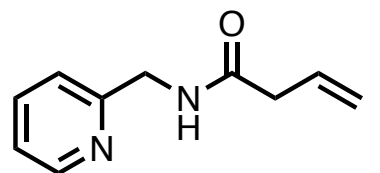

$N$-(pyridin-2-ylmethyl)but-3-enamide (1xa): The title compound was previously prepared in our laboratory according to the published procedure (43). Analytical data are reproduced below for the reader's convenience. ${ }^{1} \mathbf{H}$ NMR $\left(400 \mathrm{MHz}, \mathrm{CDCl}_{3}\right) \delta 8.54(\mathrm{~d}, J=4.1 \mathrm{~Hz}, 1 \mathrm{H})$, $7.66(\mathrm{td}, J=7.7,1.8 \mathrm{~Hz}, 1 \mathrm{H}), 7.35-7.11(\mathrm{~m}, 3 \mathrm{H}), 6.87(\mathrm{~s}, 2 \mathrm{H}), 6.12-5.90(\mathrm{~m}, 1 \mathrm{H}), 5.43-5.12(\mathrm{~m}$, $3 \mathrm{H}), 4.56(\mathrm{~d}, J=5.0 \mathrm{~Hz}, 3 \mathrm{H}), 3.10(\mathrm{~d}, J=7.1,1.4 \mathrm{~Hz}, 3 \mathrm{H}) .{ }^{13} \mathbf{C} \mathbf{~ N M R}\left(125 \mathrm{MHz}, \mathrm{CDCl}_{3}\right) \delta 170.87$, $156.49,149.21,137.03,131.47,122.61,122.37,119.90,44.70,41.77$. HRMS calcd. for $\mathrm{C}_{10} \mathrm{H}_{13} \mathrm{~N}_{2} \mathrm{O}^{+}[\mathrm{M}+\mathrm{H}]+$ : 177.1022, Found: 177.1022.

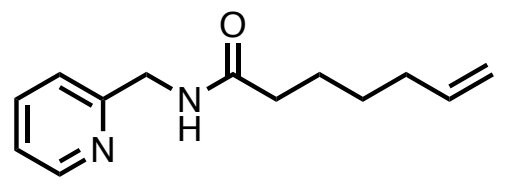

$N$-(pyridin-2-ylmethyl)hept-6-enamide (1y): The title compound was prepared according to General Procedure D using 6-pentenoic acid (10 mmol) as the carboxylic acid to afford 1.436 g $(66 \%$ yield $)$ of $1 \mathbf{y}$ as a pale-yellow oil. ${ }^{1} \mathbf{H}$ NMR $(600 \mathrm{MHz}$, $\left.\mathrm{CDCl}_{3}\right) \delta 8.29-8.13(\mathrm{~m}, 1 \mathrm{H}), 7.49(\mathrm{t}, J=5.7 \mathrm{~Hz}, 1 \mathrm{H}), 7.40(\mathrm{td}, J=7.7,1.8 \mathrm{~Hz}, 1 \mathrm{H}), 7.03(\mathrm{dt}, J=$ 7.8, 1.0 Hz, 1H), 6.93 (ddd, $J=7.5,4.9,1.2 \mathrm{~Hz}, 1 \mathrm{H}), 5.54$ (ddt, $J=16.9,10.2,6.7 \mathrm{~Hz}, 1 \mathrm{H}), 4.75$ $(\mathrm{dq}, J=17.1,1.7 \mathrm{~Hz}, 1 \mathrm{H}), 4.69$ (ddt, $J=10.2,2.3,1.2 \mathrm{~Hz}, 1 \mathrm{H}), 4.28(\mathrm{~d}, J=5.7 \mathrm{~Hz}, 2 \mathrm{H}), 2.10$ $2.01(\mathrm{~m}, 2 \mathrm{H}), 1.86-1.76(\mathrm{~m}, 2 \mathrm{H}), 1.46-1.37(\mathrm{~m}, 2 \mathrm{H}), 1.17(\mathrm{tt}, J=9.8,6.5 \mathrm{~Hz}, 2 \mathrm{H}) .{ }^{13} \mathbf{C}$ NMR $(151$ 
$\left.\mathrm{MHz}, \mathrm{CDCl}_{3}\right) \delta 173.23,157.01,146.85,138.12,136.39,121.77,121.39,114.09,44.21,35.75$, 33.02, 28.05, 24.77. HRMS calcd. for $\mathrm{C}_{13} \mathrm{H}_{19} \mathrm{~N}_{2} \mathrm{O}^{+}[\mathrm{M}+\mathrm{H}]^{+}:$219.1492, Found: 219.1492 .

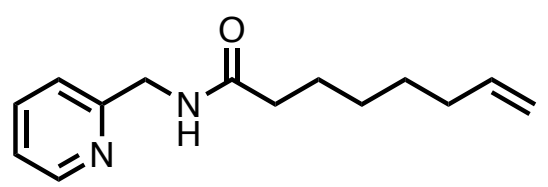

$N$-(pyridin-2-ylmethyl)oct-7-enamide (1z): The title compound was prepared according to General Procedure D using 7-octenoic acid (10 mmol) as the carboxylic acid to afford $1.890 \mathrm{~g}(81 \%$ yield $)$ of $\mathbf{1 z}$ as a pale-yellow oil. ${ }^{\mathbf{1}} \mathbf{H}$ NMR $(600$ $\left.\mathrm{MHz}, \mathrm{CDCl}_{3}\right) \delta 8.54(\mathrm{dd}, J=5.0,1.7 \mathrm{~Hz}, 1 \mathrm{H}), 7.66(\mathrm{ddt}, J=7.9,5.0,2.5 \mathrm{~Hz}, 1 \mathrm{H}), 7.25(\mathrm{~s}, 1 \mathrm{H})$, $7.20(\mathrm{dd}, J=7.6,4.7 \mathrm{~Hz}, 1 \mathrm{H}), 6.73(\mathrm{~s}, J=22.4 \mathrm{~Hz}, 1 \mathrm{H}), 5.86-5.68(\mathrm{~m}, 1 \mathrm{H}), 4.98$ (dq, $J=17.0$, $1.9 \mathrm{~Hz}, 1 \mathrm{H}), 4.95-4.90(\mathrm{~m}, 1 \mathrm{H}), 4.56(\mathrm{t}, J=4.7 \mathrm{~Hz}, 2 \mathrm{H}), 2.39-2.19(\mathrm{~m}, 2 \mathrm{H}), 2.04(\mathrm{q}, J=7.0 \mathrm{~Hz}$, $2 \mathrm{H}), 1.68(\mathrm{q}, J=7.5 \mathrm{~Hz}, 3 \mathrm{H}), 1.47-1.26(\mathrm{~m}, 3 \mathrm{H}) .{ }^{13} \mathbf{C} \mathbf{N M R}\left(151 \mathrm{MHz}, \mathrm{CDCl}_{3}\right) \delta 173.29,156.57$, 149.13, 139.03, 136.92, 122.51, 122.32, 114.52, 44.53, 36.78, 33.73, 28.92, 28.75, 25.71. HRMS calcd. for $\mathrm{C}_{14} \mathrm{H}_{21} \mathrm{~N}_{2} \mathrm{O}^{+}[\mathrm{M}+\mathrm{H}]^{+}:$: 233.1648, Found: 233.1648 .

\section{PRODUCT CHARACTERIZATION}

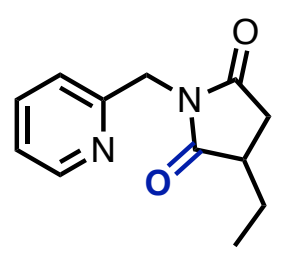

3-ethyl-1-(pyridin-2-ylmethyl)pyrrolidine-2,5-dione (2a): The title compound was synthesized from alkene $1 \mathrm{a}(38 \mathrm{mg}, 0.2 \mathrm{mmol})$ according to General Procedure A with a reaction time of $24 \mathrm{~h}$. The product was isolated by flash silica chromatography to afford $40 \mathrm{mg}$ ( $92 \%$ yield) of $\mathbf{2 a}$ as a yellow oil. The reaction was also conducted on a large scale following General Procedure

A (using a 500-mL Schlenk tube) using alkene 1a (951 mg, $5.00 \mathrm{mmol}$ ) according with a reaction time of $24 \mathrm{~h}$. The product was isolated by flash silica chromatography to afford $970 \mathrm{mg}$ ( $89 \%$ yield) of $\mathbf{2} \mathbf{a}$ as a yellow oil. The analytical data for the large-scale reaction matched that of the smaller scale reaction. ${ }^{1} \mathbf{H} \mathbf{~ N M R}\left(600 \mathrm{MHz}, \mathrm{CDCl}_{3}\right) \delta 8.50$ (ddd, $J=4.9,1.8$, $1.0 \mathrm{~Hz}, 1 \mathrm{H}), 7.62(\mathrm{td}, J=7.7,1.8 \mathrm{~Hz}, 1 \mathrm{H}), 7.21(\mathrm{dt}, J=7.8,0.9 \mathrm{~Hz}, 1 \mathrm{H}), 7.15(\mathrm{ddd}, J=7.6,4.9$, $1.1 \mathrm{~Hz}, 1 \mathrm{H}), 4.81(\mathrm{~s}, 2 \mathrm{H}), 2.96-2.82(\mathrm{~m}, 2 \mathrm{H}), 2.48(\mathrm{dd}, J=17.8,4.0 \mathrm{~Hz}, 1 \mathrm{H}), 1.95(\mathrm{dqd}, J=13.7$, 7.5, $4.6 \mathrm{~Hz}, 1 \mathrm{H}), 1.70-1.60(\mathrm{~m}, 1 \mathrm{H}), 1.00(\mathrm{t}, J=7.4 \mathrm{~Hz}, 3 \mathrm{H}) \cdot{ }^{13} \mathbf{C}$ NMR $\left(151 \mathrm{MHz}, \mathrm{CDCl}_{3}\right) \delta$ 179.82, 176.67, 154.71, 149.75, 136.71, 123.36, 121.84, 43.60, 41.41, 33.47, 24.54, 11.05. HRMS calcd. for $\mathrm{C}_{12} \mathrm{H}_{15} \mathrm{~N}_{2} \mathrm{O}_{2}{ }^{+}[\mathrm{M}+\mathrm{H}]^{+}: 219.1128$, Found: 219.1129 .

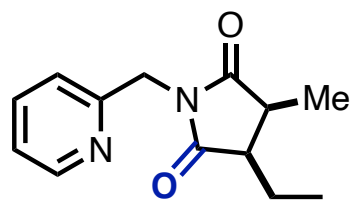

(cis)-3-ethyl-4-methyl-1-(pyridin-2-ylmethyl)pyrrolidine-2,5-dione (2b) (Major diastereomer): The title compound was synthesized from alkene 1b (42 mg, $0.2 \mathrm{mmol}$ ) according to General Procedure A with a reaction time of $48 \mathrm{~h}$. The product was isolated by flash silica chromatography to afford $39.5 \mathrm{mg}$ (85\% yield; $3: 1$ d.r.) of $\mathbf{2 b}$ as a yellow oil. The two diastereomers were obtained as a mixture, and peaks corresponding to each of the isomers could be assigned in the ${ }^{1} \mathrm{H}$ NMR spectrum of the mixture; the ${ }^{13} \mathrm{C}$ NMR spectral data correspond to the mixture. ${ }^{1} \mathbf{H}$ NMR $\left(600 \mathrm{MHz}, \mathrm{CDCl}_{3}\right) \delta 8.55-8.49(\mathrm{~m}, 1 \mathrm{H}), 7.64$ (td, $J=7.7$, $1.8 \mathrm{~Hz}, 1 \mathrm{H}), 7.22$ (t, $J=7.3 \mathrm{~Hz}, 1 \mathrm{H}), 7.19-7.14(\mathrm{~m}, 1 \mathrm{H}), 4.82(\mathrm{~d}, J=4.3 \mathrm{~Hz}, 2 \mathrm{H}), 3.13-3.03$ (m, major, $1 \mathrm{H}), 2.85$ (td, $J=8.2,6.2 \mathrm{~Hz}$, major, $1 \mathrm{H}), 2.63(\mathrm{qd}, J=7.4,4.9 \mathrm{~Hz}$, minor, $1 \mathrm{H}), 2.45$ (dt, $J$ $=8.2,4.9 \mathrm{~Hz}$, minor, $1 \mathrm{H}), 1.96(\mathrm{dtd}, J=15.0,7.5,5.0 \mathrm{~Hz}$, minor, $1 \mathrm{H}), 1.86(\mathrm{tt}, J=13.8,7.4 \mathrm{~Hz}$, $1 \mathrm{H}), 1.71(\mathrm{tt}, J=14.6,7.5 \mathrm{~Hz}$, major, $1 \mathrm{H}), 1.41(\mathrm{~d}, J=7.4 \mathrm{~Hz}$, minor, $3 \mathrm{H}), 1.31(\mathrm{~d}, J=7.5 \mathrm{~Hz}$, major, $3 \mathrm{H}), 1.09$ (t, $J=7.4 \mathrm{~Hz}$, major, $3 \mathrm{H}), 1.06$ (t, $J=7.4 \mathrm{~Hz}$, minor, $3 \mathrm{H}) .{ }^{13} \mathbf{C}$ NMR $(151 \mathrm{MHz}$, $\left.\mathrm{CDCl}_{3}\right) \delta 180.44,179.90,179.46,179.01,154.86,154.78,149.71,149.70,136.69,122.55,121.77$, $121.67,49.53,45.31,43.54,43.35,40.57,38.48,23.77,19.81,16.60,12.56,11.76,11.18$. HRMS calcd. for $\mathrm{C}_{13} \mathrm{H}_{17} \mathrm{~N}_{2} \mathrm{O}_{2}{ }^{+}[\mathrm{M}+\mathrm{H}]^{+}:$233.1285, Found: 233.1285. 


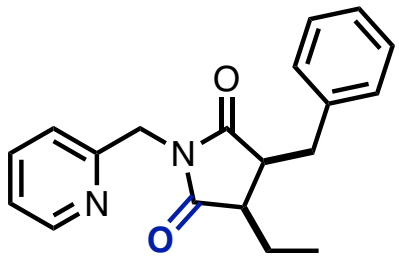

(cis)-3-benzyl-4-ethyl-1-(pyridin-2-ylmethyl)pyrrolidine-2,5-dione (2c) (Major diastereomer) : The title compound was synthesized from alkene $1 \mathrm{c}(56 \mathrm{mg}, 0.2 \mathrm{mmol})$ according to General Procedure A with a reaction time of $48 \mathrm{~h}$. The product was isolated by flash silica chromatography to afford $49 \mathrm{mg}$ ( $79 \%$ yield; $3: 1$ d.r.) of $\mathbf{2 c}$ as a yellow oil. The diastereomeric mixture of $\mathbf{2} \mathbf{c}$ was further purified by preparative

HPLC to afford $31 \mathrm{mg}$ (50\% yield; 9:1 d.r.) of the major diastereomer of $\mathbf{2 c}$. The analytical data for the major diastereomer is reported below. ${ }^{1} \mathbf{H}$ NMR $\left(600 \mathrm{MHz}, \mathrm{CDCl}_{3}\right) \delta 8.55$ (dtd, $J=6.3$, $3.2,2.7,1.8 \mathrm{~Hz}, 1 \mathrm{H}), 7.65(\mathrm{td}, J=7.6,1.8 \mathrm{~Hz}, 1 \mathrm{H}), 7.39-7.34(\mathrm{~m}, 2 \mathrm{H}), 7.33-7.27(\mathrm{~m}, 3 \mathrm{H}), 7.26-$ $7.22(\mathrm{~m}, 1 \mathrm{H}), 7.21-7.16(\mathrm{~m}, 1 \mathrm{H}), 4.89(\mathrm{~d}, J=3.8 \mathrm{~Hz}, 2 \mathrm{H}), 3.75(\mathrm{~d}, J=5.0 \mathrm{~Hz}, 1 \mathrm{H}), 3.00(\mathrm{dt}, J=$ 8.6, $5.0 \mathrm{~Hz}, 1 \mathrm{H}), 1.98$ (dddd, $J=13.8,9.6,6.8,5.1 \mathrm{~Hz}, 1 \mathrm{H}), 1.80-1.71(\mathrm{~m}, 1 \mathrm{H}), 1.52-1.40(\mathrm{~m}$, $1 \mathrm{H}), 0.90(\mathrm{t}, J=7.3 \mathrm{~Hz}, 3 \mathrm{H}) .{ }^{13} \mathrm{C}$ NMR $\left(151 \mathrm{MHz}, \mathrm{CDCl}_{3}\right) \delta 178.48,176.78,153.82,149.04$, $137.25,136.24,128.66,127.48,127.33,122.10,121.25,52.38,48.80,43.09,32.86,19.56,13.37$. HRMS calcd. for $\mathrm{C}_{19} \mathrm{H}_{21} \mathrm{~N}_{2} \mathrm{O}_{2}{ }^{+}[\mathrm{M}+\mathrm{H}]^{+}: 309.1598$, Found: 309.1599 .

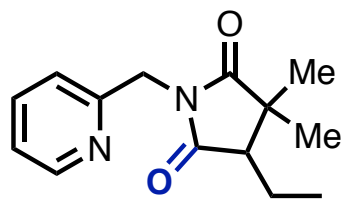

4-ethyl-3,3-dimethyl-1-(pyridin-2-ylmethyl)pyrrolidine-2,5-dione (2d): The title compound was synthesized from alkene 1d (44 $\mathrm{mg}, 0.2 \mathrm{mmol})$ according to General Procedure A with a reaction time of $48 \mathrm{~h}$. The product was isolated by flash silica chromatography to afford $19.5 \mathrm{mg}$ ( $40 \%$ yield) of $\mathbf{2 d}$ as a yellow oil. ${ }^{1} \mathbf{H}$ NMR $\left(600 \mathrm{MHz}, \mathrm{CDCl}_{3}\right) \delta 8.50(\mathrm{~d}, J=4.9 \mathrm{~Hz}$, $1 \mathrm{H}), 7.62(\mathrm{td}, J=7.6,1.8 \mathrm{~Hz}, 1 \mathrm{H}), 7.18(\mathrm{~d}, J=7.8 \mathrm{~Hz}, 1 \mathrm{H}), 7.15(\mathrm{dd}, J=7.5,4.9 \mathrm{~Hz}, 1 \mathrm{H}), 4.78$ (s, $2 \mathrm{H}), 2.46(\mathrm{t}, J=7.2 \mathrm{~Hz}, 1 \mathrm{H}), 1.91(\mathrm{dp}, J=14.5,7.4 \mathrm{~Hz}, 1 \mathrm{H}), 1.67-1.52(\mathrm{~m}, 1 \mathrm{H}), 1.38(\mathrm{~s}, 3 \mathrm{H})$, $1.25(\mathrm{~d}, J=4.7 \mathrm{~Hz}, 3 \mathrm{H}), 1.14(\mathrm{t}, J=7.5 \mathrm{~Hz}, 3 \mathrm{H}) .{ }^{13} \mathbf{C} \mathbf{N M R}\left(151 \mathrm{MHz}, \mathrm{CDCl}_{3}\right) \delta 182.97,178.80$, $154.99,149.76,136.71,122.55,121.67,52.83,43.88,43.37,25.58,21.10,19.72,13.21$. HRMS calcd. for $\mathrm{C}_{14} \mathrm{H}_{19} \mathrm{~N}_{2} \mathrm{O}_{2}{ }^{+}[\mathrm{M}+\mathrm{H}]^{+}:$247.1441, Found: 247.1440 .

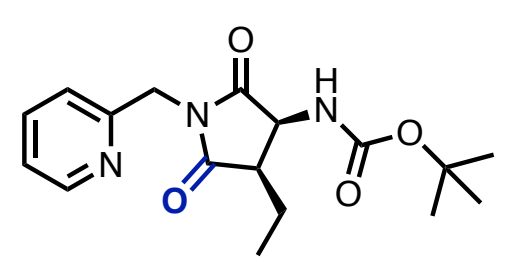

tert-butyl

((3S,4R)-4-ethyl-2,5-dioxo-1-(pyridin-2ylmethyl)pyrrolidin-3-yl)carbamate (2e) (Major diastereomer): The title compound was synthesized from alkene 1 e- $(S)(53 \mathrm{mg}, 0.19 \mathrm{mmol})$ according to General Procedure A with a reaction time of $24 \mathrm{~h}$. The product was isolated by flash silica chromatography to afford $51 \mathrm{mg}$ ( $87 \%$ yield; $2.1: 1$ d.r.) of $\mathbf{2 e}$ as a yellow oil. The mixture of diastereomers could be separated by preparative HPLC to afford the major diastereomer of $\mathbf{2 e}$ in $50 \%$ yield $(29 \mathrm{mg} ; 98 \% e e)$ as a yellow wax. The purified major diastereomer was determined to have been formed in $98 \%$ ee according to the method below. The same procedure using $2 \mathrm{e}-(\boldsymbol{R})$ instead of $2 \mathrm{e}-(\boldsymbol{S})$ provided the product which matched the analytical data for the product of $\mathbf{2 e}-(\boldsymbol{S}) .{ }^{1} \mathbf{H}$ NMR $\left(600 \mathrm{MHz}, \mathrm{CD}_{3} \mathrm{OD}\right) \delta 8.45(\mathrm{~d}, J=4.9 \mathrm{~Hz}, 1 \mathrm{H}), 7.79(\mathrm{t}, J$ $=7.8 \mathrm{~Hz}, 1 \mathrm{H}), 7.42(\mathrm{~d}, J=7.9 \mathrm{~Hz}, 1 \mathrm{H}), 7.31(\mathrm{t}, J=6.3 \mathrm{~Hz}, 1 \mathrm{H}), 4.86(\mathrm{~d}, J=1.4 \mathrm{~Hz}, 2 \mathrm{H}), 4.71(\mathrm{~d}$, $J=9.0 \mathrm{~Hz}, 1 \mathrm{H}), 2.95(\mathrm{q}, J=8.0 \mathrm{~Hz}, 1 \mathrm{H}), 1.74(\mathrm{dt}, J=14.4,7.2 \mathrm{~Hz}, 1 \mathrm{H}), 1.63$ (dt, $J=14.4,7.4$ $\mathrm{Hz}, 1 \mathrm{H}), 1.46$ (s, 9H), 1.07 (t, $J=7.4 \mathrm{~Hz}, 3 \mathrm{H}) .{ }^{13} \mathbf{C}$ NMR $\left(151 \mathrm{MHz}, \mathrm{CD}_{3} \mathrm{OD}\right) \delta$ 179.91, 177.66, $158.14,156.35,149.80,138.82,124.05,123.28,80.98,53.41,46.47,44.09,28.63,20.56,12.85$. HRMS calcd. for $\mathrm{C}_{17} \mathrm{H}_{24} \mathrm{~N}_{3} \mathrm{O}_{4}{ }^{+}[\mathrm{M}+\mathrm{H}]^{+}: 334.1761$, Found: 334.1762 . 


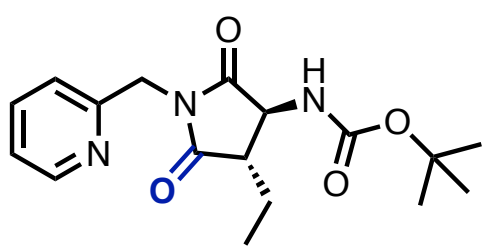

tert-butyl

$((3 S, 4 S)-4-e t h y l-2,5-d i o x o-1-(p y r i d i n-2-$ ylmethyl)pyrrolidin-3-yl)carbamate (2e) (Minor diastereomer): The title compound was synthesized as described in the preceding entry. Purification by flash silica chromatography followed by preparative HPLC afforded $10 \mathrm{mg}$ (17\% yield; $51.7 \%$ $e e)$ of the minor diastereomer of $2 \mathbf{e}$ in as a yellow wax. The purified minor diastereomer of $\mathbf{2 e}-(S)$ was determined to have been formed in $51.7 \%$ ee according to the method below. The same procedure using $2 \mathrm{e}-(\boldsymbol{R})$ instead of $2 \mathrm{e}-(\boldsymbol{S})$ provided the product which matched the analytical data for the product of $\mathbf{2 e}-(\boldsymbol{S}) .{ }^{1} \mathbf{H} \mathbf{N M R}\left(600 \mathrm{MHz}, \mathrm{CD}_{3} \mathrm{OD}\right) \delta 8.51-$ $8.43(\mathrm{~m}, 1 \mathrm{H}), 7.80(\mathrm{td}, J=7.8,1.8 \mathrm{~Hz}, 1 \mathrm{H}), 7.44(\mathrm{~d}, J=7.9 \mathrm{~Hz}, 1 \mathrm{H}), 7.33(\mathrm{dd}, J=7.6,5.0 \mathrm{~Hz}$, $1 \mathrm{H}), 4.83(\mathrm{~s}, 2 \mathrm{H}), 4.22(\mathrm{~d}, J=6.3 \mathrm{~Hz}, 1 \mathrm{H}), 2.93-2.83(\mathrm{~m}, 1 \mathrm{H}), 2.10-1.92(\mathrm{~m}, 1 \mathrm{H}), 1.84-1.67(\mathrm{~m}$, $1 \mathrm{H}), 1.48(\mathrm{~s}, 9 \mathrm{H}), 1.09(\mathrm{t}, J=7.4 \mathrm{~Hz}, 3 \mathrm{H}) .{ }^{13} \mathbf{C} \mathbf{N M R}\left(151 \mathrm{MHz}, \mathrm{CD}_{3} \mathrm{OD}\right) \delta 178.47,177.28,157.67$, $156.33,149.83,138.82,124.02,122.98,81.10,56.45,44.17,28.66,23.16,11.43$. One carbon underneath solvent peak could not be cleanly assigned for minor diastereomer, but is detectable in major diastereomer at 846.47 . HRMS calcd. for $\mathrm{C}_{17} \mathrm{H}_{24} \mathrm{~N}_{3} \mathrm{O}_{4}{ }^{+}[\mathrm{M}+\mathrm{H}]^{+}$: 334.1761 , Found: 334.1762 .

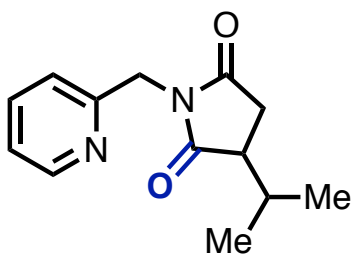

3-isopropyl-1-(pyridin-2-ylmethyl)pyrrolidine-2,5-dione (2f): The title compound was synthesized from alkene 1 f ( $58 \mathrm{mg}, 0.2 \mathrm{mmol})$ according to General Procedure A with a reaction time of $48 \mathrm{~h}$. The product was isolated by flash silica chromatography to afford $30 \mathrm{mg}(65 \%$ yield) of $\mathbf{2 f}$ as a yellow oil. ${ }^{1} \mathbf{H}$ NMR $\left(600 \mathrm{MHz}, \mathrm{CDCl}_{3}\right) \delta 8.50(\mathrm{ddd}, J=4.9,1.8,1.0$ $\mathrm{Hz}, 1 \mathrm{H}), 7.62(\mathrm{td}, J=7.7,1.8 \mathrm{~Hz}, 1 \mathrm{H}), 7.22(\mathrm{dd}, J=7.8,1.2 \mathrm{~Hz}, 1 \mathrm{H}), 7.15$ (ddd, $J=7.6,4.9,1.1 \mathrm{~Hz}, 1 \mathrm{H}), 4.81(\mathrm{~s}, 2 \mathrm{H}), 2.89$ (dt, $J=9.1,4.5 \mathrm{~Hz}, 1 \mathrm{H}), 2.76$ (dd, $J=18.4,9.3$ $\mathrm{Hz}, 1 \mathrm{H}), 2.55$ (dd, $J=18.4,4.6 \mathrm{~Hz}, 1 \mathrm{H}), 2.35$ (pd, $J=6.9,4.4 \mathrm{~Hz}, 1 \mathrm{H}), 1.01$ (d, $J=6.9 \mathrm{~Hz}, 3 \mathrm{H})$, $0.91(\mathrm{~d}, J=6.8 \mathrm{~Hz}, 3 \mathrm{H}) .{ }^{13} \mathbf{C}$ NMR $\left(151 \mathrm{MHz}, \mathrm{CDCl}_{3}\right) \delta 179.36,176.86,154.73,149.68,136.74$, 122.63, 121.92, 43.59, 30.45, 28.86, 20.30, 17.47. HRMS calcd. for $\mathrm{C}_{13} \mathrm{H}_{17} \mathrm{~N}_{2} \mathrm{O}_{2}{ }^{+}[\mathrm{M}+\mathrm{H}]^{+}$: 233.1285, Found: 233.1285.

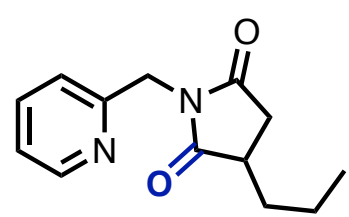

3-propyl-1-(pyridin-2-ylmethyl)pyrrolidine-2,5-dione (2g): The title compound was synthesized from alkene 1ga or 1gb (37 mg, $0.2 \mathrm{mmol})$ according to General Procedure A with a reaction time of $48 \mathrm{~h}$. The product was isolated by flash silica chromatography to afford $33 \mathrm{mg}$ ( $71 \%$ yield) from 1gb and $43 \mathrm{mg}$ (92\% yield) from 1ga as a yellow oil. The spectra of the product from $\mathbf{1 f a}$ and $\mathbf{1 f b}$ were identical. ${ }^{\mathbf{1}} \mathbf{H} \mathbf{~ N M R}\left(600 \mathrm{MHz}, \mathrm{CDCl}_{3}\right)$ $\delta 8.50(\mathrm{~d}, J=4.8 \mathrm{~Hz}, 1 \mathrm{H}), 7.62(\mathrm{t}, J=7.5 \mathrm{~Hz}, 1 \mathrm{H}), 7.22(\mathrm{~s}, 1 \mathrm{zH}), 7.15(\mathrm{dd}, J=7.5,4.9 \mathrm{~Hz}, 1 \mathrm{H})$, $4.80(\mathrm{~s}, 2 \mathrm{H}), 2.96-2.86(\mathrm{~m}, 2 \mathrm{H}), 2.51-2.43(\mathrm{~m}, 1 \mathrm{H}), 1.92(\mathrm{tt}, J=12.8,5.4 \mathrm{~Hz}, 1 \mathrm{H}), 1.54(\mathrm{ddd}, J=$ 14.1, 9.3, 5.7 Hz, 1H), $1.43(\mathrm{~h}, J=9.2,8.2 \mathrm{~Hz}, 2 \mathrm{H}), 0.95(\mathrm{t}, J=7.3 \mathrm{~Hz}, 3 \mathrm{H}) .{ }^{13} \mathrm{C}$ NMR $(151 \mathrm{MHz}$, $\left.\mathrm{CDCl}_{3}\right) \delta 180.02,176.67,154.71,149.74,136.73,122.62,121.87,43.58,39.99,34.55,33.57$, 20.17, 13.90. HRMS calcd. for $\mathrm{C}_{13} \mathrm{H}_{17} \mathrm{~N}_{2} \mathrm{O}_{2}{ }^{+}[\mathrm{M}+\mathrm{H}]^{+}:$233.1285, Found: 233.1286.

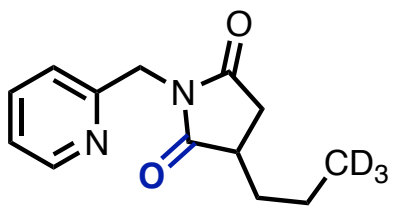

d3-3-propyl-1-(pyridin-2-ylmethyl)pyrrolidine-2,5-dione (2g-d3): The title compound was synthesized from alkene 1g-d3 (41 mg, 0.2 mmol) according to General Procedure A with a reaction time of $48 \mathrm{~h}$. The product was isolated by flash silica chromatography to afford $41 \mathrm{mg}$ 
(88\% yield) of $\mathbf{2 g - d 3}$ as a yellow oil. ${ }^{\mathbf{1}} \mathbf{H} \mathbf{~ N M R}\left(600 \mathrm{MHz}, \mathrm{CDCl}_{3}\right) \delta 8.50(\mathrm{dd}, J=5.1,1.7 \mathrm{~Hz}, 1$ H), $7.61(\mathrm{td}, J=7.7,1.8 \mathrm{~Hz}, 1 \mathrm{H}), 7.20(\mathrm{~d}, J=7.8 \mathrm{~Hz}, 1 \mathrm{H}), 7.15(\mathrm{dd}, J=7.6,4.9 \mathrm{~Hz}, 1 \mathrm{H}), 4.80$ (s, 2 H), 2.93-2.84 (m, 2 H), 2.60-2.39 (m, 1 H), 1.91 (dddd, $J=13.6,9.2,7.1,4.8$ Hz, 1 H), 1.65$1.47(\mathrm{~m}, 1 \mathrm{H}), 1.41(\mathrm{q}, J=8.5,7.8 \mathrm{~Hz}, 2 \mathrm{H}) .{ }^{13} \mathbf{C ~ N M R}\left(151 \mathrm{MHz}, \mathrm{CDCl}_{3}\right) \delta 179.87,176.52$, $153.84,147.84,138.68,123.22$, 122.55, 42.54, 40.56, 40.42, 40.28, 40.14, 40.03, 40.00, 39.86, 39.72, 34.57, 33.27, 19.84. HRMS calcd. For $\mathrm{C}_{13} \mathrm{H}_{14} \mathrm{D}_{3} \mathrm{~N}_{2} \mathrm{O}_{4}{ }^{+}[\mathrm{M}+\mathrm{H}]^{+}$: 236.1473 , Found: 236.1473 .

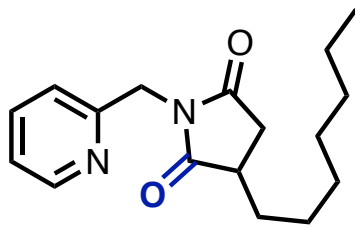

3-heptyl-1-(pyridin-2-ylmethyl)pyrrolidine-2,5-dione (2h): The title compound was synthesized from alkene 1 ha or $\mathbf{1 h b}(52 \mathrm{mg}, 0.2 \mathrm{mmol})$ according to General Procedure A with a reaction time of $72 \mathrm{~h}$ for $\mathbf{1 h a}$ and $48 \mathrm{~h}$ for $\mathbf{1 h b}$. Starting from $\mathbf{1 h b}$, the product was isolated by flash silica chromatography to afford $47 \mathrm{mg}(85 \%$ yield $)$ of $\mathbf{2 h}$ as a yellow oil. Starting from 1 ha, the yield was found to be $6 \%$ as determined by ${ }^{1} \mathrm{H} \mathrm{NMR}$ using $\mathrm{CH}_{2} \mathrm{Br}_{2}$ as an internal standard. ${ }^{1} \mathbf{H}$ NMR $\left(600 \mathrm{MHz}, \mathrm{CDCl}_{3}\right) \delta 8.51(\mathrm{dd}, J=4.9,1.6 \mathrm{~Hz}, 1 \mathrm{H}), 7.62(\mathrm{td}, J=7.7$, $1.8 \mathrm{~Hz}, 1 \mathrm{H}), 7.22(\mathrm{~d}, J=7.8 \mathrm{~Hz}, 1 \mathrm{H}), 7.16(\mathrm{dd}, J=7.5,4.9 \mathrm{~Hz}, 1 \mathrm{H}), 4.81(\mathrm{~s}, 2 \mathrm{H}), 2.96-2.84(\mathrm{~m}$, 2H), 2.50-2.45 (m, 1H), 1.99-1.89 (m, 1H), $1.57(\mathrm{dd}, J=13.8,6.6 \mathrm{~Hz}, 2 \mathrm{H}), 1.42-1.34(\mathrm{~m}, 2 \mathrm{H})$, $1.34-1.21(\mathrm{~m}, 7 \mathrm{H}), 0.88(\mathrm{t}, J=6.9 \mathrm{~Hz}, 3 \mathrm{H}) .{ }^{13} \mathbf{C} \mathbf{N M R}\left(151 \mathrm{MHz}, \mathrm{CDCl}_{3}\right) \delta 180.03,176.70,154.74$, $149.75,136.73,122.63,121.89,43.60,40.19$, 34.56, 31.87, 31.50, 29.42, 29.20, 26.85, 22.75, 14.21. HRMS calcd. for $\mathrm{C}_{17} \mathrm{H}_{25} \mathrm{~N}_{2} \mathrm{O}_{2}{ }^{+}[\mathrm{M}+\mathrm{H}]^{+}: 289.1911$, Found: 289.1910 .

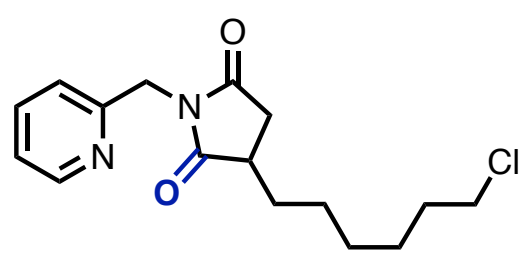

3-(6-chlorohexyl)-1-(pyridin-2-ylmethyl)pyrrolidine-2,5dione (2i): The title compound was synthesized from alkene $\mathbf{1 i}$ (58 $\mathrm{mg}, 0.2 \mathrm{mmol}$ ) according to General Procedure A with a reaction time of $72 \mathrm{~h}$. The product was isolated by flash silica chromatography to afford $49 \mathrm{mg}\left(76 \%\right.$ yield) as a yellow oil. ${ }^{1} \mathbf{H}$ NMR $\left(600 \mathrm{MHz}, \mathrm{CDCl}_{3}\right) \delta 8.53(\mathrm{ddd}, J=4.9,1.9,0.9 \mathrm{~Hz}, 1 \mathrm{H})$, $7.66(\mathrm{td}, J=7.7,1.8 \mathrm{~Hz}, 1 \mathrm{H}), 7.25(\mathrm{dt}, J=7.8,1.0 \mathrm{~Hz}, 1 \mathrm{H}), 7.19(\mathrm{ddd}, J=7.7,4.8,1.1 \mathrm{~Hz}, 1 \mathrm{H})$, $4.83(\mathrm{~s}, 2 \mathrm{H}), 3.55(\mathrm{t}, J=6.7 \mathrm{~Hz}, 2 \mathrm{H}), 2.99-2.87(\mathrm{~m}, 2 \mathrm{H}), 2.52-2.48(\mathrm{~m}, 1 \mathrm{H}), 2.00-1.92(\mathrm{~m}, 1 \mathrm{H})$, $1.78(\mathrm{dq}, J=7.9,6.7 \mathrm{~Hz}, 2 \mathrm{H}), 1.66-1.57(\mathrm{~m}, 1 \mathrm{H}), 1.51-1.34(\mathrm{~m}, 6 \mathrm{H}) .{ }^{13} \mathbf{C} \mathbf{N M R}\left(151 \mathrm{MHz}, \mathrm{CDCl}_{3}\right)$ $\delta 179.87,176.56,154.62,149.66,136.83,122.67,121.94,45.11,43.54,40.10,34.54,32.56,31.38$, 28.74, 26.77, 26.68. HRMS calcd. for $\mathrm{C}_{16} \mathrm{H}_{22} \mathrm{ClN}_{2} \mathrm{O}_{2}{ }^{+}[\mathrm{M}+\mathrm{H}]^{+}:$309.1364, Found: 309.1363.

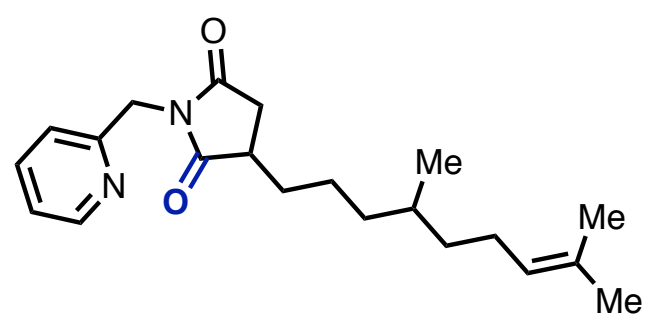

3-(4,8-dimethylnon-7-en-1-yl)-1-(pyridin-2-
ylmethyl)pyrrolidine-2,5-dione (2j): The title
compound was synthesized from alkene $\mathbf{1 j}(67 \mathrm{mg}, 0.2$
mmol) according to General Procedure A with a reaction
time of $72 \mathrm{~h}$. The product was isolated by flash silica
chromatography to afford $53 \mathrm{mg}(74 \%$ yield; $1: 1 \mathrm{~d} . \mathrm{r}$.) of
$\mathbf{2 j}$ as a colorless oil. ${ }^{\mathbf{1}} \mathbf{H} \mathbf{N M R}\left(600 \mathrm{MHz}, \mathrm{CDCl}_{3}\right) \delta 8.48$ $(\mathrm{d}, J=5.0 \mathrm{~Hz}, 1 \mathrm{H}), 7.66-7.57(\mathrm{~m}, 1 \mathrm{H}), 7.20(\mathrm{~d}, J=7.9 \mathrm{~Hz}, 1 \mathrm{H}), 7.14(\mathrm{dd}, J=7.6,4.9 \mathrm{~Hz}, 1 \mathrm{H})$, $5.07(\mathrm{t}, J=7.2 \mathrm{~Hz}, 1 \mathrm{H}), 4.79(\mathrm{~s}, 2 \mathrm{H}), 2.96-2.84(\mathrm{~m}, 2 \mathrm{H}), 2.52-2.43(\mathrm{~m}, 1 \mathrm{H}), 2.07-1.84(\mathrm{~m}, 3 \mathrm{H})$, $1.66(\mathrm{~s}, 3 \mathrm{H}), 1.58(\mathrm{~s}, 3 \mathrm{H}), 1.57-1.49(\mathrm{~m}, 2 \mathrm{H}) 1.45-1.25(\mathrm{~m}, 4 \mathrm{H}), 1.20-1.05(\mathrm{~m}, 2 \mathrm{H}), 0.84(\mathrm{~d}, J=$ $6.7 \mathrm{~Hz}, 3 \mathrm{H}) .{ }^{13} \mathbf{C}$ NMR $\left(151 \mathrm{MHz}, \mathrm{CDCl}_{3}\right) \delta 179.86,176.54,154.58,149.57,136.62,131.15$, $124.81,122.49,121.76,43.43,40.06,40.02,37.03,36.97,36.62,36.57,34.42,34.37,32.21,32.20$, $31.67,31.60,25.73,25.52,25.50,24.14,24.10,19.49,19.44,17.65$. The peaks reported for $13 \mathrm{C}$ 
NMR correspond to both diastereomers which are present in a 1:1 to ratio. 9 of the $12 s p 3$ carbons were chemical shift distinct and peaks are reported to include both diastereomers. HRMS calcd. For $\mathrm{C}_{21} \mathrm{H}_{31} \mathrm{~N}_{2} \mathrm{O}_{2}{ }^{+}[\mathrm{M}+\mathrm{H}]^{+}$: 343.2380, Found: 343.2381 .

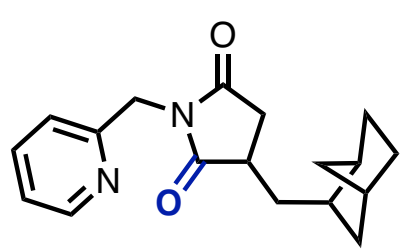

3-((bicyclo[2.2.1]heptan-2-yl)methyl)-1-(pyridin-2-ylmethyl)pyrrolidine-

2,5-dione (2k): The title compound was synthesized from alkene $1 \mathbf{k}$ (55 $\mathrm{mg}, 0.2 \mathrm{mmol}$ ) according to General Procedure A with a reaction time of $72 \mathrm{~h}$. The product was isolated by flash silica chromatography to afford $22 \mathrm{mg}$ (40\% yield; $1: 1$ d.r.) of $\mathbf{2} \mathbf{j}$ as a colorless oil. ${ }^{\mathbf{1}} \mathbf{H} \mathbf{~ N M R}$ $\left(600 \mathrm{MHz}, \mathrm{CDCl}_{3}\right) \delta 8.51(\mathrm{dt}, J=4.7,2.2 \mathrm{~Hz}, 1 \mathrm{H}), 7.62(\mathrm{td}, J=7.7$, $1.9 \mathrm{~Hz}, 1 \mathrm{H}), 7.21(\mathrm{dd}, J=7.9,3.9 \mathrm{~Hz}, 1 \mathrm{H}), 7.16(\mathrm{dd}, J=7.5,4.9 \mathrm{~Hz}, 1 \mathrm{H}), 4.81(\mathrm{~d}, J=2.6 \mathrm{~Hz}$, 2H), $3.00-2.72(\mathrm{~m}, 2 \mathrm{H}), 2.61-2.40(\mathrm{~m}, 1 \mathrm{H}), 2.30-2.13(\mathrm{~m}, 1 \mathrm{H}), 2.07-1.96(\mathrm{~m}, 1 \mathrm{H}), 1.96-$ $1.85(\mathrm{~m}, 1 \mathrm{H}), 1.78(\mathrm{~m}, J=14.6,10.5,5.5 \mathrm{~Hz}, 1 \mathrm{H}), 1.53(\mathrm{~m}, J=20.7,14.0,7.0,3.5 \mathrm{~Hz}, 4 \mathrm{H}), 1.43$ $-1.28(\mathrm{~m}, 2 \mathrm{H}), 1.14(\mathrm{~m}, J=21.6,14.6,8.6,2.3 \mathrm{~Hz}, 2 \mathrm{H}), 0.67\left(\mathrm{~m}, J=14.7,11.9,5.3,2.3 \mathrm{~Hz} .{ }^{13} \mathrm{C}\right.$ NMR $\left(151 \mathrm{MHz}, \mathrm{CDCl}_{3}\right) \delta 180.16,180.12,176.68,176.63,154.76,154.74,149.77,136.71$, $122.61,121.89,121.87,121.86,43.60,43.58,41.94,40.76,40.26,40.13,39.96,39.94,39.85$, 39.65, 39.41, 39.27, 38.65, 38.64, 38.51, 38.34, 37.53, 37.33, 37.29, 37.18, 36.80, 36.61, 36.47, 35.48, 35.40, 35.11, 34.94, 34.89, 34.62, 34.50, 30.25, 30.19, 30.10, 28.78, 28.74, 22.69, 22.34.

For $\mathrm{C}_{18} \mathrm{H}_{23} \mathrm{~N}_{2} \mathrm{O}_{2}{ }^{+}[\mathrm{M}+\mathrm{H}]^{+}: 299.1754$, Found: 299.1753 .

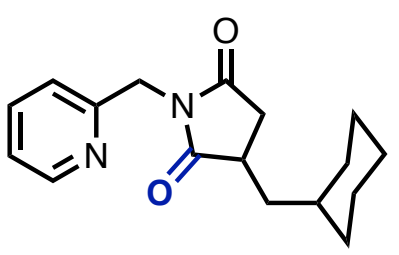

3-(cyclohexylmethyl)-1-(pyridin-2-ylmethyl)pyrrolidine-2,5-dione (2l): The title compound was synthesized from alkene 11 (52 $\mathrm{mg}, 0.2$ mmol) according to General Procedure A with a reaction time of $72 \mathrm{~h}$. The product was isolated by flash silica chromatography to afford $48 \mathrm{mg}$ $(84 \%$ yield $)$ of $2 \mathrm{l}$ as a yellow oil. ${ }^{1} \mathbf{H}$ NMR $\left(600 \mathrm{MHz}, \mathrm{CDCl}_{3}\right) \delta 8.51(\mathrm{~d}$, $J=5.0 \mathrm{~Hz}, 1 \mathrm{H}), 7.62(\mathrm{td}, J=7.7,3.8 \mathrm{~Hz}, 1 \mathrm{H}), 7.22(\mathrm{~d}, J=7.9 \mathrm{~Hz}, 1 \mathrm{H})$, $7.16(\mathrm{dd}, J=7.6,4.9 \mathrm{~Hz}, 1 \mathrm{H}), 4.81(\mathrm{~s}, 2 \mathrm{H}), 3.02-2.83(\mathrm{~m}, 2 \mathrm{H}), 2.46(\mathrm{dd}, J=17.2,3.4 \mathrm{~Hz}, 1 \mathrm{H})$, $1.89(\mathrm{td}, J=11.0,10.5,4.7 \mathrm{~Hz}, 1 \mathrm{H}), 1.83-1.61(\mathrm{~m}, 5 \mathrm{H}), 1.40(\mathrm{ddt}, J=14.8,9.1,5.5 \mathrm{~Hz}, 2 \mathrm{H}), 1.35-$ $1.08(\mathrm{~m}, 3 \mathrm{H}), 1.08-0.86(\mathrm{~m}, 2 \mathrm{H}) .{ }^{13} \mathbf{C}$ NMR $\left(151 \mathrm{MHz}, \mathrm{CDCl}_{3}\right) \delta 180.83,176.54,154.01,149.61$, 136.61, 122.49, 121.74, 43.45, 39.23, 37.82, 35.48, 35.04, 33.80, 32.26, 26.37, 26.17, 26.05. HRMS calcd. for $\mathrm{C}_{17} \mathrm{H}_{23} \mathrm{~N}_{2} \mathrm{O}_{2}{ }^{+}[\mathrm{M}+\mathrm{H}]^{+}: 287.1754$, Found: 287.1754 .

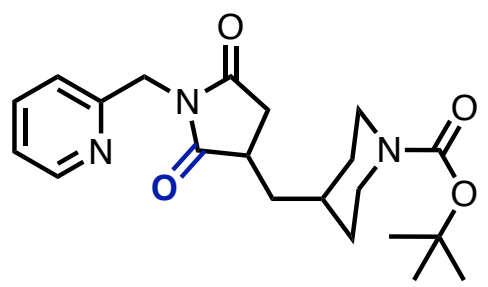

tert-butyl 4-((2,5-dioxo-1-(pyridin-2-ylmethyl)pyrrolidin-3yl)methyl)piperidine-1-carboxylate (2m): The title compound was synthesized from alkene $1 \mathrm{~m}(36 \mathrm{mg}, 0.1 \mathrm{mmol})$ according to General Procedure A with a reaction time of $72 \mathrm{~h}$. The product was isolated by flash silica chromatography to afford $36 \mathrm{mg}$ (93\% yield) of $\mathbf{2 m}$ as a hard yellow oil. ${ }^{1} \mathbf{H}$ NMR (600 MHz, Acetone) $\delta 8.61$

(ddd, $J=4.9,1.8,1.0 \mathrm{~Hz}, 1 \mathrm{H}), 7.86(\mathrm{td}, J=7.7,1.8 \mathrm{~Hz}, 1 \mathrm{H}), 7.42-7.36(\mathrm{~m}, 2 \mathrm{H}), 4.85(\mathrm{~d}, J=1.6$ $\mathrm{Hz}, 2 \mathrm{H}), 4.18$ (s, 2H), 3.11 (ddt, $J=10.0,9.0,4.6 \mathrm{~Hz}, 1 \mathrm{H}), 3.05$ (dd, $J=17.7,9.0 \mathrm{~Hz}, 1 \mathrm{H}), 2.59$ (dd, $J=17.8,4.4 \mathrm{~Hz}, 1 \mathrm{H}), 2.10$ (p, $J=2.5 \mathrm{~Hz}, 3 \mathrm{H}), 1.93$ (ddd, $J=13.4,8.3,4.7 \mathrm{~Hz}, 1 \mathrm{H}), 1.86$ (dt, $J=12.9,2.9 \mathrm{~Hz}, 1 \mathrm{H}), 1.83-1.74(\mathrm{~m}, 2 \mathrm{H}), 1.63(\mathrm{ddd}, J=13.6,10.1,5.5 \mathrm{~Hz}, 1 \mathrm{H}), 1.57$ (s, 9H), 1.21 (dtdd, $J=39.2,12.7,11.3,4.4 \mathrm{~Hz}, 2 \mathrm{H})$. 1 proton could not be detected and likely sits underneath 
the solvent peaks. ${ }^{13} \mathrm{C}$ NMR (151 MHz, Acetone) $\delta$ 181.21, 177.57, 156.24, 155.40, 150.14, 137.68, 123.41, 122.28, 79.57, 43.98, 38.68, 38.33, 35.45, 34.51, 28.53. HRMS calcd. for $\mathrm{C}_{21} \mathrm{H}_{30} \mathrm{~N}_{3} \mathrm{O}_{4}^{+}[\mathrm{M}+\mathrm{H}]^{+}:$388.2231, Found: 388.2231.

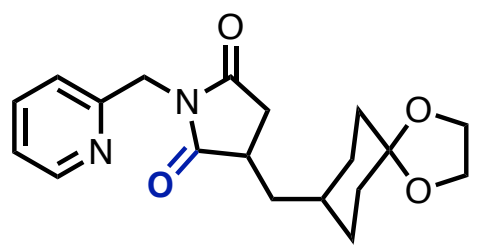

3-((1,4-dioxaspiro[4.5]decan-8-yl)methyl)-1-(pyridin-2ylmethyl)pyrrolidine-2,5-dione (2n): The title compound was synthesized from alkene $1 \mathrm{n}(60.5 \mathrm{mg}, 0.19 \mathrm{mmol})$ according to General Procedure A with a reaction time of $72 \mathrm{~h}$. The product was isolated by flash silica chromatography to afford $56.5 \mathrm{mg}(86 \%$ yield) of $\mathbf{2 n}$ as a yellow oil. ${ }^{\mathbf{1}} \mathbf{H} \mathbf{N M R}\left(600 \mathrm{MHz}, \mathrm{CDCl}_{3}\right) \delta 8.51(\mathrm{~d}$, $J=4.9 \mathrm{~Hz}, 1 \mathrm{H}), 7.64(\mathrm{qd}, J=7.9,1.9 \mathrm{~Hz}, 1 \mathrm{H}), 7.23(\mathrm{t}, J=7.9 \mathrm{~Hz}, 1 \mathrm{H}), 7.16(\mathrm{dd}, J=7.6,5.0 \mathrm{~Hz}$, $1 \mathrm{H}), 4.81(\mathrm{~d}, J=9.3 \mathrm{~Hz}, 2 \mathrm{H}), 3.94(\mathrm{qt}, J=8.5,5.5,4.1 \mathrm{~Hz}, 2 \mathrm{H}), 3.06-2.90(\mathrm{~m}, 2 \mathrm{H}), 2.58-2.29$ (m, 2H), 2.10 (dddt, $J=19.2,12.8,5.8,3.0 \mathrm{~Hz}, 1 \mathrm{H}), 2.04-1.90$ (m, 1H), 1.75 (tq, $J=10.1,3.4 \mathrm{~Hz}$, $3 \mathrm{H}), 1.57-1.39(\mathrm{~m}, 5 \mathrm{H}), 1.39-1.22(\mathrm{~m}, 2 \mathrm{H}) .{ }^{13} \mathbf{C}$ NMR $\left(151 \mathrm{MHz}, \mathrm{CDCl}_{3}\right) \delta 180.84,176.66$, 149.76, 136.81, 122.75, 122.68, 122.07, 121.96, 108.86, 64.41, 43.59, 40.66, 40.59, 38.38, 38.22, $38.09,37.86,35.32,34.52,34.43,34.40,33.95,32.89,32.20,30.66,29.57$. HRMS calcd. for $\mathrm{C}_{19} \mathrm{H}_{25} \mathrm{~N}_{2} \mathrm{O}_{4}^{+}[\mathrm{M}+\mathrm{H}]^{+}: 345.1809$, Found: 345.1808 .

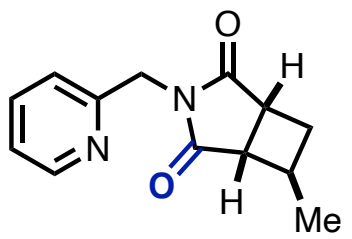

cis-6-methyl-3-(pyridin-2-ylmethyl)-3-azabicyclo[3.2.0]heptane-2,4dione (20): The title compound was synthesized from alkene $10(20.5 \mathrm{mg}$, $0.2 \mathrm{mmol}$ ) according to General Procedure B with a reaction time of $24 \mathrm{~h}$. The product was isolated by flash silica chromatography to afford $15 \mathrm{mg}$ $\left(65 \%\right.$ yield; $>20: 1$ d.r.) of $\mathbf{2 0}$ as a yellow oil. ${ }^{1} \mathbf{H} \mathbf{~ N M R}\left(600 \mathrm{MHz}, \mathrm{CDCl}_{3}\right)$ $\delta 8.52(\mathrm{dd}, J=5.0,1.6 \mathrm{~Hz}, 1 \mathrm{H}), 7.67(\mathrm{td}, J=7.7,1.8 \mathrm{~Hz}, 1 \mathrm{H}), 7.28-7.23$ (m, 1H), $7.19(\mathrm{dd}, J=7.5,4.9 \mathrm{~Hz}, 1 \mathrm{H}), 4.86(\mathrm{~s}, 2 \mathrm{H}), 3.31$ (ddd, $J=10.7,6.6,4.1 \mathrm{~Hz}, 1 \mathrm{H}), 2.97$ (dd, $J=6.6,4.3 \mathrm{~Hz}, 1 \mathrm{H}), 2.68$ (dddd, $J=14.0,11.3,9.1,5.6 \mathrm{~Hz}, 1 \mathrm{H}), 2.45$ (ddd, $J=12.8,8.6,4.0$ $\mathrm{Hz}, 1 \mathrm{H}), 2.20$ (ddd, $J=12.8,10.6,6.6 \mathrm{~Hz}, 1 \mathrm{H}), 1.35$ (dd, $J=7.1,0.9 \mathrm{~Hz}, 3 \mathrm{H}) .{ }^{13} \mathbf{C}$ NMR $(151$ $\left.\mathrm{MHz}, \mathrm{CDCl}_{3}\right) \delta 180.06,179.11,178.43,154.68,149.40,137.23,122.77,121.98,46.19,43.17$, 35.65, 33.10, 31.00, 22.28. HRMS calcd. for $\mathrm{C}_{13} \mathrm{H}_{15} \mathrm{~N}_{2} \mathrm{O}_{2}{ }^{+}[\mathrm{M}+\mathrm{H}]^{+}$: 231.1128, Found: 231.1127 .

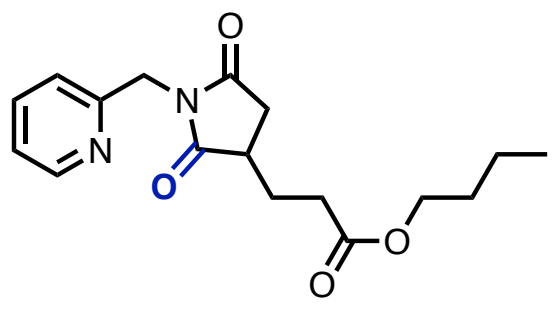

butyl 3-(2,5-dioxo-1-(pyridin-2-ylmethyl)pyrrolidin-3yl)propanoate (2p): The title compound was synthesized from alkene 1p (50 mg, $0.17 \mathrm{mmol}$ ) according to General Procedure A with a reaction time of $48 \mathrm{~h}$. The product was isolated by flash silica chromatography to afford $45 \mathrm{mg}$ ( $82 \%$ yield) of $\mathbf{2 p}$ as a colorless oil. ${ }^{1} \mathbf{H}$ NMR $\left(500 \mathrm{MHz}, \mathrm{CDCl}_{3}\right) \delta 8.49$ (ddd, $J$ $=4.9,1.9,0.9 \mathrm{~Hz}, 1 \mathrm{H}), 7.63(\mathrm{td}, J=7.7,1.8 \mathrm{~Hz}, 1 \mathrm{H}), 7.22(\mathrm{dd}$, $J=8.0,1.3 \mathrm{~Hz}, 1 \mathrm{H}), 7.16(\mathrm{ddd}, J=7.5,4.9,1.1 \mathrm{~Hz}, 1 \mathrm{H}), 4.81(\mathrm{~s}, 2 \mathrm{H}), 4.08(\mathrm{t}, J=6.7 \mathrm{~Hz}, 2 \mathrm{H})$, 3.05-2.82 (m, 2H), 2.57-2.40 (m, 3H), 2.26-2.16 (m, 1H), 2.01-1.90 (m, 1H), 1.64-1.55 (m, 2H), $1.43-1.31(\mathrm{~m}, 2 \mathrm{H}), 0.93(\mathrm{t}, J=7.4 \mathrm{~Hz}, 3 \mathrm{H}) .{ }^{13} \mathbf{C} \mathbf{N M R}\left(126 \mathrm{MHz}, \mathrm{CDCl}_{3}\right) \delta 179.22,176.10,172.77$, $154.41,149.68,136.82,122.69,121.92,64.73,43.50,39.22,34.60,31.56,30.75,26.81$, 19.25.13.82. HRMS calcd. For $\mathrm{C}_{17} \mathrm{H}_{23} \mathrm{~N}_{2} \mathrm{O}_{4}{ }^{+}[\mathrm{M}+\mathrm{H}]^{+}: 319.1652$, Found: 319.1653 .

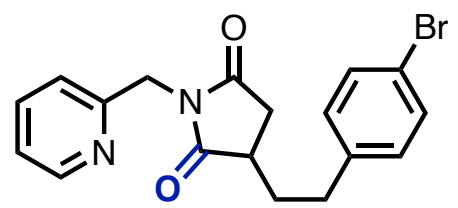

4-(4-bromophenethyl)-1-(pyridin-2-ylmethyl)pyrrolidine-2,5dione (2q): The title compound was synthesized from alkene 1q (32 $\mathrm{mg}, 0.093 \mathrm{mmol}$ ) according to General Procedure A with a reaction time of $48 \mathrm{~h}$. The product was isolated by flash silica 
chromatography to afford $32 \mathrm{mg}$ (93\% yield) of $\mathbf{2 q}$ as a yellow oil. ${ }^{\mathbf{1}} \mathbf{H} \mathbf{~ N M R}\left(600 \mathrm{MHz}, \mathrm{CDCl}_{3}\right)$ $\delta 8.49(\mathrm{dt}, J=4.7,1.6 \mathrm{~Hz}, 1 \mathrm{H}), 7.67-7.59(\mathrm{~m}, 1 \mathrm{H}), 7.42-7.40(\mathrm{~m}, 2 \mathrm{H}), 7.24-7.02(\mathrm{~m}, 4 \mathrm{H}), 4.81$ (s, 2H), 2.98-2.66 (m, 4H), 2.54-2.43 (m, 1H), 2.37-2.21 (m, 1H), $1.87(\mathrm{dtd}, J=14.6,8.9,6.0 \mathrm{~Hz}$, 1H). ${ }^{13}$ C NMR $\left(151 \mathrm{MHz}, \mathrm{CDCl}_{3}\right) \delta 179.54,176.24,154.47,149.70,139.57,136.79,131.79$, $130.34,122.69,121.96,120.25,43.54,39.25,34.60,33.05,32.49$. HRMS calcd. for $\mathrm{C}_{18} \mathrm{H}_{18} \mathrm{BrN}_{2} \mathrm{O}_{2}{ }^{+}[\mathrm{M}+\mathrm{H}]^{+}$373.0546, Found: 373.0548 .

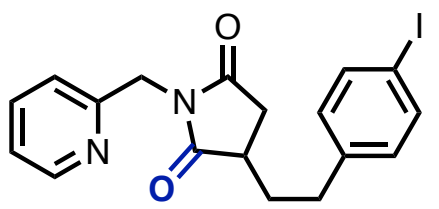

3-(4-iodophenethyl)-1-(pyridin-2-ylmethyl)pyrrolidine-2,5-dione (2r): The title compound was synthesized from alkene $1 \mathbf{r}(78 \mathrm{mg}, 0.2$ mmol) according to General Procedure A with a reaction time of $48 \mathrm{~h}$. The product was isolated by flash silica chromatography to afford 65 mg $\left(78 \%\right.$ yield) of $\mathbf{2 r}$ as a yellow oil. ${ }^{1} \mathbf{H} \mathbf{~ N M R}\left(600 \mathrm{MHz}, \mathrm{CDCl}_{3}\right) \delta$ 8.49 (ddd, $J=4.8,1.9,1.0 \mathrm{~Hz}, 1 \mathrm{H}), 7.66-7.58(\mathrm{~m}, 3 \mathrm{H}), 7.23$ (dt, $J=7.9,1.0 \mathrm{~Hz}, 1 \mathrm{H}), 7.16$ (ddd, $J=7.6,4.9,1.1 \mathrm{~Hz}, 1 \mathrm{H}), 6.97-6.94(\mathrm{~m}, 2 \mathrm{H}), 4.81$ (s, 2H), $2.92(\mathrm{dd}, J=17.7,9.1 \mathrm{~Hz}, 1 \mathrm{H}), 2.89-$ $2.82(\mathrm{~m}, 1 \mathrm{H}), 2.72$ (dddd, $J=41.7,14.0,9.1,6.4 \mathrm{~Hz}, 2 \mathrm{H}), 2.48$ (dd, $J=17.7,4.2 \mathrm{~Hz}, 1 \mathrm{H}), 2.25$ (dddd, $J=13.7,9.3,6.8,5.3 \mathrm{~Hz}, 1 \mathrm{H}), 1.87(\mathrm{dtd}, J=13.8,8.8,6.0 \mathrm{~Hz}, 1 \mathrm{H}) .{ }^{13} \mathrm{C}$ NMR $(151 \mathrm{MHz}$, $\left.\mathrm{CDCl}_{3}\right) \delta 179.55,176.26,154.44,149.66,140.26,137.79,136.88,130.70,122.72,121.99,91.58$, 43.52, 39.27, 34.63, 33.03, 32.61. HRMS calcd. for $\mathrm{C}_{18} \mathrm{H}_{18} \mathrm{IN}_{2} \mathrm{O}_{2}{ }^{+}[\mathrm{M}+\mathrm{H}]^{+}:$421.0407, Found: 421.0408 .

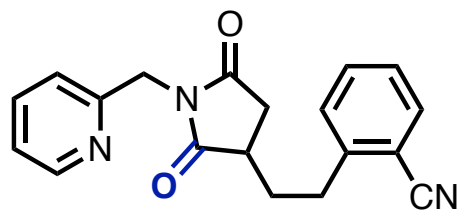

2-(2-(2,5-dioxo-1-(pyridin-2-ylmethyl)pyrrolidin-3yl)ethyl)benzonitrile (2s): The title compound was synthesized from alkene $1 \mathrm{~s}$ (40 $\mathrm{mg}, 0.13 \mathrm{mmol}$ ) according to General Procedure A with a reaction time of $72 \mathrm{~h}$. The product was isolated by flash silica chromatography to afford $30 \mathrm{mg}(68 \%$ yield) of $2 \mathrm{~s}$ as a yellow oil. ${ }^{1} \mathbf{H}$ NMR $\left(600 \mathrm{MHz}, \mathrm{CDCl}_{3}\right) \delta 8.49(\mathrm{~d}, J=4.9 \mathrm{~Hz}, 1 \mathrm{H}), 7.69-7.59(\mathrm{~m}, 2 \mathrm{H}), 7.53(\mathrm{t}, J=7.7$ $\mathrm{Hz}, 1 \mathrm{H}), 7.38(\mathrm{~d}, J=7.8 \mathrm{~Hz}, 1 \mathrm{H}), 7.33(\mathrm{t}, J=7.6 \mathrm{~Hz}, 1 \mathrm{H}), 7.23(\mathrm{~d}, J=7.9 \mathrm{~Hz}, 1 \mathrm{H}), 7.16(\mathrm{dd}, J=$ 7.5, 5.1 Hz, 1H), $4.82(\mathrm{~s}, 2 \mathrm{H}), 3.09-2.96(\mathrm{~m}, 3 \mathrm{H}), 2.92(\mathrm{~d}, J=5.1 \mathrm{~Hz}, 1 \mathrm{H}), 2.57(\mathrm{dd}, J=18.1,4.6$ $\mathrm{Hz}, 1 \mathrm{H}), 2.32(\mathrm{dq}, J=10.9,4.2,2.8 \mathrm{~Hz}, 1 \mathrm{H}), 1.97(\mathrm{dt}, J=14.3,7.9 \mathrm{~Hz}, 1 \mathrm{H}) .{ }^{13} \mathbf{C}$ NMR $(151 \mathrm{MHz}$, $\left.\mathrm{CDCl}_{3}\right) \delta 179.26,176.09,154.47,149.77,144.73,136.78,133.21,133.12,129.90,127.23,122.69$, 121.95, 118.02, 112.56, 43.63, 39.49, 34.66, 32.66, 31.91. HRMS calcd. for $\mathrm{C}_{19} \mathrm{H}_{18} \mathrm{~N}_{3} \mathrm{O}_{2}{ }^{+}[\mathrm{M}+\mathrm{H}]^{+}$: 320.1394, Found: 320.1393.

(cis)-2-(pyridin-2-ylmethyl)tetrahydrocyclopentapyrrole-1,3(2H,3H)-

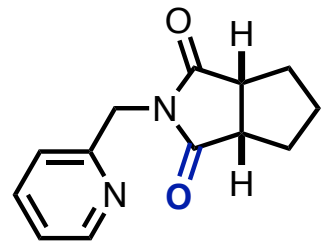

dione (2t): The title compound was synthesized from alkene 1t $(40.5 \mathrm{mg}$, $0.2 \mathrm{mmol}$ ) according to General Procedure A with a reaction time of $24 \mathrm{~h}$. The product was isolated by flash silica chromatography to afford $39 \mathrm{mg}$ ( $85 \%$ yield) of $\mathbf{2 t}$ as a white solid. ${ }^{1} \mathbf{H}$ NMR $\left(600 \mathrm{MHz}, \mathrm{CDCl}_{3}\right) \delta 8.49$ (ddd, $J=4.8,1.8,0.9 \mathrm{~Hz}, 1 \mathrm{H}), 7.62(\mathrm{td}, J=7.7,1.8 \mathrm{~Hz}, 1 \mathrm{H}), 7.20(\mathrm{dt}, J=7.8,0.9$ $\mathrm{Hz}, 1 \mathrm{H}), 7.15(\mathrm{ddd}, J=7.6,4.9,1.1 \mathrm{~Hz}, 1 \mathrm{H}), 4.79(\mathrm{~s}, 2 \mathrm{H}), 3.30-3.18(\mathrm{~m}, 2 \mathrm{H})$, 2.20 (ddd, $J=13.1,6.4,1.8 \mathrm{~Hz}, 2 \mathrm{H}), 1.96-1.84$ (m, 2H), 1.77 (dddt, $J=12.8,6.4,4.4,2.0 \mathrm{~Hz}$, $1 \mathrm{H}), 1.52(\mathrm{dp}, J=18.7,6.3 \mathrm{~Hz}, 1 \mathrm{H}) .{ }^{13} \mathbf{C} \mathbf{N M R}\left(151 \mathrm{MHz}, \mathrm{CDCl}_{3}\right) \delta 180.41,154.65,150.16$, 137.28, 122.60, 121.69, 45.95, 43.24, 30.65, 25.32. HRMS calcd. for $\mathrm{C}_{13} \mathrm{H}_{15} \mathrm{~N}_{2} \mathrm{O}_{2}{ }^{+}[\mathrm{M}+\mathrm{H}]^{+}$: 231.1128 , Found: 231.1128. 


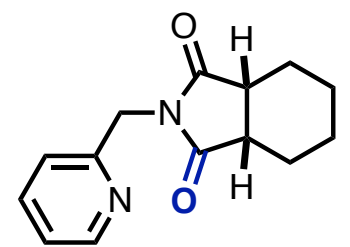

(cis)-2-(pyridin-2-ylmethyl)hexahydro- $1 H$-isoindole-1,3(2H)-dione (2u): The title compound was synthesized from alkene $1 \mathbf{u}(43 \mathrm{mg}, 0.2$ $\mathrm{mmol}$ ) according to General Procedure A with a reaction time of $24 \mathrm{~h}$. The product was isolated by flash silica chromatography to afford $33 \mathrm{mg}(65 \%$ yield) of $\mathbf{2} \mathbf{u}$ as a white solid. Single crystals suitable for X-Ray diffraction were grown by slow diffusion of hexanes into a concentrated solution of product in acetone. The product partially isomerizes to the trans configuration if left heating for 48-72 h. ${ }^{1} \mathbf{H}$ NMR $\left(600 \mathrm{MHz}, \mathrm{CDCl}_{3}\right) \delta 8.50(\mathrm{~d}, J=4.9 \mathrm{~Hz}, 1 \mathrm{H}), 7.62(\mathrm{t}, J=7.5 \mathrm{~Hz}, 1 \mathrm{H}), 7.21$ $(\mathrm{d}, J=7.7 \mathrm{~Hz}, 1 \mathrm{H}), 7.15(\mathrm{dd}, J=7.5,4.9 \mathrm{~Hz}, 1 \mathrm{H}), 4.80(\mathrm{~s}, 2 \mathrm{H}), 2.95(\mathrm{p}, J=7.8 \mathrm{~Hz}, 2 \mathrm{H}), 1.87$ (q, $J=6.3 \mathrm{~Hz}, 4 \mathrm{H}), 1.47$ (m, 4H). ${ }^{13} \mathbf{C}$ NMR $\left(151 \mathrm{MHz}, \mathrm{CDCl}_{3}\right) \delta 179.75,155.02,149.69,136.71$, 122.57, 121.81, 43.28, 40.04, 23.88, 21.82. HRMS calcd. for $\mathrm{C}_{14} \mathrm{H}_{17} \mathrm{~N}_{2} \mathrm{O}_{2}{ }^{+}[\mathrm{M}+\mathrm{H}]^{+}$245.1285, Found: 245.1285. X-ray: CCDC (2008992).

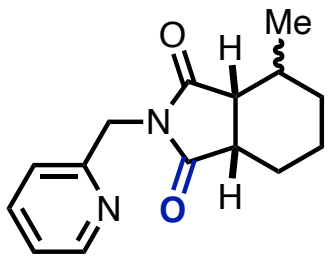

(cis)-4-methyl-2-(pyridin-2-ylmethyl)hexahydro-1H-isoindole-1,3(2H)dione (2v): The title compound was synthesized from alkene 1v (46 mg, 0.2 $\mathrm{mmol}$ ) according to General Procedure A with a reaction time of $48 \mathrm{~h}$. The product was isolated by flash silica chromatography to afford $21 \mathrm{mg}(42 \%$ yield; 2.1:1 d.r.) of $\mathbf{2} \mathbf{v}$ as a yellow oil. The two diastereomers could be separated analytically by LCMS, but could not be separated on a preparative scale. The methyl group on cyclohexyl ring shows a clear doublet with 2 distinct chemical shifts at 1.18 and $1.12 \mathrm{ppm}$. The integration of these peaks corresponded to a 2.1:1 ratio. The relative stereochemistry of this methyl group could not be assigned from the mixture, however the two bridging hydrogens show a clear NOE and are in agreement with related compounds $\mathbf{2 t}$ and $\mathbf{2 u}$ which were isolated as single diastereomers and are assigned to be in the cis configuration to one another as confirmed by X-ray crystallography for $\mathbf{2 u}$. All data given below is for the mixture of diastereomers. ${ }^{1} \mathbf{H}$ NMR $\left(600 \mathrm{MHz}, \mathrm{CDCl}_{3}\right) \delta 8.43(\mathrm{~d}, J=4.7 \mathrm{~Hz}, 1 \mathrm{H}), 7.56(\mathrm{t}, J=7.7 \mathrm{~Hz}, 1 \mathrm{H})$, $7.13(\mathrm{~d}, J=7.9 \mathrm{~Hz}, 1 \mathrm{H}), 7.08$ (dd, $J=7.5,5.0 \mathrm{~Hz}, 1 \mathrm{H}), 4.81-4.62(\mathrm{~m}, 2 \mathrm{H}), 2.93$ (ddd, $J=16.7$, $8.2,3.7 \mathrm{~Hz}, 1 \mathrm{H}), 2.42(\mathrm{t}, J=8.7 \mathrm{~Hz}, 1 \mathrm{H}), 2.17(\mathrm{dt}, J=13.3,4.4 \mathrm{~Hz}, 1 \mathrm{H}), 2.02-1.79(\mathrm{~m}, 1 \mathrm{H}), 1.76-$ $1.47(\mathrm{~m}, 4 \mathrm{H}), 1.18\left(\mathrm{~d}, J=7.1 \mathrm{~Hz}\right.$, minor), $1.12(\mathrm{~d}, J=6.4 \mathrm{~Hz}$, major, $3 \mathrm{H}), 1.07-0.88(\mathrm{~m}, 1 \mathrm{H}) .{ }^{13} \mathrm{C}$ NMR $\left(151 \mathrm{MHz}, \mathrm{CDCl}_{3}\right) \delta 180.14,179.30,179.18,178.46,155.12,149.69,149.65,136.70$, $122.55,122.53,121.94,121.69,47.38,44.57,43.26,43.21,41.25,40.50,33.19,32.10,29.36$, 28.14, 23.53, 22.27, 21.81, 21.02, 19.80, 18.76. HRMS calcd. for $\mathrm{C}_{15} \mathrm{H}_{19} \mathrm{~N}_{2} \mathrm{O}_{2}{ }^{+}[\mathrm{M}+\mathrm{H}]^{+}: 259.1441$, Found: 259.1441

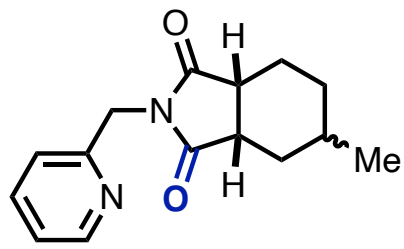

(cis)-5-methyl-2-(pyridin-2-ylmethyl)hexahydro-1 $H$-isoindole1,3(2H)-dione (2w): The title compound was synthesized from alkene $1 \mathbf{w}(46 \mathrm{mg}, 0.2 \mathrm{mmol})$ according to General Procedure A with a reaction time of $48 \mathrm{~h}$. The product was isolated by flash silica chromatography to afford $20 \mathrm{mg}$ ( $40 \%$ yield; $1.9: 1$ d.r.) of $\mathbf{2 w}$ as a yellow oil. The two diastereomers could be separated analytically by LCMS, but could not be separated on a preparative scale. The methyl group on cyclohexyl ring shows a clear doublet with 2 distinct chemical shifts at 0.95 and $0.92 \mathrm{ppm}$. The integration of these peaks corresponded to a 1.9:1 ratio. The relative stereochemistry of this methyl group could not be assigned from the mixture, however the two bridging hydrogens show a clear NOE and are in agreement with related compounds $\mathbf{2} \mathbf{u}$ and $\mathbf{2 t}$, which were isolated as single diastereomers and 
are assigned to be in the cis configuration to one another as confirmed by X-ray crystallography for $\mathbf{2 u}$. All data given below is for the mixture of diastereomers. ${ }^{1} \mathbf{H} \mathbf{~ N M R}\left(600 \mathrm{MHz}, \mathrm{CDCl}_{3}\right) \delta$ $8.51(\mathrm{~s}, 1 \mathrm{H}), 7.63(\mathrm{t}, J=7.7 \mathrm{~Hz}, 1 \mathrm{H}), 7.19(\mathrm{~m}, 2 \mathrm{H}), 4.79(\mathrm{~s}, 2 \mathrm{H}), 3.05(\mathrm{td}, J=7.4,2.6 \mathrm{~Hz}, 1 \mathrm{H})$, 2.99-2.92 (m, 1H), 2.88 (dt, $J=10.0,7.4 \mathrm{~Hz}, 1 \mathrm{H}), 2.39-2.26(\mathrm{~m}, 1 \mathrm{H}), 2.15$ (dddd, $J=13.9,7.0$, $5.5,3.8 \mathrm{~Hz}, 1 \mathrm{H}), 1.76-1.58(\mathrm{~m}, 4 \mathrm{H}), 1.54-1.38(\mathrm{~m}, 2 \mathrm{H}), 1.27(\mathrm{ddd}, J=14.0,11.6,6.9 \mathrm{~Hz}, 1 \mathrm{H})$, $1.08-0.96(\mathrm{~m}, 1 \mathrm{H}), 0.95\left(\mathrm{~d}, J=6.5 \mathrm{~Hz}\right.$, major) and $0.92(\mathrm{~d}, J=6.5 \mathrm{~Hz}$, minor, $3 \mathrm{H}) .{ }^{13} \mathbf{C}$ NMR $(151$ $\left.\mathrm{MHz} \mathrm{CDCl}_{3}\right) \delta 180.09,180.04,179.37,179.12,136.68,43.30,40.79,40.38,39.83,39.69,35.21$, 30.83, 30.03, 29.41, 28.25, 26.30, 22.42, 22.17, 21.66. HRMS calcd. for $\mathrm{C}_{15} \mathrm{H}_{19} \mathrm{~N}_{2} \mathrm{O}_{2}{ }^{+}[\mathrm{M}+\mathrm{H}]^{+}$ 259.1441, Found: 259.1443.

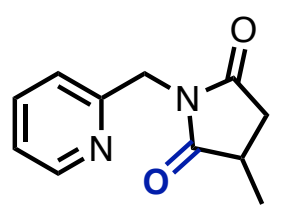

3-methyl-1-(pyridin-2-ylmethyl)pyrrolidine-2,5-dione (2x): The title compound was synthesized from alkene 1wa (35 $\mathrm{mg}, 0.2 \mathrm{mmol})$ according to General Procedure A with a reaction time of $24 \mathrm{~h}$. The product was isolated by flash silica chromatography to afford $37 \mathrm{mg}$ (91\% yield) of $\mathbf{2 x}$ as a yellow oil.

${ }^{1} \mathbf{H}$ NMR $\left(600 \mathrm{MHz}, \mathrm{CDCl}_{3}\right) \delta 8.51(\mathrm{ddd}, J=4.8,1.8,1.0 \mathrm{~Hz}, 1 \mathrm{H}), 7.63(\mathrm{td}, J$ $=7.7,1.8 \mathrm{~Hz}, 1 \mathrm{H}), 7.22(\mathrm{dt}, J=7.7,1.0 \mathrm{~Hz}, 1 \mathrm{H}), 7.16(\mathrm{ddd}, J=7.5,4.9,1.1 \mathrm{~Hz}, 1 \mathrm{H}), 4.81(\mathrm{~s}, 2 \mathrm{H})$, 3.09-2.87 (m, 2H), $2.41(\mathrm{dd}, J=17.7,4.1 \mathrm{~Hz}, 1 \mathrm{H}), 1.38(\mathrm{~d}, J=7.2 \mathrm{~Hz}, 3 \mathrm{H}) .{ }^{13} \mathbf{C}$ NMR $(150 \mathrm{MHz}$, $\left.\mathrm{CDCl}_{3}\right) \delta 180.55,176.45,154.67,149.77,136.68,122.65,121.91,43.60,36.66,34.98,16.97$. HRMS calcd. for $\mathrm{C}_{11} \mathrm{H}_{13} \mathrm{~N}_{2} \mathrm{O}_{2}{ }^{+}[\mathrm{M}+\mathrm{H}]^{+}:$205.0972, Found: 205.0974.

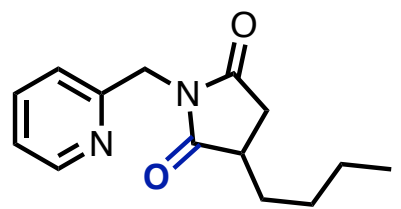

3-butyl-1-(pyridin-2-ylmethyl)pyrrolidine-2,5-dione (2y): The title compound was synthesized from alkene $1 \mathbf{y}(44 \mathrm{mg}, 0.2 \mathrm{mmol})$ according to General Procedure A with a reaction time of $48 \mathrm{~h}$. The product was isolated isolated by flash silica chromatography to afford $16.5 \mathrm{mg} \mathrm{(33 \%}$ yield) of $\mathbf{2 y}$ as a yellow oil. ${ }^{1} \mathbf{H} \mathbf{N M R}\left(600 \mathrm{MHz}, \mathrm{CDCl}_{3}\right) \delta 8.51(\mathrm{~d}, J=$ $4.8 \mathrm{~Hz}, 1 \mathrm{H}), 7.63(\mathrm{td}, J=7.7,1.8 \mathrm{~Hz}, 1 \mathrm{H}), 7.22(\mathrm{~d}, J=7.8 \mathrm{~Hz}, 1 \mathrm{H}), 7.16(\mathrm{dd}, J=7.2,5.2 \mathrm{~Hz}, 1 \mathrm{H})$, $4.81(\mathrm{~s}, 2 \mathrm{H}), 2.96-2.85(\mathrm{~m}, 2 \mathrm{H}), 2.53-2.44(\mathrm{~m}, 1 \mathrm{H}), 1.95(\mathrm{td}, J=9.1,5.0 \mathrm{~Hz}, 1 \mathrm{H}), 1.57(\mathrm{dt}, J=$ 14.1, 8.3 Hz, 1H), 1.40-1.32 (m, 4H), 0.94-0.89 (m, 2H). ${ }^{13} \mathbf{C ~ N M R ~ ( 1 5 1 ~ M H z , ~ C D C l ~} 3$ ) $\delta 180.05$, 176.72, 154.73, 149.75, 136.74, 122.64, 121.91, 43.60, 40.17, 34.56, 31.21, 29.00, 22.57, 14.02. HRMS calcd. for $\mathrm{C}_{14} \mathrm{H}_{19} \mathrm{~N}_{2} \mathrm{O}_{2}{ }^{+}[\mathrm{M}+\mathrm{H}]^{+}:$247.1441, Found: 247.1441 .

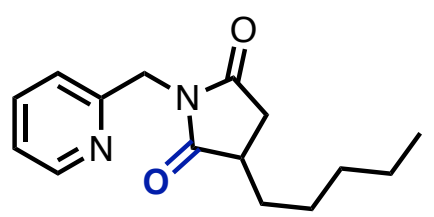

3-pentyl-1-(pyridin-2-ylmethyl)pyrrolidine-2,5-dione (2z): The title compound was synthesized from alkene $1 \mathbf{z}(46 \mathrm{mg}, 0.2 \mathrm{mmol})$ according to General Procedure A with a reaction time of $72 \mathrm{~h}$. The product was isolated by flash silica chromatography to afford $9 \mathrm{mg}$ (17\% yield) of $\mathbf{2 z}$ as a yellow oil. ${ }^{1} \mathbf{H}$ NMR $\left(600 \mathrm{MHz}, d_{6}\right.$-DMSO) $\delta$ $8.42(\mathrm{dt}, J=4.8,1.4 \mathrm{~Hz}, 1 \mathrm{H}), 7.72$ (td, $J=7.6,1.8 \mathrm{~Hz}, 1 \mathrm{H}), 7.24$ (ddd, $J=7.4,6.3,1.4 \mathrm{~Hz}, 2 \mathrm{H}$ ), 
$4.62(\mathrm{~s}, 2 \mathrm{H}), 2.93-2.82(\mathrm{~m}, 2 \mathrm{H}), 2.44(\mathrm{~d}, J=7.8 \mathrm{~Hz}, 1 \mathrm{H}), 1.75-1.65(\mathrm{~m}, 1 \mathrm{H}), 1.51-1.42(\mathrm{~m}, 1 \mathrm{H})$, $1.35-1.16(\mathrm{~m}, 6 \mathrm{H}), 0.86-0.80(\mathrm{~m}, 3 \mathrm{H}) .{ }^{13} \mathbf{C}$ NMR (151 MHz, $d_{6}$-DMSO) $\delta 179.89,176.67,155.46$, $149.05,136.83,122.50,121.14,42.67,40.05,33.89,31.03,30.41,25.77,21.97,13.91$. HRMS calcd. for $\mathrm{C}_{15} \mathrm{H}_{21} \mathrm{~N}_{2} \mathrm{O}_{2}{ }^{+}[\mathrm{M}+\mathrm{H}]^{+}:$261.1598, Found: 261.1597 .<smiles>CCC1CC(=O)N(C(C)c2ccccn2)C1=O</smiles>

3-ethyl-1(S)-(1-(pyridin-2-yl)ethyl)pyrrolidine-2,5-dione (2aa): The title compound was synthesized from alkene $(S)$-DG7-SM $(41 \mathrm{mg}, 0.2 \mathrm{mmol})$ according to modified General Procedure A using $\mathrm{W}(\mathrm{CO})_{6}(25 \mathrm{mg}, 0.055 \mathrm{mmol})$ with a reaction time of $48 \mathrm{~h}$. The product was isolated by flash silica chromatography to afford $35 \mathrm{mg}$ (75\% yield; $5.3: 1$ d.r.; $>99 \%$ ee) of 2 aa as a colorless oil. The two diastereomers and pairs of enantiomers were separated by SFC with the method shown below. The two diastereomers are reported as mixture. The spectra matched that from the racemic compound. ${ }^{1} \mathbf{H} \mathbf{N M R}\left(600 \mathrm{MHz}, \mathrm{CDCl}_{3}\right) \delta 8.52(\mathrm{~d}, J=4.9 \mathrm{~Hz}, 1 \mathrm{H})$, $7.68(\mathrm{t}, J=7.5 \mathrm{~Hz}, 1 \mathrm{H}), 7.37(\mathrm{~d}, J=7.9 \mathrm{~Hz}, 1 \mathrm{H}), 7.18(\mathrm{dd}, J=7.5,5.0 \mathrm{~Hz}, 1 \mathrm{H}), 5.47(\mathrm{q}, J=7.3$ $\mathrm{Hz}, 1 \mathrm{H}), 2.93-2.74(\mathrm{~m}, 2 \mathrm{H}), 2.49-2.35(\mathrm{~m}, 1 \mathrm{H}), 1.97-1.84(\mathrm{~m}, 1 \mathrm{H}), 1.82(\mathrm{~d}, J=7.4 \mathrm{~Hz}, 3 \mathrm{H}), 1.71-$ $1.56(\mathrm{~m}, 1 \mathrm{H}), 0.98(\mathrm{~m}, 3 \mathrm{H}) .{ }^{13} \mathbf{C}$ NMR $\left(151 \mathrm{MHz}, \mathrm{CDCl}_{3}\right) \delta 179.82,176.65,158.16,148.98,148.93$, 136.84, 136.80, 122.38, 120.95, 50.90, 50.81, 40.98, 40.96, 33.86, 33.80, 24.41, 24.35, 15.97, 15.94, 10.78, 10.73. HRMS calcd. for $\mathrm{C}_{13} \mathrm{H}_{17} \mathrm{~N}_{2} \mathrm{O}_{2}{ }^{+}[\mathrm{M}+\mathrm{H}]^{+}:$233.1285, Found: 233.1287 . 


\section{REMOVAL OF DIRECTING GROUP FROM 2a}

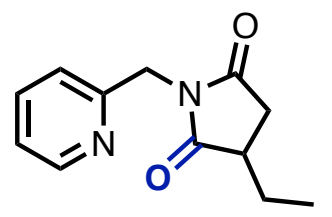

2a

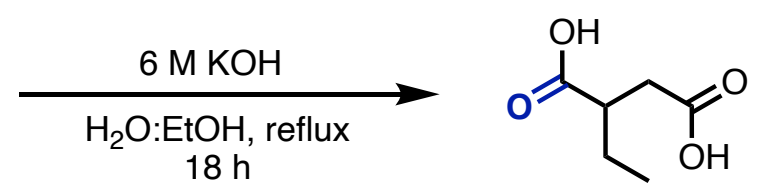

3a

$92 \%$ yield

Scheme S2 Directing group removal

To a $5-\mathrm{mL}$ disposable vial equipped with magnetic stir bar, 2a (100 $\mathrm{mg}, 0.458 \mathrm{mmol})$ and $\mathrm{KOH}$ (116 mg, $2.06 \mathrm{mmol})$ were added. The solids were dissolved in $\mathrm{H}_{2} \mathrm{O}(340 \mu \mathrm{L})$ and ethanol $(4.5$ $\mathrm{mL}$ ). The vial was sealed and placed in a preheated oil bath at $100{ }^{\circ} \mathrm{C}$ for $18 \mathrm{~h}$. The reaction was then allowed to cool to room temperature, and the organic solvent was removed by rotary evaporator. The crude was then diluted with $\mathrm{DCM}$ and aq. $\mathrm{NaHCO}_{3}$, and the organic phase was discarded. The aqueous layer was extracted with DCM $(\times 2)$. Next, the aqueous layer was acidified with $6 \mathrm{M} \mathrm{HCl}$ until it had reached $\mathrm{pH}<1$, as monitored by $\mathrm{pH}$ paper. The aqueous layer was then extracted with EtOAc $(\times 3)$, and the organic layers were combined, dried over $\mathrm{MgSO}_{4}$, filtered, and evaporated to dryness. The resulting solid was washed with cold $\mathrm{Et}_{2} \mathrm{O}$ and then dried under vacuum, to afford $61 \mathrm{mg}$ (92\% yield) of 3a as a white solid. Analytical data match previously published data (48). 
<smiles>C=CCC(=O)NCc1ccccn1</smiles>

$1 \times a$

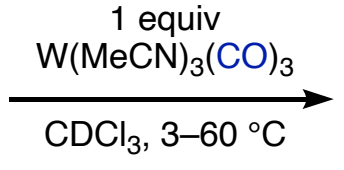

formation is observed after $10 \mathrm{~m}$

$\mathrm{W}(\mathrm{MeCN})_{3}(\mathrm{CO})_{3}(12 \mathrm{mg}, 0.030 \mathrm{mmol})$ and $1 \times 2 a(5.2 \mathrm{mg}, 0.030 \mathrm{mmol})$ were added to a $\mathrm{J}$ Young NMR tube followed by $0.75 \mathrm{~mL}$ of $\mathrm{CDCl}_{3}$. The NMR tube was shaken vigorously for 2 minutes, at which point data collection ensued. The stacked spectra below show data collected at 10 minutes (top) and $1 \mathrm{~h}$ (bottom). The sweep width for these experiments was from $10 \mathrm{ppm}$ to $-15 \mathrm{ppm}$ to account for possible formation of a metal hydride; however, no signals were observed in the hydride region $(<0 \mathrm{ppm})$.
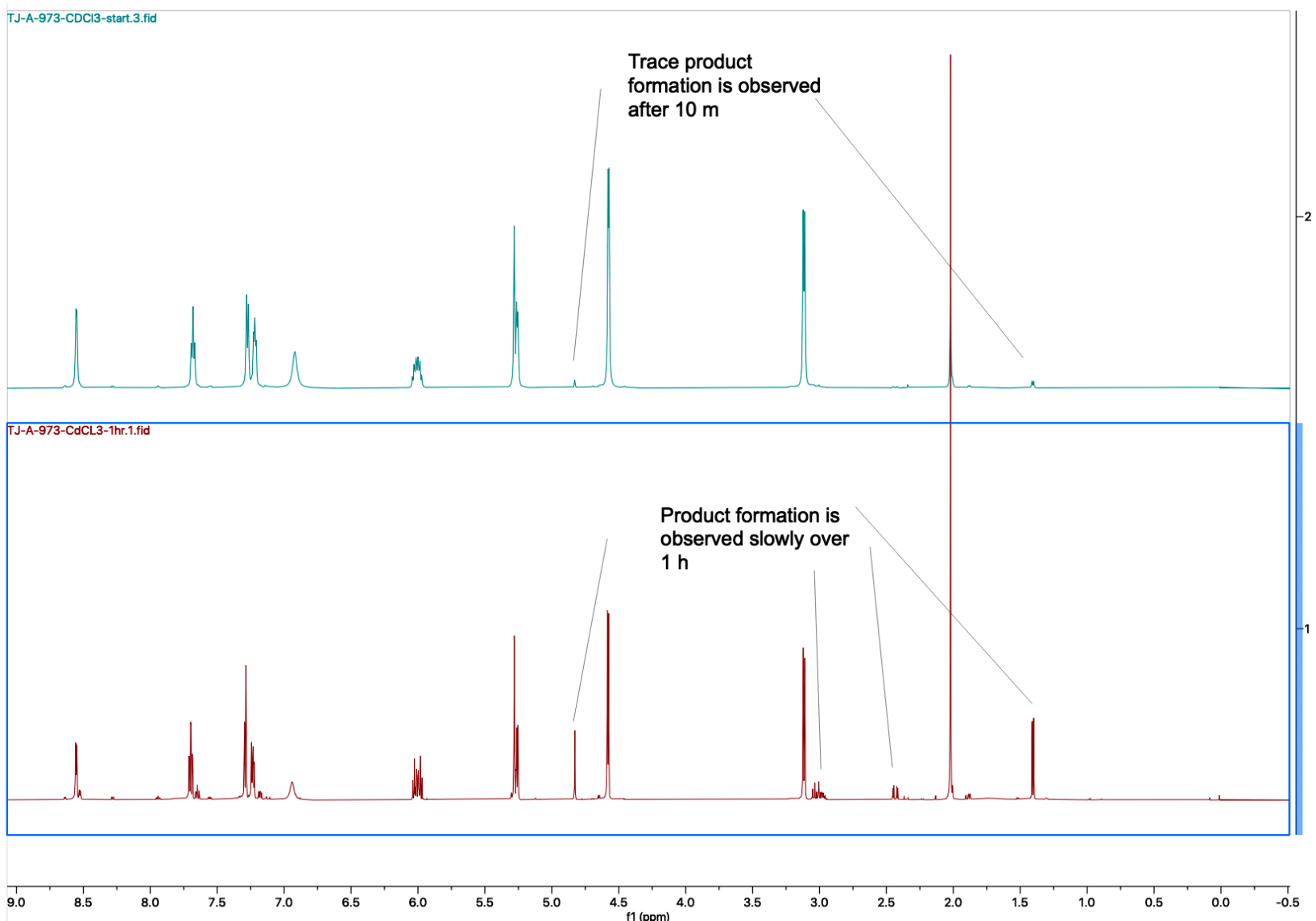

Figure S4 Time-monitored progress of stoichiometric reaction followed by ${ }^{1} \mathrm{H}$ NMR. The top ${ }^{1} \mathrm{H}$ spectrum corresponds to a timepoint $t=10 \mathrm{~min}$ after the reaction started. The bottom ${ }^{1} \mathrm{H}$ spectrum corresponds to a timepoint $t=1$ hour after the reaction started. Both spectra were acquired at room temperature, and the NMR tube was allowed to stand at room temperature in between acquisitions. 


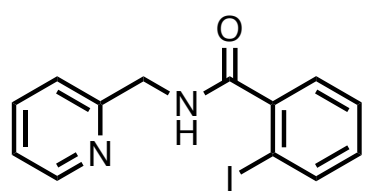

2-iodo- $N$-(pyridin-2-ylmethyl)benzamide (SM-3): The title compound was prepared according to the General Procedure D using 2-iodobenzoic acid $(1.500 \mathrm{~g}, 4.44 \mathrm{mmol})$ as the carboxylic acid. The product was isolated by flash silica chromatography to afford $1.105 \mathrm{~g}$ (71\% yield) of $\mathbf{S M - 3}$ as a white solid. ${ }^{1} \mathbf{H}$ NMR $\left(600 \mathrm{MHz}, \mathrm{CDCl}_{3}\right) \delta 8.56(\mathrm{~d}, J=4.9 \mathrm{~Hz}, 1 \mathrm{H}), 7.87(\mathrm{~d}, J=8.0 \mathrm{~Hz}, 1 \mathrm{H})$, $7.82(\mathrm{t}, J=7.7 \mathrm{~Hz}, 1 \mathrm{H}), 7.51(\mathrm{~d}, J=7.9 \mathrm{~Hz}, 1 \mathrm{H}), 7.48(\mathrm{~d}, J=7.5 \mathrm{~Hz}, 1 \mathrm{H}), 7.39(\mathrm{t}, J=7.5 \mathrm{~Hz}, 1 \mathrm{H})$, 7.36-7.29 (m, 2H), 7.11 (t, $J=7.7 \mathrm{~Hz}, 1 \mathrm{H}), 4.82(\mathrm{~d}, J=5.1 \mathrm{~Hz}, 2 \mathrm{H}) ;{ }^{13} \mathbf{C} \mathbf{N M R}\left(151 \mathrm{MHz}, \mathrm{CDCl}_{3}\right)$ $\delta$ 169.53, 155.42, 147.69, 141.76, 140.15, 138.54, 131.38, 128.51, 128.32, 123.50, 123.19, 92.76, 44.32; HRMS calcd. for $\mathrm{C}_{13} \mathrm{H}_{12} \mathrm{~N}_{2} \mathrm{OI}^{+}[\mathrm{M}+\mathrm{H}]^{+}: 338.9989$, Found: 338.9989 .

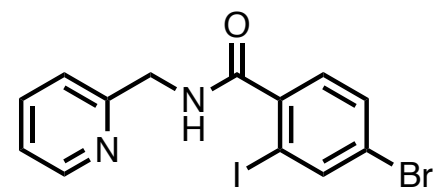

4-bromo-2-iodo- $N$-(pyridin-2-ylmethyl)benzamide (SM-2): The title compound was prepared according to General Procedure D using 2-iodo-4-bromo benzoic acid $(1.500 \mathrm{~g}, 3.66 \mathrm{mmol})$ as the carboxylic acid. The product was isolated by flash silica chromatography to afford $1.125 \mathrm{~g}$ (58\% yield) of SM-2 as a white solid. ${ }^{1} \mathbf{H}$ NMR $(600$ $\left.\mathrm{MHz}, \mathrm{CDCl}_{3}\right) \delta 8.57(\mathrm{~d}, J=6.2 \mathrm{~Hz}, 1 \mathrm{H}), 8.04(\mathrm{~d}, J=4.5 \mathrm{~Hz}, 1 \mathrm{H}), 7.89(\mathrm{dq}, J=15.8,7.6 \mathrm{~Hz}, 1 \mathrm{H})$, 7.66-7.30 (m, 4H), 4.93-4.76 (m, 2H); ${ }^{13} \mathbf{C}$ NMR $\left(151 \mathrm{MHz}, \mathrm{CDCl}_{3}\right) \delta 168.66,154.83,147.46$, 142.31, 142.29, 140.14, 131.55, 129.55, 124.74, 124.23, 123.65, 93.40, 43.80; HRMS calcd. for $\mathrm{C}_{13} \mathrm{H}_{11} \mathrm{~N}_{2} \mathrm{OIBr}^{+}[\mathrm{M}+\mathrm{H}]^{+}:$416.9094, Found: 416.9096 .<smiles>O=C(CCI)NCc1ccccn1</smiles>

3-iodo- $N$-(pyridin-2-ylmethyl)propenamide (SM-1): A flame-dried 10$\mathrm{mL}$ Schlenk tube equipped with magnetic stir bar was charged with 3iodopropanoic acid $(2.00 \mathrm{~g}, 10.00 \mathrm{mmol})$ and DMF $(40 \mu \mathrm{L}, 0.05 \mathrm{mmol})$ and was then cooled to $0{ }^{\circ} \mathrm{C}$. Oxalyl chloride $(875 \mu \mathrm{L}, 10.00 \mathrm{mmol})$ was added dropwise over $15 \mathrm{~min}$, and the reaction solution was allowed to continue stirring at $0{ }^{\circ} \mathrm{C}$ for $30 \mathrm{~min}$ before being allowed to warm to room temperature and stir for an additional $1 \mathrm{~h}$. The reaction was then cooled back down to $0{ }^{\circ} \mathrm{C}$, and under vigorous stirring 2-picolylamine $(1.622 \mathrm{~g}$, $15.00 \mathrm{mmol}$ ) was added. The reaction mixture was stirred for $10 \mathrm{~min}$, at which point it was diluted with EtOAc and quenched by addition of a saturated solution of aqueous $\mathrm{NH}_{4} \mathrm{Cl}$. The organic layer was separated, evaporated to dryness, redissolved in $\mathrm{MeOH}(4 \mathrm{~mL})$, and purified by HPLC. The product-containing fractions were combined and lyophilized to afford $455 \mathrm{mg}$ (16\% yield) of SM1 as a white powder in which was stored at $-40{ }^{\circ} \mathrm{C} .{ }^{1} \mathbf{H} \mathbf{~ N M R}\left(600 \mathrm{MHz}, \mathrm{CDCl}_{3}\right) \delta 8.53(\mathrm{~d}, J=$ $5.1 \mathrm{~Hz}, 1 \mathrm{H}), 7.70(\mathrm{tt}, J=7.5,1.8 \mathrm{~Hz}, 1 \mathrm{H}), 7.32(\mathrm{~d}, J=7.8 \mathrm{~Hz}, 1 \mathrm{H}), 7.24(\mathrm{dd}, J=7.5,5.0 \mathrm{~Hz}, 1 \mathrm{H})$, $7.02(\mathrm{~s}, 1 \mathrm{H}), 4.59(\mathrm{~d}, J=4.9 \mathrm{~Hz}, 2 \mathrm{H}), 3.41(\mathrm{td}, J=7.1,1.7 \mathrm{~Hz}, 2 \mathrm{H}), 2.91(\mathrm{td}, J=7.0,1.7 \mathrm{~Hz}, 2 \mathrm{H})$; ${ }^{13}$ C NMR $\left(151 \mathrm{MHz}, \mathrm{CDCl}_{3}\right) \delta 170.55,155.93,148.65,137.47,122.78,122.67,44.38,40.61$, -1.77; HRMS calcd. for $\mathrm{C}_{9} \mathrm{H}_{12} \mathrm{~N}_{2} \mathrm{O}^{+}[\mathrm{M}+\mathrm{H}]^{+}: 290.9989$, Found: 290.9990 .
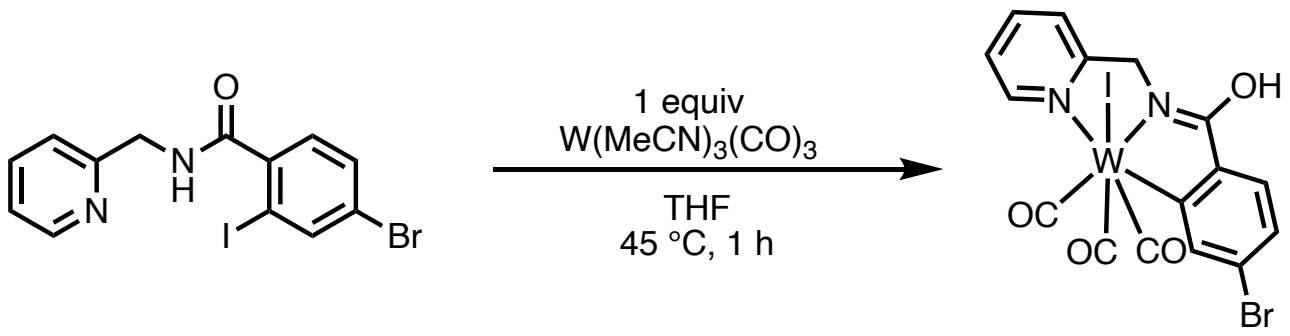

Inside an argon-filled glovebox, a 1 dram vial containing of SM-2 (106 mg, $0.255 \mathrm{mmol})$ and $\mathrm{W}(\mathrm{MeCN})_{3}(\mathrm{CO})_{3}(100 \mathrm{mg}, 0.255 \mathrm{mmol})$ was dissolved in $2 \mathrm{~mL}$ of THF then stirred and heated at $45^{\circ} \mathrm{C}$ for $1 \mathrm{~h}$. The solution turned a vibrant yellow. After $1 \mathrm{~h}$ it was then allowed to cool to room temperature and then filtered through a PFE syringe filter into a vial of ether. The filtered solution 


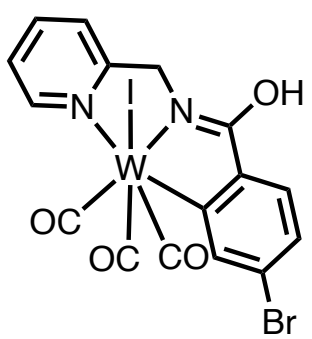

was then allowed to slowly evaporate in the glovebox brought to saturation to afford red cube crystals. The crystals were collected by filtration and washed with hexanes to afford $45 \mathrm{mg}$ (26\% yield) of $\mathbf{W}-\mathbf{2}$ as red cubic crystals. The above procedure was not optimized for isolated yield. The single crystals collected were used for x-ray crystallography, NMR, HRMS, and IR characterization. Oil and grease appear in the NMR as the crystals collected for diffraction were all submerged in oil for initial characterization by x-ray crystallography and these were used for characterization. ${ }^{1} \mathbf{H}$ NMR $(600 \mathrm{MHz}$, THF) $\delta 11.82(\mathrm{~s}, 1 \mathrm{H}), 8.94(\mathrm{~d}, J=5.6 \mathrm{~Hz}, 1 \mathrm{H}), 8.06-7.92(\mathrm{~m}, 2 \mathrm{H}), 7.73(\mathrm{~d}, J=8.3 \mathrm{~Hz}, 1 \mathrm{H}), 7.67$ $(\mathrm{d}, J=7.9 \mathrm{~Hz}, 1 \mathrm{H}), 7.47(\mathrm{t}, J=6.6 \mathrm{~Hz}, 1 \mathrm{H}), 7.33(\mathrm{dd}, J=8.3,1.9 \mathrm{~Hz}, 1 \mathrm{H}), 5.78-5.56(\mathrm{~m}, 2 \mathrm{H}) .{ }^{13} \mathbf{C}$ NMR (151 MHz, THF) $\delta$ 226.12, 223.68, 221.56, 169.34, 166.36, 166.09, 154.19, 146.70, 140.88, 137.76, 129.26, 127.11, 126.80, 125.56, 123.24, 57.09. IR $\left(\mathrm{cm}^{-1}\right)$ 1998, 1907, 1865, 1604, 1566, 1397, 1242, 1164, 1043, 1017, 875, 821, 770, 749, 725, 672. HRMS calcd. For $\mathrm{C}_{16} \mathrm{H}_{10} \mathrm{~N}_{2} \mathrm{O}_{4} \mathrm{BrIW}^{+}$ $[\mathrm{M}]^{+}:$683.8372. Found 683.4350. X-ray (CCDC 2020047).

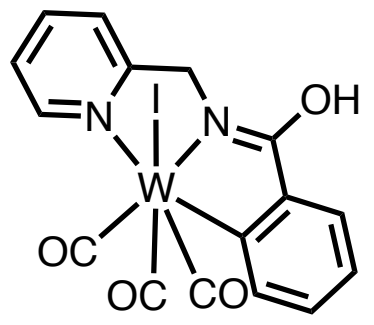

Inside an argon filled glovebox, a 1 dram vial containing of SM-3 $(50 \mathrm{mg}$, $0.15 \mathrm{mmol})$ and $\mathrm{W}(\mathrm{MeCN})_{3}(\mathrm{CO})_{3}(58 \mathrm{mg}, 0.255 \mathrm{mmol})$ was dissolved in $2 \mathrm{~mL}$ of THF then stirred and heated at $45^{\circ} \mathrm{C}$ for $1 \mathrm{~h}$. The solution turned brown. After $1 \mathrm{~h}$ it was then allowed to cool to room temperature and then filtered through a PFE syringe filter. The filtered solution was then allowed to slowly evaporate in the glovebox and brought to saturation at which point the solution was subject to slow vapor diffusion with pentanes to afford red cube crystals. The crystals were collected by filtration and washed with hexanes to afford $16 \mathrm{mg}$ (18\% yield) of $\mathbf{W}-\mathbf{3}$ as red cubic crystals. The above procedure was not optimized for isolated yield. The single crystals collected were used for x-ray crystallography, NMR, HRMS, and IR characterization. Oil and grease appear in the NMR as the crystals collected were all submerged in oil for initial characterization by x-ray crystallography. ${ }^{1} \mathbf{H}$ NMR $(600 \mathrm{MHz}$, $\left.\mathrm{CD}_{2} \mathrm{Cl}_{2}\right) \delta 8.88(\mathrm{~d}, J=5.4 \mathrm{~Hz}, 1 \mathrm{H}), 7.93(\mathrm{~d}, J=7.9 \mathrm{~Hz}, 1 \mathrm{H}), 7.82(\mathrm{~d}, J=7.7 \mathrm{~Hz}, 1 \mathrm{H}), 7.71(\mathrm{~d}, J=$ $7.8 \mathrm{~Hz}, 1 \mathrm{H}), 7.53(\mathrm{~d}, J=7.8 \mathrm{~Hz}, 1 \mathrm{H}), 7.37(\mathrm{~d}, J=6.2 \mathrm{~Hz}, 1 \mathrm{H}), 7.28(\mathrm{~d}, J=7.9 \mathrm{~Hz}, 1 \mathrm{H}), 7.22(\mathrm{~d}, J$ $=7.8 \mathrm{~Hz}, 1 \mathrm{H}), 5.64(\mathrm{~s}, 2 \mathrm{H}) .{ }^{13} \mathbf{C}$ NMR $\left(151 \mathrm{MHz}, \mathrm{CD}_{2} \mathrm{Cl}_{2}\right) \delta 223.55,218.12,216.25,167.54$, $165.05,162.21,153.46,144.97,140.23,136.94,131.81,127.10,124.90,123.47,122.48,56.33$. IR $\left(\mathrm{cm}^{-1}\right) 1998.5,1879.2$ (d), 1557.5, 1523.6, 1392.1, 762.5, 737.7. HRMS calcd. For $\mathrm{C}_{16} \mathrm{H}_{10} \mathrm{~N}_{2} \mathrm{O}_{4} \mathrm{IW}^{+}[\mathrm{M}]^{+}:$606.9346, Found: 606.9350. X-ray (CCDC 2050458).

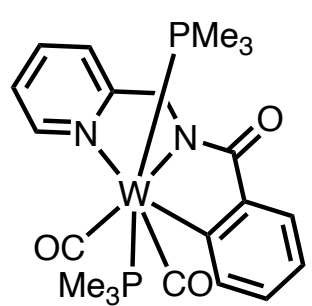

In a argon-filled glovebox, to a 20 -mL vial were added 2 -iodo- $N$-(pyridin-2ylmethyl)benzamide $(100 \mathrm{mg}, 0.30 \mathrm{mmol}), \mathrm{W}(\mathrm{MeCN})_{3}(\mathrm{CO})_{3}(116 \mathrm{mg}, 0.30$ $\mathrm{mmol})$, and THF (4 mL). The reaction was heated to $45^{\circ} \mathrm{C}$ for $2 \mathrm{~h}$ resulting in a homogenous brown solution. After complete conversion of the starting material, the reaction vessel was removed from the heat source and allowed to cool to room temperature, at which point silver trifluormethylsulfonate (76 $\mathrm{mg}, 0.30 \mathrm{mmol}$ ) was added to the solution. The reaction mixture was heated to $45^{\circ} \mathrm{C}$ for $30 \mathrm{~min}$. The reaction was cooled to room temperature and filtered, and the filtrate was transferred into a separate vial containing trimethylphosphine $(49.5 \mathrm{mg}, 0.65 \mathrm{mmol})$. The reaction mixture was stirred for $15 \mathrm{~min}$ at room temperature, resulting in a dark-red solution. Potassium tert-butoxide ( $33 \mathrm{mg}, 0.30 \mathrm{mmol}$ ) was added to the reaction mixture, resulting in immediate formation of a dark-purple solution. Next, 18-crown-6 $(78 \mathrm{mg}, 0.30 \mathrm{mmol})$ was added, resulting in formation of yellow/orange solution. The reaction mixture was stirred for $1 \mathrm{~h}$ at room 
temperature, resulting in slow precipitation of KOTf-18C6. The reaction solution was filtered to remove KOTf-18C6. Slow evaporation of the solvent resulted in further precipitation of the remaining KOTf-18C6. A second filtration was then performed. The product can be isolated by flash chromatography on neutral alumina using $\mathrm{DCM} / \mathrm{MeOH}(97 / 3)$ as the eluent to afford $56 \mathrm{mg}$ (31\% overall yield) of $\mathbf{W}-\mathbf{3}$ ' as a yellow solid. Vapor diffusion of pentane into a concentrated solution of $\mathbf{W}-3$ ' provided single crystals suitable for X-ray diffraction. ${ }^{1} \mathbf{H}$ NMR $(600 \mathrm{MHz}$, $\left.\mathrm{CD}_{2} \mathrm{Cl}_{2}\right) \delta 8.75(\mathrm{~d}, J=5.7 \mathrm{~Hz}, 1 \mathrm{H}), 7.83(\mathrm{t}, J=7.7 \mathrm{~Hz}, 1 \mathrm{H}), 7.62(\mathrm{~d}, J=7.5 \mathrm{~Hz}, 1 \mathrm{H}), 7.51(\mathrm{~d}, J=$ $8.0 \mathrm{~Hz}, 1 \mathrm{H}), 7.48(\mathrm{~d}, J=7.6 \mathrm{~Hz}, 1 \mathrm{H}), 7.25$ (t, $J=6.7 \mathrm{~Hz}, 1 \mathrm{H}), 7.05(\mathrm{t}, J=7.3 \mathrm{~Hz}, 1 \mathrm{H}), 6.95$ (t, $J$ $=7.4 \mathrm{~Hz}, 1 \mathrm{H}), 5.21(\mathrm{~d}, J=22.1 \mathrm{~Hz}, 1 \mathrm{H}), 5.06(\mathrm{~d}, J=22.1 \mathrm{~Hz}, 1 \mathrm{H}), 1.02(\mathrm{~d}, J=8.0 \mathrm{~Hz}, 10 \mathrm{H}), 0.75$ $(\mathrm{d}, J=8.2 \mathrm{~Hz}, 10 \mathrm{H}) .{ }^{13} \mathrm{C}$ NMR $\left(151 \mathrm{MHz}, \mathrm{CD}_{2} \mathrm{Cl}_{2}\right) \delta 177.30,167.86,165.58,165.40,153.09$, $145.48,142.19(\mathrm{~d}, J=3.2 \mathrm{~Hz}), 138.98,129.30-129.19(\mathrm{~m}), 128.89,128.15(\mathrm{~d}, J=221.6 \mathrm{~Hz})$, $127.42,127.27,124.12,123.36,122.12(\mathrm{~d}, J=2.4 \mathrm{~Hz}), 56.64,14.86(\mathrm{~d}, J=24.2 \mathrm{~Hz}), 12.62(\mathrm{~d}, J$ $=26.5 \mathrm{~Hz}) .{ }^{31} \mathbf{P}$ NMR $\left(162 \mathrm{MHz}, \mathrm{CD}_{2} \mathrm{Cl}_{2}\right) \delta-15.83(\mathrm{~d}, J=170.2 \mathrm{~Hz}),-18.38(\mathrm{~d}, J=168.1 \mathrm{~Hz}) . \mathbf{I R}$ $\left(\mathrm{cm}^{-1}\right)$ 1886.6, 1809.8, 1102.0, 944, 892.5, 726.3, 669, 630. HRMS calcd. For $\mathrm{C}_{21} \mathrm{H}_{29} \mathrm{~N}_{2} \mathrm{O}_{3} \mathrm{P}_{2} \mathrm{~W}^{+}$ $[\mathrm{M}+\mathrm{H}]^{+}:$603.1157, Found: 603.1157. X-ray (CCDC 2045639).

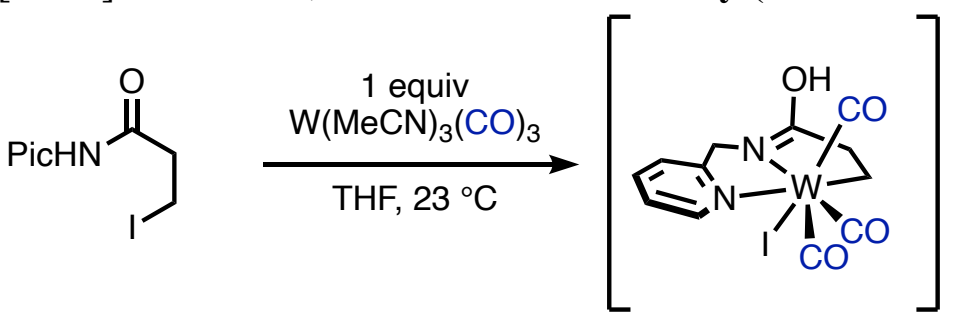

SM-1
$\mathbf{W}-1$

$\left[{ }^{1} \mathrm{H},{ }^{13} \mathrm{C}\right.$ NMR, IR]

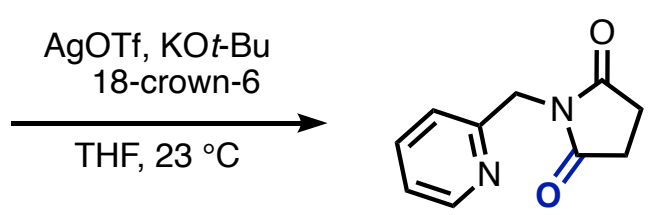

P-1

$76 \%$ yield

Inside an argon-filled glovebox, $\mathrm{W}(\mathrm{MeCN})_{3}(\mathrm{CO})_{3}(40 \mathrm{mg}, 0.102 \mathrm{mmol})$ and SM-1 $(30 \mathrm{mg}, 0.102$ mmol) were added to a $20 \mathrm{~mL}$ vial equipped with magnetic stir bar and dissolved in $3 \mathrm{~mL}$ of THF. The stir rate was set to $1000 \mathrm{rpm}$ and stirred for $2 \mathrm{~h}$ at $25{ }^{\circ} \mathrm{C}$. After $2 \mathrm{~h}$, silver trifluoromethanesulfonate $(26 \mathrm{mg}, 0.102 \mathrm{mmol})$, potassium tert-butoxide (11.5 $\mathrm{mg}, 0.102 \mathrm{mmol})$, and 18-crown-6 (27 mg, $0.102 \mathrm{mmol})$ were added, the vial was removed form the glovebox and allowed to stir for $48 \mathrm{~h}$. The crude material was filtered through celite and GCMS analysis of the crude material showed P-1 and small amounts of proto-demetalated material. The product was isolated by PTLC (1:1 acetone:hexanes) to afford $15 \mathrm{mg}$ (76\% yield) of P-1 as a colorless oil.

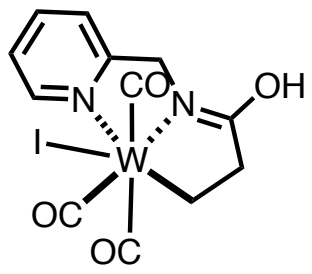

This intermediate is detecting in situ. Upon evaporation of solvent a dark brown oil resulted and various attempts at crystallization were unsuccessful resulting only in formation of oils or decomposition to form $\mathbf{P - 1}$ in some cases. ${ }^{1}$ H NMR $(600 \mathrm{MHz}, \mathrm{THF}) \delta 12.15(\mathrm{~s}, 1 \mathrm{H}), 8.82(\mathrm{~d}, J=5.7 \mathrm{~Hz}, 1 \mathrm{H}), 7.87(\mathrm{td}$, $J=7.7,1.6 \mathrm{~Hz}, 1 \mathrm{H}), 7.48(\mathrm{~d}, J=7.9 \mathrm{~Hz}, 1 \mathrm{H}), 7.37-7.28(\mathrm{~m}, 1 \mathrm{H}), 5.01(\mathrm{~d}, J$ $=12.0 \mathrm{~Hz}, 2 \mathrm{H}), 3.50(\mathrm{dt}, J=17.3,6.0 \mathrm{~Hz}, 1 \mathrm{H}), 3.32-3.19(\mathrm{~m}, 1 \mathrm{H}), 2.50(\mathrm{dt}$, $J=11.9,6.1 \mathrm{~Hz}, 1 \mathrm{H}), 2.41(\mathrm{ddd}, J=11.3,8.0,5.8 \mathrm{~Hz}, 1 \mathrm{H}) .{ }^{13} \mathbf{C} \mathbf{N M R}(151 \mathrm{MHz}, \mathrm{THF}) \delta 175.37$, 164.46, 153.54, 139.81, 124.98, 123.04, 55.26, 42.57, 5.83. IR $\left(\mathrm{cm}^{-1}\right)$ 1989.5, 1886.7, 1857.6, $1611.9,1403.7,1232.6,1090,887.8,763.9,628.1$. The parent compound could not be detected by HRMS, with the major mass signal being the organic product below. 


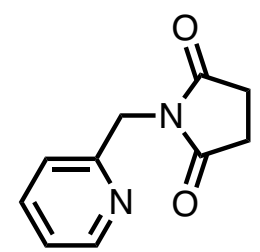

${ }^{1} \mathbf{H}$ NMR $\left(600 \mathrm{MHz}, \mathrm{CDCl}_{3}\right) \delta 8.54(\mathrm{dt}, J=5.0,1.4 \mathrm{~Hz}, 1 \mathrm{H}), 7.68(\mathrm{td}, J=7.7$, $1.8 \mathrm{~Hz}, 1 \mathrm{H}), 7.28(\mathrm{~d}, J=7.9 \mathrm{~Hz}, 1 \mathrm{H}), 7.23-7.19(\mathrm{~m}, 1 \mathrm{H}), 4.85(\mathrm{~s}, 2 \mathrm{H}), 2.82(\mathrm{~s}$, 4H). ${ }^{13} \mathrm{C}$ NMR $\left(151 \mathrm{MHz}, \mathrm{CDCl}_{3}\right) \delta 177.17,154.40,149.52,137.81,122.91$, 122.31, 43.45, 28.50. HRMS calcd. For $\mathrm{C}_{10} \mathrm{H}_{11} \mathrm{~N}_{2} \mathrm{O}_{2}{ }^{+}[\mathrm{M}]^{+}:$: 191.0815, Found 191.0815 . 


\section{MONITORING REACTION PROGRESS OF FORMATION OF 2a}

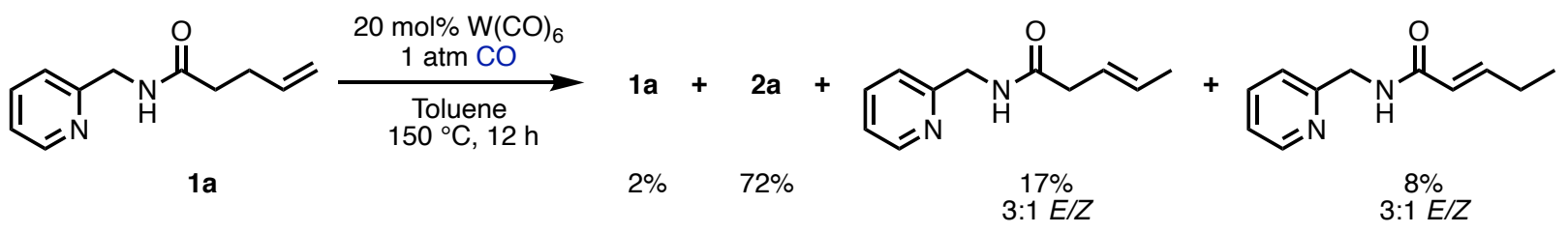

Scheme S4 Catalytic reaction stopped early to detect isomerized intermediates

The following reaction was run to determine the buildup of intermediate alkenes. The alkene 1a (38 mg, $0.2 \mathrm{mmol}$ ) was subject to General Procedure A with an abridged reaction time of $12 \mathrm{~h}$. The crude material was then analyzed by ${ }^{1} \mathrm{H}$ NMR using $\mathrm{CBr}_{2} \mathrm{H}_{2}$ as an internal standard. The presence of internal alkenes suggests that the substrate can dissociate from the catalyst during the course of the isomerization/carbonylation sequence. 


\section{DETERMINATION OF DEUTERIUM INCORPORATION}

Deuterium Labeling Procedure: Inside an argon-filled glovebox $\left(\mathrm{O}_{2}\right.$ levels between 35.0-55.0 ppm, $\mathrm{H}_{2} \mathrm{O}$ levels unknown), an oven dried 6-mL vial containing a Teflon-coated magnetic stir bar was charged with $\mathrm{W}(\mathrm{CO})_{6}(36 \mathrm{mg}, 0.1 \mathrm{mmol})$, the alkene of interest $(0.1 \mathrm{mmol}), d_{4}$-methanol $(75$ $\mu \mathrm{L}, 1.00 \mathrm{mmol})$ and toluene $(1.0 \mathrm{~mL})$, with care taken to ensure that the solids on the wall were washed into the bottom of the tube. The vial was sealed tightly with a disposable cap and electric tape. The vial was placed in a preheated oil bath and allowed to heat for the allotted amount of time. The vessel was allowed to cool to room temperature and was then carefully vented. The crude reaction mixture was diluted with acetone and filtered through a plug of celite and evaporated to dryness. The crude material was purified by flash silica column chromatography using $30-40 \%$ acetone:hexanes, and the purified product was analyzed by ${ }^{1} \mathrm{H}$ NMR to determine the site(s) and extent of deuterium incorporation.

Deuterium Labeling Control: Inside an argon-filled glovebox $\left(\mathrm{O}_{2}\right.$ levels between $35.0-55.0 \mathrm{ppm}$, $\mathrm{H}_{2} \mathrm{O}$ levels unknown), a J. Young tube, was charged with alkene 1a $(0.1 \mathrm{mmol}), \mathrm{MeOD}(37 \mu \mathrm{L}$, $1.00 \mathrm{mmol})$, and $d_{8}$-toluene $(1.0 \mathrm{~mL})$. The tube was heated to $150^{\circ} \mathrm{C}$ for $1 \mathrm{~h}$ and was then allowed to cool to room temperature. ${ }^{1} \mathrm{H}$ NMR analysis of the crude mixture showed partial chemical shift overlap of the $\mathrm{N}-\mathrm{H}$ proton with one aromatic proton. Nevertheless, the integration of these two protons together was $1.02 \mathrm{H}$, showing that the conditions used in the following experiments for in situ $\mathrm{N}-\mathrm{H}$ to $\mathrm{N}-\mathrm{D}$ exchange provide sufficiently high levels of $\mathrm{D}$ incorporation. The ${ }^{1} \mathrm{H}$ NMR data for these experiments is shown below. 


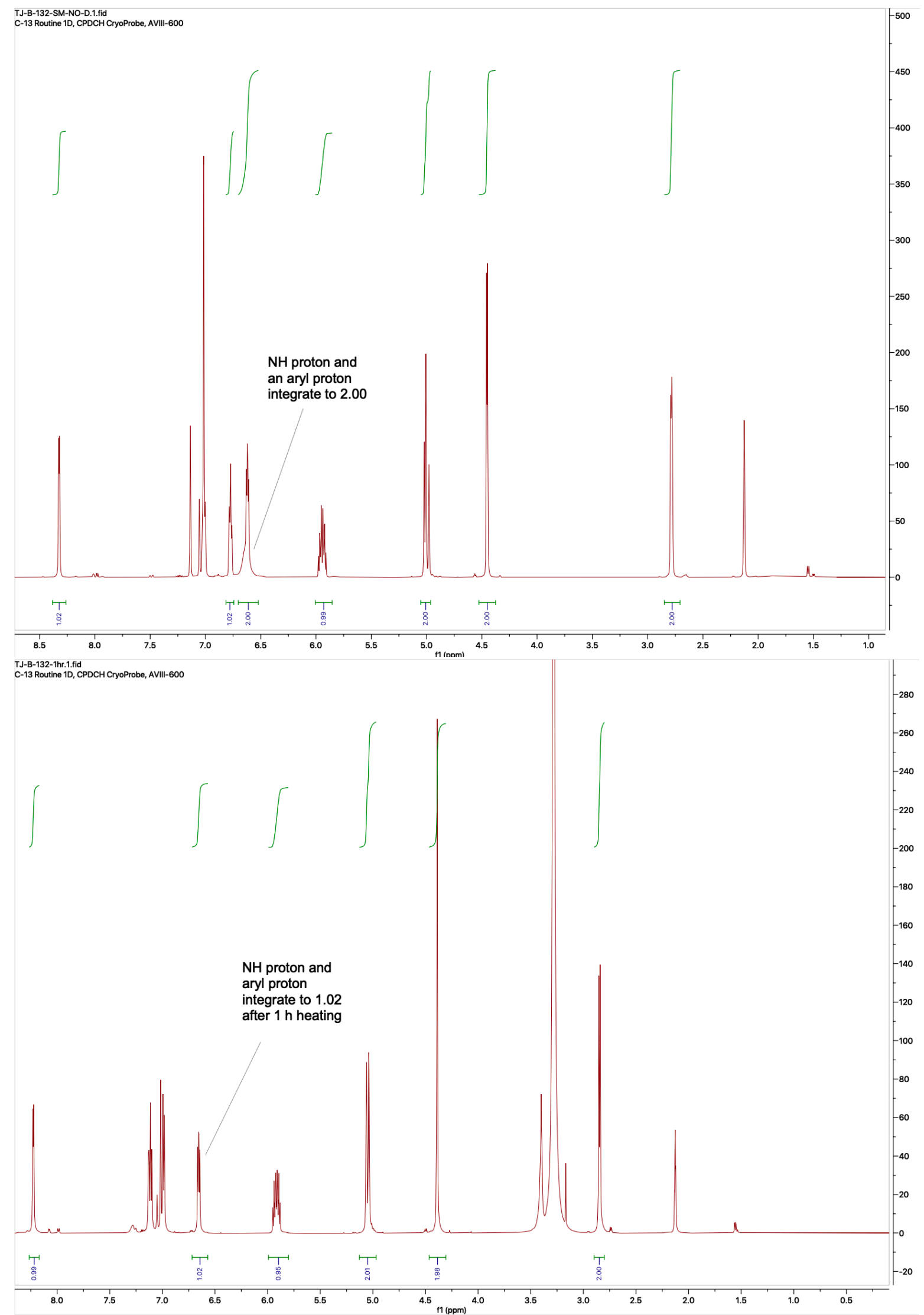

Figure S5 The top spectra corresponds to the 1xa in $d_{8}$-toluene. The bottom spectra is 1xa in $d_{8}$-toluene with 10 equiv MeOD after heating to $150^{\circ} \mathrm{C}$ for $1 \mathrm{~h}$. 
All compounds were analyzed by quantitative ${ }^{1} \mathrm{H}$ NMR using standard protocols outlined by Bruker, and the integral values below are reported as their relative quantities. $d_{6}$-DMSO or $\mathrm{C}_{6} \mathrm{D}_{6}$ were used as the solvent of choice, as the water and grease chemical shifts in these solvents did not overlap with the peaks of interest in the compound being analyzed. The ${ }^{13} \mathrm{C}$ NMR spectra showed several peaks with low signal intensity due to the high levels of deuterium incorporation and the presence of multiple deuterium atoms per molecule; therefore, this spectral data is not included below. ${ }^{13} \mathrm{C}$ NMR spectral data for the corresponding non-deuterated products are given above.

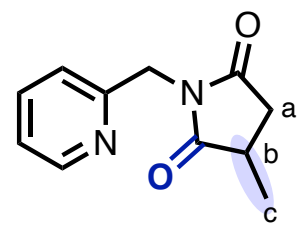

${ }^{1} \mathbf{H}$ NMR $\left(600 \mathrm{MHz}, \mathrm{CDCl}_{3}\right) \delta 8.58-8.42(\mathrm{~m}, 0.98 \mathrm{H}), 7.63(\mathrm{td}, J=7.7,1.8 \mathrm{~Hz}, 1.03 \mathrm{H}), 7.22(\mathrm{~d}, J$ $=7.8 \mathrm{~Hz}, 0.97 \mathrm{H}), 7.16(\mathrm{dd}, J=7.6,4.9 \mathrm{~Hz}, 1.00 \mathrm{H}), 4.81(\mathrm{~s}, 1.98 \mathrm{H}), 3.07-2.85(\mathrm{~m}, 1.64 \mathrm{H}, \mathbf{a}), 2.44-$ $2.36(\mathrm{~m}, 0.92 \mathrm{H}, \mathbf{b}), 1.41-1.34(\mathrm{~m}, 2.10 \mathrm{H}, \mathbf{c})$.

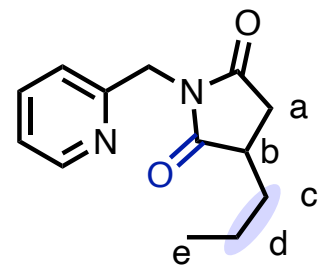

${ }^{1}$ H NMR $\left(600 \mathrm{MHz}, d_{6}\right.$-DMSO) $\delta 8.46(\mathrm{~d}, J=4.9 \mathrm{~Hz}, 1.18 \mathrm{H}), 7.76(\mathrm{td}, J=7.7,1.8 \mathrm{~Hz}, 1.00 \mathrm{H})$, $7.27(\mathrm{t}, J=6.5 \mathrm{~Hz}, 2.00 \mathrm{H}), 4.66(\mathrm{~s}, 1.96 \mathrm{H}), 2.97-2.84(\mathrm{~m}, 1.66 \mathrm{H}, \mathbf{a}, \mathbf{b}), 1.72(\mathrm{~d}, J=13.9 \mathrm{~Hz}, 0.45 \mathrm{H}$, c), $1.48(\mathrm{dt}, J=15.3,6.6 \mathrm{~Hz}, 0.55 \mathrm{H}, \mathbf{c}), 1.37(\mathrm{dq}, J=13.7,7.1,6.5 \mathrm{~Hz}, 1.21 \mathrm{H}, \mathbf{d}), 0.89(\mathrm{~d}, J=8.4$ $\mathrm{Hz}, 3.00 \mathrm{H}, \mathbf{e})$.

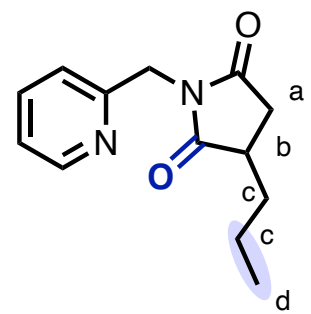

${ }^{1} \mathbf{H}$ NMR $\left(600 \mathrm{MHz}, \mathrm{C}_{6} \mathrm{D}_{6}\right) \delta 8.35(\mathrm{~d}, J=6.0 \mathrm{~Hz}, 1.00 \mathrm{H}), 6.96(\mathrm{td}, J=7.6,1.8 \mathrm{~Hz}, 1.00 \mathrm{H}), 6.81$ $(\mathrm{d}, J=7.8 \mathrm{~Hz}, 1.00 \mathrm{H}), 6.53(\mathrm{dd}, J=7.5,4.8 \mathrm{~Hz}, 0.99 \mathrm{H}), 4.73(\mathrm{~s}, 1.95 \mathrm{H}), 2.24-2.10(\mathrm{~m}, 1.52 \mathrm{H}, \mathbf{a})$, $1.89-1.80(\mathrm{~m}, 0.97 \mathrm{H}, \mathbf{b}), 1.66-1.50(\mathrm{~m}, 0.41 \mathrm{H}, \mathbf{c}), 1.38(\mathrm{~m}, 0.70 \mathrm{H}, \mathbf{c}), 1.14-0.89(\mathrm{~m}, 1.61 \mathrm{H}, \mathbf{c})$, $0.65(\mathrm{q}, J=10.2,9.1 \mathrm{~Hz}, 2.04 \mathrm{H}, \mathbf{d})$.<smiles>CC1(C)C(=O)N(Cc2ccccn2)C(=O)C1CCl</smiles>

${ }^{1} \mathbf{H}$ NMR $\left(600 \mathrm{MHz}, \mathrm{C}_{6} \mathrm{D}_{6}\right) \delta 8.38-8.24(\mathrm{~m}, 0.95 \mathrm{H}), 6.94(\mathrm{td}, J=7.7,1.8 \mathrm{~Hz}, 1.01 \mathrm{H}), 6.76(\mathrm{~d}, J=$ $7.8 \mathrm{~Hz}, 0.96 \mathrm{H}), 6.51(\mathrm{dd}, J=7.5,4.8 \mathrm{~Hz}, 1.00 \mathrm{H}), 4.78-4.64(\mathrm{~m}, 1.98 \mathrm{H}), 2.04(\mathrm{~d}, J=7.5 \mathrm{~Hz}, 0.38 \mathrm{H}$, 
b), 1.78-1.64 (m, 0.37H, c), 1.29-1.19 (m, 0.44H, c), $1.09(\mathrm{~d}, J=1.8 \mathrm{~Hz}, 2.94 \mathrm{H}, \mathbf{a}), 1.00$ (s, 2.83H, a), $0.91(\mathrm{~m}, 2.37 \mathrm{H}, \mathbf{d})$.

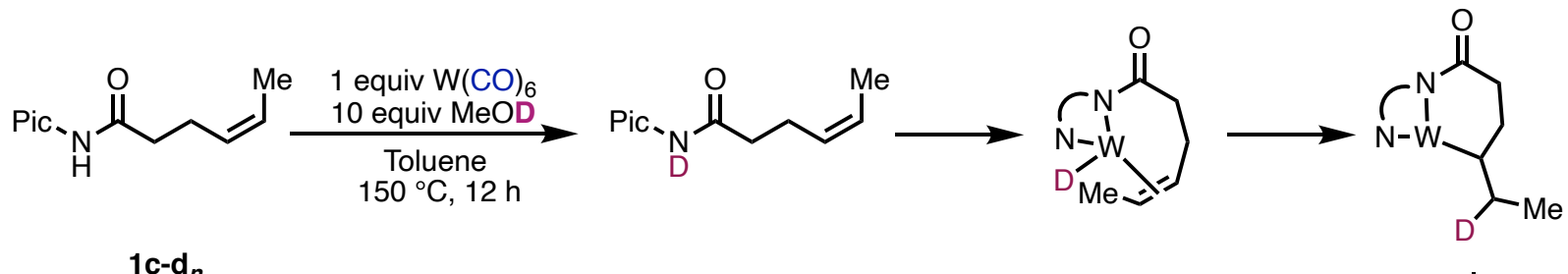

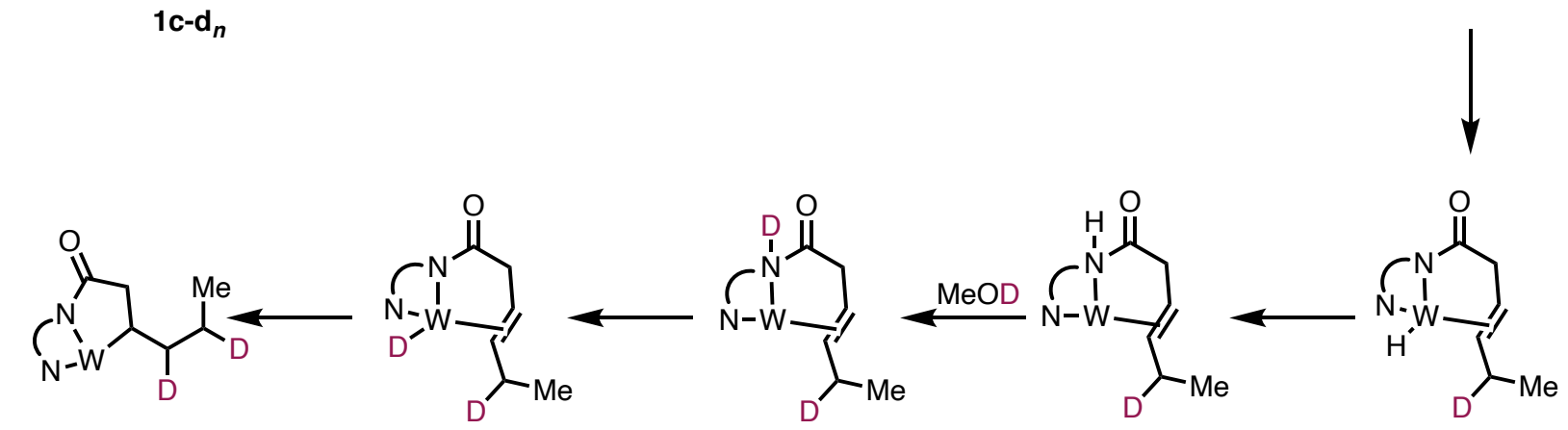<smiles>[R]C([R])C(C([2H])[2H])C1CC(=O)N(C(=O)c2ccccc2)C1=O</smiles>

Scheme S5 Potential pathway that can lead to multiple deuterium incorporations on the same molecule. Substrate 1c was used as a model for this scheme, but an analogous pathway with the other molecules examined would lead to multiple deuterium per molecule. 


\section{DETERMINATION OF ENANTIOMERIC EXCESS OF COMPOUNDS 2e AND DG7-P}

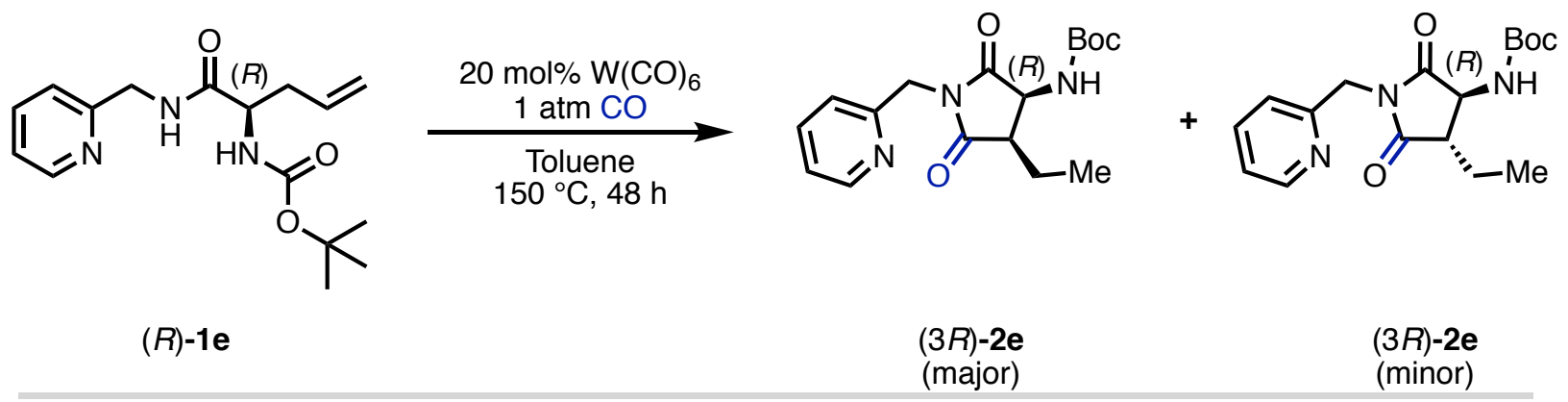

Scheme $\mathbf{S 6}$ Synthesis and isolation of both diastereomers of $(3 R)-2 \mathrm{e}$
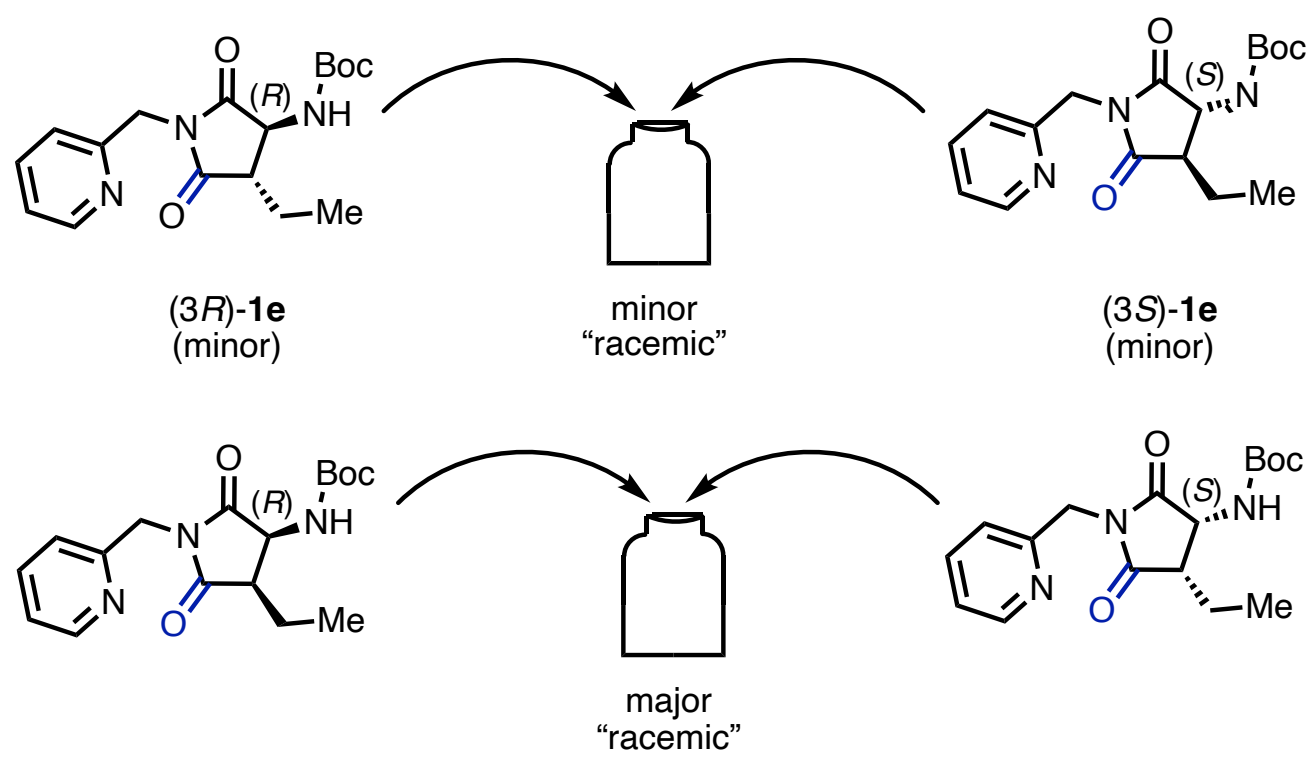

$(3 R)-2 e$

(major)

$(3 R)-2 e$

(major)

Figure S6 Mixing of both enantiomers to create the racemic mixture for chiral SFC analysis

Two samples of product $\mathbf{2 e}$ were synthesized according to General Procedure A starting from either the $(R)$ - or $(S)$-configured starting material. The $(3 R)$ - and $(3 S)$-configured products $(\mathbf{2 e})$ were isolated by reverse phase HPLC, which allowed for separation of the major and minor diastereomers, and the enantiomeric excess of both diastereomers was then determined. The samples were analyzed on a Waters UPC2 SFC with a Daicel IC (major diastereomer) and Daicel IA (minor diastereomer) column $(3 \mu \mathrm{m}, 4.6 \times 250 \mathrm{~mm})$ under isocratic conditions $(4 \mathrm{~mL} / \mathrm{min}, 35 \%$ $\mathrm{MeOH} / \mathrm{CO}_{2}, 1600$ psi backpressure) at $30{ }^{\circ} \mathrm{C}$. The enantiomers were detected by UV light (260 $\mathrm{nm})$. "Racemic" samples of both the major and the minor diastereomers were made by preparing a $1 \mathrm{mg} / \mathrm{mL}$ solution of the major and minor products from arising from each of the enantiomeric starting materials and combining them in equal portions; deviation from $0 \%$ ee was due to weighing errors. The major diastereomer of $\mathbf{2 e}$ was found to be enantiomerically pure $(98 \%$ ee by SFC) starting from either the $(R)$ - or $(S)$-configured starting material. The minor diastereomer of 2e was found to have $52 \%$ ee starting from the $(S)$-configured starting material. 


\begin{tabular}{|l|l|l|l|l|l|}
\hline Entry & \% Area Ent1 & \% Area Ent2 & ee & Area Ent1 & Area Ent2 \\
\hline 2e major ("racemic") & 55.94 & 44.06 & 11.88 & 325658 & 256479 \\
\hline 2e minor ("racemic") & 67.35 & 32.65 & 34.70 & 172413 & 83582 \\
\hline
\end{tabular}

Table S2 Integrations for "racemic" samples of major and minor diastereomers of $\mathbf{2 e}$

Auto-Scaled Chromatogram

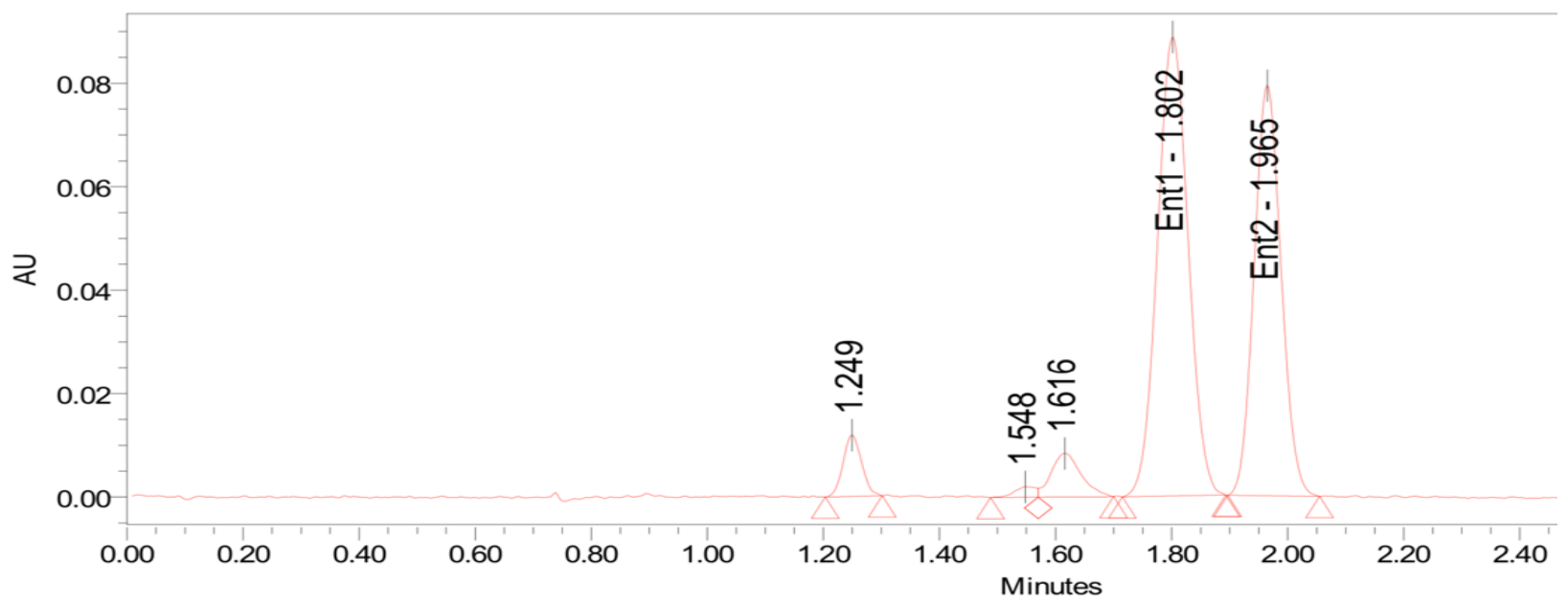

Figure $\mathbf{5 7}$ "Racemic" sample of the major diastereomer of $\mathbf{2 e}$

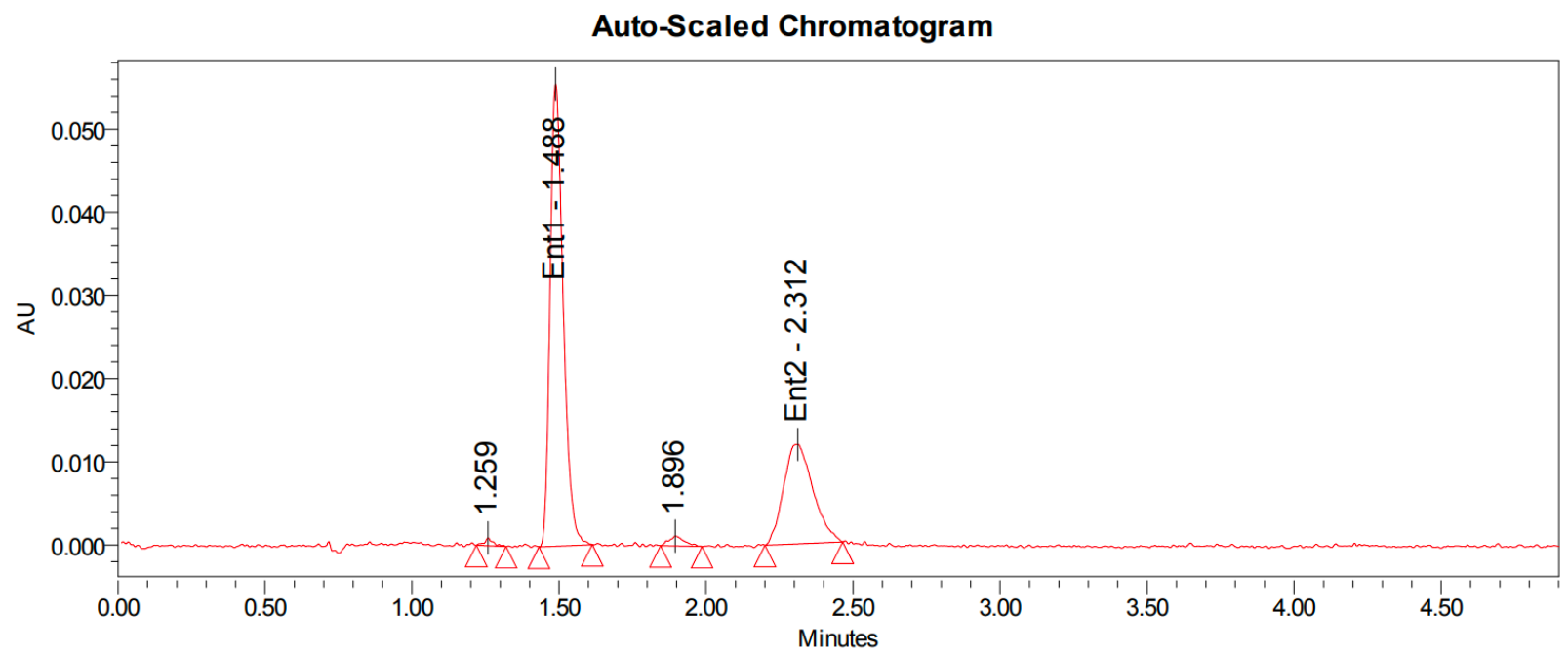

Figure S8 "Racemic" sample of minor diastereomer of $\mathbf{2 e}$ 


\begin{tabular}{|l|l|l|l|l|l|}
\hline Entry & \% Area Ent1 & \% Area Ent2 & $e e$ & Area Ent1 & Area Ent2 \\
\hline$(3 S)$-2e major & 99.04 & 0.96 & 98.08 & 275520 & 2665 \\
\hline
\end{tabular}

Table S3 Integrations for (3S)-2e (major diastereomer)

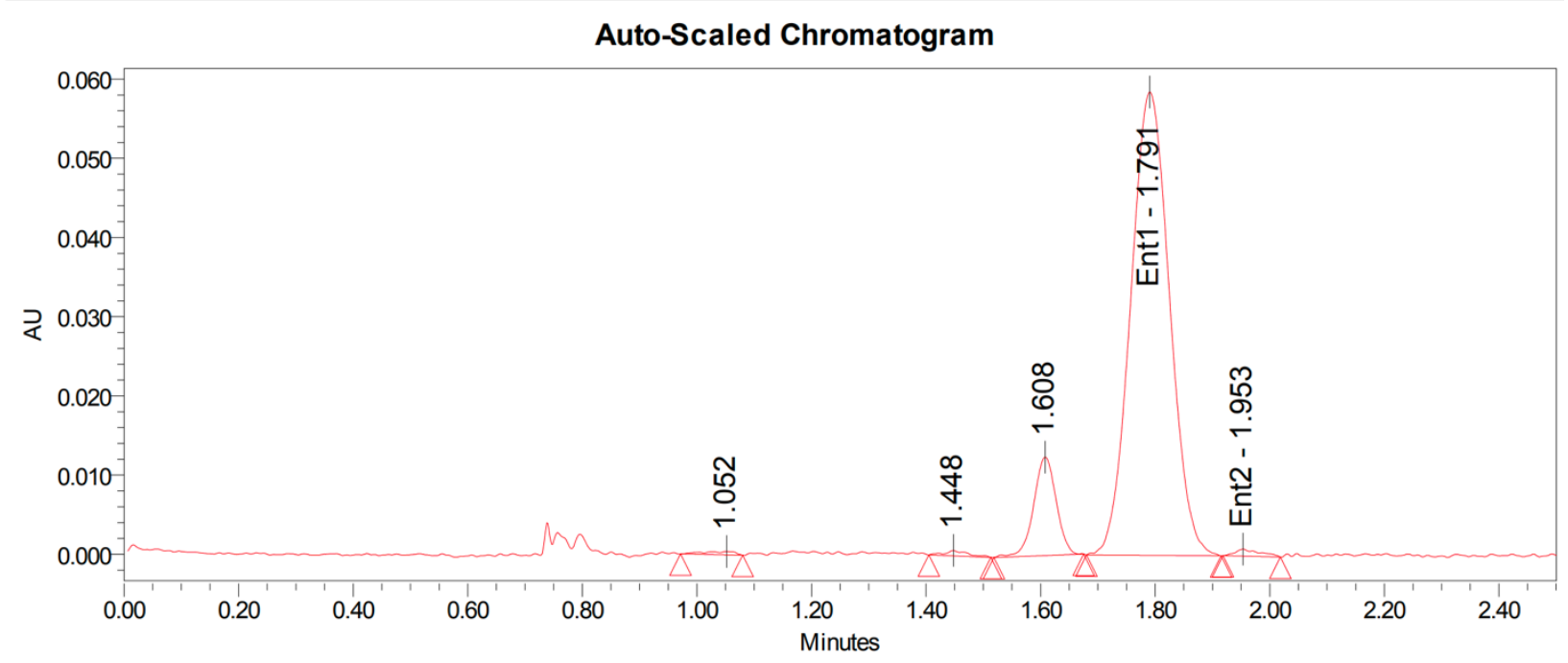

Figure S9 Chromatogram for major diastereomer of (3S)-2e 


\begin{tabular}{|l|l|l|l|l|l|}
\hline Entry & \% Area Ent1 & \% Area Ent2 & $e e$ & Area Ent1 & Area Ent2 \\
\hline$(3 S)$-2e minor & 75.83 & 24.17 & 51.66 & 230606 & 73507 \\
\hline
\end{tabular}

Table S4 Integration for minor diastereomer of (3S)-2e.

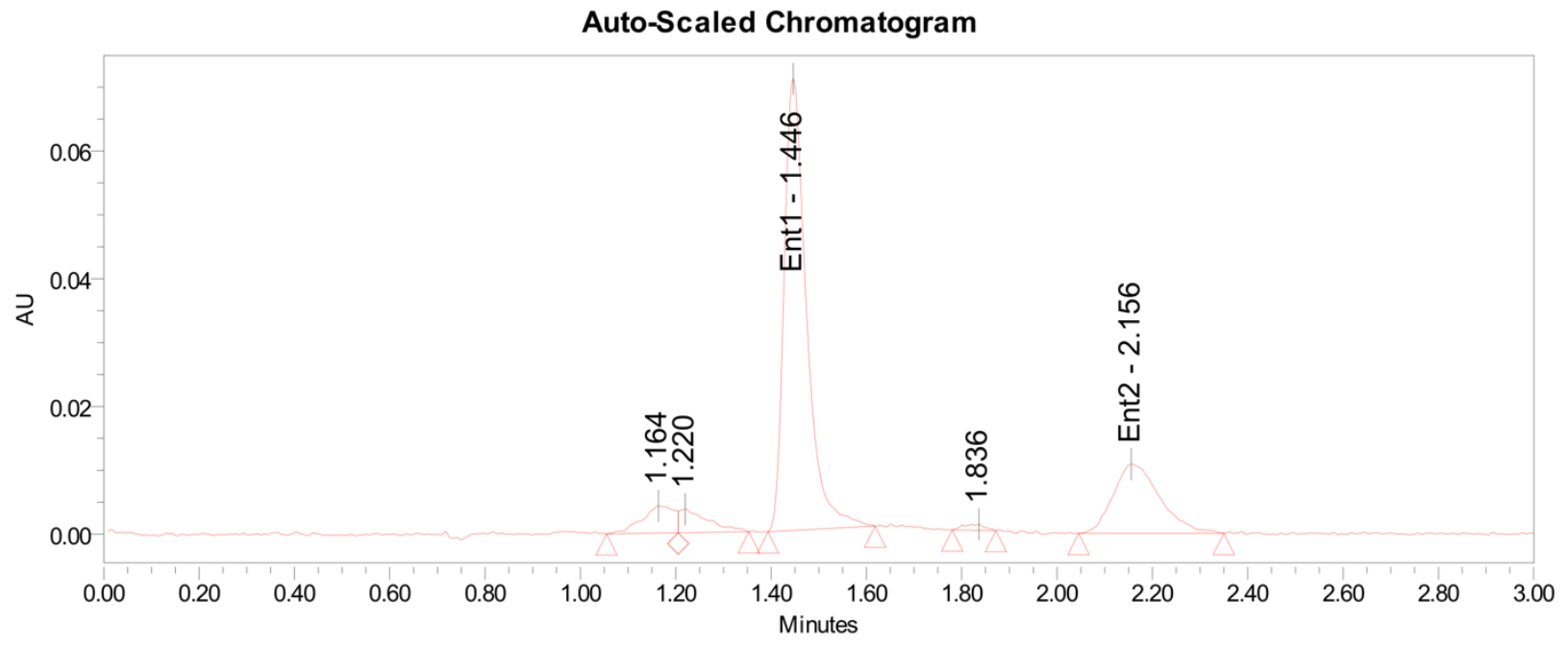

Figure S10 Chromatogram for minor diastereomer of (3S)-2e. 
Racemic and enanioenriched samples of compound DG7-SM were synthesized according to General Procedure $\mathrm{C}$ from (rac)- and $(S)$-1-(pyridin-2-yl)ethan-1-amine. The compounds were then used as starting materials in the carbonylation reaction according to General Procedure A. Products from both reactions were isolated by flash silica chromatography. The racemic product was analyzed on a Waters UPC2 SFC with a Daicel CEL1 column $(3 \mu \mathrm{m}, 4.6 \times 250 \mathrm{~mm})$ under isocratic conditions ( $4 \mathrm{~mL} / \mathrm{min}, 3 \% \mathrm{IPA} / \mathrm{CO}_{2}, 1600 \mathrm{psi}$ backpressure) at $30{ }^{\circ} \mathrm{C}$. Separation conditions were able to all four diastereomers in a single run. The two sets of enantiomers were detected by UV light $(212 \mathrm{~nm})$. When the $(S)$-configured starting material was used, both major and minor diastereomers were found to be enantiomerically pure ( $>99 \%$ ee by SFC).

\begin{tabular}{|l|l|l|l|l|l|}
\hline Entry & \%Area Ent_1 & \% Area Ent_2 & $e e$ & Area Ent_1 & Area Ent_2 \\
\hline DG7-P major (racemic) & 59.18 & 49.82 & 0.36 & 122446 & 121560 \\
\hline DG7-P minor (racemic) & 49.87 & 50.13 & -0.27 & 23616 & 23742 \\
\hline
\end{tabular}

Table S5 Integration for the four diastereomers of (rac)-2aa . Using this separation method, the diastereomeric ratio (d.r. $=5: 1$ ) was found to be consistent with ${ }^{1} \mathrm{H}$ NMR data.

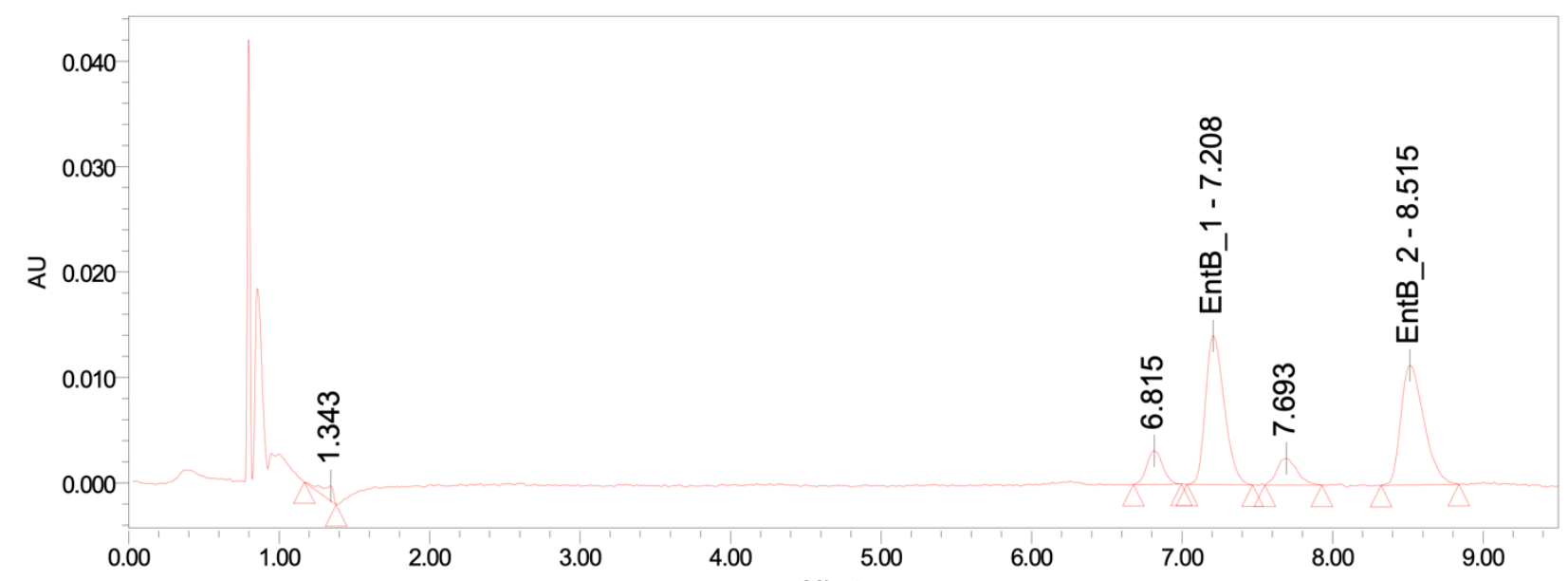

Figure S11 Separation of the four diastereomers of (rac)-2aa. The peaks labeled EntB_1 and EntB_2 correspond to the major diastereomers.

Auto-Scaled Chromatogram

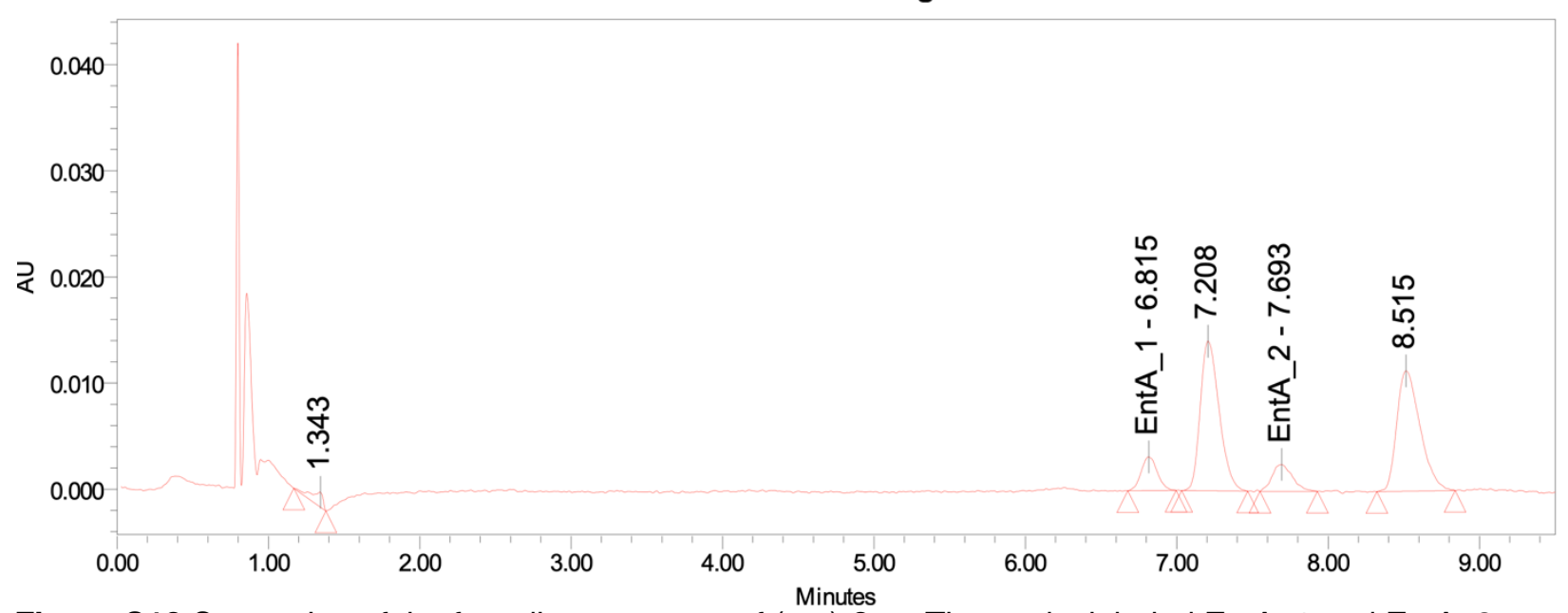

Figure S12 Separation of the four diastereomers of (rac)-2aa. The peaks labeled EntA_1 and EntA_2 correspond to the minor diastereomers. 


\begin{tabular}{|l|l|l|l|l|l|}
\hline Entry & \% Area Ent_1 & \% Area Ent_2 & $e e$ & Area Ent_1 & Area Ent_2 \\
\hline$(S)$-DG7-P major & n.d. & 100.00 & 100.00 & n.d. & 320557 \\
\hline$(S)$-DG7-P minor & n.d. & 100.00 & 100.00 & n.d. & 69303 \\
\hline
\end{tabular}

Table S6 Integration for both diastereomers of the racemic mixture 2aa. Using this separation method, the diastereomeric ratio (d.r. $=5: 1$ ) was also confirmed to be consistent with ${ }^{1} \mathrm{H}$ NMR data. $n . d .=$ not detectable.

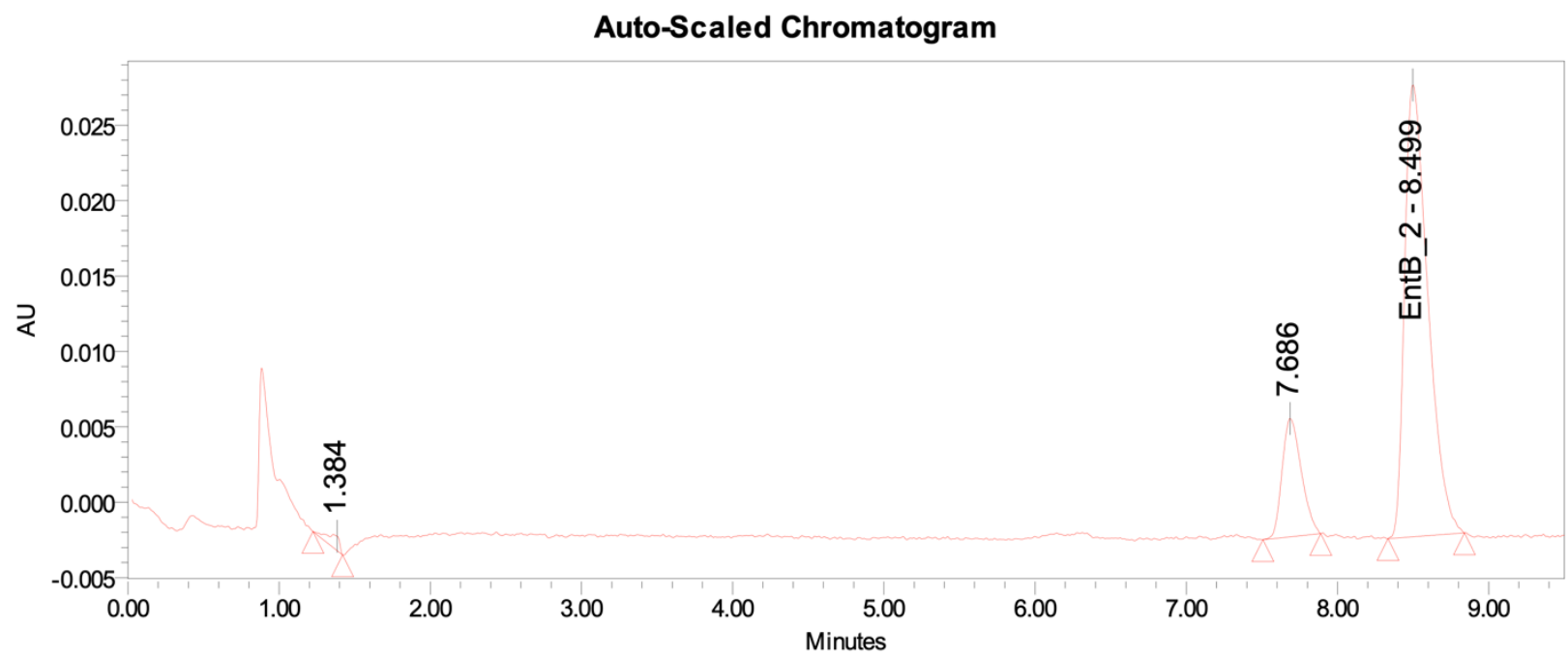

Figure S13 Chromatogram of product (S)-DG7-Pfrom the reaction run with enantiopure starting material, (S)-DG7-SM.The major diastereomer (EntB_2) and minor diastereomer (retention time: 7.686) were determined to be $>99 \%$ ee with no detectable amounts of opposite enantiomer. 


\section{X-RAY CRYSTALOGRAPHY}

\section{$\underline{\text { Experimental Summary }}$}

The single crystal X-ray diffraction studies were carried out on a Bruker X8 APEX II CCD diffractometer equipped with $\mathrm{Mo} \mathrm{K}_{\alpha}$ radiation $(\lambda=0.71073)$. Crystals of the subject compound were used as received (grown from Ethylacetate/Hexane). A $0.250 \times 0.20 \times 0.20 \mathrm{~mm}$ colorless plate was mounted on a Cryoloop with Paratone oil.

Data were collected in a nitrogen gas stream at 100(2) K using $\phi$ and $\varpi$ scans. Crystal-to-detector distance was $40 \mathrm{~mm}$ using exposure time $5.0 \mathrm{~s}$ (depending on the detector $2 \theta$ position) with a scan width of $0.70^{\circ}$. Data collection was $100.0 \%$ complete to $25.242^{\circ}$ in $\mathrm{A}$ total of 13272 reflections were collected covering the indices, $-9<=\mathrm{h}<=9,-11<=\mathrm{k}<=11,-12<=\mathrm{l}<=12.2651$ reflections were found to be symmetry independent, with a $\mathrm{R}_{\text {int }}$ of 0.0507 . Indexing and unit cell refinement indicated a Primitive, Triclinic lattice. The space group was found to be $\boldsymbol{P}$-1. The data were integrated using the Bruker SAINT Software program and scaled using the SADABS software program. Solution by direct methods (SHELXT) produced a complete phasing model consistent with the proposed structure.

All nonhydrogen atoms were refined anisotropically by full-matrix least-squares (SHELXL-2014). All carbon bonded hydrogen atoms were placed using a riding model. Their positions were constrained relative to their parent atom using the appropriate HFIX command in SHELXL-2014.

Crystallographic data are summarized in Table S6. 


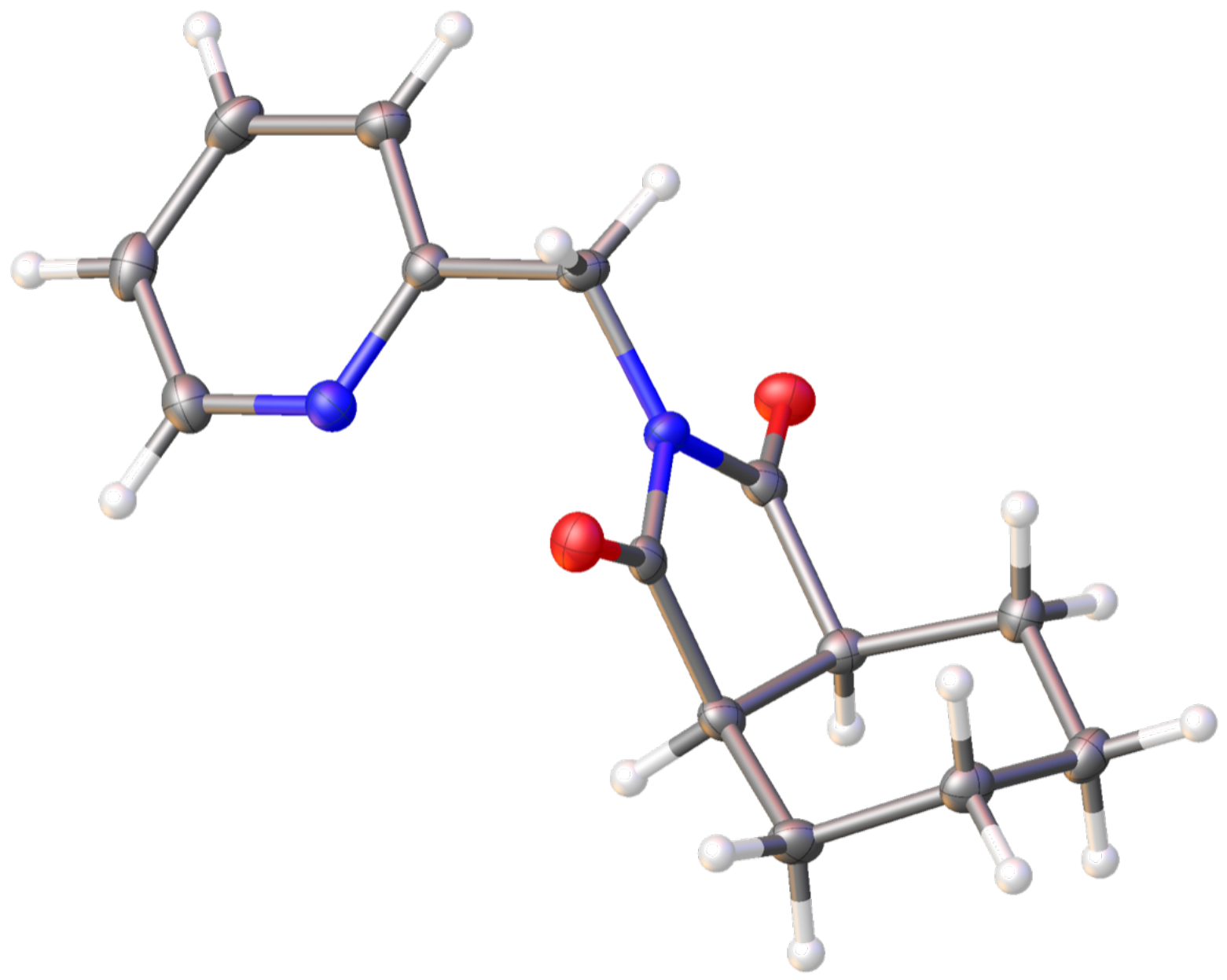

Table S7 Crystal data and structure refinement for $\mathbf{2 u}$ (CCDC 2008992).

Empirical formula

Molecular formula

Formula weight

Temperature

Wavelength

Crystal system

Space group

Unit cell dimensions

Volume

Z

Density (calculated)

Absorption coefficient

$\mathrm{F}(000)$
C14 H16 N2 O2

C14 H16 N2 O2

244.29

$100.0 \mathrm{~K}$

$0.71073 \AA$

Triclinic

P-1

$\mathrm{a}=7.7012(7) \AA$

$\alpha=64.252(2)^{\circ}$.

$\mathrm{b}=9.2939(8) \AA$

$\beta=83.457(2)^{\circ}$.

$\mathrm{c}=9.4109(8) \AA$

$\gamma=85.058(2)^{\circ}$.

602.24(9) $\AA^{3}$

2

$1.347 \mathrm{Mg} / \mathrm{m}^{3}$

$0.091 \mathrm{~mm}^{-1}$

260 
Crystal size

Crystal color, habit

Theta range for data collection

Index ranges

Reflections collected

Independent reflections

Completeness to theta $=25.242^{\circ}$

Absorption correction

Max. and min. transmission

Refinement method

Data / restraints / parameters

Goodness-of-fit on $\mathrm{F}^{2}$

Final $\mathrm{R}$ indices [I $>2 \operatorname{sigma}(\mathrm{I})]$

$\mathrm{R}$ indices (all data)

Largest diff. peak and hole
$0.25 \times 0.2 \times 0.2 \mathrm{~mm}^{3}$

colorless plate

2.412 to $27.103^{\circ}$.

$-9<=\mathrm{h}<=9,-11<=\mathrm{k}<=11,-12<=\mathrm{l}<=12$

13272

$2651[\mathrm{R}(\mathrm{int})=0.0507]$

$100.0 \%$

Semi-empirical from equivalents

0.7456 and 0.7011

Full-matrix least-squares on $\mathrm{F}^{2}$

$2651 / 0 / 163$

1.040

$\mathrm{R} 1=0.0371, \mathrm{wR} 2=0.0913$

$\mathrm{R} 1=0.0428, \mathrm{wR} 2=0.0961$

0.382 and -0.189 e. $\AA^{-3}$ 
Table S8 Atomic coordinates (x $\left.10^{4}\right)$ and equivalent isotropic displacement parameters $\left(\AA^{2} \times 10^{3}\right)$ for $2 \mathbf{u}$. U(eq) is defined as one third of the trace of the orthogonalized $U^{i j}$ tensor.

\begin{tabular}{lcccc}
\hline & $\mathrm{x}$ & $\mathrm{y}$ & $\mathrm{z}$ & $\mathrm{U}(\mathrm{eq})$ \\
\hline $\mathrm{O}(1)$ & & & & \\
$\mathrm{O}(2)$ & $8146(1)$ & $3162(1)$ & $1259(1)$ & $21(1)$ \\
$\mathrm{N}(1)$ & $4026(1)$ & $2716(1)$ & $5292(1)$ & $21(1)$ \\
$\mathrm{N}(2)$ & $6280(1)$ & $3191(1)$ & $3346(1)$ & $15(1)$ \\
$\mathrm{C}(1)$ & $8992(1)$ & $1753(1)$ & $5292(1)$ & $18(1)$ \\
$\mathrm{C}(2)$ & $9926(2)$ & $858(2)$ & $6521(2)$ & $21(1)$ \\
$\mathrm{C}(3)$ & $10155(2)$ & $1285(2)$ & $7726(1)$ & $22(1)$ \\
$\mathrm{C}(4)$ & $9368(2)$ & $2702(2)$ & $7675(2)$ & $22(1)$ \\
$\mathrm{C}(5)$ & $8409(2)$ & $3651(2)$ & $6402(2)$ & $20(1)$ \\
$\mathrm{C}(6)$ & $8263(2)$ & $3135(1)$ & $5242(1)$ & $15(1)$ \\
$\mathrm{C}(7)$ & $7290(2)$ & $4157(1)$ & $3800(1)$ & $17(1)$ \\
$\mathrm{C}(8)$ & $6861(2)$ & $2688(1)$ & $2171(1)$ & $15(1)$ \\
$\mathrm{C}(9)$ & $4694(2)$ & $2559(1)$ & $4137(1)$ & $15(1)$ \\
$\mathrm{C}(10)$ & $1428(1)$ & $2323(1)$ & $16(1)$ \\
$\mathrm{C}(11)$ & $5634(2)$ & $1319(1)$ & $792(1)$ & $19(1)$ \\
$\mathrm{C}(12)$ & $5386(2)$ & $2656(1)$ & $-252(1)$ & $18(1)$ \\
$\mathrm{C}(13)$ & $4167(2)$ & $2686(2)$ & $680(1)$ & $19(1)$ \\
$\mathrm{C}(14)$ & $2422(2)$ & $2105(1)$ & $17(1)$ \\
\hline & $2674(2)$ & $2999(1)$ & $3222(1)$ & $15(1)$ \\
& $3974(2)$ & $1773(1)$ & & \\
\hline
\end{tabular}


Table S9 Bond lengths $[\AA]$ and angles $\left[{ }^{\circ}\right]$ for $\mathbf{2 u}$.

\begin{tabular}{|c|c|c|c|}
\hline $\mathrm{O}(1)-\mathrm{C}(7)$ & $1.2099(15)$ & $\mathrm{C}(14)-\mathrm{H}(14)$ & 1.0000 \\
\hline $\mathrm{O}(2)-\mathrm{C}(8)$ & $1.2113(15)$ & & \\
\hline $\mathrm{N}(1)-\mathrm{C}(6)$ & $1.4570(14)$ & $\mathrm{C}(7)-\mathrm{N}(1)-\mathrm{C}(6)$ & $124.04(10)$ \\
\hline $\mathrm{N}(1)-\mathrm{C}(7)$ & $1.3937(15)$ & $\mathrm{C}(8)-\mathrm{N}(1)-\mathrm{C}(6)$ & $123.12(10)$ \\
\hline $\mathrm{N}(1)-\mathrm{C}(8)$ & $1.3882(15)$ & $\mathrm{C}(8)-\mathrm{N}(1)-\mathrm{C}(7)$ & $112.63(10)$ \\
\hline $\mathrm{N}(2)-\mathrm{C}(1)$ & $1.3410(16)$ & $\mathrm{C}(5)-\mathrm{N}(2)-\mathrm{C}(1)$ & $117.20(10)$ \\
\hline $\mathrm{N}(2)-\mathrm{C}(5)$ & $1.3407(15)$ & $\mathrm{N}(2)-\mathrm{C}(1)-\mathrm{H}(1)$ & 118.2 \\
\hline $\mathrm{C}(1)-\mathrm{H}(1)$ & 0.9500 & $\mathrm{~N}(2)-\mathrm{C}(1)-\mathrm{C}(2)$ & $123.53(12)$ \\
\hline $\mathrm{C}(1)-\mathrm{C}(2)$ & $1.3867(18)$ & $\mathrm{C}(2)-\mathrm{C}(1)-\mathrm{H}(1)$ & 118.2 \\
\hline $\mathrm{C}(2)-\mathrm{H}(2)$ & 0.9500 & $\mathrm{C}(1)-\mathrm{C}(2)-\mathrm{H}(2)$ & 120.7 \\
\hline $\mathrm{C}(2)-\mathrm{C}(3)$ & $1.3859(19)$ & $C(3)-C(2)-C(1)$ & $118.66(11)$ \\
\hline $\mathrm{C}(3)-\mathrm{H}(3)$ & 0.9500 & $\mathrm{C}(3)-\mathrm{C}(2)-\mathrm{H}(2)$ & 120.7 \\
\hline $\mathrm{C}(3)-\mathrm{C}(4)$ & $1.3887(17)$ & $\mathrm{C}(2)-\mathrm{C}(3)-\mathrm{H}(3)$ & 120.7 \\
\hline $\mathrm{C}(4)-\mathrm{H}(4)$ & 0.9500 & $\mathrm{C}(2)-\mathrm{C}(3)-\mathrm{C}(4)$ & $118.55(11)$ \\
\hline $\mathrm{C}(4)-\mathrm{C}(5)$ & $1.3882(17)$ & $\mathrm{C}(4)-\mathrm{C}(3)-\mathrm{H}(3)$ & 120.7 \\
\hline$C(5)-C(6)$ & $1.5148(16)$ & $\mathrm{C}(3)-\mathrm{C}(4)-\mathrm{H}(4)$ & 120.6 \\
\hline $\mathrm{C}(6)-\mathrm{H}(6 \mathrm{~A})$ & 0.9900 & $\mathrm{C}(5)-\mathrm{C}(4)-\mathrm{C}(3)$ & 118.81(11) \\
\hline $\mathrm{C}(6)-\mathrm{H}(6 \mathrm{~B})$ & 0.9900 & $\mathrm{C}(5)-\mathrm{C}(4)-\mathrm{H}(4)$ & 120.6 \\
\hline $\mathrm{C}(7)-\mathrm{C}(9)$ & $1.5157(16)$ & $\mathrm{N}(2)-\mathrm{C}(5)-\mathrm{C}(4)$ & $123.23(11)$ \\
\hline $\mathrm{C}(8)-\mathrm{C}(14)$ & $1.5190(16)$ & $\mathrm{N}(2)-\mathrm{C}(5)-\mathrm{C}(6)$ & $116.00(10)$ \\
\hline $\mathrm{C}(9)-\mathrm{H}(9)$ & 1.0000 & $\mathrm{C}(4)-\mathrm{C}(5)-\mathrm{C}(6)$ & $120.74(11)$ \\
\hline $\mathrm{C}(9)-\mathrm{C}(10)$ & $1.5220(15)$ & $\mathrm{N}(1)-\mathrm{C}(6)-\mathrm{C}(5)$ & 111.63(9) \\
\hline$C(9)-C(14)$ & $1.5405(16)$ & $\mathrm{N}(1)-\mathrm{C}(6)-\mathrm{H}(6 \mathrm{~A})$ & 109.3 \\
\hline $\mathrm{C}(10)-\mathrm{H}(10 \mathrm{~A})$ & 0.9900 & $\mathrm{~N}(1)-\mathrm{C}(6)-\mathrm{H}(6 \mathrm{~B})$ & 109.3 \\
\hline $\mathrm{C}(10)-\mathrm{H}(10 \mathrm{~B})$ & 0.9900 & $\mathrm{C}(5)-\mathrm{C}(6)-\mathrm{H}(6 \mathrm{~A})$ & 109.3 \\
\hline$C(10)-C(11)$ & $1.5295(16)$ & $\mathrm{C}(5)-\mathrm{C}(6)-\mathrm{H}(6 \mathrm{~B})$ & 109.3 \\
\hline $\mathrm{C}(11)-\mathrm{H}(11 \mathrm{~A})$ & 0.9900 & $\mathrm{H}(6 \mathrm{~A})-\mathrm{C}(6)-\mathrm{H}(6 \mathrm{~B})$ & 108.0 \\
\hline $\mathrm{C}(11)-\mathrm{H}(11 \mathrm{~B})$ & 0.9900 & $\mathrm{O}(1)-\mathrm{C}(7)-\mathrm{N}(1)$ & $124.55(11)$ \\
\hline$C(11)-C(12)$ & $1.5236(17)$ & $\mathrm{O}(1)-\mathrm{C}(7)-\mathrm{C}(9)$ & $128.33(11)$ \\
\hline $\mathrm{C}(12)-\mathrm{H}(12 \mathrm{~A})$ & 0.9900 & $\mathrm{~N}(1)-\mathrm{C}(7)-\mathrm{C}(9)$ & $107.07(10)$ \\
\hline $\mathrm{C}(12)-\mathrm{H}(12 \mathrm{~B})$ & 0.9900 & $\mathrm{O}(2)-\mathrm{C}(8)-\mathrm{N}(1)$ & $123.90(11)$ \\
\hline$C(12)-C(13)$ & $1.5257(16)$ & $\mathrm{O}(2)-\mathrm{C}(8)-\mathrm{C}(14)$ & $128.66(11)$ \\
\hline $\mathrm{C}(13)-\mathrm{H}(13 \mathrm{~A})$ & 0.9900 & $\mathrm{~N}(1)-\mathrm{C}(8)-\mathrm{C}(14)$ & 107.33(9) \\
\hline $\mathrm{C}(13)-\mathrm{H}(13 \mathrm{~B})$ & 0.9900 & $\mathrm{C}(7)-\mathrm{C}(9)-\mathrm{H}(9)$ & 106.9 \\
\hline$C(13)-C(14)$ & $1.5517(16)$ & $C(7)-C(9)-C(10)$ & $115.65(10)$ \\
\hline
\end{tabular}




\begin{tabular}{|c|c|}
\hline$C(7)-C(9)-C(14)$ & $103.22(9)$ \\
\hline $\mathrm{C}(10)-\mathrm{C}(9)-\mathrm{H}(9)$ & 106.9 \\
\hline$C(10)-C(9)-C(14)$ & $116.55(10)$ \\
\hline $\mathrm{C}(14)-\mathrm{C}(9)-\mathrm{H}(9)$ & 106.9 \\
\hline $\mathrm{C}(9)-\mathrm{C}(10)-\mathrm{H}(10 \mathrm{~A})$ & 109.1 \\
\hline $\mathrm{C}(9)-\mathrm{C}(10)-\mathrm{H}(10 \mathrm{~B})$ & 109.1 \\
\hline $\mathrm{C}(9)-\mathrm{C}(10)-\mathrm{C}(11)$ & $112.68(10)$ \\
\hline $\mathrm{H}(10 \mathrm{~A})-\mathrm{C}(10)-\mathrm{H}(10 \mathrm{~B})$ & 107.8 \\
\hline $\mathrm{C}(11)-\mathrm{C}(10)-\mathrm{H}(10 \mathrm{~A})$ & 109.1 \\
\hline $\mathrm{C}(11)-\mathrm{C}(10)-\mathrm{H}(10 \mathrm{~B})$ & 109.1 \\
\hline $\mathrm{C}(10)-\mathrm{C}(11)-\mathrm{H}(11 \mathrm{~A})$ & 109.6 \\
\hline $\mathrm{C}(10)-\mathrm{C}(11)-\mathrm{H}(11 \mathrm{~B})$ & 109.6 \\
\hline $\mathrm{H}(11 \mathrm{~A})-\mathrm{C}(11)-\mathrm{H}(11 \mathrm{~B})$ & 108.1 \\
\hline $\mathrm{C}(12)-\mathrm{C}(11)-\mathrm{C}(10)$ & $110.28(10)$ \\
\hline $\mathrm{C}(12)-\mathrm{C}(11)-\mathrm{H}(11 \mathrm{~A})$ & 109.6 \\
\hline $\mathrm{C}(12)-\mathrm{C}(11)-\mathrm{H}(11 \mathrm{~B})$ & 109.6 \\
\hline $\mathrm{C}(11)-\mathrm{C}(12)-\mathrm{H}(12 \mathrm{~A})$ & 109.5 \\
\hline $\mathrm{C}(11)-\mathrm{C}(12)-\mathrm{H}(12 \mathrm{~B})$ & 109.5 \\
\hline$C(11)-C(12)-C(13)$ & $110.93(10)$ \\
\hline $\mathrm{H}(12 \mathrm{~A})-\mathrm{C}(12)-\mathrm{H}(12 \mathrm{~B})$ & 108.0 \\
\hline $\mathrm{C}(13)-\mathrm{C}(12)-\mathrm{H}(12 \mathrm{~A})$ & 109.5 \\
\hline $\mathrm{C}(13)-\mathrm{C}(12)-\mathrm{H}(12 \mathrm{~B})$ & 109.5 \\
\hline $\mathrm{C}(12)-\mathrm{C}(13)-\mathrm{H}(13 \mathrm{~A})$ & 109.0 \\
\hline $\mathrm{C}(12)-\mathrm{C}(13)-\mathrm{H}(13 \mathrm{~B})$ & 109.0 \\
\hline$C(12)-C(13)-C(14)$ & $113.00(10)$ \\
\hline $\mathrm{H}(13 \mathrm{~A})-\mathrm{C}(13)-\mathrm{H}(13 \mathrm{~B})$ & 107.8 \\
\hline $\mathrm{C}(14)-\mathrm{C}(13)-\mathrm{H}(13 \mathrm{~A})$ & 109.0 \\
\hline $\mathrm{C}(14)-\mathrm{C}(13)-\mathrm{H}(13 \mathrm{~B})$ & 109.0 \\
\hline$C(8)-C(14)-C(9)$ & $102.43(9)$ \\
\hline$C(8)-C(14)-C(13)$ & $107.50(9)$ \\
\hline $\mathrm{C}(8)-\mathrm{C}(14)-\mathrm{H}(14)$ & 111.2 \\
\hline$C(9)-C(14)-C(13)$ & 112.92(9) \\
\hline $\mathrm{C}(9)-\mathrm{C}(14)-\mathrm{H}(14)$ & 111.2 \\
\hline $\mathrm{C}(13)-\mathrm{C}(14)-\mathrm{H}(14)$ & 111.2 \\
\hline
\end{tabular}


Table S10 Anisotropic displacement parameters $\left(\AA^{2} \times 10^{3}\right)$ for $\mathbf{2 u}$. The anisotropic displacement factor exponent takes the form: $-2 \pi^{2}\left[h^{2} a^{* 2} U^{11}+\ldots+2 h k a^{*} b^{*} U^{12}\right]$.

\begin{tabular}{lllllll}
\hline & $\mathrm{U}^{11}$ & $\mathrm{U}^{22}$ & $\mathrm{U}^{33}$ & $\mathrm{U}^{23}$ & $\mathrm{U}^{13}$ & $\mathrm{U}^{12}$ \\
\hline $\mathrm{O}(1)$ & $18(1)$ & $25(1)$ & $19(1)$ & $-10(1)$ & $0(1)$ & $-1(1)$ \\
$\mathrm{O}(2)$ & $25(1)$ & $23(1)$ & $16(1)$ & $-11(1)$ & $1(1)$ & $-1(1)$ \\
$\mathrm{N}(1)$ & $16(1)$ & $14(1)$ & $14(1)$ & $-7(1)$ & $-4(1)$ & $0(1)$ \\
$\mathrm{N}(2)$ & $19(1)$ & $18(1)$ & $17(1)$ & $-7(1)$ & $-2(1)$ & $1(1)$ \\
$\mathrm{C}(1)$ & $19(1)$ & $20(1)$ & $20(1)$ & $-6(1)$ & $-2(1)$ & $2(1)$ \\
$\mathrm{C}(2)$ & $17(1)$ & $27(1)$ & $16(1)$ & $-4(1)$ & $-4(1)$ & $-2(1)$ \\
$\mathrm{C}(3)$ & $22(1)$ & $31(1)$ & $17(1)$ & $-12(1)$ & $-3(1)$ & $-6(1)$ \\
$\mathrm{C}(4)$ & $22(1)$ & $20(1)$ & $20(1)$ & $-11(1)$ & $-3(1)$ & $-1(1)$ \\
$\mathrm{C}(5)$ & $14(1)$ & $16(1)$ & $15(1)$ & $-6(1)$ & $-1(1)$ & $-2(1)$ \\
$\mathrm{C}(6)$ & $21(1)$ & $14(1)$ & $16(1)$ & $-7(1)$ & $-5(1)$ & $-1(1)$ \\
$\mathrm{C}(7)$ & $17(1)$ & $15(1)$ & $13(1)$ & $-6(1)$ & $-6(1)$ & $4(1)$ \\
$\mathrm{C}(8)$ & $19(1)$ & $12(1)$ & $14(1)$ & $-4(1)$ & $-4(1)$ & $2(1)$ \\
$\mathrm{C}(9)$ & $20(1)$ & $13(1)$ & $14(1)$ & $-6(1)$ & $-4(1)$ & $2(1)$ \\
$\mathrm{C}(10)$ & $26(1)$ & $18(1)$ & $17(1)$ & $-10(1)$ & $-5(1)$ & $1(1)$ \\
$\mathrm{C}(11)$ & $23(1)$ & $19(1)$ & $14(1)$ & $-6(1)$ & $-4(1)$ & $-1(1)$ \\
$\mathrm{C}(12)$ & $19(1)$ & $21(1)$ & $17(1)$ & $-6(1)$ & $-6(1)$ & $-3(1)$ \\
$\mathrm{C}(13)$ & $15(1)$ & $20(1)$ & $17(1)$ & $-7(1)$ & $-3(1)$ & $-1(1)$ \\
$\mathrm{C}(14)$ & $18(1)$ & $14(1)$ & $13(1)$ & $-5(1)$ & $-1(1)$ & $-2(1)$ \\
\hline & & & & & & \\
\hline
\end{tabular}


Table S11 Hydrogen coordinates (x $\left.10^{4}\right)$ and isotropic displacement parameters $\left(\AA^{2} \times 10^{3}\right)$ for $\mathbf{2 u}$.

\begin{tabular}{|c|c|c|c|c|}
\hline & $\mathrm{x}$ & $\mathrm{y}$ & $\mathrm{z}$ & $\mathrm{U}(\mathrm{eq})$ \\
\hline $\mathrm{H}(1)$ & 10460 & -121 & 6569 & 25 \\
\hline $\mathrm{H}(2)$ & 10838 & 618 & 8570 & 26 \\
\hline $\mathrm{H}(3)$ & 9481 & 3019 & 8493 & 27 \\
\hline $\mathrm{H}(4)$ & 7864 & 4635 & 6327 & 24 \\
\hline $\mathrm{H}(6 \mathrm{~A})$ & 6492 & 4937 & 4032 & 20 \\
\hline $\mathrm{H}(6 \mathrm{~B})$ & 8139 & 4764 & 2906 & 20 \\
\hline $\mathrm{H}(9)$ & 6146 & 370 & 3050 & 19 \\
\hline $\mathrm{H}(10 \mathrm{~A})$ & 4900 & 273 & 1051 & 23 \\
\hline $\mathrm{H}(10 \mathrm{~B})$ & 6540 & 1370 & 192 & 23 \\
\hline $\mathrm{H}(11 \mathrm{~A})$ & 4717 & 3698 & -632 & 22 \\
\hline $\mathrm{H}(11 \mathrm{~B})$ & 3970 & 2482 & -1186 & 22 \\
\hline $\mathrm{H}(12 \mathrm{~A})$ & 1866 & 1649 & 1047 & 23 \\
\hline $\mathrm{H}(12 \mathrm{~B})$ & 1633 & 3534 & -18 & 23 \\
\hline $\mathrm{H}(13 \mathrm{~A})$ & 1528 & 2963 & 2711 & 21 \\
\hline $\mathrm{H}(13 \mathrm{~B})$ & 3111 & 4087 & 1724 & 21 \\
\hline $\mathrm{H}(14)$ & 3388 & 763 & 3955 & 18 \\
\hline
\end{tabular}




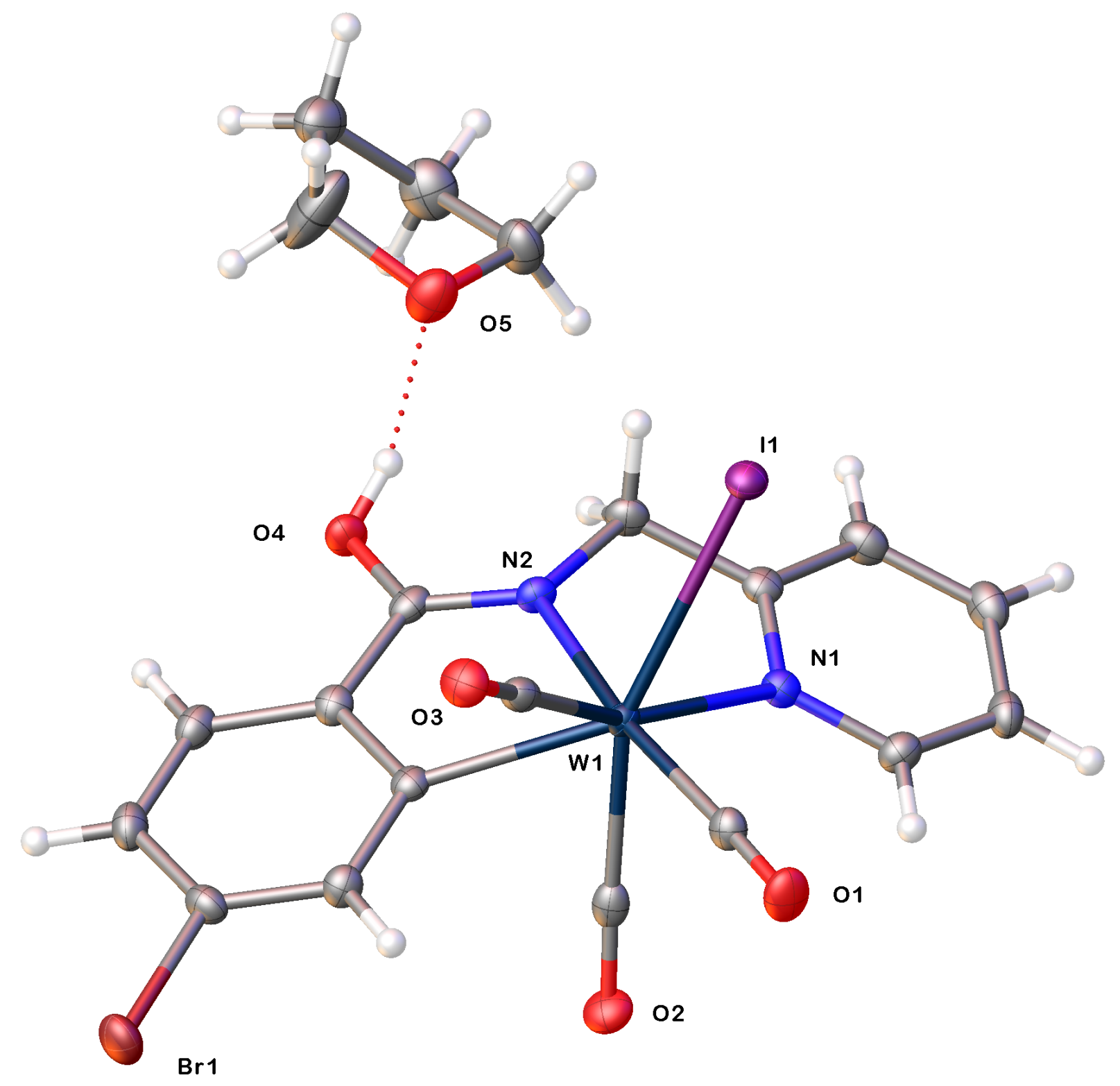

\section{Experimental Summary}

The single crystal X-ray diffraction studies were carried out on a Bruker APEX II Ultra CCD diffractometer equipped with Mo $\mathrm{K}_{\alpha}$ radiation $(\lambda=0.71073)$. Crystals of the subject compound were used as received (grown from $\mathrm{THF} / \mathrm{Et}_{2} \mathrm{O}$ ). A $0.000 \times 0.075 \times 0.070 \mathrm{~mm}$ yellow block was mounted on a Cryoloop with Paratone oil.

Data were collected in a nitrogen gas stream at 100(2) K using $\phi$ and $\varpi$ scans. Crystal-to-detector distance was $45 \mathrm{~mm}$ using exposure time 1.0s (depending on the detector $2 \theta$ position) with a scan width of $0.75^{\circ}$. Data collection was $100.0 \%$ complete to $25.242^{\circ}$ in $\theta$. A total of 18321 reflections were collected covering the indices, $-12<=\mathrm{h}<=12,-13<=\mathrm{k}<=13,-14<=\mathrm{l}<=14.4457$ reflections were found to be symmetry 
independent, with a $\mathrm{R}_{\text {int }}$ of 0.0405 . Indexing and unit cell refinement indicated a Primitive, Triclinic lattice. The space group was found to be $\boldsymbol{P} \mathbf{- 1}$. The data were integrated using the Bruker SAINT Software program and scaled using the SADABS software program. Solution by direct methods (SHELXT) produced a complete phasing model consistent with the proposed structure.

All nonhydrogen atoms were refined anisotropically by full-matrix least-squares (SHELXL-2014). All carbon bonded hydrogen atoms were placed using a riding model. Their positions were constrained relative to their parent atom using the appropriate HFIX command in SHELXL-2014.

Crystallographic data are summarized in Table S10.

Notes: Excellent data and refinement, THF solvent "hold" by OH bond

Table S12 Crystal data and structure refinement for W-2 (CCDC 2020047).

Empirical formula

Molecular formula

Formula weight

Temperature

Wavelength

Crystal system

Space group

Unit cell dimensions

Volume

Z

Density (calculated)

Absorption coefficient

$\mathrm{F}(000)$

Crystal size

Crystal color, habit

Theta range for data collection

Index ranges

Reflections collected

Independent reflections

Completeness to theta $=25.242^{\circ}$

Absorption correction
C20 H18 Br I N2 O5 W

C16 H10 Br I N2 O4 W, C4 H8 O

757.02

$100.0 \mathrm{~K}$

$0.71073 \AA$

Triclinic

P-1

$\mathrm{a}=9.8119(8) \AA \quad \alpha=115.3720(10)^{\circ}$.

$\mathrm{b}=11.1754(9) \AA \quad \beta=96.9760(10)^{\circ}$.

$\mathrm{c}=11.6513(10) \AA \quad \gamma=102.9580(10)^{\circ}$.

1090.09(16) $\AA^{3}$

2

$2.306 \mathrm{Mg} / \mathrm{m}^{3}$

$8.581 \mathrm{~mm}^{-1}$

708

$0.1 \times 0.075 \times 0.07 \mathrm{~mm}^{3}$

yellow block

1.996 to $26.369^{\circ}$.

$-12<=\mathrm{h}<=12,-13<=\mathrm{k}<=13,-14<=\mathrm{k}<=14$

18321

$4457[\mathrm{R}(\mathrm{int})=0.0405]$

$100.0 \%$

Semi-empirical from equivalents

S-59 
Max. and min. transmission

Refinement method

Data / restraints / parameters

Goodness-of-fit on $\mathrm{F}^{2}$

Final $\mathrm{R}$ indices [I $>2 \operatorname{sigma}(\mathrm{I})]$

$\mathrm{R}$ indices (all data)

Largest diff. peak and hole
0.4915 and 0.3653

Full-matrix least-squares on $\mathrm{F}^{2}$

4457 / 0 / 272

1.040

$\mathrm{R} 1=0.0178, \mathrm{wR} 2=0.0445$

$\mathrm{R} 1=0.0188, \mathrm{wR} 2=0.0450$

0.716 and -0.453 e. $\AA^{-3}$ 
Table S13 Atomic coordinates ( $\mathrm{x} 10^{4}$ ) and equivalent isotropic displacement parameters $\left(\AA^{2} \mathrm{x} 10^{3}\right)$ for $\mathbf{W}-\mathbf{2}$. U(eq) is defined as one third of the trace of the orthogonalized $\mathrm{U}^{\mathrm{ij}}$ tensor.

\begin{tabular}{|c|c|c|c|c|}
\hline & $\mathrm{x}$ & $\mathrm{y}$ & $\mathrm{z}$ & $\mathrm{U}(\mathrm{eq})$ \\
\hline$\overline{W(1)}$ & 4042(1) & $3810(1)$ & 1908(1) & $12(1)$ \\
\hline $\mathrm{I}(1)$ & 4806(1) & $2724(1)$ & $3625(1)$ & $18(1)$ \\
\hline $\operatorname{Br}(1)$ & $270(1)$ & $7380(1)$ & $1743(1)$ & $25(1)$ \\
\hline $\mathrm{O}(1)$ & 1355(2) & $1142(2)$ & $248(2)$ & $26(1)$ \\
\hline $\mathrm{O}(2)$ & $3214(2)$ & $3837(2)$ & $-747(2)$ & $23(1)$ \\
\hline $\mathrm{O}(3)$ & $1720(2)$ & $4316(2)$ & $3570(2)$ & $22(1)$ \\
\hline $\mathrm{O}(4)$ & 7294(2) & $7851(2)$ & $3962(2)$ & $19(1)$ \\
\hline $\mathrm{N}(1)$ & $5787(3)$ & 2995(3) & 1101(2) & $15(1)$ \\
\hline $\mathrm{N}(2)$ & $6069(3)$ & $5471(2)$ & $2947(2)$ & $14(1)$ \\
\hline$C(1)$ & 2348(3) & $2104(3)$ & $864(3)$ & $17(1)$ \\
\hline$C(2)$ & 3541(3) & $3866(3)$ & $229(3)$ & $17(1)$ \\
\hline$C(3)$ & 2578(3) & $4155(3)$ & 2989(3) & $16(1)$ \\
\hline$C(4)$ & $5542(3)$ & $1760(3)$ & $48(3)$ & $18(1)$ \\
\hline$C(5)$ & $6612(3)$ & $1154(3)$ & $-289(3)$ & $20(1)$ \\
\hline$C(6)$ & $8007(3)$ & $1866(3)$ & $477(3)$ & $22(1)$ \\
\hline$C(7)$ & $8282(3)$ & $3160(3)$ & $1539(3)$ & $21(1)$ \\
\hline $\mathrm{C}(8)$ & $7156(3)$ & $3701(3)$ & $1829(3)$ & $16(1)$ \\
\hline$C(9)$ & 7401(3) & $5095(3)$ & 2998(3) & $18(1)$ \\
\hline$C(10)$ & $6112(3)$ & $6755(3)$ & $3338(3)$ & $16(1)$ \\
\hline$C(11)$ & 4755(3) & $6986(3)$ & $3007(3)$ & $16(1)$ \\
\hline$C(12)$ & 3579(3) & $5770(3)$ & 2241(3) & $15(1)$ \\
\hline$C(13)$ & $2252(3)$ & 5934(3) & 1847(3) & $17(1)$ \\
\hline$C(14)$ & $2135(3)$ & $7248(3)$ & $2240(3)$ & $18(1)$ \\
\hline$C(15)$ & $3289(3)$ & $8457(3)$ & $3008(3)$ & $20(1)$ \\
\hline$C(16)$ & $4605(3)$ & $8309(3)$ & $3379(3)$ & $19(1)$ \\
\hline $\mathrm{O}(5)$ & 9481(2) & $7775(3)$ & $5427(2)$ & $30(1)$ \\
\hline$C(17)$ & $10787(4)$ & $7435(4)$ & $5201(4)$ & $30(1)$ \\
\hline$C(18)$ & $11948(4)$ & $8816(4)$ & $5819(4)$ & $35(1)$ \\
\hline$C(19)$ & $11499(4)$ & $9634(4)$ & $7068(4)$ & $31(1)$ \\
\hline$C(20)$ & $9867(5)$ & $9026(5)$ & $6654(4)$ & $54(1)$ \\
\hline
\end{tabular}


Table S14 Bond lengths $[\AA ̊]$ and angles $\left[^{\circ}\right]$ for $\mathbf{W}-2$.

\begin{tabular}{|c|c|c|c|}
\hline $\mathrm{W}(1)-\mathrm{I}(1)$ & $2.8567(3)$ & $\mathrm{N}(2)-\mathrm{W}(1)-\mathrm{N}(1)$ & $72.41(9)$ \\
\hline $\mathrm{W}(1)-\mathrm{N}(1)$ & $2.237(2)$ & $\mathrm{N}(2)-\mathrm{W}(1)-\mathrm{C}(12)$ & $73.43(10)$ \\
\hline $\mathrm{W}(1)-\mathrm{N}(2)$ & $2.168(2)$ & $\mathrm{C}(1)-\mathrm{W}(1)-\mathrm{I}(1)$ & $89.80(9)$ \\
\hline $\mathrm{W}(1)-\mathrm{C}(1)$ & 1.994(3) & $\mathrm{C}(1)-\mathrm{W}(1)-\mathrm{N}(1)$ & $99.72(10)$ \\
\hline $\mathrm{W}(1)-\mathrm{C}(2)$ & $1.989(3)$ & $\mathrm{C}(1)-\mathrm{W}(1)-\mathrm{N}(2)$ & $171.88(10)$ \\
\hline $\mathrm{W}(1)-\mathrm{C}(3)$ & $2.018(3)$ & $\mathrm{C}(1)-\mathrm{W}(1)-\mathrm{C}(3)$ & $76.73(12)$ \\
\hline $\mathrm{W}(1)-\mathrm{C}(12)$ & $2.218(3)$ & $\mathrm{C}(1)-\mathrm{W}(1)-\mathrm{C}(12)$ & $114.03(11)$ \\
\hline $\operatorname{Br}(1)-C(14)$ & $1.908(3)$ & $\mathrm{C}(2)-\mathrm{W}(1)-\mathrm{I}(1)$ & $158.16(8)$ \\
\hline $\mathrm{O}(1)-\mathrm{C}(1)$ & $1.149(4)$ & $\mathrm{C}(2)-\mathrm{W}(1)-\mathrm{N}(1)$ & $84.48(10)$ \\
\hline $\mathrm{O}(2)-\mathrm{C}(2)$ & $1.128(4)$ & $\mathrm{C}(2)-\mathrm{W}(1)-\mathrm{N}(2)$ & $103.23(10)$ \\
\hline $\mathrm{O}(3)-\mathrm{C}(3)$ & $1.141(4)$ & $\mathrm{C}(2)-\mathrm{W}(1)-\mathrm{C}(1)$ & $77.52(12)$ \\
\hline $\mathrm{O}(4)-\mathrm{C}(10)$ & $1.330(4)$ & $\mathrm{C}(2)-\mathrm{W}(1)-\mathrm{C}(3)$ & $114.21(11)$ \\
\hline $\mathrm{N}(1)-\mathrm{C}(4)$ & $1.340(4)$ & $\mathrm{C}(2)-\mathrm{W}(1)-\mathrm{C}(12)$ & $68.88(11)$ \\
\hline $\mathrm{N}(1)-\mathrm{C}(8)$ & $1.350(4)$ & $\mathrm{C}(3)-\mathrm{W}(1)-\mathrm{I}(1)$ & $79.24(8)$ \\
\hline $\mathrm{N}(2)-\mathrm{C}(9)$ & $1.461(4)$ & $\mathrm{C}(3)-\mathrm{W}(1)-\mathrm{N}(1)$ & $159.12(10)$ \\
\hline $\mathrm{N}(2)-\mathrm{C}(10)$ & $1.295(4)$ & $\mathrm{C}(3)-\mathrm{W}(1)-\mathrm{N}(2)$ & $109.86(10)$ \\
\hline $\mathrm{C}(4)-\mathrm{C}(5)$ & $1.381(4)$ & $\mathrm{C}(3)-\mathrm{W}(1)-\mathrm{C}(12)$ & $68.72(11)$ \\
\hline $\mathrm{C}(5)-\mathrm{C}(6)$ & $1.383(5)$ & $\mathrm{C}(12)-\mathrm{W}(1)-\mathrm{I}(1)$ & $132.94(7)$ \\
\hline$C(6)-C(7)$ & $1.381(5)$ & $\mathrm{C}(12)-\mathrm{W}(1)-\mathrm{N}(1)$ & $129.77(9)$ \\
\hline $\mathrm{C}(7)-\mathrm{C}(8)$ & $1.384(4)$ & $\mathrm{C}(4)-\mathrm{N}(1)-\mathrm{W}(1)$ & $123.90(19)$ \\
\hline $\mathrm{C}(8)-\mathrm{C}(9)$ & $1.508(4)$ & $\mathrm{C}(4)-\mathrm{N}(1)-\mathrm{C}(8)$ & $118.2(2)$ \\
\hline $\mathrm{C}(10)-\mathrm{C}(11)$ & $1.451(4)$ & $\mathrm{C}(8)-\mathrm{N}(1)-\mathrm{W}(1)$ & $117.20(19)$ \\
\hline$C(11)-C(12)$ & $1.408(4)$ & $\mathrm{C}(9)-\mathrm{N}(2)-\mathrm{W}(1)$ & $118.24(18)$ \\
\hline$C(11)-C(16)$ & $1.399(4)$ & $\mathrm{C}(10)-\mathrm{N}(2)-\mathrm{W}(1)$ & $120.3(2)$ \\
\hline$C(12)-C(13)$ & $1.405(4)$ & $\mathrm{C}(10)-\mathrm{N}(2)-\mathrm{C}(9)$ & $120.6(3)$ \\
\hline$C(13)-C(14)$ & $1.376(4)$ & $\mathrm{O}(1)-\mathrm{C}(1)-\mathrm{W}(1)$ & $178.0(3)$ \\
\hline$C(14)-C(15)$ & $1.393(4)$ & $\mathrm{O}(2)-\mathrm{C}(2)-\mathrm{W}(1)$ & $176.8(3)$ \\
\hline$C(15)-C(16)$ & $1.380(4)$ & $\mathrm{O}(3)-\mathrm{C}(3)-\mathrm{W}(1)$ & $178.0(3)$ \\
\hline $\mathrm{O}(5)-\mathrm{C}(17)$ & $1.440(4)$ & $\mathrm{N}(1)-\mathrm{C}(4)-\mathrm{C}(5)$ & $123.0(3)$ \\
\hline $\mathrm{O}(5)-\mathrm{C}(20)$ & $1.435(4)$ & $C(4)-C(5)-C(6)$ & $118.6(3)$ \\
\hline$C(17)-C(18)$ & $1.503(5)$ & $C(7)-C(6)-C(5)$ & $118.9(3)$ \\
\hline $\mathrm{C}(18)-\mathrm{C}(19)$ & $1.531(5)$ & $C(6)-C(7)-C(8)$ & $119.5(3)$ \\
\hline \multirow[t]{2}{*}{$C(19)-C(20)$} & $1.517(5)$ & $\mathrm{N}(1)-\mathrm{C}(8)-\mathrm{C}(7)$ & $121.7(3)$ \\
\hline & & $\mathrm{N}(1)-\mathrm{C}(8)-\mathrm{C}(9)$ & $116.9(2)$ \\
\hline $\mathrm{N}(1)-\mathrm{W}(1)-\mathrm{I}(1)$ & $80.18(6)$ & $\mathrm{C}(7)-\mathrm{C}(8)-\mathrm{C}(9)$ & $121.3(3)$ \\
\hline $\mathrm{N}(2)-\mathrm{W}(1)-\mathrm{I}(1)$ & $86.89(6)$ & $\mathrm{N}(2)-\mathrm{C}(9)-\mathrm{C}(8)$ & $108.7(2)$ \\
\hline
\end{tabular}




$\begin{array}{ll}\mathrm{O}(4)-\mathrm{C}(10)-\mathrm{C}(11) & 118.3(3) \\ \mathrm{N}(2)-\mathrm{C}(10)-\mathrm{O}(4) & 125.5(3) \\ \mathrm{N}(2)-\mathrm{C}(10)-\mathrm{C}(11) & 116.2(3) \\ \mathrm{C}(12)-\mathrm{C}(11)-\mathrm{C}(10) & 115.1(3) \\ \mathrm{C}(16)-\mathrm{C}(11)-\mathrm{C}(10) & 123.5(3) \\ \mathrm{C}(16)-\mathrm{C}(11)-\mathrm{C}(12) & 121.4(3) \\ \mathrm{C}(11)-\mathrm{C}(12)-\mathrm{W}(1) & 114.6(2) \\ \mathrm{C}(13)-\mathrm{C}(12)-\mathrm{W}(1) & 127.8(2) \\ \mathrm{C}(13)-\mathrm{C}(12)-\mathrm{C}(11) & 117.5(3) \\ \mathrm{C}(14)-\mathrm{C}(13)-\mathrm{C}(12) & 119.8(3) \\ \mathrm{C}(13)-\mathrm{C}(14)-\mathrm{Br}(1) & 117.1(2) \\ \mathrm{C}(13)-\mathrm{C}(14)-\mathrm{C}(15) & 123.2(3) \\ \mathrm{C}(15)-\mathrm{C}(14)-\mathrm{Br}(1) & 119.7(2) \\ \mathrm{C}(16)-\mathrm{C}(15)-\mathrm{C}(14) & 117.6(3) \\ \mathrm{C}(15)-\mathrm{C}(16)-\mathrm{C}(11) & 120.6(3) \\ \mathrm{C}(20)-\mathrm{O}(5)-\mathrm{C}(17) & 107.2(3) \\ \mathrm{O}(5)-\mathrm{C}(17)-\mathrm{C}(18) & 104.8(3) \\ \mathrm{C}(17)-\mathrm{C}(18)-\mathrm{C}(19) & 101.7(3) \\ \mathrm{C}(20)-\mathrm{C}(19)-\mathrm{C}(18) & 102.8(3) \\ \mathrm{O}(5)-\mathrm{C}(20)-\mathrm{C}(19) & 108.2(3) \\ & \end{array}$


Table S15 Anisotropic displacement parameters $\left(\AA^{2} \mathrm{x} 10^{3}\right)$ for W-2. The anisotropic displacement factor exponent takes the form: $-2 \pi^{2}\left[h^{2} a^{* 2} U^{11}+\ldots+2 h k a^{*} b^{*} U^{12}\right]$.

\begin{tabular}{|c|c|c|c|c|c|c|}
\hline & $\mathrm{U}^{11}$ & $\mathrm{U}^{22}$ & $\mathrm{U}^{33}$ & $\mathrm{U}^{23}$ & $\mathrm{U}^{13}$ & $\mathrm{U}^{12}$ \\
\hline$\overline{\mathrm{W}(1)}$ & $10(1)$ & $12(1)$ & $12(1)$ & $5(1)$ & $3(1)$ & $2(1)$ \\
\hline $\mathrm{I}(1)$ & $21(1)$ & $19(1)$ & $16(1)$ & $10(1)$ & $5(1)$ & $6(1)$ \\
\hline $\operatorname{Br}(1)$ & 21(1) & $26(1)$ & $32(1)$ & $15(1)$ & $7(1)$ & $13(1)$ \\
\hline $\mathrm{O}(1)$ & $17(1)$ & $18(1)$ & $32(1)$ & $6(1)$ & $2(1)$ & $0(1)$ \\
\hline $\mathrm{O}(2)$ & $24(1)$ & $28(1)$ & $17(1)$ & $10(1)$ & $9(1)$ & $9(1)$ \\
\hline $\mathrm{O}(3)$ & $20(1)$ & $28(1)$ & $23(1)$ & $13(1)$ & 11(1) & $9(1)$ \\
\hline $\mathrm{O}(4)$ & $14(1)$ & $16(1)$ & $22(1)$ & $7(1)$ & $0(1)$ & $1(1)$ \\
\hline $\mathrm{N}(1)$ & $13(1)$ & $17(1)$ & $17(1)$ & $10(1)$ & $5(1)$ & $5(1)$ \\
\hline $\mathrm{N}(2)$ & $11(1)$ & $16(1)$ & $14(1)$ & $7(1)$ & $3(1)$ & $2(1)$ \\
\hline$C(1)$ & $14(1)$ & $17(1)$ & $20(2)$ & $8(1)$ & $7(1)$ & $6(1)$ \\
\hline$C(2)$ & 11(1) & $15(1)$ & $23(2)$ & $6(1)$ & $6(1)$ & $3(1)$ \\
\hline$C(3)$ & $16(1)$ & $16(1)$ & $16(1)$ & $8(1)$ & 1(1) & $3(1)$ \\
\hline$C(4)$ & $17(2)$ & $19(2)$ & $17(2)$ & $7(1)$ & $4(1)$ & $4(1)$ \\
\hline$C(5)$ & $26(2)$ & $18(2)$ & $21(2)$ & $9(1)$ & $10(1)$ & $11(1)$ \\
\hline$C(6)$ & $23(2)$ & $25(2)$ & $26(2)$ & $15(1)$ & $14(1)$ & $14(1)$ \\
\hline$C(7)$ & $16(2)$ & $27(2)$ & $26(2)$ & $16(1)$ & $7(1)$ & $8(1)$ \\
\hline$C(8)$ & $17(1)$ & $18(1)$ & $16(1)$ & 11(1) & $6(1)$ & $5(1)$ \\
\hline$C(9)$ & $12(1)$ & $21(2)$ & $20(2)$ & $9(1)$ & $2(1)$ & $4(1)$ \\
\hline$C(10)$ & $18(1)$ & $16(1)$ & $12(1)$ & $5(1)$ & $5(1)$ & $2(1)$ \\
\hline$C(11)$ & $17(1)$ & $17(1)$ & $16(1)$ & $8(1)$ & $7(1)$ & $5(1)$ \\
\hline$C(12)$ & $16(1)$ & $16(1)$ & $12(1)$ & $7(1)$ & $5(1)$ & $5(1)$ \\
\hline$C(13)$ & $15(1)$ & $17(1)$ & $19(2)$ & $7(1)$ & $5(1)$ & $4(1)$ \\
\hline$C(14)$ & $18(2)$ & $23(2)$ & $20(2)$ & $12(1)$ & $6(1)$ & $10(1)$ \\
\hline$C(15)$ & $27(2)$ & $15(1)$ & $22(2)$ & $9(1)$ & $10(1)$ & $8(1)$ \\
\hline$C(16)$ & $22(2)$ & $15(1)$ & $17(2)$ & $6(1)$ & $6(1)$ & $3(1)$ \\
\hline $\mathrm{O}(5)$ & 21(1) & $28(1)$ & $30(1)$ & $6(1)$ & $4(1)$ & $6(1)$ \\
\hline$C(17)$ & $22(2)$ & $27(2)$ & $38(2)$ & $13(2)$ & $6(2)$ & $11(1)$ \\
\hline$C(18)$ & $26(2)$ & $38(2)$ & $44(2)$ & $21(2)$ & $13(2)$ & $11(2)$ \\
\hline$C(19)$ & $34(2)$ & $26(2)$ & $30(2)$ & $13(2)$ & $3(2)$ & $6(2)$ \\
\hline$C(20)$ & $36(2)$ & $44(2)$ & $39(2)$ & $-12(2)$ & $10(2)$ & $2(2)$ \\
\hline
\end{tabular}


Table S16 Hydrogen coordinates (x $\left.10^{4}\right)$ and isotropic displacement parameters $\left(\AA^{2} \times 10^{3}\right)$ for $\mathbf{W}-\mathbf{2}$.

\begin{tabular}{|c|c|c|c|c|}
\hline & $\mathrm{x}$ & $\mathrm{y}$ & $\mathrm{z}$ & $\mathrm{U}(\mathrm{eq})$ \\
\hline $\mathrm{H}(4)$ & 7919 & 7655 & 4348 & 28 \\
\hline $\mathrm{H}(4 \mathrm{~A})$ & 4587 & 1280 & -492 & 22 \\
\hline $\mathrm{H}(5)$ & 6393 & 267 & -1033 & 24 \\
\hline $\mathrm{H}(6)$ & 8765 & 1471 & 276 & 26 \\
\hline $\mathrm{H}(7)$ & 9237 & 3675 & 2067 & 26 \\
\hline $\mathrm{H}(9 \mathrm{~A})$ & 7675 & 5044 & 3818 & 21 \\
\hline $\mathrm{H}(9 \mathrm{~B})$ & 8194 & 5810 & 2983 & 21 \\
\hline $\mathrm{H}(13)$ & 1437 & 5139 & 1311 & 21 \\
\hline $\mathrm{H}(15)$ & 3174 & 9351 & 3267 & 25 \\
\hline $\mathrm{H}(16)$ & 5417 & 9113 & 3893 & 23 \\
\hline $\mathrm{H}(17 \mathrm{~A})$ & 10715 & 6917 & 4251 & 35 \\
\hline $\mathrm{H}(17 \mathrm{~B})$ & 10987 & 6862 & 5616 & 35 \\
\hline $\mathrm{H}(18 \mathrm{~A})$ & 11949 & 9263 & 5245 & 42 \\
\hline $\mathrm{H}(18 \mathrm{~B})$ & 12914 & 8720 & 6024 & 42 \\
\hline $\mathrm{H}(19 \mathrm{~A})$ & 11913 & 9485 & 7796 & 37 \\
\hline $\mathrm{H}(19 \mathrm{~B})$ & 11804 & 10643 & 7342 & 37 \\
\hline $\mathrm{H}(20 \mathrm{~A})$ & 9512 & 8815 & 7327 & 64 \\
\hline $\mathrm{H}(20 \mathrm{~B})$ & 9426 & 9703 & 6557 & 64 \\
\hline
\end{tabular}




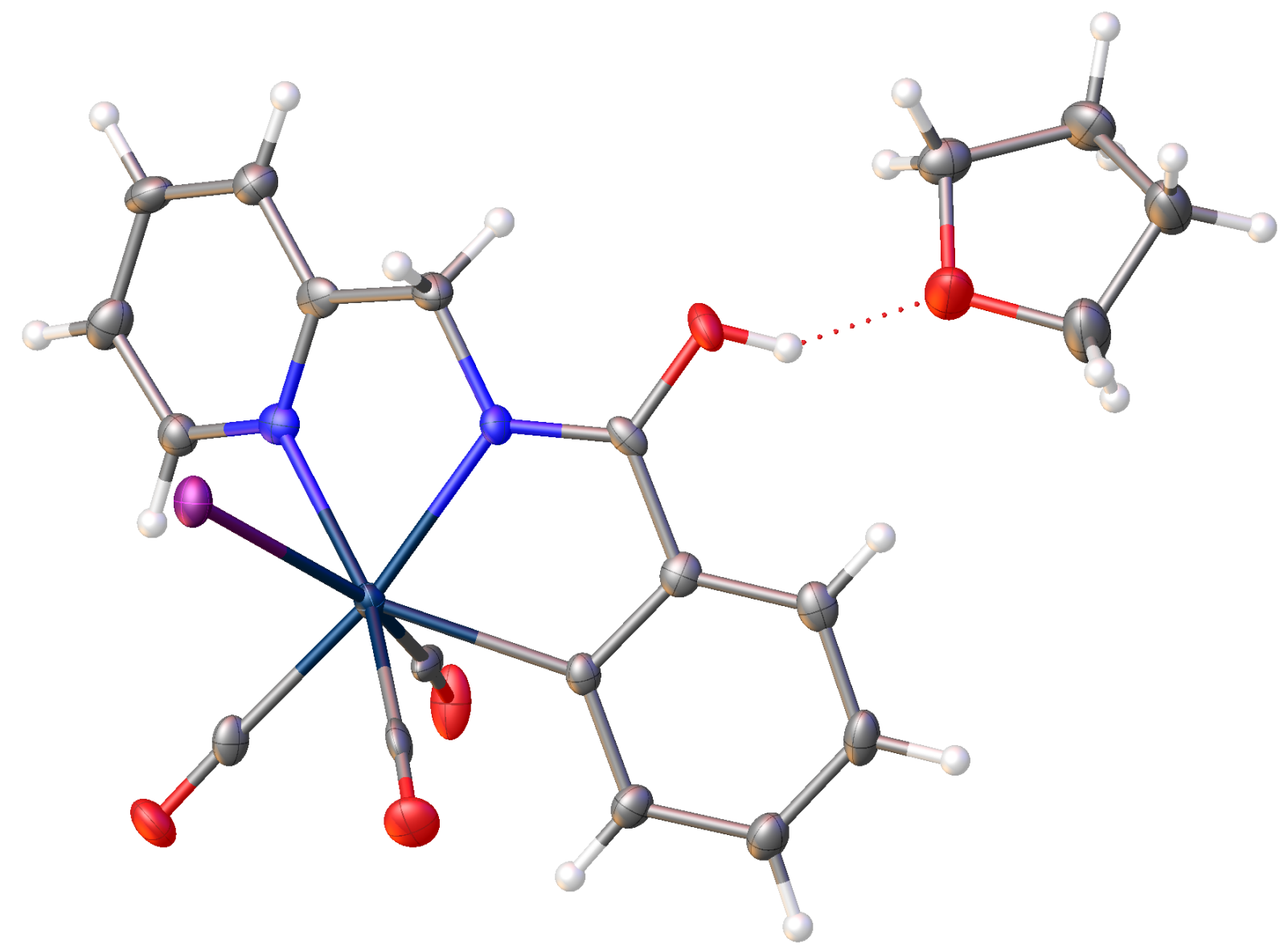

\section{$\underline{\text { Experimental Summary }}$}

The single crystal X-ray diffraction studies were carried out on a Bruker APEX II Ultra diffractometer equipped with Mo $\mathrm{K}_{\alpha}$ radiation $(\lambda=0.71073)$. Crystals of the subject compound were used as received (grown from THF/Pentane). A $0.160 \times 0.160 \times 0.060 \mathrm{~mm}$ yellow crystal was mounted on a Cryoloop with Paratone oil.

Data were collected in a nitrogen gas stream at 100(2) K using $\phi$ and $\varpi$ scans. Crystal-to-detector distance was $40 \mathrm{~mm}$ using exposure time $2.0 \mathrm{~s}$ (depending on the detector $2 \theta$ position) with a scan width of $0.75^{\circ}$. Data collection was $100.0 \%$ complete to $25.242^{\circ}$ in $\theta$. A total of 10663 reflections were collected. 10663 reflections were found to be symmetry independent, with a $\mathrm{R}_{\text {int }}$ of 0.0416 . Indexing and unit cell refinement indicated a Primitive, Triclinic lattice. The space group was found to be $\boldsymbol{P}-\mathbf{1}$. The data were integrated using the Bruker SAINT Software program and scaled using the SADABS software program. Solution by direct methods (SHELXT) produced a complete phasing model consistent with the proposed structure. 
All nonhydrogen atoms were refined anisotropically by full-matrix least-squares (SHELXL-2014). All carbon bonded hydrogen atoms were placed using a riding model. Their positions were constrained relative to their parent atom using the appropriate HFIX command in SHELXL-2014.

Crystallographic data are summarized in Table S15.

Notes: Excellent data and refinement.

Minor Dizo on THF.

Table S17 Crystal data and structure refinement for W-3 (CCDC 2050458).

Empirical formula

Molecular formula

Formula weight

Temperature

Wavelength

Crystal system

Space group

Unit cell dimensions

Volume

Z

Density (calculated)

Absorption coefficient

$\mathrm{F}(000)$

Crystal size

Crystal color, habit

Theta range for data collection

Index ranges

Reflections collected

Independent reflections

Completeness to theta $=25.242^{\circ}$

Absorption correction

Max. and min. transmission

Refinement method

Data / restraints / parameters

Goodness-of-fit on $\mathrm{F}^{2}$
C20 H19 I N2 O5 W

C16 H11 I N2 O4 W, C4 H8 O

678.12

$100.0 \mathrm{~K}$

$0.71073 \AA$

Triclinic

P-1

$\mathrm{a}=9.5844(7) \AA$ $\alpha=114.892(2)^{\circ}$.

$\mathrm{b}=10.9537(8) \AA$ $\beta=104.036(2)^{\circ}$.

$\mathrm{c}=11.6929(9) \AA$ $\gamma=99.239(2)^{\circ}$.

$1031.06(13) \AA^{3}$

2

$2.184 \mathrm{Mg} / \mathrm{m}^{3}$

$7.133 \mathrm{~mm}^{-1}$

640

$0.18 \times 0.18 \times 0.06 \mathrm{~mm}^{3}$

yellow plate

2.047 to $26.021^{\circ}$.

$-11<=\mathrm{h}<=11,-13<=\mathrm{k}<=13,-14<=\mathrm{l}<=14$

10663

$4065[\mathrm{R}(\mathrm{int})=0.0416]$

$100.0 \%$

Semi-empirical from equivalents

0.0937 and 0.0586

Full-matrix least-squares on $\mathrm{F}^{2}$

4065 / 7 / 270

1.055 
Final $\mathrm{R}$ indices [I $>2 \operatorname{sigma}(\mathrm{I})]$

$\mathrm{R}$ indices (all data)

Largest diff. peak and hole
$\mathrm{R} 1=0.0248, \mathrm{wR} 2=0.0605$

$\mathrm{R} 1=0.0266, \mathrm{wR} 2=0.0617$

1.663 and -0.657 e. $\AA^{-3}$ 
Table S18 Atomic coordinates (x $\left.10^{4}\right)$ and equivalent isotropic displacement parameters $\left(\AA^{2} \mathrm{x} 10^{3}\right)$ for $\mathbf{W}-\mathbf{3} \mathrm{U}(\mathrm{eq})$ is defined as one third of the trace of the orthogonalized $U^{i j}$ tensor.

\begin{tabular}{|c|c|c|c|c|}
\hline & $\mathrm{x}$ & $\mathrm{y}$ & $\mathrm{z}$ & $\mathrm{U}(\mathrm{eq})$ \\
\hline $\mathrm{W}(1)$ & $6496(1)$ & $6017(1)$ & $3150(1)$ & $18(1)$ \\
\hline $\mathrm{I}(1)$ & $5525(1)$ & $7187(1)$ & $1434(1)$ & $28(1)$ \\
\hline $\mathrm{O}(1)$ & $8585(4)$ & $5327(3)$ & 1404(3) & $34(1)$ \\
\hline $\mathrm{O}(2)$ & $7731(4)$ & $5969(3)$ & $5837(3)$ & $35(1)$ \\
\hline $\mathrm{O}(3)$ & $9413(3)$ & $8619(3)$ & 4899(3) & $31(1)$ \\
\hline $\mathrm{O}(4)$ & $2772(3)$ & $2212(3)$ & 1173(3) & $28(1)$ \\
\hline $\mathrm{N}(1)$ & 4898(4) & $7015(4)$ & $4046(3)$ & $20(1)$ \\
\hline $\mathrm{N}(2)$ & 4286(4) & $4475(3)$ & 2143(3) & $19(1)$ \\
\hline $\mathrm{C}(1)$ & $7810(5)$ & $5544(4)$ & 2021(4) & $26(1)$ \\
\hline $\mathrm{C}(2)$ & $7257(5)$ & $5935(4)$ & $4863(5)$ & $25(1)$ \\
\hline $\mathrm{C}(3)$ & $8340(5)$ & $7674(4)$ & $4234(4)$ & $22(1)$ \\
\hline $\mathrm{C}(4)$ & $5340(5)$ & $8255(4)$ & $5169(4)$ & $23(1)$ \\
\hline$C(5)$ & $4347(5)$ & $8955(5)$ & $5621(5)$ & $32(1)$ \\
\hline $\mathrm{C}(6)$ & $2817(5)$ & $8315(5)$ & $4883(5)$ & $36(1)$ \\
\hline$C(7)$ & $2350(5)$ & $7018(5)$ & $3742(5)$ & $33(1)$ \\
\hline$C(8)$ & $3408(5)$ & $6394(5)$ & $3341(4)$ & $23(1)$ \\
\hline $\mathrm{C}(9)$ & $2980(5)$ & $5002(5)$ & 2097(4) & $25(1)$ \\
\hline$C(10)$ & $4143(5)$ & $3156(4)$ & $1760(4)$ & $21(1)$ \\
\hline $\mathrm{C}(11)$ & $5539(5)$ & $2789(4)$ & $2027(4)$ & $24(1)$ \\
\hline$C(12)$ & $5595(5)$ & $1413(5)$ & $1623(4)$ & $28(1)$ \\
\hline $\mathrm{C}(13)$ & $6951(6)$ & $1149(5)$ & $1938(5)$ & $35(1)$ \\
\hline$C(14)$ & $8253(6)$ & $2280(5)$ & $2705(6)$ & $36(1)$ \\
\hline$C(15)$ & $8221(5)$ & $3646(5)$ & $3107(5)$ & $32(1)$ \\
\hline$C(16)$ & $6857(5)$ & $3949(4)$ & 2761(4) & $23(1)$ \\
\hline $\mathrm{O}(5)$ & 1999(4) & $-115(4)$ & $1310(5)$ & $48(1)$ \\
\hline$C(17)$ & $728(5)$ & $-16(5)$ & $1754(5)$ & $29(1)$ \\
\hline $\mathrm{C}(18)$ & $201(7)$ & $-1364(6)$ & $1789(6)$ & $48(1)$ \\
\hline$C(19)$ & $1047(16)$ & $-2368(13)$ & $1076(13)$ & $33(3)$ \\
\hline$C(19 A)$ & $650(11)$ & $-2350(12)$ & $620(10)$ & $33(3)$ \\
\hline$C(20)$ & $1616(13)$ & $-1600(8)$ & $368(10)$ & $34(2)$ \\
\hline$C(20 A)$ & $2267(11)$ & $-1430(9)$ & $1066(12)$ & $34(2)$ \\
\hline
\end{tabular}


Table S18 Bond lengths $[\AA]$ and angles $\left[{ }^{\circ}\right]$ for $\mathbf{W}-\mathbf{3}$.

\begin{tabular}{|c|c|c|c|}
\hline $\mathrm{W}(1)-\mathrm{I}(1)$ & $2.8588(3)$ & $\mathrm{C}(15)-\mathrm{H}(15)$ & 0.9500 \\
\hline $\mathrm{W}(1)-\mathrm{N}(1)$ & $2.234(3)$ & $C(15)-C(16)$ & $1.407(6)$ \\
\hline $\mathrm{W}(1)-\mathrm{N}(2)$ & $2.166(3)$ & $\mathrm{O}(5)-\mathrm{C}(17)$ & $1.437(5)$ \\
\hline $\mathrm{W}(1)-\mathrm{C}(1)$ & $2.009(4)$ & $\mathrm{O}(5)-\mathrm{C}(20)$ & $1.449(8)$ \\
\hline $\mathrm{W}(1)-\mathrm{C}(2)$ & $2.004(5)$ & $\mathrm{O}(5)-\mathrm{C}(20 \mathrm{~A})$ & $1.424(8)$ \\
\hline $\mathrm{W}(1)-\mathrm{C}(3)$ & $1.992(4)$ & $\mathrm{C}(17)-\mathrm{H}(17 \mathrm{~A})$ & 0.9900 \\
\hline $\mathrm{W}(1)-\mathrm{C}(16)$ & $2.218(4)$ & $\mathrm{C}(17)-\mathrm{H}(17 \mathrm{~B})$ & 0.9900 \\
\hline $\mathrm{O}(1)-\mathrm{C}(1)$ & $1.141(5)$ & $\mathrm{C}(17)-\mathrm{C}(18)$ & $1.503(7)$ \\
\hline $\mathrm{O}(2)-\mathrm{C}(2)$ & $1.101(5)$ & $\mathrm{C}(18)-\mathrm{H}(18 \mathrm{~A})$ & 0.9900 \\
\hline $\mathrm{O}(3)-\mathrm{C}(3)$ & $1.152(5)$ & $\mathrm{C}(18)-\mathrm{H}(18 \mathrm{~B})$ & 0.9900 \\
\hline $\mathrm{O}(4)-\mathrm{H}(4)$ & 0.8400 & $\mathrm{C}(18)-\mathrm{H}(18 \mathrm{C})$ & 0.9900 \\
\hline $\mathrm{O}(4)-\mathrm{C}(10)$ & $1.340(5)$ & $\mathrm{C}(18)-\mathrm{H}(18 \mathrm{D})$ & 0.9900 \\
\hline $\mathrm{N}(1)-\mathrm{C}(4)$ & $1.339(5)$ & $\mathrm{C}(18)-\mathrm{C}(19)$ & $1.551(8)$ \\
\hline $\mathrm{N}(1)-\mathrm{C}(8)$ & $1.352(5)$ & $\mathrm{C}(18)-\mathrm{C}(19 \mathrm{~A})$ & $1.552(8)$ \\
\hline $\mathrm{N}(2)-\mathrm{C}(9)$ & $1.459(5)$ & $\mathrm{C}(19)-\mathrm{H}(19 \mathrm{~A})$ & 0.9900 \\
\hline $\mathrm{N}(2)-\mathrm{C}(10)$ & $1.292(5)$ & $\mathrm{C}(19)-\mathrm{H}(19 \mathrm{~B})$ & 0.9900 \\
\hline $\mathrm{C}(4)-\mathrm{H}(4 \mathrm{~A})$ & 0.9500 & $C(19)-C(20)$ & $1.532(8)$ \\
\hline $\mathrm{C}(4)-\mathrm{C}(5)$ & $1.382(6)$ & $\mathrm{C}(19 \mathrm{~A})-\mathrm{H}(19 \mathrm{C})$ & 0.9900 \\
\hline $\mathrm{C}(5)-\mathrm{H}(5)$ & 0.9500 & $\mathrm{C}(19 \mathrm{~A})-\mathrm{H}(19 \mathrm{D})$ & 0.9900 \\
\hline$C(5)-C(6)$ & $1.391(7)$ & $C(19 A)-C(20 A)$ & $1.534(8)$ \\
\hline $\mathrm{C}(6)-\mathrm{H}(6)$ & 0.9500 & $\mathrm{C}(20)-\mathrm{H}(20 \mathrm{~A})$ & 0.9900 \\
\hline $\mathrm{C}(6)-\mathrm{C}(7)$ & $1.382(7)$ & $\mathrm{C}(20)-\mathrm{H}(20 \mathrm{~B})$ & 0.9900 \\
\hline $\mathrm{C}(7)-\mathrm{H}(7)$ & 0.9500 & $\mathrm{C}(20 \mathrm{~A})-\mathrm{H}(20 \mathrm{C})$ & 0.9900 \\
\hline$C(7)-C(8)$ & $1.377(6)$ & $\mathrm{C}(20 \mathrm{~A})-\mathrm{H}(20 \mathrm{D})$ & 0.9900 \\
\hline $\mathrm{C}(8)-\mathrm{C}(9)$ & $1.500(6)$ & & \\
\hline $\mathrm{C}(9)-\mathrm{H}(9 \mathrm{~A})$ & 0.9900 & $\mathrm{~N}(1)-\mathrm{W}(1)-\mathrm{I}(1)$ & $80.51(8)$ \\
\hline $\mathrm{C}(9)-\mathrm{H}(9 \mathrm{~B})$ & 0.9900 & $\mathrm{~N}(2)-\mathrm{W}(1)-\mathrm{I}(1)$ & $87.55(9)$ \\
\hline$C(10)-C(11)$ & $1.457(6)$ & $\mathrm{N}(2)-\mathrm{W}(1)-\mathrm{N}(1)$ & $71.83(13)$ \\
\hline$C(11)-C(12)$ & $1.392(6)$ & $\mathrm{N}(2)-\mathrm{W}(1)-\mathrm{C}(16)$ & $73.41(14)$ \\
\hline$C(11)-C(16)$ & $1.410(6)$ & $\mathrm{C}(1)-\mathrm{W}(1)-\mathrm{I}(1)$ & 79.31(13) \\
\hline $\mathrm{C}(12)-\mathrm{H}(12)$ & 0.9500 & $\mathrm{C}(1)-\mathrm{W}(1)-\mathrm{N}(1)$ & $159.37(16)$ \\
\hline$C(12)-C(13)$ & $1.373(7)$ & $\mathrm{C}(1)-\mathrm{W}(1)-\mathrm{N}(2)$ & $111.38(15)$ \\
\hline C(13)-H(13) & 0.9500 & $\mathrm{C}(1)-\mathrm{W}(1)-\mathrm{C}(16)$ & $69.13(16)$ \\
\hline C(13)-C(14) & $1.386(7)$ & $\mathrm{C}(2)-\mathrm{W}(1)-\mathrm{I}(1)$ & $158.36(12)$ \\
\hline C(14)-H(14) & 0.9500 & $\mathrm{C}(2)-\mathrm{W}(1)-\mathrm{N}(1)$ & $84.76(15)$ \\
\hline$C(14)-C(15)$ & \multicolumn{2}{|c|}{ S-70 } & $102.85(15)$ \\
\hline
\end{tabular}




\begin{tabular}{|c|c|c|c|}
\hline$C(2)-W(1)-C(1)$ & $113.29(18)$ & $\mathrm{N}(2)-\mathrm{C}(9)-\mathrm{H}(9 \mathrm{~B})$ & 110.1 \\
\hline$C(2)-W(1)-C(16)$ & $68.60(16)$ & $\mathrm{C}(8)-\mathrm{C}(9)-\mathrm{H}(9 \mathrm{~A})$ & 110.1 \\
\hline C(3)-W(1)-I(1) & $89.60(12)$ & $\mathrm{C}(8)-\mathrm{C}(9)-\mathrm{H}(9 \mathrm{~B})$ & 110.1 \\
\hline $\mathrm{C}(3)-\mathrm{W}(1)-\mathrm{N}(1)$ & $98.01(14)$ & $\mathrm{H}(9 \mathrm{~A})-\mathrm{C}(9)-\mathrm{H}(9 \mathrm{~B})$ & 108.4 \\
\hline $\mathrm{C}(3)-\mathrm{W}(1)-\mathrm{N}(2)$ & $169.77(15)$ & $\mathrm{O}(4)-\mathrm{C}(10)-\mathrm{C}(11)$ & $123.5(4)$ \\
\hline$C(3)-W(1)-C(1)$ & $77.67(16)$ & $\mathrm{N}(2)-\mathrm{C}(10)-\mathrm{O}(4)$ & $120.4(4)$ \\
\hline$C(3)-W(1)-C(2)$ & $76.80(17)$ & $\mathrm{N}(2)-\mathrm{C}(10)-\mathrm{C}(11)$ & $116.1(4)$ \\
\hline$C(3)-W(1)-C(16)$ & $115.33(16)$ & $C(12)-C(11)-C(10)$ & $123.7(4)$ \\
\hline C(16)-W(1)-I(1) & $132.99(11)$ & $C(12)-C(11)-C(16)$ & $121.5(4)$ \\
\hline $\mathrm{C}(16)-\mathrm{W}(1)-\mathrm{N}(1)$ & $129.46(13)$ & $C(16)-C(11)-C(10)$ & $114.8(4)$ \\
\hline $\mathrm{C}(10)-\mathrm{O}(4)-\mathrm{H}(4)$ & 109.5 & $\mathrm{C}(11)-\mathrm{C}(12)-\mathrm{H}(12)$ & 119.8 \\
\hline $\mathrm{C}(4)-\mathrm{N}(1)-\mathrm{W}(1)$ & $123.4(3)$ & $\mathrm{C}(13)-\mathrm{C}(12)-\mathrm{C}(11)$ & $120.5(4)$ \\
\hline $\mathrm{C}(4)-\mathrm{N}(1)-\mathrm{C}(8)$ & $118.6(4)$ & $\mathrm{C}(13)-\mathrm{C}(12)-\mathrm{H}(12)$ & 119.8 \\
\hline $\mathrm{C}(8)-\mathrm{N}(1)-\mathrm{W}(1)$ & $117.6(3)$ & $\mathrm{C}(12)-\mathrm{C}(13)-\mathrm{H}(13)$ & 120.6 \\
\hline $\mathrm{C}(9)-\mathrm{N}(2)-\mathrm{W}(1)$ & $117.5(3)$ & $C(12)-C(13)-C(14)$ & $118.8(4)$ \\
\hline $\mathrm{C}(10)-\mathrm{N}(2)-\mathrm{W}(1)$ & $120.6(3)$ & $\mathrm{C}(14)-\mathrm{C}(13)-\mathrm{H}(13)$ & 120.6 \\
\hline $\mathrm{C}(10)-\mathrm{N}(2)-\mathrm{C}(9)$ & $121.2(3)$ & $\mathrm{C}(13)-\mathrm{C}(14)-\mathrm{H}(14)$ & 119.2 \\
\hline $\mathrm{O}(1)-\mathrm{C}(1)-\mathrm{W}(1)$ & $177.5(4)$ & $\mathrm{C}(15)-\mathrm{C}(14)-\mathrm{C}(13)$ & $121.6(5)$ \\
\hline $\mathrm{O}(2)-\mathrm{C}(2)-\mathrm{W}(1)$ & $175.8(4)$ & $\mathrm{C}(15)-\mathrm{C}(14)-\mathrm{H}(14)$ & 119.2 \\
\hline $\mathrm{O}(3)-\mathrm{C}(3)-\mathrm{W}(1)$ & $177.4(4)$ & $\mathrm{C}(14)-\mathrm{C}(15)-\mathrm{H}(15)$ & 119.5 \\
\hline $\mathrm{N}(1)-\mathrm{C}(4)-\mathrm{H}(4 \mathrm{~A})$ & 118.5 & $\mathrm{C}(14)-\mathrm{C}(15)-\mathrm{C}(16)$ & $121.0(4)$ \\
\hline $\mathrm{N}(1)-\mathrm{C}(4)-\mathrm{C}(5)$ & $123.1(4)$ & $\mathrm{C}(16)-\mathrm{C}(15)-\mathrm{H}(15)$ & 119.5 \\
\hline $\mathrm{C}(5)-\mathrm{C}(4)-\mathrm{H}(4 \mathrm{~A})$ & 118.5 & $C(11)-C(16)-W(1)$ & $114.8(3)$ \\
\hline $\mathrm{C}(4)-\mathrm{C}(5)-\mathrm{H}(5)$ & 121.0 & $\mathrm{C}(15)-\mathrm{C}(16)-\mathrm{W}(1)$ & $128.6(3)$ \\
\hline$C(4)-C(5)-C(6)$ & $117.9(5)$ & $\mathrm{C}(15)-\mathrm{C}(16)-\mathrm{C}(11)$ & $116.5(4)$ \\
\hline $\mathrm{C}(6)-\mathrm{C}(5)-\mathrm{H}(5)$ & 121.0 & $\mathrm{C}(17)-\mathrm{O}(5)-\mathrm{C}(20)$ & $103.5(5)$ \\
\hline $\mathrm{C}(5)-\mathrm{C}(6)-\mathrm{H}(6)$ & 120.3 & $\mathrm{C}(20 \mathrm{~A})-\mathrm{O}(5)-\mathrm{C}(17)$ & $109.8(5)$ \\
\hline$C(7)-C(6)-C(5)$ & 119.3(4) & $\mathrm{O}(5)-\mathrm{C}(17)-\mathrm{H}(17 \mathrm{~A})$ & 110.5 \\
\hline $\mathrm{C}(7)-\mathrm{C}(6)-\mathrm{H}(6)$ & 120.3 & $\mathrm{O}(5)-\mathrm{C}(17)-\mathrm{H}(17 \mathrm{~B})$ & 110.5 \\
\hline $\mathrm{C}(6)-\mathrm{C}(7)-\mathrm{H}(7)$ & 120.2 & $\mathrm{O}(5)-\mathrm{C}(17)-\mathrm{C}(18)$ & $105.9(4)$ \\
\hline$C(8)-C(7)-C(6)$ & $119.5(4)$ & $\mathrm{H}(17 \mathrm{~A})-\mathrm{C}(17)-\mathrm{H}(17 \mathrm{~B})$ & 108.7 \\
\hline $\mathrm{C}(8)-\mathrm{C}(7)-\mathrm{H}(7)$ & 120.2 & $\mathrm{C}(18)-\mathrm{C}(17)-\mathrm{H}(17 \mathrm{~A})$ & 110.5 \\
\hline $\mathrm{N}(1)-\mathrm{C}(8)-\mathrm{C}(7)$ & $121.6(4)$ & $\mathrm{C}(18)-\mathrm{C}(17)-\mathrm{H}(17 \mathrm{~B})$ & 110.5 \\
\hline $\mathrm{N}(1)-\mathrm{C}(8)-\mathrm{C}(9)$ & $116.2(4)$ & $\mathrm{C}(17)-\mathrm{C}(18)-\mathrm{H}(18 \mathrm{~A})$ & 112.1 \\
\hline $\mathrm{C}(7)-\mathrm{C}(8)-\mathrm{C}(9)$ & $122.2(4)$ & $\mathrm{C}(17)-\mathrm{C}(18)-\mathrm{H}(18 \mathrm{~B})$ & 112.1 \\
\hline $\mathrm{N}(2)-\mathrm{C}(9)-\mathrm{C}(8)$ & 108.2(3) & $\mathrm{C}(17)-\mathrm{C}(18)-\mathrm{H}(18 \mathrm{C})$ & 110.4 \\
\hline $\mathrm{N}(2)-\mathrm{C}(9)-\mathrm{H}(9 \mathrm{~A})$ & 110.1 & $\mathrm{C}(17)-\mathrm{C}(18)-\mathrm{H}(18 \mathrm{D})$ & 110.4 \\
\hline
\end{tabular}




\begin{tabular}{|c|c|}
\hline $\mathrm{C}(17)-\mathrm{C}(18)-\mathrm{C}(19)$ & $106.8(5)$ \\
\hline$C(17)-C(18)-C(19 A)$ & $98.2(6)$ \\
\hline $\mathrm{H}(18 \mathrm{~A})-\mathrm{C}(18)-\mathrm{H}(18 \mathrm{~B})$ & 109.8 \\
\hline $\mathrm{H}(18 \mathrm{C})-\mathrm{C}(18)-\mathrm{H}(18 \mathrm{D})$ & 108.6 \\
\hline $\mathrm{C}(19)-\mathrm{C}(18)-\mathrm{H}(18 \mathrm{C})$ & 110.4 \\
\hline $\mathrm{C}(19)-\mathrm{C}(18)-\mathrm{H}(18 \mathrm{D})$ & 110.4 \\
\hline $\mathrm{C}(19 \mathrm{~A})-\mathrm{C}(18)-\mathrm{H}(18 \mathrm{~A})$ & 112.1 \\
\hline $\mathrm{C}(19 \mathrm{~A})-\mathrm{C}(18)-\mathrm{H}(18 \mathrm{~B})$ & 112.1 \\
\hline $\mathrm{C}(18)-\mathrm{C}(19)-\mathrm{H}(19 \mathrm{~A})$ & 111.9 \\
\hline $\mathrm{C}(18)-\mathrm{C}(19)-\mathrm{H}(19 \mathrm{~B})$ & 111.9 \\
\hline $\mathrm{H}(19 \mathrm{~A})-\mathrm{C}(19)-\mathrm{H}(19 \mathrm{~B})$ & 109.6 \\
\hline$C(20)-C(19)-C(18)$ & $99.2(7)$ \\
\hline $\mathrm{C}(20)-\mathrm{C}(19)-\mathrm{H}(19 \mathrm{~A})$ & 111.9 \\
\hline $\mathrm{C}(20)-\mathrm{C}(19)-\mathrm{H}(19 \mathrm{~B})$ & 111.9 \\
\hline $\mathrm{C}(18)-\mathrm{C}(19 \mathrm{~A})-\mathrm{H}(19 \mathrm{C})$ & 112.1 \\
\hline $\mathrm{C}(18)-\mathrm{C}(19 \mathrm{~A})-\mathrm{H}(19 \mathrm{D})$ & 112.1 \\
\hline H(19C)-C(19A)-H(19D) & 109.8 \\
\hline$C(20 A)-C(19 A)-C(18)$ & $98.2(7)$ \\
\hline $\mathrm{C}(20 \mathrm{~A})-\mathrm{C}(19 \mathrm{~A})-\mathrm{H}(19 \mathrm{C})$ & 112.1 \\
\hline$C(20 A)-C(19 A)-H(19 D)$ & 112.1 \\
\hline $\mathrm{O}(5)-\mathrm{C}(20)-\mathrm{C}(19)$ & $104.8(8)$ \\
\hline $\mathrm{O}(5)-\mathrm{C}(20)-\mathrm{H}(20 \mathrm{~A})$ & 110.8 \\
\hline $\mathrm{O}(5)-\mathrm{C}(20)-\mathrm{H}(20 \mathrm{~B})$ & 110.8 \\
\hline $\mathrm{C}(19)-\mathrm{C}(20)-\mathrm{H}(20 \mathrm{~A})$ & 110.8 \\
\hline $\mathrm{C}(19)-\mathrm{C}(20)-\mathrm{H}(20 \mathrm{~B})$ & 110.8 \\
\hline $\mathrm{H}(20 \mathrm{~A})-\mathrm{C}(20)-\mathrm{H}(20 \mathrm{~B})$ & 108.9 \\
\hline $\mathrm{O}(5)-\mathrm{C}(20 \mathrm{~A})-\mathrm{C}(19 \mathrm{~A})$ & $99.9(7)$ \\
\hline $\mathrm{O}(5)-\mathrm{C}(20 \mathrm{~A})-\mathrm{H}(20 \mathrm{C})$ & 111.8 \\
\hline $\mathrm{O}(5)-\mathrm{C}(20 \mathrm{~A})-\mathrm{H}(20 \mathrm{D})$ & 111.8 \\
\hline$C(19 A)-C(20 A)-H(20 C)$ & 111.8 \\
\hline$C(19 A)-C(20 A)-H(20 D)$ & 111.8 \\
\hline $\mathrm{H}(20 \mathrm{C})-\mathrm{C}(20 \mathrm{~A})-\mathrm{H}(20 \mathrm{D})$ & 109.5 \\
\hline
\end{tabular}


Table S19 Anisotropic displacement parameters $\left(\AA^{2} \mathrm{x} 10^{3}\right)$ for $\mathbf{W}-3$. The anisotropic displacement factor exponent takes the form: $-2 \pi^{2}\left[h^{2} a^{* 2} U^{11}+\ldots+2 h k a^{*} b^{*} U^{12}\right]$.

\begin{tabular}{|c|c|c|c|c|c|c|}
\hline & $\mathrm{U}^{11}$ & $\mathrm{U}^{22}$ & $\mathrm{U}^{33}$ & $\mathrm{U}^{23}$ & $\mathrm{U}^{13}$ & $\mathrm{U}^{12}$ \\
\hline $\mathrm{W}(1)$ & 21(1) & $14(1)$ & $19(1)$ & $6(1)$ & $10(1)$ & $4(1)$ \\
\hline $\mathrm{I}(1)$ & $43(1)$ & $20(1)$ & 21(1) & 11(1) & $14(1)$ & $6(1)$ \\
\hline $\mathrm{O}(1)$ & $35(2)$ & $31(2)$ & $34(2)$ & $10(2)$ & $22(2)$ & $5(1)$ \\
\hline $\mathrm{O}(2)$ & $61(2)$ & $25(2)$ & $29(2)$ & $16(2)$ & $25(2)$ & $13(2)$ \\
\hline $\mathrm{O}(3)$ & $27(2)$ & $23(2)$ & $38(2)$ & $11(2)$ & $12(1)$ & $1(1)$ \\
\hline $\mathrm{O}(4)$ & $31(2)$ & $18(2)$ & $25(2)$ & $9(1)$ & $4(1)$ & $-3(1)$ \\
\hline $\mathrm{N}(1)$ & $21(2)$ & $21(2)$ & $19(2)$ & $12(2)$ & $8(1)$ & $6(1)$ \\
\hline $\mathrm{N}(2)$ & $23(2)$ & $15(2)$ & $15(2)$ & $7(1)$ & $5(1)$ & $1(1)$ \\
\hline $\mathrm{C}(1)$ & $28(2)$ & $15(2)$ & $26(2)$ & $4(2)$ & $10(2)$ & $-1(2)$ \\
\hline$C(2)$ & $21(2)$ & $11(2)$ & $35(3)$ & $6(2)$ & $4(2)$ & $6(2)$ \\
\hline$C(3)$ & $28(2)$ & $16(2)$ & $22(2)$ & $7(2)$ & $14(2)$ & $7(2)$ \\
\hline$C(4)$ & $27(2)$ & $21(2)$ & $22(2)$ & $10(2)$ & $11(2)$ & $7(2)$ \\
\hline$C(5)$ & $43(3)$ & $26(3)$ & $35(2)$ & $15(2)$ & $24(2)$ & $15(2)$ \\
\hline$C(6)$ & $32(3)$ & $35(3)$ & $59(3)$ & $29(3)$ & $28(2)$ & $20(2)$ \\
\hline$C(7)$ & $23(2)$ & $30(3)$ & $51(3)$ & $24(2)$ & $13(2)$ & $11(2)$ \\
\hline $\mathrm{C}(8)$ & $23(2)$ & $25(2)$ & $29(2)$ & $20(2)$ & $11(2)$ & $8(2)$ \\
\hline$C(9)$ & $21(2)$ & $24(2)$ & $27(2)$ & $15(2)$ & $2(2)$ & $2(2)$ \\
\hline$C(10)$ & $25(2)$ & $20(2)$ & $14(2)$ & $7(2)$ & $7(2)$ & $-1(2)$ \\
\hline $\mathrm{C}(11)$ & $36(2)$ & $17(2)$ & $21(2)$ & $7(2)$ & $17(2)$ & $8(2)$ \\
\hline$C(12)$ & $39(3)$ & $20(2)$ & $27(2)$ & $9(2)$ & $19(2)$ & $4(2)$ \\
\hline$C(13)$ & $47(3)$ & $21(2)$ & $48(3)$ & $15(2)$ & $34(2)$ & $17(2)$ \\
\hline$C(14)$ & $38(3)$ & $26(3)$ & $58(3)$ & $20(2)$ & $30(2)$ & $19(2)$ \\
\hline$C(15)$ & $29(2)$ & $23(2)$ & $45(3)$ & $14(2)$ & $20(2)$ & $11(2)$ \\
\hline$C(16)$ & $27(2)$ & $15(2)$ & $27(2)$ & $8(2)$ & $16(2)$ & $6(2)$ \\
\hline $\mathrm{O}(5)$ & $46(2)$ & $34(2)$ & $89(3)$ & $35(2)$ & $47(2)$ & $20(2)$ \\
\hline$C(17)$ & $29(2)$ & $29(3)$ & $27(2)$ & $12(2)$ & $12(2)$ & $10(2)$ \\
\hline $\mathrm{C}(18)$ & $57(3)$ & $38(3)$ & $73(4)$ & $32(3)$ & $47(3)$ & $22(3)$ \\
\hline$C(19)$ & $35(6)$ & $26(3)$ & $51(7)$ & $24(5)$ & $21(6)$ & $18(4)$ \\
\hline$C(19 A)$ & $35(6)$ & $26(3)$ & $51(7)$ & $24(5)$ & $21(6)$ & $18(4)$ \\
\hline$C(20)$ & $36(5)$ & $32(4)$ & $45(5)$ & $23(4)$ & $22(4)$ & $16(4)$ \\
\hline$C(20 A)$ & $36(5)$ & $32(4)$ & $45(5)$ & $23(4)$ & $22(4)$ & $16(4)$ \\
\hline
\end{tabular}


Table S20 Hydrogen coordinates (x $\left.10^{4}\right)$ and isotropic displacement parameters $\left(\AA^{2} \times 10^{3}\right)$ for $\mathbf{W}-\mathbf{3}$.

\begin{tabular}{|c|c|c|c|c|}
\hline & $\mathrm{x}$ & $\mathrm{y}$ & z & $\mathrm{U}(\mathrm{eq})$ \\
\hline $\mathrm{H}(4)$ & 2849 & 1441 & 1129 & 42 \\
\hline $\mathrm{H}(4 \mathrm{~A})$ & 6386 & 8674 & 5680 & 28 \\
\hline $\mathrm{H}(5)$ & 4698 & 9845 & 6410 & 38 \\
\hline $\mathrm{H}(6)$ & 2099 & 8764 & 5160 & 43 \\
\hline $\mathrm{H}(7)$ & 1307 & 6559 & 3237 & 39 \\
\hline $\mathrm{H}(9 \mathrm{~A})$ & 2125 & 4324 & 2056 & 30 \\
\hline $\mathrm{H}(9 \mathrm{~B})$ & 2668 & 5121 & 1288 & 30 \\
\hline $\mathrm{H}(12)$ & 4690 & 651 & 1127 & 34 \\
\hline $\mathrm{H}(13)$ & 6996 & 209 & 1636 & 42 \\
\hline $\mathrm{H}(14)$ & 9190 & 2107 & 2959 & 44 \\
\hline $\mathrm{H}(15)$ & 9135 & 4397 & 3625 & 38 \\
\hline $\mathrm{H}(17 \mathrm{~A})$ & -82 & 86 & 1122 & 34 \\
\hline $\mathrm{H}(17 \mathrm{~B})$ & 1027 & 806 & 2658 & 34 \\
\hline $\mathrm{H}(18 \mathrm{~A})$ & -899 & -1650 & 1598 & 57 \\
\hline $\mathrm{H}(18 \mathrm{~B})$ & 744 & -1306 & 2655 & 57 \\
\hline $\mathrm{H}(18 \mathrm{C})$ & -901 & -1789 & 1316 & 57 \\
\hline $\mathrm{H}(18 \mathrm{D})$ & 434 & -1181 & 2729 & 57 \\
\hline $\mathrm{H}(19 \mathrm{~A})$ & 1886 & -2417 & 1726 & 39 \\
\hline $\mathrm{H}(19 \mathrm{~B})$ & 360 & -3330 & 428 & 39 \\
\hline $\mathrm{H}(19 \mathrm{C})$ & 619 & -3268 & 596 & 39 \\
\hline $\mathrm{H}(19 \mathrm{D})$ & 14 & -2506 & -263 & 39 \\
\hline $\mathrm{H}(20 \mathrm{~A})$ & 2511 & -1843 & 168 & 41 \\
\hline $\mathrm{H}(20 \mathrm{~B})$ & 822 & -1853 & -484 & 41 \\
\hline $\mathrm{H}(20 \mathrm{C})$ & 2930 & -1376 & 1890 & 41 \\
\hline $\mathrm{H}(20 \mathrm{D})$ & 2705 & -1769 & 347 & 41 \\
\hline
\end{tabular}


Table S21 Hydrogen bonds for $\mathbf{W}-3\left[\AA\right.$ and $\left.^{\circ}\right]$.

\begin{tabular}{lcccc}
\hline D-H...A & d(D-H) & $d(H \ldots A)$ & $d(D \ldots A)$ & $<(\mathrm{DHA})$ \\
\hline $\mathrm{O}(4)-\mathrm{H}(4) \ldots \mathrm{O}(5)$ & 0.84 & 1.89 & $2.621(5)$ & 145.3 \\
\hline
\end{tabular}

Symmetry transformations used to generate equivalent atoms: 


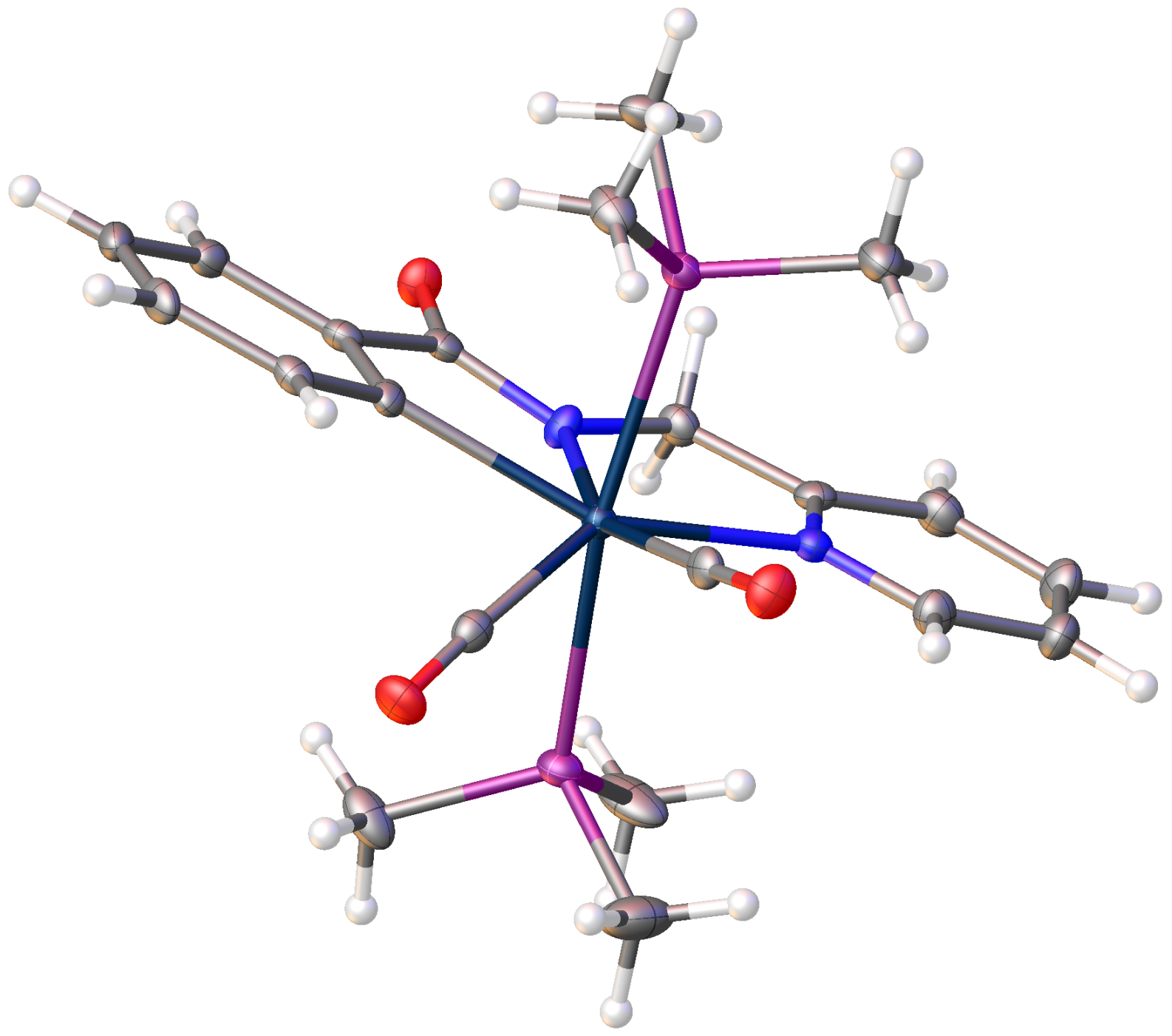

S-76 
Table S22 Crystal data and structure refinement for W-3' (CCDC 2045639).

Empirical formula

Molecular formula

Formula weight

Temperature

Wavelength

Crystal system

Space group

Unit cell dimensions

Volume

Z

Density (calculated)

Absorption coefficient

$\mathrm{F}(000)$

Crystal size

Crystal color, habit

Theta range for data collection

Index ranges

Reflections collected

Independent reflections

Completeness to theta $=25.242^{\circ}$

Absorption correction

Max. and min. transmission

Refinement method

Data / restraints / parameters

Goodness-of-fit on $\mathrm{F}^{2}$

Final $\mathrm{R}$ indices [I $>2 \operatorname{sigma}(\mathrm{I})]$

$\mathrm{R}$ indices (all data)

Largest diff. peak and hole
C21 H28 N2 O3 P2 W

C21 H28 N2 O3 P2 W

602.24

$100.0 \mathrm{~K}$

$0.71073 \AA$

Monoclinic

P 1 21/n 1

$\mathrm{a}=15.2659(4) \AA \quad \alpha=90^{\circ}$.

$\mathrm{b}=9.7429(2) \AA$

$\beta=111.3810(10)^{\circ}$.

$\mathrm{c}=16.2231(4) \AA$

$\gamma=90^{\circ}$.

$2246.86(9) \AA^{3}$

4

$1.780 \mathrm{Mg} / \mathrm{m}^{3}$

$5.308 \mathrm{~mm}^{-1}$

1184

$0.16 \times 0.115 \times 0.08 \mathrm{~mm}^{3}$

yellow block

1.569 to $26.373^{\circ}$.

$-19<=\mathrm{h}<=15,-12<=\mathrm{k}<=12,-13<=\mathrm{l}<=20$

30856

$4596[\mathrm{R}(\mathrm{int})=0.0756]$

$100.0 \%$

Semi-empirical from equivalents

0.1467 and 0.1020

Full-matrix least-squares on $\mathrm{F}^{2}$

4596 / 0 / 268

1.049

$\mathrm{R} 1=0.0245, \mathrm{wR} 2=0.0566$

$\mathrm{R} 1=0.0301, \mathrm{wR} 2=0.0601$

0.823 and -0.524 e. $\AA^{-3}$ 
Table S23 Atomic coordinates (x 10 $\left.{ }^{4}\right)$ and equivalent isotropic displacement parameters $\left(\AA^{2} \times 10^{3}\right)$ for $\mathbf{W}-\mathbf{3}^{\prime}$. U(eq) is defined as one third of the trace of the orthogonalized $U^{i j}$ tensor.

\begin{tabular}{|c|c|c|c|c|}
\hline & $\mathrm{x}$ & $\mathrm{y}$ & $\mathrm{z}$ & $\mathrm{U}(\mathrm{eq})$ \\
\hline $\mathrm{W}(1)$ & $2300(1)$ & $3595(1)$ & $5190(1)$ & $11(1)$ \\
\hline $\mathrm{P}(1)$ & 1914(1) & $1327(1)$ & 4401(1) & $17(1)$ \\
\hline $\mathrm{P}(2)$ & $3010(1)$ & $5643(1)$ & 6134(1) & $14(1)$ \\
\hline $\mathrm{O}(1)$ & $1479(2)$ & $3390(3)$ & $6695(2)$ & $22(1)$ \\
\hline $\mathrm{O}(2)$ & $110(2)$ & $3442(3)$ & $4387(2)$ & $22(1)$ \\
\hline $\mathrm{O}(3)$ & $3920(2)$ & $4979(2)$ & $3680(2)$ & $17(1)$ \\
\hline $\mathrm{N}(1)$ & $3551(2)$ & 2329(3) & $6028(2)$ & $14(1)$ \\
\hline $\mathrm{N}(2)$ & $3368(2)$ & $3814(3)$ & $4622(2)$ & $14(1)$ \\
\hline $\mathrm{C}(1)$ & 1779(3) & $3448(3)$ & $6121(2)$ & $15(1)$ \\
\hline$C(2)$ & $924(3)$ & $3526(3)$ & $4676(2)$ & $16(1)$ \\
\hline$C(3)$ & $1825(3)$ & 5331(3) & $4243(2)$ & $14(1)$ \\
\hline$C(4)$ & 1037(3) & 6192(3) & $4029(2)$ & $15(1)$ \\
\hline$C(5)$ & $837(3)$ & $7180(4)$ & $3368(2)$ & $18(1)$ \\
\hline$C(6)$ & $1422(3)$ & 7387(4) & $2895(2)$ & $18(1)$ \\
\hline$C(7)$ & $2222(3)$ & $6579(3)$ & $3103(2)$ & $16(1)$ \\
\hline $\mathrm{C}(8)$ & $2420(2)$ & 5563(3) & $3761(2)$ & $14(1)$ \\
\hline $\mathrm{C}(9)$ & $3305(3)$ & 4764(3) & $4006(2)$ & $14(1)$ \\
\hline$C(10)$ & $4270(3)$ & $3111(4)$ & 4997(2) & $16(1)$ \\
\hline$C(11)$ & $4305(3)$ & $2284(3)$ & $5782(2)$ & $15(1)$ \\
\hline$C(12)$ & $5084(3)$ & 1471(3) & $6236(3)$ & $20(1)$ \\
\hline$C(13)$ & $5088(3)$ & $672(4)$ & $6926(2)$ & $21(1)$ \\
\hline$C(14)$ & $4306(3)$ & $707(4)$ & $7179(2)$ & $21(1)$ \\
\hline$C(15)$ & $3567(3)$ & $1548(3)$ & $6723(2)$ & $18(1)$ \\
\hline$C(16)$ & $2865(3)$ & $255(4)$ & 4331(3) & $34(1)$ \\
\hline$C(17)$ & $1150(3)$ & 1462(4) & $3255(3)$ & $26(1)$ \\
\hline $\mathrm{C}(18)$ & $1281(4)$ & 196(4) & 4871(3) & $38(1)$ \\
\hline$C(19)$ & $3876(3)$ & $6657(4)$ & $5880(3)$ & $23(1)$ \\
\hline$C(20)$ & $2187(3)$ & $6914(4)$ & $6235(3)$ & $21(1)$ \\
\hline $\mathrm{C}(21)$ & $3655(3)$ & $5186(4)$ & $7292(2)$ & $23(1)$ \\
\hline
\end{tabular}


Table S24 Bond lengths $[\AA ̊]$ and angles $\left[{ }^{\circ}\right]$ for $\mathbf{W}-3$ '.

\begin{tabular}{|c|c|c|c|}
\hline $\mathrm{W}(1)-\mathrm{P}(1)$ & $2.5135(9)$ & $C(12)-C(13)$ & $1.362(5)$ \\
\hline $\mathrm{W}(1)-\mathrm{P}(2)$ & $2.5087(9)$ & $\mathrm{C}(13)-\mathrm{H}(13)$ & 0.9500 \\
\hline $\mathrm{W}(1)-\mathrm{N}(1)$ & $2.263(3)$ & $C(13)-C(14)$ & $1.397(5)$ \\
\hline $\mathrm{W}(1)-\mathrm{N}(2)$ & $2.156(3)$ & $\mathrm{C}(14)-\mathrm{H}(14)$ & 0.9500 \\
\hline $\mathrm{W}(1)-\mathrm{C}(1)$ & $1.953(4)$ & $C(14)-C(15)$ & $1.372(5)$ \\
\hline $\mathrm{W}(1)-\mathrm{C}(2)$ & $1.959(4)$ & $\mathrm{C}(15)-\mathrm{H}(15)$ & 0.9500 \\
\hline $\mathrm{W}(1)-\mathrm{C}(3)$ & $2.221(3)$ & $\mathrm{C}(16)-\mathrm{H}(16 \mathrm{~A})$ & 0.9800 \\
\hline$P(1)-C(16)$ & $1.825(4)$ & $\mathrm{C}(16)-\mathrm{H}(16 \mathrm{~B})$ & 0.9800 \\
\hline $\mathrm{P}(1)-\mathrm{C}(17)$ & $1.804(4)$ & $\mathrm{C}(16)-\mathrm{H}(16 \mathrm{C})$ & 0.9800 \\
\hline $\mathrm{P}(1)-\mathrm{C}(18)$ & $1.807(4)$ & $\mathrm{C}(17)-\mathrm{H}(17 \mathrm{~A})$ & 0.9800 \\
\hline $\mathrm{P}(2)-\mathrm{C}(19)$ & $1.815(4)$ & $\mathrm{C}(17)-\mathrm{H}(17 \mathrm{~B})$ & 0.9800 \\
\hline $\mathrm{P}(2)-\mathrm{C}(20)$ & $1.813(4)$ & $\mathrm{C}(17)-\mathrm{H}(17 \mathrm{C})$ & 0.9800 \\
\hline $\mathrm{P}(2)-\mathrm{C}(21)$ & $1.829(4)$ & $\mathrm{C}(18)-\mathrm{H}(18 \mathrm{~A})$ & 0.9800 \\
\hline $\mathrm{O}(1)-\mathrm{C}(1)$ & $1.179(4)$ & $\mathrm{C}(18)-\mathrm{H}(18 \mathrm{~B})$ & 0.9800 \\
\hline $\mathrm{O}(2)-\mathrm{C}(2)$ & $1.160(5)$ & $\mathrm{C}(18)-\mathrm{H}(18 \mathrm{C})$ & 0.9800 \\
\hline $\mathrm{O}(3)-\mathrm{C}(9)$ & $1.251(4)$ & $\mathrm{C}(19)-\mathrm{H}(19 \mathrm{~A})$ & 0.9800 \\
\hline $\mathrm{N}(1)-\mathrm{C}(11)$ & $1.350(4)$ & $\mathrm{C}(19)-\mathrm{H}(19 \mathrm{~B})$ & 0.9800 \\
\hline $\mathrm{N}(1)-\mathrm{C}(15)$ & $1.353(4)$ & $\mathrm{C}(19)-\mathrm{H}(19 \mathrm{C})$ & 0.9800 \\
\hline $\mathrm{N}(2)-\mathrm{C}(9)$ & $1.339(4)$ & $\mathrm{C}(20)-\mathrm{H}(20 \mathrm{~A})$ & 0.9800 \\
\hline $\mathrm{N}(2)-\mathrm{C}(10)$ & $1.458(4)$ & $\mathrm{C}(20)-\mathrm{H}(20 \mathrm{~B})$ & 0.9800 \\
\hline $\mathrm{C}(3)-\mathrm{C}(4)$ & $1.403(5)$ & $\mathrm{C}(20)-\mathrm{H}(20 \mathrm{C})$ & 0.9800 \\
\hline $\mathrm{C}(3)-\mathrm{C}(8)$ & $1.416(5)$ & $\mathrm{C}(21)-\mathrm{H}(21 \mathrm{~A})$ & 0.9800 \\
\hline $\mathrm{C}(4)-\mathrm{H}(4)$ & 0.9500 & $\mathrm{C}(21)-\mathrm{H}(21 \mathrm{~B})$ & 0.9800 \\
\hline $\mathrm{C}(4)-\mathrm{C}(5)$ & $1.389(5)$ & $\mathrm{C}(21)-\mathrm{H}(21 \mathrm{C})$ & 0.9800 \\
\hline $\mathrm{C}(5)-\mathrm{H}(5)$ & 0.9500 & & \\
\hline$C(5)-C(6)$ & $1.389(5)$ & $\mathrm{P}(2)-\mathrm{W}(1)-\mathrm{P}(1)$ & $168.31(3)$ \\
\hline $\mathrm{C}(6)-\mathrm{H}(6)$ & 0.9500 & $\mathrm{~N}(1)-\mathrm{W}(1)-\mathrm{P}(1)$ & $79.45(7)$ \\
\hline $\mathrm{C}(6)-\mathrm{C}(7)$ & $1.387(5)$ & $\mathrm{N}(1)-\mathrm{W}(1)-\mathrm{P}(2)$ & $89.12(7)$ \\
\hline $\mathrm{C}(7)-\mathrm{H}(7)$ & 0.9500 & $\mathrm{~N}(2)-\mathrm{W}(1)-\mathrm{P}(1)$ & $86.76(8)$ \\
\hline$C(7)-C(8)$ & $1.407(5)$ & $\mathrm{N}(2)-\mathrm{W}(1)-\mathrm{P}(2)$ & $87.52(8)$ \\
\hline $\mathrm{C}(8)-\mathrm{C}(9)$ & $1.482(5)$ & $\mathrm{N}(2)-\mathrm{W}(1)-\mathrm{N}(1)$ & $72.98(11)$ \\
\hline $\mathrm{C}(10)-\mathrm{H}(10 \mathrm{~A})$ & 0.9900 & $\mathrm{~N}(2)-\mathrm{W}(1)-\mathrm{C}(3)$ & $74.69(12)$ \\
\hline $\mathrm{C}(10)-\mathrm{H}(10 \mathrm{~B})$ & 0.9900 & $\mathrm{C}(1)-\mathrm{W}(1)-\mathrm{P}(1)$ & $104.08(10)$ \\
\hline $\mathrm{C}(10)-\mathrm{C}(11)$ & $1.491(5)$ & $\mathrm{C}(1)-\mathrm{W}(1)-\mathrm{P}(2)$ & $78.03(10)$ \\
\hline $\mathrm{C}(11)-\mathrm{C}(12)$ & $1.394(5)$ & $\mathrm{C}(1)-\mathrm{W}(1)-\mathrm{N}(1)$ & $89.31(13)$ \\
\hline $\mathrm{C}(12)-\mathrm{H}(12)$ & \multicolumn{2}{|c|}{ S-79 } & $157.38(14)$ \\
\hline
\end{tabular}




\begin{tabular}{|c|c|c|c|}
\hline $\mathrm{C}(1)-\mathrm{W}(1)-\mathrm{C}(2)$ & $69.51(15)$ & $\mathrm{C}(4)-\mathrm{C}(5)-\mathrm{C}(6)$ & 121.5(3) \\
\hline $\mathrm{C}(1)-\mathrm{W}(1)-\mathrm{C}(3)$ & $117.90(13)$ & $\mathrm{C}(6)-\mathrm{C}(5)-\mathrm{H}(5)$ & 119.3 \\
\hline$C(2)-W(1)-P(1)$ & $74.77(10)$ & $\mathrm{C}(5)-\mathrm{C}(6)-\mathrm{H}(6)$ & 121.0 \\
\hline $\mathrm{C}(2)-\mathrm{W}(1)-\mathrm{P}(2)$ & $116.36(10)$ & $C(7)-C(6)-C(5)$ & 118.0(3) \\
\hline $\mathrm{C}(2)-\mathrm{W}(1)-\mathrm{N}(1)$ & $140.92(12)$ & $\mathrm{C}(7)-\mathrm{C}(6)-\mathrm{H}(6)$ & 121.0 \\
\hline $\mathrm{C}(2)-\mathrm{W}(1)-\mathrm{N}(2)$ & $133.03(13)$ & $\mathrm{C}(6)-\mathrm{C}(7)-\mathrm{H}(7)$ & 119.6 \\
\hline $\mathrm{C}(2)-\mathrm{W}(1)-\mathrm{C}(3)$ & $72.68(14)$ & $\mathrm{C}(6)-\mathrm{C}(7)-\mathrm{C}(8)$ & $120.7(3)$ \\
\hline $\mathrm{C}(3)-\mathrm{W}(1)-\mathrm{P}(1)$ & $111.13(9)$ & $\mathrm{C}(8)-\mathrm{C}(7)-\mathrm{H}(7)$ & 119.6 \\
\hline$C(3)-W(1)-P(2)$ & $77.06(9)$ & $\mathrm{C}(3)-\mathrm{C}(8)-\mathrm{C}(9)$ & $118.3(3)$ \\
\hline $\mathrm{C}(3)-\mathrm{W}(1)-\mathrm{N}(1)$ & $145.26(12)$ & $\mathrm{C}(7)-\mathrm{C}(8)-\mathrm{C}(3)$ & $121.9(3)$ \\
\hline $\mathrm{C}(16)-\mathrm{P}(1)-\mathrm{W}(1)$ & $119.36(14)$ & $\mathrm{C}(7)-\mathrm{C}(8)-\mathrm{C}(9)$ & $119.7(3)$ \\
\hline $\mathrm{C}(17)-\mathrm{P}(1)-\mathrm{W}(1)$ & $113.84(13)$ & $\mathrm{O}(3)-\mathrm{C}(9)-\mathrm{N}(2)$ & $124.8(3)$ \\
\hline C(17)-P(1)-C(16) & $101.9(2)$ & $\mathrm{O}(3)-\mathrm{C}(9)-\mathrm{C}(8)$ & $123.4(3)$ \\
\hline C(17)-P(1)-C(18) & $103.6(2)$ & $\mathrm{N}(2)-\mathrm{C}(9)-\mathrm{C}(8)$ & $111.9(3)$ \\
\hline $\mathrm{C}(18)-\mathrm{P}(1)-\mathrm{W}(1)$ & $112.55(14)$ & $\mathrm{N}(2)-\mathrm{C}(10)-\mathrm{H}(10 \mathrm{~A})$ & 109.6 \\
\hline C(18)-P(1)-C(16) & $103.8(2)$ & N(2)-C(10)-H(10B) & 109.6 \\
\hline$C(19)-P(2)-W(1)$ & $118.82(13)$ & $\mathrm{N}(2)-\mathrm{C}(10)-\mathrm{C}(11)$ & $110.2(3)$ \\
\hline C(19)-P(2)-C(21) & $101.65(19)$ & $\mathrm{H}(10 \mathrm{~A})-\mathrm{C}(10)-\mathrm{H}(10 \mathrm{~B})$ & 108.1 \\
\hline$C(20)-P(2)-W(1)$ & $116.04(13)$ & $\mathrm{C}(11)-\mathrm{C}(10)-\mathrm{H}(10 \mathrm{~A})$ & 109.6 \\
\hline C(20)-P(2)-C(19) & $103.59(19)$ & $\mathrm{C}(11)-\mathrm{C}(10)-\mathrm{H}(10 \mathrm{~B})$ & 109.6 \\
\hline $\mathrm{C}(20)-\mathrm{P}(2)-\mathrm{C}(21)$ & $101.87(18)$ & $\mathrm{N}(1)-\mathrm{C}(11)-\mathrm{C}(10)$ & $117.8(3)$ \\
\hline $\mathrm{C}(21)-\mathrm{P}(2)-\mathrm{W}(1)$ & $112.60(12)$ & $\mathrm{N}(1)-\mathrm{C}(11)-\mathrm{C}(12)$ & $121.2(3)$ \\
\hline C(11)-N(1)-W(1) & $117.6(2)$ & $\mathrm{C}(12)-\mathrm{C}(11)-\mathrm{C}(10)$ & $121.0(3)$ \\
\hline $\mathrm{C}(11)-\mathrm{N}(1)-\mathrm{C}(15)$ & $118.0(3)$ & $\mathrm{C}(11)-\mathrm{C}(12)-\mathrm{H}(12)$ & 119.8 \\
\hline C(15)-N(1)-W(1) & $124.2(2)$ & $\mathrm{C}(13)-\mathrm{C}(12)-\mathrm{C}(11)$ & $120.4(4)$ \\
\hline $\mathrm{C}(9)-\mathrm{N}(2)-\mathrm{W}(1)$ & $121.9(2)$ & $\mathrm{C}(13)-\mathrm{C}(12)-\mathrm{H}(12)$ & 119.8 \\
\hline $\mathrm{C}(9)-\mathrm{N}(2)-\mathrm{C}(10)$ & $115.8(3)$ & $\mathrm{C}(12)-\mathrm{C}(13)-\mathrm{H}(13)$ & 120.7 \\
\hline C(10)-N(2)-W(1) & $121.4(2)$ & $\mathrm{C}(12)-\mathrm{C}(13)-\mathrm{C}(14)$ & $118.6(4)$ \\
\hline $\mathrm{O}(1)-\mathrm{C}(1)-\mathrm{W}(1)$ & $178.1(3)$ & $\mathrm{C}(14)-\mathrm{C}(13)-\mathrm{H}(13)$ & 120.7 \\
\hline $\mathrm{O}(2)-\mathrm{C}(2)-\mathrm{W}(1)$ & $177.6(3)$ & $\mathrm{C}(13)-\mathrm{C}(14)-\mathrm{H}(14)$ & 120.7 \\
\hline$C(4)-C(3)-W(1)$ & $131.4(3)$ & $C(15)-C(14)-C(13)$ & $118.7(3)$ \\
\hline$C(4)-C(3)-C(8)$ & $115.6(3)$ & $\mathrm{C}(15)-\mathrm{C}(14)-\mathrm{H}(14)$ & 120.7 \\
\hline$C(8)-C(3)-W(1)$ & $112.9(2)$ & $\mathrm{N}(1)-\mathrm{C}(15)-\mathrm{C}(14)$ & $123.1(4)$ \\
\hline $\mathrm{C}(3)-\mathrm{C}(4)-\mathrm{H}(4)$ & 118.9 & $\mathrm{~N}(1)-\mathrm{C}(15)-\mathrm{H}(15)$ & 118.4 \\
\hline$C(5)-C(4)-C(3)$ & $122.2(3)$ & $\mathrm{C}(14)-\mathrm{C}(15)-\mathrm{H}(15)$ & 118.4 \\
\hline $\mathrm{C}(5)-\mathrm{C}(4)-\mathrm{H}(4)$ & 118.9 & $\mathrm{P}(1)-\mathrm{C}(16)-\mathrm{H}(16 \mathrm{~A})$ & 109.5 \\
\hline $\mathrm{C}(4)-\mathrm{C}(5)-\mathrm{H}(5)$ & 119.3 & $\mathrm{P}(1)-\mathrm{C}(16)-\mathrm{H}(16 \mathrm{~B})$ & 109.5 \\
\hline
\end{tabular}




\begin{tabular}{|c|c|}
\hline $\mathrm{P}(1)-\mathrm{C}(16)-\mathrm{H}(16 \mathrm{C})$ & 109.5 \\
\hline $\mathrm{H}(16 \mathrm{~A})-\mathrm{C}(16)-\mathrm{H}(16 \mathrm{~B})$ & 109.5 \\
\hline $\mathrm{H}(16 \mathrm{~A})-\mathrm{C}(16)-\mathrm{H}(16 \mathrm{C})$ & 109.5 \\
\hline $\mathrm{H}(16 \mathrm{~B})-\mathrm{C}(16)-\mathrm{H}(16 \mathrm{C})$ & 109.5 \\
\hline $\mathrm{P}(1)-\mathrm{C}(17)-\mathrm{H}(17 \mathrm{~A})$ & 109.5 \\
\hline $\mathrm{P}(1)-\mathrm{C}(17)-\mathrm{H}(17 \mathrm{~B})$ & 109.5 \\
\hline $\mathrm{P}(1)-\mathrm{C}(17)-\mathrm{H}(17 \mathrm{C})$ & 109.5 \\
\hline $\mathrm{H}(17 \mathrm{~A})-\mathrm{C}(17)-\mathrm{H}(17 \mathrm{~B})$ & 109.5 \\
\hline $\mathrm{H}(17 \mathrm{~A})-\mathrm{C}(17)-\mathrm{H}(17 \mathrm{C})$ & 109.5 \\
\hline $\mathrm{H}(17 \mathrm{~B})-\mathrm{C}(17)-\mathrm{H}(17 \mathrm{C})$ & 109.5 \\
\hline $\mathrm{P}(1)-\mathrm{C}(18)-\mathrm{H}(18 \mathrm{~A})$ & 109.5 \\
\hline $\mathrm{P}(1)-\mathrm{C}(18)-\mathrm{H}(18 \mathrm{~B})$ & 109.5 \\
\hline $\mathrm{P}(1)-\mathrm{C}(18)-\mathrm{H}(18 \mathrm{C})$ & 109.5 \\
\hline $\mathrm{H}(18 \mathrm{~A})-\mathrm{C}(18)-\mathrm{H}(18 \mathrm{~B})$ & 109.5 \\
\hline $\mathrm{H}(18 \mathrm{~A})-\mathrm{C}(18)-\mathrm{H}(18 \mathrm{C})$ & 109.5 \\
\hline $\mathrm{H}(18 \mathrm{~B})-\mathrm{C}(18)-\mathrm{H}(18 \mathrm{C})$ & 109.5 \\
\hline $\mathrm{P}(2)-\mathrm{C}(19)-\mathrm{H}(19 \mathrm{~A})$ & 109.5 \\
\hline $\mathrm{P}(2)-\mathrm{C}(19)-\mathrm{H}(19 \mathrm{~B})$ & 109.5 \\
\hline $\mathrm{P}(2)-\mathrm{C}(19)-\mathrm{H}(19 \mathrm{C})$ & 109.5 \\
\hline $\mathrm{H}(19 \mathrm{~A})-\mathrm{C}(19)-\mathrm{H}(19 \mathrm{~B})$ & 109.5 \\
\hline $\mathrm{H}(19 \mathrm{~A})-\mathrm{C}(19)-\mathrm{H}(19 \mathrm{C})$ & 109.5 \\
\hline $\mathrm{H}(19 \mathrm{~B})-\mathrm{C}(19)-\mathrm{H}(19 \mathrm{C})$ & 109.5 \\
\hline $\mathrm{P}(2)-\mathrm{C}(20)-\mathrm{H}(20 \mathrm{~A})$ & 109.5 \\
\hline $\mathrm{P}(2)-\mathrm{C}(20)-\mathrm{H}(20 \mathrm{~B})$ & 109.5 \\
\hline $\mathrm{P}(2)-\mathrm{C}(20)-\mathrm{H}(20 \mathrm{C})$ & 109.5 \\
\hline $\mathrm{H}(20 \mathrm{~A})-\mathrm{C}(20)-\mathrm{H}(20 \mathrm{~B})$ & 109.5 \\
\hline $\mathrm{H}(20 \mathrm{~A})-\mathrm{C}(20)-\mathrm{H}(20 \mathrm{C})$ & 109.5 \\
\hline $\mathrm{H}(20 \mathrm{~B})-\mathrm{C}(20)-\mathrm{H}(20 \mathrm{C})$ & 109.5 \\
\hline $\mathrm{P}(2)-\mathrm{C}(21)-\mathrm{H}(21 \mathrm{~A})$ & 109.5 \\
\hline $\mathrm{P}(2)-\mathrm{C}(21)-\mathrm{H}(21 \mathrm{~B})$ & 109.5 \\
\hline $\mathrm{P}(2)-\mathrm{C}(21)-\mathrm{H}(21 \mathrm{C})$ & 109.5 \\
\hline $\mathrm{H}(21 \mathrm{~A})-\mathrm{C}(21)-\mathrm{H}(21 \mathrm{~B})$ & 109.5 \\
\hline $\mathrm{H}(21 \mathrm{~A})-\mathrm{C}(21)-\mathrm{H}(21 \mathrm{C})$ & 109.5 \\
\hline $\mathrm{H}(21 \mathrm{~B})-\mathrm{C}(21)-\mathrm{H}(21 \mathrm{C})$ & 109.5 \\
\hline
\end{tabular}


Table S25 Anisotropic displacement parameters $\left(\AA^{2} \times 10^{3}\right)$ for $\mathbf{W}-3^{\prime}$. The anisotropic displacement factor exponent takes the form: $-2 \pi^{2}\left[h^{2} a^{* 2} U^{11}+\ldots+2 h k a^{*} b^{*} U^{12}\right]$.

\begin{tabular}{|c|c|c|c|c|c|c|}
\hline & $\mathrm{U}^{11}$ & $\mathrm{U}^{22}$ & $\mathrm{U}^{33}$ & $\mathrm{U}^{23}$ & $\mathrm{U}^{13}$ & $\mathrm{U}^{12}$ \\
\hline $\mathrm{W}(1)$ & $10(1)$ & 11(1) & 11(1) & $0(1)$ & $4(1)$ & $0(1)$ \\
\hline $\mathrm{P}(1)$ & $16(1)$ & $14(1)$ & $18(1)$ & $-4(1)$ & $5(1)$ & $-1(1)$ \\
\hline $\mathrm{P}(2)$ & $12(1)$ & $14(1)$ & $15(1)$ & $-1(1)$ & $4(1)$ & $-1(1)$ \\
\hline $\mathrm{O}(1)$ & $23(2)$ & $24(1)$ & $22(2)$ & $3(1)$ & $13(1)$ & $4(1)$ \\
\hline $\mathrm{O}(2)$ & $13(2)$ & $27(2)$ & $24(2)$ & $-2(1)$ & $4(1)$ & $-2(1)$ \\
\hline $\mathrm{O}(3)$ & $16(1)$ & $22(1)$ & $18(1)$ & $3(1)$ & $9(1)$ & $2(1)$ \\
\hline $\mathrm{N}(1)$ & $14(2)$ & $12(1)$ & $14(2)$ & $-1(1)$ & $3(1)$ & $-2(1)$ \\
\hline $\mathrm{N}(2)$ & $15(2)$ & $13(1)$ & $16(2)$ & $4(1)$ & $8(1)$ & $4(1)$ \\
\hline $\mathrm{C}(1)$ & $11(2)$ & $15(2)$ & $17(2)$ & $2(1)$ & $2(2)$ & $3(1)$ \\
\hline$C(2)$ & $20(2)$ & $14(2)$ & $14(2)$ & $1(1)$ & $8(2)$ & $1(2)$ \\
\hline$C(3)$ & $17(2)$ & $13(2)$ & $9(2)$ & $-2(1)$ & $2(1)$ & $0(1)$ \\
\hline C(4) & $12(2)$ & $16(2)$ & $14(2)$ & $-4(1)$ & $3(2)$ & $0(1)$ \\
\hline$C(5)$ & $13(2)$ & $16(2)$ & $18(2)$ & $-1(2)$ & $-1(2)$ & $5(2)$ \\
\hline$C(6)$ & $22(2)$ & $14(2)$ & $13(2)$ & $1(2)$ & $0(2)$ & $-1(2)$ \\
\hline$C(7)$ & $19(2)$ & $16(2)$ & $13(2)$ & $-1(1)$ & $5(2)$ & $-4(2)$ \\
\hline $\mathrm{C}(8)$ & $12(2)$ & $13(2)$ & $16(2)$ & $-4(1)$ & $3(1)$ & $-3(1)$ \\
\hline$C(9)$ & $14(2)$ & $13(2)$ & $13(2)$ & $-4(1)$ & $3(1)$ & $-3(1)$ \\
\hline$C(10)$ & $12(2)$ & $17(2)$ & $17(2)$ & $-1(2)$ & $3(2)$ & $1(2)$ \\
\hline $\mathrm{C}(11)$ & $16(2)$ & $10(2)$ & $17(2)$ & $-3(1)$ & $4(2)$ & $-3(1)$ \\
\hline$C(12)$ & $15(2)$ & $23(2)$ & $21(2)$ & $-2(2)$ & $5(2)$ & $-1(2)$ \\
\hline$C(13)$ & $19(2)$ & $19(2)$ & $22(2)$ & $5(2)$ & $5(2)$ & $6(2)$ \\
\hline$C(14)$ & $22(2)$ & $18(2)$ & $19(2)$ & $5(2)$ & $5(2)$ & $1(2)$ \\
\hline$C(15)$ & $18(2)$ & $21(2)$ & $17(2)$ & $2(2)$ & $7(2)$ & $0(2)$ \\
\hline$C(16)$ & $25(2)$ & $27(2)$ & $42(3)$ & $-22(2)$ & $4(2)$ & $2(2)$ \\
\hline$C(17)$ & $21(2)$ & $35(2)$ & $19(2)$ & $-10(2)$ & $3(2)$ & $6(2)$ \\
\hline$C(18)$ & $52(3)$ & $25(2)$ & $41(3)$ & $-8(2)$ & $23(2)$ & $-16(2)$ \\
\hline$C(19)$ & $23(2)$ & $23(2)$ & $26(2)$ & $-9(2)$ & $11(2)$ & $-11(2)$ \\
\hline$C(20)$ & $19(2)$ & $20(2)$ & $21(2)$ & $-6(2)$ & $4(2)$ & $5(2)$ \\
\hline$C(21)$ & $24(2)$ & $19(2)$ & $21(2)$ & $-2(2)$ & $2(2)$ & $-1(2)$ \\
\hline
\end{tabular}


Table S26 Hydrogen coordinates (x $\left.10^{4}\right)$ and isotropic displacement parameters $\left(\AA^{2} \times 10^{3}\right)$ for $\mathbf{W}-3$ '.

\begin{tabular}{|c|c|c|c|c|}
\hline & $\mathrm{x}$ & $\mathrm{y}$ & z & $\mathrm{U}(\mathrm{eq})$ \\
\hline $\mathrm{H}(4)$ & 626 & 6096 & 4346 & 18 \\
\hline $\mathrm{H}(5)$ & 287 & 7726 & 3237 & 22 \\
\hline $\mathrm{H}(6)$ & 1279 & 8062 & 2442 & 22 \\
\hline $\mathrm{H}(7)$ & 2641 & 6715 & 2798 & 20 \\
\hline $\mathrm{H}(10 \mathrm{~A})$ & 4786 & 3794 & 5176 & 19 \\
\hline $\mathrm{H}(10 \mathrm{~B})$ & 4359 & 2502 & 4546 & 19 \\
\hline $\mathrm{H}(12)$ & 5615 & 1476 & 6062 & 24 \\
\hline $\mathrm{H}(13)$ & 5612 & 101 & 7228 & 25 \\
\hline $\mathrm{H}(14)$ & 4287 & 161 & 7657 & 25 \\
\hline $\mathrm{H}(15)$ & 3042 & 1583 & 6904 & 22 \\
\hline $\mathrm{H}(16 \mathrm{~A})$ & 3198 & 748 & 4007 & 51 \\
\hline $\mathrm{H}(16 \mathrm{~B})$ & 2602 & -599 & 4019 & 51 \\
\hline $\mathrm{H}(16 \mathrm{C})$ & 3305 & 41 & 4929 & 51 \\
\hline $\mathrm{H}(17 \mathrm{~A})$ & 528 & 1777 & 3218 & 39 \\
\hline $\mathrm{H}(17 \mathrm{~B})$ & 1092 & 561 & 2971 & 39 \\
\hline $\mathrm{H}(17 \mathrm{C})$ & 1416 & 2119 & 2953 & 39 \\
\hline $\mathrm{H}(18 \mathrm{~A})$ & 694 & 639 & 4844 & 57 \\
\hline $\mathrm{H}(18 \mathrm{~B})$ & 1669 & 1 & 5490 & 57 \\
\hline $\mathrm{H}(18 \mathrm{C})$ & 1136 & -663 & 4535 & 57 \\
\hline $\mathrm{H}(19 \mathrm{~A})$ & 4434 & 6095 & 5963 & 35 \\
\hline $\mathrm{H}(19 \mathrm{~B})$ & 4054 & 7454 & 6274 & 35 \\
\hline $\mathrm{H}(19 \mathrm{C})$ & 3608 & 6970 & 5264 & 35 \\
\hline $\mathrm{H}(20 \mathrm{~A})$ & 1876 & 7365 & 5662 & 32 \\
\hline $\mathrm{H}(20 \mathrm{~B})$ & 2526 & 7600 & 6678 & 32 \\
\hline $\mathrm{H}(20 \mathrm{C})$ & 1714 & 6463 & 6418 & 32 \\
\hline $\mathrm{H}(21 \mathrm{~A})$ & 3238 & 4683 & 7523 & 35 \\
\hline $\mathrm{H}(21 \mathrm{~B})$ & 3878 & 6023 & 7640 & 35 \\
\hline $\mathrm{H}(21 \mathrm{C})$ & 4194 & 4607 & 7332 & 35 \\
\hline
\end{tabular}


Table S27 Atomic coordinates (x $\left.10^{4}\right)$ and equivalent isotropic displacement parameters $\left(\AA^{2} \times 10^{3}\right)$ for $\mathbf{W}-3$ '. U(eq) is defined as one third of the trace of the orthogonalized $\mathrm{U}^{\mathrm{ij}}$ tensor.

\begin{tabular}{|c|c|c|c|c|}
\hline & $\mathrm{x}$ & $\mathrm{y}$ & $\mathrm{z}$ & $\mathrm{U}(\mathrm{eq})$ \\
\hline $\mathrm{W}(1)$ & $3077(1)$ & 7113(1) & 4911(1) & $11(1)$ \\
\hline $\mathrm{P}(1)$ & 2533(1) & $5879(1)$ & $3510(1)$ & $14(1)$ \\
\hline $\mathrm{P}(2)$ & $3330(1)$ & $8224(1)$ & $6338(1)$ & $15(1)$ \\
\hline $\mathrm{O}(1)$ & $5337(2)$ & $7168(2)$ & $5686(2)$ & $21(1)$ \\
\hline $\mathrm{O}(2)$ & $4027(2)$ & $8457(2)$ & $3618(2)$ & $21(1)$ \\
\hline $\mathrm{O}(3)$ & $19(2)$ & $7275(2)$ & $4479(2)$ & $23(1)$ \\
\hline $\mathrm{N}(1)$ & 3094(2) & $5210(3)$ & $5515(2)$ & $12(1)$ \\
\hline $\mathrm{N}(2)$ & $1626(2)$ & $6729(3)$ & 4987(2) & $15(1)$ \\
\hline $\mathrm{C}(1)$ & 4492(3) & $7130(3)$ & $5374(2)$ & $15(1)$ \\
\hline$C(2)$ & $3667(3)$ & 7954(3) & $4108(2)$ & $15(1)$ \\
\hline$C(3)$ & 3884(3) & $4472(4)$ & $5759(2)$ & $17(1)$ \\
\hline$C(4)$ & $3866(3)$ & $3284(4)$ & $6069(2)$ & 19(1) \\
\hline$C(5)$ & 2980(3) & $2807(3)$ & 6111(3) & $20(1)$ \\
\hline$C(6)$ & 2161(3) & $3536(3)$ & $5856(2)$ & $17(1)$ \\
\hline$C(7)$ & $2240(2)$ & $4738(3)$ & $5575(2)$ & $14(1)$ \\
\hline $\mathrm{C}(8)$ & 1374(3) & $5580(3)$ & $5344(2)$ & $15(1)$ \\
\hline $\mathrm{C}(9)$ & 1012(3) & $5790(4)$ & $6159(2)$ & 19(1) \\
\hline $\mathrm{C}(10)$ & $901(3)$ & $7516(4)$ & $4613(2)$ & $16(1)$ \\
\hline $\mathrm{C}(11)$ & 1273(3) & $8733(4)$ & $4412(2)$ & $16(1)$ \\
\hline$C(12)$ & $634(3)$ & $9726(4)$ & $4173(2)$ & $24(1)$ \\
\hline$C(13)$ & $979(3)$ & $10896(4)$ & 4081(3) & $31(1)$ \\
\hline$C(14)$ & 1970(3) & $11063(4)$ & $4215(3)$ & $29(1)$ \\
\hline$C(15)$ & 2604(3) & $10075(4)$ & $4433(2)$ & $21(1)$ \\
\hline$C(16)$ & $2285(3)$ & $8876(3)$ & $4548(2)$ & $15(1)$ \\
\hline $\mathrm{C}(17)$ & $3451(3)$ & $5259(4)$ & $3043(2)$ & $23(1)$ \\
\hline $\mathrm{C}(18)$ & 1748(3) & $4544(4)$ & $3478(3)$ & $35(1)$ \\
\hline$C(19)$ & 1798(3) & $6818(4)$ & $2629(2)$ & $23(1)$ \\
\hline $\mathrm{C}(20)$ & $3822(3)$ & $7227(4)$ & $7289(2)$ & $21(1)$ \\
\hline $\mathrm{C}(21)$ & 2295(3) & $8976(4)$ & $6587(2)$ & $20(1)$ \\
\hline $\mathrm{C}(22)$ & $4209(3)$ & $9486(4)$ & $6515(2)$ & $21(1)$ \\
\hline
\end{tabular}


Table S28 Bond lengths $[\AA ̊]$ and angles $\left[{ }^{\circ}\right]$ for $\mathbf{W}-3$ '.

\begin{tabular}{|c|c|c|c|}
\hline $\mathrm{W}(1)-\mathrm{P}(1)$ & $2.5259(9)$ & $C(11)-C(16)$ & $1.417(5)$ \\
\hline $\mathrm{W}(1)-\mathrm{P}(2)$ & $2.5013(10)$ & $\mathrm{C}(12)-\mathrm{H}(12)$ & 0.9500 \\
\hline $\mathrm{W}(1)-\mathrm{N}(1)$ & $2.264(3)$ & $C(12)-C(13)$ & $1.378(6)$ \\
\hline $\mathrm{W}(1)-\mathrm{N}(2)$ & $2.159(3)$ & $\mathrm{C}(13)-\mathrm{H}(13)$ & 0.9500 \\
\hline $\mathrm{W}(1)-\mathrm{C}(1)$ & $1.960(4)$ & $C(13)-C(14)$ & $1.390(6)$ \\
\hline $\mathrm{W}(1)-\mathrm{C}(2)$ & $1.940(4)$ & $\mathrm{C}(14)-\mathrm{H}(14)$ & 0.9500 \\
\hline $\mathrm{W}(1)-\mathrm{C}(16)$ & $2.208(4)$ & $C(14)-C(15)$ & $1.382(5)$ \\
\hline$P(1)-C(17)$ & $1.811(4)$ & $\mathrm{C}(15)-\mathrm{H}(15)$ & 0.9500 \\
\hline $\mathrm{P}(1)-\mathrm{C}(18)$ & $1.821(4)$ & $C(15)-C(16)$ & $1.401(5)$ \\
\hline $\mathrm{P}(1)-\mathrm{C}(19)$ & $1.812(4)$ & $\mathrm{C}(17)-\mathrm{H}(17 \mathrm{~A})$ & 0.9800 \\
\hline$P(2)-C(20)$ & $1.831(4)$ & $\mathrm{C}(17)-\mathrm{H}(17 \mathrm{~B})$ & 0.9800 \\
\hline $\mathrm{P}(2)-\mathrm{C}(21)$ & $1.828(4)$ & $\mathrm{C}(17)-\mathrm{H}(17 \mathrm{C})$ & 0.9800 \\
\hline $\mathrm{P}(2)-\mathrm{C}(22)$ & $1.824(4)$ & $\mathrm{C}(18)-\mathrm{H}(18 \mathrm{~A})$ & 0.9800 \\
\hline $\mathrm{O}(1)-\mathrm{C}(1)$ & $1.176(4)$ & $\mathrm{C}(18)-\mathrm{H}(18 \mathrm{~B})$ & 0.9800 \\
\hline $\mathrm{O}(2)-\mathrm{C}(2)$ & $1.179(4)$ & $\mathrm{C}(18)-\mathrm{H}(18 \mathrm{C})$ & 0.9800 \\
\hline $\mathrm{O}(3)-\mathrm{C}(10)$ & $1.251(4)$ & $\mathrm{C}(19)-\mathrm{H}(19 \mathrm{~A})$ & 0.9800 \\
\hline $\mathrm{N}(1)-\mathrm{C}(3)$ & $1.351(4)$ & $\mathrm{C}(19)-\mathrm{H}(19 \mathrm{~B})$ & 0.9800 \\
\hline $\mathrm{N}(1)-\mathrm{C}(7)$ & $1.354(4)$ & $\mathrm{C}(19)-\mathrm{H}(19 \mathrm{C})$ & 0.9800 \\
\hline $\mathrm{N}(2)-\mathrm{C}(8)$ & $1.450(5)$ & $\mathrm{C}(20)-\mathrm{H}(20 \mathrm{~A})$ & 0.9800 \\
\hline $\mathrm{N}(2)-\mathrm{C}(10)$ & $1.347(4)$ & $\mathrm{C}(20)-\mathrm{H}(20 \mathrm{~B})$ & 0.9800 \\
\hline $\mathrm{C}(3)-\mathrm{H}(3)$ & 0.9500 & $\mathrm{C}(20)-\mathrm{H}(20 \mathrm{C})$ & 0.9800 \\
\hline $\mathrm{C}(3)-\mathrm{C}(4)$ & $1.376(5)$ & $\mathrm{C}(21)-\mathrm{H}(21 \mathrm{~A})$ & 0.9800 \\
\hline $\mathrm{C}(4)-\mathrm{H}(4)$ & 0.9500 & $\mathrm{C}(21)-\mathrm{H}(21 \mathrm{~B})$ & 0.9800 \\
\hline $\mathrm{C}(4)-\mathrm{C}(5)$ & $1.391(5)$ & $\mathrm{C}(21)-\mathrm{H}(21 \mathrm{C})$ & 0.9800 \\
\hline $\mathrm{C}(5)-\mathrm{H}(5)$ & 0.9500 & $\mathrm{C}(22)-\mathrm{H}(22 \mathrm{~A})$ & 0.9800 \\
\hline$C(5)-C(6)$ & $1.378(5)$ & $\mathrm{C}(22)-\mathrm{H}(22 \mathrm{~B})$ & 0.9800 \\
\hline $\mathrm{C}(6)-\mathrm{H}(6)$ & 0.9500 & $\mathrm{C}(22)-\mathrm{H}(22 \mathrm{C})$ & 0.9800 \\
\hline$C(6)-C(7)$ & $1.386(5)$ & & \\
\hline$C(7)-C(8)$ & $1.501(5)$ & $\mathrm{P}(2)-\mathrm{W}(1)-\mathrm{P}(1)$ & $169.72(3)$ \\
\hline $\mathrm{C}(8)-\mathrm{H}(8)$ & 1.0000 & $\mathrm{~N}(1)-\mathrm{W}(1)-\mathrm{P}(1)$ & $81.99(7)$ \\
\hline $\mathrm{C}(8)-\mathrm{C}(9)$ & $1.541(5)$ & $\mathrm{N}(1)-\mathrm{W}(1)-\mathrm{P}(2)$ & $93.90(8)$ \\
\hline C(9)-H(9A) & 0.9800 & $\mathrm{~N}(2)-\mathrm{W}(1)-\mathrm{P}(1)$ & $83.08(8)$ \\
\hline C(9)-H(9B) & 0.9800 & $\mathrm{~N}(2)-\mathrm{W}(1)-\mathrm{P}(2)$ & $86.70(8)$ \\
\hline C(9)-H(9C) & 0.9800 & $\mathrm{~N}(2)-\mathrm{W}(1)-\mathrm{N}(1)$ & $72.53(11)$ \\
\hline$C(10)-C(11)$ & $1.485(5)$ & $\mathrm{N}(2)-\mathrm{W}(1)-\mathrm{C}(16)$ & $75.25(13)$ \\
\hline$C(11)-C(12)$ & $1.393(5)$ & $\mathrm{C}(1)-\mathrm{W}(1)-\mathrm{P}(1)$ & $111.85(11)$ \\
\hline
\end{tabular}




\begin{tabular}{|c|c|}
\hline $\mathrm{C}(1)-\mathrm{W}(1)-\mathrm{P}(2)$ & $77.23(11)$ \\
\hline $\mathrm{C}(1)-\mathrm{W}(1)-\mathrm{N}(1)$ & $87.73(13)$ \\
\hline $\mathrm{C}(1)-\mathrm{W}(1)-\mathrm{N}(2)$ & $153.68(13)$ \\
\hline $\mathrm{C}(1)-\mathrm{W}(1)-\mathrm{C}(16)$ & $119.67(14)$ \\
\hline $\mathrm{C}(2)-\mathrm{W}(1)-\mathrm{P}(1)$ & $75.59(11)$ \\
\hline$C(2)-W(1)-P(2)$ & $113.09(11)$ \\
\hline $\mathrm{C}(2)-\mathrm{W}(1)-\mathrm{N}(1)$ & $138.35(13)$ \\
\hline $\mathrm{C}(2)-\mathrm{W}(1)-\mathrm{N}(2)$ & $136.81(13)$ \\
\hline $\mathrm{C}(2)-\mathrm{W}(1)-\mathrm{C}(1)$ & $69.37(15)$ \\
\hline $\mathrm{C}(2)-\mathrm{W}(1)-\mathrm{C}(16)$ & $73.28(14)$ \\
\hline$C(16)-W(1)-P(1)$ & $102.22(9)$ \\
\hline $\mathrm{C}(16)-\mathrm{W}(1)-\mathrm{P}(2)$ & $76.10(9)$ \\
\hline $\mathrm{C}(16)-\mathrm{W}(1)-\mathrm{N}(1)$ & $146.74(12)$ \\
\hline C(17)-P(1)-W(1) & $118.27(12)$ \\
\hline $\mathrm{C}(17)-\mathrm{P}(1)-\mathrm{C}(18)$ & $102.2(2)$ \\
\hline C(17)-P(1)-C(19) & $102.89(18)$ \\
\hline C(18)-P(1)-W(1) & $118.69(14)$ \\
\hline C(19)-P(1)-W(1) & $111.08(13)$ \\
\hline C(19)-P(1)-C(18) & $101.35(19)$ \\
\hline $\mathrm{C}(20)-\mathrm{P}(2)-\mathrm{W}(1)$ & $113.17(13)$ \\
\hline $\mathrm{C}(21)-\mathrm{P}(2)-\mathrm{W}(1)$ & $119.08(12)$ \\
\hline $\mathrm{C}(21)-\mathrm{P}(2)-\mathrm{C}(20)$ & $103.43(18)$ \\
\hline $\mathrm{C}(22)-\mathrm{P}(2)-\mathrm{W}(1)$ & $114.72(13)$ \\
\hline $\mathrm{C}(22)-\mathrm{P}(2)-\mathrm{C}(20)$ & $102.59(18)$ \\
\hline $\mathrm{C}(22)-\mathrm{P}(2)-\mathrm{C}(21)$ & $101.81(18)$ \\
\hline $\mathrm{C}(3)-\mathrm{N}(1)-\mathrm{W}(1)$ & $124.5(2)$ \\
\hline $\mathrm{C}(3)-\mathrm{N}(1)-\mathrm{C}(7)$ & $117.5(3)$ \\
\hline $\mathrm{C}(7)-\mathrm{N}(1)-\mathrm{W}(1)$ & $117.8(2)$ \\
\hline $\mathrm{C}(8)-\mathrm{N}(2)-\mathrm{W}(1)$ & $122.3(2)$ \\
\hline $\mathrm{C}(10)-\mathrm{N}(2)-\mathrm{W}(1)$ & $119.6(3)$ \\
\hline $\mathrm{C}(10)-\mathrm{N}(2)-\mathrm{C}(8)$ & $117.8(3)$ \\
\hline $\mathrm{O}(1)-\mathrm{C}(1)-\mathrm{W}(1)$ & $176.9(3)$ \\
\hline $\mathrm{O}(2)-\mathrm{C}(2)-\mathrm{W}(1)$ & $179.6(3)$ \\
\hline $\mathrm{N}(1)-\mathrm{C}(3)-\mathrm{H}(3)$ & 118.1 \\
\hline $\mathrm{N}(1)-\mathrm{C}(3)-\mathrm{C}(4)$ & $123.7(4)$ \\
\hline $\mathrm{C}(4)-\mathrm{C}(3)-\mathrm{H}(3)$ & 118.1 \\
\hline $\mathrm{C}(3)-\mathrm{C}(4)-\mathrm{H}(4)$ & 121.0 \\
\hline
\end{tabular}

\begin{tabular}{|c|c|}
\hline$C(3)-C(4)-C(5)$ & $118.0(4)$ \\
\hline $\mathrm{C}(5)-\mathrm{C}(4)-\mathrm{H}(4)$ & 121.0 \\
\hline $\mathrm{C}(4)-\mathrm{C}(5)-\mathrm{H}(5)$ & 120.3 \\
\hline$C(6)-C(5)-C(4)$ & $119.4(4)$ \\
\hline $\mathrm{C}(6)-\mathrm{C}(5)-\mathrm{H}(5)$ & 120.3 \\
\hline $\mathrm{C}(5)-\mathrm{C}(6)-\mathrm{H}(6)$ & 120.3 \\
\hline $\mathrm{C}(5)-\mathrm{C}(6)-\mathrm{C}(7)$ & $119.3(4)$ \\
\hline $\mathrm{C}(7)-\mathrm{C}(6)-\mathrm{H}(6)$ & 120.3 \\
\hline $\mathrm{N}(1)-\mathrm{C}(7)-\mathrm{C}(6)$ & $122.1(3)$ \\
\hline $\mathrm{N}(1)-\mathrm{C}(7)-\mathrm{C}(8)$ & $117.3(3)$ \\
\hline$C(6)-C(7)-C(8)$ & $120.6(3)$ \\
\hline $\mathrm{N}(2)-\mathrm{C}(8)-\mathrm{C}(7)$ & $109.5(3)$ \\
\hline $\mathrm{N}(2)-\mathrm{C}(8)-\mathrm{H}(8)$ & 108.4 \\
\hline $\mathrm{N}(2)-\mathrm{C}(8)-\mathrm{C}(9)$ & $112.5(3)$ \\
\hline $\mathrm{C}(7)-\mathrm{C}(8)-\mathrm{H}(8)$ & 108.4 \\
\hline $\mathrm{C}(7)-\mathrm{C}(8)-\mathrm{C}(9)$ & $109.4(3)$ \\
\hline $\mathrm{C}(9)-\mathrm{C}(8)-\mathrm{H}(8)$ & 108.4 \\
\hline $\mathrm{C}(8)-\mathrm{C}(9)-\mathrm{H}(9 \mathrm{~A})$ & 109.5 \\
\hline $\mathrm{C}(8)-\mathrm{C}(9)-\mathrm{H}(9 \mathrm{~B})$ & 109.5 \\
\hline $\mathrm{C}(8)-\mathrm{C}(9)-\mathrm{H}(9 \mathrm{C})$ & 109.5 \\
\hline $\mathrm{H}(9 \mathrm{~A})-\mathrm{C}(9)-\mathrm{H}(9 \mathrm{~B})$ & 109.5 \\
\hline $\mathrm{H}(9 \mathrm{~A})-\mathrm{C}(9)-\mathrm{H}(9 \mathrm{C})$ & 109.5 \\
\hline $\mathrm{H}(9 \mathrm{~B})-\mathrm{C}(9)-\mathrm{H}(9 \mathrm{C})$ & 109.5 \\
\hline $\mathrm{O}(3)-\mathrm{C}(10)-\mathrm{N}(2)$ & $124.5(4)$ \\
\hline $\mathrm{O}(3)-\mathrm{C}(10)-\mathrm{C}(11)$ & $123.6(3)$ \\
\hline $\mathrm{N}(2)-\mathrm{C}(10)-\mathrm{C}(11)$ & $111.9(3)$ \\
\hline$C(12)-C(11)-C(10)$ & $119.3(3)$ \\
\hline$C(12)-C(11)-C(16)$ & $121.9(4)$ \\
\hline$C(16)-C(11)-C(10)$ & $118.5(3)$ \\
\hline $\mathrm{C}(11)-\mathrm{C}(12)-\mathrm{H}(12)$ & 119.9 \\
\hline$C(13)-C(12)-C(11)$ & $120.3(4)$ \\
\hline $\mathrm{C}(13)-\mathrm{C}(12)-\mathrm{H}(12)$ & 119.9 \\
\hline $\mathrm{C}(12)-\mathrm{C}(13)-\mathrm{H}(13)$ & 120.5 \\
\hline$C(12)-C(13)-C(14)$ & $119.0(4)$ \\
\hline $\mathrm{C}(14)-\mathrm{C}(13)-\mathrm{H}(13)$ & 120.5 \\
\hline $\mathrm{C}(13)-\mathrm{C}(14)-\mathrm{H}(14)$ & 119.6 \\
\hline$C(15)-C(14)-C(13)$ & $120.9(4)$ \\
\hline
\end{tabular}




\begin{tabular}{|c|c|c|c|}
\hline $\mathrm{C}(15)-\mathrm{C}(14)-\mathrm{H}(14)$ & 119.6 & $\mathrm{P}(2)-\mathrm{C}(22)-\mathrm{H}(22 \mathrm{~A})$ & 109.5 \\
\hline $\mathrm{C}(14)-\mathrm{C}(15)-\mathrm{H}(15)$ & 119.0 & $\mathrm{P}(2)-\mathrm{C}(22)-\mathrm{H}(22 \mathrm{~B})$ & 109.5 \\
\hline$C(14)-C(15)-C(16)$ & $121.9(4)$ & $\mathrm{P}(2)-\mathrm{C}(22)-\mathrm{H}(22 \mathrm{C})$ & 109.5 \\
\hline $\mathrm{C}(16)-\mathrm{C}(15)-\mathrm{H}(15)$ & 119.0 & $\mathrm{H}(22 \mathrm{~A})-\mathrm{C}(22)-\mathrm{H}(22 \mathrm{~B})$ & 109.5 \\
\hline $\mathrm{C}(11)-\mathrm{C}(16)-\mathrm{W}(1)$ & $112.2(3)$ & $\mathrm{H}(22 \mathrm{~A})-\mathrm{C}(22)-\mathrm{H}(22 \mathrm{C})$ & 109.5 \\
\hline $\mathrm{C}(15)-\mathrm{C}(16)-\mathrm{W}(1)$ & $131.8(3)$ & $\mathrm{H}(22 \mathrm{~B})-\mathrm{C}(22)-\mathrm{H}(22 \mathrm{C})$ & 109. \\
\hline $\mathrm{C}(15)-\mathrm{C}(16)-\mathrm{C}(11)$ & $116.0(3)$ & & \\
\hline $\mathrm{P}(1)-\mathrm{C}(17)-\mathrm{H}(17 \mathrm{~A})$ & 109.5 & & \\
\hline $\mathrm{P}(1)-\mathrm{C}(17)-\mathrm{H}(17 \mathrm{~B})$ & 109.5 & & \\
\hline $\mathrm{P}(1)-\mathrm{C}(17)-\mathrm{H}(17 \mathrm{C})$ & 109.5 & & \\
\hline $\mathrm{H}(17 \mathrm{~A})-\mathrm{C}(17)-\mathrm{H}(17 \mathrm{~B})$ & 109.5 & & \\
\hline $\mathrm{H}(17 \mathrm{~A})-\mathrm{C}(17)-\mathrm{H}(17 \mathrm{C})$ & 109.5 & & \\
\hline $\mathrm{H}(17 \mathrm{~B})-\mathrm{C}(17)-\mathrm{H}(17 \mathrm{C})$ & 109.5 & & \\
\hline $\mathrm{P}(1)-\mathrm{C}(18)-\mathrm{H}(18 \mathrm{~A})$ & 109.5 & & \\
\hline $\mathrm{P}(1)-\mathrm{C}(18)-\mathrm{H}(18 \mathrm{~B})$ & 109.5 & & \\
\hline $\mathrm{P}(1)-\mathrm{C}(18)-\mathrm{H}(18 \mathrm{C})$ & 109.5 & & \\
\hline $\mathrm{H}(18 \mathrm{~A})-\mathrm{C}(18)-\mathrm{H}(18 \mathrm{~B})$ & 109.5 & & \\
\hline $\mathrm{H}(18 \mathrm{~A})-\mathrm{C}(18)-\mathrm{H}(18 \mathrm{C})$ & 109.5 & & \\
\hline $\mathrm{H}(18 \mathrm{~B})-\mathrm{C}(18)-\mathrm{H}(18 \mathrm{C})$ & 109.5 & & \\
\hline $\mathrm{P}(1)-\mathrm{C}(19)-\mathrm{H}(19 \mathrm{~A})$ & 109.5 & & \\
\hline $\mathrm{P}(1)-\mathrm{C}(19)-\mathrm{H}(19 \mathrm{~B})$ & 109.5 & & \\
\hline $\mathrm{P}(1)-\mathrm{C}(19)-\mathrm{H}(19 \mathrm{C})$ & 109.5 & & \\
\hline $\mathrm{H}(19 \mathrm{~A})-\mathrm{C}(19)-\mathrm{H}(19 \mathrm{~B})$ & 109.5 & & \\
\hline $\mathrm{H}(19 \mathrm{~A})-\mathrm{C}(19)-\mathrm{H}(19 \mathrm{C})$ & 109.5 & & \\
\hline H(19B)-C(19)-H(19C) & 109.5 & & \\
\hline $\mathrm{P}(2)-\mathrm{C}(20)-\mathrm{H}(20 \mathrm{~A})$ & 109.5 & & \\
\hline $\mathrm{P}(2)-\mathrm{C}(20)-\mathrm{H}(20 \mathrm{~B})$ & 109.5 & & \\
\hline $\mathrm{P}(2)-\mathrm{C}(20)-\mathrm{H}(20 \mathrm{C})$ & 109.5 & & \\
\hline $\mathrm{H}(20 \mathrm{~A})-\mathrm{C}(20)-\mathrm{H}(20 \mathrm{~B})$ & 109.5 & & \\
\hline $\mathrm{H}(20 \mathrm{~A})-\mathrm{C}(20)-\mathrm{H}(20 \mathrm{C})$ & 109.5 & & \\
\hline $\mathrm{H}(20 \mathrm{~B})-\mathrm{C}(20)-\mathrm{H}(20 \mathrm{C})$ & 109.5 & & \\
\hline $\mathrm{P}(2)-\mathrm{C}(21)-\mathrm{H}(21 \mathrm{~A})$ & 109.5 & & \\
\hline $\mathrm{P}(2)-\mathrm{C}(21)-\mathrm{H}(21 \mathrm{~B})$ & 109.5 & & \\
\hline $\mathrm{P}(2)-\mathrm{C}(21)-\mathrm{H}(21 \mathrm{C})$ & 109.5 & & \\
\hline $\mathrm{H}(21 \mathrm{~A})-\mathrm{C}(21)-\mathrm{H}(21 \mathrm{~B})$ & 109.5 & & \\
\hline $\mathrm{H}(21 \mathrm{~A})-\mathrm{C}(21)-\mathrm{H}(21 \mathrm{C})$ & 109.5 & & \\
\hline $\mathrm{H}(21 \mathrm{~B})-\mathrm{C}(21)-\mathrm{H}(21 \mathrm{C})$ & 109.5 & & \\
\hline
\end{tabular}


NMR AND IR SPECTRA

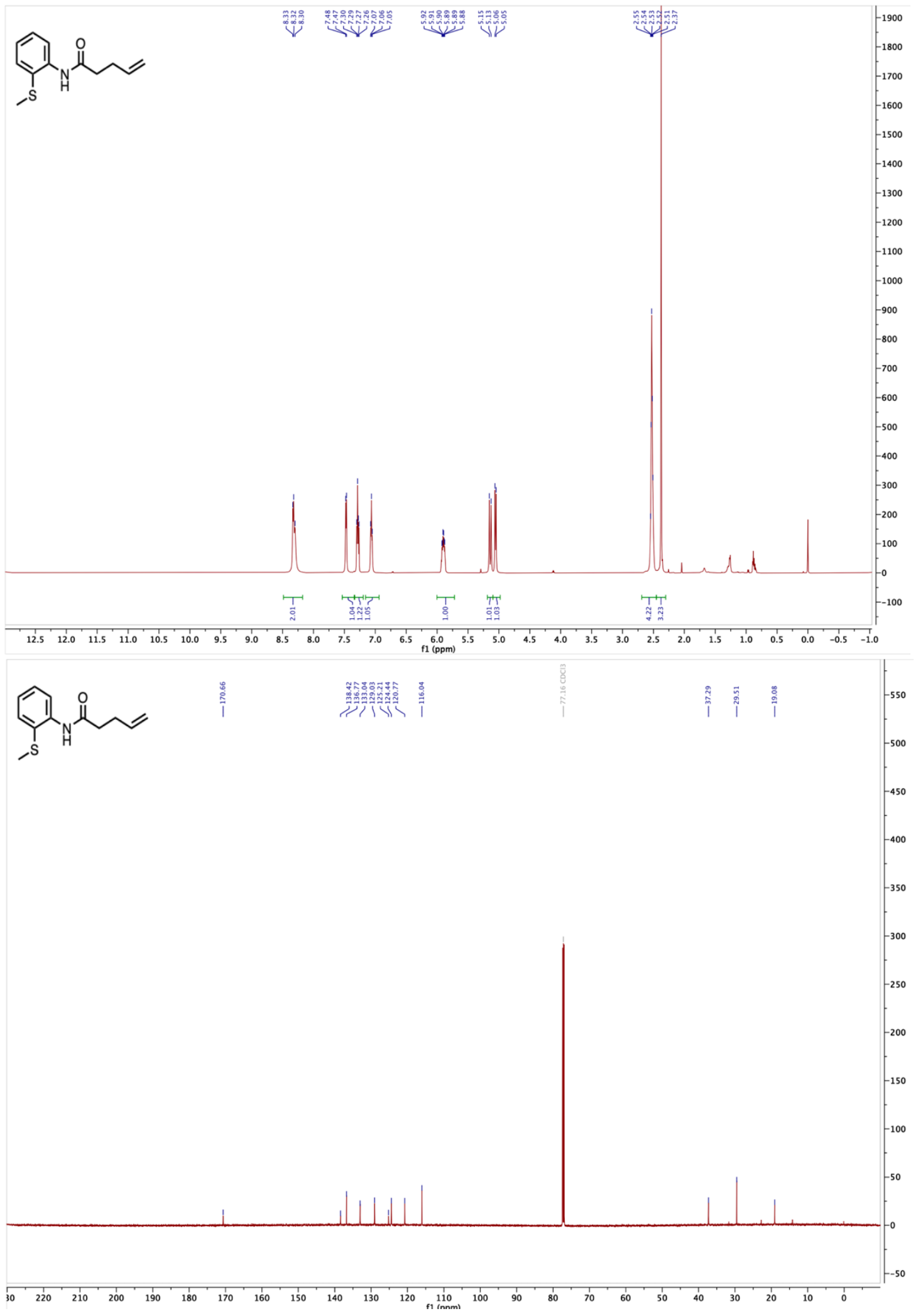




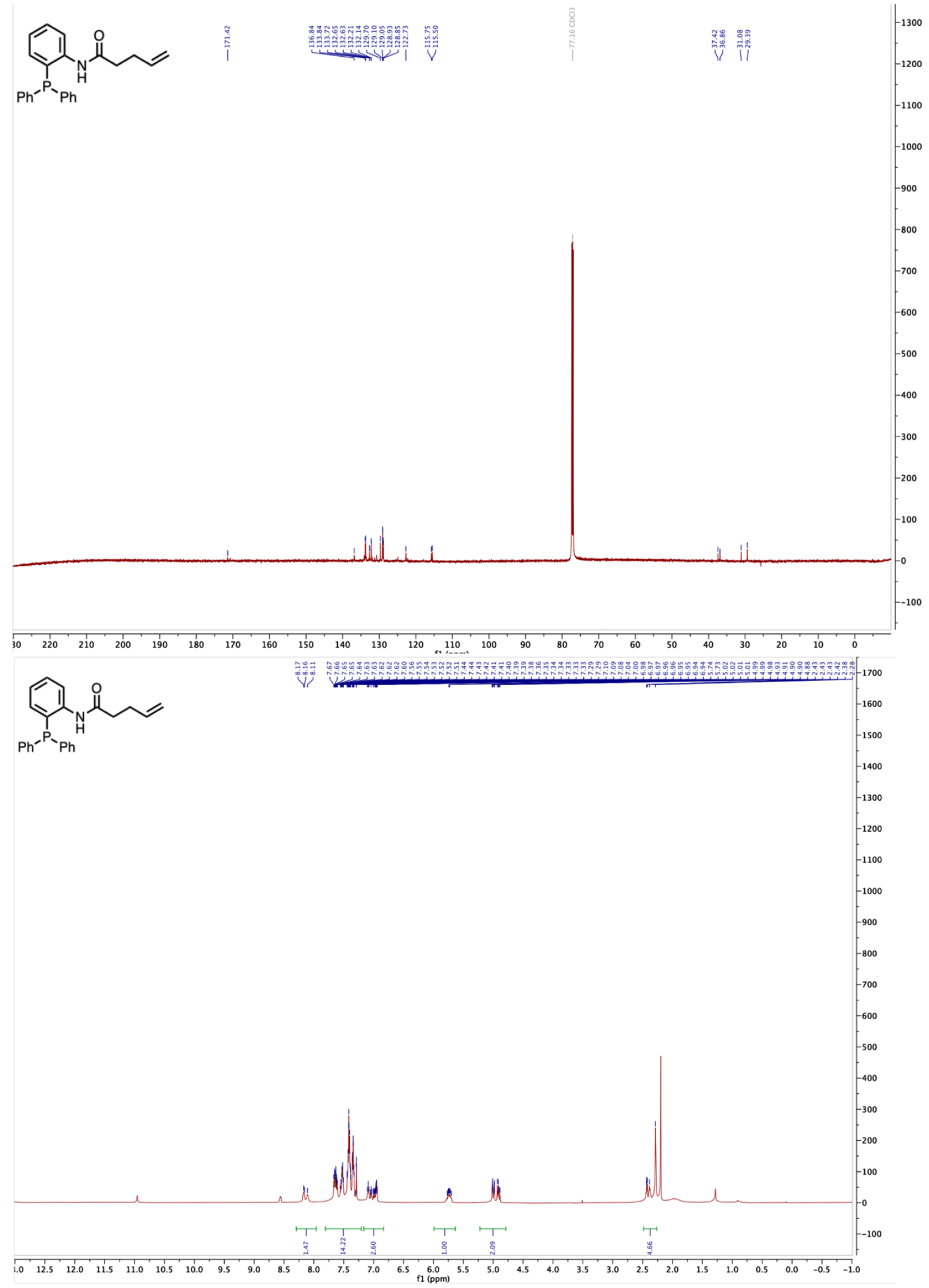




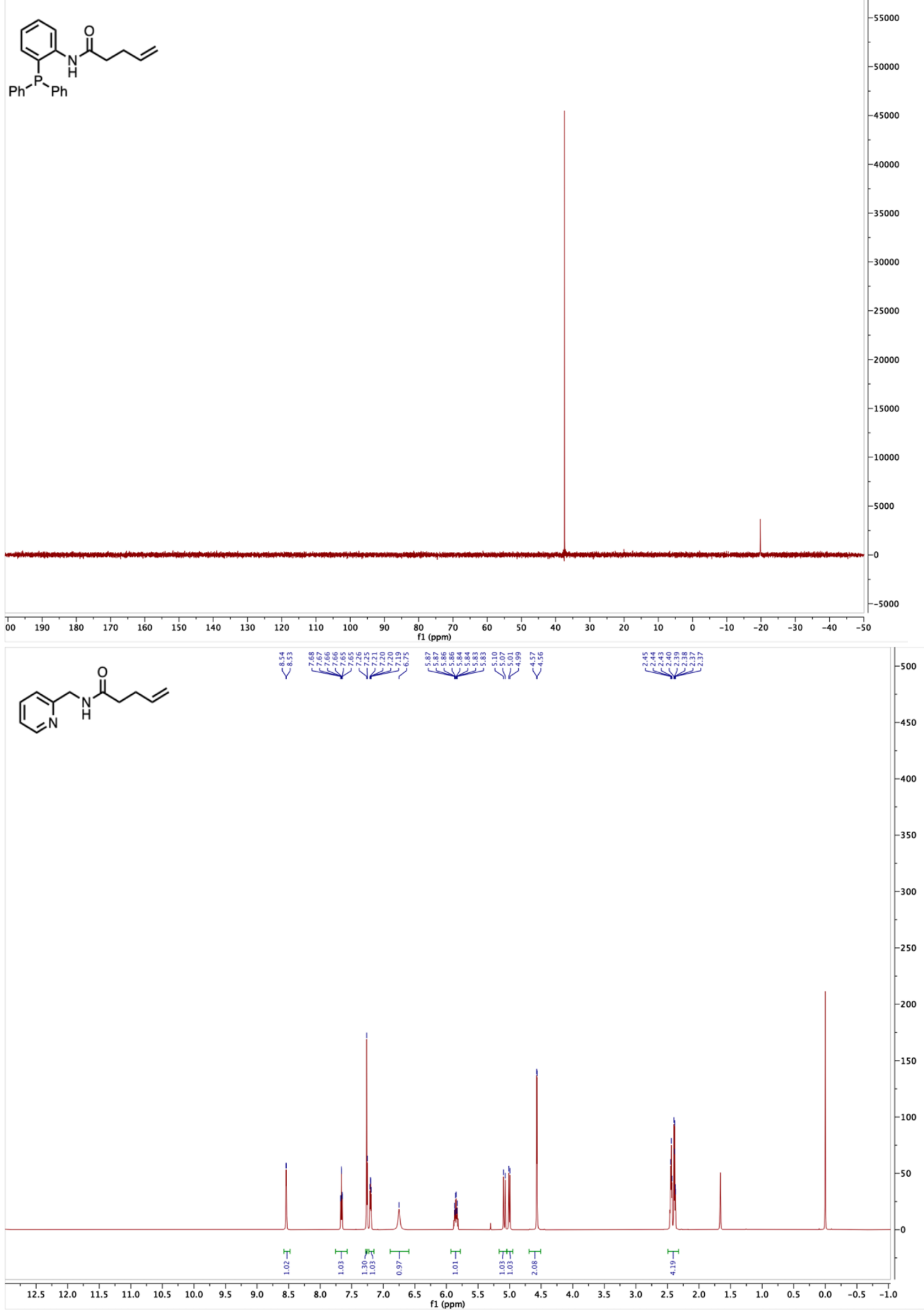



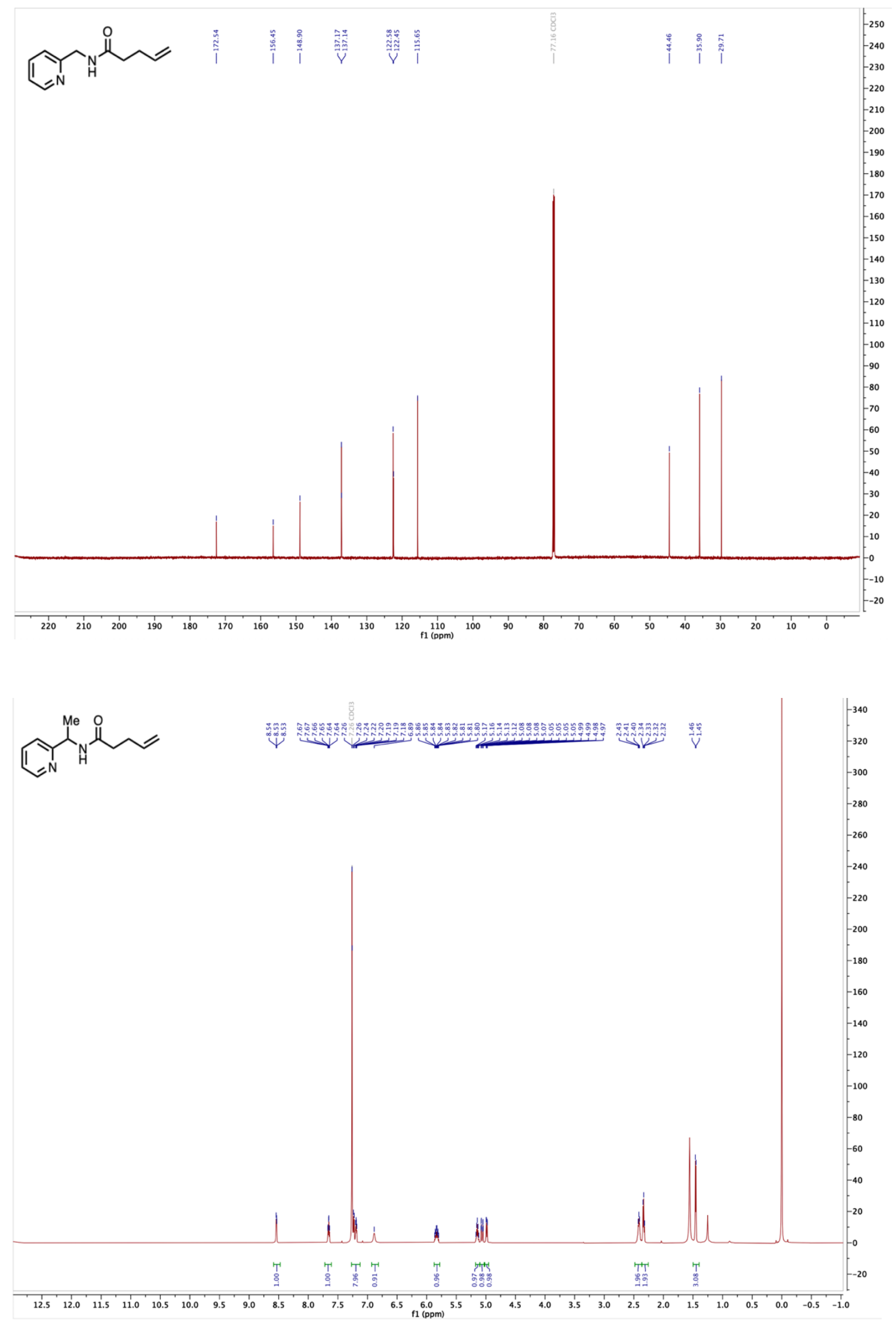

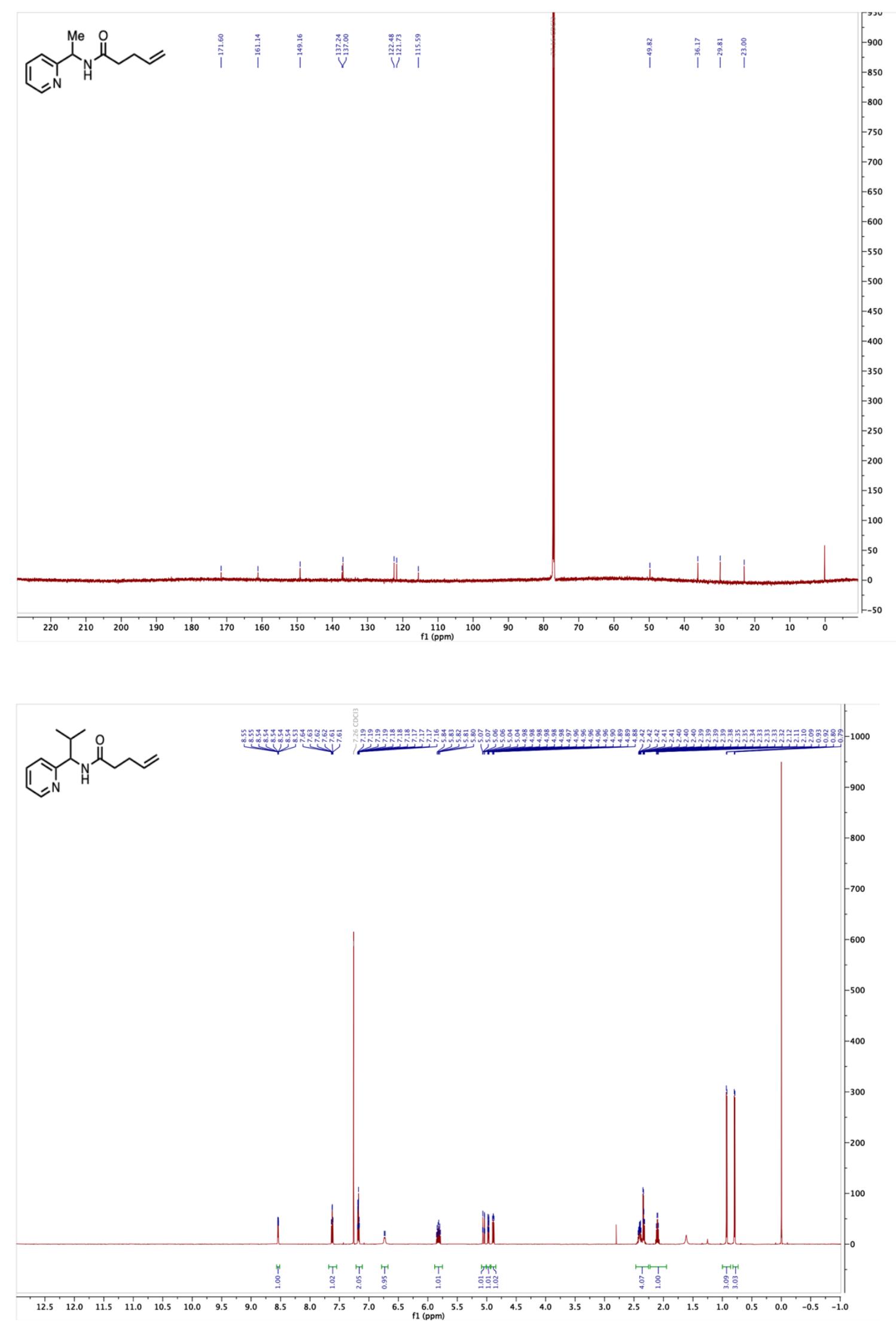


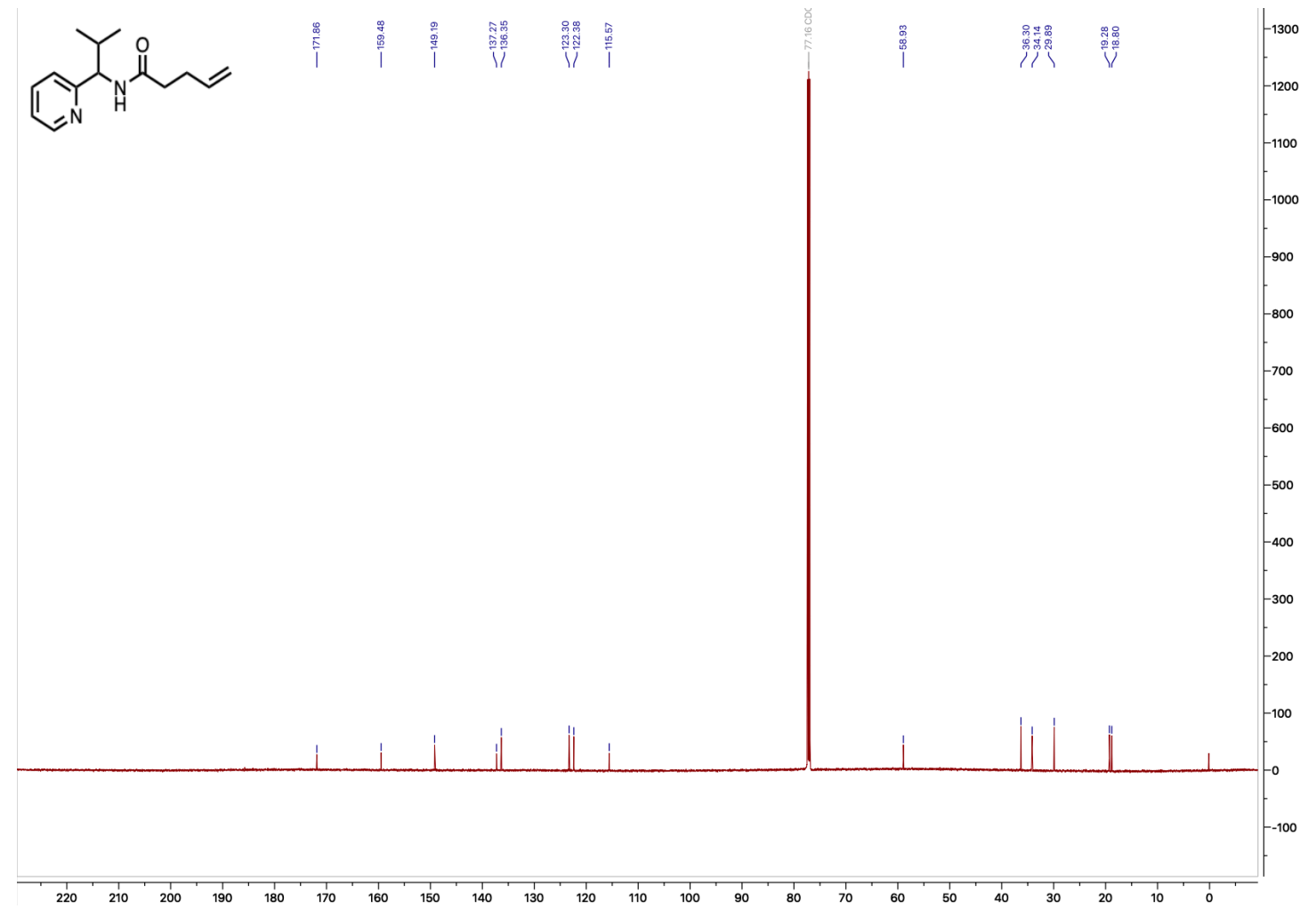




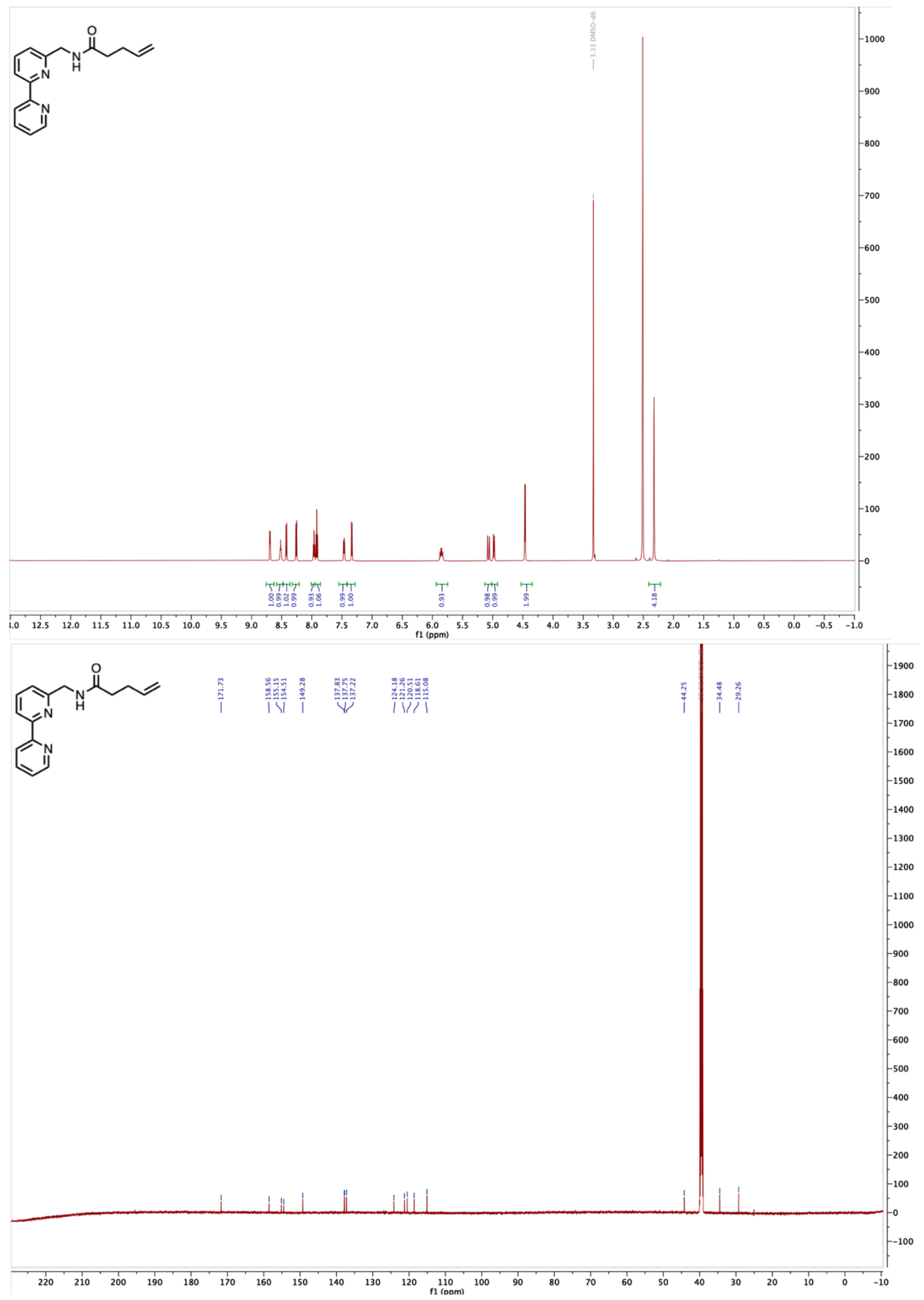

S-94 

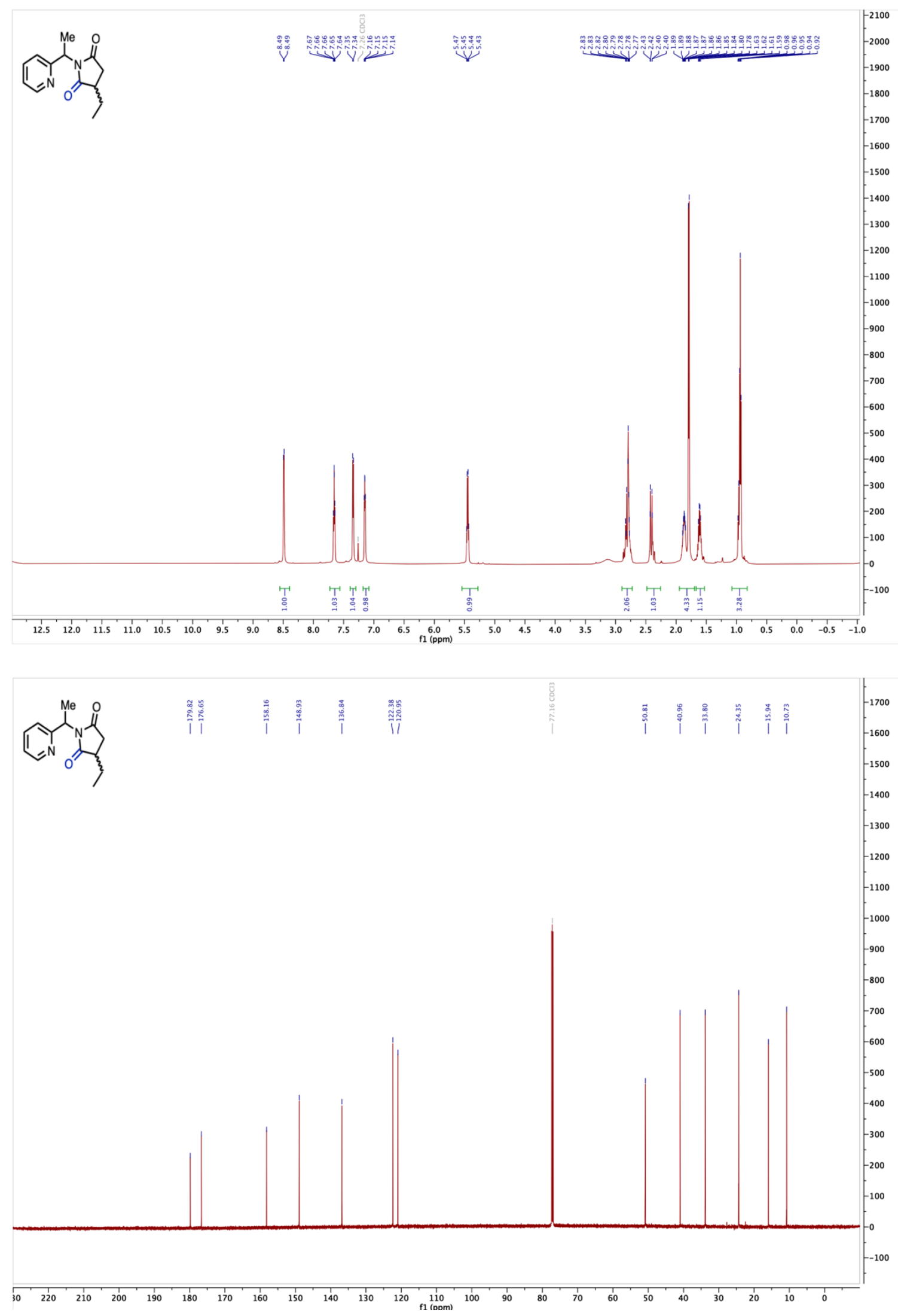

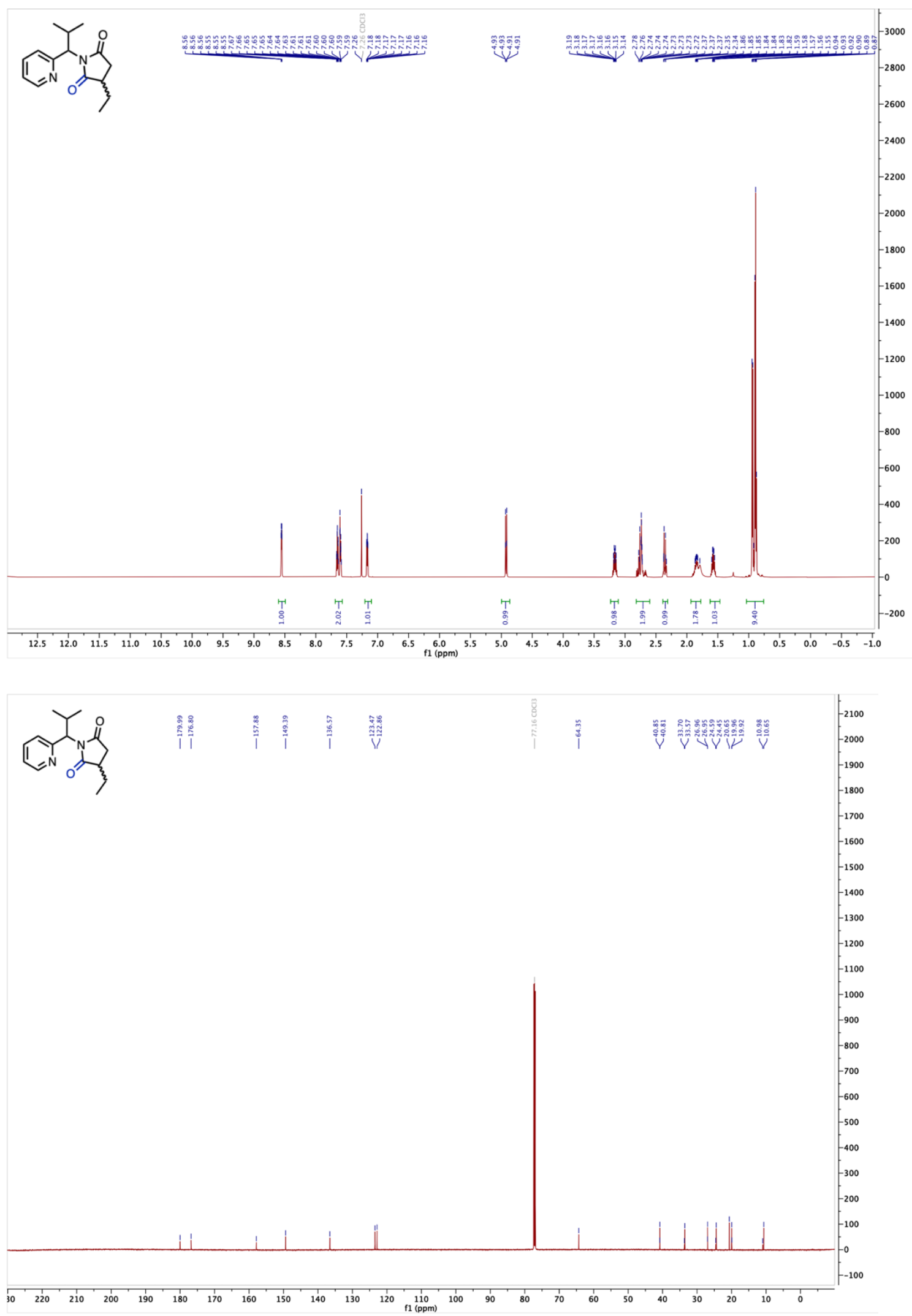

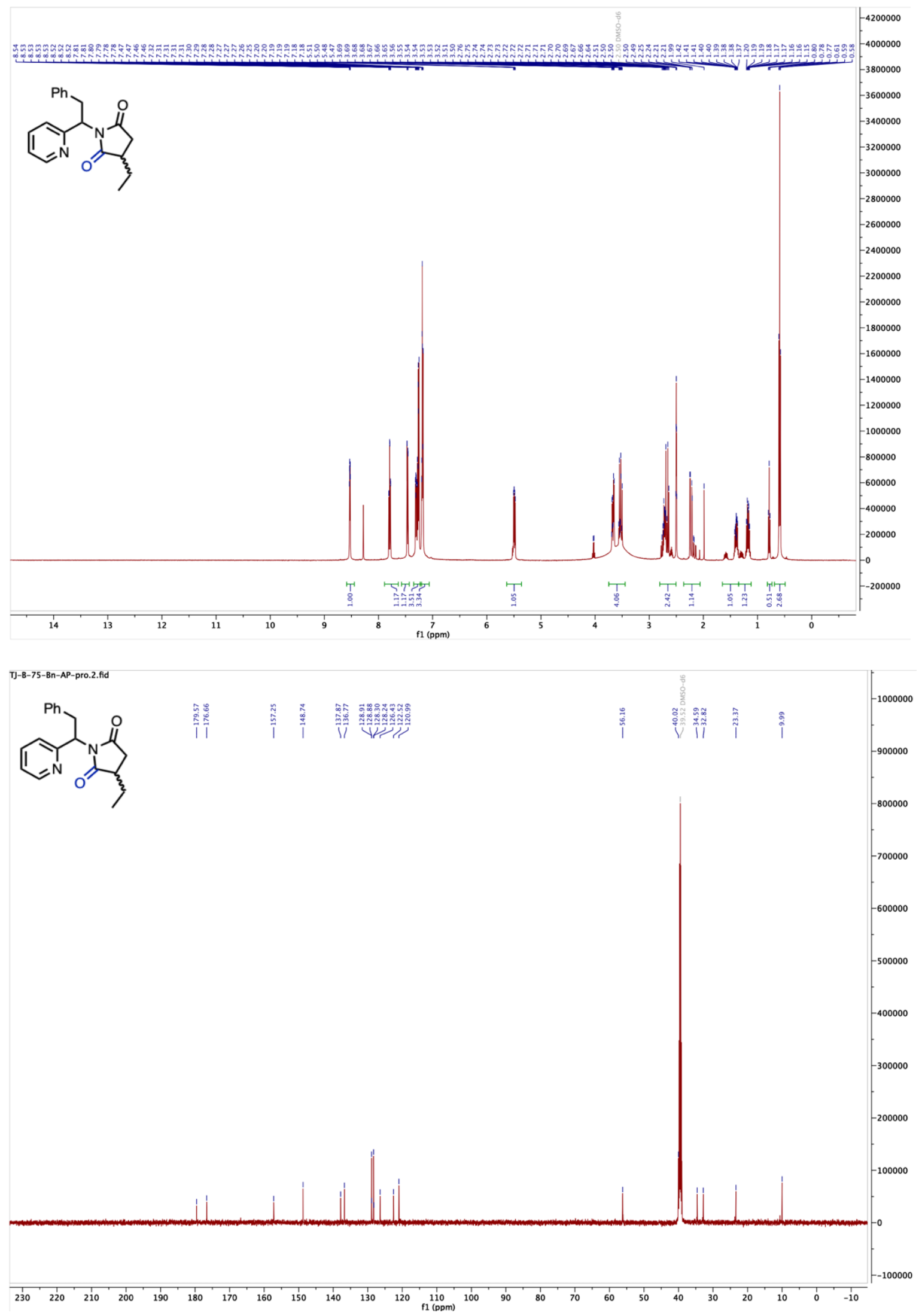

S-97 


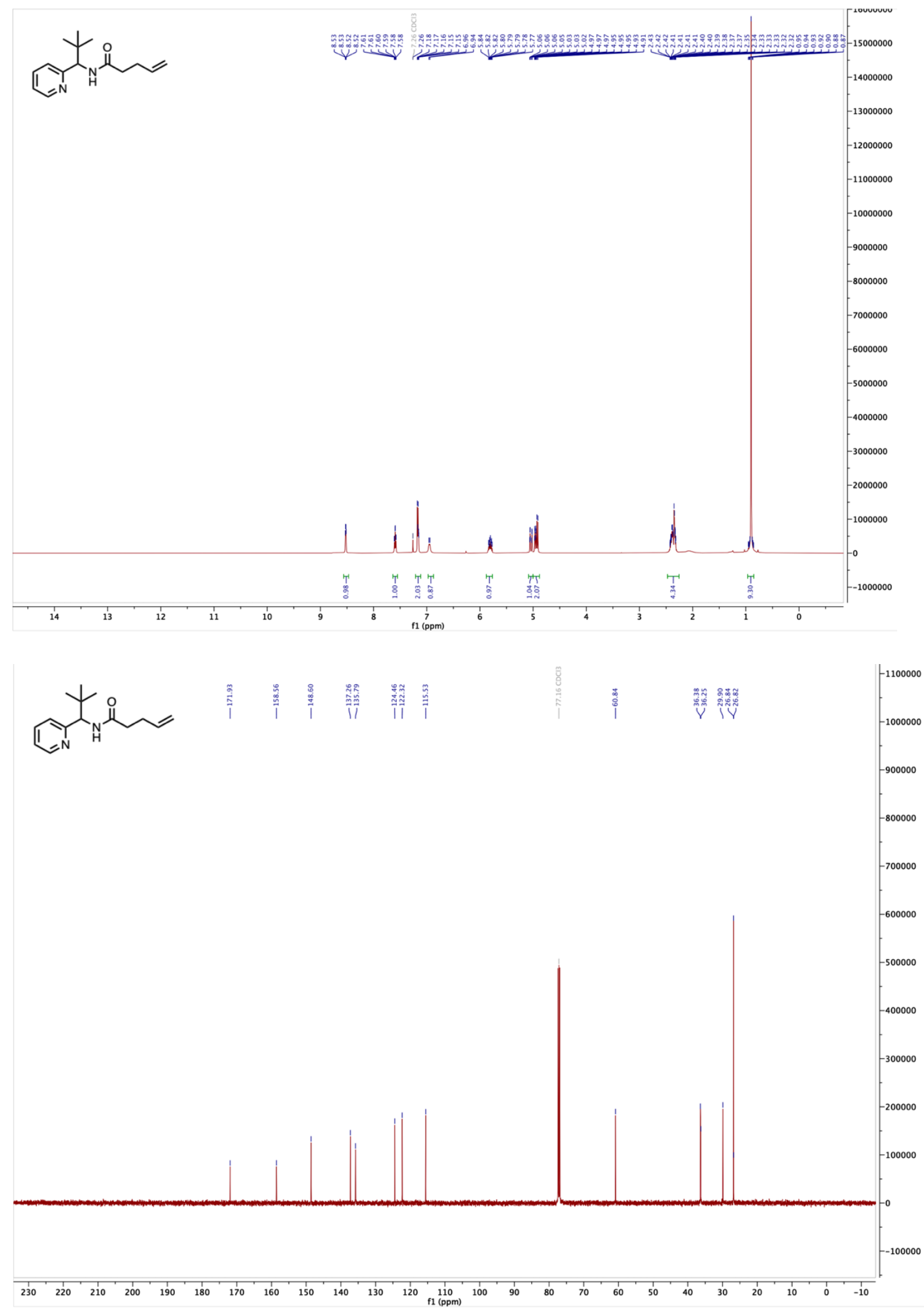



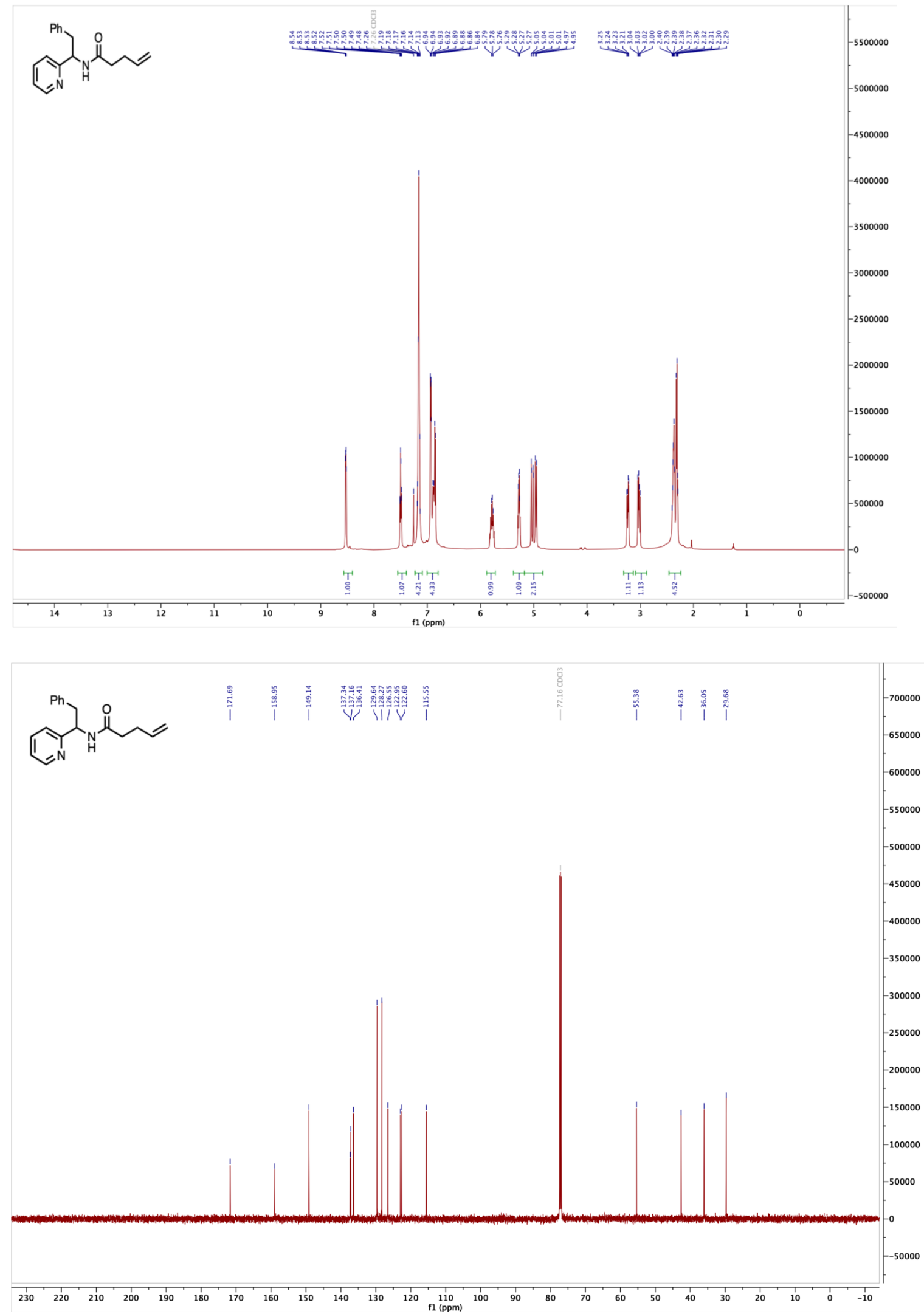

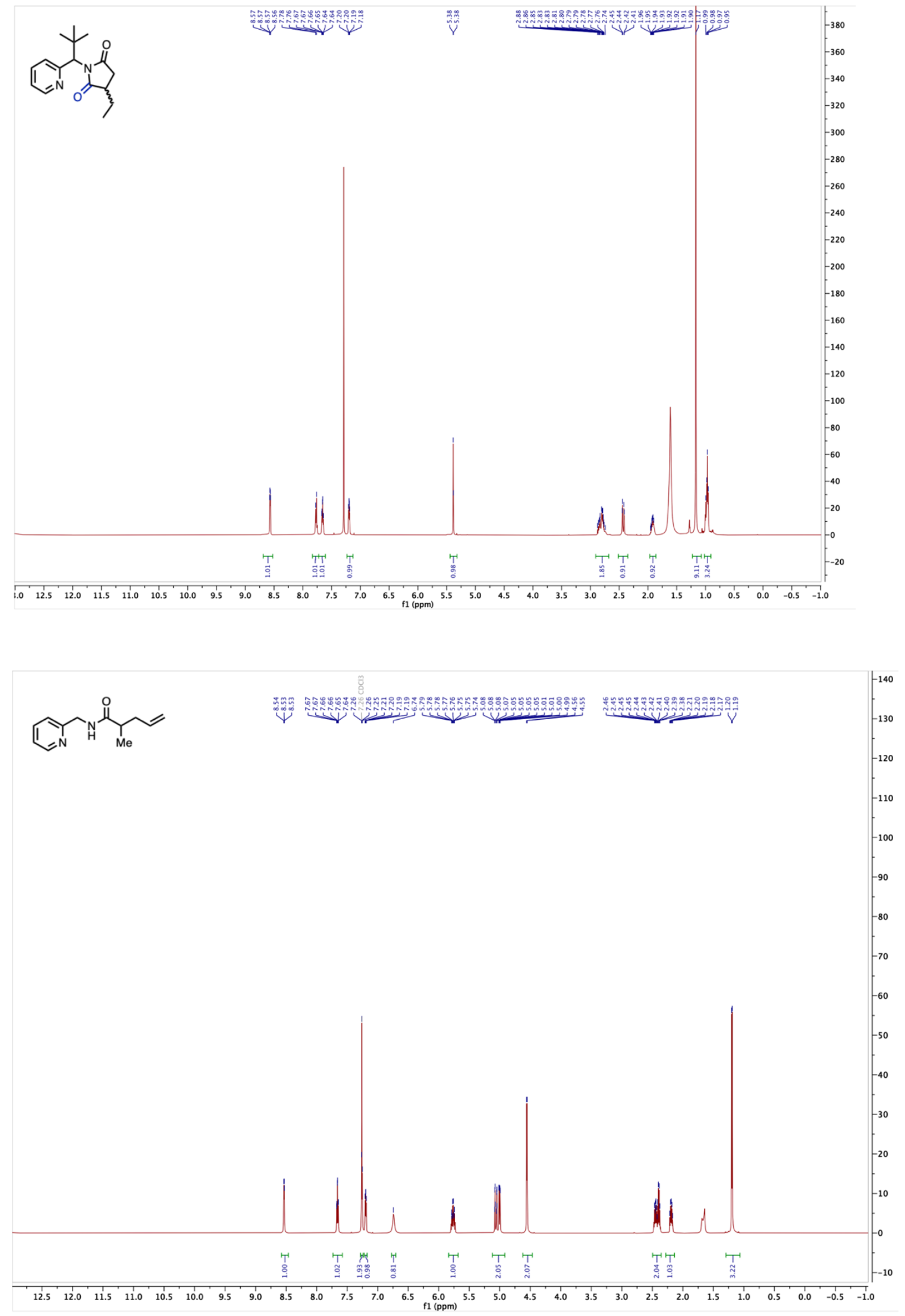

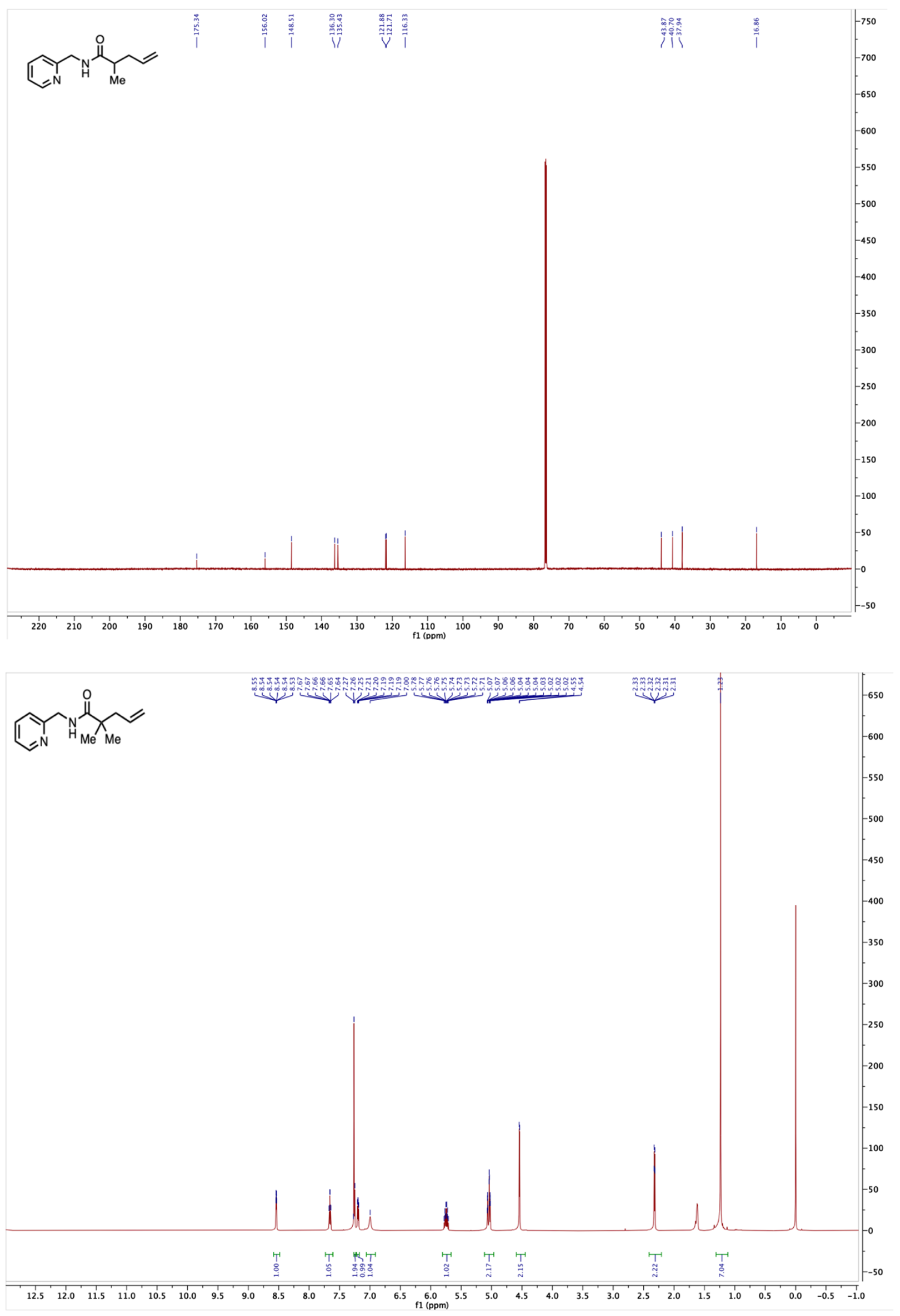

S-101 


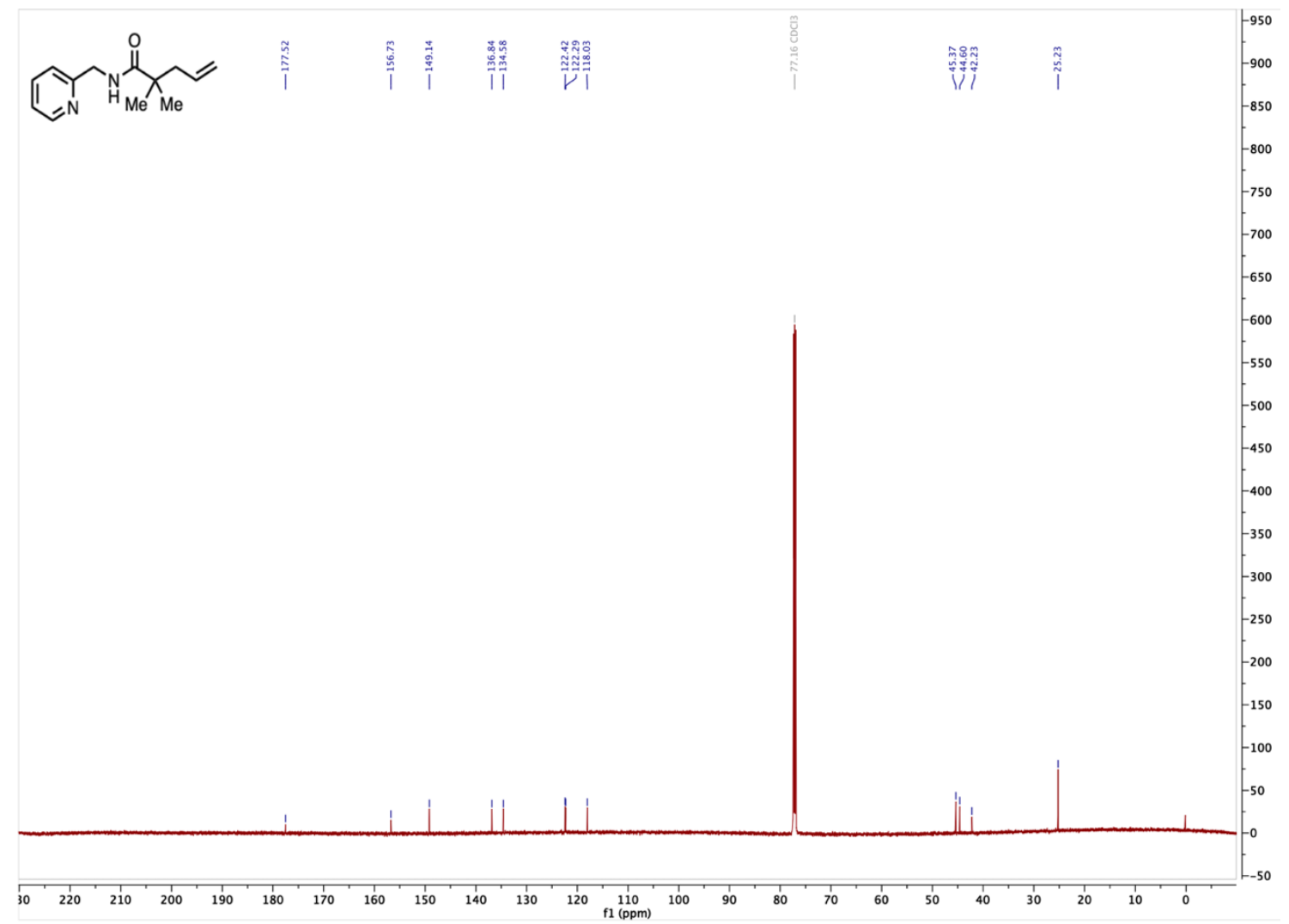

S-102 

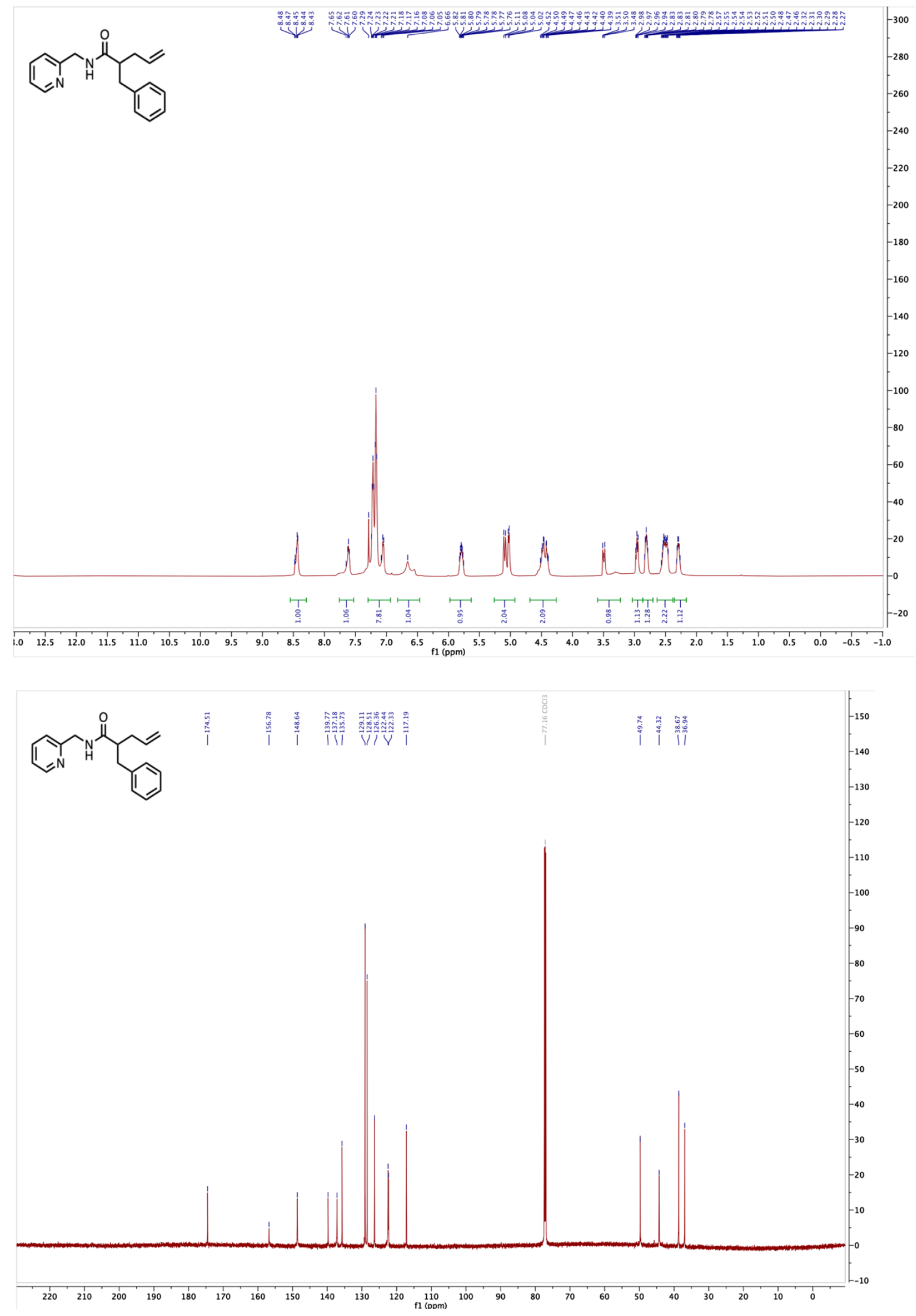

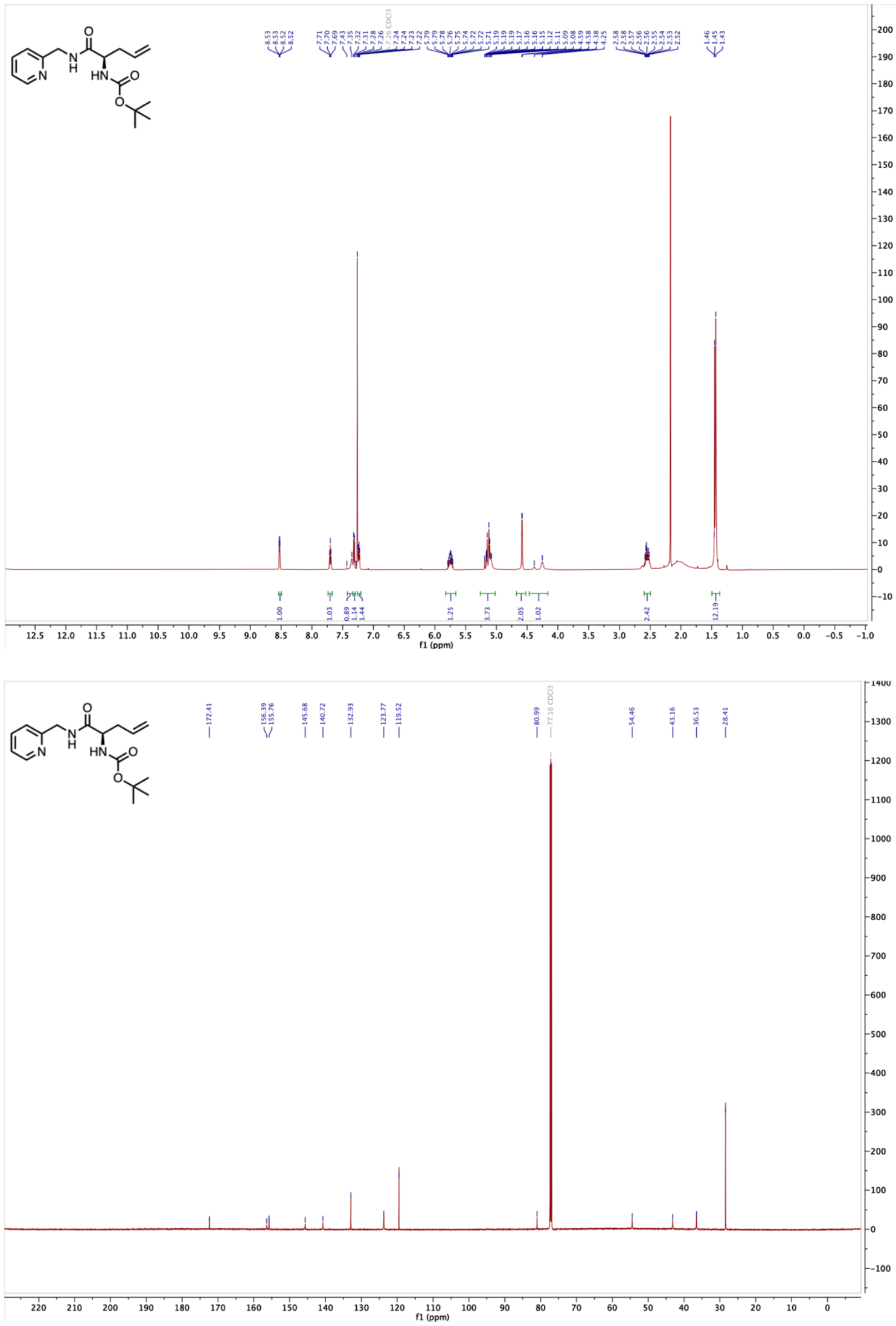

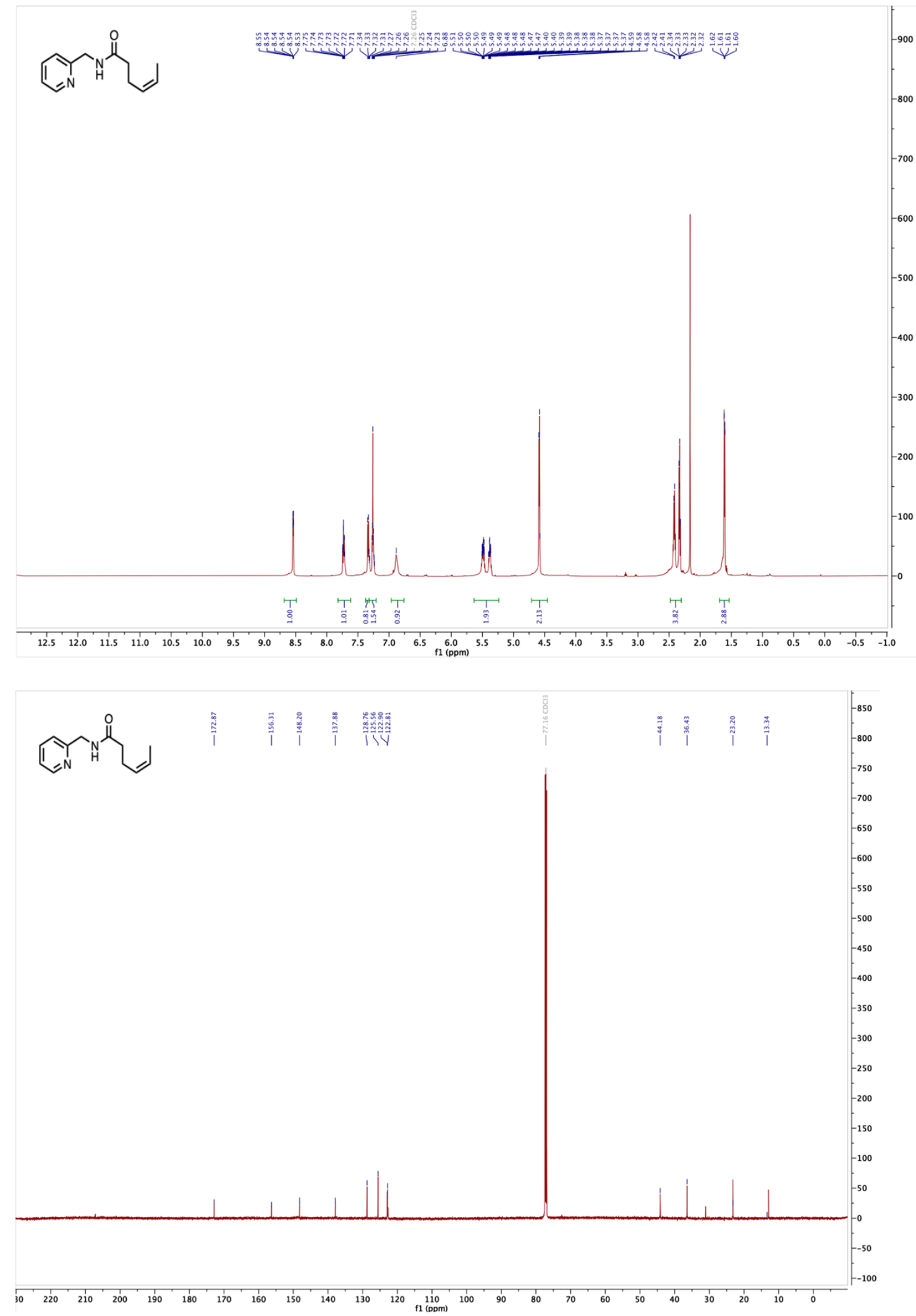

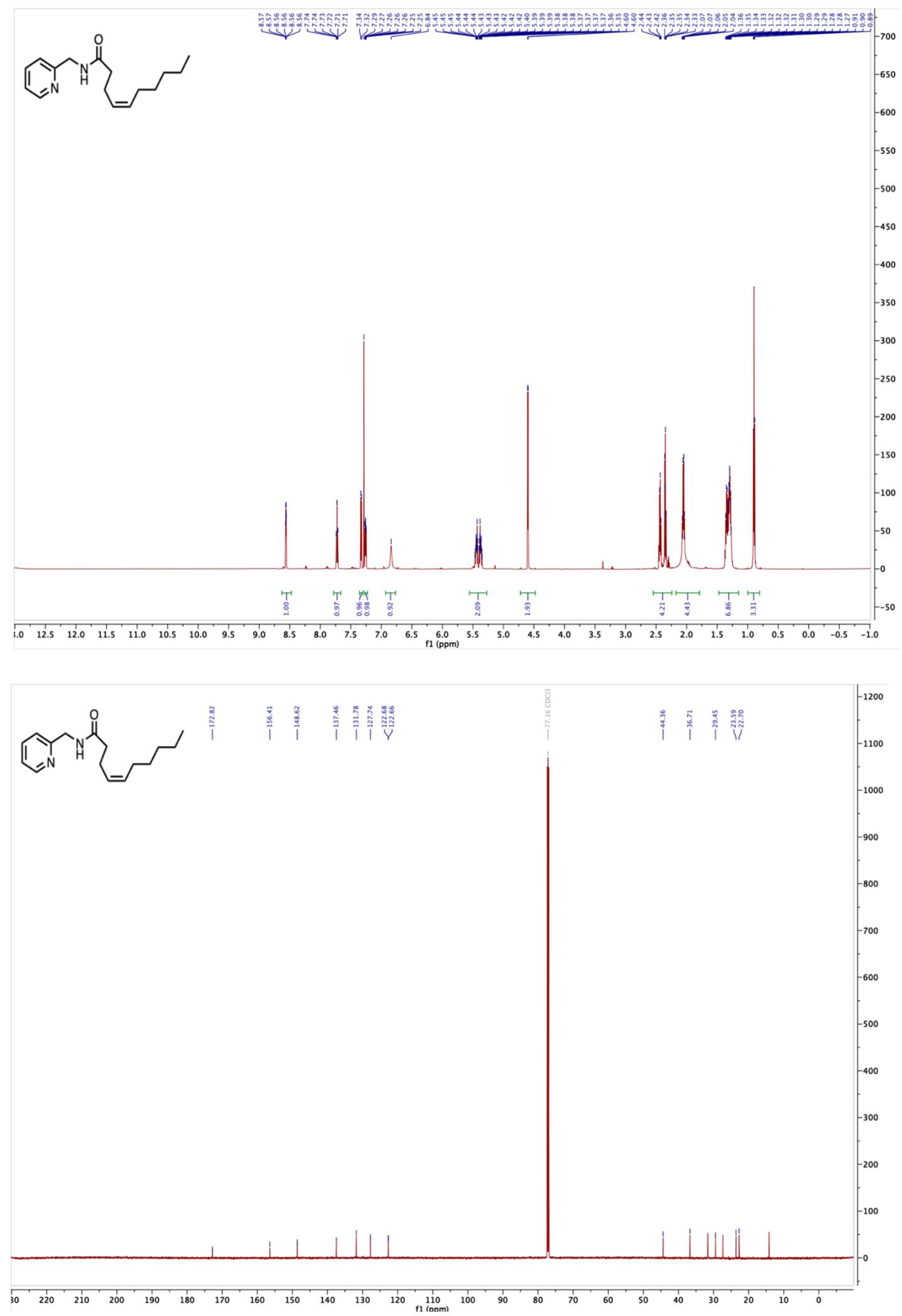

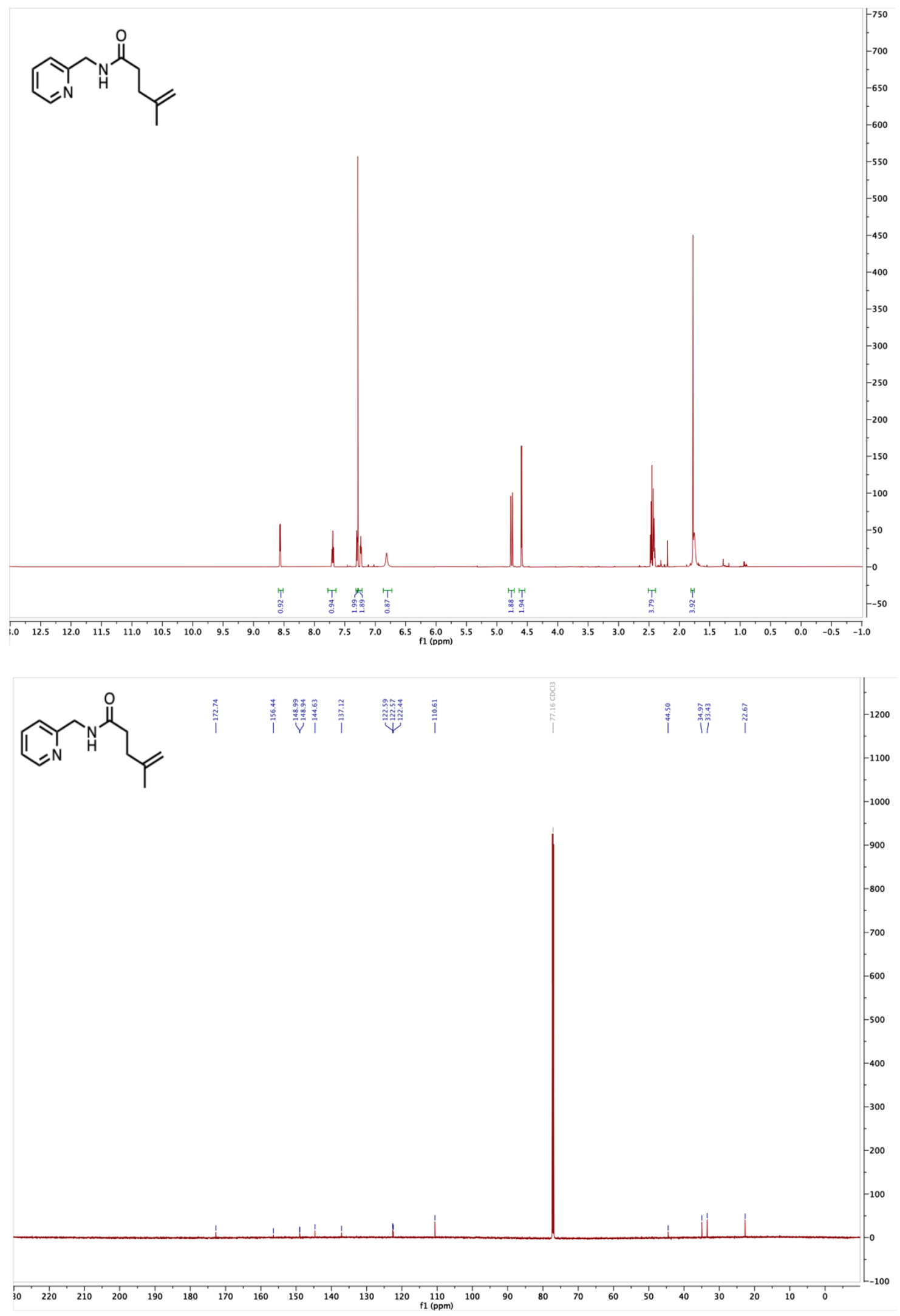

S-107 

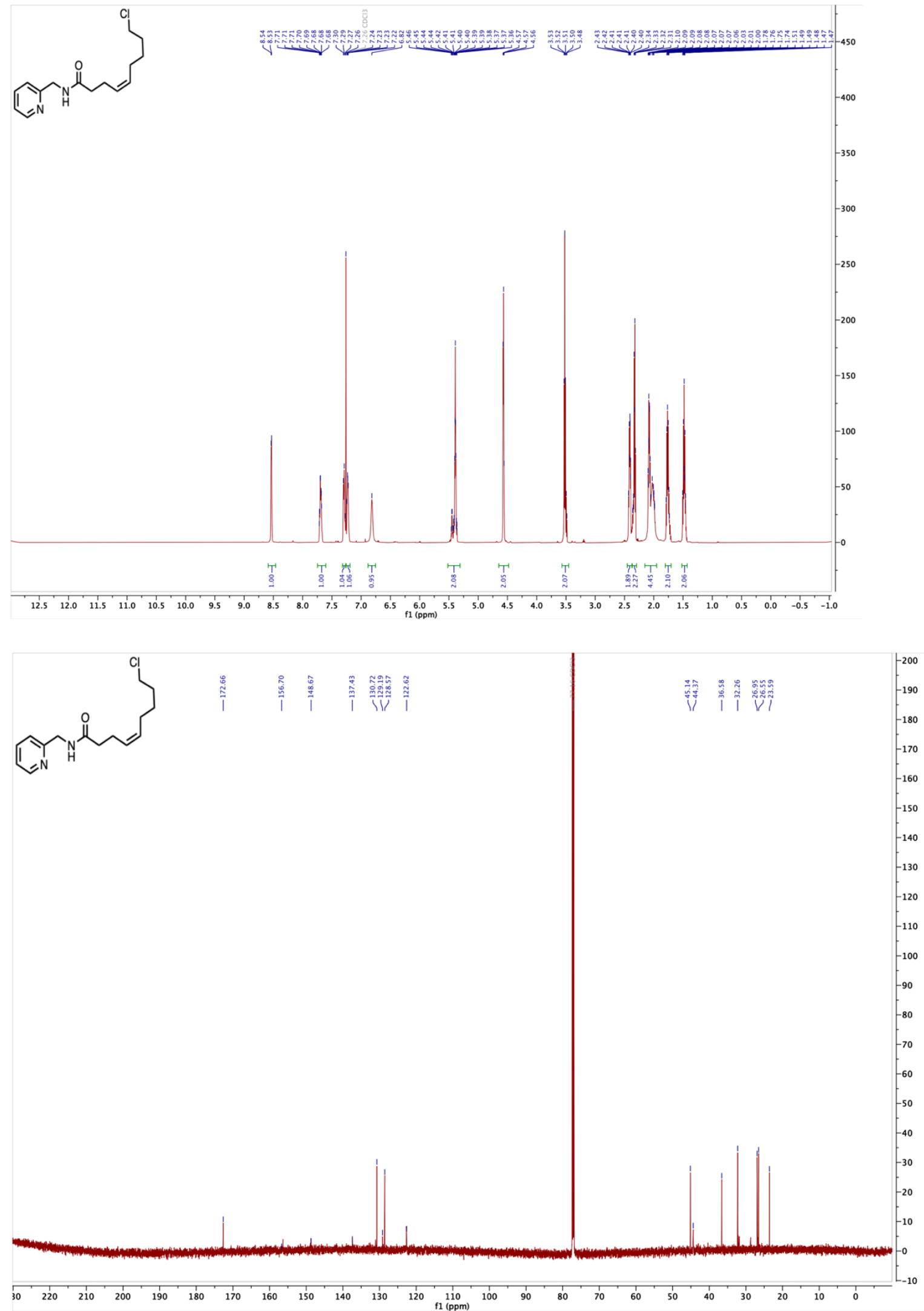

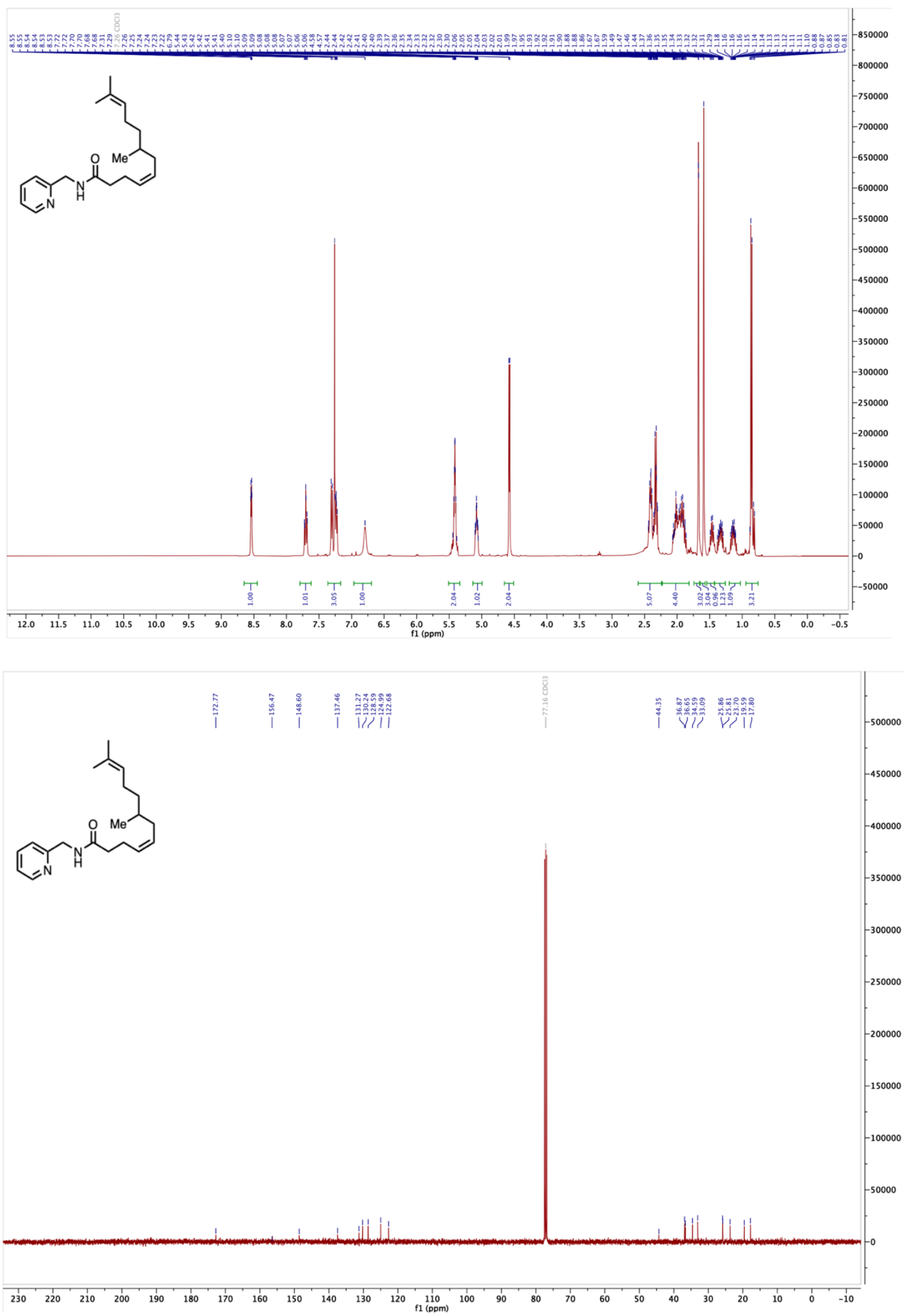

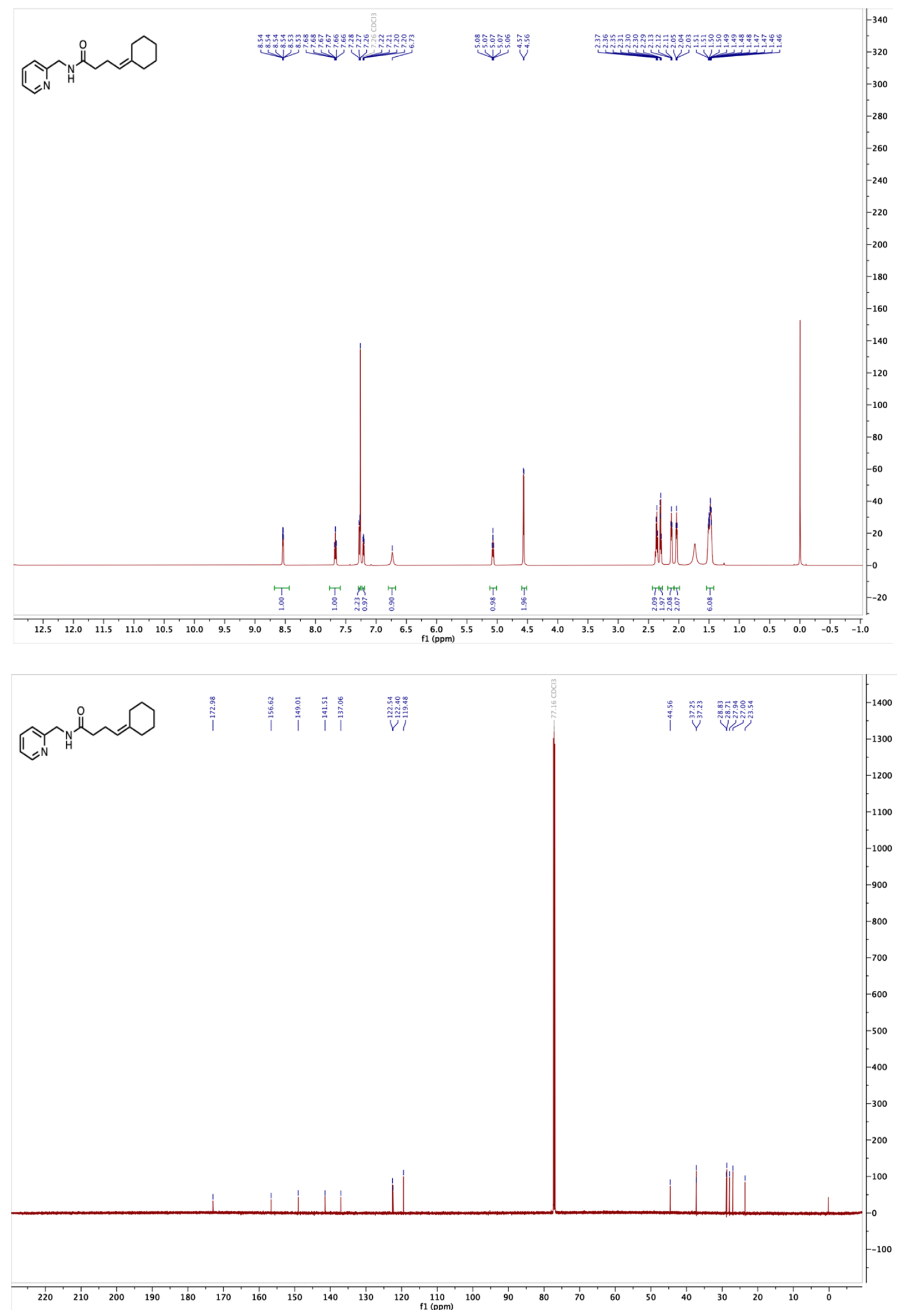

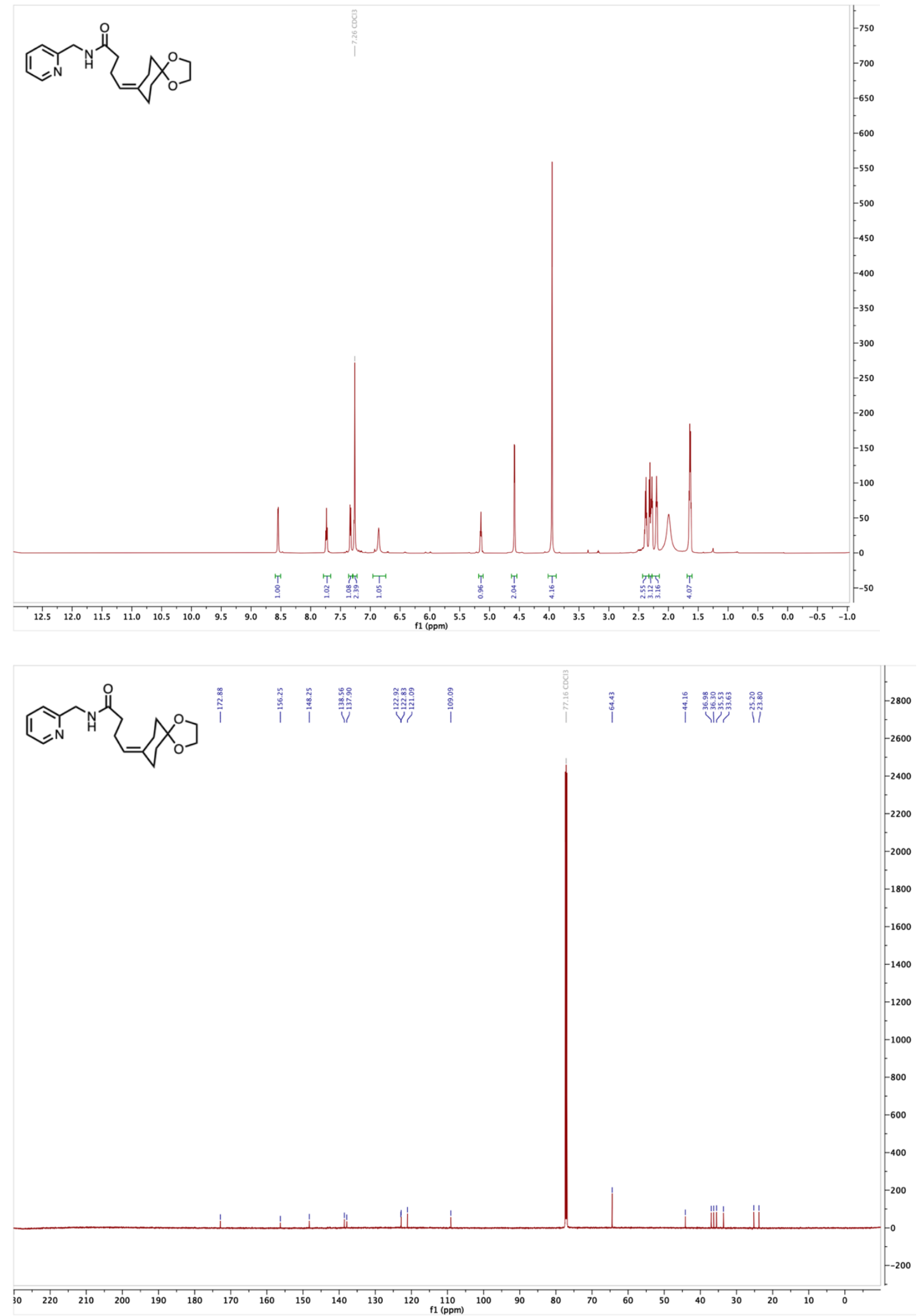

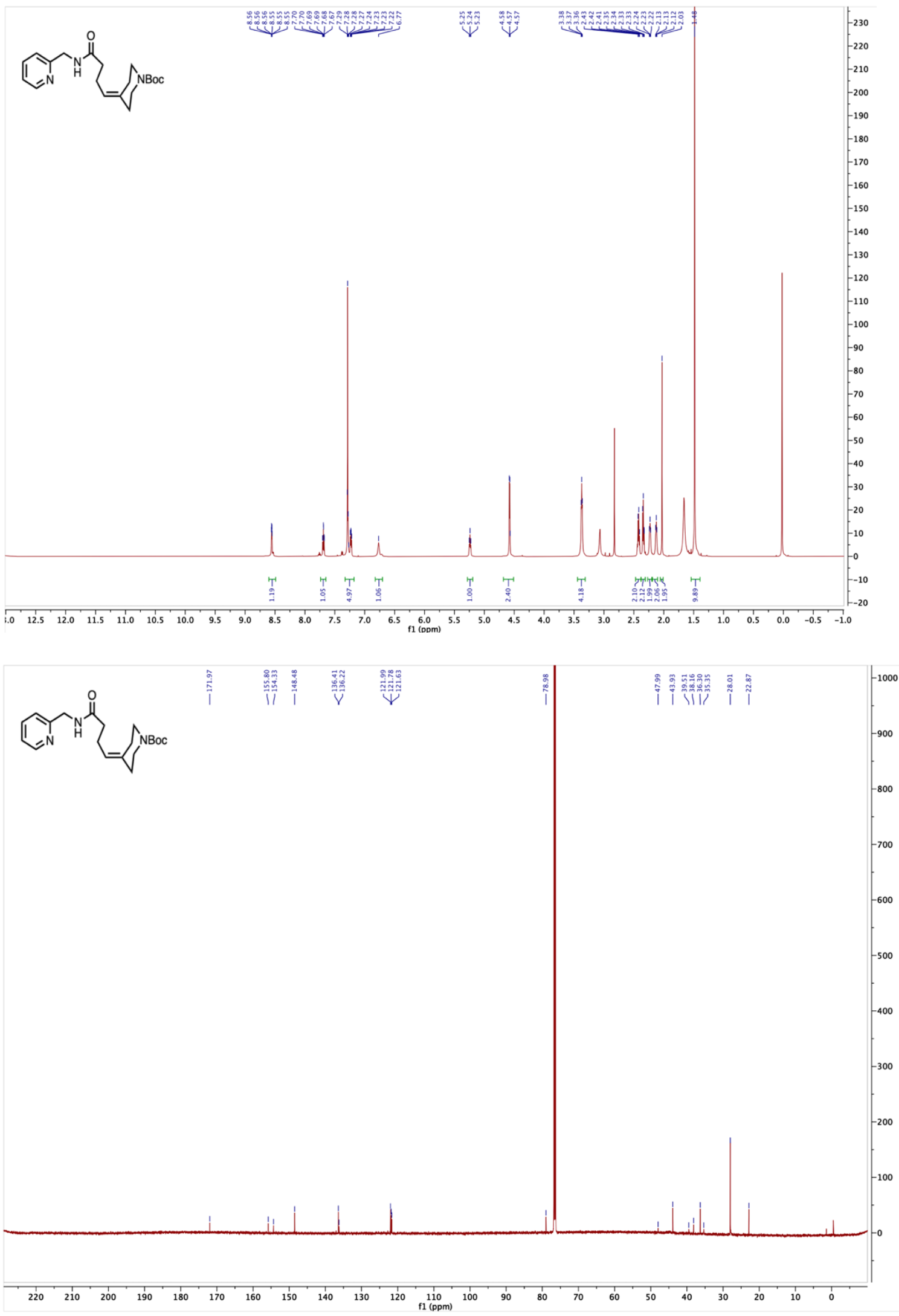

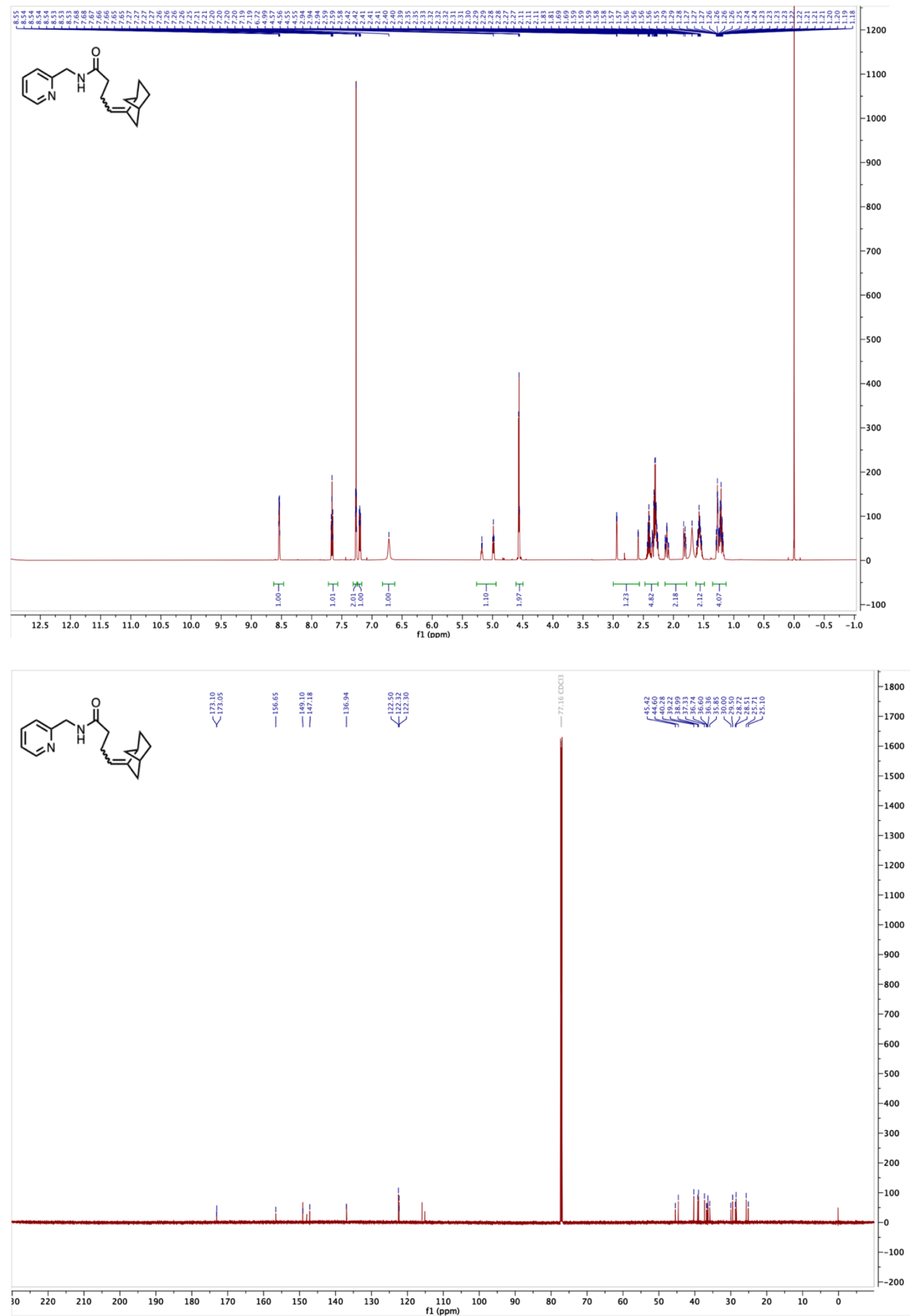

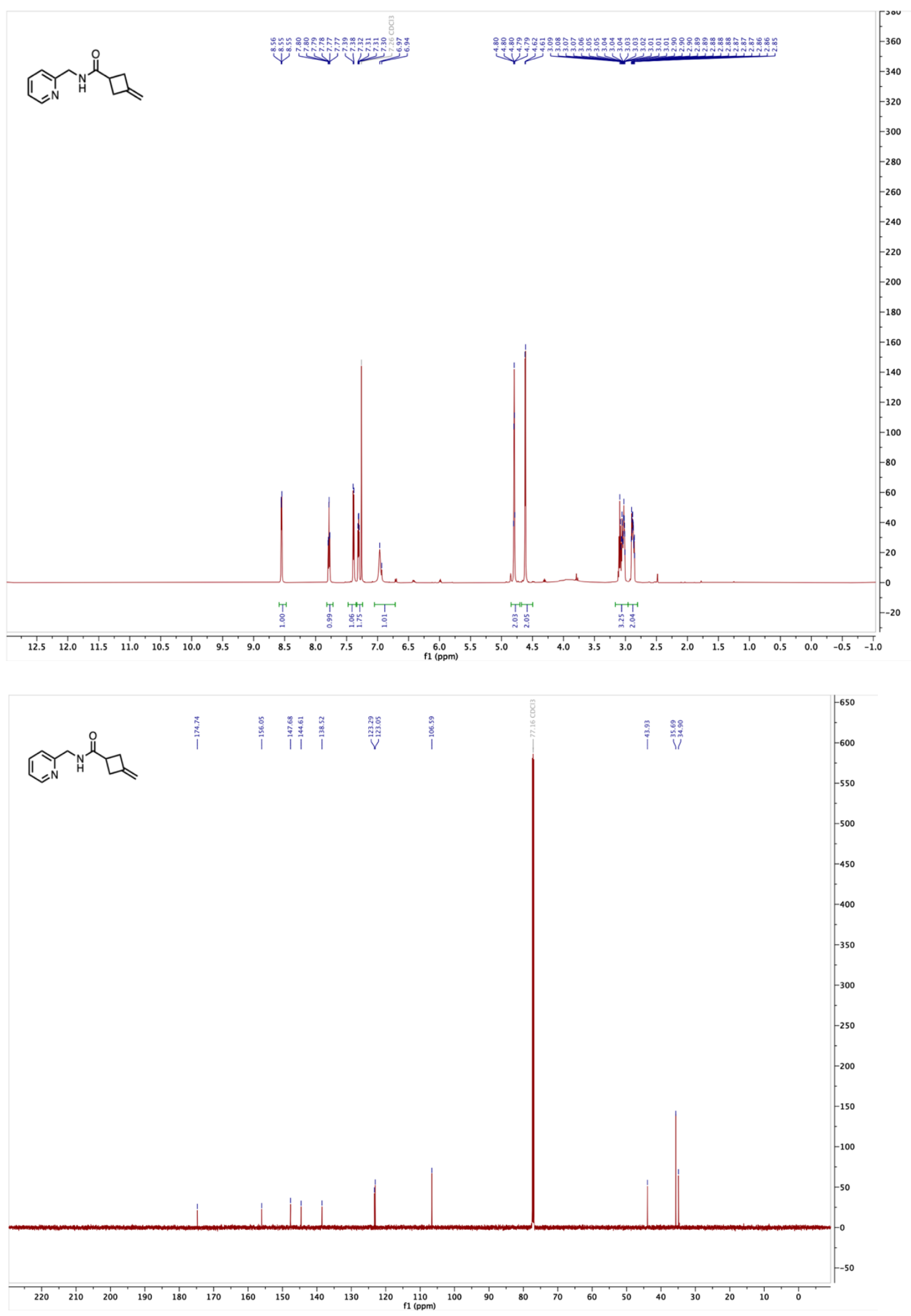

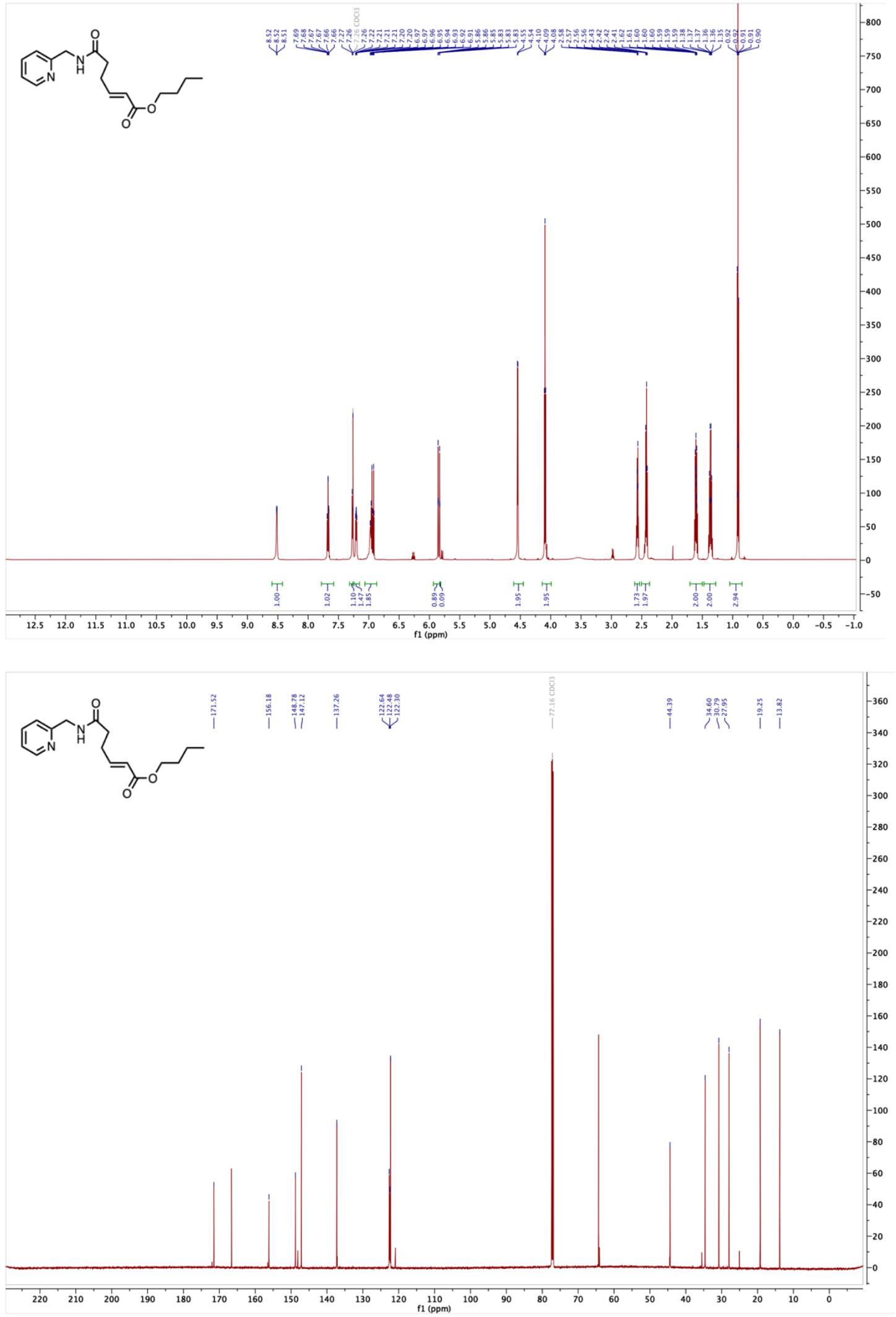

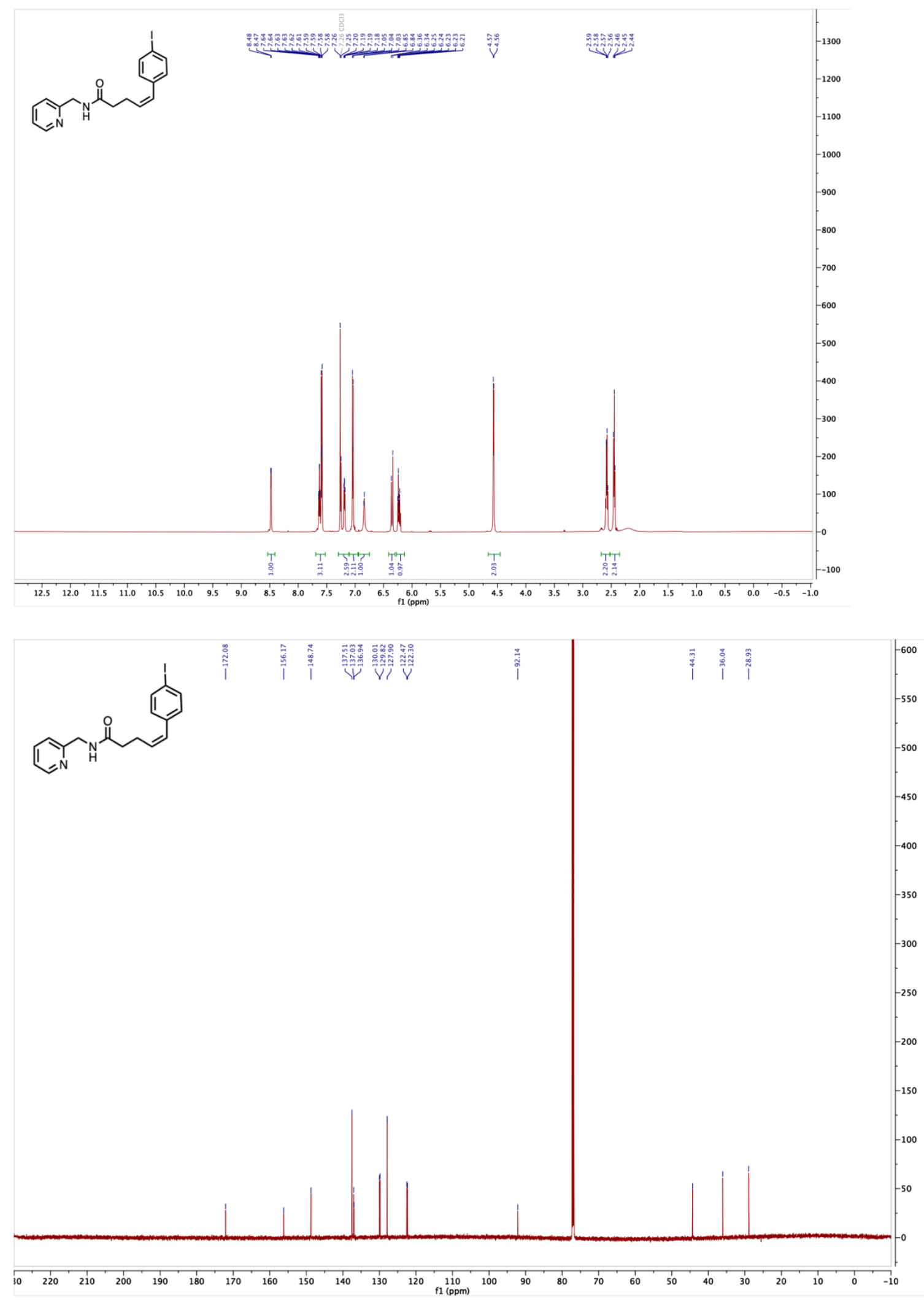

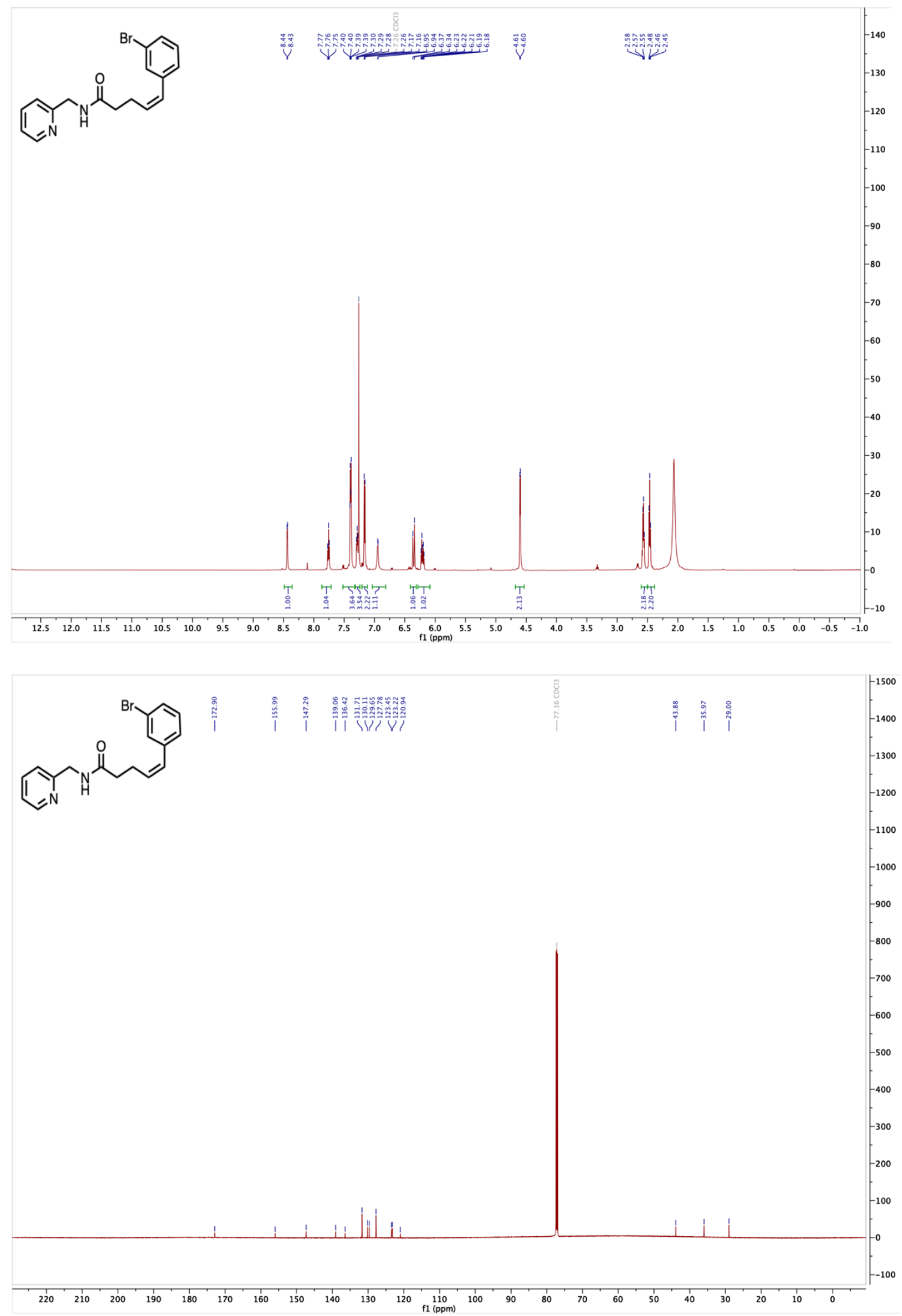

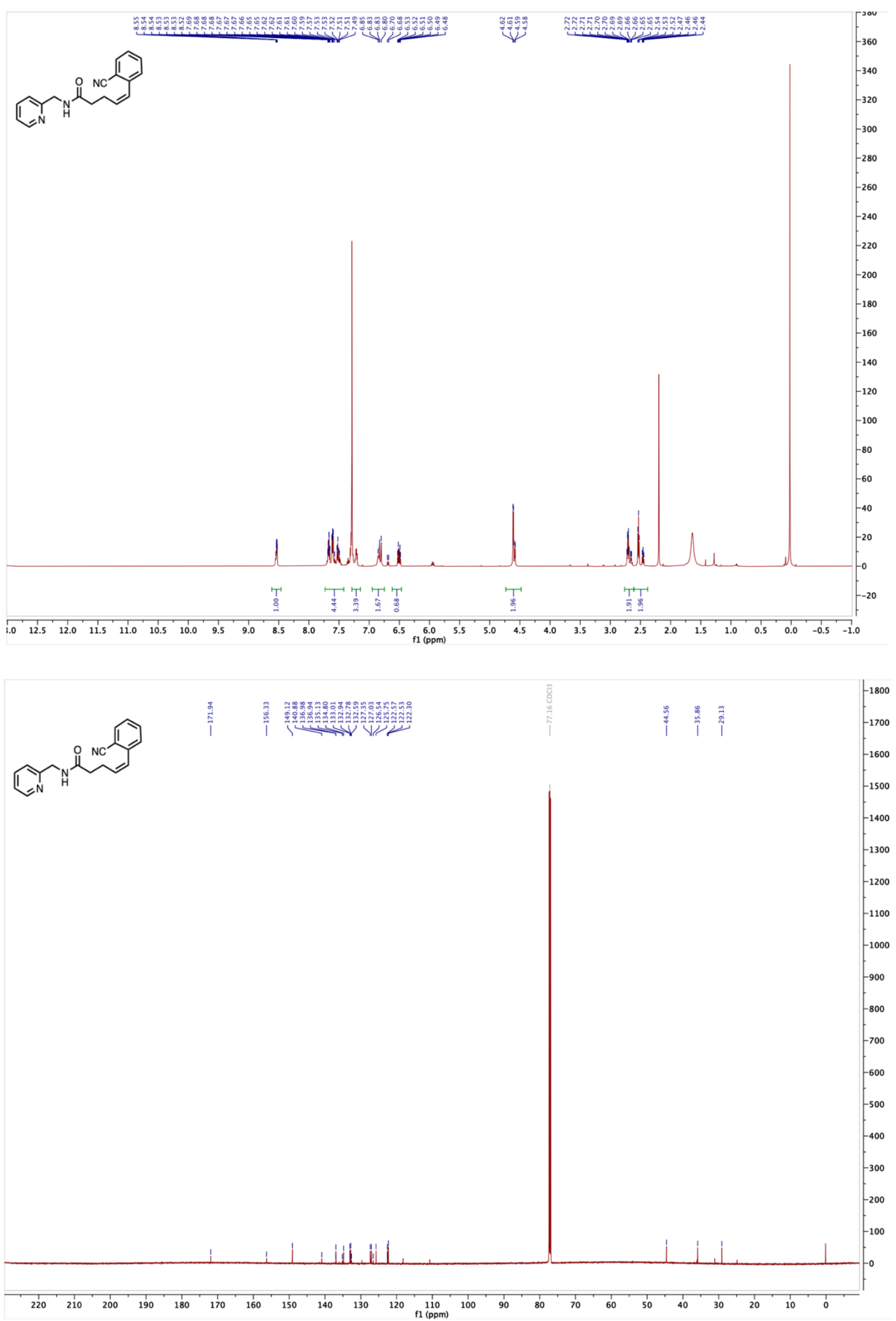


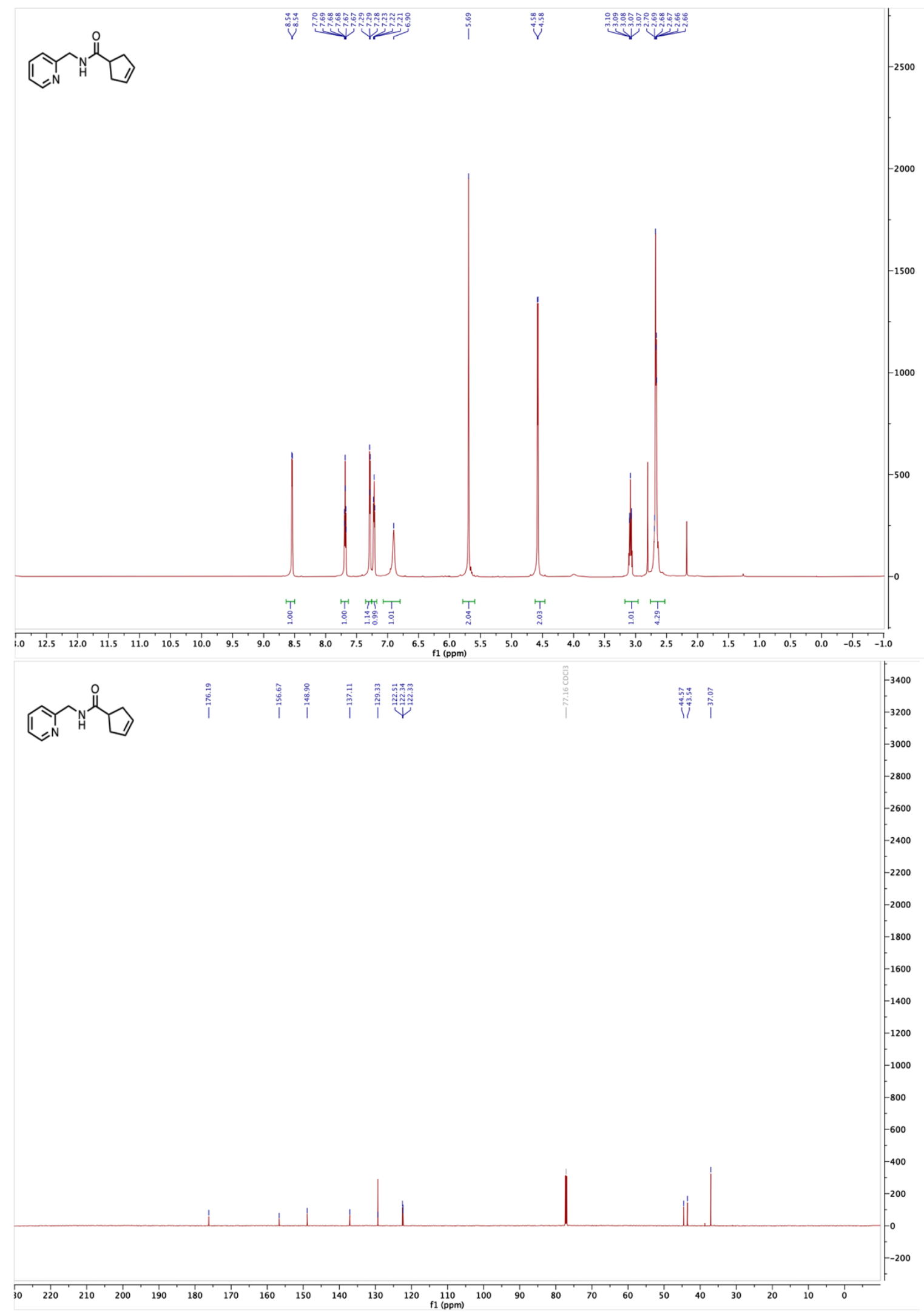



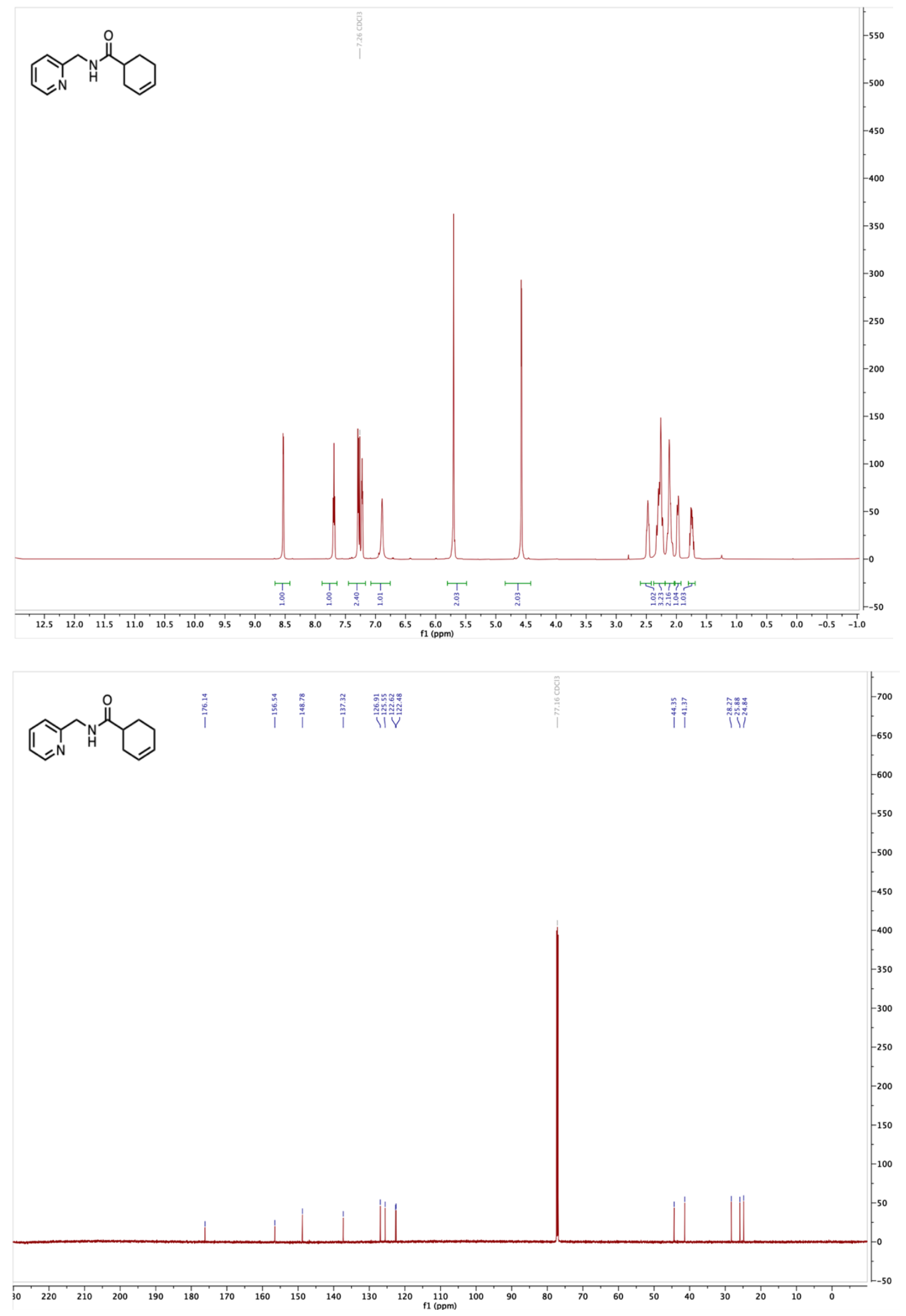

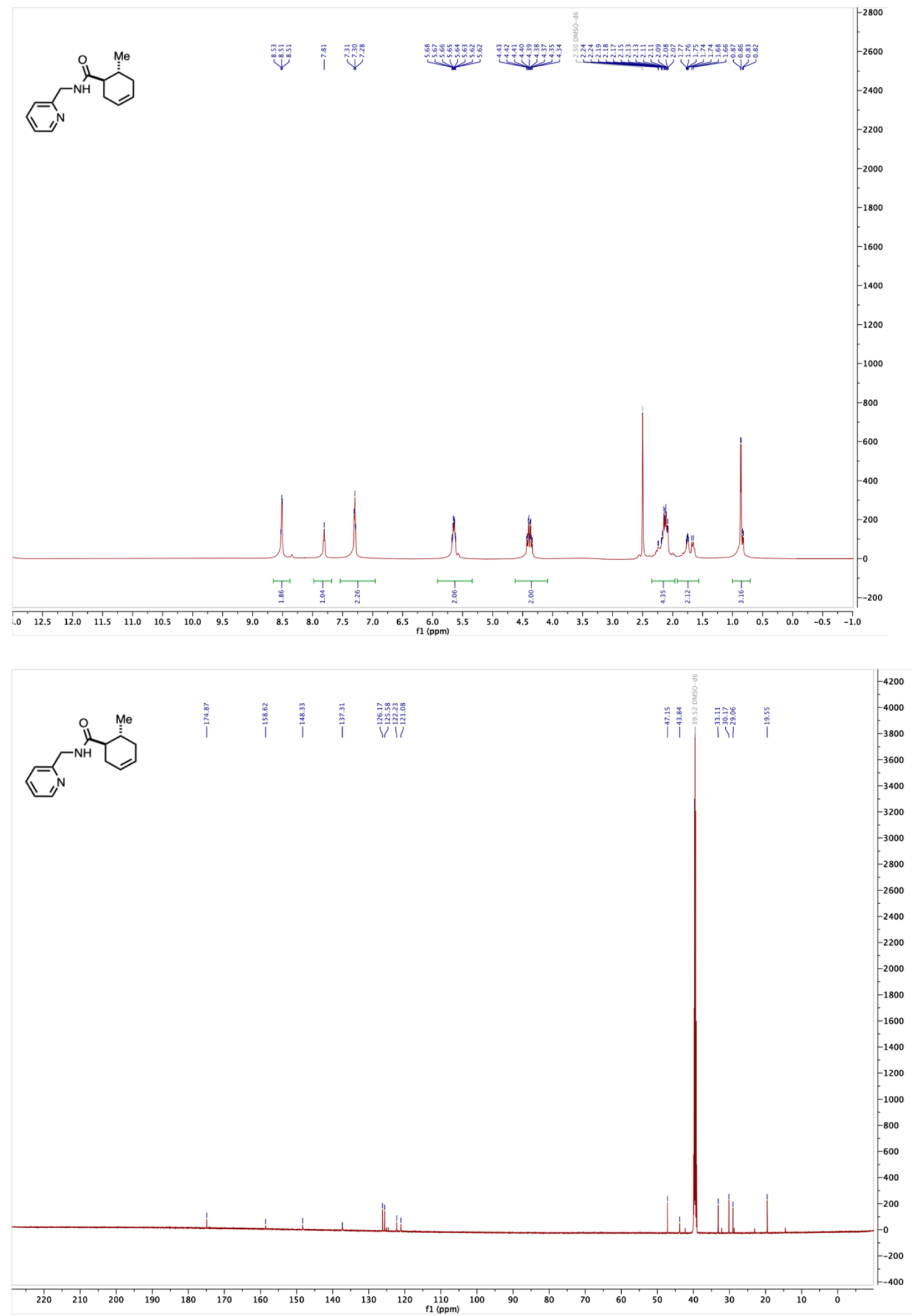


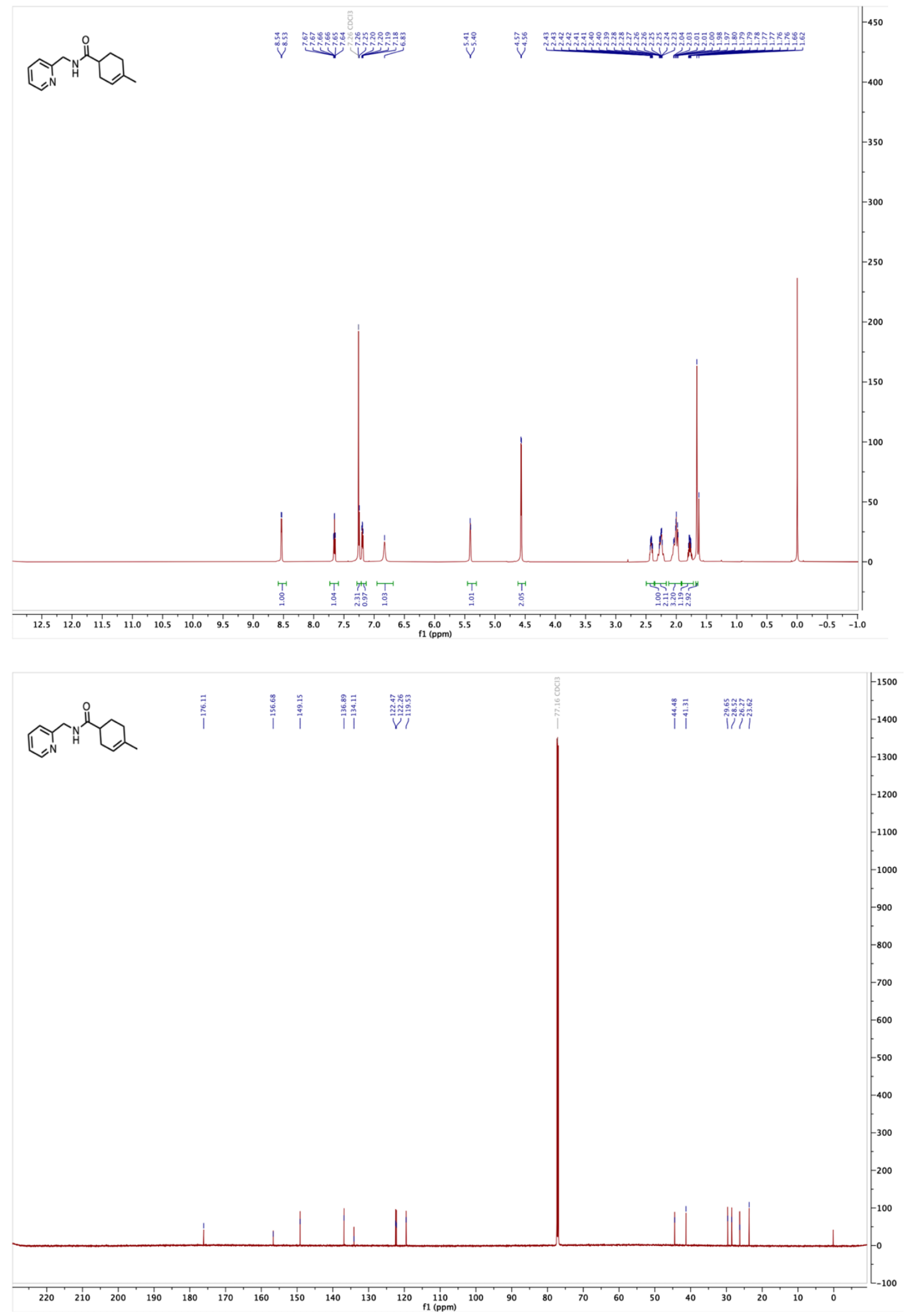

S-122 

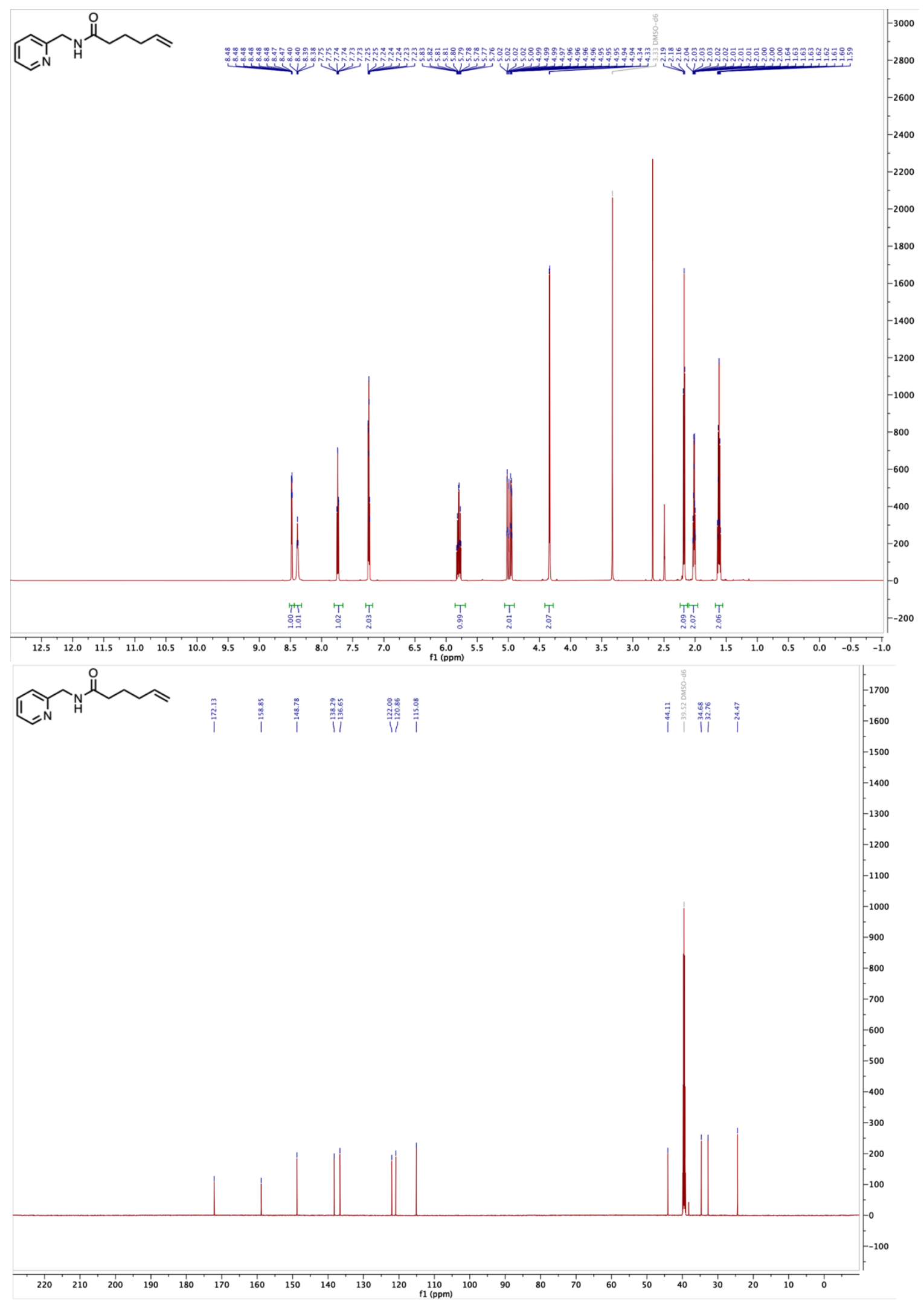

S-123 

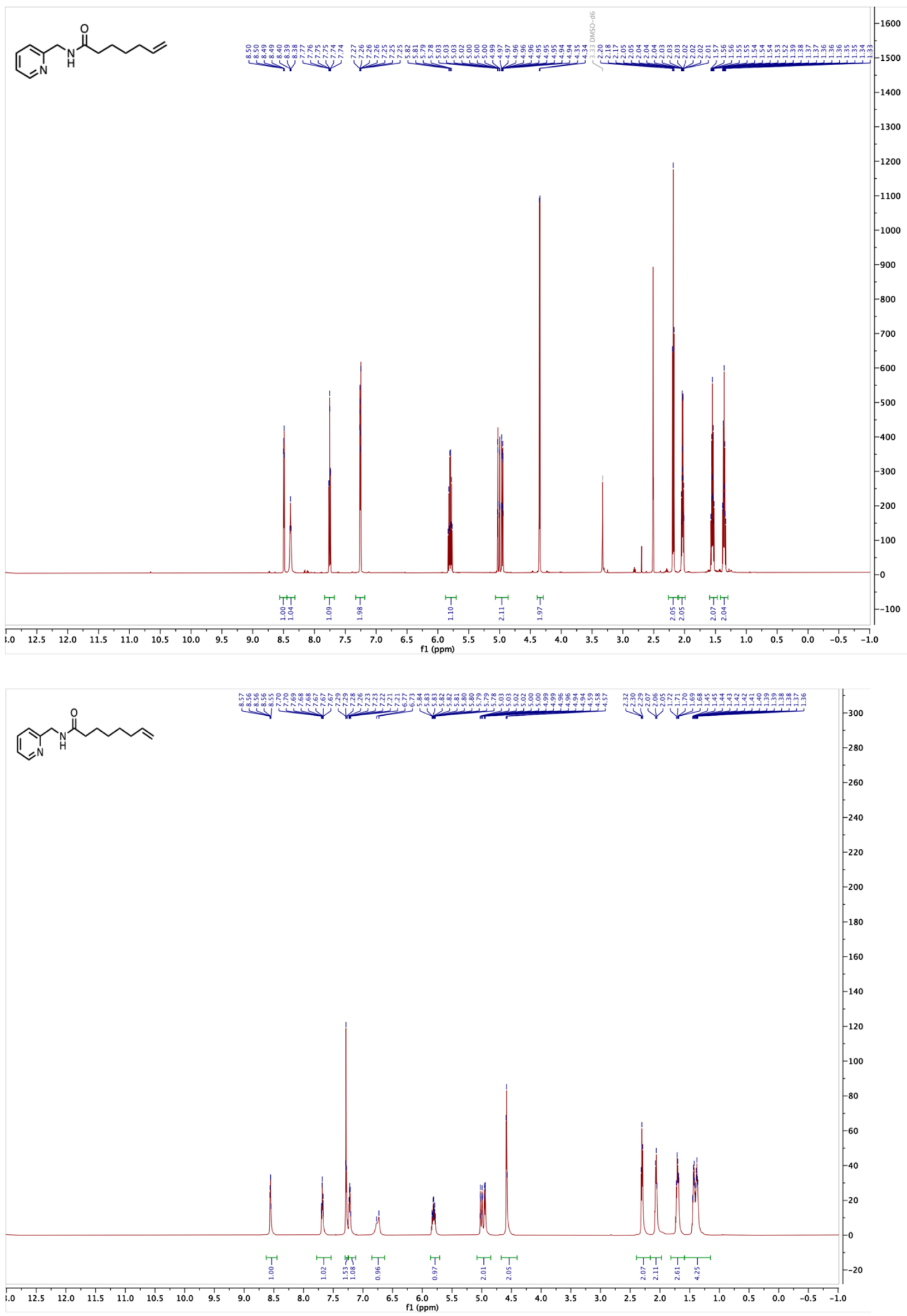

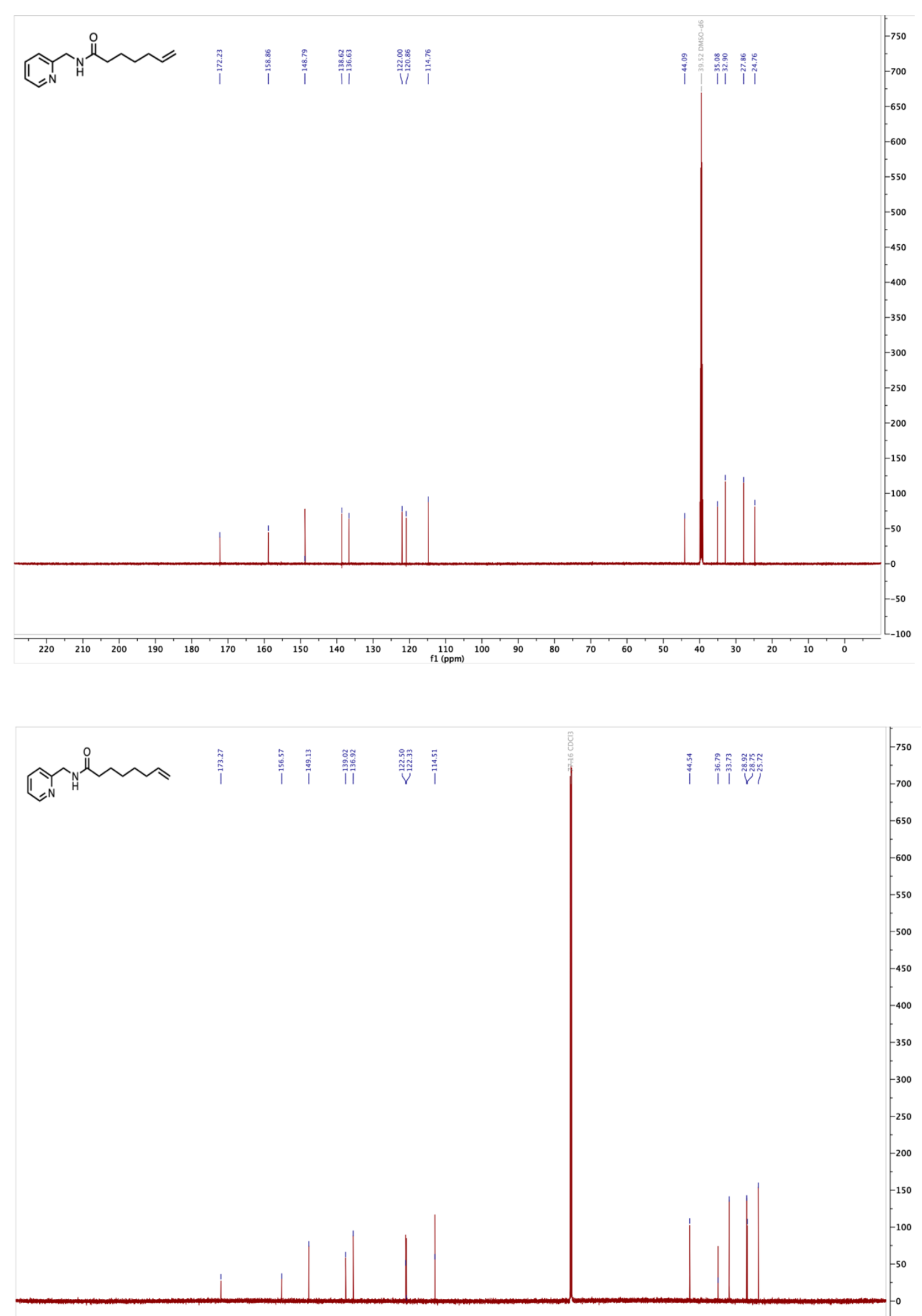

S-125 


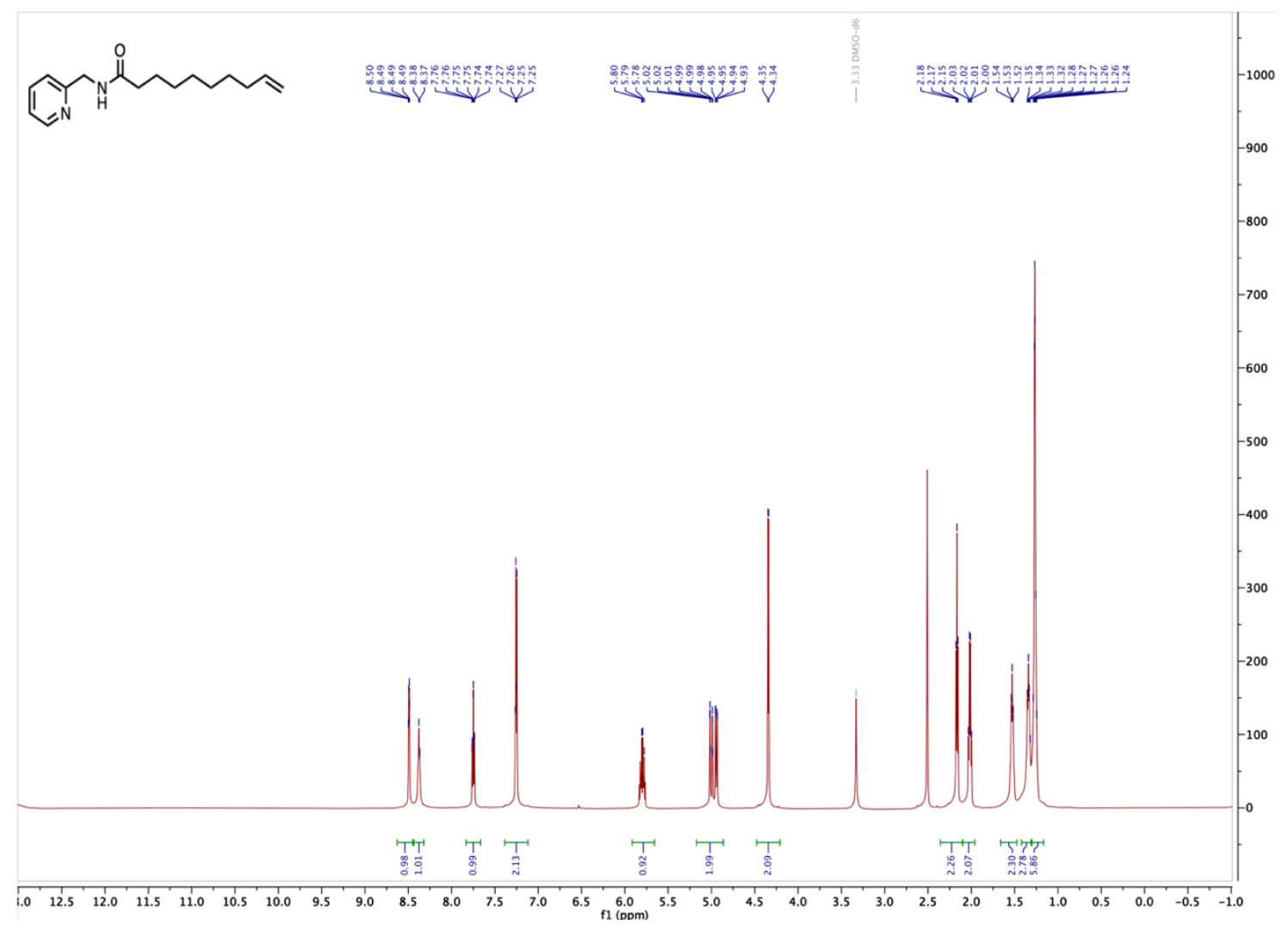

S-126 

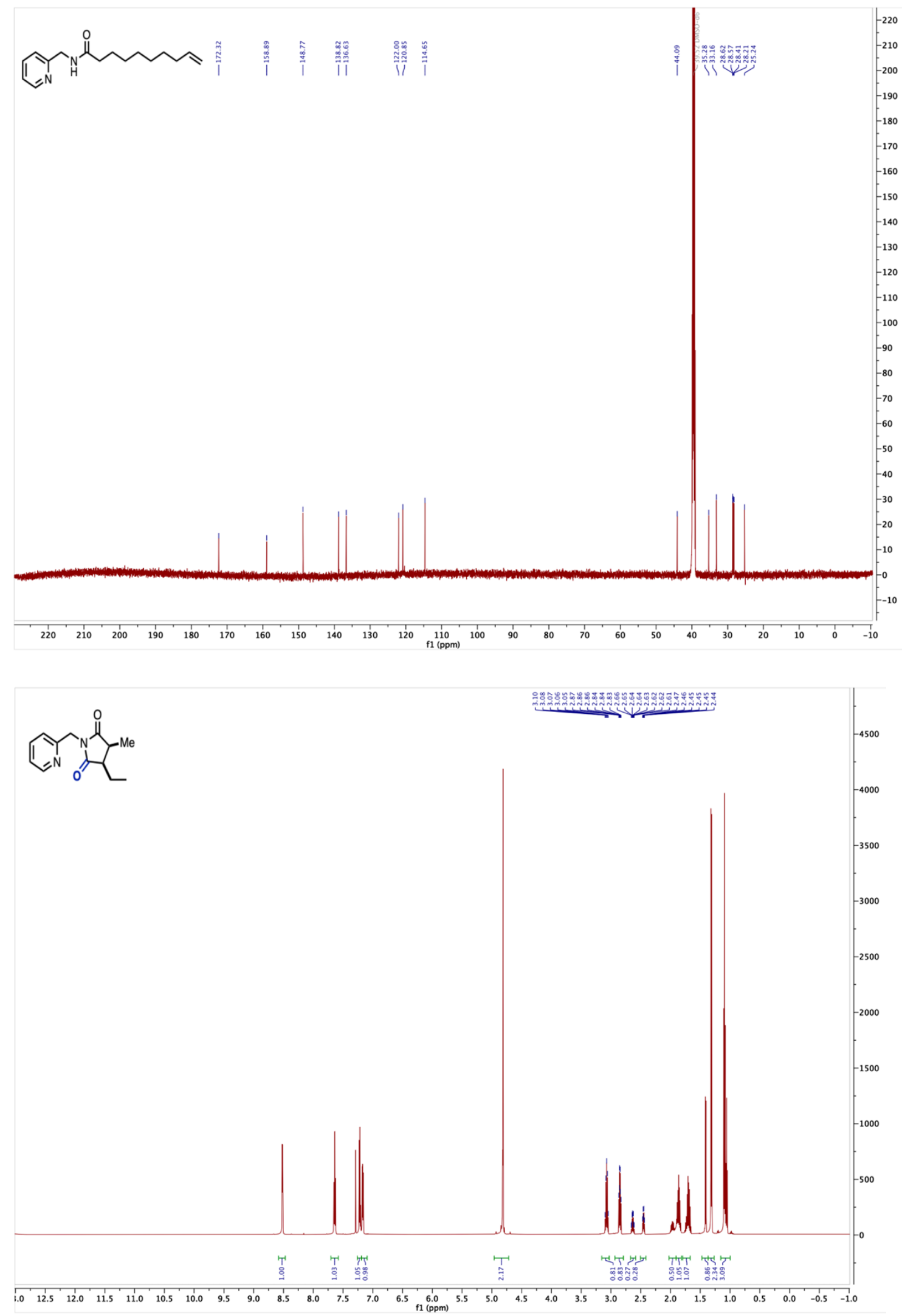

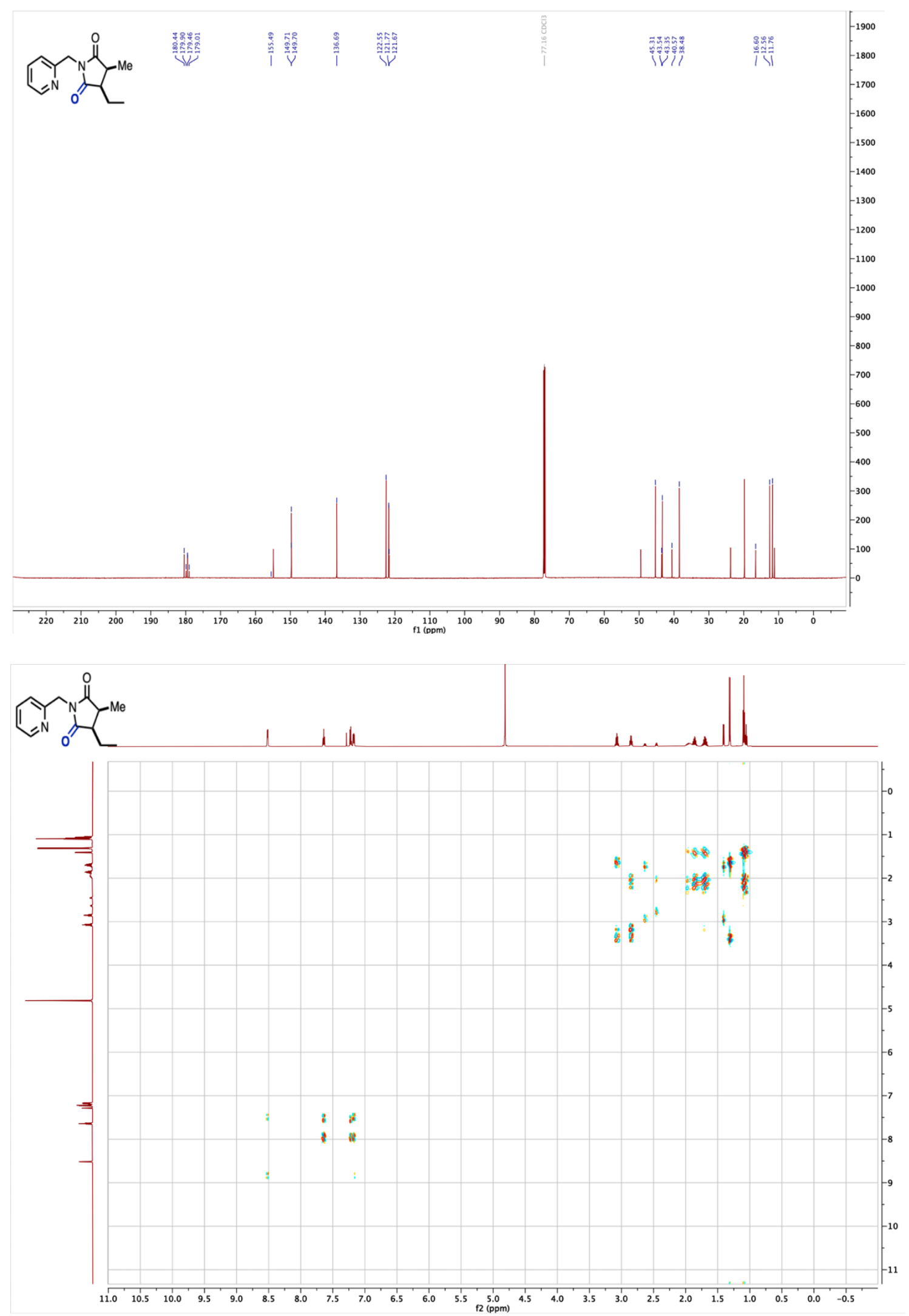

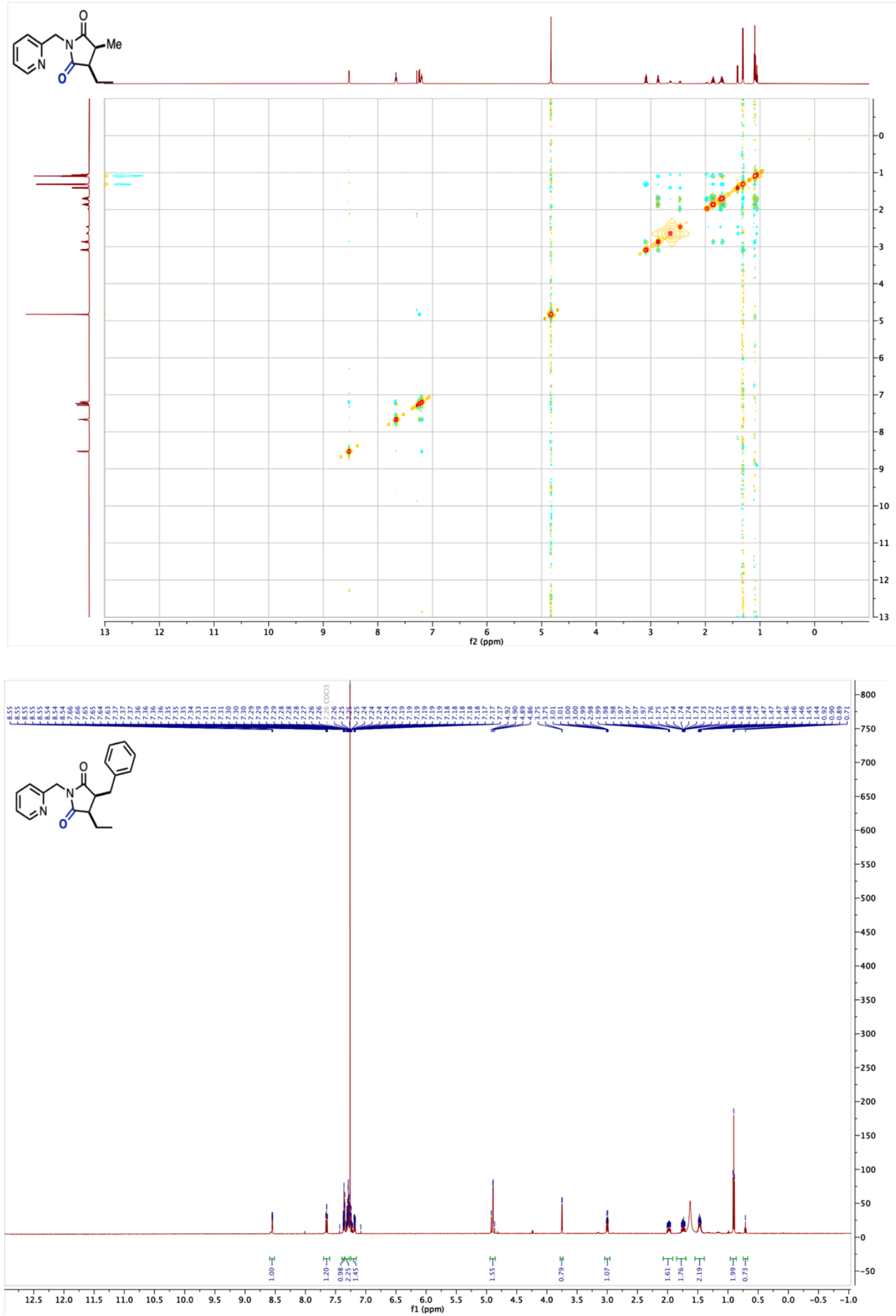

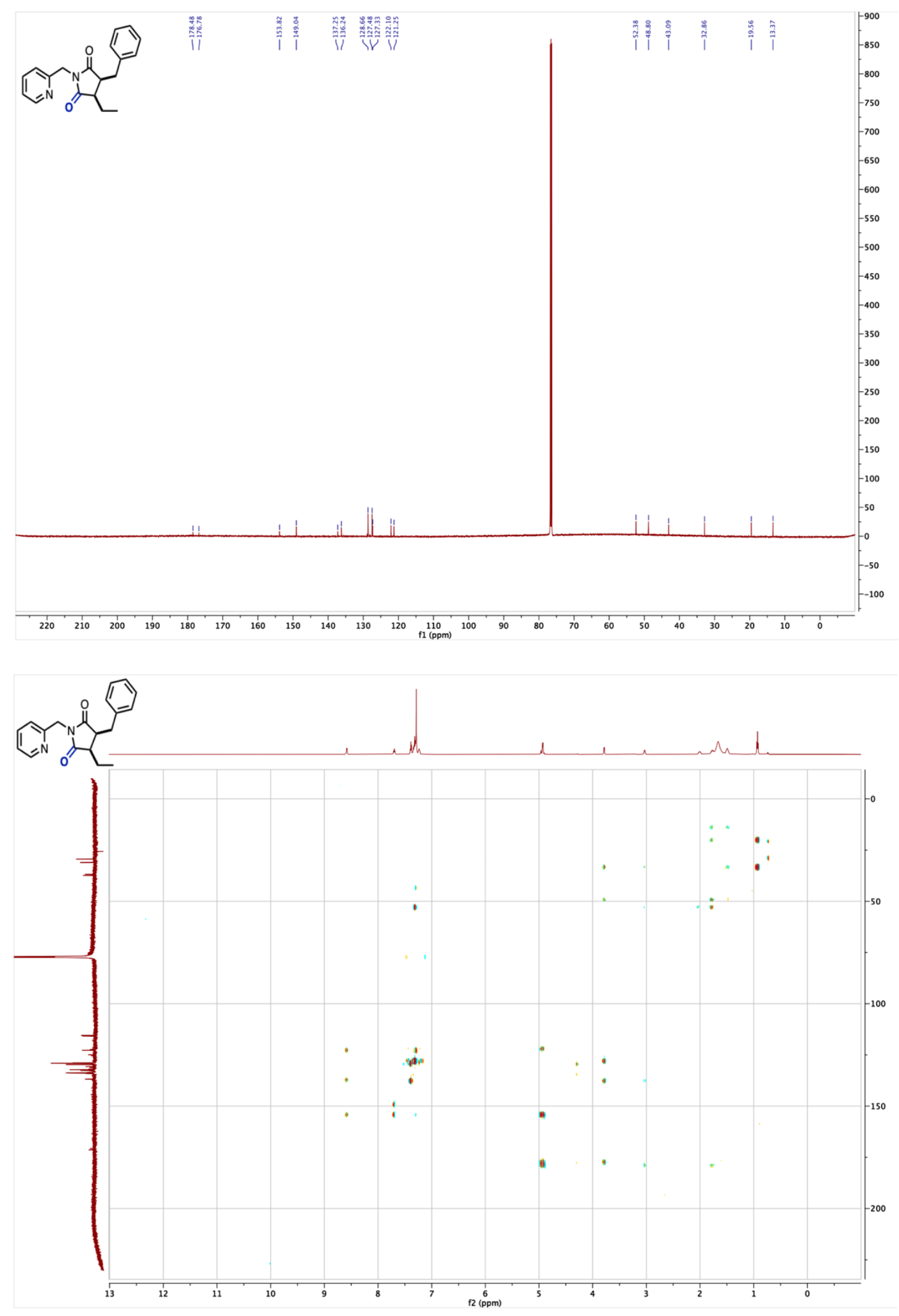

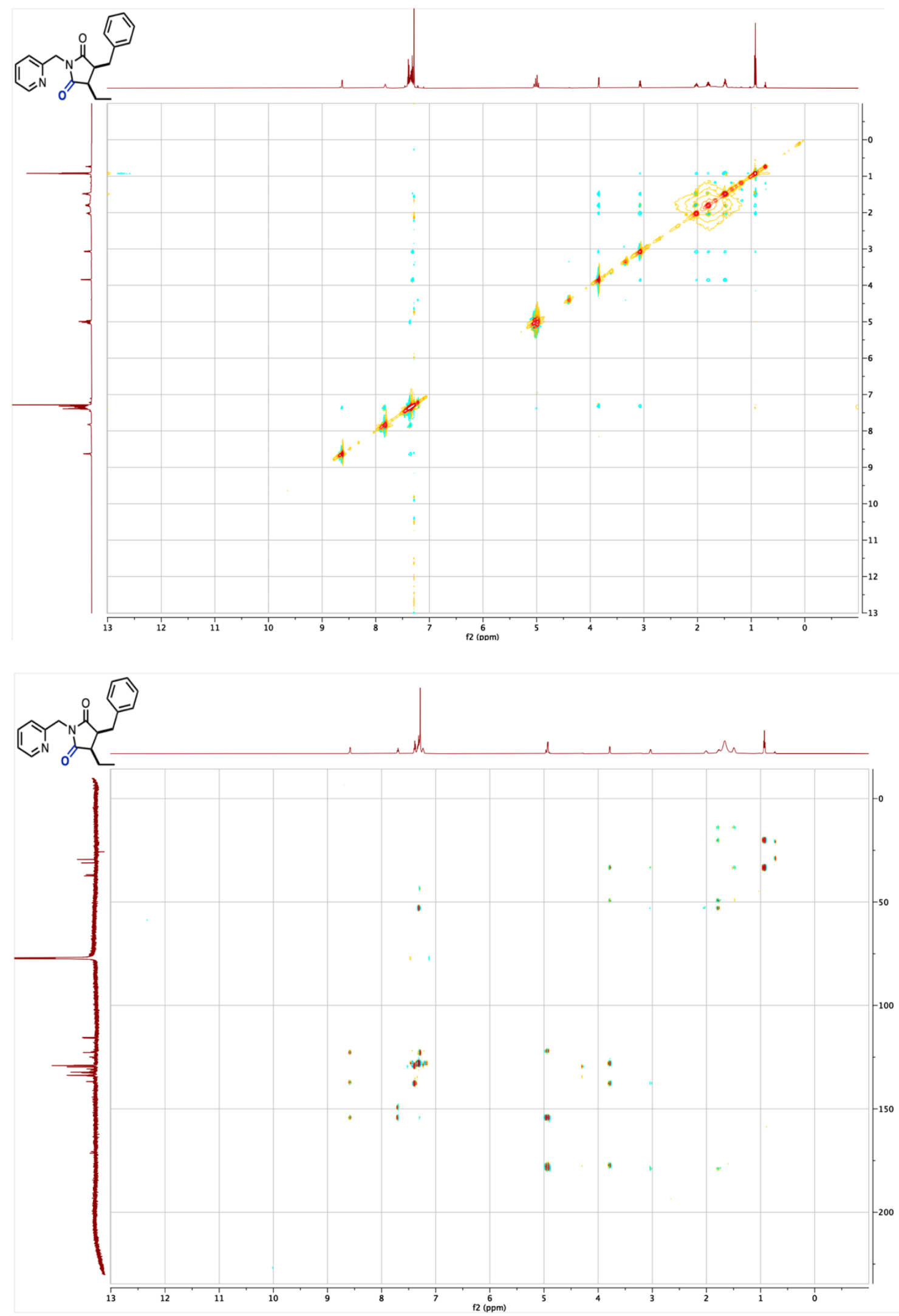

S-131 

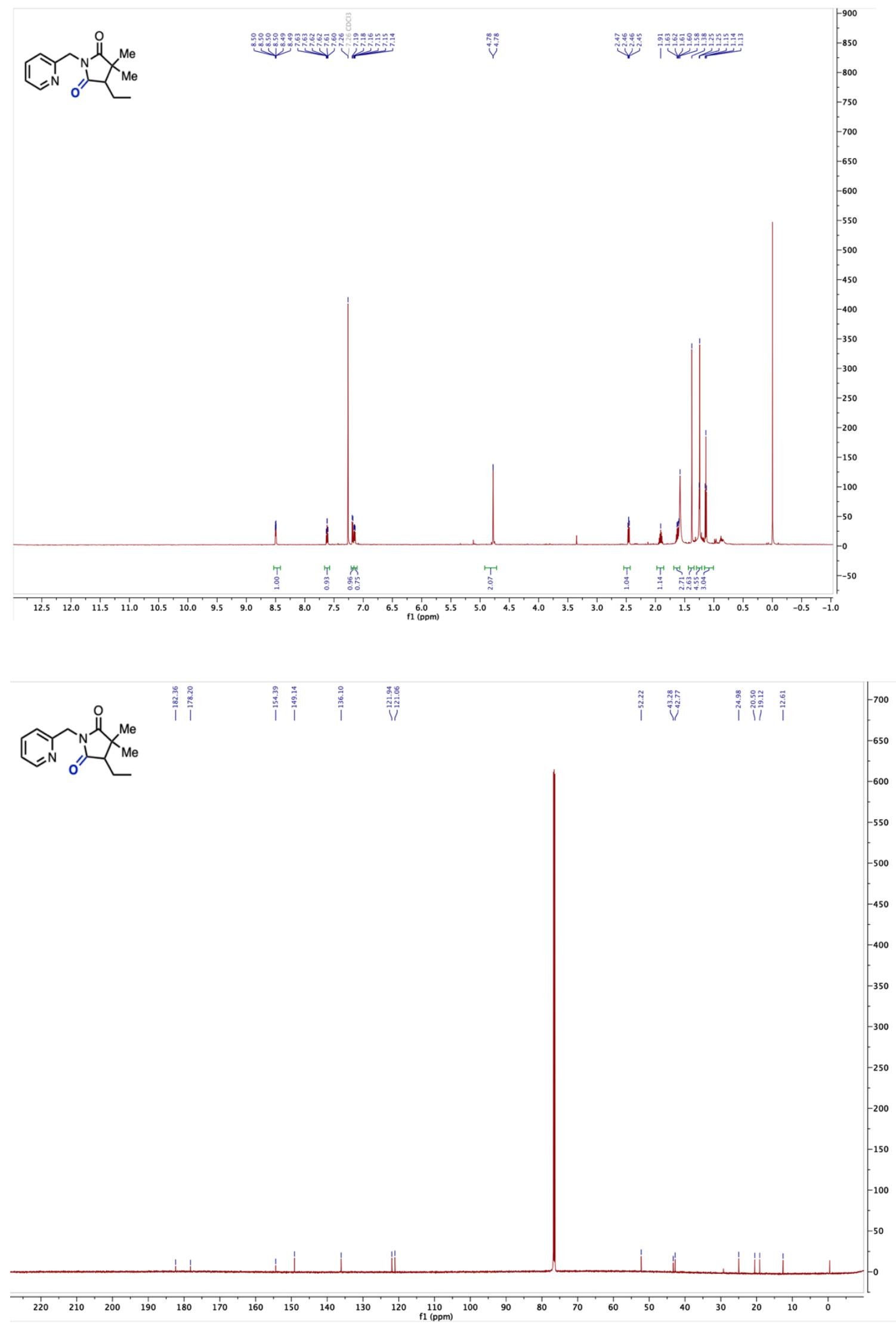

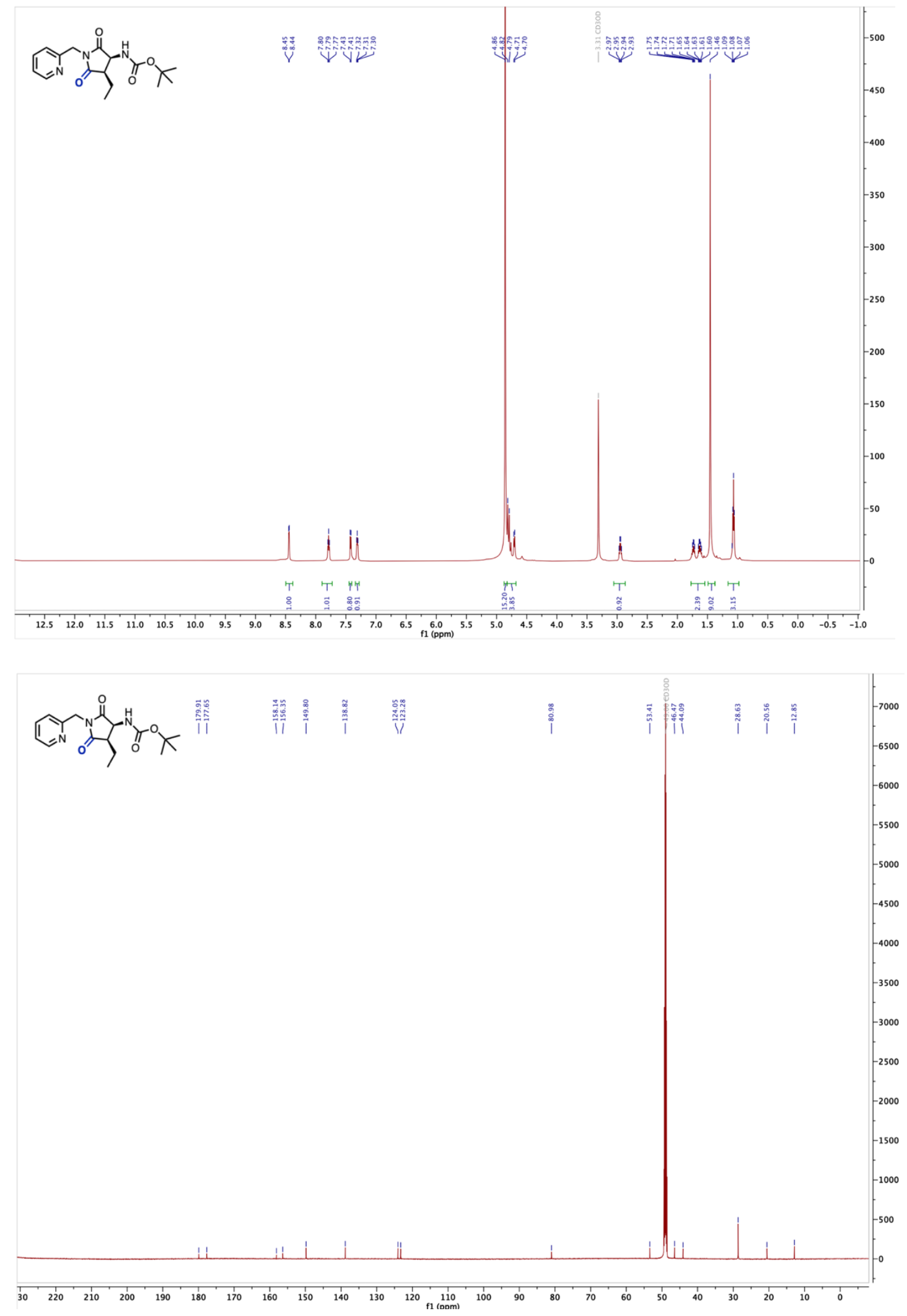

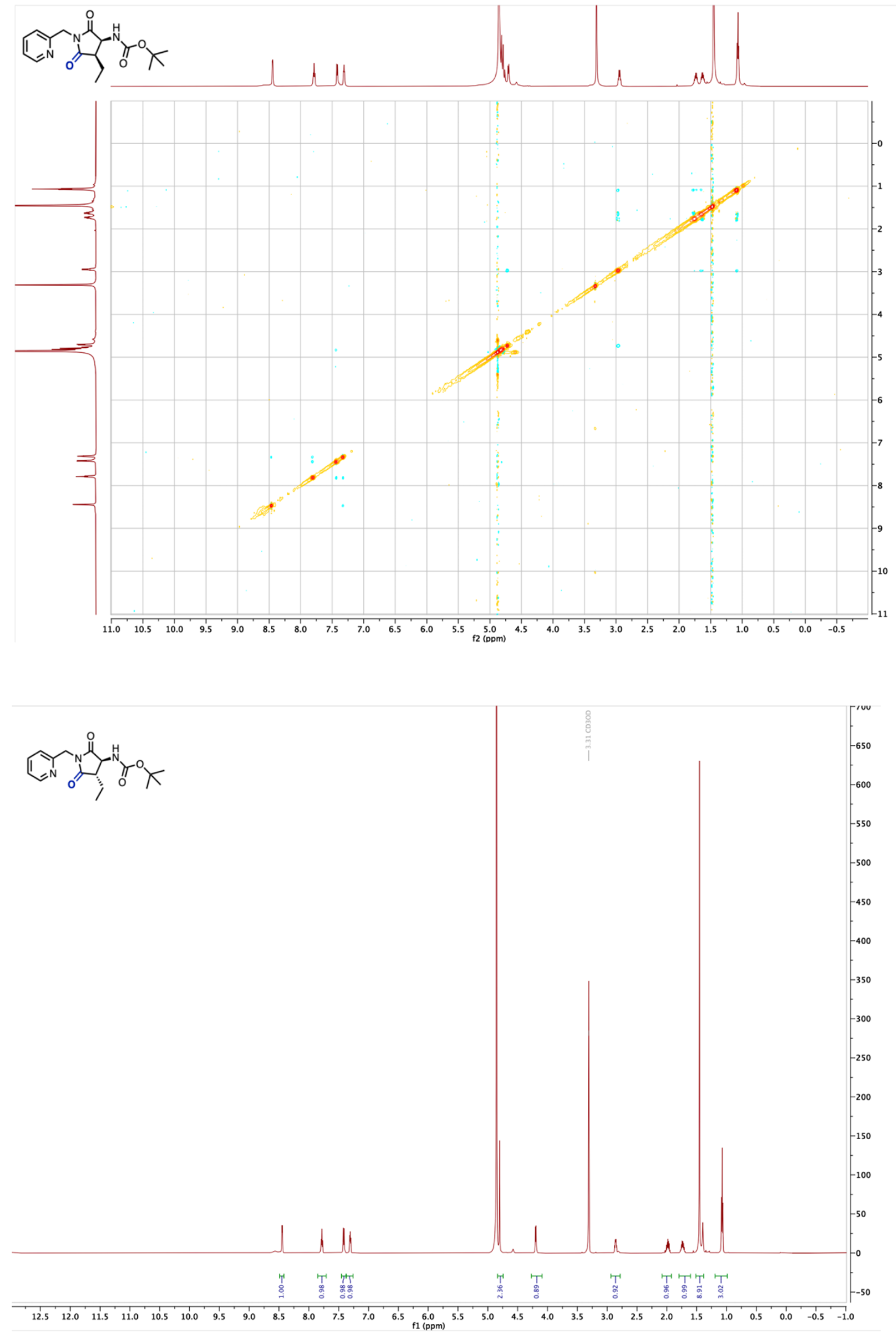

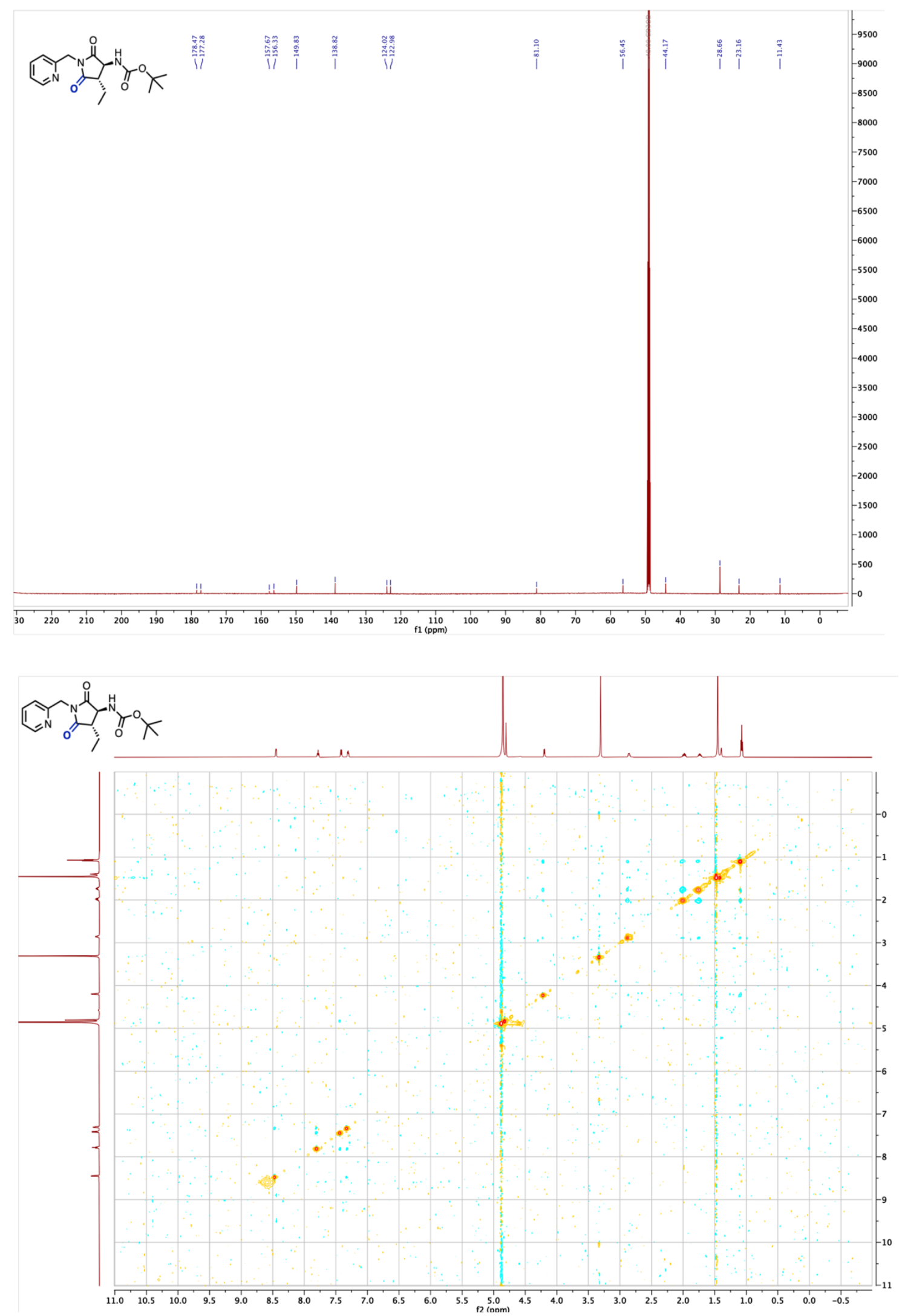

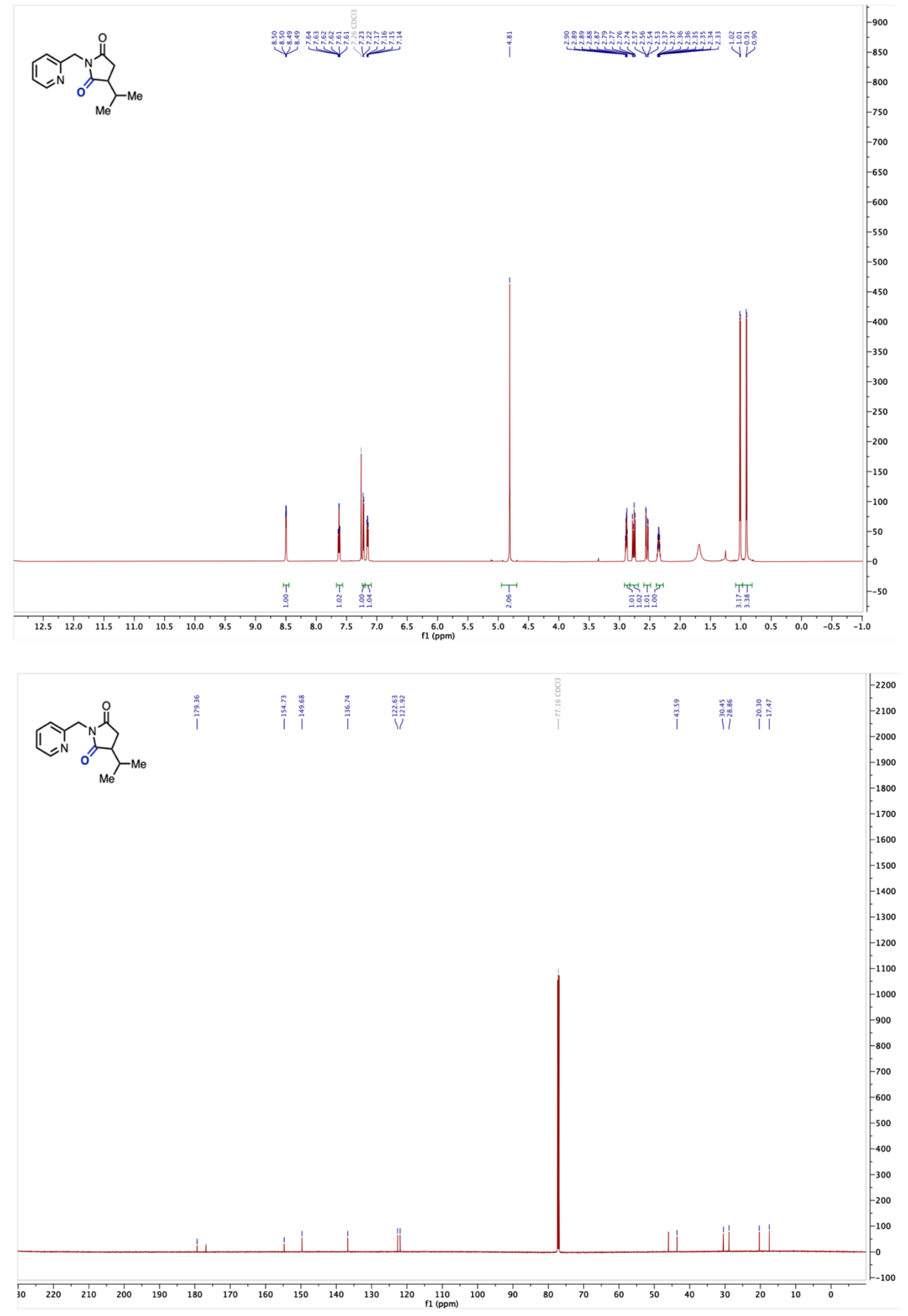

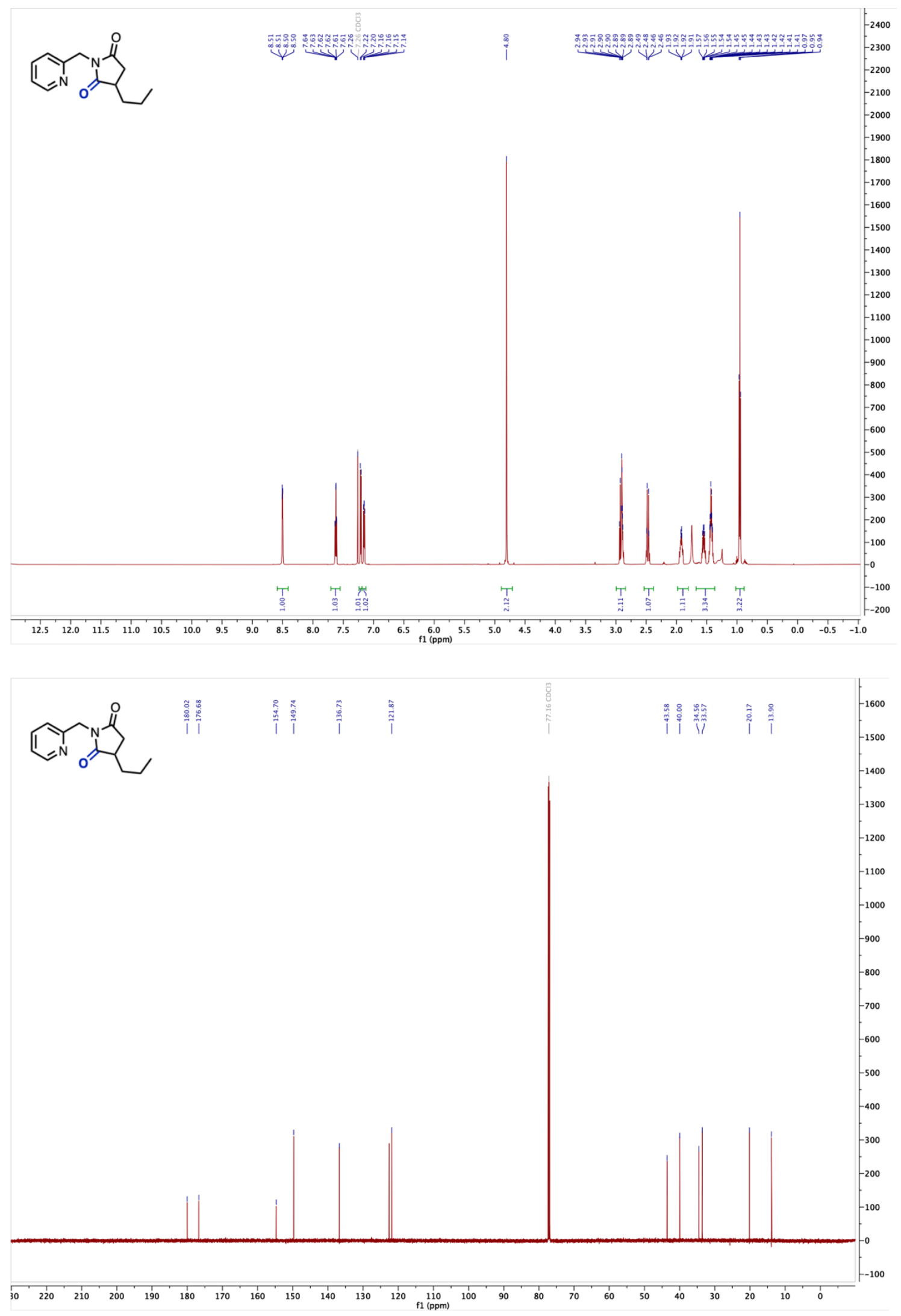

S-137 

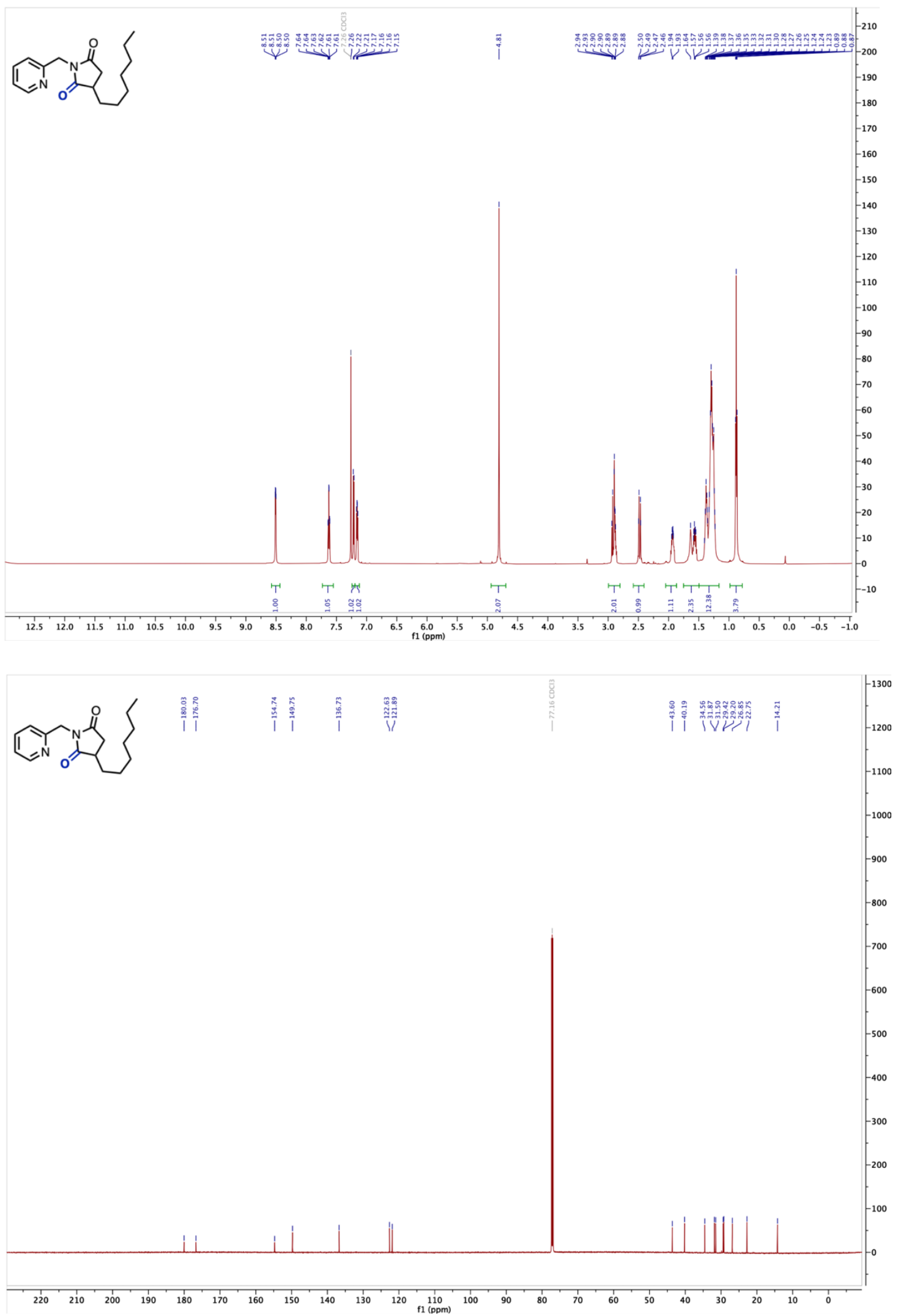

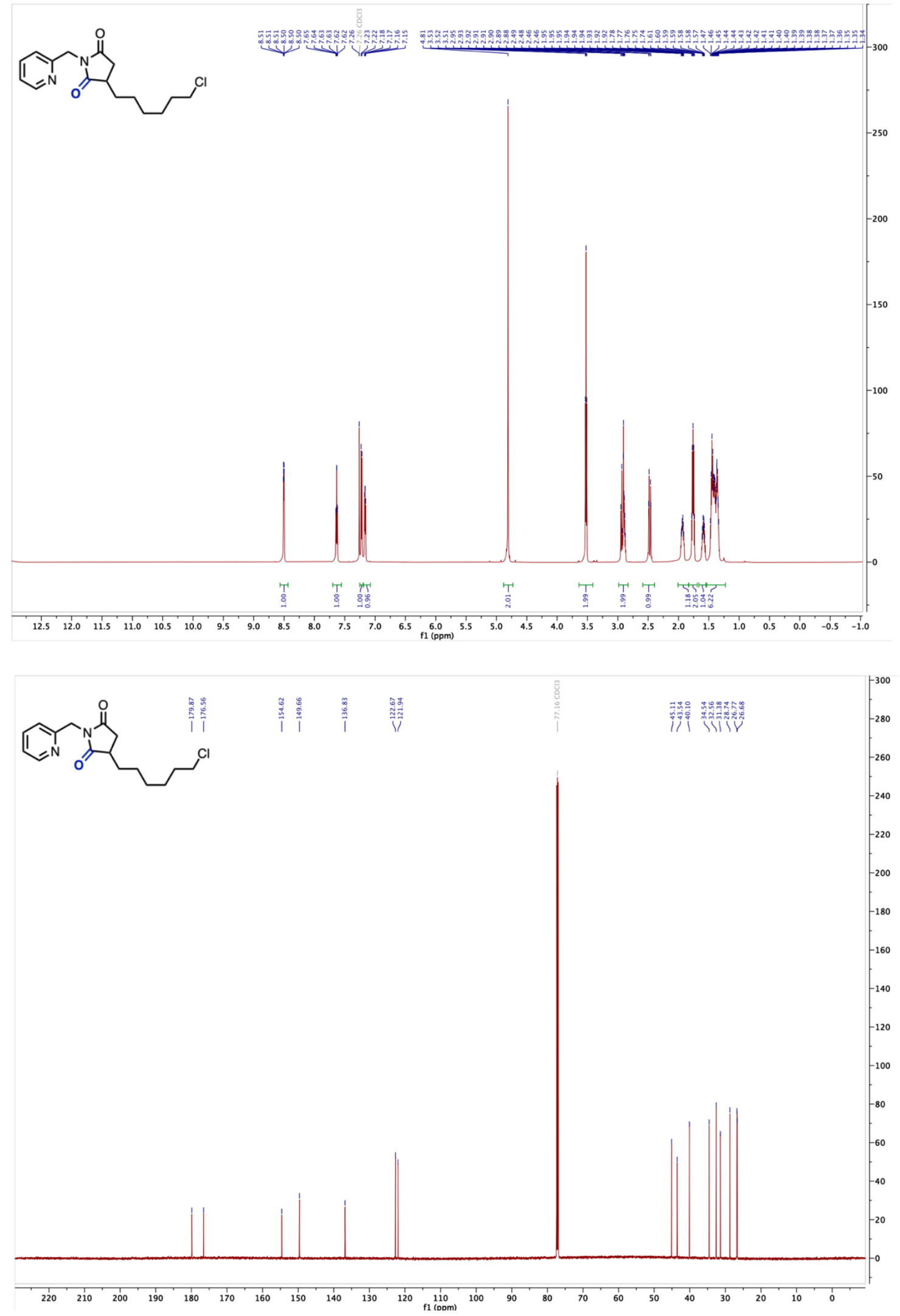

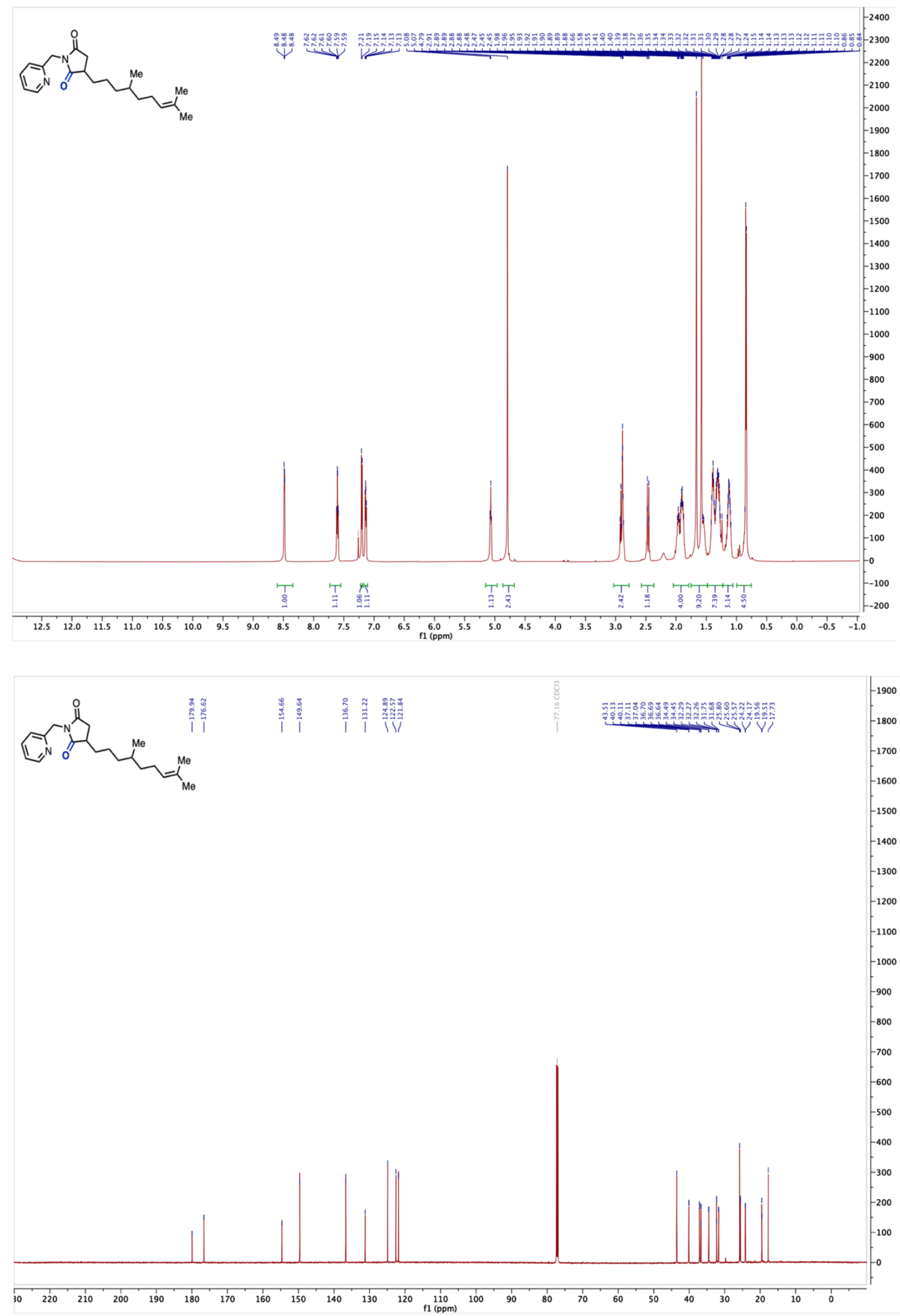

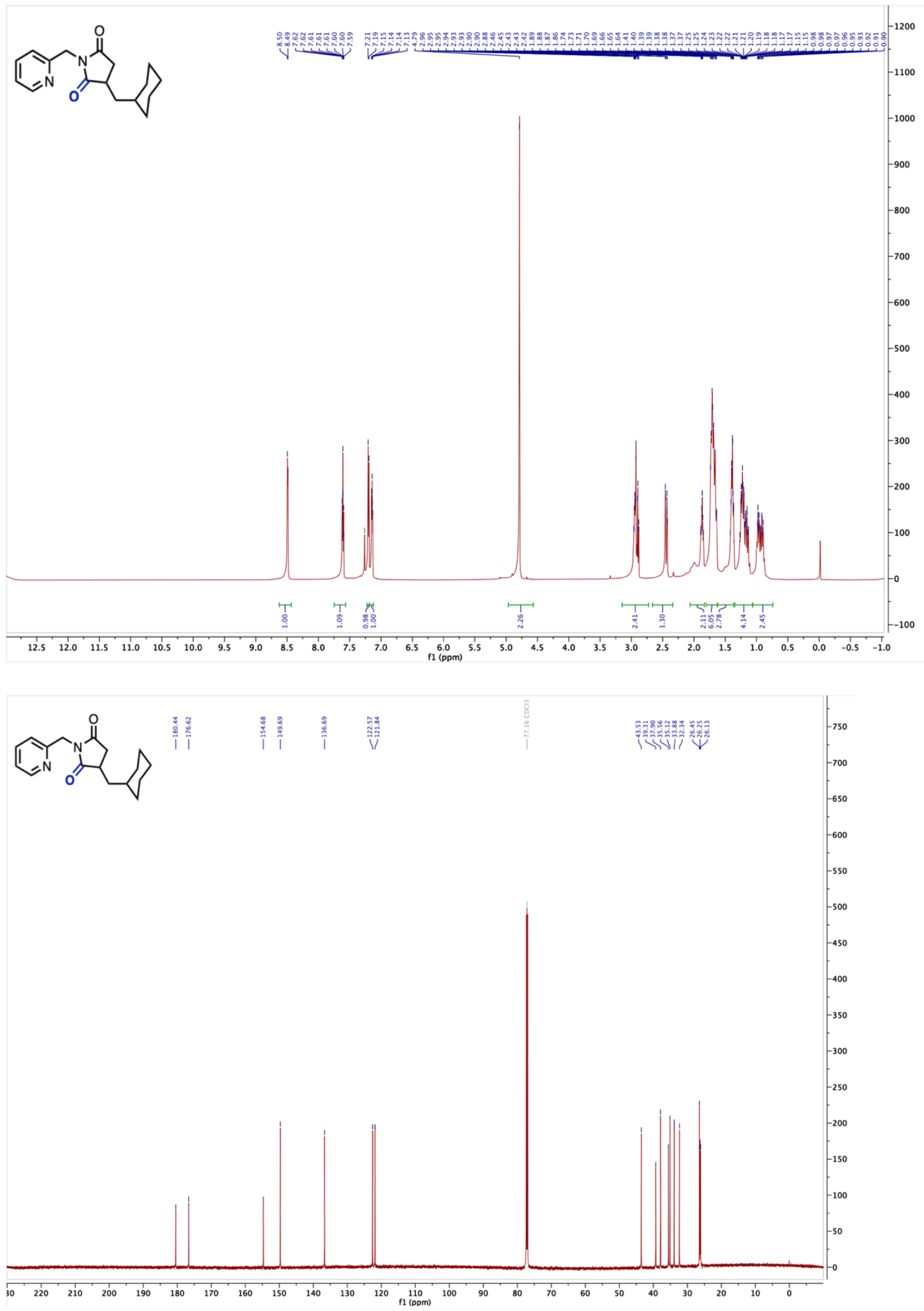


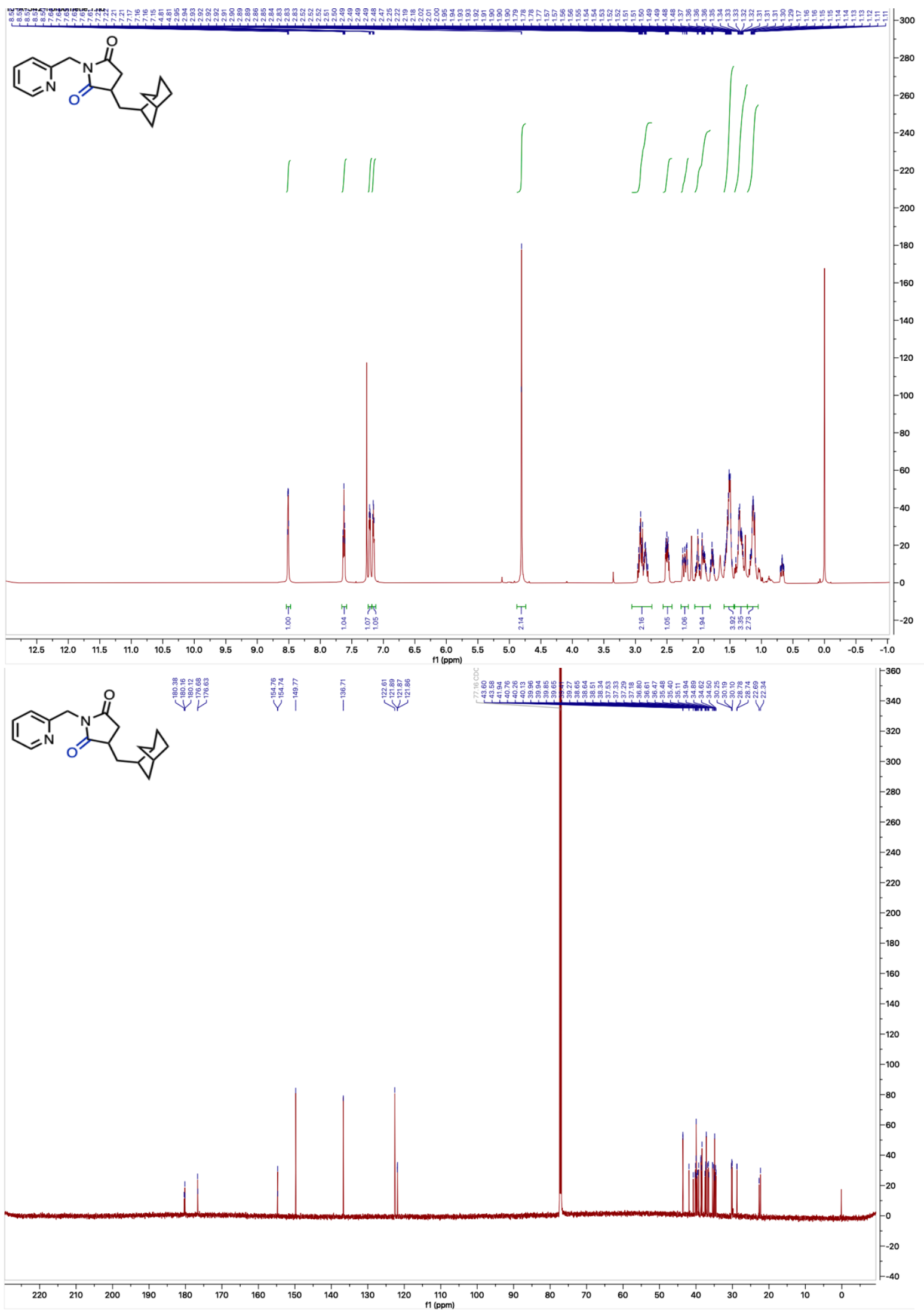




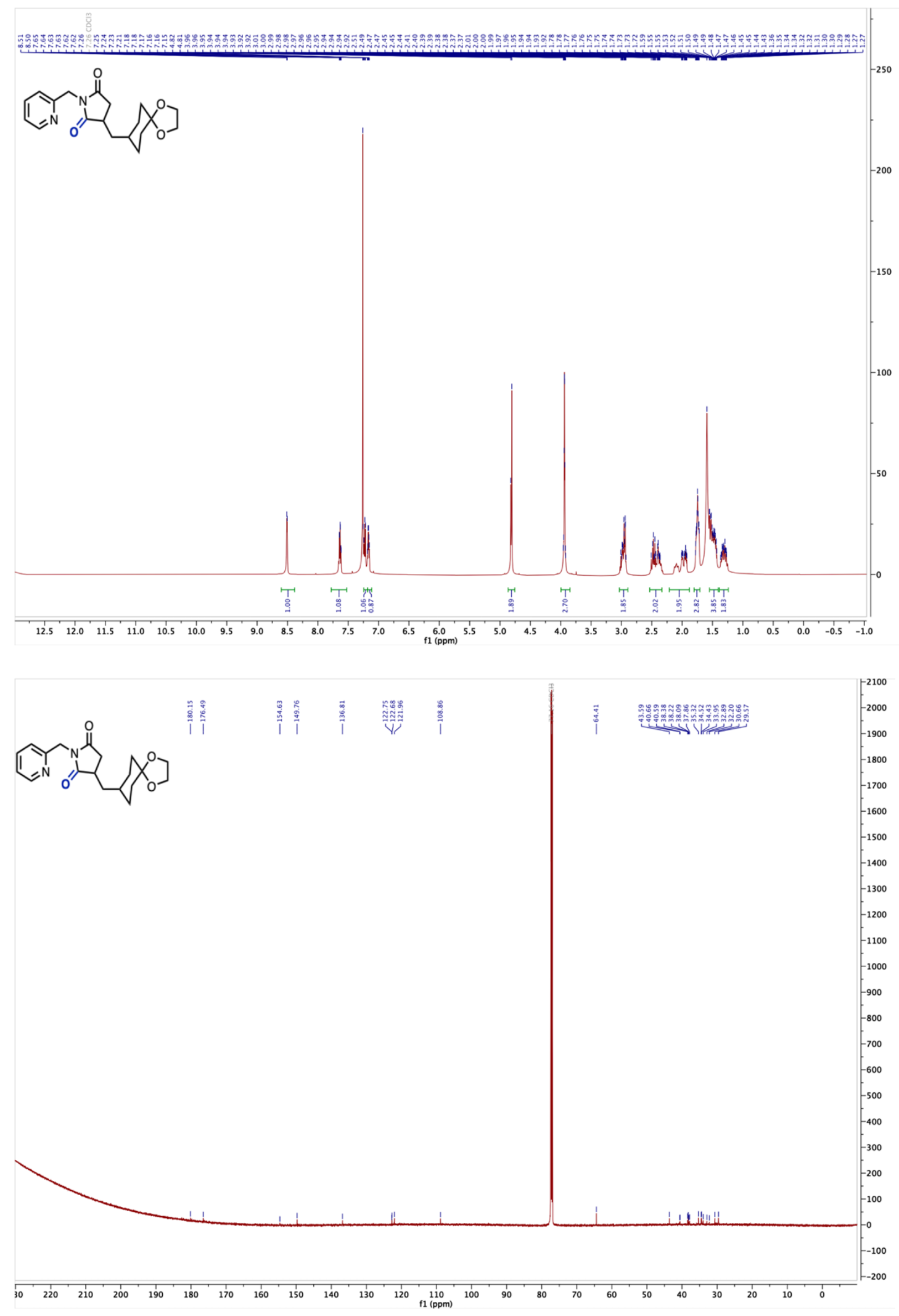



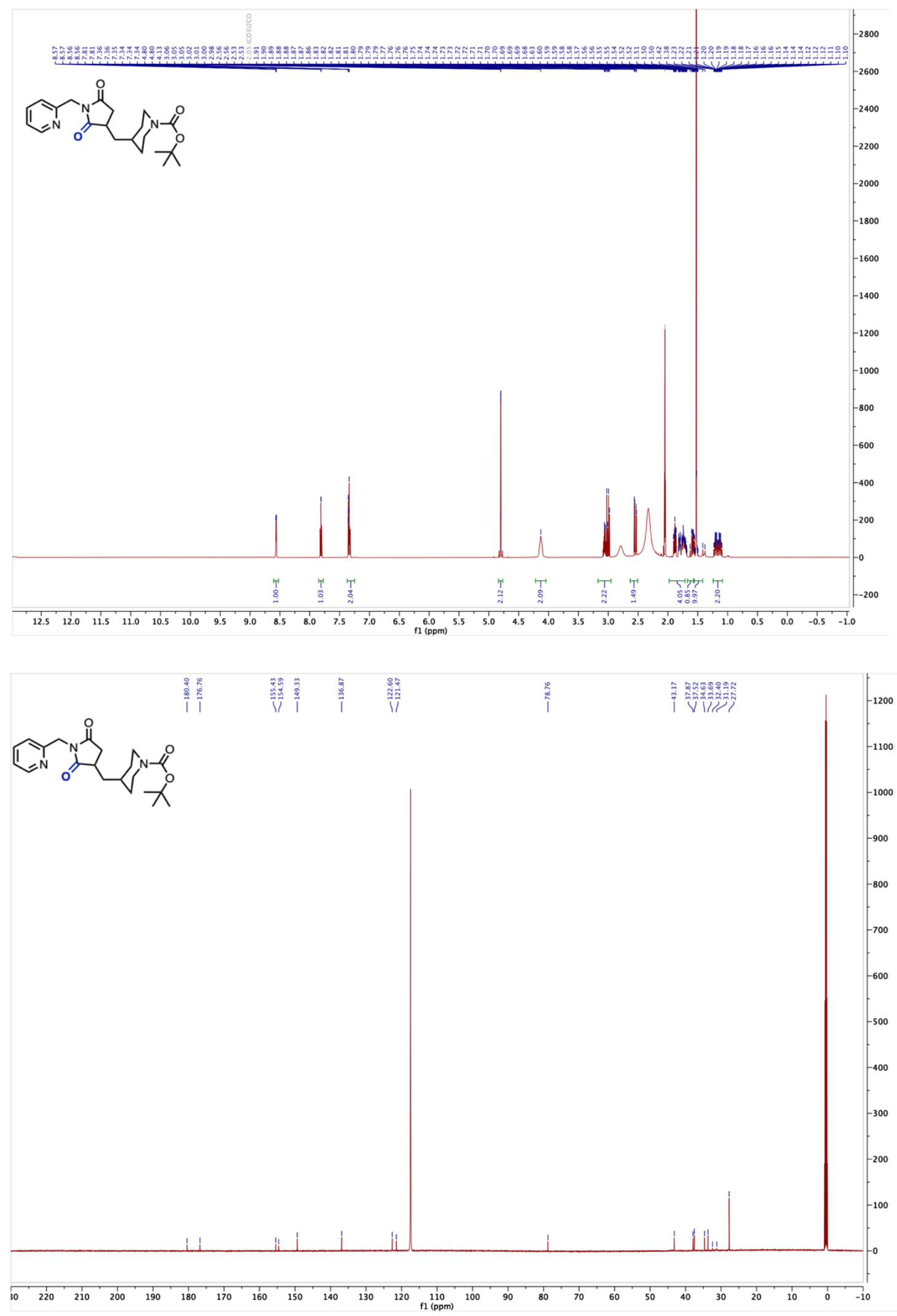


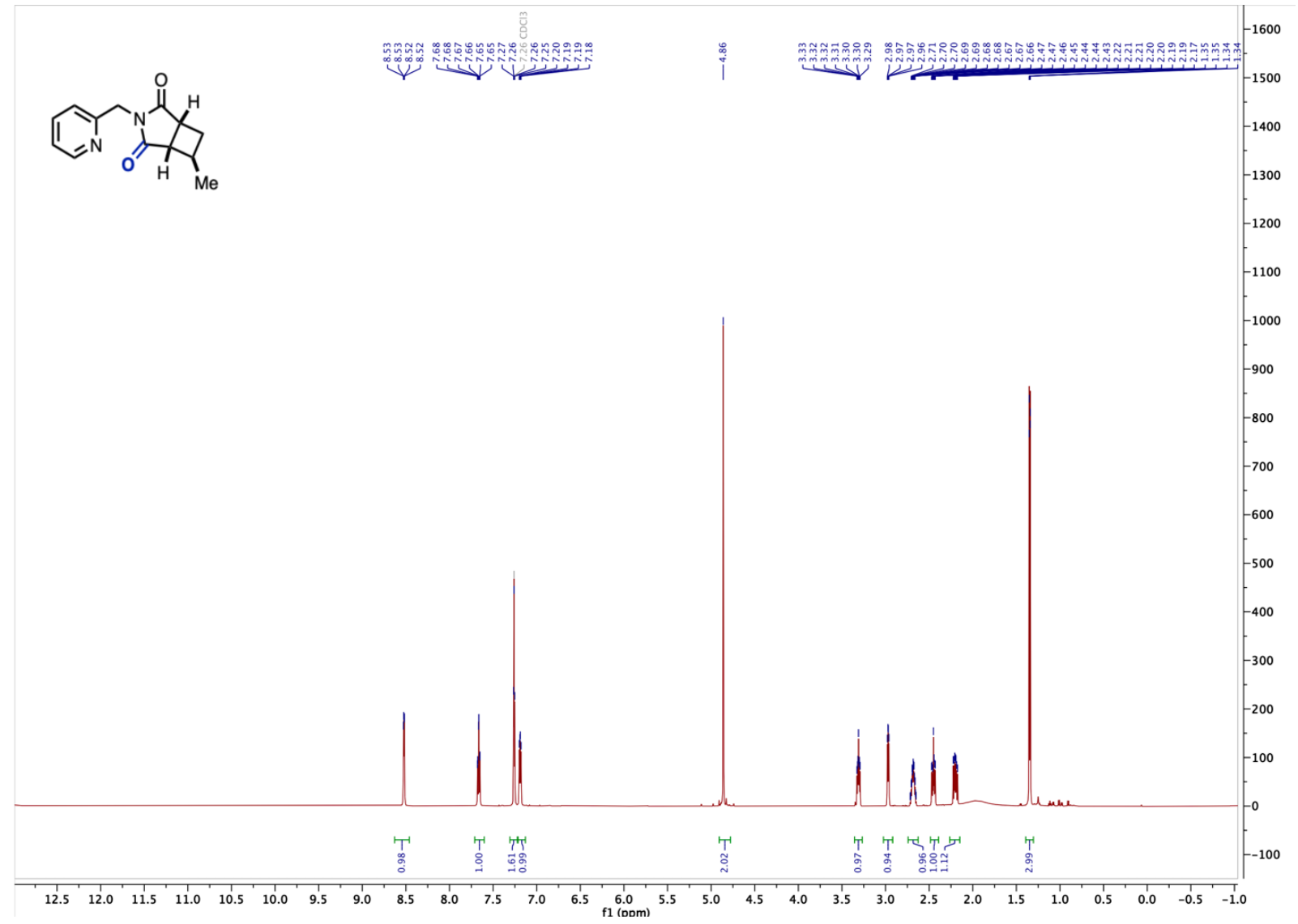

S-145 

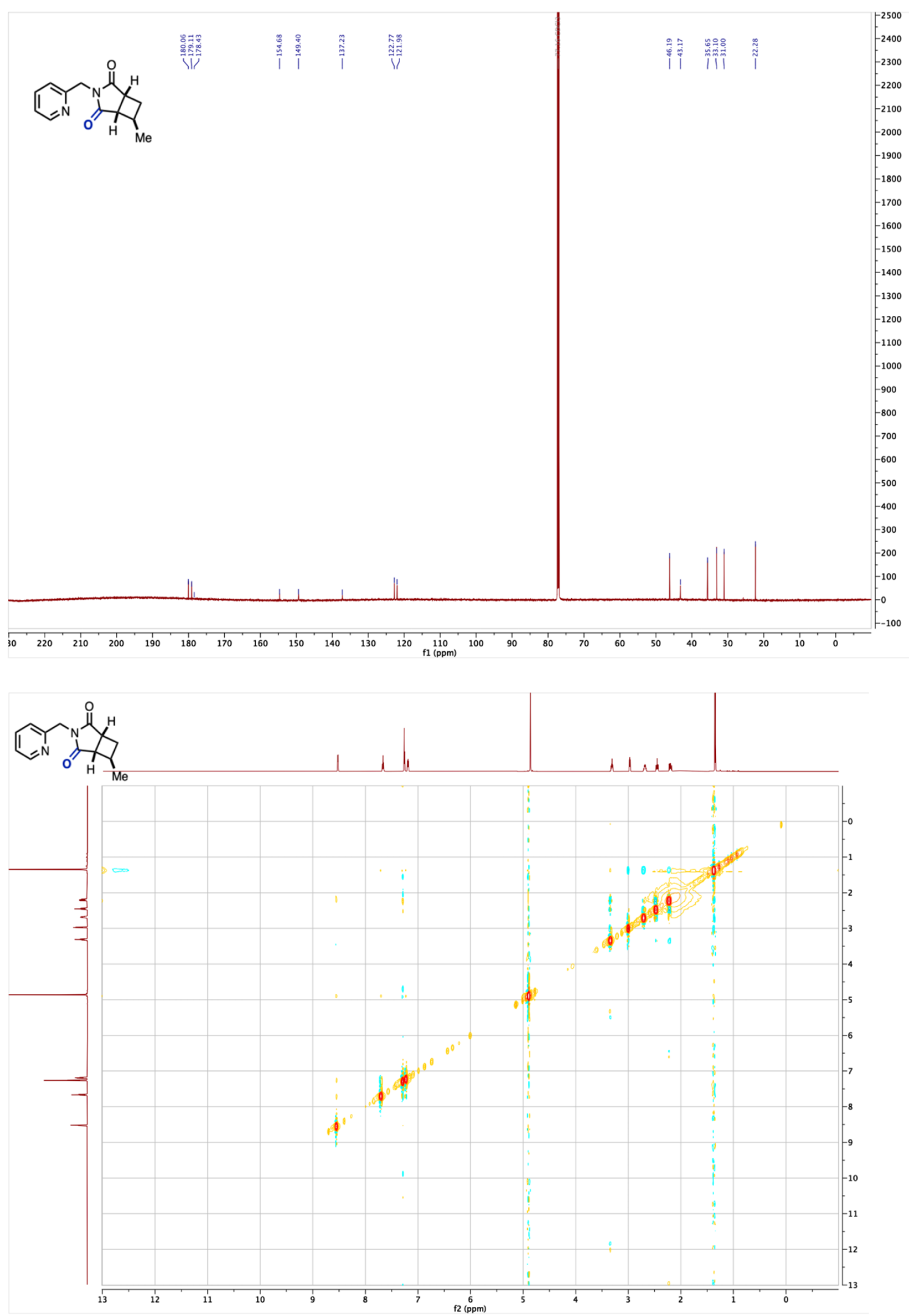

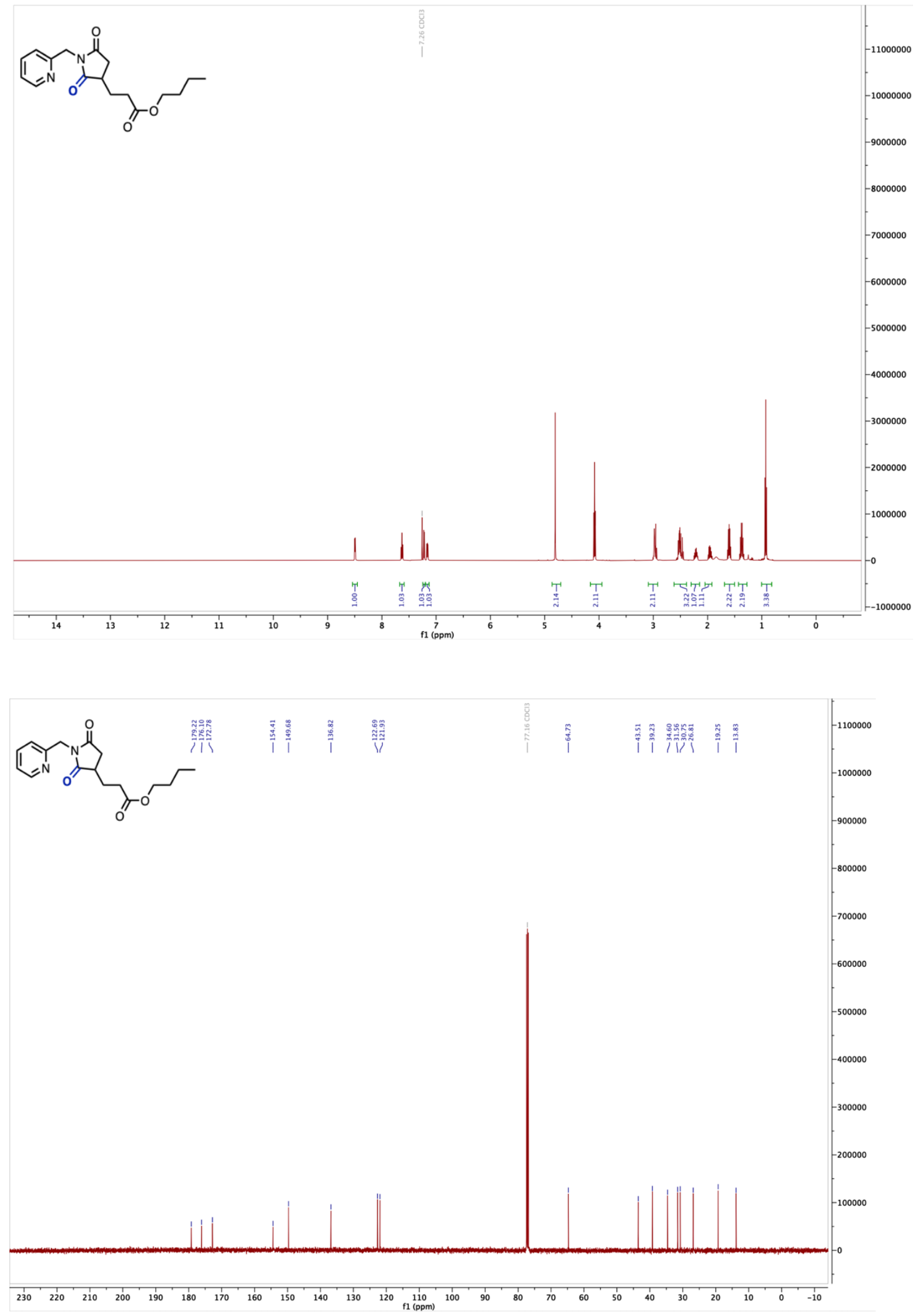

S-147 


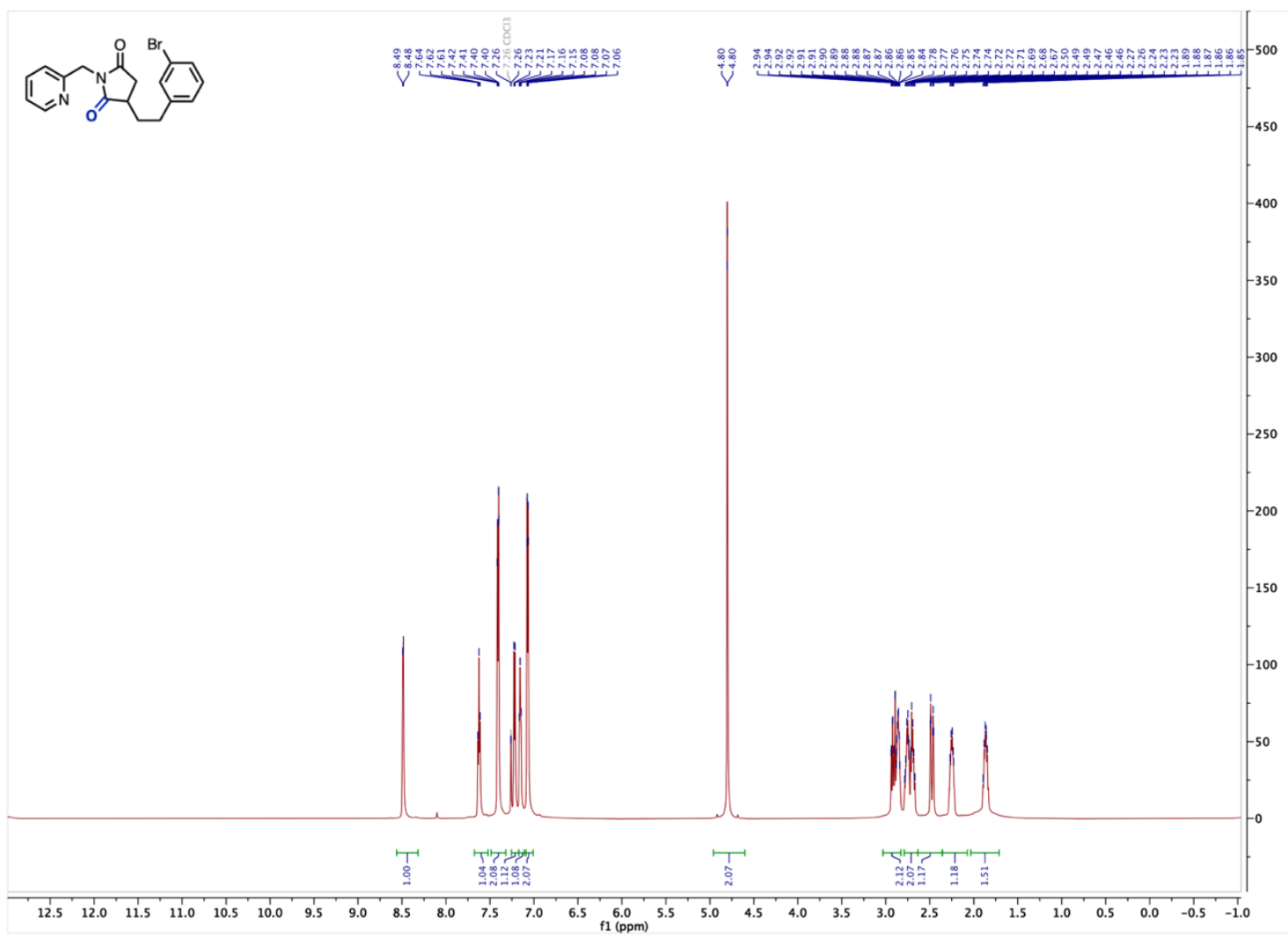



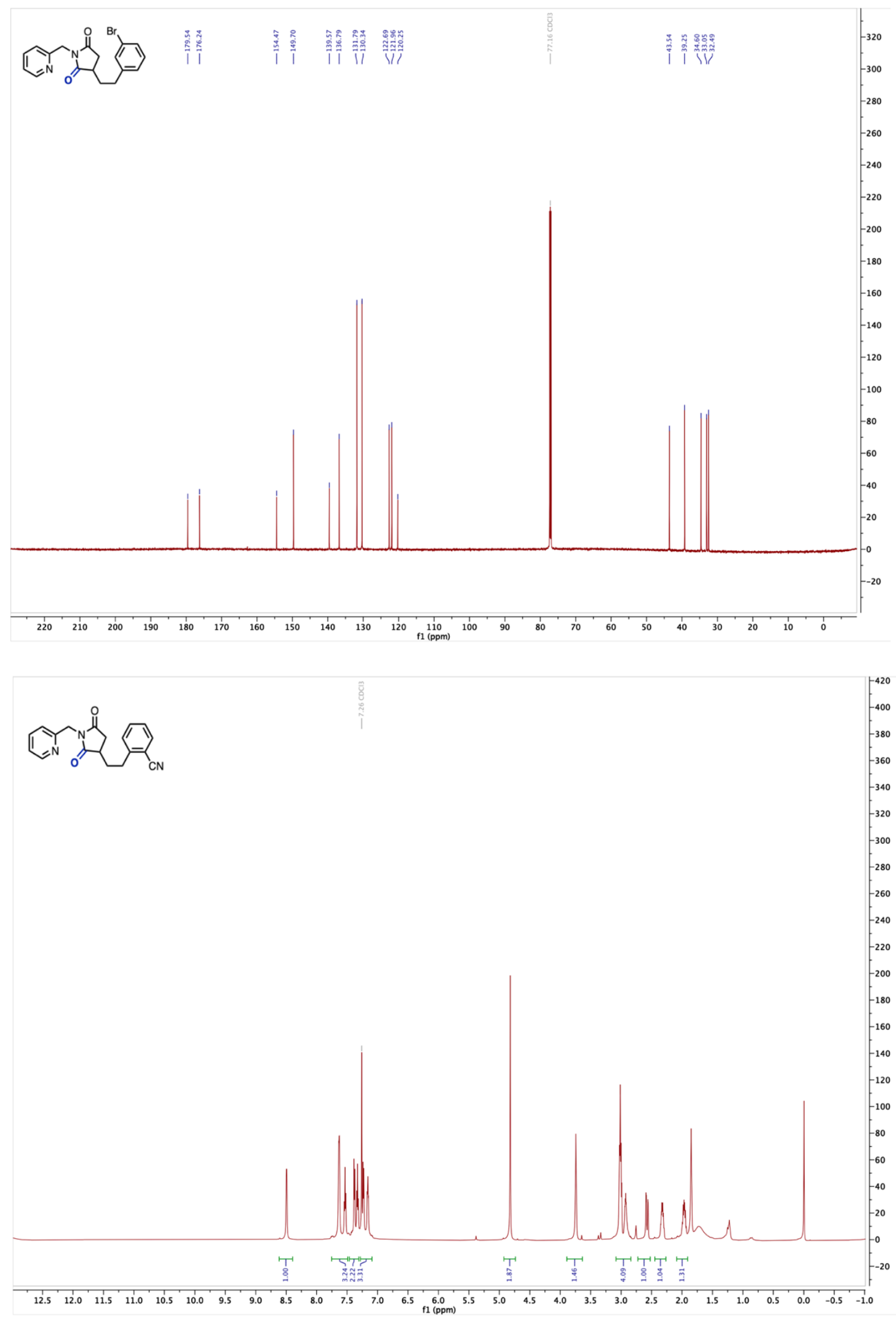


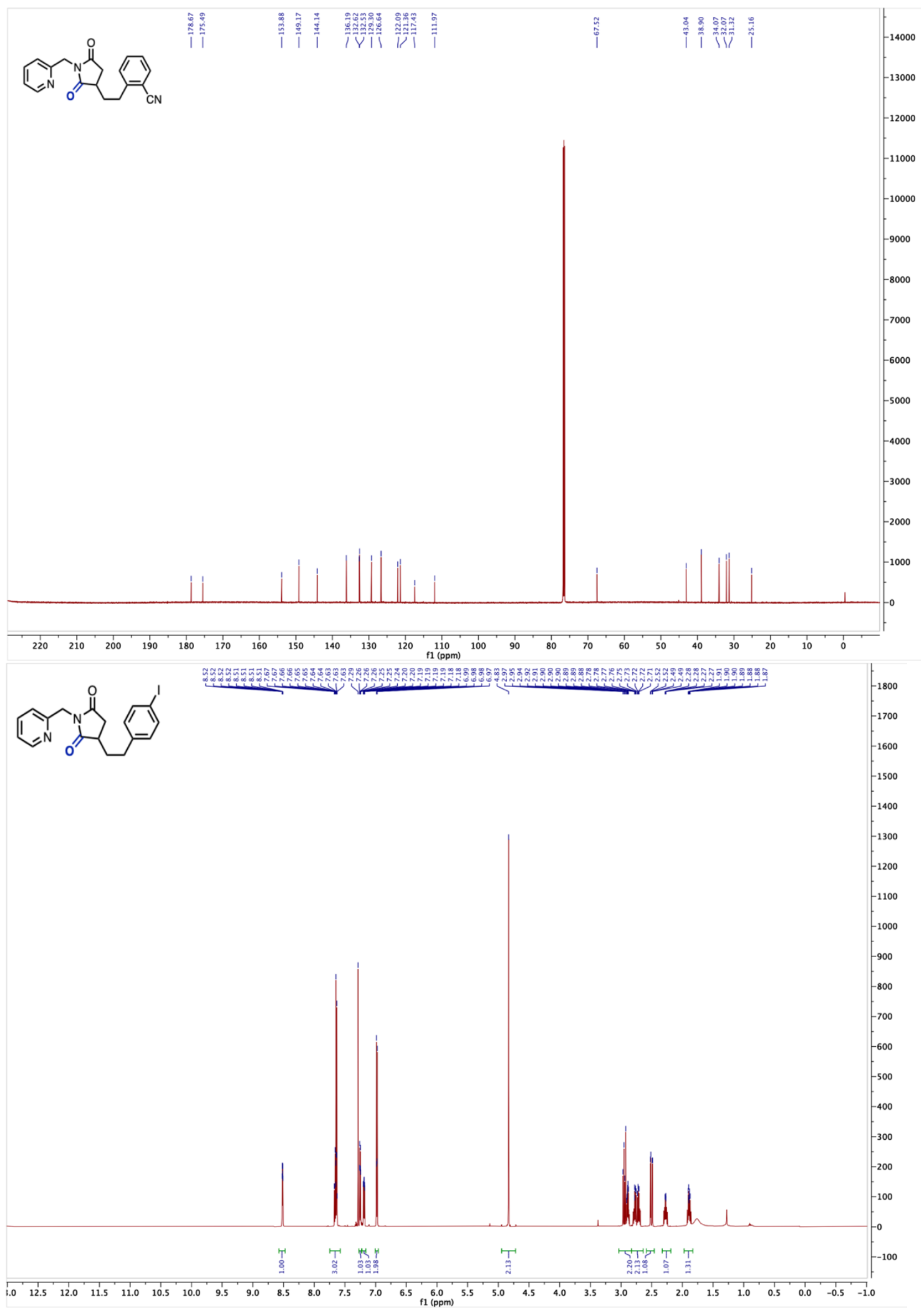



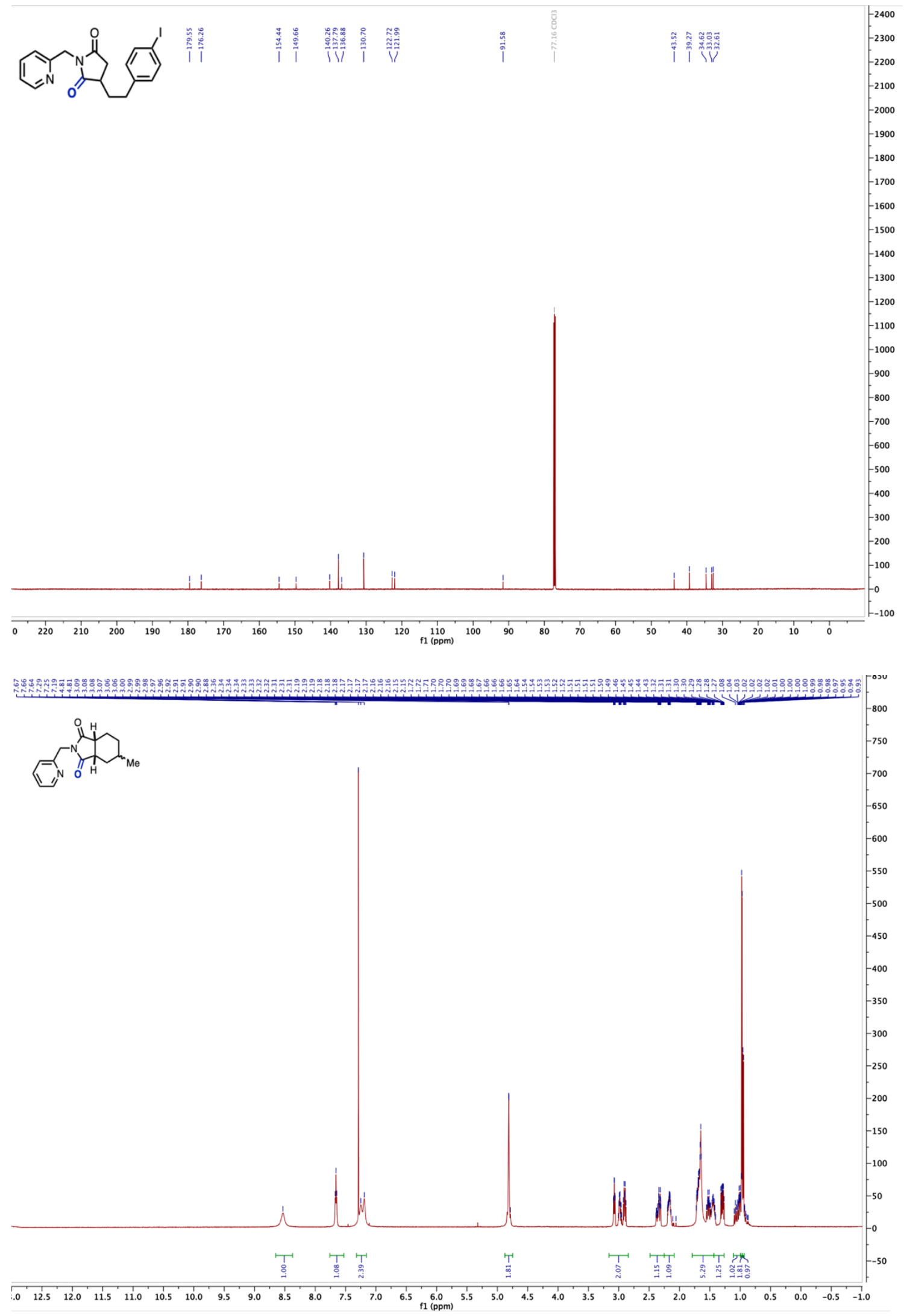

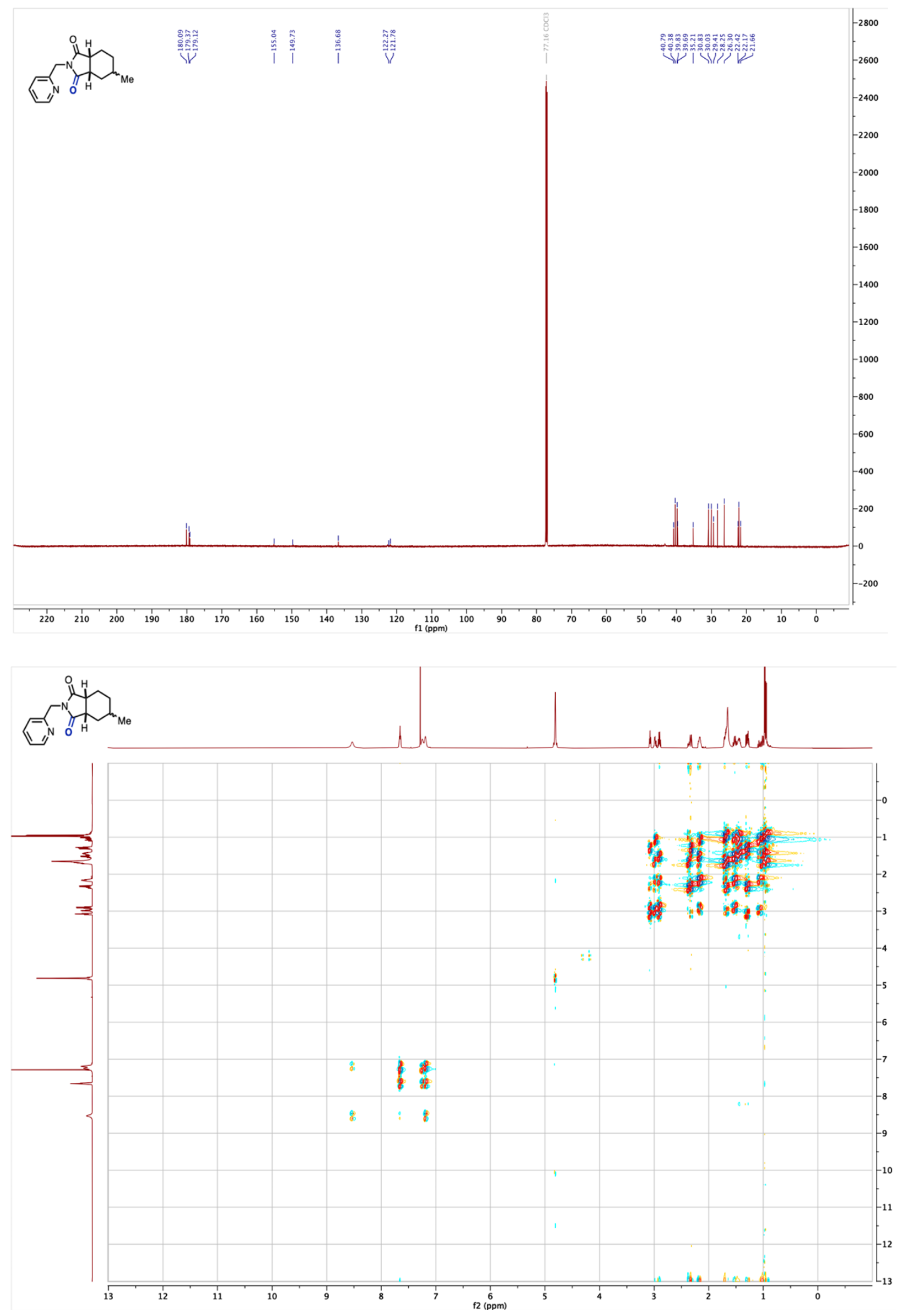

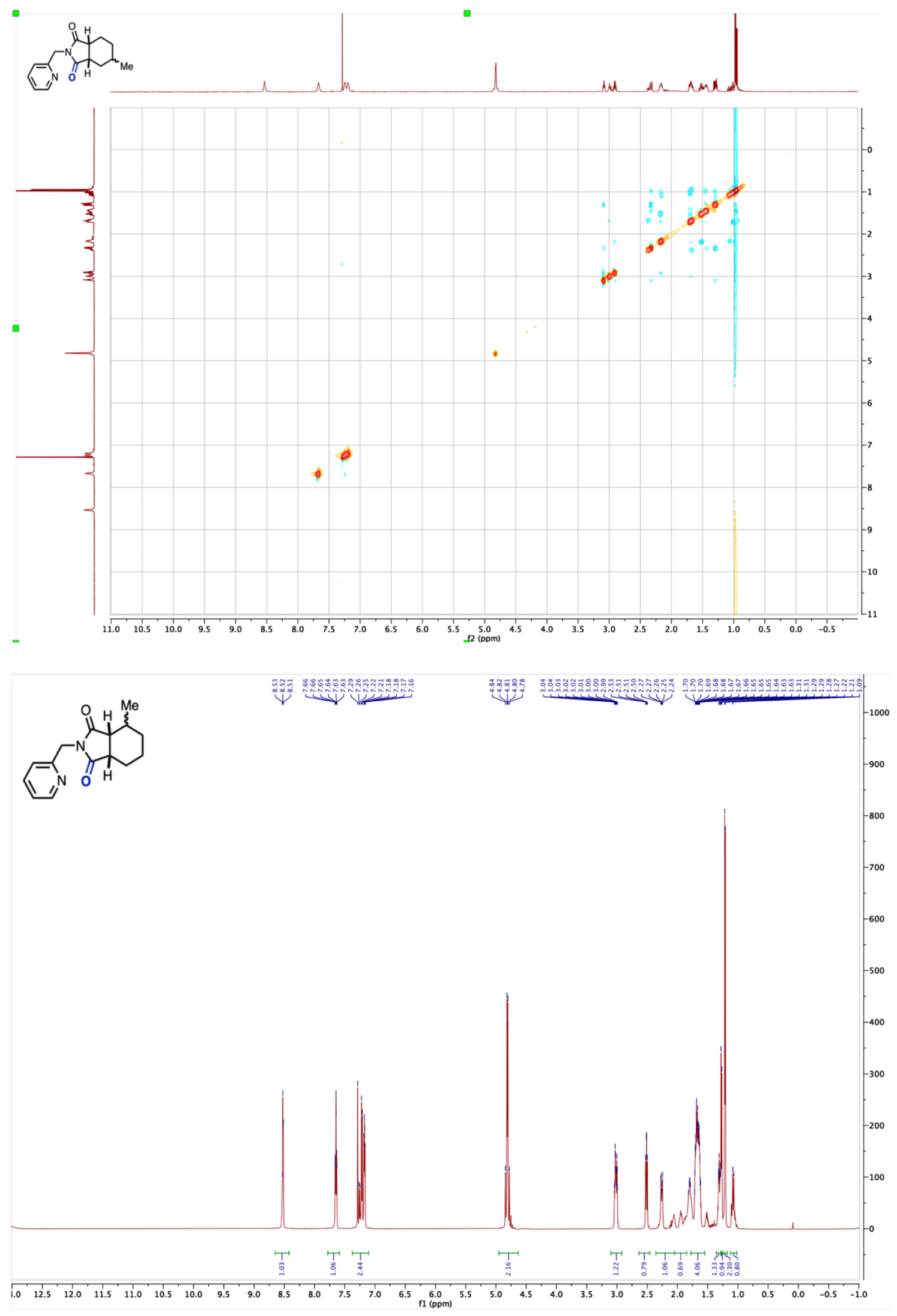


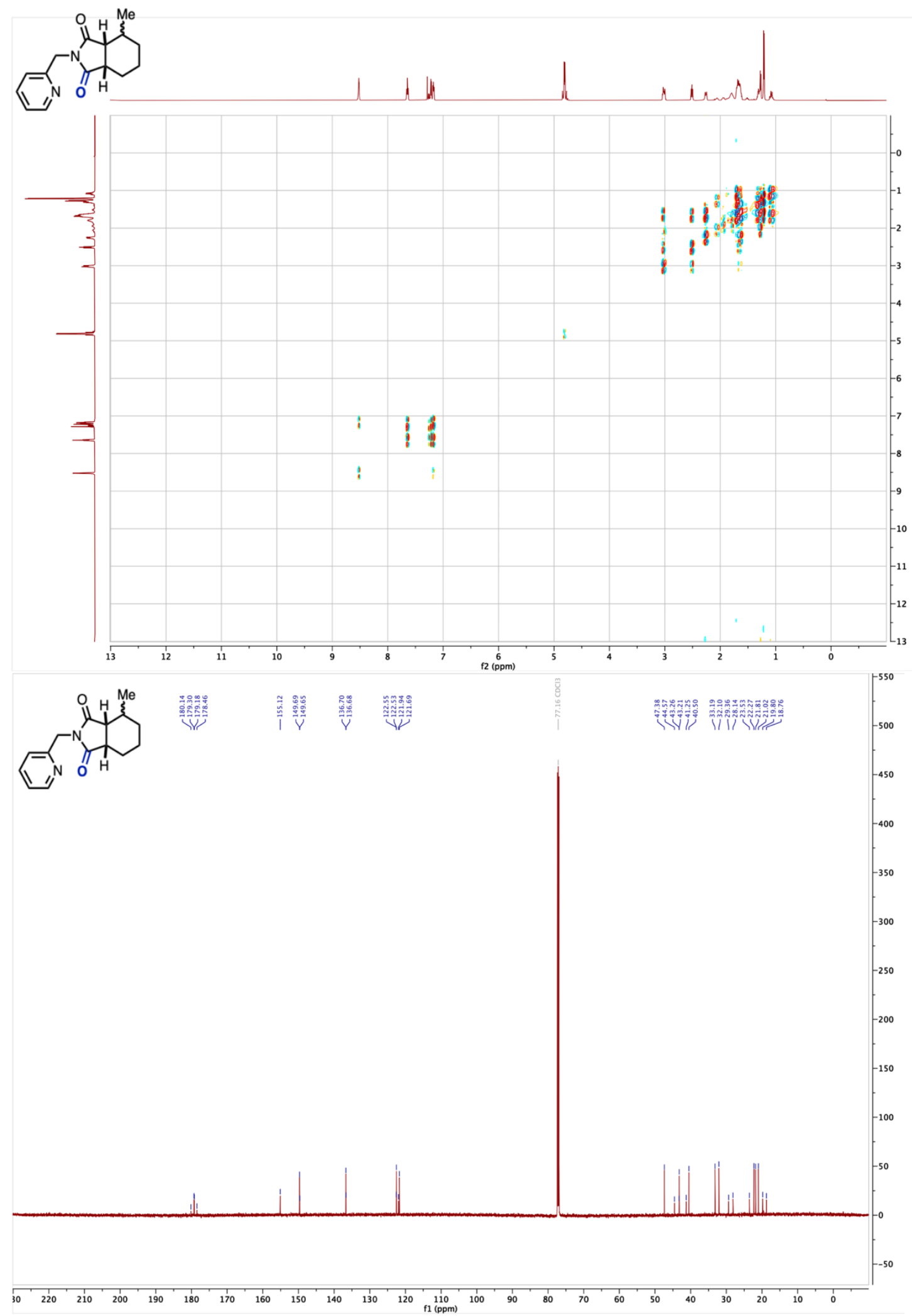



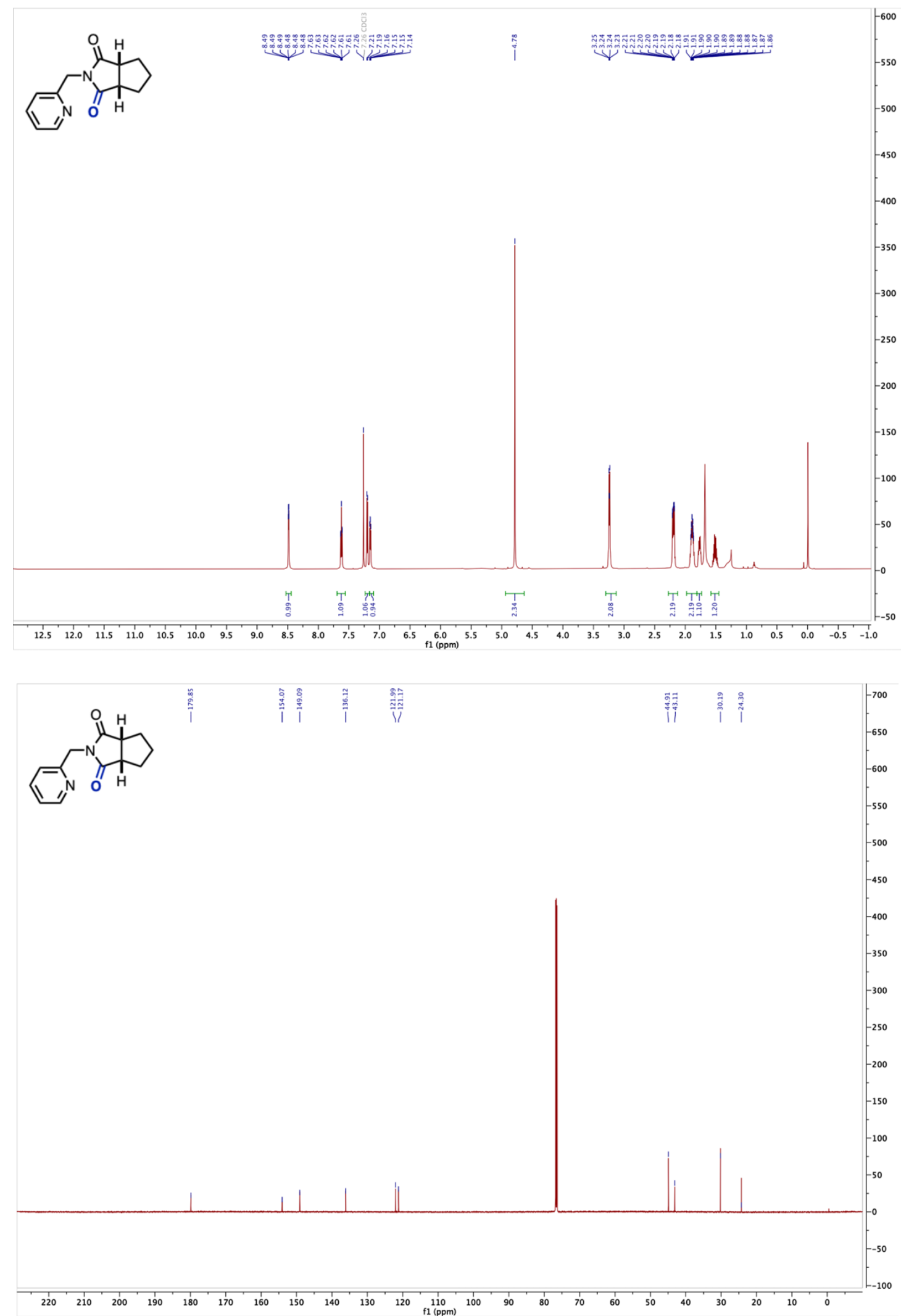

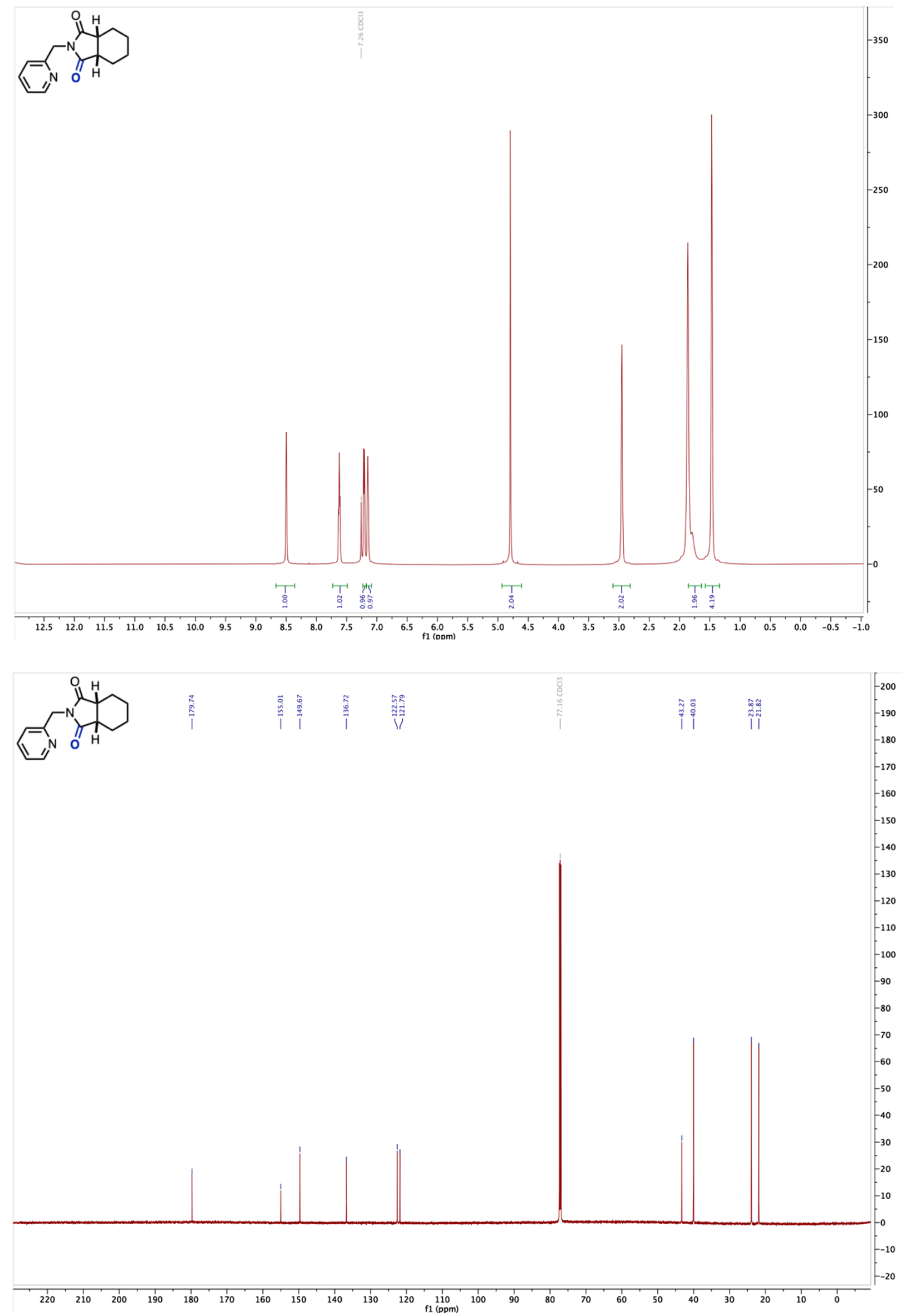

S-156 

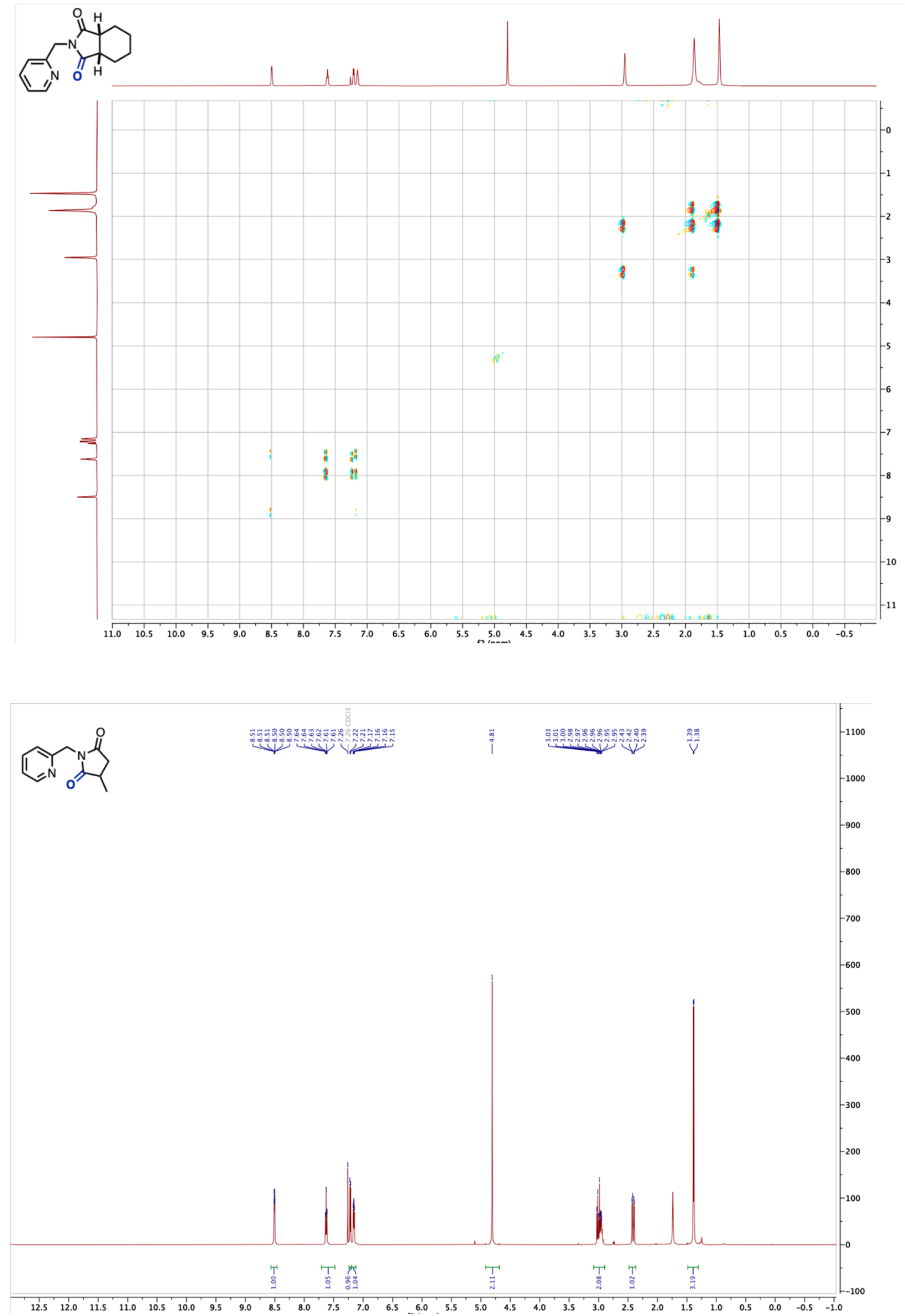

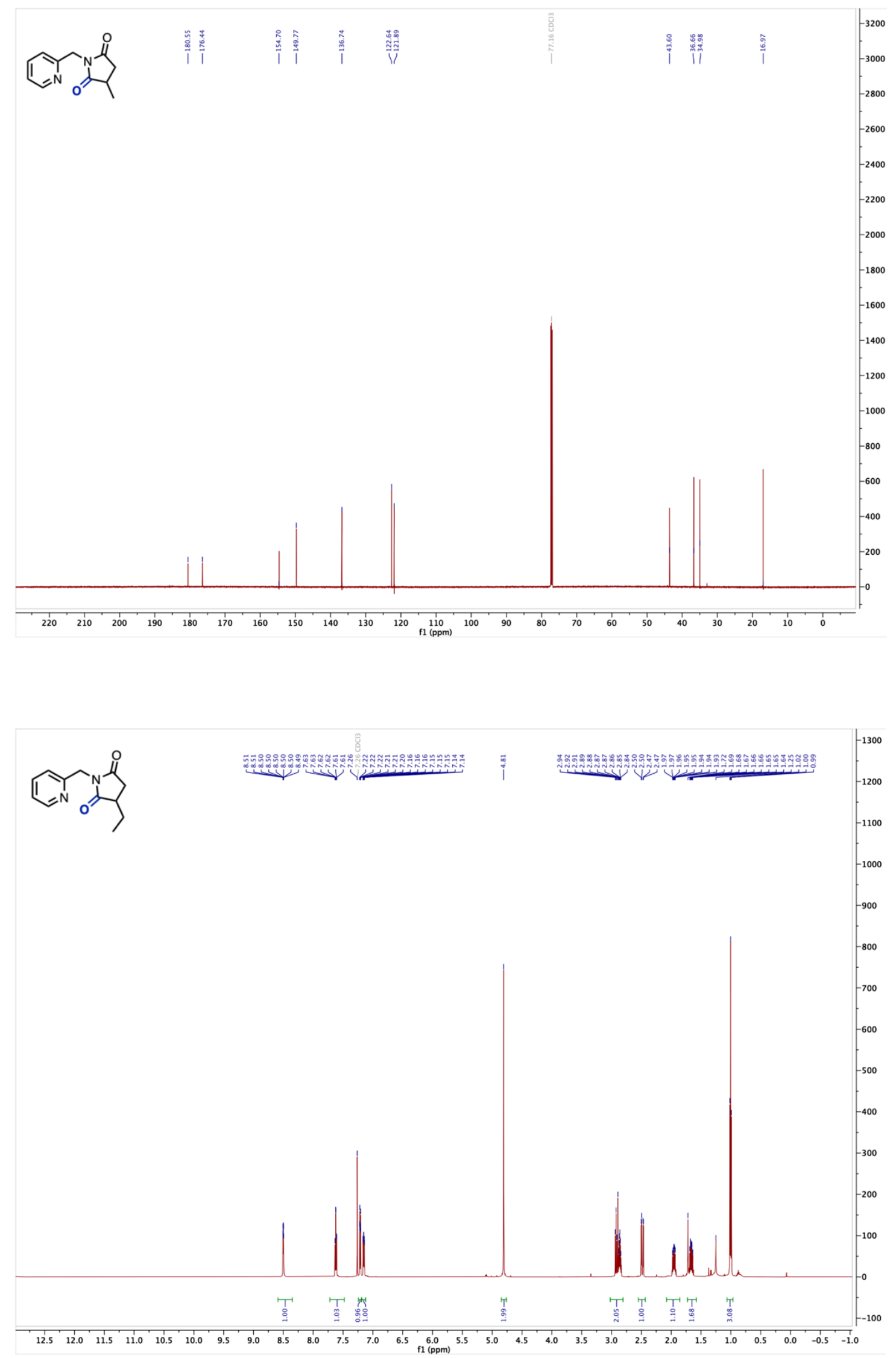


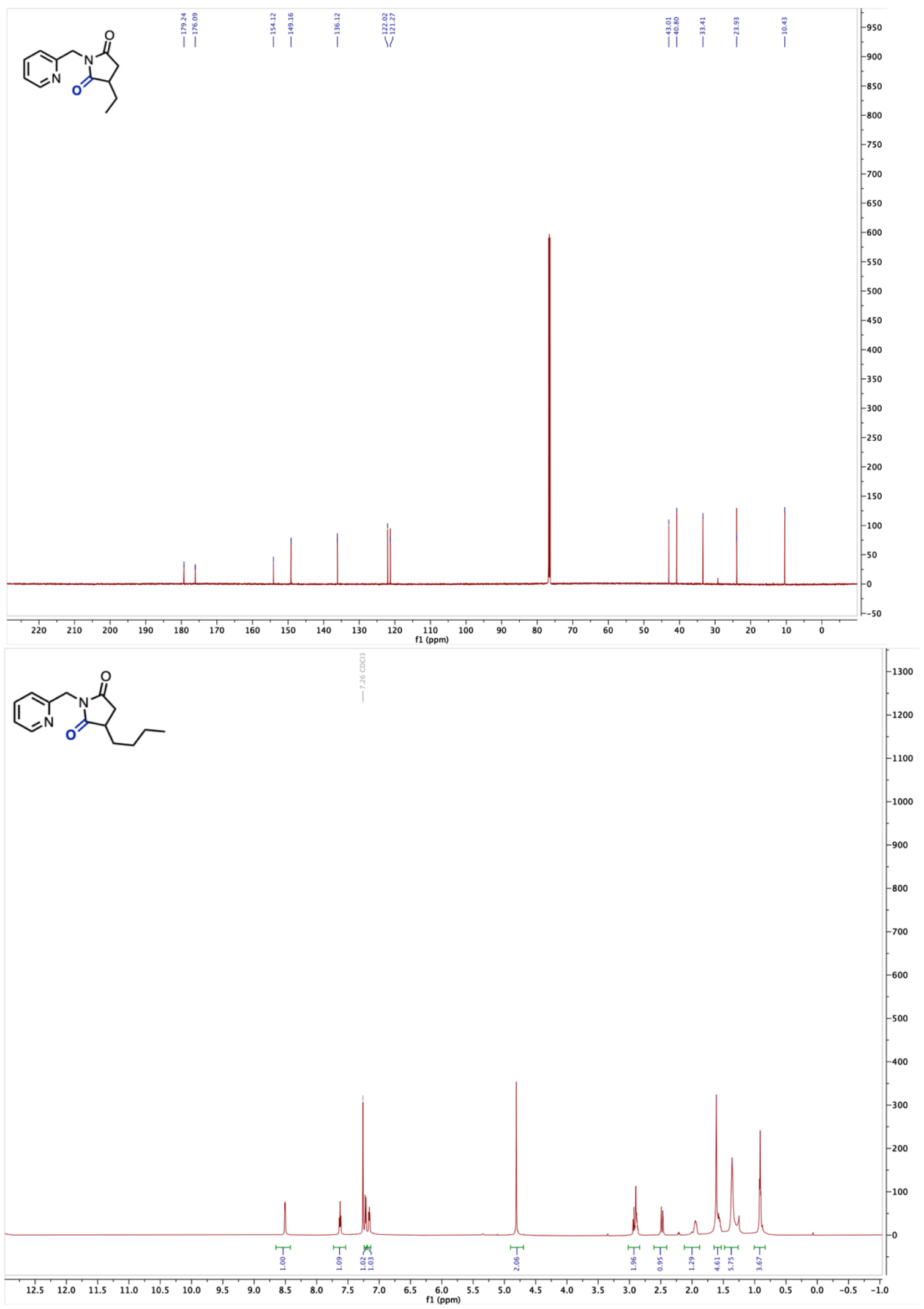

S-159 


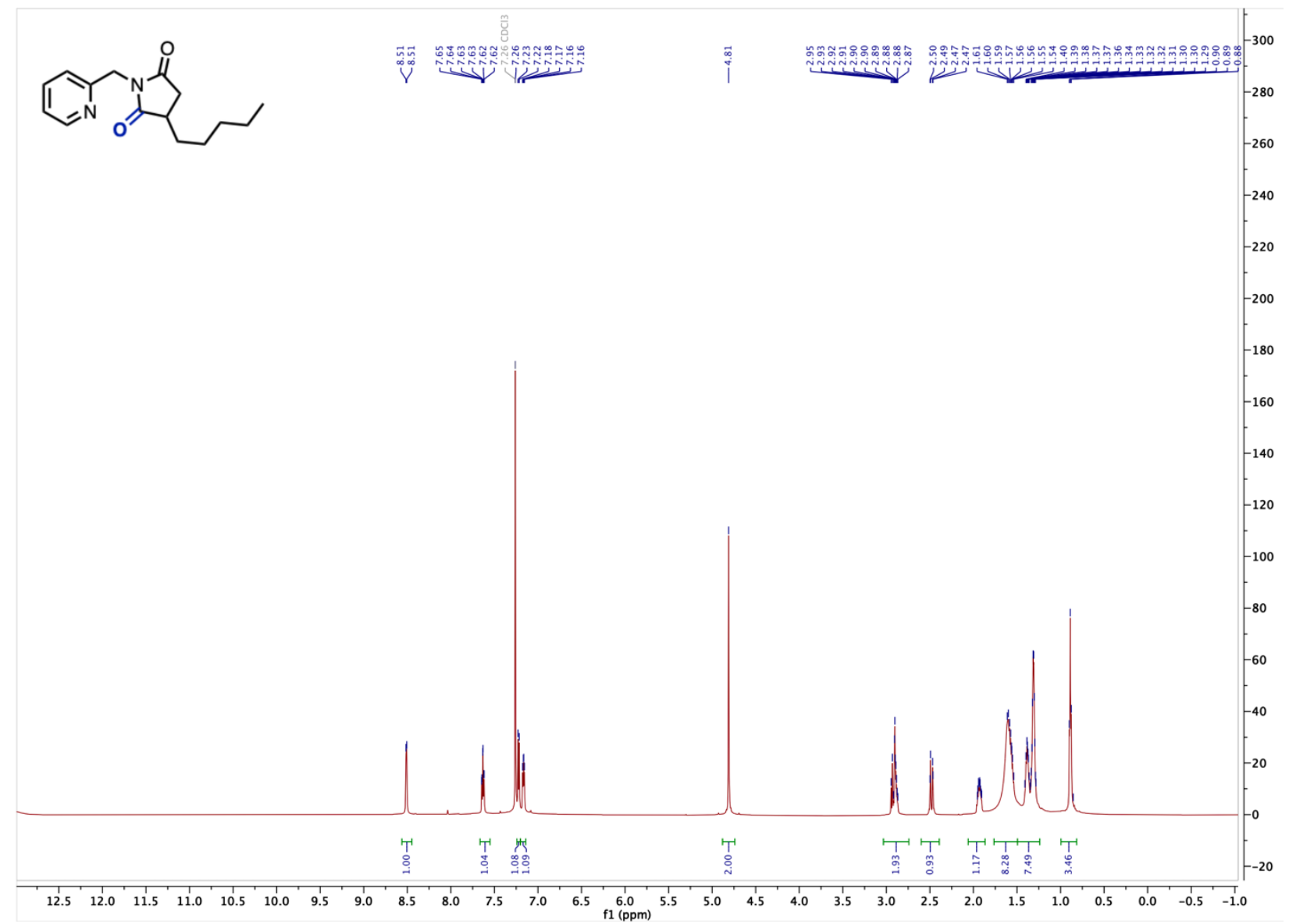

S-160 


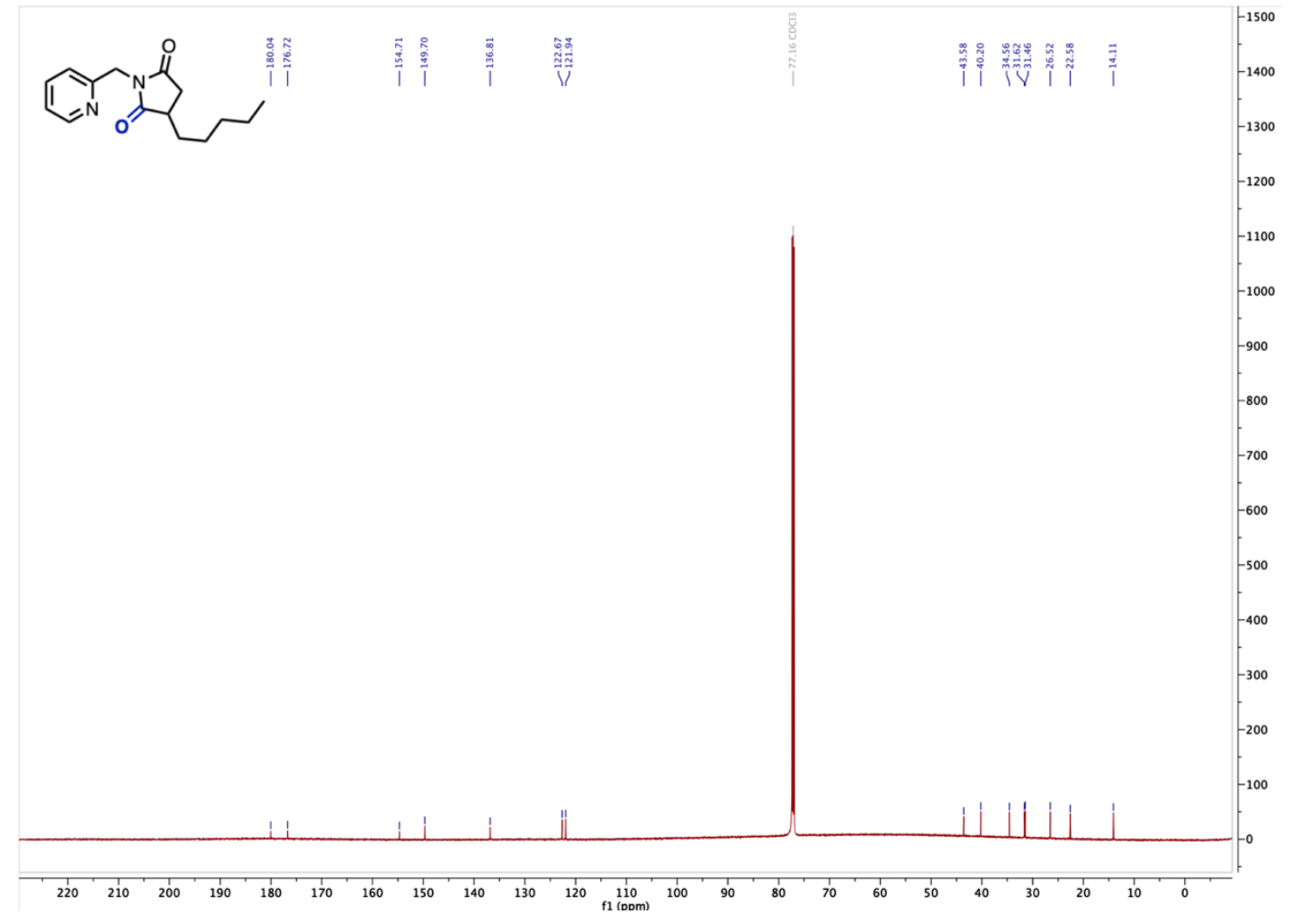

S-161 

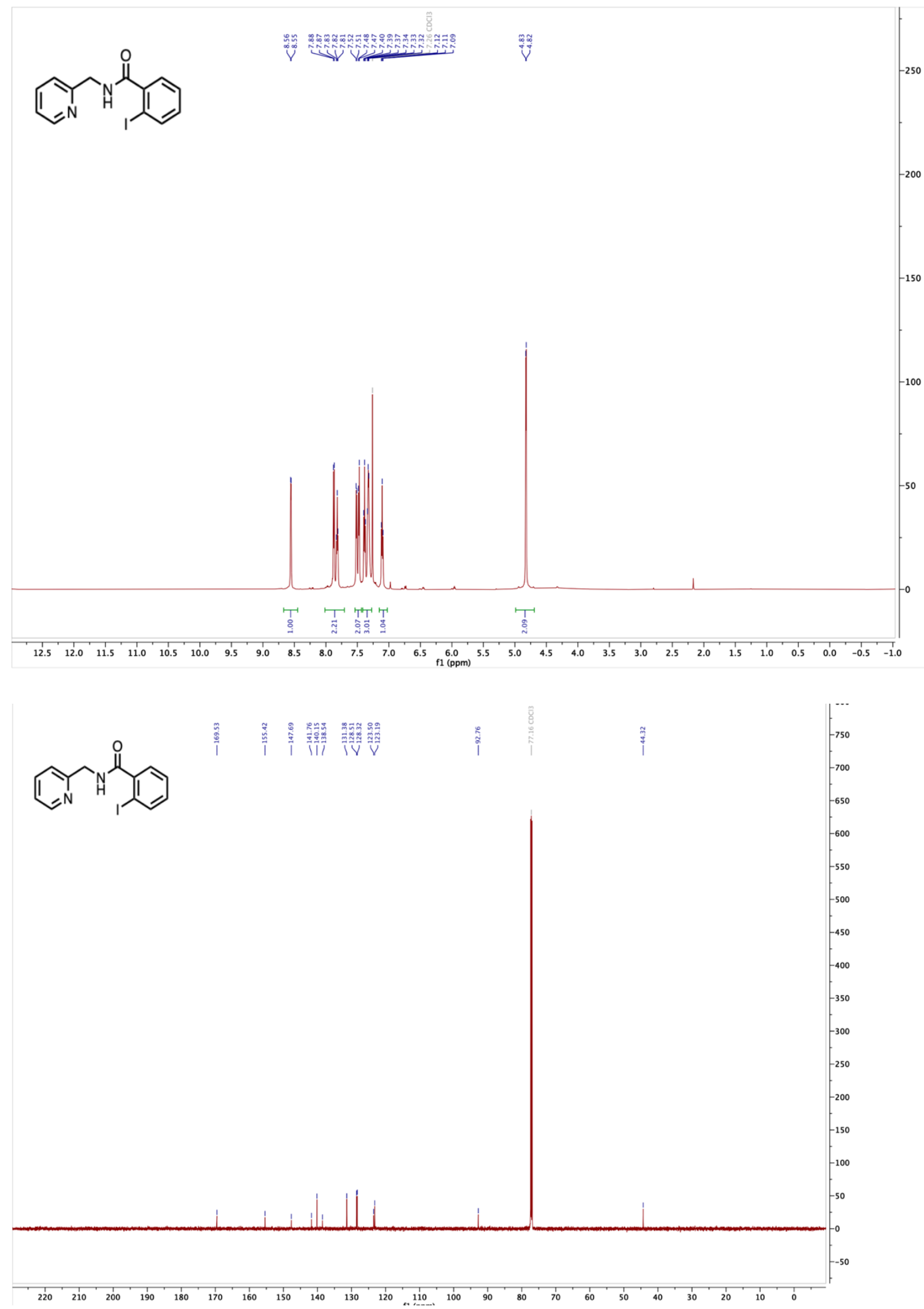

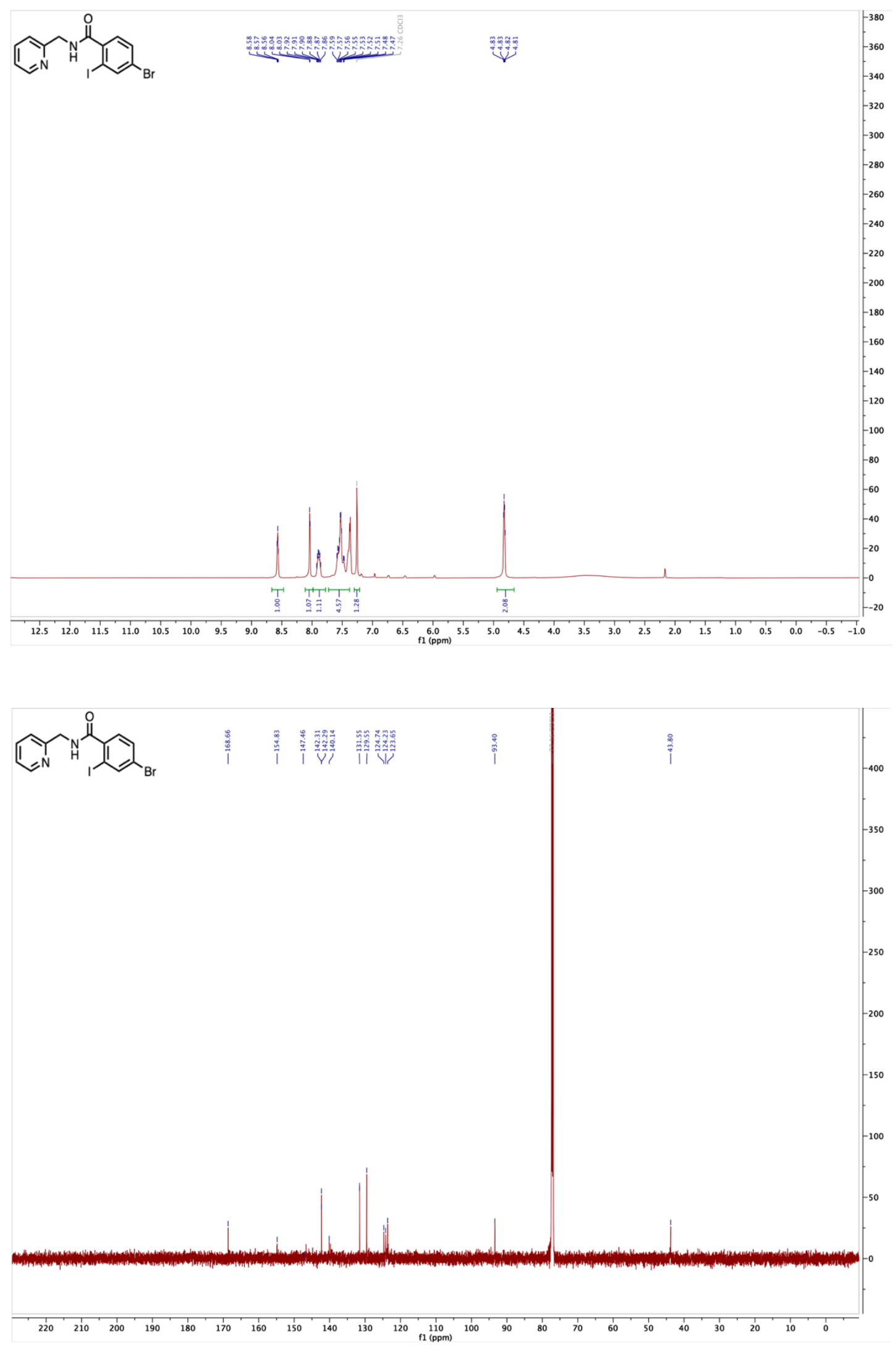

$$
\text { S-163 }
$$



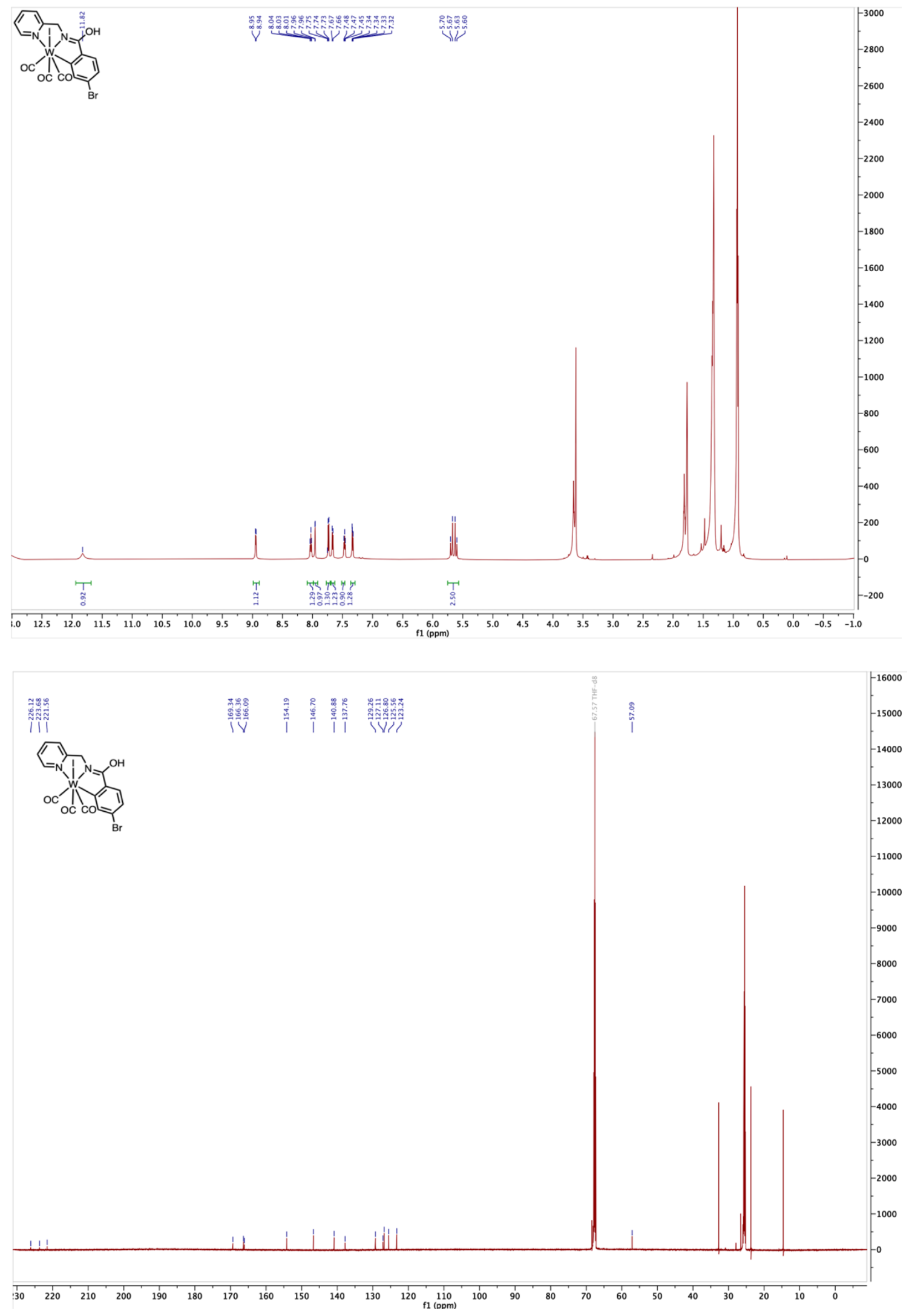

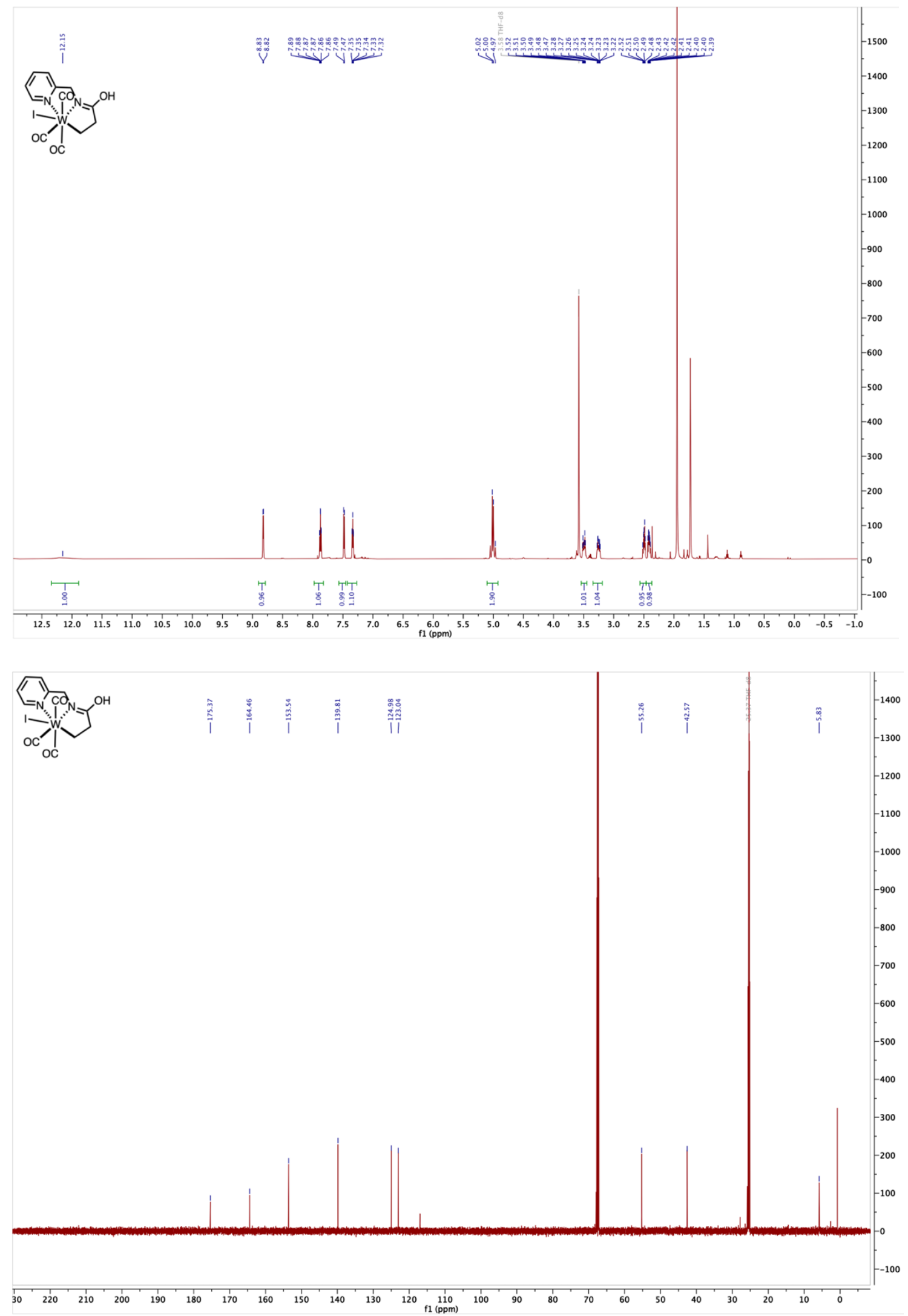

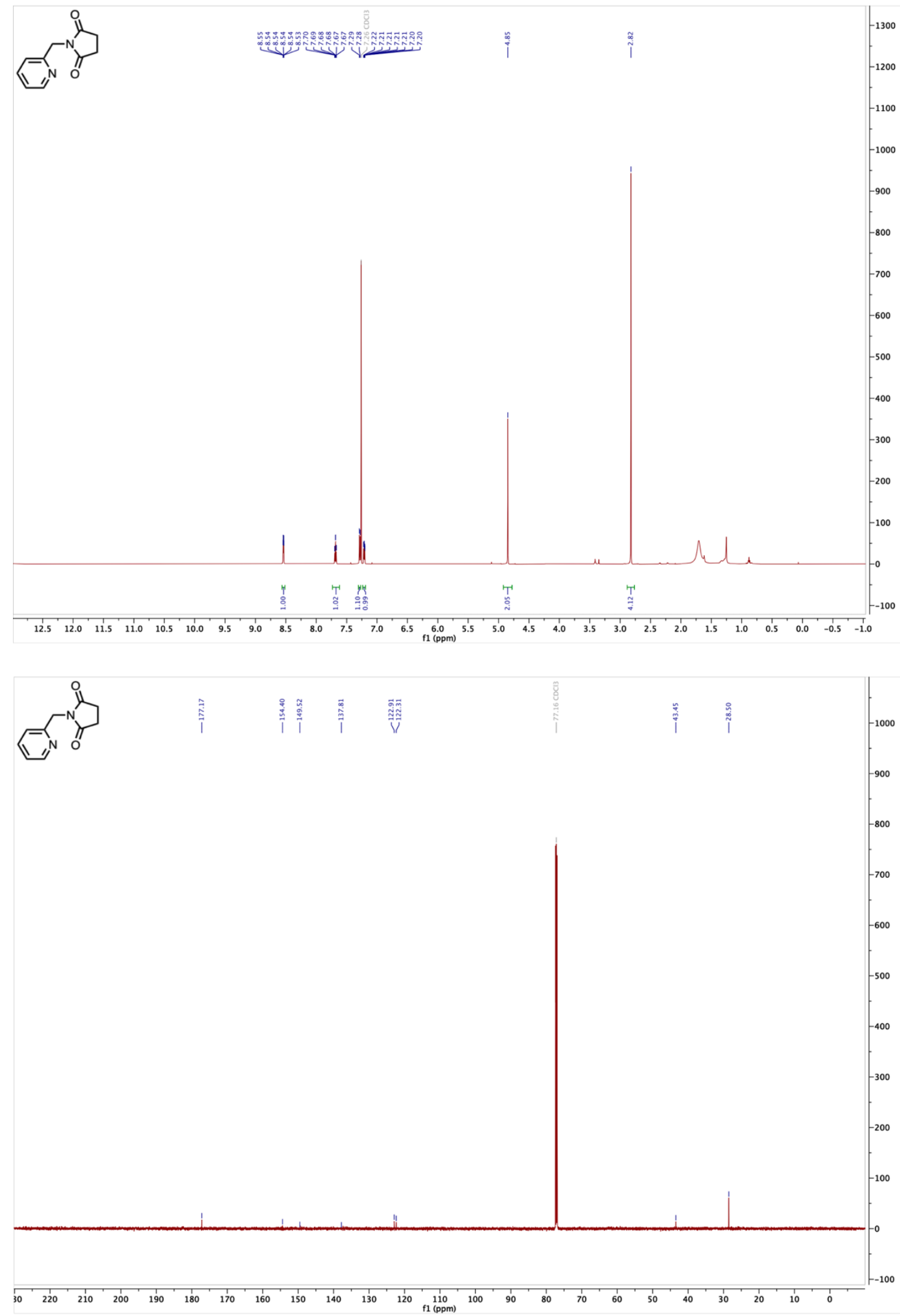

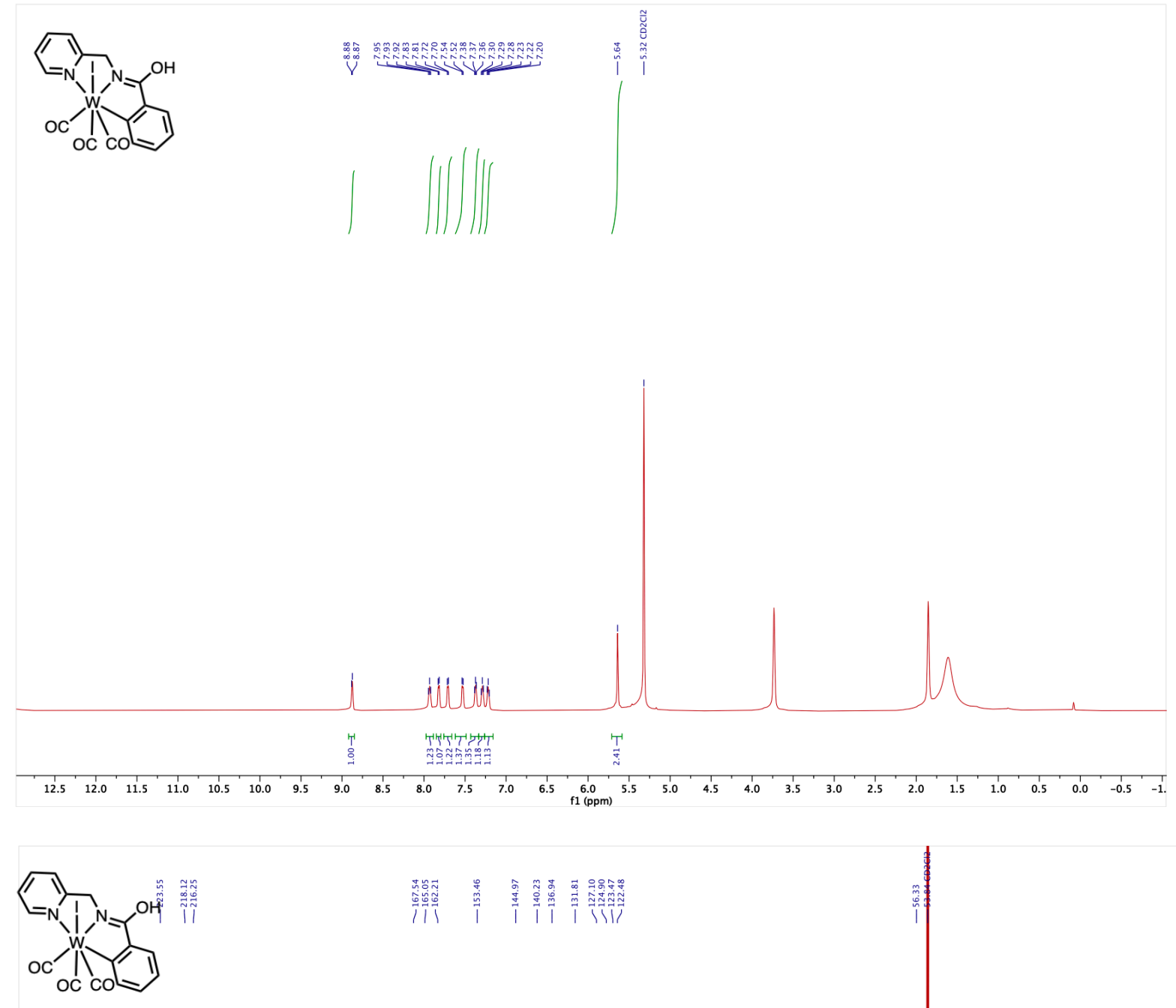

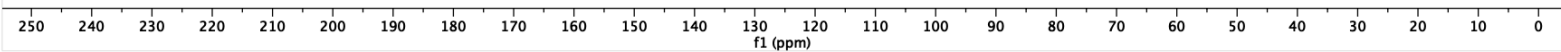



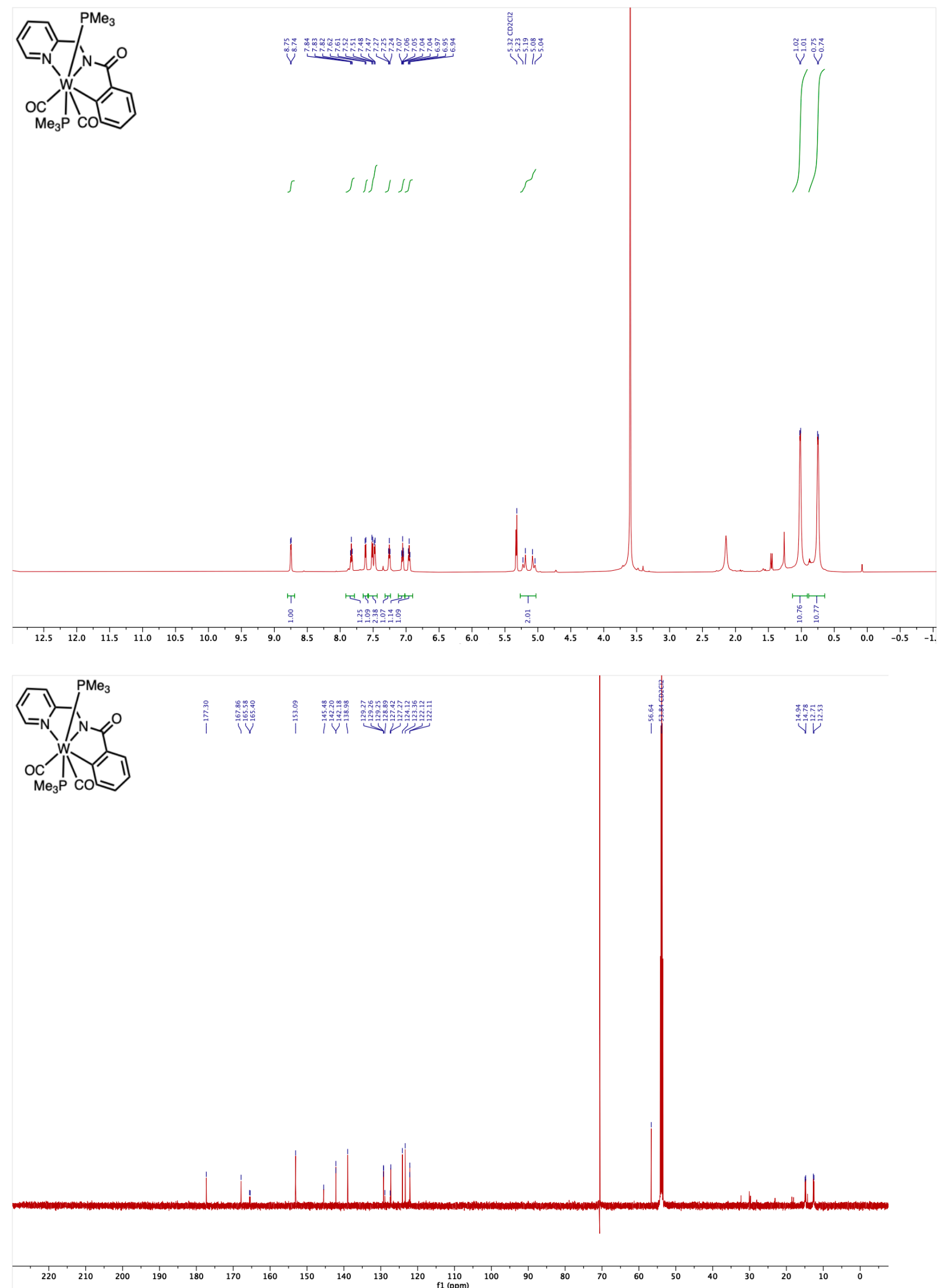

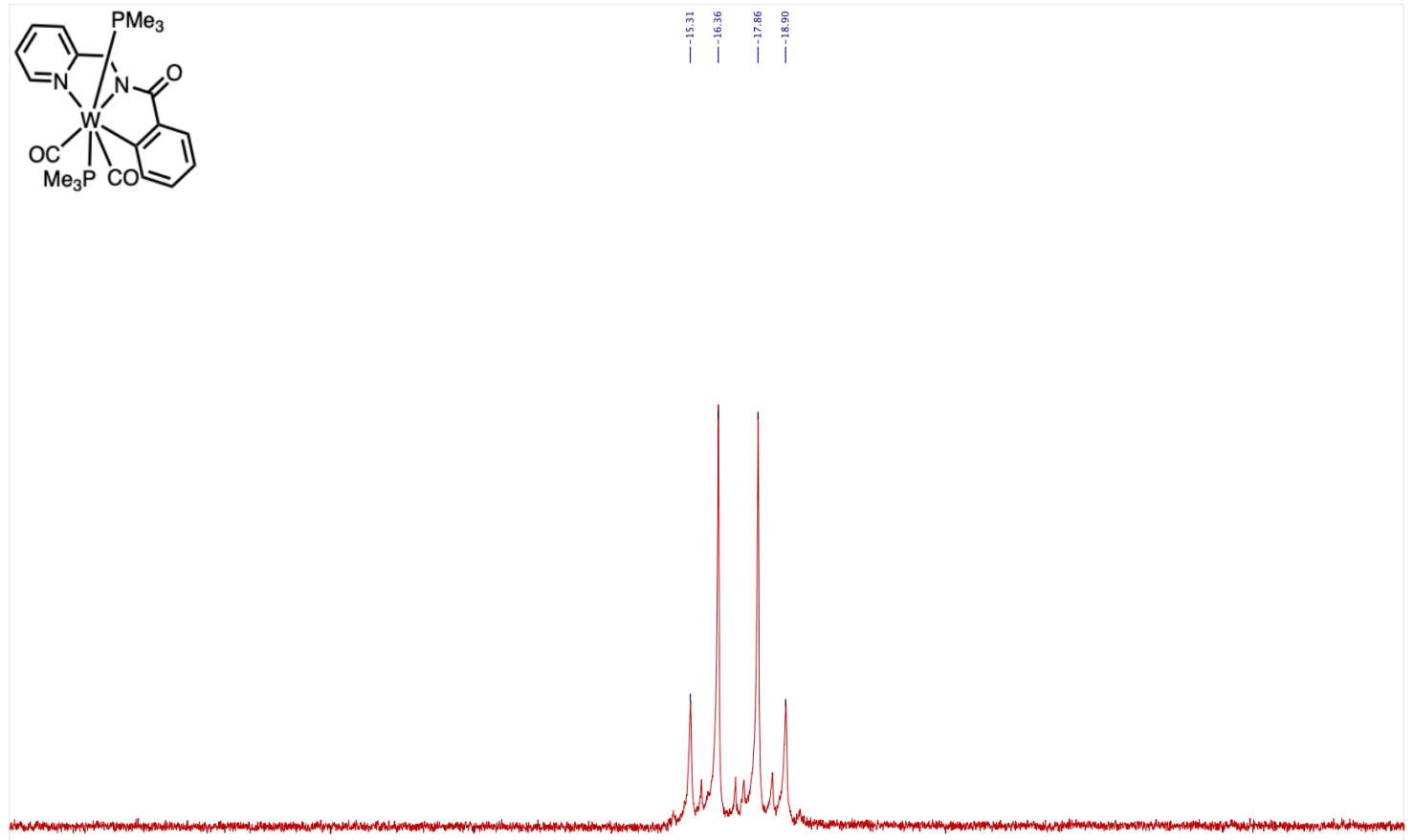

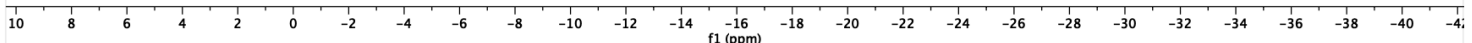

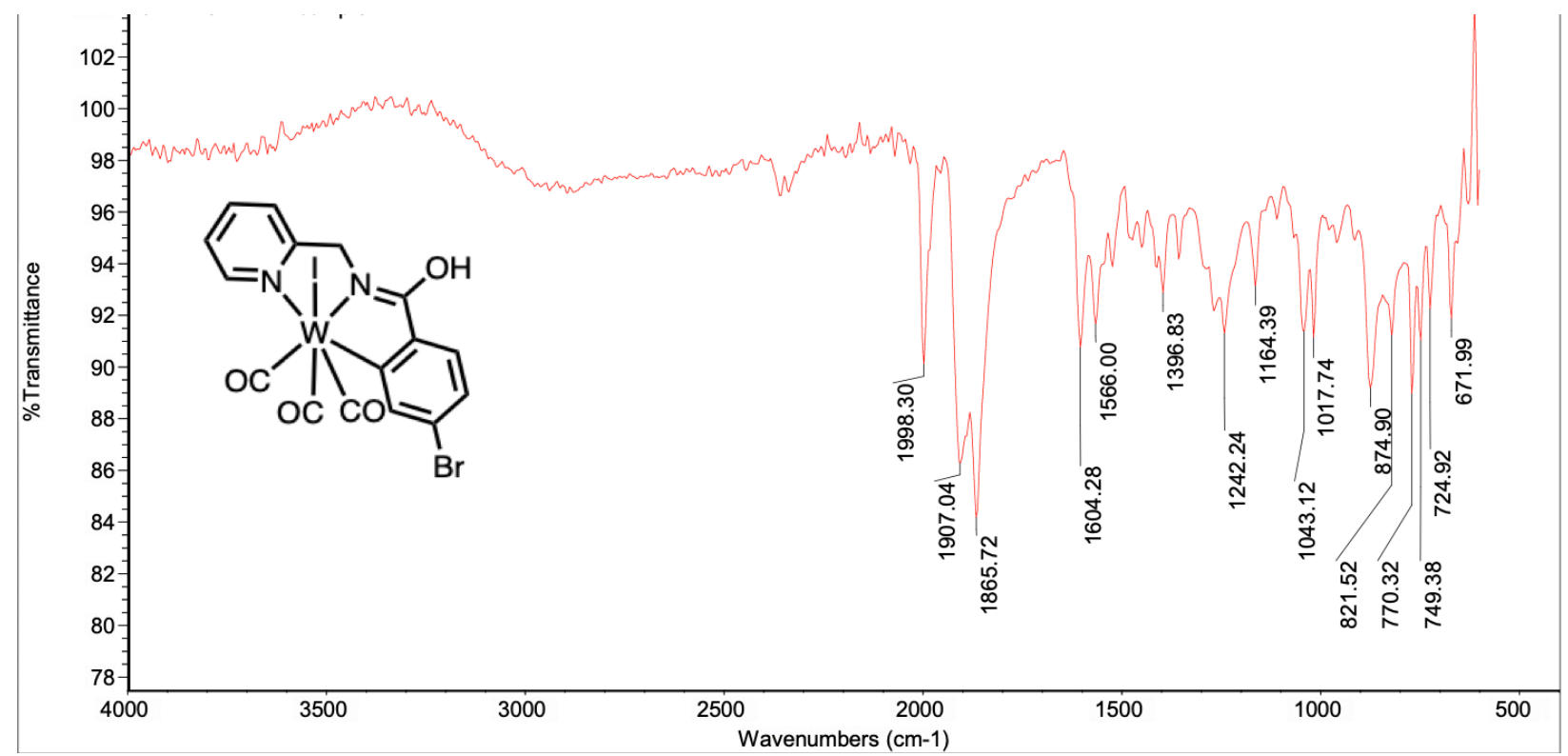



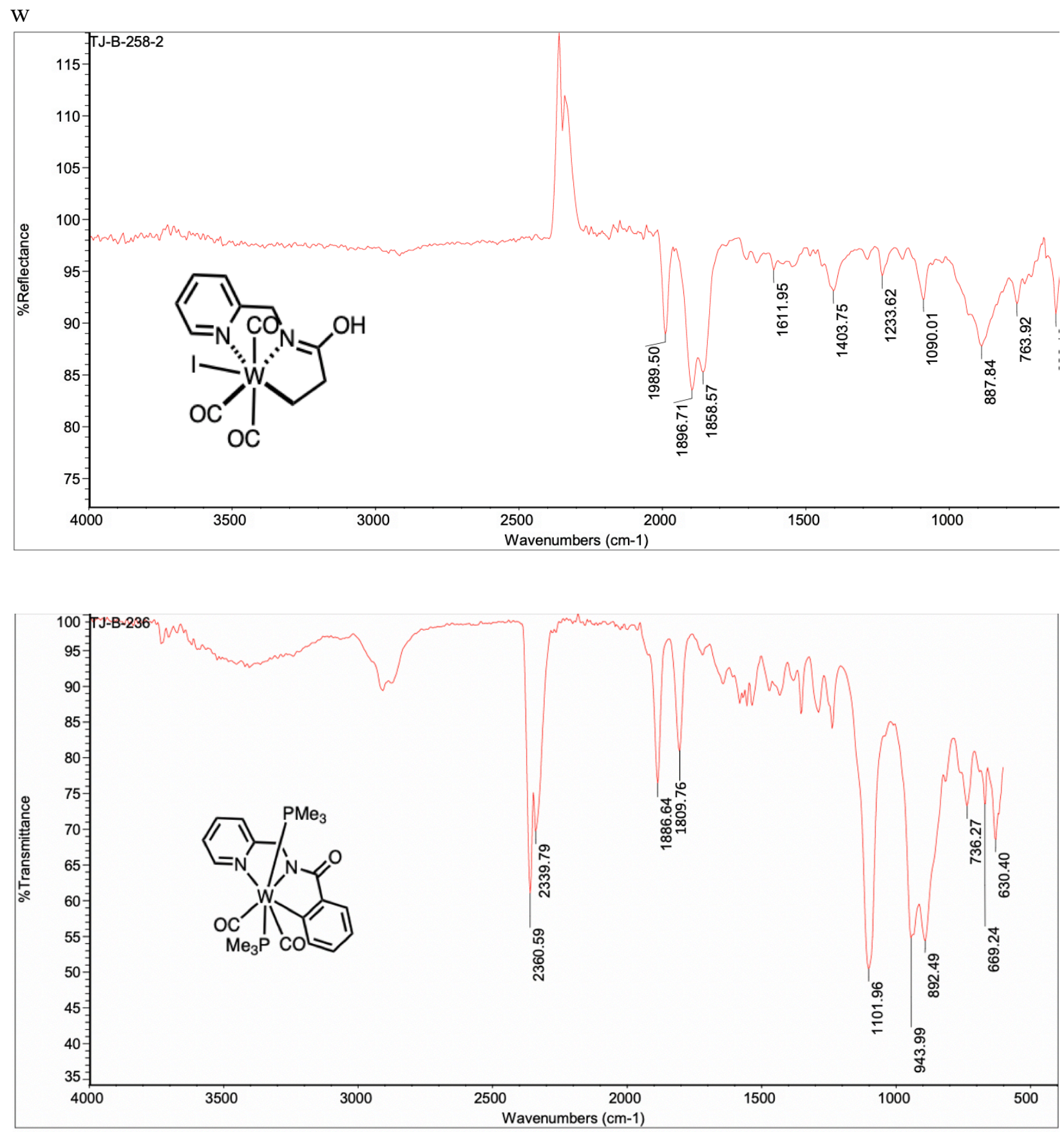


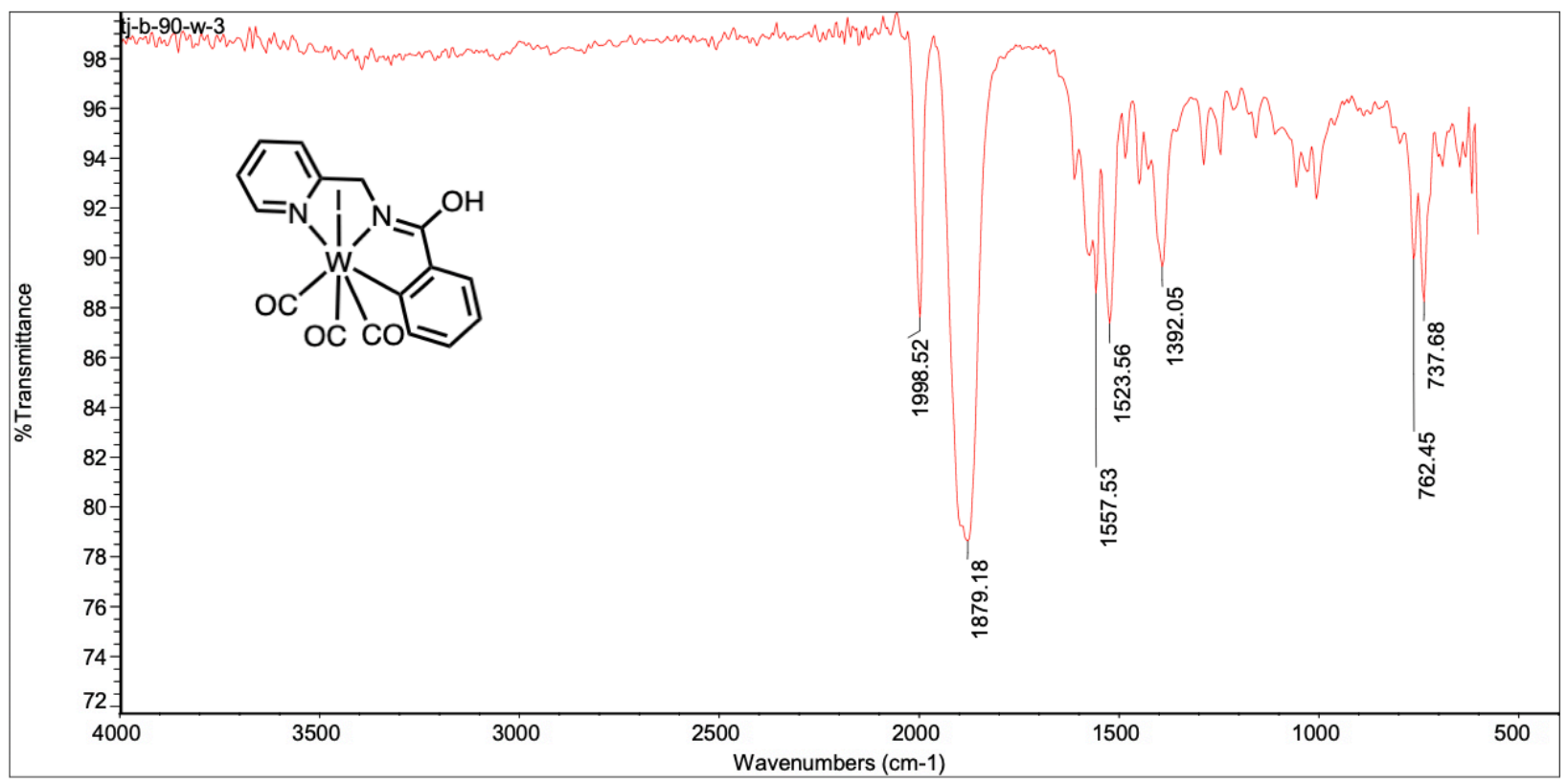


NMR SPECTRA FOR DEUTERIUM INCORPORATION EXPERIMENTS
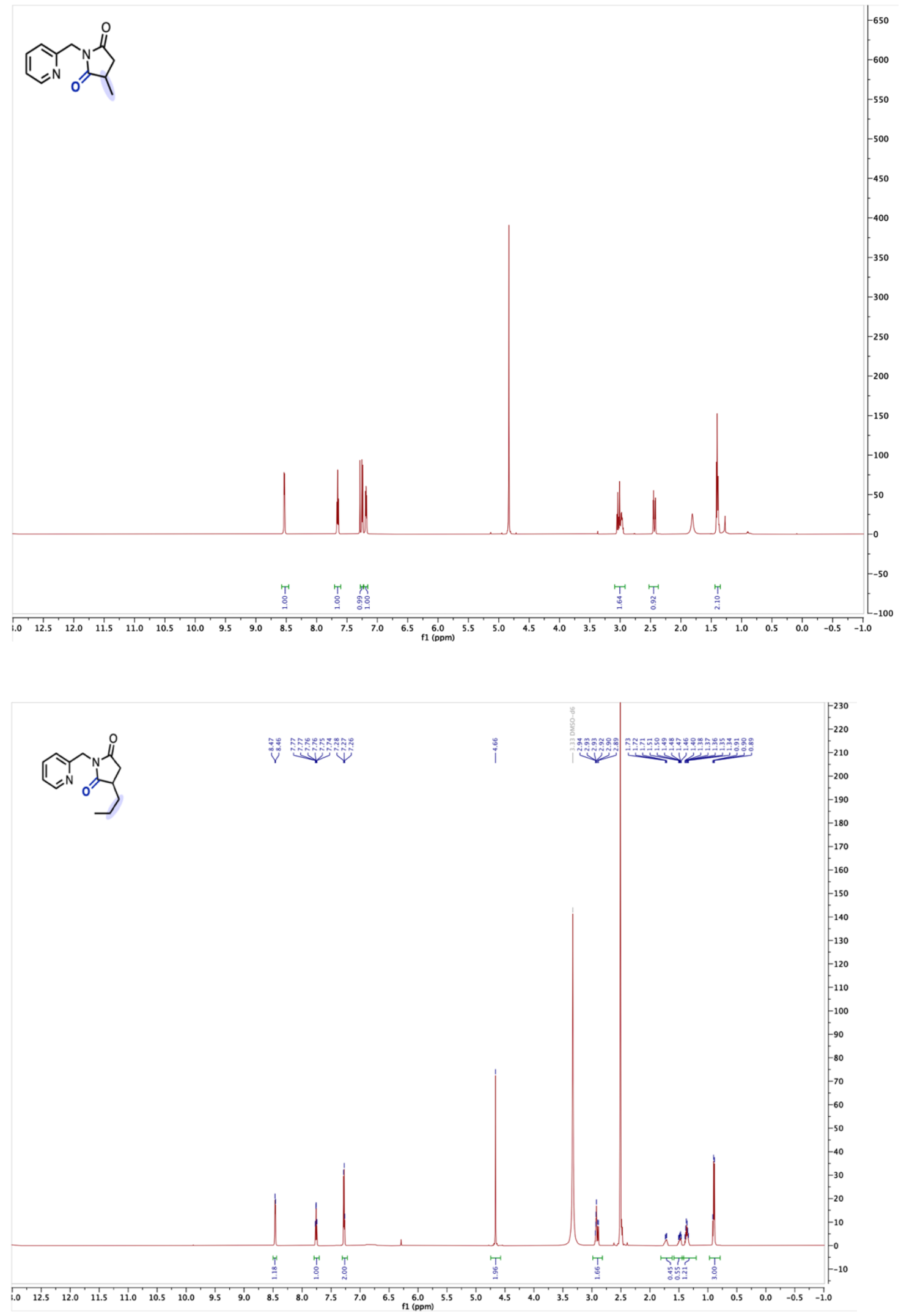

S-172 


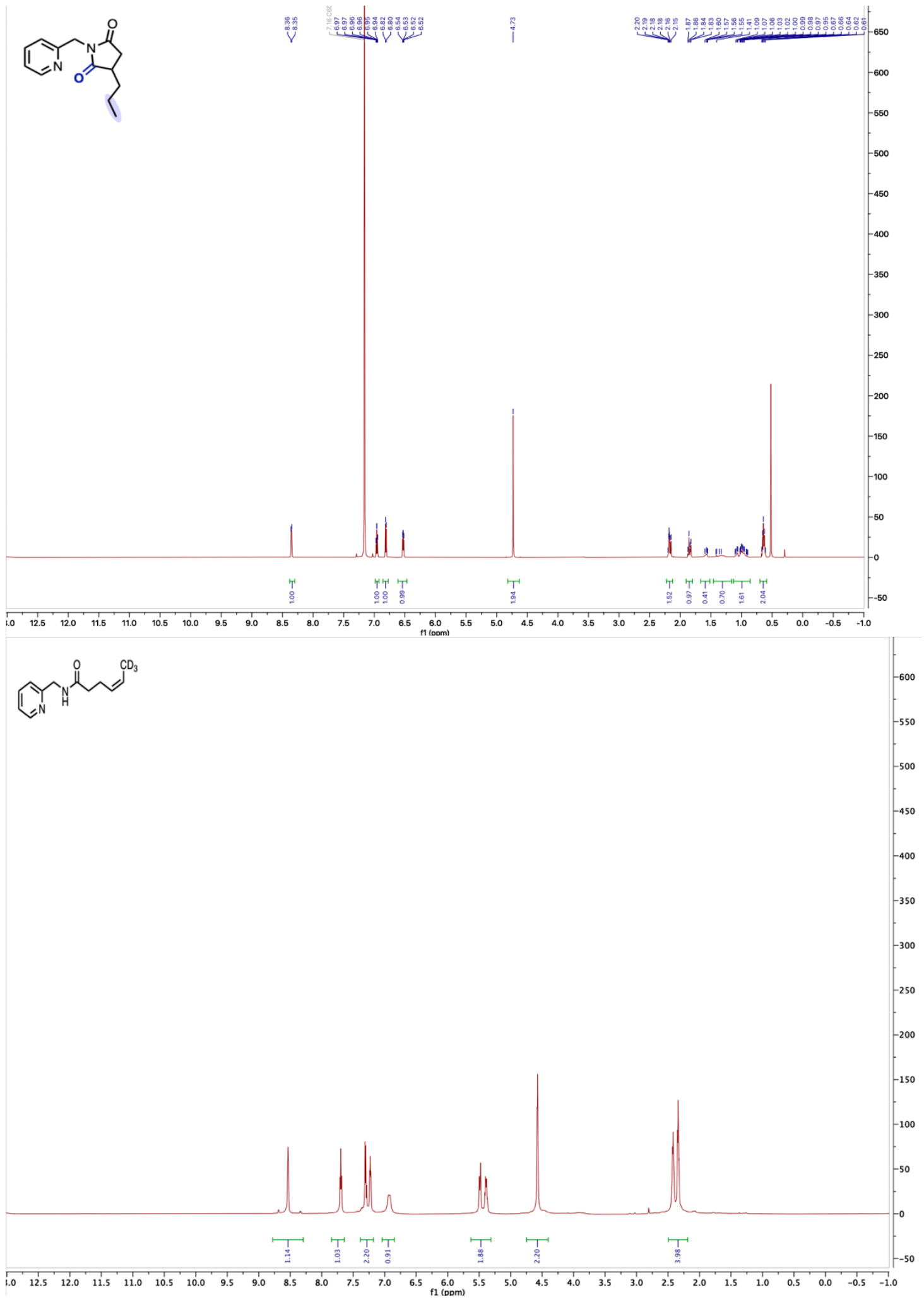



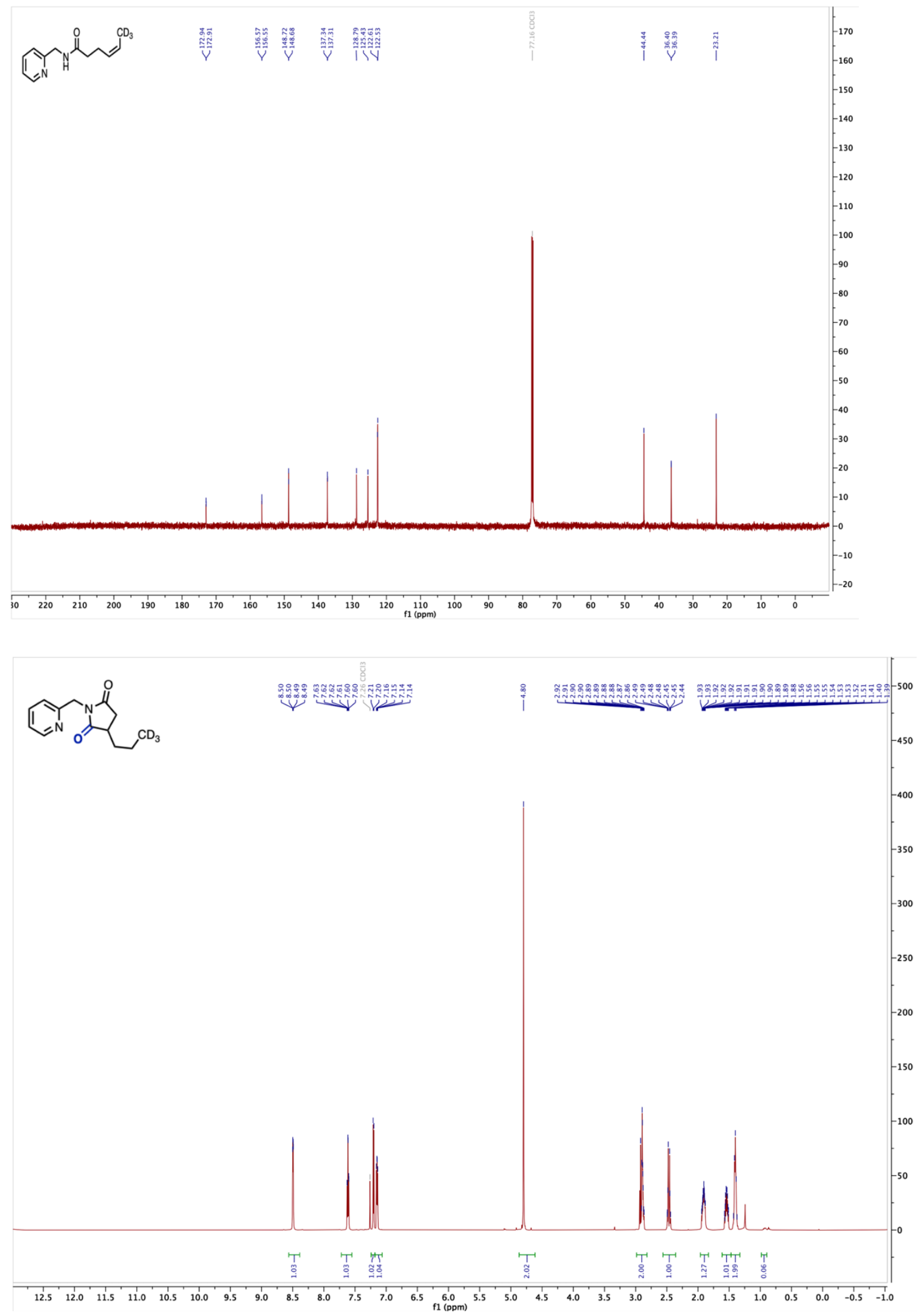


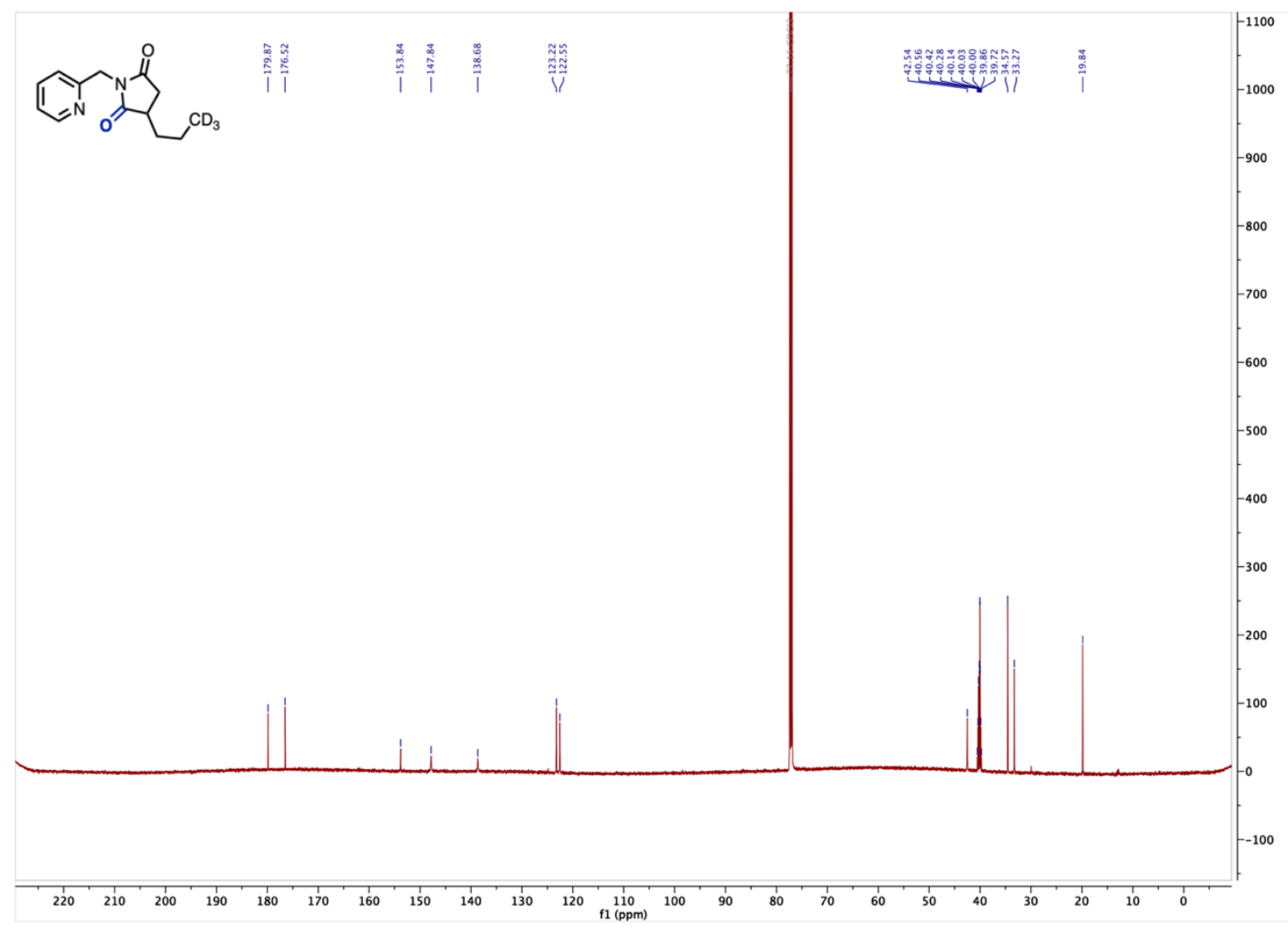

S-175 


\section{COMPUTATIONAL DETAILS}

\section{Computational Methods}

All density functional theory (DFT) calculations were carried out using the Gaussian 16 program (50). Geometries of intermediates and transition states were optimized using the B3LYP functional (51) with Grimme's DFT-D3 dispersion correction (52) and a mixed basis set of LANL2DZ (53) for $\mathrm{W}$ and 6-31G(d) for other atoms. Vibrational frequency calculations were performed for all intermediates and transition states to confirm if each optimized structure is a local minimum or a transition state structure. Each optimized transition state structure has only one imaginary (negative) frequency, and all minima have no imaginary frequencies. Single-point energy calculations were performed using the M06 functional (54) with Grimme's DFT-D3 dispersion correction and a mixed basis set of SDD (55) for $\mathrm{W}$ and 6-311+G(d,p) for other atoms in toluene solvent using the SMD continuum solvation model (56). The reported Gibbs free energies and enthalpies include thermal corrections at $298 \mathrm{~K}$. Gibbs free energies and enthalpies at $150{ }^{\circ} \mathrm{C}$ were also calculated and are provided below. All reported $\mathrm{W}$ species have singlet spin state.

\section{Catalyst Activation and Substrate Coordination Steps to Form the Reactant Complex I-1}

The computed reaction energy profile to form the substrate complex I-1 from the $\mathrm{W}(\mathrm{CO})_{6}$ precatalyst is shown in Figure $\mathrm{S} 14 . \mathrm{W}(\mathrm{CO})_{6}$ is known to be relatively stable due to its 18 -electron configuration (57). The catalyst initiation process requires dissociation of one of the $\mathrm{CO}$ ligands to form $\mathrm{W}(\mathrm{CO})_{5}(57) . \mathrm{W}(\mathrm{CO})_{5}$ then undergoes facile ligand exchange to replace a second $\mathrm{CO}$ ligand with the substrate (1a) to form I-9. The alkenyl group can then coordinate to the $\mathrm{W}$ center, replacing a third CO ligand to form $\pi$-alkene complex I-1.

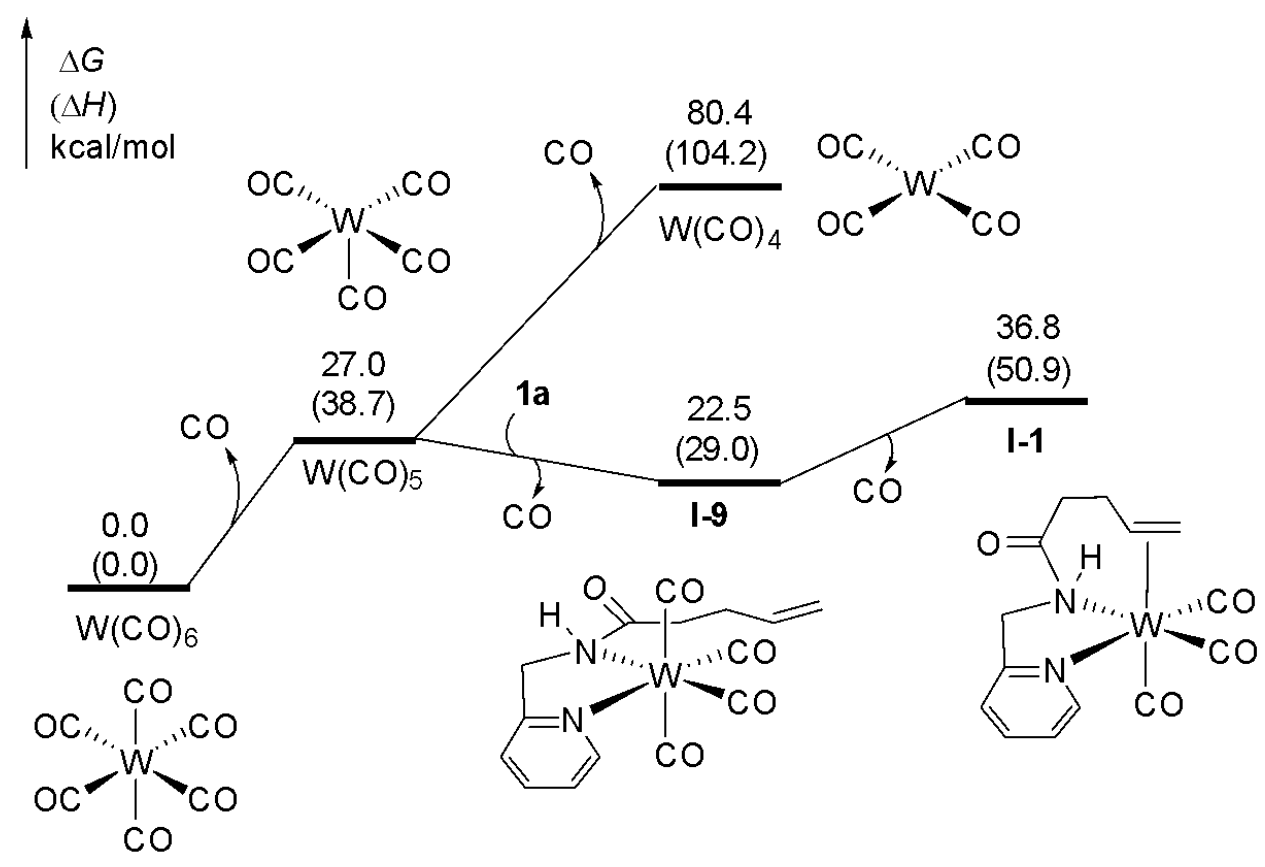


Figure S14 Substrate coordination to the W center.

Several isomers of the $\pi$-alkene complex I-1 were located (Figure S15). The most stable isomer $\mathbf{I} \mathbf{- 1}$ has a facial coordination geometry, in which the pyridine and amide nitrogen atoms and the alkene are all cis to one another. The meridional isomer I-1a, in which the pyridine and amide nitrogen atoms and the alkene are coplanar, is less stable by $3.1 \mathrm{kcal} / \mathrm{mol}$. Here, the meridional isomer is destabilized due to the strong trans effect of the trans positioned CO ligands. Dissociation of the alkenyl group from I-1 to form five-coordinate $\mathrm{W}$ complex $\mathbf{I}-\mathbf{1 b}$ is endergonic by $12.0 \mathrm{kcal} / \mathrm{mol}$. Other isomers of the five-coordinate $\mathrm{W}$ complex (I-1c-e) are also much less stable than the six-coordinate octahedral complex I-1. Dissociation of the pyridine from I-1 to form five-coordinate complex I-1f is endergonic by $16.7 \mathrm{kcal} / \mathrm{mol}$. Taken together, these results indicate that the octahedral W(0) complexes I-1 and I-1a are the most stable complexes formed after the substrate binds to the W.

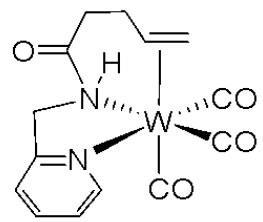

I-1

$\Delta G(\Delta H)$

$\mathrm{kcal} / \mathrm{mol}$

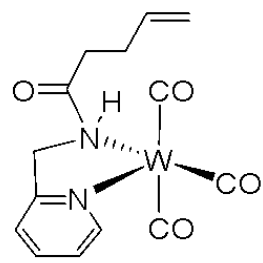

I-1d

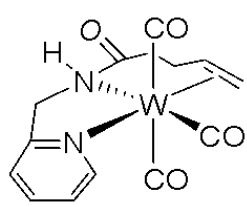

I-1a

$3.1(3.6)$

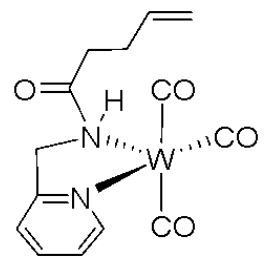

I-1e

$37.1(40.3)$

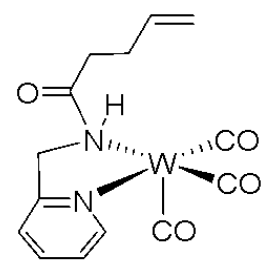

I-1b

$12.0(15.6)$<smiles>O=C1CCC(=O)[N+]([O-])([O-])N1Cc1ccccn1</smiles>

I-1f

$16.7(18.7)$

$\Delta G(\Delta H) \quad 32.1(34.8)$

$\mathrm{kcal} / \mathrm{mol}$

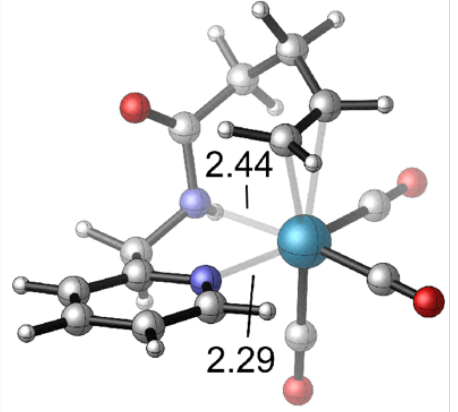

$\mathrm{I}-1$

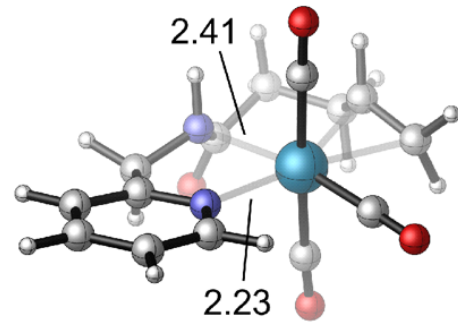

I-1a

Figure S15 Isomers of the substrate complex l-1.

Next, we considered the $\mathrm{N}-\mathrm{H}$ oxidative addition transition states from both $\mathbf{I}-\mathbf{1}$ and I-1a and the resulting $\mathrm{W}$-hydride complexes (Figure S16). The facial complex I-1 leads to transition 
state TS1, which then forms W(II) complex I-2a. On the other hand, the meridional complex I1a leads to TS1a, which then forms W(II) complex I-2. In both TS1 and I-2a, the pyridine and amide $\mathrm{N}$ atoms and the alkene are cis to one another. The planar geometry of the $s p^{2}$-hybridized amide $\mathrm{N}$ leads to substantial distortion of the substrate in I-2a. TS1, the facial isomer, is 12.9 $\mathrm{kcal} / \mathrm{mol}$ lower in energy than the meridional isomer, TS1a, while the product of TS1 (I-2) is 2.7 $\mathrm{kcal} / \mathrm{mol}$ less stable than I-2a. These results indicate that by a difference of $12.9 \mathrm{kcal} / \mathrm{mol}$, the most favorable $\mathrm{N}-\mathrm{H}$ oxidative addition process occurs from the facial $\mathrm{W}(0)$ complex I-1 via TS1 to form W(II) complex $\mathbf{I - 2 a}$, which then isomerizes to the more stable isomer $\mathbf{I}-\mathbf{2}$ prior to hydrometallation across the alkene. In I-2 and subsequent intermediates in the alkene isomerization process, the pyridine $\mathrm{N}$, the amide $\mathrm{N}$, and the alkene are coplanar. This geometry is consistent with the crystal structures of the seven-coordinated W(II) complexes.

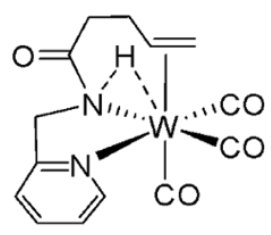

$\Delta G^{\ddagger}\left(\Delta H^{\ddagger}\right) \quad 22.8(23.2)$ $\mathrm{kcal} / \mathrm{mol}$

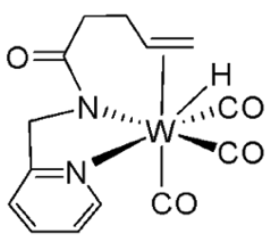

$\Delta G(\Delta H)$

$\mathrm{kcal} / \mathrm{mol}$

Figure S16 Isomers of the $\mathrm{N}-\mathrm{H}$ oxidative addition transition state TS1 and the seven-coordinate W(II) hydride complex I-2. All Gibbs free energies and enthalpies are with respect to I-1.
TS1

I-2a
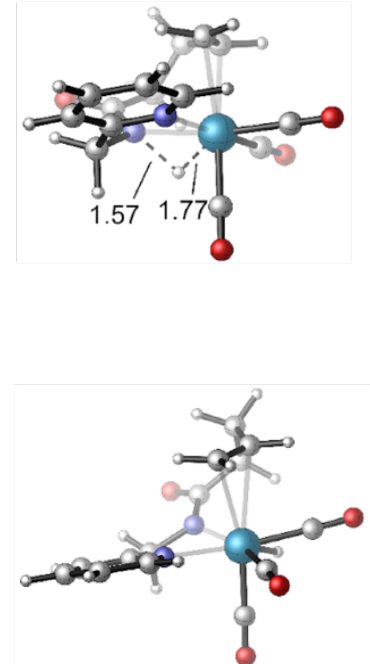

$9.1(10.6)$

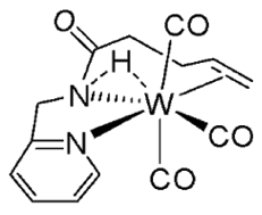

TS1a

35.7 (36.7)

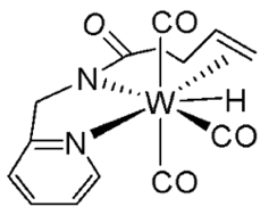

I-2

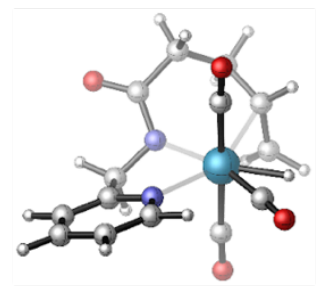

$6.4(6.2)$

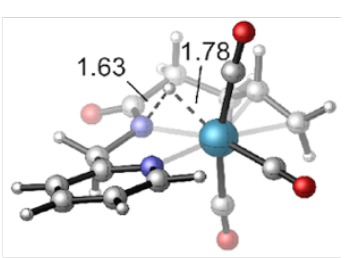

\section{Alternative Reaction Pathways}

\section{1,3-Hydride Shift}

We considered the 1,3-hydride shift pathway, which initiates via the oxidative addition of the allylic $\mathrm{C}-\mathrm{H}$ bond in substrate complex $\mathbf{I}-\mathbf{1}$ to form a $\pi$-allyltungsten-hydride complex, followed by $\mathrm{C}-\mathrm{H}$ reductive elimination to shuttle the $\mathrm{H}$ atom to the terminal carbon of the allyl moiety, thereby forming the isomerized alkene with an internal $\mathrm{C}=\mathrm{C}$ double bond. We carefully considered various isomers of the allylic $\mathrm{C}-\mathrm{H}$ oxidative addition transition state. Because complex I-1 is already six-coordinate, one of the ligands from I-1 needs to dissociate prior to the allylic $\mathrm{C}-\mathrm{H}$ oxidative addition step. We have considered the following possibilities: dissociation of the amide N (TS7a), dissociation of the pyridine (TS7b), dissociation of one of the CO ligands (TS7c), and dissociation of the alkenyl group (TS7d) from I-1 (Figure S17). Our calculations indicate that 
the most favorable allylic $\mathrm{C}-\mathrm{H}$ oxidative addition is TS7a, which requires $27.5 \mathrm{kcal} / \mathrm{mol}$ with respect to I-1. Because the $\mathrm{N}-\mathrm{H}$ oxidative addition from I-1 (TS1) requires a lower barrier $\left(\Delta G^{\star}\right.$ $=22.8 \mathrm{kcal} / \mathrm{mol}$ ), the 1,2 -hydride shift pathway via $\mathrm{N}-\mathrm{H}$ oxidative addition is more favorable than the 1,3-hydride shift pathway.

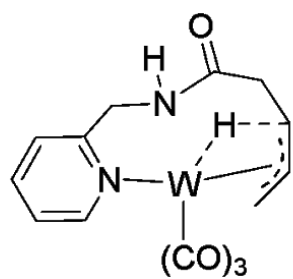

TS7a

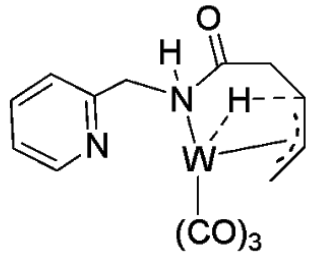

TS7b

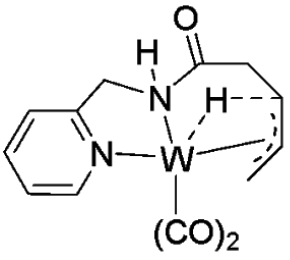

TS7c

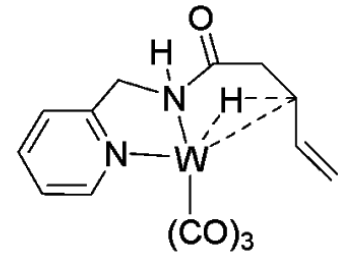

TS7d

$\mathrm{kcal} / \mathrm{mol}$

34.3 (35.4)

46.5 (56.8)

38.3 (39.4)

Figure S17 Isomers of the allylic $\mathrm{C}-\mathrm{H}$ oxidative addition transition states. All Gibbs free energies and enthalpies are with respect to $\mathbf{l}-\mathbf{1}$.

\section{Other N-H Oxidative Addition Transition States}

Besides TS1 and TS1a discussed above, we have considered several $\mathrm{N}-\mathrm{H}$ oxidative addition transition states, including reactions from both five- and six-coordinated $\mathrm{W}(0)$ complexes with and without the alkenyl group of the substrate binding to the W center. Figure S18 illustrates the alternative pathway involving the $\mathrm{N}-\mathrm{H}$ oxidative addition from two different five-coordinate $\mathrm{W}$ complexes (I-10 and I-1c), formed by dissociation of a CO ligand and the alkenyl group, respectively, from the octahedral complex I-1. Formation of both five-coordinated complexes are endergonic (by 27.2 and $11.2 \mathrm{kcal} / \mathrm{mol}$ to form I-10 and I-1c, respectively). Subsequent N-H oxidative addition (TS1b and TS1c) requires activation free energies of 48.1 and $34.2 \mathrm{kcal} / \mathrm{mol}$, respectively. Both are much less favorable than $\mathrm{N}-\mathrm{H}$ oxidative addition from the octahedral complex I-1. These results indicate the oxidative addition with a six-coordinate, 18-electron $\mathrm{W}(0)$ complex to form a seven-coordinate W(II)-hydride intermediate is much more favorable than the oxidative addition with a five-coordinate, 16-electron $\mathrm{W}(0)$ complex to form a six-coordinate W(II)-hydride. 

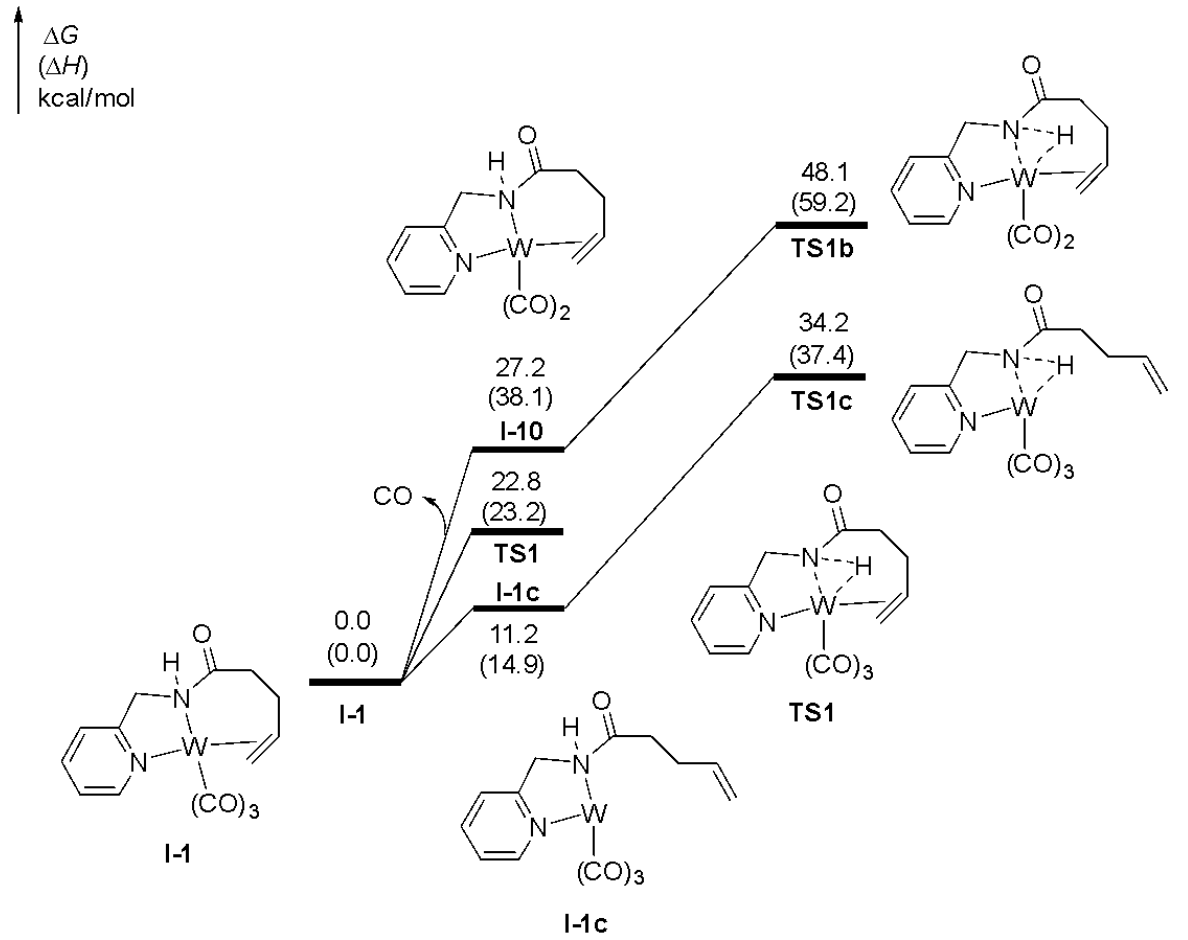

Figure S18 Alternative $\mathrm{N}-\mathrm{H}$ oxidative addition pathways. All Gibbs free energies and enthalpies are with respect to $\mathbf{l}-\mathbf{1}$.

Next, we considered the N-H oxidative addition from an octahedral complex I-9, which involves the $N, N$-bidentate coordination of the substrate onto a $\mathrm{W}(0)$ center with four carbonyl ligands. Complex I-9 is $14.3 \mathrm{kcal} / \mathrm{mol}$ more stable than I-1 in terms of Gibbs free energy (Figure S19), indicating that I-9 may accumulate, especially under relatively high CO concentrations. Nonetheless, I-9 is less reactive than $\mathbf{I - 1}$ in the $\mathrm{N}-\mathrm{H}$ oxidative addition step, which requires an activation free energy of $36.8 \mathrm{kcal} / \mathrm{mol}$ (TS1d) with respect to I-9, much higher than the $\mathrm{N}-\mathrm{H}$ oxidative addition barrier from I-1 $(22.8 \mathrm{kcal} / \mathrm{mol})$. Therefore, I-9 is unlikely to be the active species involved in the $\mathrm{N}-\mathrm{H}$ oxidative addition step. 
A.

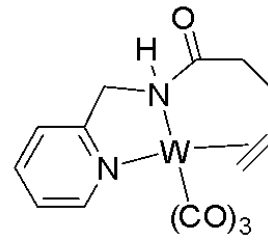

$\mathrm{I}-1$

$\Delta G=0.0 \mathrm{kcal} / \mathrm{mol}$

$\Delta H=0.0 \mathrm{kcal} / \mathrm{mol}$

B.

$1-9$

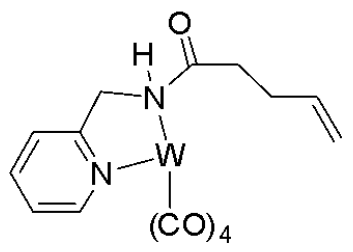

$1-9$

$\Delta G=-14.3 \mathrm{kcal} / \mathrm{mol}$

$\Delta H=-21.9 \mathrm{kcal} / \mathrm{mol}$

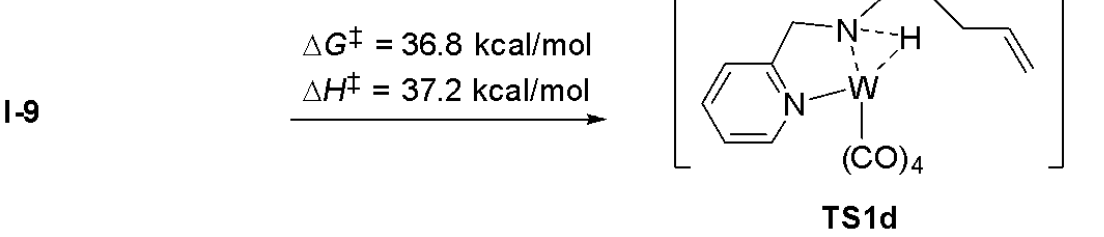

Figure $\mathbf{S 1 9}$ The $\mathrm{N}-\mathrm{H}$ oxidative addition pathway via six-coordinate W complex I-9.

\section{Reaction Energy Profile of a Bis(CO)-Ligated Pathway Involving Five- and Six-Coordinate W Complexes}

Here, we compared the two reaction pathways of $\mathrm{N}-\mathrm{H}$ oxidative addition and alkene isomerization through a hydride shift process via the six-coordinate tris $(\mathrm{CO})$-ligated $\mathrm{W}(0)$ complex I-1 and the five-coordinate bis(CO)-ligated W(0) complex I-10, respectively (Figures S20 and S21). In the former pathway, a seven-coordinate W(II)-hydride intermediate (I-2) is formed after the $\mathrm{N}-\mathrm{H}$ oxidative addition, which then promotes the alkene migration, shuttling between sevenand six-coordinate W(II) complexes. In the alternative pathway involving I-10, a six-coordinate W(II)-hydride intermediate is formed, and the subsequent alkene migration involves six- and fivecoordinate W(II) complexes. As discussed in the earlier section, the $\mathrm{N}-\mathrm{H}$ oxidative addition from I-10 is highly unfavorable, because of the highly endergonic dissociation of one CO molecule from $\mathbf{I - 1}$ to form $\mathbf{I}-\mathbf{1 0}$ and another $20.9 \mathrm{kcal} / \mathrm{mol}$ required to reach the $\mathrm{N}-\mathrm{H}$ oxidative addition transition state TS1b. After the N-H oxidative addition via TS1b to form I-2b, the six- and fivecoordinate W(II) intermediates (I-2b, I-3a, and I-4a) and the hydride migration transition states (TS2a, TS3a, and TS4a) in this bis(CO)-ligated pathway are all less stable than the corresponding seven- and six-coordinate W(II) complexes and transition states in tris(CO)-ligated pathway. Therefore, these results indicate that the tris $(\mathrm{CO})$-ligated pathway involving seven- and sixcoordinate $\mathrm{W}$ species is more favorable in both $\mathrm{N}-\mathrm{H}$ oxidative addition and alkene isomerization steps. 


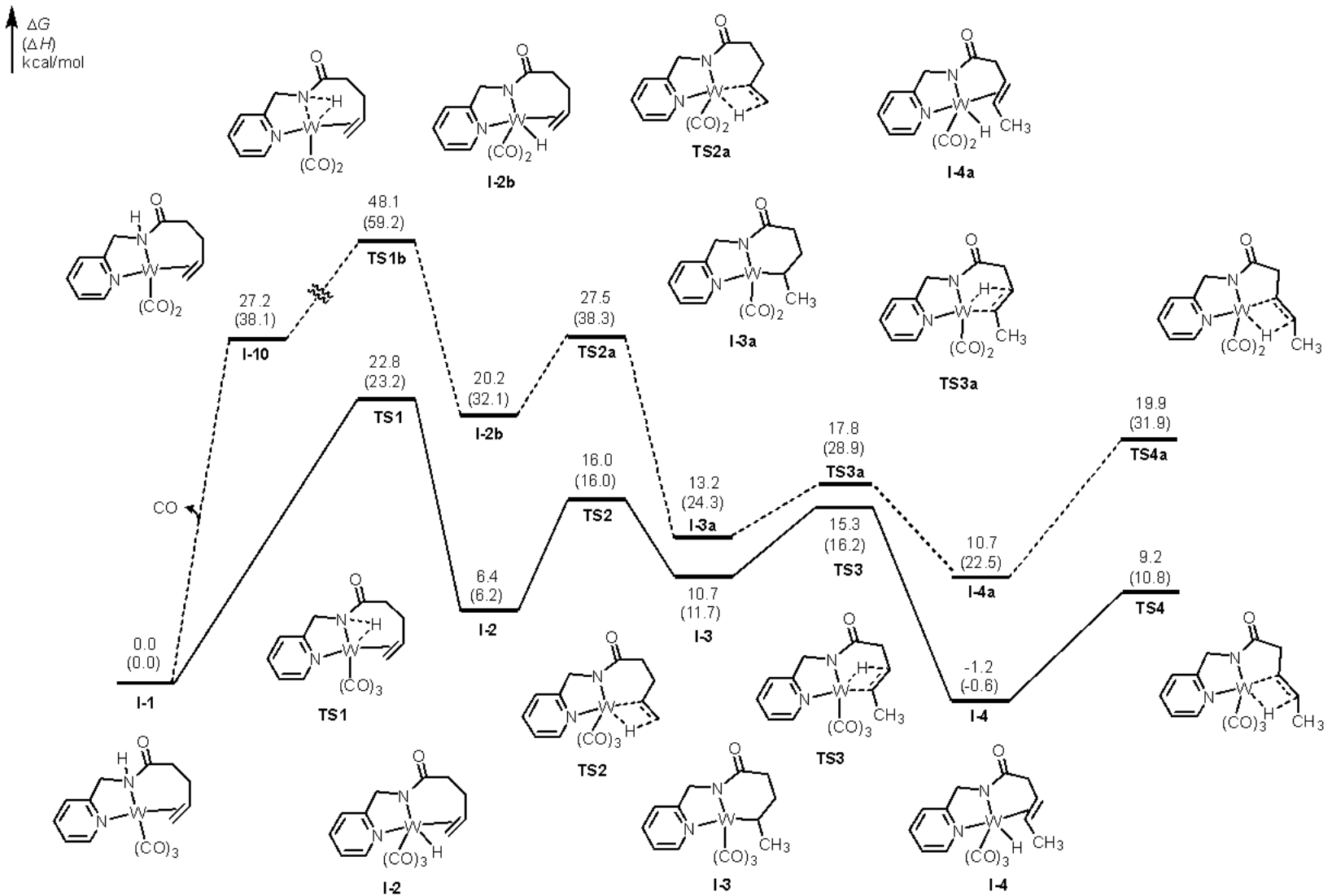

Figure S20 Reaction energy profiles of the $\mathrm{N}-\mathrm{H}$ oxidative addition and alkene isomerization pathways involving of six-coordinate W complex I-1 (in solid lines) and five-coordinate W complex I-10 (in dashed lines). All Gibbs free energies and enthalpies are with respect to I-1. 


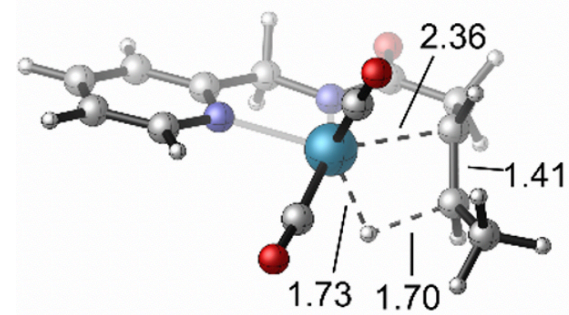

TS3a

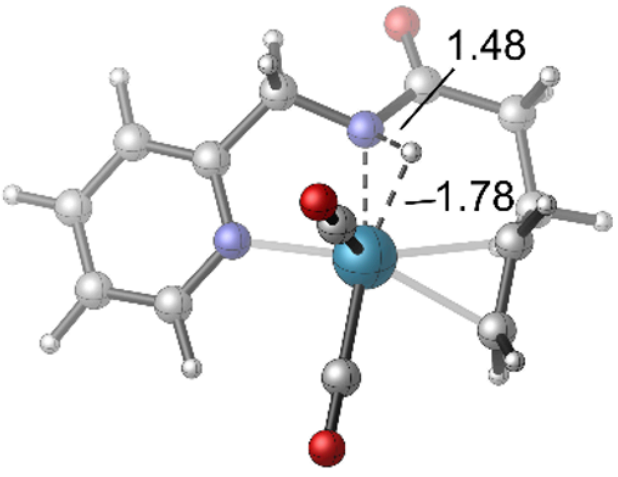

TS1b

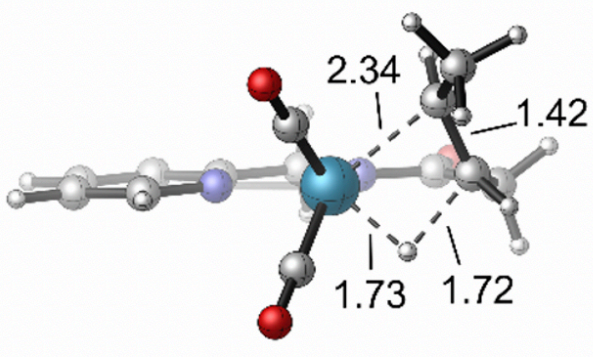

TS4a

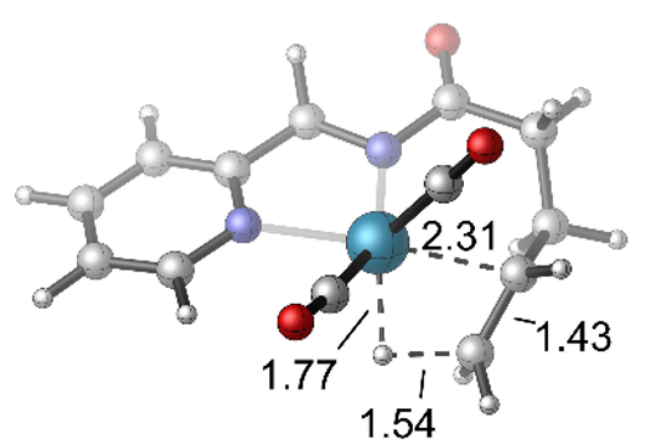

TS2a

Figure S21 3D structures of transition states in the bis(CO)-ligated reaction pathway.

\section{Agostic Interactions with $\beta-C-H$ Bonds in Alkyl-W(II) Complexes}

Agostic interactions between the W(II) center and $\beta-\mathrm{C}-\mathrm{H}$ bonds are observed in alkyl W(II) complexes I-3 and I-5 (Figure S22). Two different isomers of I-3 (I-3 and I-3b) were located, which involve agostic interactions with the endo- and exocyclic $\beta-\mathrm{C}-\mathrm{H}$ bonds, respectively. The $\beta-\mathrm{C}-\mathrm{H}$ agostic interactions in the six-membered metallacycle (I-3 and $\mathbf{I}-\mathbf{- 3 b})$ are stronger than in the five-membered metallacycle $\mathbf{I}-\mathbf{5}$, as evidenced by the shorter $\mathrm{W}-\mathrm{H}$ distances and longer $\mathrm{C}-\mathrm{H}$ distances in $\mathbf{I}-\mathbf{- 3} / \mathbf{I}-\mathbf{- 3 b}$ than in $\mathbf{I}-\mathbf{- 5}$. The relatively strong agostic interaction in $\mathbf{I}-\mathbf{3}$ promotes the subsequent endocyclic $\beta$-H elimination (TS3), which requires a low barrier $(4.6 \mathrm{kcal} / \mathrm{mol})$ with respect to $\mathbf{I}-\mathbf{3}$. 


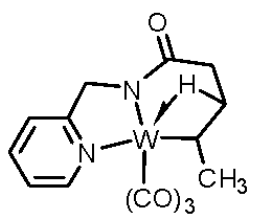

$1-3$

$\Delta G=10.7 \mathrm{kcal} / \mathrm{mol}$ $\Delta H=11.7 \mathrm{kcal} / \mathrm{mol}$<smiles></smiles>

$1-5$
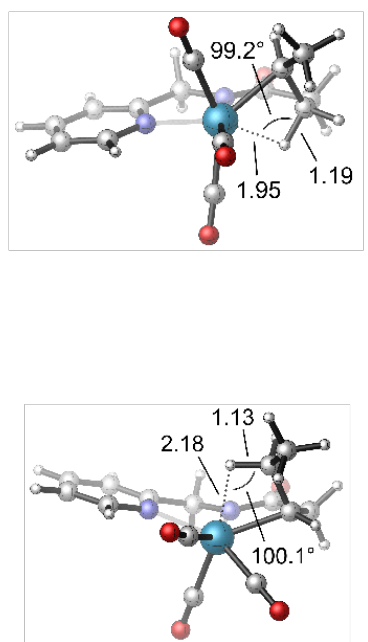
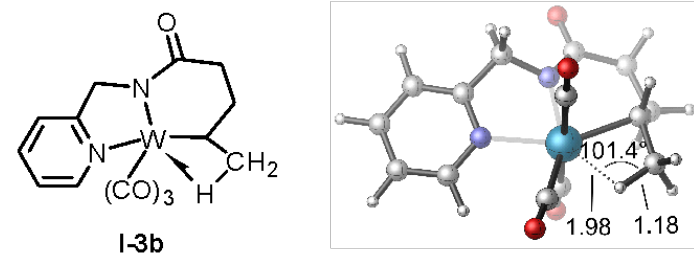

$\Delta G=11.7 \mathrm{kcal} / \mathrm{mol}$ $\Delta H=12.9 \mathrm{kcal} / \mathrm{mol}$

$\Delta G=-5.1 \mathrm{kcal} / \mathrm{mol}$ $\Delta H=-4.1 \mathrm{kcal} / \mathrm{mol}$

Figure 22 3D structures of agostic interactions with $\beta-\mathrm{C}-\mathrm{H}$ bonds in complexes I-3, I-3b, and I-5. All Gibbs free energies and enthalpies are with respect to $\mathbf{l - 1}$.

\section{Energy profile with $\Delta G$ and $\Delta H$ calculated at $150{ }^{\circ} \mathrm{C}$}

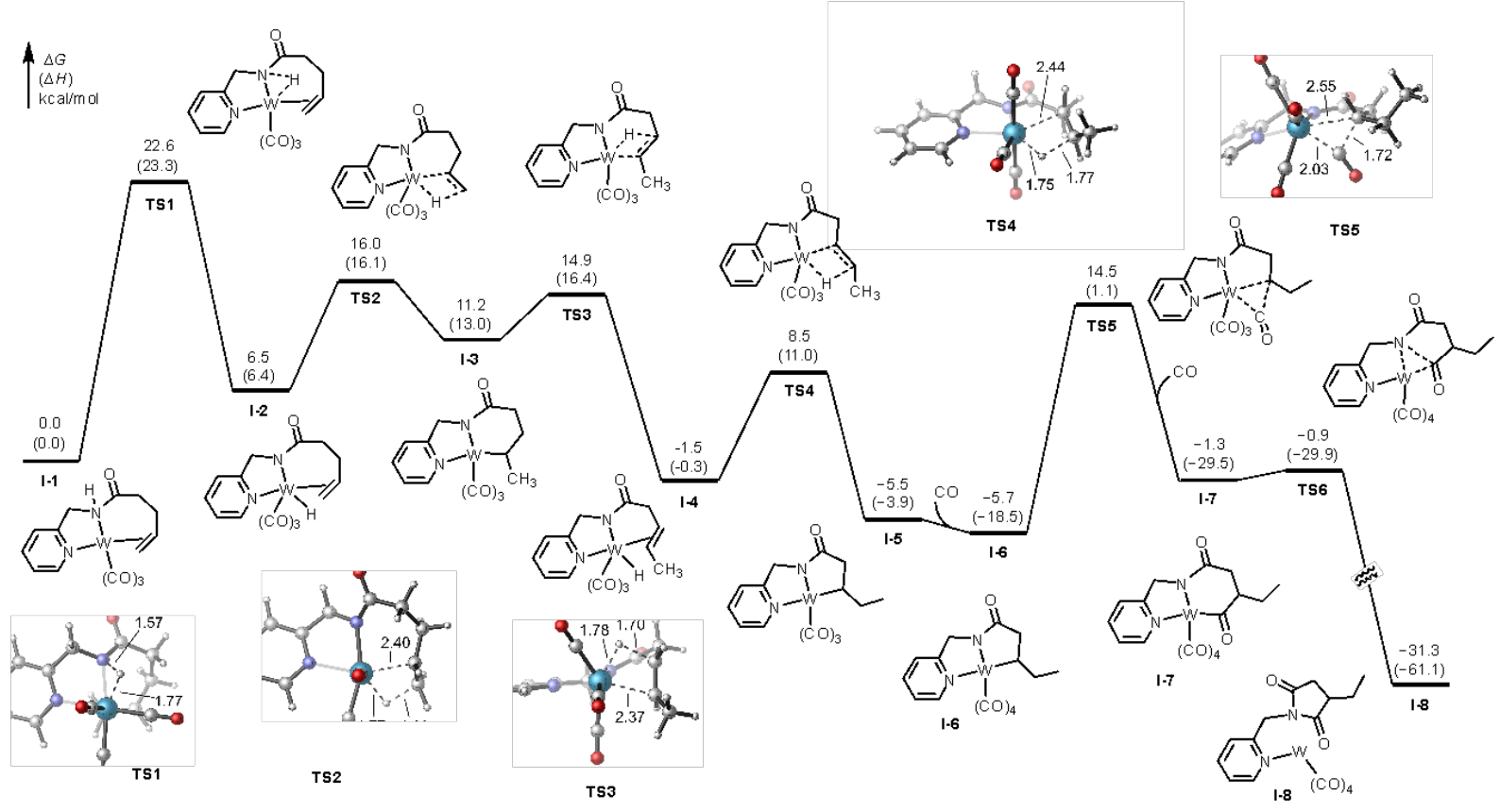

Figure S23 Reaction energy profile with $\Delta G$ and $\Delta H$ calculated at $150^{\circ} \mathrm{C}$ 


\section{Cartesian Coordinates and Energies of All Optimized Structures}

\section{I-1}

B3LYP-D3 electronic energy: $\quad-1020.264850$ a.u.

B3LYP-D3 enthalpy: $\quad-1019.977753$ a.u.

B3LYP-D3 free energy: $\quad-1020.048093$ a.u.

M06-D3 SCF energy in solution: $\quad-1019.169244$ a.u.

M06-D3 enthalpy in solution: $\quad-1018.882147$ a.u.

M06-D3 free energy in solution: $\quad-1018.952487$ a.u.

Cartesian coordinates

$\begin{array}{lrrr}\text { ATOM X } & \text { Y } & \text { Z } & \\ 74 & 0.592193000 & -0.523893000 & 0.059753000 \\ 6 & 0.886202000 & -2.152469000 & -0.969673000 \\ 6 & 0.322364000 & -1.602381000 & 1.699553000 \\ 6 & 2.518613000 & -0.388566000 & 0.478977000 \\ 8 & 0.158321000 & -2.229240000 & 2.673062000 \\ 8 & 0.992669000 & -3.113699000 & -1.634672000 \\ 8 & 3.646879000 & -0.238167000 & 0.759008000 \\ 7 & -1.683273000 & -0.395728000 & -0.129934000 \\ 6 & -2.344517000 & 0.519267000 & 0.614014000 \\ 6 & -2.389428000 & -1.140950000 & -1.006740000 \\ 6 & -3.714854000 & 0.731370000 & 0.475951000 \\ 6 & -1.542376000 & 1.250407000 & 1.666854000 \\ 6 & -3.760012000 & -0.999384000 & -1.182364000 \\ 1 & -1.813927000 & -1.864558000 & -1.572700000 \\ 6 & -4.438450000 & -0.037553000 & -0.432555000 \\ 1 & -4.201404000 & 1.493064000 & 1.076875000 \\ 1 & -2.025099000 & 2.200096000 & 1.916658000 \\ 1 & -1.494753000 & 0.622240000 & 2.562879000 \\ 7 & -0.146518000 & 1.473493000 & 1.246144000 \\ 1 & -4.276941000 & -1.628186000 & -1.899444000 \\ 1 & -5.507095000 & 0.111557000 & -0.553453000 \\ 6 & 0.103736000 & 2.583653000 & 0.396530000 \\ 6 & 1.571210000 & 2.849839000 & 0.124469000 \\ 8 & -0.814196000 & 3.173541000 & -0.139093000 \\ 1 & 1.745937000 & 3.924521000 & 0.245144000 \\ 1 & 2.207579000 & 2.307649000 & 0.829397000 \\ 6 & 1.937591000 & 2.438879000 & -1.323294000 \\ 1 & 1.464230000 & 3.156352000 & -2.004582000 \\ 1 & 3.020096000 & 2.558457000 & -1.428971000 \\ 6 & 1.544417000 & 1.031397000 & -1.768355000 \\ 1 & 2.352984000 & 0.417300000 & -2.154130000 \\ 6 & 0.245618000 & 0.677625000 & -2.078020000 \\ 1 & 0.043330000 & -0.158745000 & -2.740733000 \\ 1 & -0.563525000 & 1.393690000 & -1.955303000 \\ 1 & 0.524750000 & 1.383990000 & 2.004655000\end{array}$

TS1

B3LYP-D3 electronic energy:

B3LYP-D3 enthalpy:

B3LYP-D3 free energy:

M06-D3 SCF energy in solution:

M06-D3 enthalpy in solution:

M06-D3 free energy in solution:

-1020.220051 a.u.

$$
\begin{aligned}
& -1019.940935 \text { a.u. } \\
& -1020.011912 \text { a.u. } \\
& -1019.124279 \text { a.u. } \\
& -1018.845163 \text { a.u. } \\
& -1018.916140 \text { a.u. }
\end{aligned}
$$


Cartesian coordinates

$\begin{array}{lrrrr}\text { ATOM } & \text { X } & \text { Y } & \text { Z } & \\ 74 & 0.450126000 & -0.573082000 & 0.121057000 \\ 6 & 0.482673000 & -2.414242000 & -0.697285000 \\ 6 & -0.186116000 & -1.497331000 & 1.764162000 \\ 6 & 2.397510000 & -0.881408000 & 0.421388000 \\ 8 & -0.589261000 & -2.037985000 & 2.711548000 \\ 8 & 0.475911000 & -3.469513000 & -1.184750000 \\ 8 & 3.539371000 & -1.040996000 & 0.584361000 \\ 7 & -1.763161000 & -0.15259000 & -0.223924000 \\ 6 & -2.234010000 & 0.963751000 & 0.380135000 \\ 6 & -2.604605000 & -0.904505000 & -0.959466000 \\ 6 & -3.566263000 & 1.353402000 & 0.243121000 \\ 6 & -1.244064000 & 1.716637000 & 1.236277000 \\ 6 & -3.943315000 & -0.577482000 & -1.133734000 \\ 1 & -2.172869000 & -1.792237000 & -1.409137000 \\ 6 & -4.434240000 & 0.577257000 & -0.521663000 \\ 1 & -3.908254000 & 2.258914000 & 0.734008000 \\ 1 & -1.480329000 & 2.783662000 & 1.276063000 \\ 1 & -1.312172000 & 1.313207000 & 2.259437000 \\ 7 & 0.110210000 & 1.537839000 & 0.730971000 \\ 1 & -4.580491000 & -1.215999000 & -1.736150000 \\ 1 & -5.474018000 & 0.867706000 & -0.639819000 \\ 6 & 0.843811000 & 2.672488000 & 0.470855000 \\ 6 & 2.265436000 & 2.426336000 & -0.017128000 \\ 8 & 0.393615000 & 3.814075000 & 0.575718000 \\ 1 & 2.799307000 & 3.374629000 & 0.084762000 \\ 1 & 2.770252000 & 1.676663000 & 0.598858000 \\ 6 & 2.311414000 & 1.995265000 & -1.503485000 \\ 1 & 1.811671000 & 2.775508000 & -2.091241000 \\ 1 & 3.361128000 & 1.983707000 & -1.816967000 \\ 6 & 1.696495000 & 0.653660000 & -1.867481000 \\ 1 & 2.388346000 & -0.135677000 & -2.150179000 \\ 6 & 0.363727000 & 0.473826000 & -2.128235000 \\ 1 & 0.012999000 & -0.395942000 & -2.679495000 \\ 1 & -0.329888000 & 1.306577000 & -2.048482000 \\ 1 & 0.927831000 & 0.436317000 & 1.491052000\end{array}$

\section{I-2}

B3LYP-D3 electronic energy: $\quad-1020.24472$ a.u. B3LYP-D3 enthalpy: $\quad-1019.963578$ a.u. B3LYP-D3 free energy: -1020.033628 a.u.

M06-D3 SCF energy in solution: $\quad-1019.153350$ a.u. M06-D3 enthalpy in solution: $\quad-1018.872208$ a.u. M06-D3 free energy in solution: $\quad-1018.942258$ a.u.

Cartesian coordinates
$\begin{array}{lllc}\text { ATOM } \mathrm{X} & \mathrm{Y} & \mathrm{Z} & \\ 74 & -0.427963000 & -0.641053000 & 0.054251000 \\ 6 & 0.061802000 & -1.158238000 & 1.978990000 \\ 6 & 0.280733000 & -2.386909000 & -0.588497000 \\ 8 & 0.772790000 & -3.378085000 & -0.987459000 \\ 8 & 0.328453000 & -1.512025000 & 3.045772000 \\ 7 & 1.729077000 & 0.053361000 & -0.134036000\end{array}$




$\begin{array}{rrrr}6 & 1.995571000 & 1.211774000 & 0.515915000 \\ 6 & 2.718043000 & -0.563046000 & -0.813853000 \\ 6 & 3.269901000 & 1.776645000 & 0.490691000 \\ 6 & 0.827292000 & 1.810807000 & 1.256314000 \\ 6 & 4.006973000 & -0.050960000 & -0.877727000 \\ 1 & 2.456263000 & -1.488522000 & -1.311044000 \\ 6 & 4.290149000 & 1.143329000 & -0.213353000 \\ 1 & 3.441569000 & 2.711304000 & 1.014362000 \\ 1 & 0.820556000 & 1.396046000 & 2.277026000 \\ 1 & 0.932434000 & 2.896894000 & 1.323558000 \\ 7 & -0.408469000 & 1.454851000 & 0.569760000 \\ 1 & 4.765615000 & -0.581538000 & -1.442819000 \\ 1 & 5.286088000 & 1.575097000 & -0.249653000 \\ 6 & -1.009455000 & 2.509005000 & -0.075597000 \\ 6 & -2.310429000 & 2.202637000 & -0.820304000 \\ 8 & -0.589092000 & 3.669330000 & -0.054795000 \\ 1 & -2.825476000 & 3.162374000 & -0.920140000 \\ 1 & -2.080064000 & 1.871383000 & -1.838645000 \\ 6 & -3.232779000 & 1.196503000 & -0.117524000 \\ 1 & -3.407031000 & 1.557255000 & 0.902835000 \\ 1 & -4.208157000 & 1.212305000 & -0.622415000 \\ 6 & -0.715444000 & -0.217867000 & -1.922407000 \\ 8 & -0.843482000 & -0.059776000 & -3.060079000 \\ 1 & -1.078065000 & -2.320451000 & -0.196742000 \\ 6 & -2.801879000 & -0.265692000 & -0.040759000 \\ 1 & -3.181923000 & -0.915205000 & -0.825886000 \\ 6 & -2.495277000 & -0.848138000 & 1.196529000 \\ 1 & -2.680330000 & -1.900122000 & 1.389192000 \\ 1 & -2.477012000 & -0.211034000 & 2.077739000\end{array}$

TS2

B3LYP-D3 electronic energy: $\quad-1020.227829$ a.u. B3LYP-D3 enthalpy: $\quad-1019.94845$ a.u.

B3LYP-D3 free energy: $\quad-1020.018797$ a.u.

M06-D3 SCF energy in solution: $\quad-1019.135985$ a.u.

M06-D3 enthalpy in solution: $\quad-1018.856606$ a.u.

M06-D3 free energy in solution: $\quad-1018.926953$ a.u.

Cartesian coordinates

$\begin{array}{lrrr}\text { ATOM X } & \text { Y } & \text { Z } & \\ 74 & 0.393410000 & -0.615209000 & -0.105484000 \\ 6 & -0.013119000 & -0.612552000 & -2.136710000 \\ 6 & -0.218170000 & -2.455204000 & 0.366275000 \\ 8 & -0.606698000 & -3.510716000 & 0.678953000 \\ 8 & -0.252085000 & -0.621600000 & -3.265447000 \\ 7 & -1.780583000 & -0.005680000 & 0.116341000 \\ 6 & -2.070520000 & 1.256269000 & -0.276948000 \\ 6 & -2.777185000 & -0.784895000 & 0.591404000 \\ 6 & -3.371738000 & 1.757144000 & -0.210247000 \\ 6 & -0.915155000 & 2.053766000 & -0.807620000 \\ 6 & -4.091309000 & -0.349298000 & 0.678366000 \\ 1 & -2.499039000 & -1.781151000 & 0.909536000 \\ 6 & -4.397674000 & 0.950262000 & 0.269377000 \\ 1 & -3.558381000 & 2.777635000 & -0.528655000 \\ 1 & -0.915472000 & 1.948869000 & -1.907107000\end{array}$




$\begin{array}{rrrr}1 & -1.042615000 & 3.116366000 & -0.579807000 \\ 7 & 0.343597000 & 1.570889000 & -0.256168000 \\ 1 & -4.851458000 & -1.017476000 & 1.068457000 \\ 1 & -5.413943000 & 1.327844000 & 0.334595000 \\ 6 & 1.106156000 & 2.556628000 & 0.310113000 \\ 6 & 2.507219000 & 2.148082000 & 0.757233000 \\ 8 & 0.760471000 & 3.738741000 & 0.418467000 \\ 1 & 3.090242000 & 3.071556000 & 0.799485000 \\ 1 & 2.467832000 & 1.749252000 & 1.780211000 \\ 6 & 3.162581000 & 1.120739000 & -0.176988000 \\ 1 & 2.931083000 & 1.363002000 & -1.220853000 \\ 1 & 4.256325000 & 1.179456000 & -0.068992000 \\ 6 & 0.692220000 & -0.483786000 & 1.902308000 \\ 8 & 0.865945000 & -0.414911000 & 3.044074000 \\ 1 & 1.255117000 & -2.040146000 & -0.712891000 \\ 6 & 2.761433000 & -0.300427000 & 0.132583000 \\ 1 & 3.070597000 & -0.635958000 & 1.121839000 \\ 6 & 2.664403000 & -1.304513000 & -0.849695000 \\ 1 & 3.025248000 & -2.305476000 & -0.618189000 \\ 1 & 2.755077000 & -1.030188000 & -1.898087000\end{array}$

I-3

B3LYP-D3 electronic energy: $\quad-1020.233099$ a.u.

B3LYP-D3 enthalpy: $\quad-1019.950957$ a.u.

B3LYP-D3 free energy: $\quad-1020.022862$ a.u.

M06-D3 SCF energy in solution: $\quad-1019.145707$ a.u.

M06-D3 enthalpy in solution: $\quad-1018.863565$ a.u.

M06-D3 free energy in solution: $\quad-1018.935470$ a.u.

\begin{tabular}{lrrr}
\multicolumn{4}{l}{ Cartesian coordinates } \\
ATOM X X Y Y & $\mathrm{Z}$ & \\
74 & -0.409014000 & -0.348440000 & 0.158177000 \\
6 & 0.178770000 & -0.654448000 & 2.116191000 \\
6 & -0.917576000 & -2.258442000 & 0.381953000 \\
8 & -1.240433000 & -3.375454000 & 0.511562000 \\
8 & 0.513249000 & -0.991185000 & 3.171448000 \\
7 & 1.779952000 & -0.199827000 & -0.105457000 \\
6 & 2.274498000 & 1.047652000 & -0.309192000 \\
6 & 2.623417000 & -1.256195000 & -0.060075000 \\
6 & 3.648963000 & 1.242731000 & -0.470035000 \\
6 & 1.305429000 & 2.199828000 & -0.370721000 \\
6 & 3.994126000 & -1.119643000 & -0.215932000 \\
1 & 2.153877000 & -2.217771000 & 0.106996000 \\
6 & 4.517755000 & 0.158457000 & -0.425338000 \\
1 & 4.018622000 & 2.251158000 & -0.627071000 \\
1 & 1.649159000 & 3.008005000 & 0.292826000 \\
1 & 1.344008000 & 2.632193000 & -1.386349000 \\
7 & -0.032584000 & 1.770442000 & -0.026889000 \\
1 & 4.630458000 & -1.996636000 & -0.172159000 \\
1 & 5.586692000 & 0.305215000 & -0.549096000 \\
6 & -0.927366000 & 2.767499000 & 0.152083000 \\
6 & -2.324301000 & 2.291071000 & 0.587003000 \\
8 & -0.689842000 & 3.973524000 & 0.027209000 \\
1 & -2.471453000 & 2.616757000 & 1.624519000 \\
1 & -3.068456000 & 2.820233000 & -0.016927000
\end{tabular}




$\begin{array}{rrrr}6 & -2.550333000 & 0.780750000 & 0.466301000 \\ 1 & -1.861441000 & 0.271900000 & 1.297443000 \\ 6 & -2.343559000 & 0.186418000 & -0.887035000 \\ 1 & -2.127865000 & 0.956185000 & -1.629101000 \\ 6 & -3.322617000 & -0.867150000 & -1.368942000 \\ 1 & -4.288995000 & -0.410837000 & -1.627433000 \\ 1 & -3.497787000 & -1.628310000 & -0.601829000 \\ 6 & -0.250314000 & -0.945601000 & -1.777104000 \\ 8 & -0.212083000 & -1.397202000 & -2.842574000 \\ 1 & -2.947591000 & -1.375578000 & -2.262783000 \\ 1 & -3.492259000 & 0.442731000 & 0.916193000\end{array}$

TS3

B3LYP-D3 electronic energy: $\quad-1020.222274$ a.u. B3LYP-D3 enthalpy: $\quad-1019.94403$ a.u.

B3LYP-D3 free energy: $\quad-1020.015846$ a.u.

M06-D3 SCF energy in solution: $\quad-1019.13453$ a.u.

M06-D3 enthalpy in solution: $\quad-1018.856286$ a.u.

M06-D3 free energy in solution: $\quad-1018.928102$ a.u.

Cartesian coordinates

$\begin{array}{lrrr}\text { ATOM } & \text { X } & \text { Y } & \text { Z } \\ 74 & 0.423493000 & -0.321074000 & -0.143745000 \\ 6 & -0.059179000 & -1.096859000 & -1.916837000 \\ 6 & 1.196918000 & -2.163262000 & -0.029217000 \\ 8 & 1.680725000 & -3.220291000 & 0.066987000 \\ 8 & -0.334976000 & -1.590855000 & -2.934315000 \\ 7 & -1.814237000 & -0.270182000 & 0.038481000 \\ 6 & -2.360504000 & 0.937821000 & 0.319045000 \\ 6 & -2.619531000 & -1.343048000 & -0.120409000 \\ 6 & -3.744780000 & 1.084904000 & 0.429950000 \\ 6 & -1.409709000 & 2.081626000 & 0.548775000 \\ 6 & -4.000189000 & -1.259153000 & -0.018184000 \\ 1 & -2.116271000 & -2.277815000 & -0.335906000 \\ 6 & -4.575723000 & -0.017550000 & 0.260388000 \\ 1 & -4.152502000 & 2.067088000 & 0.646862000 \\ 1 & -1.799165000 & 3.008976000 & 0.109790000 \\ 1 & -1.360504000 & 2.263364000 & 1.639401000 \\ 7 & -0.106210000 & 1.754049000 & 0.011754000 \\ 1 & -4.604255000 & -2.149155000 & -0.156534000 \\ 1 & -5.653550000 & 0.087620000 & 0.342188000 \\ 6 & 0.695164000 & 2.806273000 & -0.279568000 \\ 6 & 2.043846000 & 2.393427000 & -0.889846000 \\ 8 & 0.409827000 & 3.995965000 & -0.124834000 \\ 1 & 1.976707000 & 2.564973000 & -1.971431000 \\ 1 & 2.812825000 & 3.073106000 & -0.506064000 \\ 6 & 2.454191000 & 0.956480000 & -0.620020000 \\ 1 & 1.284091000 & 0.216636000 & -1.603559000 \\ 6 & 2.510323000 & 0.423526000 & 0.688027000 \\ 1 & 2.172406000 & 1.104026000 & 1.471002000 \\ 6 & 3.549103000 & -0.589275000 & 1.116392000 \\ 1 & 4.455150000 & -0.075393000 & 1.466105000 \\ 1 & 3.828722000 & -1.249601000 & 0.289847000 \\ 6 & 0.194462000 & -0.734917000 & 1.899359000 \\ 8 & 0.204374000 & -1.115484000 & 2.988369000\end{array}$

S-189 


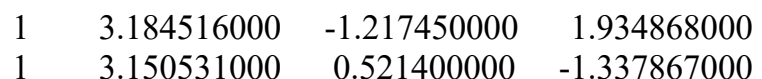

I-4

B3LYP-D3 electronic energy: $\quad-1020.254023$ a.u.

B3LYP-D3 enthalpy: $\quad-1019.973918$ a.u.

B3LYP-D3 free energy: $\quad-1020.045163$ a.u.

M06-D3 SCF energy in solution: $\quad-1019.163283$ a.u.

M06-D3 enthalpy in solution: $\quad-1018.883178$ a.u.

M06-D3 free energy in solution: $\quad-1018.954423$ a.u.

Cartesian coordinates

$\begin{array}{lrrr}\text { ATOM X } & \text { Y } & \text { Z } & \\ 74 & 0.420195000 & -0.459976000 & 0.089278000 \\ 6 & 0.337247000 & -0.901001000 & -1.905386000 \\ 6 & 0.012954000 & -2.366004000 & 0.538305000 \\ 8 & -0.275189000 & -3.470270000 & 0.802893000 \\ 8 & 0.330896000 & -1.198554000 & -3.022987000 \\ 7 & -1.811422000 & -0.123223000 & -0.013495000 \\ 6 & -2.194896000 & 1.091623000 & -0.481847000 \\ 6 & -2.760588000 & -1.014240000 & 0.350136000 \\ 6 & -3.545419000 & 1.426312000 & -0.590505000 \\ 6 & -1.096387000 & 2.032695000 & -0.906991000 \\ 6 & -4.117408000 & -0.738787000 & 0.263765000 \\ 1 & -2.406319000 & -1.968867000 & 0.717542000 \\ 6 & -4.520843000 & 0.508332000 & -0.216167000 \\ 1 & -3.812702000 & 2.409714000 & -0.963898000 \\ 1 & -1.030856000 & 1.991737000 & -2.010598000 \\ 1 & -1.338787000 & 3.069774000 & -0.645688000 \\ 7 & 0.144303000 & 1.627409000 & -0.293684000 \\ 1 & -4.836000000 & -1.490779000 & 0.571081000 \\ 1 & -5.574490000 & 0.760451000 & -0.291301000 \\ 6 & 1.007082000 & 2.595722000 & 0.102915000 \\ 6 & 2.248174000 & 2.029003000 & 0.811189000 \\ 8 & 0.847427000 & 3.808683000 & -0.045084000 \\ 1 & 3.110383000 & 2.641573000 & 0.520886000 \\ 1 & 2.104986000 & 2.184201000 & 1.887801000 \\ 6 & 2.522476000 & 0.558836000 & 0.529225000 \\ 1 & 1.439921000 & -1.902556000 & 0.370505000 \\ 6 & 2.597631000 & 0.065451000 & -0.782804000 \\ 1 & 2.385824000 & 0.778599000 & -1.579074000 \\ 6 & 3.487921000 & -1.090024000 & -1.180926000 \\ 1 & 3.668611000 & -1.764494000 & -0.338153000 \\ 1 & 4.457108000 & -0.700108000 & -1.521966000 \\ 6 & 0.377815000 & -0.057376000 & 2.098563000 \\ 8 & 0.365435000 & 0.149900000 & 3.234179000 \\ 1 & 3.058468000 & -1.674238000 & -2.000541000 \\ 1 & 3.066146000 & 0.012568000 & 1.298268000\end{array}$

TS4

B3LYP-D3 electronic energy: $\quad-1020.237110$ a.u.

B3LYP-D3 enthalpy: $\quad-1019.958547$ a.u.

B3LYP-D3 free energy: $\quad-1020.031354$ a.u.

M06-D3 SCF energy in solution: $\quad-1019.143542$ a.u.

M06-D3 enthalpy in solution: $\quad-1018.864979$ a.u. 
M06-D3 free energy in solution: $\quad-1018.937786$ a.u.

\begin{tabular}{lrrr}
\multicolumn{4}{l}{ Cartesian coordinates } \\
ATOM X & $\mathrm{Y}$ & $\mathrm{Z}$ & \\
74 & -0.408479000 & -0.379223000 & 0.078894000 \\
6 & -0.184912000 & 0.014744000 & 2.084043000 \\
6 & -0.226299000 & -2.378780000 & 0.108493000 \\
8 & -0.090493000 & -3.535523000 & 0.086015000 \\
8 & -0.053409000 & 0.234883000 & 3.210626000 \\
7 & 1.828912000 & -0.282272000 & -0.032714000 \\
6 & 2.371859000 & 0.927003000 & -0.322844000 \\
6 & 2.663986000 & -1.320283000 & 0.215356000 \\
6 & 3.757074000 & 1.106925000 & -0.367195000 \\
6 & 1.430755000 & 2.061469000 & -0.616057000 \\
6 & 4.043868000 & -1.201710000 & 0.189010000 \\
1 & 2.194501000 & -2.268680000 & 0.440314000 \\
6 & 4.608502000 & 0.040478000 & -0.110039000 \\
1 & 4.146147000 & 2.093290000 & -0.600006000 \\
1 & 1.753592000 & 2.970597000 & -0.089689000 \\
1 & 1.506523000 & 2.303693000 & -1.691857000 \\
7 & 0.080534000 & 1.705946000 & -0.252138000 \\
1 & 4.657554000 & -2.071039000 & 0.399105000 \\
1 & 5.686068000 & 0.171337000 & -0.138324000 \\
6 & -0.793972000 & 2.730452000 & -0.115042000 \\
6 & -2.176704000 & 2.222207000 & 0.318766000 \\
8 & -0.537655000 & 3.925160000 & -0.274348000 \\
1 & -2.201677000 & 2.179699000 & 1.416281000 \\
1 & -2.930900000 & 2.949759000 & -0.001663000 \\
6 & -2.476245000 & 0.863247000 & -0.268155000 \\
1 & -1.670252000 & -1.375283000 & 0.780006000 \\
6 & -2.974852000 & -0.217728000 & 0.453859000 \\
1 & -3.112857000 & -0.080375000 & 1.525801000 \\
6 & -3.826559000 & -1.286387000 & -0.196186000 \\
1 & -3.503188000 & -1.468084000 & -1.225144000 \\
1 & -4.869542000 & -0.943291000 & -0.215045000 \\
6 & -0.629047000 & -0.691755000 & -1.918139000 \\
8 & -0.803162000 & -0.900740000 & -3.045488000 \\
1 & -3.790327000 & -2.233229000 & 0.349764000 \\
1 & -2.651295000 & 0.858860000 & -1.343392000
\end{tabular}

\section{I-5}

B3LYP-D3 electronic energy: $\quad-1020.263138$ a.u. B3LYP-D3 enthalpy: $\quad-1019.979245$ a.u.

B3LYP-D3 free energy: $\quad-1020.05119$ a.u.

M06-D3 SCF energy in solution: $\quad-1019.172528$ a.u. M06-D3 enthalpy in solution: $\quad-1018.888635$ a.u. M06-D3 free energy in solution: $\quad-1018.96058$ a.u.

Cartesian coordinates

$\begin{array}{lccc}\text { ATOM } \mathrm{X} & \mathrm{Y} & \mathrm{Z} & \\ 74 & -0.430700000 & -0.342226000 & 0.194806000 \\ 6 & -2.060353000 & -1.102280000 & 1.059368000 \\ 8 & -3.007788000 & -1.539269000 & 1.571714000 \\ 7 & 1.815043000 & -0.309223000 & -0.290487000 \\ 6 & 2.432623000 & 0.882472000 & -0.108505000\end{array}$




$\begin{array}{rrrr}6 & 2.555383000 & -1.380875000 & -0.656046000 \\ 6 & 3.812646000 & 1.015931000 & -0.284756000 \\ 6 & 1.566263000 & 2.037726000 & 0.306823000 \\ 6 & 3.926963000 & -1.314280000 & -0.843353000 \\ 1 & 2.014599000 & -2.308192000 & -0.798506000 \\ 6 & 4.571185000 & -0.088359000 & -0.652977000 \\ 1 & 4.270818000 & 1.988145000 & -0.132314000 \\ 1 & 1.809643000 & 2.298352000 & 1.351531000 \\ 1 & 1.804243000 & 2.932328000 & -0.283738000 \\ 7 & 0.169847000 & 1.687083000 & 0.161392000 \\ 1 & 4.473466000 & -2.204520000 & -1.135050000 \\ 1 & 5.643863000 & 0.002104000 & -0.796614000 \\ 6 & -0.703069000 & 2.738966000 & 0.077994000 \\ 6 & -2.143301000 & 2.251424000 & -0.013288000 \\ 8 & -0.379216000 & 3.925524000 & 0.085072000 \\ 1 & -2.588057000 & 2.321689000 & 0.987714000 \\ 1 & -2.710176000 & 2.934862000 & -0.660049000 \\ 6 & -2.210719000 & 0.812186000 & -0.502553000 \\ 6 & -1.691768000 & 0.561396000 & -1.923555000 \\ 1 & -1.434463000 & 1.518763000 & -2.394947000 \\ 6 & -2.624986000 & -0.287869000 & -2.789475000 \\ 1 & -3.576505000 & 0.232363000 & -2.943988000 \\ 1 & -2.836363000 & -1.243623000 & -2.297917000 \\ 6 & -0.478577000 & -2.218504000 & -0.508423000 \\ 8 & -0.457926000 & -3.277847000 & -0.994195000 \\ 1 & -2.185546000 & -0.499035000 & -3.770355000 \\ 1 & -3.214119000 & 0.402087000 & -0.386101000 \\ 6 & 0.217675000 & -0.600132000 & 2.052132000 \\ 8 & 0.616451000 & -0.681756000 & 3.137849000 \\ 1 & -0.685772000 & 0.044360000 & -1.935492000\end{array}$

\section{I-6}

B3LYP-D3 electronic energy: $\quad-1133.60247$ a.u. B3LYP-D3 enthalpy: $\quad-1133.307005$ a.u. B3LYP-D3 free energy: -1133.384956 a.u.

M06-D3 SCF energy in solution: $\quad-1132.480477$ a.u. M06-D3 enthalpy in solution: $\quad-1132.185012$ a.u. M06-D3 free energy in solution: $\quad-1132.262963$ a.u.

Cartesian coordinates

$\begin{array}{lrrrl}\text { ATOM } & \text { X } & \text { Y } & \text { Z } & \\ 74 & 0.167144000 & -0.554636000 & -0.037444000 \\ 6 & 1.695988000 & -1.821722000 & 0.243034000 \\ 8 & 2.571417000 & -2.559240000 & 0.433368000 \\ 7 & -2.085560000 & 0.092605000 & 0.074772000 \\ 6 & -2.285435000 & 1.404217000 & 0.342040000 \\ 6 & -3.164161000 & -0.701624000 & -0.098715000 \\ 6 & -3.571370000 & 1.938232000 & 0.452233000 \\ 6 & -1.049721000 & 2.236349000 & 0.536489000 \\ 6 & -4.467304000 & -0.236124000 & -0.003183000 \\ 1 & -2.967823000 & -1.741386000 & -0.325267000 \\ 6 & -4.677892000 & 1.114868000 & 0.280494000 \\ 1 & -3.684257000 & 2.996932000 & 0.662867000 \\ 1 & -1.178242000 & 3.243940000 & 0.125044000 \\ 1 & -0.891169000 & 2.355850000 & 1.624610000\end{array}$




$\begin{array}{rrrr}7 & 0.080252000 & 1.584108000 & -0.084371000 \\ 1 & -5.293805000 & -0.921961000 & -0.154636000 \\ 1 & -5.683970000 & 1.516867000 & 0.355525000 \\ 6 & 0.987982000 & 2.386885000 & -0.711317000 \\ 6 & 2.144924000 & 1.568520000 & -1.267781000 \\ 8 & 0.904503000 & 3.610345000 & -0.818442000 \\ 1 & 1.906385000 & 1.277006000 & -2.297768000 \\ 1 & 3.026372000 & 2.217577000 & -1.329837000 \\ 6 & 2.432418000 & 0.338659000 & -0.402583000 \\ 6 & 3.070270000 & 0.690629000 & 0.945963000 \\ 1 & 2.433042000 & 1.418703000 & 1.463196000 \\ 6 & 4.497806000 & 1.250970000 & 0.814253000 \\ 1 & 4.518266000 & 2.203311000 & 0.274723000 \\ 1 & 5.147710000 & 0.545304000 & 0.282512000 \\ 6 & -0.628627000 & -2.430734000 & -0.163036000 \\ 8 & -1.114978000 & -3.478113000 & -0.252597000 \\ 1 & 4.930865000 & 1.424362000 & 1.806071000 \\ 1 & 3.069552000 & -0.356770000 & -0.954078000 \\ 6 & 0.165770000 & -0.615902000 & -2.089626000 \\ 8 & 0.161675000 & -0.677311000 & -3.241552000 \\ 1 & 3.111854000 & -0.198814000 & 1.584166000 \\ 6 & 0.151316000 & -0.376245000 & 2.020699000 \\ 8 & 0.153875000 & -0.290270000 & 3.170118000\end{array}$

\section{TS5}

B3LYP-D3 electronic energy: $\quad-1133.559798$ a.u. B3LYP-D3 enthalpy: $\quad-1133.266233$ a.u.

B3LYP-D3 free energy: -1133.343845 a.u.

M06-D3 SCF energy in solution: $\quad-1132.447049$ a.u. M06-D3 enthalpy in solution: $\quad-1132.153484$ a.u. M06-D3 free energy in solution: $\quad-1132.231096$ a.u.

Cartesian coordinates

$\begin{array}{lrrr}\text { ATOM } & \text { X } & \text { Y } & \text { Z } \\ 74 & 0.102975000 & -0.459908000 & 0.091439000 \\ 6 & 0.922288000 & -2.085155000 & 0.941606000 \\ 8 & 1.450153000 & -2.983806000 & 1.457539000 \\ 7 & -2.108188000 & -0.095704000 & -0.126671000 \\ 6 & -2.467164000 & 1.206838000 & 0.012913000 \\ 6 & -3.063438000 & -1.010736000 & -0.410150000 \\ 6 & -3.794243000 & 1.607309000 & -0.154171000 \\ 6 & -1.392431000 & 2.184316000 & 0.407800000 \\ 6 & -4.396917000 & -0.672906000 & -0.578872000 \\ 1 & -2.728792000 & -2.036140000 & -0.499198000 \\ 6 & -4.772578000 & 0.666363000 & -0.454127000 \\ 1 & -4.040425000 & 2.658833000 & -0.046792000 \\ 1 & -1.539987000 & 3.149232000 & -0.090036000 \\ 1 & -1.498197000 & 2.381428000 & 1.490631000 \\ 7 & -0.076114000 & 1.649818000 & 0.106263000 \\ 1 & -5.119799000 & -1.448668000 & -0.806428000 \\ 1 & -5.806720000 & 0.968466000 & -0.589217000 \\ 6 & 0.910162000 & 2.587988000 & -0.077700000 \\ 6 & 2.313066000 & 2.029315000 & -0.345613000 \\ 8 & 0.720808000 & 3.801133000 & -0.017265000 \\ 1 & 2.591785000 & 2.302213000 & -1.371073000\end{array}$




$\begin{array}{rrrr}1 & 2.996913000 & 2.563537000 & 0.322708000 \\ 6 & 2.441590000 & 0.511842000 & -0.170857000 \\ 6 & -0.289722000 & -1.923857000 & -1.203341000 \\ 8 & -0.542772000 & -2.717744000 & -2.011004000 \\ 6 & 1.406805000 & -0.067193000 & -1.419944000 \\ 8 & 1.804349000 & 0.056650000 & -2.538938000 \\ 6 & -0.553546000 & -0.335723000 & 2.165204000 \\ 8 & -0.773384000 & -0.376582000 & 3.292156000 \\ 6 & 3.809701000 & -0.113177000 & -0.466031000 \\ 1 & 3.713891000 & -1.204164000 & -0.391785000 \\ 6 & 4.915794000 & 0.369323000 & 0.479391000 \\ 1 & 4.068271000 & 0.109933000 & -1.507374000 \\ 1 & 4.670349000 & 0.148256000 & 1.525712000 \\ 1 & 5.080521000 & 1.448802000 & 0.393360000 \\ 1 & 5.863260000 & -0.129402000 & 0.246174000 \\ 1 & 2.209461000 & 0.277598000 & 0.883167000\end{array}$

\section{I-7}

B3LYP-D3 electronic energy: $\quad-1246.928254$ a.u. B3LYP-D3 enthalpy: $\quad-1246.621312$ a.u. B3LYP-D3 free energy: -1246.704444 a.u.

M06-D3 SCF energy in solution: $\quad-1245.78241$ a.u. M06-D3 enthalpy in solution: $\quad-1245.475468$ a.u. M06-D3 free energy in solution: $\quad-1245.5586$ a.u.

\begin{tabular}{lrrr}
\multicolumn{5}{l}{ Cartesian coordinates } \\
ATOM X X Y & $\mathrm{Z}$ & \\
74 & -0.343354000 & -0.838432000 & -0.037736000 \\
6 & 0.906152000 & -2.355261000 & 0.296473000 \\
8 & 1.650322000 & -3.226705000 & 0.493745000 \\
7 & -1.590787000 & 1.037765000 & -0.240285000 \\
6 & -1.476629000 & 1.931662000 & 0.765949000 \\
6 & -2.353275000 & 1.345744000 & -1.307773000 \\
6 & -2.143406000 & 3.156488000 & 0.726865000 \\
6 & -0.609032000 & 1.513493000 & 1.924739000 \\
6 & -3.043836000 & 2.544620000 & -1.412680000 \\
1 & -2.395164000 & 0.596576000 & -2.090184000 \\
6 & -2.937974000 & 3.469535000 & -0.371872000 \\
1 & -2.023656000 & 3.853198000 & 1.550222000 \\
1 & -0.144836000 & 2.379712000 & 2.406295000 \\
1 & -1.253828000 & 1.040163000 & 2.686756000 \\
7 & 0.417468000 & 0.586997000 & 1.467245000 \\
1 & -3.642383000 & 2.746906000 & -2.294206000 \\
1 & -3.458692000 & 4.421304000 & -0.421781000 \\
6 & 1.653973000 & 0.748336000 & 2.032267000 \\
6 & 2.765111000 & 0.006538000 & 1.298160000 \\
8 & 1.886539000 & 1.477667000 & 2.996456000 \\
1 & 3.713702000 & 0.312570000 & 1.743757000 \\
1 & 2.661860000 & -1.068175000 & 1.460660000 \\
6 & 2.762029000 & 0.341723000 & -0.220805000 \\
6 & 0.321316000 & -0.897361000 & -1.944624000 \\
8 & 0.681701000 & -1.001443000 & -3.042988000 \\
6 & 1.352299000 & 0.758745000 & -0.676031000 \\
8 & 1.043389000 & 1.783652000 & -1.204653000 \\
6 & -1.396540000 & -1.521422000 & 1.663969000
\end{tabular}




$\begin{array}{rrrr}8 & -1.933360000 & -2.017251000 & 2.549734000 \\ 6 & 3.788000000 & 1.435668000 & -0.581935000 \\ 1 & 4.739972000 & 1.147784000 & -0.118295000 \\ 1 & 3.480718000 & 2.377609000 & -0.111735000 \\ 6 & 3.997972000 & 1.628591000 & -2.086858000 \\ 1 & 3.086927000 & 1.982962000 & -2.576085000 \\ 1 & 4.788850000 & 2.363550000 & -2.273099000 \\ 1 & 4.298410000 & 0.687232000 & -2.564115000 \\ 1 & 2.988879000 & -0.568206000 & -0.792139000 \\ 6 & -1.749331000 & -1.975608000 & -0.951766000 \\ 8 & -2.608630000 & -2.564855000 & -1.458141000\end{array}$

TS6

B3LYP-D3 electronic energy: $\quad-1246.92825$ a.u. B3LYP-D3 enthalpy: $\quad-1246.622247$ a.u.

B3LYP-D3 free energy: $\quad-1246.702661$ a.u.

M06-D3 SCF energy in solution: $\quad-1245.781779$ a.u.

M06-D3 enthalpy in solution: $\quad-1245.475776$ a.u.

M06-D3 free energy in solution: $\quad-1245.55619$ a.u.

\begin{tabular}{|c|c|c|c|}
\hline \multicolumn{4}{|c|}{ Cartesian coordinates } \\
\hline \\
\hline 74 & -0.339976000 & -0.841699000 & -0.03966300 \\
\hline & 0.933722000 & -2.340673000 & 0.275064000 \\
\hline & 1.694626000 & -3.200690000 & 0.460719000 \\
\hline & -1.612211000 & 1.018826000 & -0.228177000 \\
\hline & -1.480277000 & 1.927006000 & 30000 \\
\hline & -2.409172000 & 1.304256000 & 10000 \\
\hline 6 & -2.161766000 & & \\
\hline & -0.57 & 1.5 & \\
\hline & -3.116345000 & 2.493800000 & \\
\hline & -2.465292000 & 107000 & $-2 .($ \\
\hline & 83000 & 3.4 & 8000 \\
\hline & 17000 & & \\
\hline & -0.1 & & \\
\hline 1 & -1.1 & & \\
\hline & & & \\
\hline & -3.7 & 2.6 & \\
\hline & 36000 & 4.3 & -0 \\
\hline & 1.67 & 0.73 & 00 \\
\hline & 2.7 & 0.0 & 000 \\
\hline & & & \\
\hline & 34000 & 0.3 & 4000 \\
\hline 1 & 2.7 & -1.0 & 6000 \\
\hline & & & \\
\hline & 0.3 & -0 & \\
\hline & 27000 & -0.9 & 000 \\
\hline & 1.342122000 & 0.79 & -0.6 \\
\hline & 385000 & 00 & -1. \\
\hline & 97000 & -1.5 & 000 \\
\hline 0 & -1.889655000 & 8000 & 2.574094000 \\
\hline 0 & 3.782593000 & 1.454131000 & -0.609204000 \\
\hline 1 & & & \\
\hline 1 & & & \\
\hline & 3.961494000 & 1.654645000 & -2.11711700 \\
\hline
\end{tabular}




$\begin{array}{rrrr}1 & 3.041730000 & 2.015390000 & -2.584900000 \\ 1 & 4.751477000 & 2.387211000 & -2.316024000 \\ 1 & 4.247396000 & 0.714605000 & -2.605667000 \\ 1 & 2.968727000 & -0.542797000 & -0.815978000 \\ 6 & -1.727413000 & -2.011069000 & -0.937512000 \\ 8 & -2.576013000 & -2.624764000 & -1.433509000\end{array}$

\section{I-8}

B3LYP-D3 electronic energy: $\quad-1246.98671$ a.u. B3LYP-D3 enthalpy: $\quad-1246.677876$ a.u.

B3LYP-D3 free energy: $\quad-1246.759371$ a.u.

M06-D3 SCF energy in solution: $\quad-1245.834413$ a.u.

M06-D3 enthalpy in solution: $\quad-1245.525579$ a.u.

M06-D3 free energy in solution: $\quad-1245.607074$ a.u.

Cartesian coordinates

$\begin{array}{lrrrr}\text { ATOM } & \text { X } & \text { Y } & \text { Z } & \\ 74 & -0.520940000 & -0.854689000 & -0.185708000 \\ 6 & 0.748575000 & -2.374133000 & -0.216297000 \\ 8 & 1.567998000 & -3.208926000 & -0.209689000 \\ 7 & -1.685167000 & 1.083202000 & -0.031819000 \\ 6 & -1.232284000 & 2.042142000 & 0.805296000 \\ 6 & -2.758003000 & 1.357824000 & -0.804634000 \\ 6 & -1.829562000 & 3.298777000 & 0.879729000 \\ 6 & -0.086844000 & 1.667521000 & 1.708930000 \\ 6 & -3.411277000 & 2.582597000 & -0.774329000 \\ 1 & -3.082224000 & 0.556830000 & -1.458596000 \\ 6 & -2.936642000 & 3.576753000 & 0.082333000 \\ 1 & -1.422820000 & 4.046236000 & 1.553064000 \\ 1 & 0.438475000 & 2.566097000 & 2.047957000 \\ 1 & -0.457599000 & 1.127114000 & 2.586077000 \\ 7 & 0.873040000 & 0.753048000 & 1.059211000 \\ 1 & -4.269187000 & 2.748919000 & -1.416779000 \\ 1 & -3.415715000 & 4.550115000 & 0.124833000 \\ 6 & 1.653200000 & -0.118433000 & 1.921665000 \\ 6 & 2.950416000 & -0.442682000 & 1.207404000 \\ 8 & 1.310083000 & -0.417412000 & 3.037634000 \\ 1 & 3.769927000 & -0.142977000 & 1.871523000 \\ 1 & 3.028104000 & -1.521737000 & 1.051542000 \\ 6 & 2.944699000 & 0.368940000 & -0.106876000 \\ 6 & 0.190796000 & -0.273555000 & -2.007462000 \\ 8 & 0.604834000 & 0.013640000 & -3.052329000 \\ 6 & 1.753375000 & 1.310533000 & 0.058927000 \\ 8 & 1.539059000 & 2.381193000 & -0.457283000 \\ 6 & -1.279668000 & -1.523674000 & 1.604684000 \\ 8 & -1.726027000 & -1.948261000 & 2.583338000 \\ 6 & 4.255381000 & 1.107645000 & -0.424127000 \\ 1 & 5.075430000 & 0.389956000 & -0.293299000 \\ 1 & 4.412783000 & 1.900134000 & 0.319973000 \\ 6 & 4.298152000 & 1.691545000 & -1.840270000 \\ 1 & 3.508581000 & 2.433652000 & -1.980201000 \\ 1 & 5.264649000 & 2.170298000 & -2.031397000 \\ 1 & 4.158105000 & 0.903165000 & -2.589737000 \\ 1 & 2.704941000 & -0.298866000 & -0.941946000 \\ 6 & -1.899608000 & -1.903612000 & -1.116415000\end{array}$




\begin{tabular}{|c|c|c|c|}
\hline \multicolumn{4}{|c|}{$\mathrm{W}(\mathrm{CO})_{6}$} \\
\hline \multicolumn{4}{|c|}{ B3LYP-D3 electronic energy: } \\
\hline \multicolumn{3}{|c|}{ B3LYP-D3 enthalpy: } & //81 a.u. \\
\hline & YP-D3 free ener & -747.9 & 72 a.u. \\
\hline \multicolumn{3}{|r|}{ in solution: } & -747.0 \\
\hline \multicolumn{3}{|c|}{ M06-D3 enthalpy in solution: } & \\
\hline \multicolumn{3}{|c|}{ M06-D3 free energy in solution: } & \\
\hline \multicolumn{4}{|c|}{ artesian coordinates } \\
\hline & $\mathrm{X}$ & Z & \\
\hline 4 & 0.000000000 & 000000000 & 0.0 \\
\hline & 0.000000000 & 0.000000 & \\
\hline & 0.0000 & 2.069526 & \\
\hline & -2.069 & 000 & \\
\hline & 0.0 & & \\
\hline & 2.0 & 0 & \\
\hline & 0.000 & 000 & \\
\hline & 3.220 & 0.000000 & \\
\hline & 0.0000 & -3.220379 & 0. \\
\hline & 0.000000000 & 0.000000000 & 9000 \\
\hline & -3.220379000 & 0.000000000 & 0.0000000 \\
\hline & 0.0000 & 3.220379 & \\
\hline & 0.000000000 & 0.000000000 & -3.220379 \\
\hline
\end{tabular}

\section{$\mathrm{W}(\mathrm{CO})_{5}$}

B3LYP-D3 electronic energy: $\quad-634.559789$ a.u.

B3LYP-D3 enthalpy: $\quad-634.505631$ a.u.

B3LYP-D3 free energy: $\quad-634.558168$ a.u.

M06-D3 SCF energy in solution: $\quad-633.689332$ a.u.

M06-D3 enthalpy in solution: $\quad-633.635174$ a.u.

M06-D3 free energy in solution: $\quad-633.687711$ a.u.

Cartesian coordinates
$\begin{array}{lrrr}\text { ATOM } & \text { X } & \text { Y } & \text { Z } \\ 74 & 0.000000000 & 0.000000000 & 0.249185000 \\ 6 & -2.062051000 & 0.000000000 & 0.269799000 \\ 6 & 0.000000000 & -2.062051000 & 0.269799000 \\ 6 & 2.062051000 & 0.000000000 & 0.269799000 \\ 6 & 0.000000000 & 2.062051000 & 0.269799000 \\ 6 & 0.000000000 & 0.000000000 & -1.707285000 \\ 8 & 0.000000000 & 3.214620000 & 0.258532000 \\ 8 & 3.214620000 & 0.000000000 & 0.258532000 \\ 8 & 0.000000000 & -3.214620000 & 0.258532000 \\ 8 & -3.214620000 & 0.000000000 & 0.258532000 \\ 8 & 0.000000000 & 0.000000000 & -2.868021000\end{array}$

\section{$\mathrm{W}(\mathrm{CO})_{4}$}

B3LYP-D3 electronic energy: $\quad-521.135937$ a.u. B3LYP-D3 enthalpy: $\quad-521.09269$ a.u.

B3LYP-D3 free energy: $\quad-521.142007$ a.u.

M06-D3 SCF energy in solution: $\quad-520.301232$ a.u.

M06-D3 enthalpy in solution: $\quad-520.257985$ a.u.

M06-D3 free energy in solution: $\quad-520.307302$ a.u. 
Cartesian coordinates

$\begin{array}{lrrc}\text { ATOM } & \text { X } & \text { Y } & \text { Z } \\ 74 & -0.000003000 & 0.000174000 & 0.000000000 \\ 6 & -0.000358000 & -0.000332000 & 2.044874000 \\ 6 & -0.688562000 & -1.925061000 & 0.000000000 \\ 6 & -0.000358000 & -0.000332000 & -2.044874000 \\ 6 & 0.688935000 & 1.925352000 & 0.000000000 \\ 8 & -0.000358000 & -0.000696000 & -3.201423000 \\ 8 & -1.077846000 & -3.014205000 & 0.000000000 \\ 8 & -0.000358000 & -0.000696000 & 3.201423000 \\ 8 & 1.078842000 & 3.014266000 & 0.000000000\end{array}$

\section{CO}

B3LYP-D3 electronic energy: $\quad-113.306913$ a.u. B3LYP-D3 enthalpy: $\quad-113.298571$ a.u. B3LYP-D3 free energy: $\quad-113.321014$ a.u.

M06-D3 SCF energy in solution: $\quad-113.281218$ a.u. M06-D3 enthalpy in solution: $\quad-113.272876$ a.u. M06-D3 free energy in solution: $\quad-113.295319$ a.u.

Cartesian coordinates

$\begin{array}{lrrr}\text { ATOM } X & \text { Y } & \text { Z } & \\ 8 & 0.000000000 & 0.000000000 & 0.487595000 \\ 6 & 0.000000000 & 0.000000000 & -0.650127000\end{array}$

\section{I-1a}

B3LYP-D3 electronic energy: $\quad-612.331963$ a.u. B3LYP-D3 enthalpy: $\quad-612.082219$ a.u. B3LYP-D3 free energy: $\quad-612.141014$ a.u. M06-D3 SCF energy in solution: $\quad-612.061983$ a.u. M06-D3 enthalpy in solution: $\quad-611.812239$ a.u. M06-D3 free energy in solution: $\quad-611.871034$ a.u.

\begin{tabular}{|c|c|c|c|}
\hline \multicolumn{4}{|c|}{ Cartes } \\
\hline \multicolumn{4}{|c|}{ Cartes } \\
\hline 7 & -2.179566000 & 0.986714000 & -0.1844840 \\
\hline & -2.304295000 & -0.324442000 & 0.056651000 \\
\hline & -3.288769000 & 1.739723000 & -0.195826000 \\
\hline & -3.546234000 & -0.928649000 & 0.295220000 \\
\hline & -1.038089000 & -1.159136000 & 0.065001000 \\
\hline & -4.564679000 & 811000 & 0.029959000 \\
\hline & -3.141873000 & & 9000 \\
\hline & -4.6914 & -0.1 & 000 \\
\hline & -3.60272 & -1.9 & 2000 \\
\hline & -0.932195000 & -1.669742000 & 41000 \\
\hline & -1.112885000 & -1.960693000 & -0.683849000 \\
\hline & 0.124033000 & -0.340845000 & 472000 \\
\hline & -5.430573000 & 1.884130000 & 0.009575000 \\
\hline & -5.667153000 & -0.581440000 & 28000 \\
\hline & -0.053 & 0.644260000 & 83000 \\
\hline & 1.3 & -0.8 & \\
\hline & 2.501 & 0.08 & 9000 \\
\hline & 1.567 & -2.081081000 & -0.0 \\
\hline & 2.743276000 & -0.043356000 & -1.635733000 \\
\hline
\end{tabular}




$\begin{array}{rrrr}1 & 2.186805000 & 1.131476000 & -0.445464000 \\ 6 & 3.752407000 & -0.204320000 & 0.276242000 \\ 1 & 3.534832000 & -0.006527000 & 1.333511000 \\ 1 & 3.958845000 & -1.278831000 & 0.191451000 \\ 6 & 4.941130000 & 0.599958000 & -0.168328000 \\ 1 & 5.267020000 & 0.430273000 & -1.196830000 \\ 6 & 5.595057000 & 1.488640000 & 0.581245000 \\ 1 & 6.450104000 & 2.042259000 & 0.201963000 \\ 1 & 5.301687000 & 1.690915000 & 1.609891000\end{array}$

\section{I-9}

B3LYP-D3 electronic energy: $\quad-1133.613675$ a.u.

B3LYP-D3 enthalpy: $\quad-1133.317052$ a.u.

B3LYP-D3 free energy: -1133.397641 a.u.

M06-D3 SCF energy in solution: $\quad-1132.486607$ a.u.

M06-D3 enthalpy in solution: $\quad-1132.189984$ a.u.

M06-D3 free energy in solution: $\quad-1132.270573$ a.u.

Cartesian coordinates

$\begin{array}{lrrr}\text { ATOM } & \text { X } & \text { Y } & \text { Z } \\ 74 & 0.216592000 & -0.676520000 & 0.104452000 \\ 6 & 0.211195000 & -0.270731000 & 2.117194000 \\ 6 & 0.985222000 & -2.456167000 & 0.455075000 \\ 6 & 0.142485000 & -1.121511000 & -1.884269000 \\ 6 & -1.615261000 & -1.41611000 & 0.289950000 \\ 8 & 0.073632000 & -1.393831000 & -3.011567000 \\ 8 & 1.513581000 & -3.481019000 & 0.642968000 \\ 8 & 0.182255000 & -0.080806000 & 3.259046000 \\ 8 & -2.700658000 & -1.838978000 & 0.389964000 \\ 7 & 2.223313000 & 0.361359000 & -0.170961000 \\ 6 & 2.246420000 & 1.715015000 & -0.168214000 \\ 6 & 3.379951000 & -0.299314000 & -0.389108000 \\ 6 & 3.416416000 & 2.434504000 & -0.403056000 \\ 6 & 0.946348000 & 2.398327000 & 0.162424000 \\ 6 & 4.586196000 & 0.351999000 & -0.616637000 \\ 1 & 3.311803000 & -1.380826000 & -0.375856000 \\ 6 & 4.607815000 & 1.746953000 & -0.628126000 \\ 1 & 3.388061000 & 3.519695000 & -0.402478000 \\ 1 & 0.805928000 & 2.429498000 & 1.247514000 \\ 1 & 0.938888000 & 3.433008000 & -0.200496000 \\ 7 & -0.204033000 & 1.636288000 & -0.372270000 \\ 1 & 5.485642000 & -0.230367000 & -0.785255000 \\ 1 & 5.531158000 & 2.288366000 & -0.810032000 \\ 1 & -0.241303000 & 1.666189000 & -1.390266000 \\ 6 & -1.485461000 & 1.977854000 & 0.202915000 \\ 6 & -2.679582000 & 1.632400000 & -0.663854000 \\ 8 & -1.547494000 & 2.512109000 & 1.287555000 \\ 1 & -2.875036000 & 2.506368000 & -1.305075000 \\ 1 & -2.439129000 & 0.794542000 & -1.325792000 \\ 6 & -3.926124000 & 1.302588000 & 0.178123000 \\ 1 & -3.696296000 & 0.448854000 & 0.821344000 \\ 1 & -4.137823000 & 2.155680000 & 0.833409000 \\ 6 & -5.107091000 & 0.985392000 & -0.699391000 \\ 1 & -5.560687000 & 1.829238000 & -1.222935000 \\ 6 & -5.586880000 & -0.244849000 & -0.888799000\end{array}$


$\begin{array}{llll}1 & -6.432344000 & -0.433662000 & -1.545468000 \\ 1 & -5.142030000 & -1.105541000 & -0.394517000\end{array}$

I-1a

B3LYP-D3 electronic energy: $\quad-1020.258031$ a.u. B3LYP-D3 enthalpy: $\quad-1019.972431$ a.u.

B3LYP-D3 free energy: $\quad-1020.04348$ a.u.

M06-D3 SCF energy in solution: $\quad-1019.162028$ a.u. M06-D3 enthalpy in solution: $\quad-1018.876428$ a.u. M06-D3 free energy in solution: $\quad-1018.947477$ a.u.

Cartesian coordinates

\begin{tabular}{|c|c|c|c|}
\hline & & Z & \\
\hline 74 & -0.310446000 & -0.544804000 & 0.005860000 \\
\hline 6 & -0.796489000 & 0.090574000 & 1.877941000 \\
\hline 6 & 0.048083000 & -2.354613000 & 0.705120000 \\
\hline 6 & 0.103285000 & -1.222159000 & -1.856254000 \\
\hline 8 & 0.324118000 & -1.625139000 & -2.927261000 \\
\hline 8 & 0.290206000 & -3.419734000 & 1.119739000 \\
\hline 8 & -1.100789000 & 0.400828000 & 2.956608000 \\
\hline 7 & 1.816106000 & 0.113432000 & 0.143968000 \\
\hline 6 & 2.132565000 & 1.401018000 & -0.142080000 \\
\hline 6 & 2.837476000 & -0.749001000 & 0.368951000 \\
\hline 6 & 3.451683000 & 1.835000000 & -0.255018000 \\
\hline 6 & 0.992320000 & 2.377570000 & -0.227407000 \\
\hline 6 & 4.172070000 & -0.376780000 & 0.301392000 \\
\hline 1 & 2.550389000 & -1.768090000 & 0.596204000 \\
\hline 6 & 4.495247000 & 0.940011000 & -0.030404000 \\
\hline 1 & 3.650241000 & 2.873063000 & -0.504389000 \\
\hline 1 & 0.774517000 & 2.755119000 & 0.776989000 \\
\hline 1 & 1.259155000 & 3.240598000 & -0.848144000 \\
\hline 7 & -0.270068000 & 1.765033000 & -0.695821000 \\
\hline 1 & 4.940363000 & -1.118217000 & 0.493666000 \\
\hline 1 & 5.529097000 & 1.260845000 & -0.110773000 \\
\hline 1 & -0.315663000 & 1.677934000 & -1.708706000 \\
\hline 6 & -1.462496000 & 2.395406000 & -0.166630000 \\
\hline 6 & -2.766185000 & 2.025680000 & -0.837585000 \\
\hline 8 & -1.396430000 & 3.116960000 & 0.804166000 \\
\hline 1 & -3.459273000 & 2.849252000 & -0.646106000 \\
\hline 1 & -2.637656000 & 1.921727000 & -1.923227000 \\
\hline 6 & -3.308509000 & 0.697147000 & -0.260228000 \\
\hline 1 & -3.320731000 & 0.760372000 & 0.834283000 \\
\hline 1 & -4.353222000 & 0.584912000 & -0.588812000 \\
\hline 6 & -2.477916000 & -0.484876000 & -0.722155000 \\
\hline 1 & -2.515510000 & -0.608491000 & -1.808231000 \\
\hline 6 & -2.377756000 & -1.686751000 & 0.027199000 \\
\hline 1 & -2.351039000 & -2.643428000 & -0.486934000 \\
\hline 1 & -2.797016000 & -1.731989000 & 1.030443000 \\
\hline
\end{tabular}

\section{I-1b}

B3LYP-D3 electronic energy: $\quad-1020.23203$ a.u.

B3LYP-D3 enthalpy: $\quad-1019.946327$ a.u.

B3LYP-D3 free energy: $\quad-1020.02237$ a.u.

M06-D3 SCF energy in solution: $\quad-1019.143032$ a.u. M06-D3 enthalpy in solution: $\quad-1018.857329$ a.u. 
M06-D3 free energy in solution: $\quad$-1018.933372 a.u.

\begin{tabular}{lrrr}
\multicolumn{5}{l}{ Cartesian coordinates } \\
ATOM X & $\mathrm{Y}$ & $\mathrm{Z}$ & \\
74 & 0.236702000 & -0.685130000 & -0.086819000 \\
6 & -0.297839000 & -0.845487000 & 1.756981000 \\
6 & 0.926884000 & -2.509352000 & -0.017602000 \\
6 & -1.520812000 & -1.393712000 & -0.598291000 \\
8 & 1.416970000 & -3.575398000 & 0.006719000 \\
8 & -0.603726000 & -0.898517000 & 2.887707000 \\
8 & -2.565395000 & -1.796987000 & -0.953515000 \\
7 & 2.266319000 & 0.278957000 & -0.120769000 \\
6 & 2.333529000 & 1.635629000 & -0.141670000 \\
6 & 3.413384000 & -0.423046000 & -0.285890000 \\
6 & 3.533423000 & 2.311848000 & -0.347834000 \\
6 & 1.049773000 & 2.363073000 & 0.148144000 \\
6 & 4.644781000 & 0.187879000 & -0.484261000 \\
1 & 3.313017000 & -1.501339000 & -0.246009000 \\
6 & 4.708843000 & 1.581711000 & -0.520813000 \\
1 & 3.542105000 & 3.397209000 & -0.364109000 \\
1 & 0.886841000 & 2.402968000 & 1.229871000 \\
1 & 1.085698000 & 3.394817000 & -0.220689000 \\
7 & -0.122711000 & 1.639943000 & -0.400501000 \\
1 & 5.532127000 & -0.423524000 & -0.607753000 \\
1 & 5.654584000 & 2.090869000 & -0.679618000 \\
1 & -0.224688000 & 1.790691000 & -1.405777000 \\
6 & -1.377362000 & 1.926199000 & 0.282390000 \\
6 & -2.629447000 & 1.689774000 & -0.535149000 \\
8 & -1.368684000 & 2.364286000 & 1.410407000 \\
1 & -2.935419000 & 2.672013000 & -0.927487000 \\
1 & -2.429149000 & 1.039998000 & -1.391854000 \\
6 & -3.765298000 & 1.093099000 & 0.320528000 \\
1 & -3.458979000 & 0.099202000 & 0.658096000 \\
1 & -3.886079000 & 1.719145000 & 1.212242000 \\
6 & -5.050331000 & 1.012225000 & -0.459006000 \\
1 & -5.564169000 & 1.959177000 & -0.636654000 \\
6 & -5.557970000 & -0.117390000 & -0.954394000 \\
1 & -6.484534000 & -0.124786000 & -1.523145000 \\
1 & -5.055264000 & -1.070911000 & -0.812941000
\end{tabular}

I-1c

B3LYP-D3 electronic energy: $\quad-1020.232948$ a.u. B3LYP-D3 enthalpy: $\quad-1019.947254$ a.u.

B3LYP-D3 free energy: $\quad-1020.023445$ a.u.

M06-D3 SCF energy in solution: $\quad-1019.144098$ a.u. M06-D3 enthalpy in solution: $\quad-1018.858404$ a.u. M06-D3 free energy in solution: $\quad-1018.934595$ a.u.

\begin{tabular}{|c|c|c|c|}
\hline \\
\hline \multicolumn{4}{|c|}{$\begin{array}{l}\text { Cartesian coordinates } \\
\text { ATOM } \mathrm{X}\end{array}$} \\
\hline 74 & -0.228095000 & -0.665500000 & -0.183913000 \\
\hline 6 & -0.951653000 & -2.384116000 & -0.767330000 \\
\hline 6 & -0.167402000 & -1.347272000 & 1.606213000 \\
\hline 6 & 1.590025000 & -1.368251000 & -0.468562000 \\
\hline 0 & -0.154276000 & -1.714602000 & 2.723967000 \\
\hline
\end{tabular}




$\begin{array}{rrrr}8 & -1.457084000 & -3.384494000 & -1.111494000 \\ 8 & 2.678156000 & -1.771301000 & -0.642915000 \\ 7 & -2.222195000 & 0.374949000 & -0.057988000 \\ 6 & -2.260491000 & 1.725545000 & 0.058049000 \\ 6 & -3.392782000 & -0.304931000 & 0.001016000 \\ 6 & -3.452986000 & 2.417878000 & 0.259408000 \\ 6 & -0.949498000 & 2.453500000 & -0.097046000 \\ 6 & -4.616658000 & 0.321261000 & 0.190209000 \\ 1 & -3.313673000 & -1.380512000 & -0.102068000 \\ 6 & -4.651606000 & 1.710653000 & 0.325717000 \\ 1 & -3.435459000 & 3.498718000 & 0.360541000 \\ 1 & -0.773151000 & 2.686220000 & -1.152493000 \\ 1 & -0.964652000 & 3.404309000 & 0.448446000 \\ 7 & 0.200529000 & 1.622399000 & 0.326560000 \\ 1 & -5.521486000 & -0.275205000 & 0.234561000 \\ 1 & -5.591204000 & 2.231593000 & 0.482300000 \\ 1 & 0.304708000 & 1.584385000 & 1.339177000 \\ 6 & 1.452843000 & 1.902815000 & -0.338497000 \\ 6 & 2.690376000 & 1.612657000 & 0.483931000 \\ 8 & 1.451412000 & 2.353073000 & -1.465676000 \\ 1 & 2.868037000 & 2.494847000 & 1.119876000 \\ 1 & 2.502753000 & 0.767553000 & 1.154299000 \\ 6 & 3.920189000 & 1.327602000 & -0.396191000 \\ 1 & 3.691979000 & 0.477754000 & -1.044542000 \\ 1 & 4.096308000 & 2.194202000 & -1.044388000 \\ 6 & 5.131314000 & 1.022710000 & 0.444846000 \\ 1 & 5.597021000 & 1.870282000 & 0.951283000 \\ 6 & 5.620887000 & -0.205310000 & 0.623287000 \\ 1 & 6.486161000 & -0.389706000 & 1.254931000 \\ 1 & 5.162322000 & -1.068728000 & 0.146296000\end{array}$

\section{I-1d}

B3LYP-D3 electronic energy: $\quad-1020.205675$ a.u. B3LYP-D3 enthalpy: $\quad-1019.921367$ a.u. B3LYP-D3 free energy: -1019.996039 a.u. M06-D3 SCF energy in solution: $\quad-1019.110968$ a.u. M06-D3 enthalpy in solution: $\quad-1018.82666$ a.u. M06-D3 free energy in solution: $\quad-1018.901332$ a.u.

Cartesian coordinates

$\begin{array}{lrrrr}\text { ATOM } & \text { X } & \text { Y } & \text { Z } & \\ 74 & -0.199481000 & -0.381241000 & 0.177689000 \\ 6 & -0.156444000 & 0.354152000 & 2.074975000 \\ 6 & -0.159580000 & -2.165772000 & 0.962355000 \\ 6 & -0.448102000 & -1.308656000 & -1.605084000 \\ 8 & -0.642064000 & -1.897222000 & -2.594656000 \\ 8 & -0.053005000 & -3.246837000 & 1.411384000 \\ 8 & -0.191564000 & 0.712062000 & 3.181751000 \\ 7 & 1.929316000 & -0.164671000 & -0.086420000 \\ 6 & 2.397565000 & 1.084003000 & -0.384789000 \\ 6 & 2.826384000 & -1.181222000 & -0.047500000 \\ 6 & 3.738046000 & 1.320784000 & -0.668763000 \\ 6 & 1.388019000 & 2.205121000 & -0.336910000 \\ 6 & 4.177647000 & -1.003984000 & -0.309055000 \\ 1 & 2.415325000 & -2.150250000 & 0.205973000\end{array}$




$\begin{array}{rrrr}6 & 4.652408000 & 0.268377000 & -0.630758000 \\ 1 & 4.057610000 & 2.329666000 & -0.911999000 \\ 1 & 1.229123000 & 2.527136000 & 0.698145000 \\ 1 & 1.731663000 & 3.074583000 & -0.908865000 \\ 7 & 0.075936000 & 1.724202000 & -0.809896000 \\ 1 & 4.842006000 & -1.860365000 & -0.259985000 \\ 1 & 5.702721000 & 0.437802000 & -0.845463000 \\ 1 & 0.044314000 & 1.549799000 & -1.812245000 \\ 6 & -1.106821000 & 2.363934000 & -0.308608000 \\ 6 & -2.400989000 & 1.757496000 & -0.835447000 \\ 8 & -1.057047000 & 3.231823000 & 0.536263000 \\ 1 & -3.156157000 & 2.550205000 & -0.853607000 \\ 1 & -2.280005000 & 1.363822000 & -1.850333000 \\ 6 & -2.890494000 & 0.617176000 & 0.092724000 \\ 1 & -2.232092000 & -0.298473000 & 0.113190000 \\ 1 & -2.963243000 & 0.995447000 & 1.116866000 \\ 6 & -4.204880000 & 0.050954000 & -0.379525000 \\ 1 & -5.053821000 & 0.733642000 & -0.329775000 \\ 6 & -4.352399000 & -1.184357000 & -0.856930000 \\ 1 & -5.315038000 & -1.552682000 & -1.199559000 \\ 1 & -3.510255000 & -1.871889000 & -0.915130000\end{array}$

I-1e

B3LYP-D3 electronic energy: $\quad-1020.195286$ a.u. B3LYP-D3 enthalpy: $\quad-1019.909802$ a.u.

B3LYP-D3 free energy: $\quad-1019.98522$ a.u.

M06-D3 SCF energy in solution: $\quad-1019.103461$ a.u. M06-D3 enthalpy in solution: $\quad-1018.817977$ a.u. M06-D3 free energy in solution: $\quad-1018.893395$ a.u.

Cartesian coordinates

$\begin{array}{lrrr}\text { ATOM } & \text { X } & \text { Y } & \text { Z } \\ 74 & 0.249118000 & -0.783083000 & 0.357551000 \\ 6 & 0.221435000 & 0.082026000 & 2.200740000 \\ 6 & 0.104903000 & -1.738151000 & -1.417641000 \\ 6 & -1.606278000 & -1.328994000 & 0.681010000 \\ 8 & -0.035504000 & -2.290187000 & -2.437388000 \\ 8 & 0.147894000 & 0.543048000 & 3.266691000 \\ 8 & -2.726995000 & -1.646753000 & 0.850846000 \\ 7 & 2.335843000 & -0.055465000 & -0.117773000 \\ 6 & 2.438244000 & 1.260972000 & -0.428074000 \\ 6 & 3.448516000 & -0.815707000 & -0.186200000 \\ 6 & 3.646696000 & 1.836267000 & -0.813701000 \\ 6 & 1.172323000 & 2.060546000 & -0.290909000 \\ 6 & 4.689732000 & -0.308271000 & -0.548794000 \\ 1 & 3.315341000 & -1.865700000 & 0.056119000 \\ 6 & 4.794525000 & 1.046386000 & -0.869629000 \\ 1 & 3.682221000 & 2.892379000 & -1.062516000 \\ 1 & 1.022701000 & 2.364399000 & 0.749798000 \\ 1 & 1.203633000 & 2.969748000 & -0.903005000 \\ 7 & -0.007914000 & 1.225182000 & -0.638306000 \\ 1 & 5.551013000 & -0.966857000 & -0.583438000 \\ 1 & 5.747012000 & 1.476969000 & -1.162720000 \\ 1 & -0.040326000 & 1.038850000 & -1.640581000 \\ 6 & -1.284087000 & 1.786809000 & -0.196971000\end{array}$




$\begin{array}{lrrr}6 & -2.481822000 & 1.354117000 & -1.015878000 \\ 8 & -1.313284000 & 2.583566000 & 0.713676000 \\ 1 & -2.581490000 & 2.076625000 & -1.842395000 \\ 1 & -2.304560000 & 0.370589000 & -1.459031000 \\ 6 & -3.771210000 & 1.332699000 & -0.173727000 \\ 1 & -3.625211000 & 0.644342000 & 0.662187000 \\ 1 & -3.928070000 & 2.332551000 & 0.247942000 \\ 6 & -4.953334000 & 0.899216000 & -0.998488000 \\ 1 & -5.339335000 & 1.627305000 & -1.714776000 \\ 6 & -5.508311000 & -0.311578000 & -0.922395000 \\ 1 & -6.350305000 & -0.595684000 & -1.548760000 \\ 1 & -5.127772000 & -1.060795000 & -0.231674000\end{array}$

\section{I-1f}

B3LYP-D3 electronic energy: $\quad-1020.229072$ a.u. B3LYP-D3 enthalpy: $\quad-1019.943741$ a.u.

B3LYP-D3 free energy: $\quad-1020.017187$ a.u.

M06-D3 SCF energy in solution: $\quad-1019.137689$ a.u.

M06-D3 enthalpy in solution: $\quad-1018.852358$ a.u.

M06-D3 free energy in solution: $\quad-1018.925804$ a.u.

Cartesian coordinates

$\begin{array}{lrrr}\text { ATOM } & \text { X } & \text { Y } & \\ 74 & 0.884295000 & -0.506724000 & -0.085440000 \\ 6 & 1.818980000 & -2.230748000 & -0.300524000 \\ 6 & -0.014956000 & -0.875083000 & -1.835406000 \\ 6 & -0.532411000 & -1.439259000 & 0.812670000 \\ 8 & -0.526110000 & -1.087852000 & -2.860592000 \\ 8 & 2.380320000 & -3.243842000 & -0.432822000 \\ 8 & -1.387454000 & -1.974348000 & 1.413197000 \\ 7 & -2.633321000 & 1.132676000 & 1.016867000 \\ 6 & -2.531295000 & 0.898327000 & -0.301526000 \\ 6 & -3.547869000 & 0.444922000 & 1.707529000 \\ 6 & -3.328825000 & -0.027311000 & -0.973939000 \\ 6 & -1.467051000 & 1.706751000 & -1.006365000 \\ 6 & -4.405095000 & -0.488567000 & 1.123130000 \\ 1 & -3.592510000 & 0.645781000 & 2.775731000 \\ 6 & -4.287565000 & -0.730320000 & -0.244176000 \\ 1 & -3.176892000 & -0.211591000 & -2.032577000 \\ 1 & -1.246561000 & 1.323909000 & -2.000389000 \\ 1 & -1.788756000 & 2.750600000 & -1.116010000 \\ 7 & -0.233428000 & 1.670467000 & -0.175078000 \\ 1 & -5.126748000 & -1.024027000 & 1.731508000 \\ 1 & -4.918597000 & -1.466540000 & -0.733594000 \\ 6 & 0.751706000 & 2.646564000 & -0.524063000 \\ 6 & 1.703975000 & 3.041194000 & 0.592763000 \\ 8 & 0.821071000 & 3.076894000 & -1.655780000 \\ 1 & 2.269872000 & 3.902904000 & 0.231475000 \\ 1 & 1.122289000 & 3.357083000 & 1.469775000 \\ 6 & 1.936490000 & 0.699070000 & 1.601815000 \\ 1 & 1.194648000 & 0.938950000 & 2.366661000 \\ 6 & 2.535292000 & -0.564737000 & 1.642271000 \\ 1 & 2.238569000 & -1.300594000 & 2.383409000 \\ 1 & 3.523074000 & -0.718916000 & 1.209621000 \\ 1 & -0.529809000 & 1.743378000 & 0.803144000\end{array}$




$\begin{array}{llll}6 & 2.656379000 & 1.898458000 & 1.001700000 \\ 1 & 3.380274000 & 2.297056000 & 1.727411000 \\ 1 & 3.251434000 & 1.595174000 & 0.126590000\end{array}$

TS1a

B3LYP-D3 electronic energy: $\quad-1020.196266$ a.u. B3LYP-D3 enthalpy: $\quad-1019.917983$ a.u. B3LYP-D3 free energy: $\quad-1019.989823$ a.u. M06-D3 SCF energy in solution: $\quad-1019.101988$ a.u. M06-D3 enthalpy in solution: $\quad-1018.823705$ a.u. M06-D3 free energy in solution: $\quad-1018.895545$ a.u.

Cartesian coordinates

$\begin{array}{lrrr}\text { ATOM } & \text { X } & \text { Y } & \text { Z } \\ 74 & -0.311181000 & -0.566640000 & 0.008928000 \\ 6 & -0.612954000 & -0.097905000 & 2.023268000 \\ 6 & 0.275172000 & -2.413241000 & 0.560000000 \\ 6 & -0.316428000 & -1.361034000 & -1.833483000 \\ 8 & -0.373347000 & -1.847646000 & -2.888416000 \\ 8 & 0.676398000 & -3.459345000 & 0.864093000 \\ 8 & -0.871638000 & 0.125062000 & 3.124071000 \\ 7 & 1.845328000 & 0.093420000 & -0.017323000 \\ 6 & 2.093978000 & 1.421204000 & 0.015645000 \\ 6 & 2.894386000 & -0.756123000 & -0.108951000 \\ 6 & 3.396827000 & 1.923168000 & -0.040124000 \\ 6 & 0.916504000 & 2.340661000 & 0.153887000 \\ 6 & 4.211295000 & -0.325554000 & -0.152263000 \\ 1 & 2.649731000 & -1.809956000 & -0.150455000 \\ 6 & 4.472198000 & 1.046301000 & -0.118115000 \\ 1 & 3.548463000 & 2.997803000 & -0.019991000 \\ 1 & 0.855770000 & 2.672490000 & 1.205543000 \\ 1 & 1.074732000 & 3.253046000 & -0.432067000 \\ 7 & -0.337111000 & 1.698263000 & -0.222737000 \\ 1 & 5.010822000 & -1.055329000 & -0.221150000 \\ 1 & 5.490488000 & 1.421089000 & -0.159761000 \\ 1 & -0.208619000 & 0.551525000 & -1.368813000 \\ 6 & -1.379164000 & 2.581694000 & -0.366610000 \\ 6 & -2.746398000 & 2.039150000 & -0.757939000 \\ 8 & -1.218632000 & 3.790490000 & -0.176207000 \\ 1 & -3.434755000 & 2.880898000 & -0.650027000 \\ 1 & -2.729355000 & 1.770127000 & -1.824498000 \\ 6 & -3.226659000 & 0.824718000 & 0.053219000 \\ 1 & -3.039215000 & 0.981743000 & 1.123098000 \\ 1 & -4.317979000 & 0.738205000 & -0.064678000 \\ 6 & -2.586556000 & -0.459781000 & -0.421247000 \\ 1 & -2.754034000 & -0.637626000 & -1.485454000 \\ 6 & -2.426869000 & -1.607419000 & 0.379052000 \\ 1 & -2.471191000 & -2.594919000 & -0.070618000 \\ 1 & -2.699188000 & -1.583037000 & 1.432271000\end{array}$

I-2a

B3LYP-D3 electronic energy: $\quad-1020.236356$ a.u. B3LYP-D3 enthalpy: $\quad-1019.955724$ a.u.

B3LYP-D3 free energy: -1020.028525 a.u.

M06-D3 SCF energy in solution: $\quad-1019.14588$ a.u. 
M06-D3 enthalpy in solution: $\quad-1018.865248$ a.u.

M06-D3 free energy in solution: $\quad-1018.938049$ a.u.

Cartesian coordinates

$\begin{array}{lrrrr}\text { ATOM } & \text { X } & \text { Y } & \text { Z } & \\ 74 & 0.463494000 & -0.545417000 & 0.173156000 \\ 6 & 0.101827000 & -2.453726000 & -0.395912000 \\ 6 & -0.104162000 & -1.245299000 & 1.938436000 \\ 6 & 2.299123000 & -1.294982000 & 0.045235000 \\ 8 & -0.451328000 & -1.649213000 & 2.969876000 \\ 8 & -0.170026000 & -3.540439000 & -0.703705000 \\ 8 & 3.379766000 & -1.713817000 & -0.064151000 \\ 7 & -1.728408000 & -0.09102000 & -0.291353000 \\ 6 & -2.191474000 & 1.043253000 & 0.283097000 \\ 6 & -2.573876000 & -0.856560000 & -1.013237000 \\ 6 & -3.526183000 & 1.429904000 & 0.140018000 \\ 6 & -1.191120000 & 1.829782000 & 1.084236000 \\ 6 & -3.906673000 & -0.523250000 & -1.202418000 \\ 1 & -2.154976000 & -1.760178000 & -1.440698000 \\ 6 & -4.394727000 & 0.644915000 & -0.610626000 \\ 1 & -3.862865000 & 2.346630000 & 0.613241000 \\ 1 & -1.399214000 & 2.903795000 & 1.034632000 \\ 1 & -1.296707000 & 1.538559000 & 2.144628000 \\ 7 & 0.147397000 & 1.548968000 & 0.588589000 \\ 1 & -4.544187000 & -1.168922000 & -1.796583000 \\ 1 & -5.433135000 & 0.937089000 & -0.736754000 \\ 6 & 0.988590000 & 2.622595000 & 0.590567000 \\ 6 & 2.335731000 & 2.409173000 & -0.097362000 \\ 8 & 0.686153000 & 3.745245000 & 1.012206000 \\ 1 & 2.899184000 & 3.337191000 & 0.022765000 \\ 1 & 2.907256000 & 1.596219000 & 0.362680000 \\ 6 & 2.127878000 & 2.124723000 & -1.607170000 \\ 1 & 1.369631000 & 2.817596000 & -1.989724000 \\ 1 & 3.062294000 & 2.347429000 & -2.138775000 \\ 6 & 1.749395000 & 0.708100000 & -1.958778000 \\ 1 & 2.578983000 & 0.012669000 & -2.069273000 \\ 6 & 0.506469000 & 0.293077000 & -2.323374000 \\ 1 & 0.347187000 & -0.676568000 & -2.786475000 \\ 1 & -0.321971000 & 0.994915000 & -2.349273000 \\ 1 & 1.735755000 & -0.195583000 & 1.285361000\end{array}$

\section{TS7a}

B3LYP-D3 electronic energy: $\quad-1020.212723$ a.u. B3LYP-D3 enthalpy: $\quad-1019.932454$ a.u.

B3LYP-D3 free energy: $\quad-1020.002884$ a.u.

M06-D3 SCF energy in solution: $\quad-1019.118579$ a.u. M06-D3 enthalpy in solution: $\quad-1018.83831$ a.u.

M06-D3 free energy in solution: $\quad-1018.90874$ a.u.

Cartesian coordinates

$\begin{array}{llll}\text { ATOM X } & \text { Y } & \text { Z } & \\ 7 & -1.367714000 & -0.767755000 & -0.097082000 \\ 6 & -2.458199000 & -0.346280000 & 0.585751000 \\ 6 & -1.542380000 & -1.786275000 & -0.971049000 \\ 6 & -3.708773000 & -0.951459000 & 0.417124000\end{array}$




$\begin{array}{lccc}6 & -2.357979000 & 0.788744000 & 1.597944000 \\ 6 & -2.751445000 & -2.430810000 & -1.189116000 \\ 1 & -0.657882000 & -2.098811000 & -1.511593000 \\ 6 & -3.867242000 & -2.007678000 & -0.469683000 \\ 1 & -4.555923000 & -0.569644000 & 0.977518000 \\ 1 & -3.374027000 & 1.121718000 & 1.829639000 \\ 1 & -1.915151000 & 0.408802000 & 2.523873000 \\ 7 & -1.555424000 & 1.921061000 & 1.173891000 \\ 1 & -2.805240000 & -3.242858000 & -1.906365000 \\ 1 & -4.836358000 & -2.478511000 & -0.605692000 \\ 1 & -0.642169000 & 1.991601000 & 1.600590000 \\ 6 & -1.670451000 & 2.405960000 & -0.103579000 \\ 6 & -0.419953000 & 3.109231000 & -0.620572000 \\ 8 & -2.654206000 & 2.191629000 & -0.801715000 \\ 1 & -0.705335000 & 3.697390000 & -1.498280000 \\ 1 & -0.009622000 & 3.789294000 & 0.133933000 \\ 6 & 0.644733000 & 2.073056000 & -1.004238000 \\ 1 & 1.049579000 & 1.587488000 & 0.608298000 \\ 6 & 0.255165000 & 0.993015000 & -1.872215000 \\ 1 & -0.815175000 & 0.852222000 & -2.010061000 \\ 6 & 1.109778000 & 0.014920000 & -2.392239000 \\ 1 & 0.673823000 & -0.769988000 & -3.002615000 \\ 1 & 2.169405000 & 0.195092000 & -2.546886000 \\ 1 & 1.635742000 & 2.496717000 & -1.157200000 \\ 74 & 0.984575000 & -0.101555000 & 0.047999000 \\ 6 & 2.912423000 & 0.287520000 & 0.084114000 \\ 6 & 1.567691000 & -2.032005000 & 0.000628000 \\ 6 & 0.765050000 & -0.316763000 & 2.020188000 \\ 8 & 2.000188000 & -3.108418000 & -0.056955000 \\ 8 & 4.055317000 & 0.521325000 & 0.070517000 \\ 8 & 0.538857000 & -0.397744000 & 3.160263000\end{array}$

TS7b

B3LYP-D3 electronic energy: $\quad-1020.199897$ a.u. B3LYP-D3 enthalpy: $\quad-1019.920568$ a.u.

B3LYP-D3 free energy: -1019.992629 a.u.

M06-D3 SCF energy in solution: $\quad-1019.105141$ a.u. M06-D3 enthalpy in solution: $\quad-1018.825812$ a.u.

M06-D3 free energy in solution: $\quad-1018.897873$ a.u.

Cartesian coordinates

$\begin{array}{lccc}\text { ATOM } & \mathrm{X} & \mathrm{Y} & \mathrm{Z} \\ 74 & -0.985991000 & -0.366891000 & 0.053423000 \\ 6 & -2.388933000 & -1.723365000 & 0.310180000 \\ 6 & -0.627427000 & -0.517782000 & 2.035283000 \\ 6 & 0.511821000 & -1.675780000 & -0.244039000 \\ 8 & -0.435346000 & -0.592204000 & 3.176090000 \\ 8 & -3.259813000 & -2.484686000 & 0.459099000 \\ 8 & 1.394214000 & -2.400622000 & -0.465479000 \\ 7 & 2.714627000 & 0.652265000 & -1.038164000 \\ 6 & 2.663727000 & 0.688299000 & 0.302572000 \\ 6 & 3.609635000 & -0.156153000 & -1.615769000 \\ 6 & 3.505894000 & -0.075746000 & 1.111391000 \\ 6 & 1.629302000 & 1.625830000 & 0.885111000 \\ 6 & 4.497270000 & -0.952942000 & -0.892810000\end{array}$




$\begin{array}{rrrr}1 & 3.611374000 & -0.168893000 & -2.703564000 \\ 6 & 4.441113000 & -0.909240000 & 0.499772000 \\ 1 & 3.415378000 & -0.028585000 & 2.192418000 \\ 1 & 1.327003000 & 1.319366000 & 1.887323000 \\ 1 & 2.030681000 & 2.644765000 & 0.959445000 \\ 7 & 0.448103000 & 1.624109000 & -0.003308000 \\ 1 & 5.199851000 & -1.598165000 & -1.410170000 \\ 1 & 5.104115000 & -1.524864000 & 1.100767000 \\ 6 & -0.434678000 & 2.744983000 & 0.155358000 \\ 6 & -1.603970000 & 2.764829000 & -0.827686000 \\ 8 & -0.282796000 & 3.551381000 & 1.043520000 \\ 1 & -2.358303000 & 3.422535000 & -0.392106000 \\ 1 & -1.271103000 & 3.220289000 & -1.771552000 \\ 6 & -1.404524000 & 0.529470000 & -1.995776000 \\ 1 & -0.500575000 & 0.936542000 & -2.449075000 \\ 6 & -1.705220000 & -0.825729000 & -2.208488000 \\ 1 & -1.043353000 & -1.405998000 & -2.844576000 \\ 1 & -2.724805000 & -1.193604000 & -2.139439000 \\ 1 & 0.808993000 & 1.535877000 & -0.960036000 \\ 6 & -2.153193000 & 1.357460000 & -1.068812000 \\ 1 & -3.237675000 & 1.271206000 & -1.085958000 \\ 1 & -2.112339000 & 0.949079000 & 0.569980000\end{array}$

TS7c

B3LYP-D3 electronic energy: $\quad-906.851797$ a.u. B3LYP-D3 enthalpy: $\quad-906.583623$ a.u. B3LYP-D3 free energy: $\quad-906.647952$ a.u.

M06-D3 SCF energy in solution: $\quad-905.786963$ a.u. M06-D3 enthalpy in solution: $\quad-905.518789$ a.u. M06-D3 free energy in solution: $\quad-905.583118$ a.u.

Cartesian coordinates

$\begin{array}{lrrr}\text { ATOM } & \text { X } & \text { Y } & \text { Z } \\ 74 & 0.713799000 & -0.295372000 & 0.015870000 \\ 6 & 1.134812000 & -1.918822000 & -0.999519000 \\ 8 & 1.351497000 & -2.861257000 & -1.660559000 \\ 7 & -1.500691000 & -0.542989000 & -0.133160000 \\ 6 & -2.293744000 & 0.375778000 & 0.473729000 \\ 6 & -2.101160000 & -1.531023000 & -0.835829000 \\ 6 & -3.680194000 & 0.346542000 & 0.364158000 \\ 6 & -1.597474000 & 1.399541000 & 1.340322000 \\ 6 & -3.480142000 & -1.641424000 & -0.954036000 \\ 1 & -1.434719000 & -2.235116000 & -1.318563000 \\ 6 & -4.292579000 & -0.679234000 & -0.353648000 \\ 1 & -4.268039000 & 1.122219000 & 0.844884000 \\ 1 & -2.209744000 & 2.301839000 & 1.431072000 \\ 1 & -1.435021000 & 0.966963000 & 2.333839000 \\ 7 & -0.260525000 & 1.713225000 & 0.802942000 \\ 1 & -3.900849000 & -2.461422000 & -1.526453000 \\ 1 & -5.373349000 & -0.722283000 & -0.445925000 \\ 1 & 0.393774000 & 1.996876000 & 1.528633000 \\ 6 & -0.235823000 & 2.606053000 & -0.336144000 \\ 6 & 1.158748000 & 2.800302000 & -0.916484000 \\ 8 & -1.262029000 & 3.052178000 & -0.792719000 \\ 1 & 1.028526000 & 3.296244000 & -1.879930000\end{array}$




$\begin{array}{rrrr}1 & 1.734349000 & 3.475195000 & -0.265703000 \\ 6 & 1.871439000 & 1.448327000 & -1.055662000 \\ 1 & 2.351731000 & 1.284673000 & -2.019755000 \\ 6 & 2.535543000 & 0.924167000 & 0.127156000 \\ 1 & 2.656762000 & 1.544571000 & 1.017372000 \\ 6 & 3.045254000 & -0.409072000 & 0.064979000 \\ 1 & 3.507211000 & -0.814567000 & 0.961744000 \\ 1 & 3.482524000 & -0.771734000 & -0.864181000 \\ 6 & 0.651793000 & -1.166143000 & 1.807617000 \\ 8 & 0.674142000 & -1.596834000 & 2.896071000 \\ 1 & 0.566480000 & 0.599776000 & -1.562067000\end{array}$

\section{TS7d}

B3LYP-D3 electronic energy: $\quad-1020.191424$ a.u. B3LYP-D3 enthalpy: $\quad-1019.912167$ a.u.

B3LYP-D3 free energy: $\quad-1019.984312$ a.u.

M06-D3 SCF energy in solution: $\quad-1019.098621$ a.u.

M06-D3 enthalpy in solution: $\quad-1018.819364$ a.u.

M06-D3 free energy in solution: $\quad-1018.891509$ a.u.

\begin{tabular}{|c|c|c|c|}
\hline \multicolumn{4}{|c|}{ Cartesian coordinates } \\
\hline & $\mathrm{X}$ & Z & \\
\hline 7 & 1.606747000 & -0.213135000 & 0.552096000 \\
\hline 6 & 2.505654000 & 0.130053000 & -0.401447000 \\
\hline 6 & 2.044207000 & -0.366037000 & 1.819530000 \\
\hline 6 & 3.852199000 & 0.328219000 & -0.110376000 \\
\hline 6 & 1.961425000 & 0.264774000 & -1.806305000 \\
\hline 6 & 3.374810000 & -0.195495000 & 2.181314000 \\
\hline 1 & 1.284789000 & -0.639023000 & 2.543026000 \\
\hline 6 & 4.299786000 & 0.158472000 & 1.198254000 \\
\hline 1 & 4.533894000 & 0.619396000 & -0.902977000 \\
\hline 1 & 2.587629000 & 0.941374000 & -2.394675000 \\
\hline 1 & 1.932731000 & -0.717482000 & -2.289036000 \\
\hline 7 & 0.564757000 & 0.748892000 & -1.724316000 \\
\hline 1 & 3.671989000 & -0.334331000 & 3.215304000 \\
\hline 1 & 5.346089000 & 0.308103000 & 1.446594000 \\
\hline 1 & 0.039755000 & 0.585035000 & -2.583367000 \\
\hline 6 & 0.466049000 & 2.144432000 & -1.296480000 \\
\hline 6 & -0.906661000 & 2.504795000 & -0.807337000 \\
\hline 8 & 1.464024000 & 2.814408000 & -1.172747000 \\
\hline 1 & -0.967487000 & 3.594102000 & -0.703931000 \\
\hline 1 & -1.686259000 & 2.164223000 & -1.497936000 \\
\hline 6 & -1.071318000 & 1.805327000 & 0.575914000 \\
\hline 1 & -0.318114000 & 2.239309000 & 1.243104000 \\
\hline 6 & -2.442031000 & 2.040442000 & 1.118042000 \\
\hline 1 & -3.261752000 & 1.704882000 & 0.483515000 \\
\hline 6 & -2.710955000 & 2.601645000 & 2.300362000 \\
\hline 1 & -3.731284000 & 2.726739000 & 2.651886000 \\
\hline 1 & -1.919391000 & 2.941616000 & 2.966047000 \\
\hline 1 & -0.836170000 & 0.326965000 & 1.400077000 \\
\hline 74 & -0.557566000 & -0.502973000 & -0.087428000 \\
\hline 6 & -2.362393000 & -0.462235000 & -0.881808000 \\
\hline 6 & -1.293267000 & -1.703323000 & 1.306968000 \\
\hline 6 & -0.015425000 & -2.205970000 & -1.047204000 \\
\hline 8 & -1.702111000 & -2.412562000 & 2.136944000 \\
\hline
\end{tabular}


$\begin{array}{rrrr}8 & -3.414745000 & -0.356098000 & -1.384192000 \\ 8 & 0.299135000 & -3.203469000 & -1.554879000\end{array}$

I-10

B3LYP-D3 electronic energy: $\quad-906.883131$ a.u. B3LYP-D3 enthalpy: $\quad-906.609273$ a.u. B3LYP-D3 free energy: $\quad-906.67457$ a.u.

M06-D3 SCF energy in solution: $\quad-905.822409$ a.u. M06-D3 enthalpy in solution: $\quad-905.548551$ a.u. M06-D3 free energy in solution: $\quad-905.613848$ a.u.

Cartesian coordinates

$\begin{array}{lcccc}\text { ATOM } & \text { X } & \text { Y } & \text { Z } & \\ 74 & -0.304404000 & -0.581022000 & -0.136861000 \\ 6 & -0.709320000 & -0.399056000 & 1.716643000 \\ 6 & 0.100905000 & -2.480075000 & 0.162242000 \\ 8 & 0.370219000 & -3.606520000 & 0.334899000 \\ 8 & -1.033590000 & -0.260085000 & 2.843324000 \\ 7 & 1.795748000 & 0.019449000 & -0.040054000 \\ 6 & 2.099660000 & 1.352765000 & -0.073903000 \\ 6 & 2.840345000 & -0.852687000 & -0.107716000 \\ 6 & 3.397360000 & 1.819999000 & -0.239650000 \\ 6 & 0.943652000 & 2.275725000 & 0.174770000 \\ 6 & 4.158824000 & -0.447351000 & -0.246058000 \\ 1 & 2.579177000 & -1.902143000 & -0.050462000 \\ 6 & 4.455925000 & 0.914856000 & -0.331312000 \\ 1 & 3.573463000 & 2.890989000 & -0.276254000 \\ 1 & 0.712394000 & 2.284108000 & 1.245021000 \\ 1 & 1.169998000 & 3.303845000 & -0.129867000 \\ 7 & -0.282195000 & 1.776208000 & -0.488497000 \\ 1 & 4.939322000 & -1.199804000 & -0.292900000 \\ 1 & 5.476768000 & 1.261668000 & -0.454563000 \\ 1 & -0.260809000 & 1.929026000 & -1.497427000 \\ 6 & -1.523712000 & 2.282033000 & 0.075811000 \\ 6 & -2.763522000 & 2.033383000 & -0.758233000 \\ 8 & -1.528113000 & 2.824585000 & 1.156478000 \\ 1 & -3.520409000 & 2.742906000 & -0.414069000 \\ 1 & -2.556007000 & 2.239646000 & -1.818116000 \\ 6 & -3.259598000 & 0.577026000 & -0.613450000 \\ 1 & -3.444147000 & 0.367301000 & 0.446032000 \\ 1 & -4.225382000 & 0.492179000 & -1.135447000 \\ 6 & -2.250067000 & -0.415268000 & -1.163574000 \\ 1 & -2.056013000 & -0.262338000 & -2.239411000 \\ 6 & -2.182043000 & -1.780352000 & -0.740715000 \\ 1 & -2.014908000 & -2.561114000 & -1.481686000 \\ 1 & -2.761042000 & -2.110045000 & 0.120021000\end{array}$

TS1b

B3LYP-D3 electronic energy: $\quad-906.843545$ a.u. B3LYP-D3 enthalpy: $\quad-906.576028$ a.u. B3LYP-D3 free energy: $\quad-906.641759$ a.u.

M06-D3 SCF energy in solution: $\quad-905.782380$ a.u. M06-D3 enthalpy in solution: $\quad-905.514863$ a.u. M06-D3 free energy in solution: $\quad-905.580594$ a.u. 
Cartesian coordinates

$\begin{array}{lrrr}\text { ATOM X } & \text { Y } & \text { Z } & \\ 74 & 0.412326000 & -0.574441000 & -0.000772000 \\ 6 & 0.090975000 & -2.502687000 & -0.433367000 \\ 6 & 0.241709000 & -1.224799000 & 1.791563000 \\ 8 & 0.126799000 & -1.594062000 & 2.903242000 \\ 8 & -0.100008000 & -3.626421000 & -0.670957000 \\ 7 & -1.703420000 & -0.041552000 & -0.209352000 \\ 6 & -2.046558000 & 1.200017000 & 0.230037000 \\ 6 & -2.660934000 & -0.805918000 & -0.789398000 \\ 6 & -3.339639000 & 1.693290000 & 0.089840000 \\ 6 & -0.946906000 & 1.969898000 & 0.905852000 \\ 6 & -3.965008000 & -0.366353000 & -0.966602000 \\ 1 & -2.353057000 & -1.797144000 & -1.100348000 \\ 6 & -4.317758000 & 0.907778000 & -0.519034000 \\ 1 & -3.567281000 & 2.690337000 & 0.453091000 \\ 1 & -1.100307000 & 3.047927000 & 0.822072000 \\ 1 & -0.950006000 & 1.705054000 & 1.974232000 \\ 7 & 0.355490000 & 1.614638000 & 0.331765000 \\ 1 & -4.688081000 & -1.021114000 & -1.441241000 \\ 1 & -5.330100000 & 1.280672000 & -0.640715000 \\ 6 & 1.175886000 & 2.687334000 & -0.005524000 \\ 6 & 2.610211000 & 2.372992000 & -0.421225000 \\ 8 & 0.793878000 & 3.851955000 & 0.049104000 \\ 1 & 2.935567000 & 3.226275000 & -1.022548000 \\ 1 & 3.217256000 & 2.392454000 & 0.496378000 \\ 6 & 2.856955000 & 1.051945000 & -1.157646000 \\ 1 & 2.201066000 & 0.990011000 & -2.040238000 \\ 1 & 3.884575000 & 1.058465000 & -1.551743000 \\ 6 & 2.674102000 & -0.172434000 & -0.275658000 \\ 1 & 3.261244000 & -0.154082000 & 0.641811000 \\ 6 & 2.392254000 & -1.434720000 & -0.847191000 \\ 1 & 2.744831000 & -2.341275000 & -0.363709000 \\ 1 & 2.306812000 & -1.517000000 & -1.932518000 \\ 1 & 1.203811000 & 0.626597000 & 1.044696000\end{array}$

TS1c

B3LYP-D3 electronic energy: $\quad-1020.196015$ a.u. B3LYP-D3 enthalpy: $\quad-1019.917285$ a.u.

B3LYP-D3 free energy: $\quad-1019.992694$ a.u.

M06-D3 SCF energy in solution: $\quad-1019.101341$ a.u. M06-D3 enthalpy in solution: $\quad-1018.822611$ a.u. M06-D3 free energy in solution: $\quad-1018.89802$ a.u.

Cartesian coordinates

$\begin{array}{lccc}\text { ATOM } \mathrm{X} & \mathrm{Y} & \mathrm{Z} & \\ 74 & -0.005431000 & -0.689523000 & 0.182457000 \\ 6 & 1.842817000 & -1.356089000 & 0.485643000 \\ 6 & -0.252635000 & -2.379481000 & -0.876606000 \\ 6 & -0.794966000 & -1.727948000 & 1.621633000 \\ 8 & -0.407910000 & -3.337278000 & -1.517146000 \\ 8 & 2.936196000 & -1.730746000 & 0.627466000 \\ 8 & -1.324724000 & -2.289960000 & 2.497791000 \\ 7 & -1.931299000 & 0.242296000 & -0.483915000 \\ 6 & -2.215255000 & 1.431197000 & 0.101069000\end{array}$




$\begin{array}{rrrr}6 & -2.803862000 & -0.273121000 & -1.377553000 \\ 6 & -3.385827000 & 2.126900000 & -0.195560000 \\ 6 & -1.210783000 & 1.918569000 & 1.111566000 \\ 6 & -3.982720000 & 0.371606000 & -1.724705000 \\ 1 & -2.531793000 & -1.231836000 & -1.804348000 \\ 6 & -4.281157000 & 1.595270000 & -1.121056000 \\ 1 & -3.580206000 & 3.076758000 & 0.291909000 \\ 1 & -1.173910000 & 3.010017000 & 1.143271000 \\ 1 & -1.518595000 & 1.561607000 & 2.105293000 \\ 7 & 0.128152000 & 1.398587000 & 0.804730000 \\ 1 & -4.650269000 & -0.080833000 & -2.449929000 \\ 1 & -5.194150000 & 2.127432000 & -1.371138000 \\ 6 & 1.147189000 & 2.362150000 & 0.766158000 \\ 6 & 2.552491000 & 1.863859000 & 0.483801000 \\ 8 & 0.909083000 & 3.558874000 & 0.881396000 \\ 1 & 3.232241000 & 2.648111000 & 0.828300000 \\ 1 & 2.777970000 & 0.946290000 & 1.033300000 \\ 6 & 2.770739000 & 1.620026000 & -1.030368000 \\ 1 & 2.105149000 & 0.816689000 & -1.376654000 \\ 1 & 2.483668000 & 2.532116000 & -1.571806000 \\ 6 & 4.197049000 & 1.256109000 & -1.338704000 \\ 1 & 4.931413000 & 2.046458000 & -1.175632000 \\ 6 & 4.601241000 & 0.054885000 & -1.751981000 \\ 1 & 5.648917000 & -0.162292000 & -1.941670000 \\ 1 & 3.899746000 & -0.762560000 & -1.902452000 \\ 1 & 0.586665000 & 0.219876000 & 1.608008000\end{array}$

\section{TS1d}

B3LYP-D3 electronic energy: $\quad-1133.543694$ a.u.

B3LYP-D3 enthalpy: $\quad-1133.254604$ a.u.

B3LYP-D3 free energy: $\quad-1133.33596$ a.u.

M06-D3 SCF energy in solution: $\quad-1132.419726$ a.u.

M06-D3 enthalpy in solution: $\quad-1132.130636$ a.u.

M06-D3 free energy in solution: $\quad-1132.211992$ a.u.

Cartesian coordinates

$\begin{array}{lrrr}\text { ATOM } \mathrm{X} & \mathrm{Y} & \mathrm{Z} & \\ 74 & 0.220768000 & -0.698853000 & 0.060733000 \\ 6 & 0.285463000 & -0.607259000 & 2.175741000 \\ 6 & 1.187631000 & -2.458393000 & 0.291955000 \\ 6 & 0.075338000 & -1.321973000 & -1.849789000 \\ 6 & -1.621378000 & -1.428986000 & 0.308216000 \\ 8 & -0.022591000 & -1.711089000 & -2.937266000 \\ 8 & 1.815992000 & -3.426206000 & 0.405495000 \\ 8 & 0.249426000 & -0.666177000 & 3.321662000 \\ 8 & -2.697986000 & -1.835393000 & 0.462124000 \\ 7 & 2.179909000 & 0.430508000 & -0.178846000 \\ 6 & 2.133258000 & 1.747395000 & 0.121494000 \\ 6 & 3.336586000 & -0.099264000 & -0.627298000 \\ 6 & 3.255340000 & 2.565043000 & -0.021192000 \\ 6 & 0.821019000 & 2.260266000 & 0.650653000 \\ 6 & 4.490818000 & 0.654708000 & -0.787652000 \\ 1 & 3.314599000 & -1.158478000 & -0.856271000 \\ 6 & 4.450052000 & 2.015879000 & -0.477758000 \\ 1 & 3.178360000 & 3.619643000 & 0.222546000\end{array}$




$\begin{array}{rrrr}1 & 0.835600000 & 2.151743000 & 1.751906000 \\ 1 & 0.697179000 & 3.326544000 & 0.441264000 \\ 7 & -0.298065000 & 1.503155000 & 0.102157000 \\ 1 & 5.396590000 & 0.181536000 & -1.151049000 \\ 1 & 5.332465000 & 2.637707000 & -0.596297000 \\ 1 & -0.086367000 & 0.479996000 & -1.215298000 \\ 6 & -1.443045000 & 2.235111000 & -0.121300000 \\ 6 & -2.617440000 & 1.557476000 & -0.810441000 \\ 8 & -1.541894000 & 3.411338000 & 0.235093000 \\ 1 & -2.921939000 & 2.228546000 & -1.622652000 \\ 1 & -2.357514000 & 0.593318000 & -1.252897000 \\ 6 & -3.801038000 & 1.385012000 & 0.168336000 \\ 1 & -3.523912000 & 0.675618000 & 0.956392000 \\ 1 & -3.976281000 & 2.357463000 & 0.646599000 \\ 6 & -5.043255000 & 0.916057000 & -0.537125000 \\ 1 & -5.473280000 & 1.621820000 & -1.250761000 \\ 6 & -5.615338000 & -0.277489000 & -0.371069000 \\ 1 & -6.508649000 & -0.564236000 & -0.920311000 \\ 1 & -5.204242000 & -1.013033000 & 0.315943000\end{array}$

\section{I-2b}

B3LYP-D3 electronic energy: $\quad-906.888030$ a.u. B3LYP-D3 enthalpy: $\quad-906.618141$ a.u.

B3LYP-D3 free energy: $\quad-906.685058$ a.u.

M06-D3 SCF energy in solution: $\quad-905.828011$ a.u. M06-D3 enthalpy in solution: $\quad-905.558122$ a.u. M06-D3 free energy in solution: $\quad-905.625039$ a.u.

\begin{tabular}{lrrr}
\multicolumn{5}{l}{ Cartesian coordinates } \\
ATOM $\mathrm{X}$ & $\mathrm{Y}$ & $\mathrm{Z}$ & \\
74 & 0.397940000 & -0.595573000 & 0.021097000 \\
6 & -0.358296000 & -1.732776000 & -1.392094000 \\
6 & -0.197522000 & -1.741431000 & 1.481082000 \\
8 & -0.596917000 & -2.328281000 & 2.427400000 \\
8 & -0.855331000 & -2.311684000 & -2.271784000 \\
7 & -1.712542000 & 0.196205000 & 0.133916000 \\
6 & -1.875927000 & 1.477765000 & -0.248275000 \\
6 & -2.805030000 & -0.543256000 & 0.437972000 \\
6 & -3.145092000 & 2.053861000 & -0.351444000 \\
6 & -0.624366000 & 2.233720000 & -0.554761000 \\
6 & -4.091157000 & -0.034888000 & 0.355321000 \\
1 & -2.615793000 & -1.560909000 & 0.754544000 \\
6 & -4.267016000 & 1.291510000 & -0.051001000 \\
1 & -3.232841000 & 3.090584000 & -0.660755000 \\
1 & -0.575607000 & 2.430721000 & -1.636758000 \\
1 & -0.649163000 & 3.217879000 & -0.075729000 \\
7 & 0.566888000 & 1.486700000 & -0.124652000 \\
1 & -4.935010000 & -0.667073000 & 0.609290000 \\
1 & -5.261640000 & 1.721693000 & -0.122467000 \\
6 & 1.594846000 & 2.361147000 & 0.240195000 \\
6 & 2.886614000 & 1.761813000 & 0.768348000 \\
8 & 1.477633000 & 3.581795000 & 0.156768000 \\
1 & 3.595810000 & 2.590035000 & 0.843307000 \\
1 & 2.723237000 & 1.369629000 & 1.781218000 \\
6 & 3.414835000 & 0.646919000 & -0.137914000
\end{tabular}




$\begin{array}{rrrr}1 & 3.348627000 & 0.971205000 & -1.184644000 \\ 1 & 4.482412000 & 0.488098000 & 0.068695000 \\ 1 & 0.802392000 & -2.244451000 & 0.658051000 \\ 6 & 2.694736000 & -0.673728000 & 0.044527000 \\ 1 & 3.010603000 & -1.227303000 & 0.930034000 \\ 6 & 2.275943000 & -1.425012000 & -1.079981000 \\ 1 & 2.319722000 & -2.509363000 & -1.094096000 \\ 1 & 2.340797000 & -0.967172000 & -2.067666000\end{array}$

TS2a

B3LYP-D3 electronic energy: $\quad-906.878175$ a.u. B3LYP-D3 enthalpy: $\quad-906.609379$ a.u. B3LYP-D3 free energy: $\quad-906.674607$ a.u.

M06-D3 SCF energy in solution: $\quad-905.816990$ a.u. M06-D3 enthalpy in solution: $\quad-905.548194$ a.u. M06-D3 free energy in solution: $\quad-905.613422$ a.u.

Cartesian coordinates

$\begin{array}{lrrr}\text { ATOM } & \text { X } & \text { Y } & \text { Z } \\ 74 & 0.310086000 & -0.556097000 & -0.098768000 \\ 6 & -0.250722000 & -2.391679000 & 0.392106000 \\ 8 & -0.669742000 & -3.432862000 & 0.723467000 \\ 7 & -1.867792000 & -0.004750000 & -0.039544000 \\ 6 & -2.143238000 & 1.316394000 & 0.056032000 \\ 6 & -2.897292000 & -0.878481000 & -0.181550000 \\ 6 & -3.457697000 & 1.793262000 & -0.001033000 \\ 6 & -0.982117000 & 2.234304000 & 0.254628000 \\ 6 & -4.217920000 & -0.470806000 & -0.239160000 \\ 1 & -2.625304000 & -1.924454000 & -0.241596000 \\ 6 & -4.506024000 & 0.896534000 & -0.149560000 \\ 1 & -3.635791000 & 2.861277000 & 0.075989000 \\ 1 & -1.043977000 & 3.071462000 & -0.455291000 \\ 1 & -1.062647000 & 2.703691000 & 1.246557000 \\ 7 & 0.289531000 & 1.530677000 & 0.121903000 \\ 1 & -5.003997000 & -1.209446000 & -0.352164000 \\ 1 & -5.532071000 & 1.249858000 & -0.193592000 \\ 6 & 1.356224000 & 2.392683000 & 0.363351000 \\ 6 & 2.760262000 & 1.862917000 & 0.095177000 \\ 8 & 1.186353000 & 3.557132000 & 0.718380000 \\ 1 & 3.402241000 & 2.745750000 & 0.034702000 \\ 1 & 3.099071000 & 1.273350000 & 0.956572000 \\ 6 & 2.856838000 & 1.011547000 & -1.184149000 \\ 1 & 2.243787000 & 1.467976000 & -1.972105000 \\ 1 & 3.894775000 & 1.027542000 & -1.546844000 \\ 6 & 1.540596000 & -0.979934000 & 1.337625000 \\ 8 & 2.289049000 & -1.200241000 & 2.208535000 \\ 1 & 0.297307000 & -1.638282000 & -1.499024000 \\ 6 & 2.443873000 & -0.433812000 & -0.970040000 \\ 1 & 3.194477000 & -1.018438000 & -0.440523000 \\ 6 & 1.684584000 & -1.144389000 & -1.953803000 \\ 1 & 1.937981000 & -2.183757000 & -2.156558000 \\ 1 & 1.366118000 & -0.600287000 & -2.844591000\end{array}$

I-3a

B3LYP-D3 electronic energy: $\quad-906.904611$ a.u. 


\begin{tabular}{lccc}
\multicolumn{5}{l}{ B3LYP-D3 enthalpy: } & -906.632546 a.u. \\
B3LYP-D3 free energy: & -906.698188 a.u. \\
M06-D3 SCF energy in solution: & -905.842579 a.u. \\
M06-D3 enthalpy in solution: & -905.570514 a.u. \\
M06-D3 free energy in solution: & -905.636156 a.u. \\
\multicolumn{4}{c}{} \\
\multicolumn{5}{c}{} \\
Cartesian coordinates \\
ATOM X Y Y & Z \\
74 & -0.385945000 & -0.325064000 & 0.174235000 \\
6 & -0.524509000 & -1.670602000 & 1.595975000 \\
6 & -0.381958000 & -2.068733000 & -0.752107000 \\
8 & -0.311791000 & -3.069491000 & -1.354575000 \\
8 & -0.582964000 & -2.439421000 & 2.479613000 \\
7 & 1.758226000 & -0.154871000 & -0.103288000 \\
6 & 2.244414000 & 1.116835000 & -0.126866000 \\
6 & 2.630867000 & -1.192082000 & -0.197958000 \\
6 & 3.615028000 & 1.360714000 & -0.249353000 \\
6 & 1.255821000 & 2.244870000 & -0.020214000 \\
6 & 3.995426000 & -1.008163000 & -0.327834000 \\
1 & 2.188106000 & -2.179299000 & -0.168933000 \\
6 & 4.500806000 & 0.296680000 & -0.353779000 \\
1 & 3.966190000 & 2.387802000 & -0.262336000 \\
1 & 1.525952000 & 2.886291000 & 0.832056000 \\
1 & 1.337312000 & 2.892527000 & -0.905734000 \\
7 & -0.091649000 & 1.724849000 & 0.122892000 \\
1 & 4.647921000 & -1.871151000 & -0.402380000 \\
1 & 5.567471000 & 0.475404000 & -0.451452000 \\
6 & -1.087063000 & 2.679365000 & 0.100924000 \\
6 & -2.510625000 & 2.130290000 & 0.257774000 \\
8 & -0.878474000 & 3.881264000 & -0.025411000 \\
1 & -2.888760000 & 2.504241000 & 1.217378000 \\
1 & -3.126684000 & 2.593783000 & -0.520297000 \\
6 & -2.174708000 & -0.056637000 & -1.075657000 \\
1 & -1.897789000 & 0.673415000 & -1.844322000 \\
6 & -3.048617000 & -1.161385000 & -1.638738000 \\
1 & -3.986597000 & -0.756091000 & -2.046292000 \\
1 & -3.301448000 & -1.893623000 & -0.863430000 \\
1 & -2.537908000 & -1.697651000 & -2.444683000 \\
6 & -2.637682000 & 0.603019000 & 0.191101000 \\
1 & -3.629555000 & 0.252921000 & 0.499683000 \\
1 & -2.047690000 & 0.172449000 & 1.113532000
\end{tabular}

TS3a

B3LYP-D3 electronic energy: $\quad-906.893787$ a.u. B3LYP-D3 enthalpy: $\quad-906.625577$ a.u. B3LYP-D3 free energy: $\quad-906.691273$ a.u.

M06-D3 SCF energy in solution: $\quad-905.831352$ a.u. M06-D3 enthalpy in solution: $\quad-905.563142$ a.u. M06-D3 free energy in solution: $\quad-905.628838$ a.u.

Cartesian coordinates

$\begin{array}{llll}\text { ATOM } & \text { X } & \text { Z } & \\ 74 & -0.399377000 & -0.313210000 & 0.186637000 \\ 6 & -0.294635000 & -1.801934000 & 1.479190000 \\ 6 & -0.598230000 & -1.956179000 & -0.883512000\end{array}$




$\begin{array}{rrrr}8 & -0.667575000 & -2.894592000 & -1.579951000 \\ 8 & -0.177055000 & -2.646808000 & 2.279565000 \\ 7 & 1.779660000 & -0.157657000 & -0.073003000 \\ 6 & 2.280425000 & 1.095062000 & -0.224091000 \\ 6 & 2.626886000 & -1.215868000 & -0.097774000 \\ 6 & 3.649932000 & 1.304728000 & -0.407489000 \\ 6 & 1.299495000 & 2.231240000 & -0.183253000 \\ 6 & 3.992390000 & -1.070203000 & -0.272222000 \\ 1 & 2.165107000 & -2.187231000 & 0.028380000 \\ 6 & 4.514688000 & 0.217911000 & -0.431734000 \\ 1 & 4.017834000 & 2.319004000 & -0.526274000 \\ 1 & 1.595839000 & 2.948403000 & 0.596671000 \\ 1 & 1.347656000 & 2.795317000 & -1.12699000 \\ 7 & -0.037753000 & 1.720742000 & 0.056389000 \\ 1 & 4.630588000 & -1.946850000 & -0.283853000 \\ 1 & 5.581263000 & 0.367594000 & -0.571653000 \\ 6 & -1.017158000 & 2.685588000 & 0.159014000 \\ 6 & -2.389640000 & 2.124372000 & 0.534090000 \\ 8 & -0.817969000 & 3.886143000 & 0.013739000 \\ 1 & -2.528846000 & 2.344612000 & 1.600045000 \\ 1 & -3.149856000 & 2.701196000 & -0.005637000 \\ 6 & -2.582197000 & 0.633775000 & 0.292915000 \\ 1 & -1.574963000 & -0.151996000 & 1.439243000 \\ 6 & -2.397710000 & 0.045886000 & -0.984669000 \\ 1 & -2.038388000 & 0.712019000 & -1.771826000 \\ 6 & -3.310945000 & -1.058943000 & -1.467101000 \\ 1 & -4.246345000 & -0.629081000 & -1.852620000 \\ 1 & -3.560545000 & -1.742571000 & -0.648539000 \\ 1 & -2.858472000 & -1.648691000 & -2.268868000 \\ 1 & -3.359340000 & 0.183679000 & 0.910079000\end{array}$

I-4a

B3LYP-D3 electronic energy: $\quad-906.904521$ a.u. B3LYP-D3 enthalpy: $\quad-906.635479$ a.u.

B3LYP-D3 free energy: $\quad-906.702224$ a.u.

M06-D3 SCF energy in solution: $\quad-905.842407$ a.u. M06-D3 enthalpy in solution: $\quad-905.573365$ a.u. M06-D3 free energy in solution: $\quad-905.640110$ a.u.

Cartesian coordinates
$\begin{array}{lccc}\text { ATOM } \mathrm{X} & \mathrm{Y} & \mathrm{Z} & \\ 74 & -0.451285000 & -0.348184000 & 0.154576000 \\ 6 & -0.090134000 & -1.676214000 & 1.551228000 \\ 6 & -0.338957000 & -1.652375000 & -1.315291000 \\ 8 & -0.236891000 & -2.336436000 & -2.253804000 \\ 8 & 0.172536000 & -2.396947000 & 2.443227000 \\ 7 & 1.768057000 & -0.132837000 & 0.002953000 \\ 6 & 2.242238000 & 1.116243000 & -0.211671000 \\ 6 & 2.644685000 & -1.164094000 & 0.063714000 \\ 6 & 3.607929000 & 1.356873000 & -0.380474000 \\ 6 & 1.223232000 & 2.214444000 & -0.263468000 \\ 6 & 4.009380000 & -0.991313000 & -0.097432000 \\ 1 & 2.211485000 & -2.139019000 & 0.248407000 \\ 6 & 4.504008000 & 0.296536000 & -0.325471000 \\ 1 & 3.947693000 & 2.373657000 & -0.551110000\end{array}$




$\begin{array}{rrrr}1 & 1.475227000 & 3.004905000 & 0.456873000 \\ 1 & 1.246772000 & 2.699919000 & -1.250271000 \\ 7 & -0.097523000 & 1.668157000 & 0.012356000 \\ 1 & 4.668738000 & -1.850543000 & -0.041097000 \\ 1 & 5.568842000 & 0.466883000 & -0.453197000 \\ 6 & -1.092993000 & 2.631356000 & 0.116062000 \\ 6 & -2.451593000 & 2.059271000 & 0.497812000 \\ 8 & -0.889488000 & 3.827517000 & -0.040582000 \\ 1 & -2.653717000 & 2.416957000 & 1.514525000 \\ 1 & -3.206023000 & 2.529229000 & -0.145914000 \\ 6 & -2.536314000 & 0.539530000 & 0.463477000 \\ 1 & -1.403330000 & -1.711387000 & 0.811468000 \\ 6 & -2.592718000 & -0.167347000 & -0.763052000 \\ 1 & -2.419576000 & 0.421386000 & -1.669290000 \\ 6 & -3.458419000 & -1.386904000 & -0.979236000 \\ 1 & -4.456601000 & -1.078698000 & -1.321661000 \\ 1 & -3.577820000 & -1.951871000 & -0.048691000 \\ 1 & -3.039724000 & -2.060139000 & -1.734181000 \\ 1 & -3.051979000 & 0.088007000 & 1.310405000\end{array}$

\section{TS4a}

B3LYP-D3 electronic energy: $\quad-906.890493$ a.u. B3LYP-D3 enthalpy: $\quad-906.622177$ a.u. B3LYP-D3 free energy: $\quad-906.689304$ a.u.

M06-D3 SCF energy in solution: $\quad-905.826747$ a.u. M06-D3 enthalpy in solution: $\quad-905.558431$ a.u. M06-D3 free energy in solution: $\quad-905.625558$ a.u.

Cartesian coordinates

$\begin{array}{lrrr}\text { ATOM } & \text { X } & \text { Y } & \text { Z } \\ 74 & 0.395546000 & -0.272293000 & -0.106213000 \\ 7 & -1.805535000 & -0.299738000 & 0.012984000 \\ 6 & -2.429330000 & 0.903072000 & -0.073239000 \\ 6 & -2.569336000 & -1.418818000 & 0.111362000 \\ 6 & -3.823002000 & 1.002680000 & -0.089186000 \\ 6 & -1.550659000 & 2.114771000 & -0.140818000 \\ 6 & -3.952200000 & -1.384388000 & 0.096720000 \\ 1 & -2.029474000 & -2.352237000 & 0.201676000 \\ 6 & -4.597150000 & -0.146866000 & -0.007345000 \\ 1 & -4.279050000 & 1.985146000 & -0.162192000 \\ 1 & -1.779390000 & 2.688797000 & -1.051086000 \\ 1 & -1.784464000 & 2.792188000 & 0.693095000 \\ 7 & -0.151848000 & 1.722778000 & -0.101721000 \\ 1 & -4.511214000 & -2.310618000 & 0.173350000 \\ 1 & -5.681255000 & -0.084866000 & -0.014963000 \\ 6 & 0.718975000 & 2.784410000 & 0.067830000 \\ 6 & 2.184707000 & 2.359628000 & 0.134258000 \\ 8 & 0.365810000 & 3.954112000 & 0.144376000 \\ 1 & 2.655883000 & 2.717285000 & -0.791156000 \\ 1 & 2.645356000 & 2.928836000 & 0.948317000 \\ 6 & 2.421560000 & 0.868497000 & 0.323115000 \\ 6 & 0.954810000 & -1.264271000 & 1.461739000 \\ 8 & 1.322254000 & -1.790734000 & 2.444433000 \\ 6 & 0.350987000 & -2.202462000 & -0.656332000 \\ 8 & 0.247791000 & -3.320191000 & -0.975265000\end{array}$




$\begin{array}{rrrr}1 & 1.396488000 & -0.598355000 & -1.479704000 \\ 6 & 2.791777000 & 0.055060000 & -0.765746000 \\ 1 & 2.896230000 & 0.560031000 & -1.727564000 \\ 1 & 2.774386000 & 0.569672000 & 1.307739000 \\ 6 & 3.660203000 & -1.173169000 & -0.602486000 \\ 1 & 3.512284000 & -1.628766000 & 0.379996000 \\ 1 & 3.444752000 & -1.928505000 & -1.364312000 \\ 1 & 4.715850000 & -0.884544000 & -0.699825000\end{array}$

\section{I-3b}

B3LYP-D3 electronic energy: $\quad-1020.235130$ a.u.

B3LYP-D3 enthalpy: $\quad-1019.952530$ a.u.

B3LYP-D3 free energy: $\quad-1020.024674$ a.u.

M06-D3 SCF energy in solution: $\quad-1019.144268$ a.u.

M06-D3 enthalpy in solution: $\quad-1018.861668$ a.u.

M06-D3 free energy in solution: $\quad-1018.933812$ a.u.

Cartesian coordinates

$\begin{array}{lrrr}\text { ATOM } & \text { X } & \text { Y } & \text { Z } \\ 74 & 0.366452000 & -0.631284000 & 0.034140000 \\ 6 & 0.354904000 & -0.429512000 & -1.999668000 \\ 6 & -0.474807000 & -2.494417000 & 0.106546000 \\ 8 & -1.008679000 & -3.517339000 & 0.224274000 \\ 8 & 0.286514000 & -0.310414000 & -3.148596000 \\ 7 & -1.773960000 & 0.081142000 & -0.090390000 \\ 6 & -2.014184000 & 1.339928000 & 0.337544000 \\ 6 & -2.799139000 & -0.636414000 & -0.603913000 \\ 6 & -3.292175000 & 1.898891000 & 0.277242000 \\ 6 & -0.825592000 & 2.062620000 & 0.881746000 \\ 6 & -4.091375000 & -0.141891000 & -0.688813000 \\ 1 & -2.561706000 & -1.630952000 & -0.960233000 \\ 6 & -4.348137000 & 1.154378000 & -0.235675000 \\ 1 & -3.435990000 & 2.915940000 & 0.627032000 \\ 1 & -0.916110000 & 3.142519000 & 0.737811000 \\ 1 & -0.790367000 & 1.884936000 & 1.973286000 \\ 7 & 0.392525000 & 1.570133000 & 0.249296000 \\ 1 & -4.874244000 & -0.762823000 & -1.110804000 \\ 1 & -5.347361000 & 1.575693000 & -0.293296000 \\ 6 & 1.303140000 & 2.558426000 & 0.014918000 \\ 6 & 2.721977000 & 2.212163000 & -0.445834000 \\ 8 & 1.077220000 & 3.760478000 & 0.218455000 \\ 1 & 2.954601000 & 2.890599000 & -1.273300000 \\ 1 & 3.359456000 & 2.540154000 & 0.386643000 \\ 6 & 3.075414000 & 0.771802000 & -0.809179000 \\ 1 & 2.696196000 & 0.518268000 & -1.806371000 \\ 1 & 4.173103000 & 0.685367000 & -0.870701000 \\ 6 & 2.544933000 & -0.212424000 & 0.214894000 \\ 1 & 2.833900000 & 0.053390000 & 1.232960000 \\ 6 & 2.648726000 & -1.655836000 & -0.087655000 \\ 1 & 3.037978000 & -2.275424000 & 0.722566000 \\ 1 & 3.123839000 & -1.882168000 & -1.046096000 \\ 6 & 0.352333000 & -0.707062000 & 2.065930000 \\ 8 & 0.366239000 & -0.765252000 & 3.222825000 \\ 1 & 1.592852000 & -2.163115000 & -0.262332000\end{array}$




\section{REFERENCES}

42. K.S. Yang, J.A. Gurak, Z. Liu, K.M. Engle, Catalytic, regioselective hydrocarbofunctionalization of unactivated alkenes with diverse C-H nucleophiles. J. Am. Chem. Soc. 138, 14705-14712 (2016).

43. J.A. Gurak, K.S. Yang, Z. Liu, K.M. Engle, Directed, regiocontrolled hydroamination of unactivated alkenes via protodepalladation. J. Am. Chem. Soc. 138, 5805-5808 (2016).

44. T.R. Huffman, Y. Wu, A. Emmerich, R.A. Shenvi, Intermolecular Heck coupling with hindered alkenes directed by potassium carboxylates. Angew. Chem. Int. Ed. 58, 2371-2376 (2018).

45. T.G. Chen, L.M. Barton, Y. Lin, J. Tsien, D. Kossler, I. Bastida, S. Asai, C. Bi, J.S. Chen, M. Shan, H. Fang, F.G. Fang, H.W. Choi, L. Hawkins, T. Qin, P.S. Baran, Building C $\left(s p^{3}\right)$-rich complexity by combining cycloaddition and C-C cross-coupling reactions. Nature 560, 350-354 (2018).

46. W. Ye, G. Liu, B.V. Popp, S.S. Stahl, Mechanistic studies of Wacker-type intramolecular aerobic oxidative amination of alkenes catalyzed by $\mathrm{Pd}(\mathrm{OAc})_{2}$ /pyridine $J$. Org. Chem. 76, 1031-1044 (2011).

47. S. Mizuta, S. Verhoog, K.M. Engle, T. Khotavivattana, M. O’Duill, K. Wheelhouse, G. Rassias, M. Medebielle, V. Gouverneur, Catalytic hydrotrifluoromethylation of unactivated alkenes. J. Am. Chem. Soc. 135, 2505-2508 (2013).

48. A. Tortajada, R. Ninokata, R. Martin, Ni-Catalyzed site-selective dicarboxylation of 1,3-dienes with $\mathrm{CO}_{2}$. J. Am. Chem. Soc. 140, 2050-2053 (2018).

49. Crystallographic data for the structures reported in this manuscript have been deposited with the Cambridge Crystallographic Data Centre under the CCDC numbers: [2008992] (2u); [2045639] (W-3'); [2020047] (W-2); [2050458] (W-3). Copies of these data can be obtained free of charge from http://www.ccdc.cam.ac.uk/data request/cif.

50. Gaussian 16, Revision C.01, M.J. Frisch, G.W. Trucks, H.B. Schlegel, G.E. Scuseria, M.A. Robb, J.R. Cheeseman, G. Scalmani, V. Barone, G.A. Petersson, H. Nakatsuji, X. Li, M. Caricato, A.V. Marenich, J. Bloino, B.G. Janesko, R. Gomperts, B. Mennucci, H.P. Hratchian, J.V. Ortiz, A.F. Izmaylov, J.L. Sonnenberg, D. Williams-Young, F. Ding, F. Lipparini, F. Egidi, J. Goings, B. Peng, A. Petrone, T. Henderson, D. Ranasinghe, V.G. Zakrzewski, J. Gao, N. Rega, G. Zheng, W. Liang, M. Hada, M. Ehara, K. Toyota, R. Fukuda, J. Hasegawa, M. Ishida, T. Nakajima, Y. Honda, O. Kitao, H. Nakai, T. Vreven, K. Throssell, J.A. Montgomery, J.E. Peralta, F. Ogliaro, M.J. Bearpark, J.J. Heyd, E.N. Brothers, K.N. Kudin, V.N. Staroverov, T.A. Keith, R. Kobayashi, J. Normand, K. Raghavachari, A.P. Rendell, J.C. Burant, S.S. Iyengar, J. Tomasi, M. Cossi, J.M. Millam, M. Klene, C. Adamo, R. Cammi, J.W. Ochterski, R.L. Martin, K. Morokuma, O. Farkas, J.B. Foresman, D.J. Fox, Gaussian, Inc., Wallingford CT, (2016).

51. C. Lee, W. Yang, R.G. Parr, Development of the Colle-Salvetti correlation-energy formula into a functional of the electron density. Phys. Rev. B. 37, 785-789 (1988).

52. S. Grimme, J. Antony, S. Ehrlich, H. Krieg, A consistent and accurate ab initio parametrization of density functional dispersion correction (DFT-D) for the 94 elements H-Pu. J. Chem. Phys. 132, 154104 (2010).

53. P.J. Hay, W.R. Wadt, Ab initio effective core potentials for molecular calculations. Potentials for K to Au including the outermost core orbitals. J. Chem. Phys. 82, 299-310 (1985).

54. Y. Zhao, D.G. Truhlar, The M06 suite of density functionals for main group thermochemistry, thermochemical kinetics, noncovalent interactions, excited states, and transition elements: two new functionals and systematic testing of four M06-class functionals and 12 other functionals. Theor. Chem. Acc. 120, 215-241 (2007).

55. L.E. Roy, P.J. Hay, R.L. Martin, Revised basis sets for the LANL effective core potentials. J. Chem. Theory Comput. 4, 1029-1031 (2008).

56. A.V. Marenich, C.J. Cramer, D.G. Truhlar, Universal solvation model based on solute electron density and on a continuum model of the solvent defined by the bulk dielectric constant and atomic surface tensions. J. Phys. Chem.

$B$ 113, 6378-6396 (2009).

57. T. Ziegler, V. Tschinke, C. Ursenbach, Thermal stability and kinetic lability of the metal carbonyl bond. A theoretical study on $\mathrm{M}(\mathrm{CO})_{6}(\mathrm{M}=$ chromium, molybdenum, tungsten $), \mathrm{M}(\mathrm{CO})_{5}(\mathrm{M}=$ iron, ruthenium, osmium $)$, and $\mathrm{M}(\mathrm{CO})_{4}(\mathrm{M}=$ nickel, palladium, platinum). J. Am. Chem. Soc. 109, 4825-4837 (1987). 
Other files

2u.cif (408.74 KiB)

W-2.cif (559.85 KiB)

W-3.cif (341.66 KiB)

W-3'.cif (0.94 MiB) view on ChemRxiv • download file view on ChemRxiv • download file view on ChemRxiv • download file view on ChemRxiv - download file 